Florida International University

FIU Digital Commons

FIU Electronic Theses and Dissertations

University Graduate School

7-10-2001

\title{
Geochemical variation among small eruptive centers in the central SVZ of the Andes : an evaluation of subduction, mantle and crustal influences
}

Murong Sun

Florida International University

DOI: $10.25148 /$ etd.FI15071601

Follow this and additional works at: https://digitalcommons.fiu.edu/etd

Part of the Geology Commons

\section{Recommended Citation}

Sun, Murong, "Geochemical variation among small eruptive centers in the central SVZ of the Andes : an evaluation of subduction, mantle and crustal influences" (2001). FIU Electronic Theses and Dissertations. 2005.

https://digitalcommons.fiu.edu/etd/2005 


\section{FLORIDA INTERNATIONAL UNIVERSITY}

Miami, Florida

GEOCHEMICAL VARIATION AMONG SMALL ERUPTIVE CENTERS IN THE CENTRAL SVZ OF THE ANDES: AN EVALUATION OF SUBDUCTION, MANTLE AND CRUSTAL INFLUENCES

A dissertation submitted in partial fulfillment of the

requirements for the degree of

DOCTOR OF PHILOSOPHY

in

GEOLOGY

by

Murong Sun 
To: Dean Arthur W. Herriott

College of Arts and Sciences

This dissertation, written by Murong Sun, and entitled Geochemical Variation Among Small Eruptive Centers in the Central SVZ of the Andes: An Evaluation of Subduction, Mantle and Crustal Influences, having been approved in respect to style and intellectual content, is referred to you for judgment.

We have read this dissertation and recommend that it be approved.

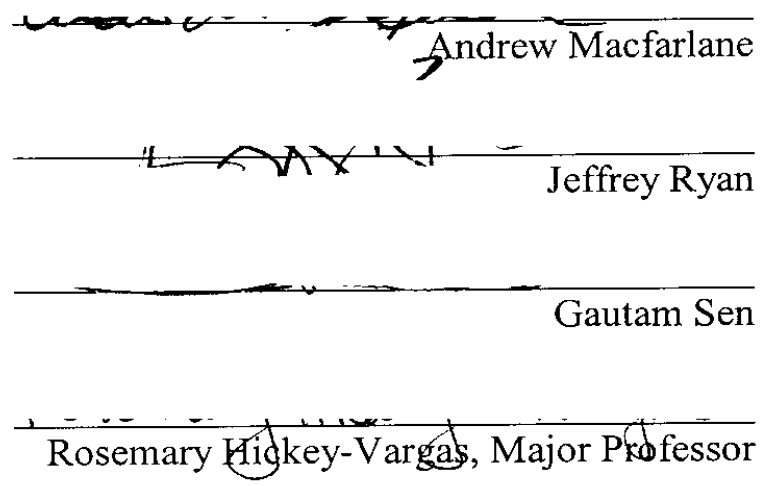

Date of Defense: July 20, 2001

The dissertation of Murong Sun is approved.

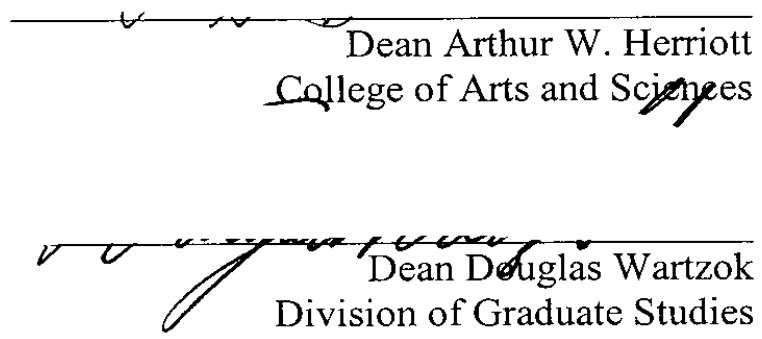

Florida International University, 2001 
(C) Copyright 2001 by Murong Sun

All rights reserved. 


\section{DEDICATION}

I dedicate this dissertation to all the people who love me and believe I can be who I want to be in my life. 


\section{ACKNOWLEDGMENTS}

I thank my major professor, Dr. Hickey, for giving me so much help throughout my five - year graduate study at FIU Geology, especially during the last two years since I started to write my dissertation. Dr. Hickey spent numerous hours on reading and correcting it and giving me a lot of helpful advice both on my study and on my personal life. I also thank her for being confident enough to let me do this great project. I really learned a lot from this research work.

I also thank my committee members, Dr. Macfarlane, Dr. Ryan and Dr. Sen, for being so patient on reading my dissertation, making revisions on every aspect of it and guiding me all the way through this project. I especially thank Dr. Ryan, for being my external committee member, and communicating with me by phone or email and providing me so much needed help throughout the years.

I thank Diane Pirie for helping me so nicely when I was working in the Geochemistry and ICP Laboratory of FIU.

Special thanks go to all the people from other laboratories and universities who have made important contributions to this work. They are: Dr. Lopez - Escobar from University of Chile who collected the SEC samples from the field; volcanologist Moreno - Roa who provided us information on the local geologic background; Dr. Plank who ran the ICPMS measurements for this work; Dr. Ryan, Ph.D. student Ivan Savov and lab technician Gene Foster in the University of South Florida who collaborated with me on the B - Be - Li analyses; Dr. Salters, Dr. Odom, lab technicians Afi Sachi - Kocher and Theodore Zateslo and Ph.D. students Michael Bizimis and Andreas Stracke at the High 
Magnetic Field National Laboratory who provided tremendous help on the measurement of $\mathrm{Sr}-\mathrm{Nd}-\mathrm{Pb}$ isotopes; Dr. Reagan who analysed $\mathrm{U}-\mathrm{Th}$ isotopes at University of Iowa and Dr. Morris who analysed ${ }^{10} \mathrm{Be}$ at the Lawrence Livermore National Laboratory.

It is also my pleasure to work with so many nice and intelligent people for the past five years. I thank all the faculty, staff and my fellow students of FIU Geology for the willing help I always receive.

This work serves as part of Dr. Hickey's NSF - funded project "Production and Ascent of Magma at Convergent Margins: Information from Small Eruptive Centers in the Central Southern Volcanic Zone, Chile". 


\title{
ABSTRACT OF THE DISSERTATION
}

\section{GEOCHEMICAL VARIATION AMONG SMALL ERUPTIVE CENTERS IN THE CENTRAL SVZ OF THE ANDES: AN EVALUATION OF SUBDUCTION, MANTLE AND CRUSTAL INFLUENCES}

\author{
by \\ Murong Sun \\ Florida International University, 2001 \\ Miami, Florida \\ Professor Rosemary Hickey-Vargas, Major Professor
}

Subduction zone magmatism is an important and extensively studied topic in igneous geochemistry. Recent studies focus on from where arc magmas are generated, how subduction components (fluids or melts) are fluxed into the source of the magmas, and whether or how the subduction components affect partial melting processes beneath volcanic arcs at convergent boundaries.

At $39.5^{\circ} \mathrm{S}$ in the Central Southern Volcanic Zone of the Andes, Volcano Villarrica is surrounded by a suite of Small Eruptive Centers (SEC). The SECs are located mostly to the east and northeast of the stratovolcano and aligned along the Liquine - Ofqui Fault Zone, the major fracture system in this area. Former studies observed the geochemical patterns of the SECs differ distinctively from those of V.Villarrica and suggested there may be a relationship between the compositions of the volcanic units and their edifice 
sizes. This work is a comprehensive geochemical study on the SECs near V.Villarrica, using a variety of geochemical tracers and tools including major, trace and REE elements, $\mathrm{Li}-\mathrm{Be}-\mathrm{B}$ elements, $\mathrm{Sr}-\mathrm{Nd}-\mathrm{Pb}$ isotopes and short - lived isotopes such as $\mathrm{U}$ - series and ${ }^{10} \mathrm{Be}$. In this work, systematic differences between the elemental and isotopic compositions of the SECs and those of V.Villarrica are revealed and more importantly, modeled in terms of magmatic processes occurring at continental arc margins. Detailed modeling calculations in this work reconstruct chemical compositions of the primary magmas, source compositions, compositions and percentages of different subduction endmembers mixed into the source, degrees of partial melting and different time scales of the SECs and V.Villarrica, respectively. Geochemical characteristics and possible origins of the two special SECs - andesitic Llizan, with crustal signatures, and Rucapillan, to the northwest toward the trench, are also discussed in this work. 


\section{TABLE OF CONTENTS}

CHAPTER

PAGE

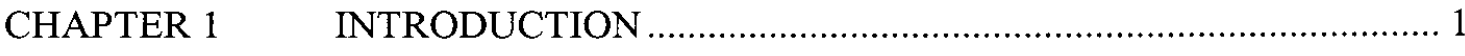

1.1 GEOCHEMICAL PROCESSES IN SUBDUCTION ZONES ............................... 1

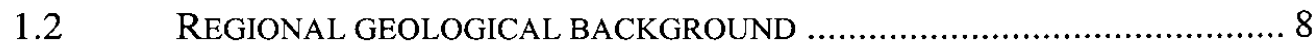

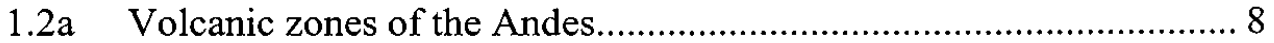

$1.2 \mathrm{~b}$ The Southern Volcanic Zone of Andes............................................. 10

1.2c The volcanic segments of the Andean SVZ ...................................... 12

1.3 GEOLOGICAL BACKGROUND AND ERUPTION HISTORY OF V.VILLARRICA AND THE SECS .................................................... 15

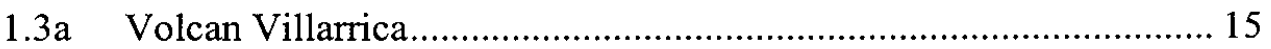

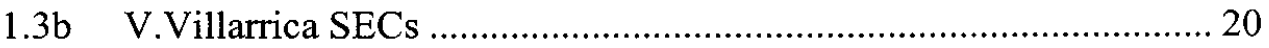

$1.4 \quad$ PREVIOUS WORK IN THIS AREA ……….......................................... 21

1.5 SPECIFIC OBJECTIVES OF THIS PROJECT ……..................................... 25

CHAPTER 2 SAMPLE LOCATIONS AND DESCRIPTIONS ………................. 27

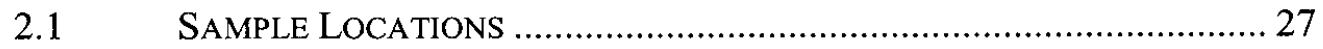

2.2 SAMPLE DESCRIPTIONS AND PETROGRAPHY ….................................. 31

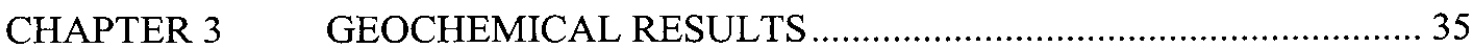

3.1 THE PROCEDURES AND INSTRUMENTS USED IN THIS WORK …….......... 35

3.2 MAJOR ELEMENT RESULTS ........................................................... 37

3.3 TRACE ELEMENT RESULTS ………….......................................... 53

3.3.1 Compatible elements..................................................................... 54

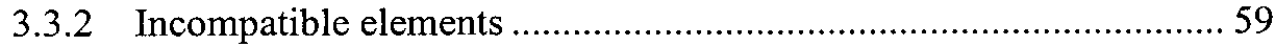

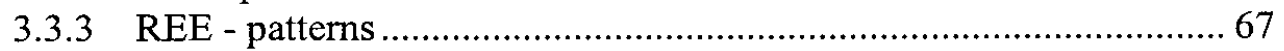

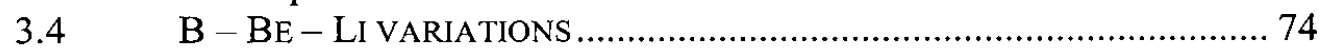

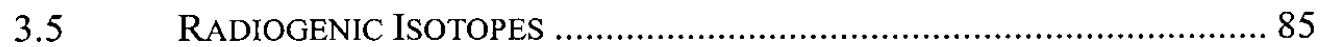

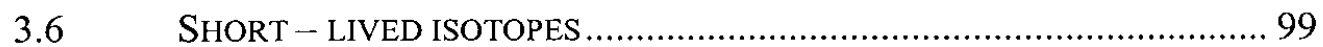

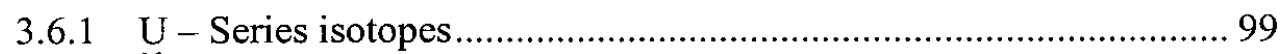

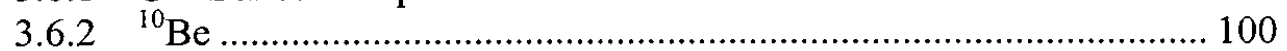

CHAPTER 4 ORIGIN OF THE GEOCHEMICAL FEATURES OF THE SMALL ERUPTIVE CENTERS.................................................. 106

4.1 POTENTIAL SOURCES AND PROCESSES FOR THE GENERATION OF ARC

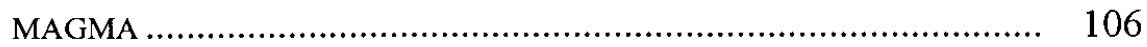

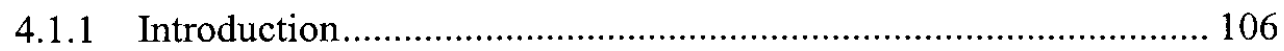

4.1.2 Sources and processes - a brief summary ……………………...... 107

4.2 CRYSTALLIZATION BEHAVIOR OF V.VILLARRICA AND SEC LAVAS BASED ON PETROLOGIC AND MAJOR ELEMENT CONSTRAINTS ............ 114

4.2.1 V.Villarrica and associated SECs ............................................... 114

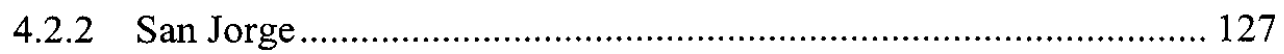




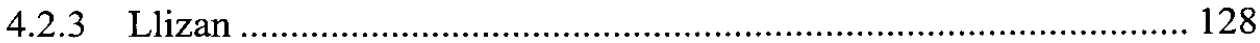

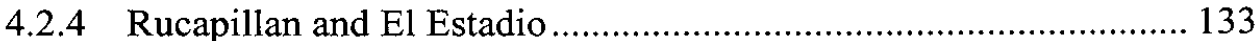

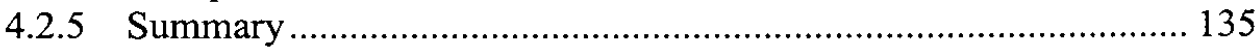

4.3 GeOchemical Modeling of SOURCE MiXing, Fluid AdDition AND PARTIAL MELTING PROCESSES FOR V.VILLARRICA AND

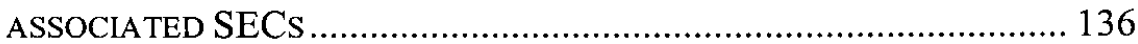

4.3.1 Calculation of primary magmas by olivine addition........................ 136

4.3.2 Calculation of the source compositions ........................................ 141

4.3.3 Modeling of the amount and compositions of the subduction

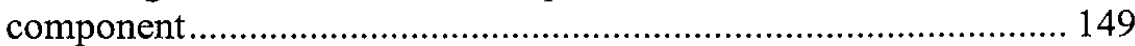

4.3.4 Radiogenic isotopes $\mathrm{Sr}-\mathrm{Nd}-\mathrm{Pb}$ systematics............................... 153

4.3.5 A possible $\mathrm{Nb}$ - bearing component from the subducted slab ........ 162

4.4 SOME IMPORTANT CONSTRAINTS FROM ${ }^{10}$ BE AND THE U - SERIES .. 166

4.5 MODELING OF LLIZAN BASALTIC ANDESITES AND ANDESITES UPPER CRUST CONTAMINATION, BINARY MIXING AND AFC

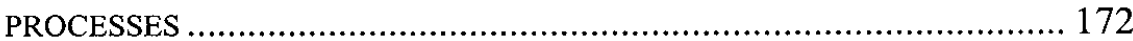

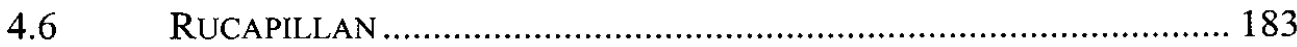

4.7 SMAll ERUPTIVE CENTERS (SEC) FROM CARRAN - Los VENADOS

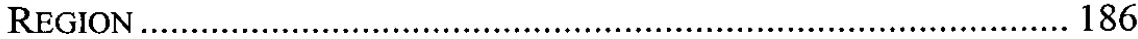

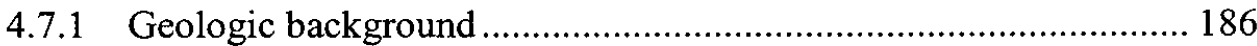

4.7.2 Geochemical features of the Carran - LV SEC samples ................. 188

CHAPTER 5 SUMMARY AND CONCLUSIONS ............................................. 197

5.1 A SUMMARY OF THE FINDINGS ABOUT THE V.VILLARRICA, SEC (TYPE I) AND SEC (TYPE II) BASALTS AND BASALTIC ANDESITES.... 197

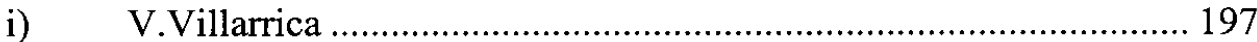

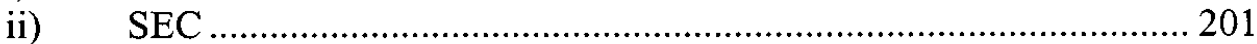

5.2 A PROPOSED PHYSICAL MODEL ………........................................ 207

5.3 IMPLICATIONS OF THE MODEL FOR THE OTHER PARTS OF THE CSVZ

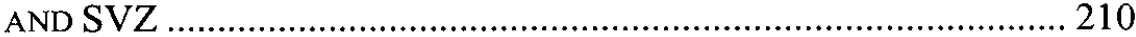

$5.4 \quad$ IMPLICATIONS OF THE MODEL FOR ARC MAGMATISM ……………..... 213

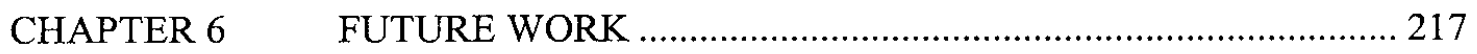

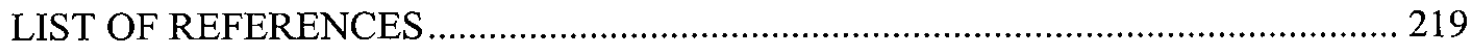

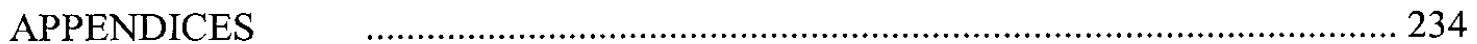

VITA 


\section{LIST OF TABLES}

TABLE

PAGE

TABle 2-2-1 MOdAl ANALySES OF 21 SAMPLES FROM V.VILlaRRICA AND THE SECS . 32

TABLE 4-2-1 AVERAGED COMPOSITIONS OF THE PHENOCRYSTS IN THE V.VILLARRICA AND SEC SAMPLES (USED FOR CALCULATING THE LLDS) 120

TABLE 4-2-2 THE ORIGINAL ROCK SAMPLE COMPOSITION (PART I) AND THE CALCULATED LIQUID COMPOSITION (PART II) FOR THE CHOSEN

V.VILLARRICA AND SEC SAMPLES. 121

TABLE 4-3-1 PRIMARY MAGMA CALCULATIONS FOR THE SAMPLES FROM

V.VILLARRICA AND THE SECS 138

TABLE 4-3-2 PRIMARY MELTS FROM THE AVERAGED PRIMITIVE UPPER MANTLE

(Plank AND_LANGMUIR, 1988) (WT\%) 139

TABLE 4-3-3 THE PARTITION COEFFICIENTS USED TO CALCULATE THE PARTIAL MELTING PROCESS OF THE V.VILLARRICA AND SEC SAMPLES (FROM GERM WEB SITE: HTTP://EARTHREF.ORG/GERM) 142

TABLE 4-3-4 SUBDUCTION - DERIVED FLUID COMPOSITIONS AND THE PROPORTIONS OF ELEMENTS ADDED TO THE SOURCE OF V.VILLARRICA AND SEC (N MORB) (IN PPM) 150

TABlE 4-3-5 FLUID COMPOSITIONS CALCULATED WITH AN E - MORB SOURCE (IN PPM)

TABLE 4-3-6 MODELED COMPOSITIONS OF SLAB - DERIVED FLUIDS ADDED TO POTENTIAL N - MORB AND E - MORB SOURCES (IN PPM) 157 
TABLE 4-3-7 THE COMPARISON BETWEEN THE MEASURED AND CALCULATED SR/ND RATIOS IN THE VILLARRICA AND SEC SAMPLES

TABLE 4-3-8 SUBDUCTION - DERIVED FLUID / MELT COMPOSITIONS AND THE PROPORTIONS OF ELEMENTS ADDED TO THE SOURCE OF V.VILLARRICA AND SEC (N - MORB) (IN PPM)

TABLE 4-4-1 BE - B CONCENTRATIONS MEASURED IN DIFFERENT GEOLOGIC SETTINGS 169

TABLE 4-5-1 COMPOSITIONS OF THE CONTAMINANTS AND THE STARTING MAGMA AND PARAMETERS AND COEFFICIENTS USED TO CALCULATE THE AFC /

BINARY MIXING TRENDS OF THE LLIZAN SAMPLES 180

TABLE 4-5-2 CALCULATED ELEMENTAL AND ISOTOPIC COMPOSITIONS FOR SEC

LliZAN BY BINARY MIXING MOdEl (From SubrouP III) 181

TABLE 4-5-3 CALCULATED ELEMENTAL AND ISOTOPIC COMPOSITIONS FOR SEC LLIZAN BY AFC MODEL (FROM SUBGROUP III) 182 


\section{LIST OF FIGURES}

FIGURE

PAGE

Fig. 1.3.1 A) (LEFT) THE V.VIllarrica Unit II; B) (RIGHT) The V.VILlarRiCA

UNIT III (FROM MORENO - ROA ET AL., 1994)

FIG.3.2.1A OXIDE - OXIDE FOR SAMPLES FROM VOLCANO VILLARRICA (CONTINUED) 39

FIG.3.2.1A OXIDE - OXIDE FOR SAMPLES FROM VOLCANO VILLARRICA (CONTINUED) 40

FIG.3.2.1A OXIDE - OXIDE FOR SAMPLES FROM VOLCANO VILLARRICA 41

FIG. 3.2.1B OXIDE - OXIDE FOR SAMPLES FROM SEC CERRo REDONDO, SAN JORGE, la Barda, Huelemolle, Caburgua, Huililco, Pichares and RELICURA (CONTINUED) 42

FIG. 3.2.1B OXIDE - OXIDE FOr SAMPLES From SEC CERRo REDONDO, SAN Jorge, la Barda, Huelemolle, Caburgua, Huililco, Pichares and RELICURA (CONTINUED) 43

FIG. 3.2.1B OXIDE - OXIDE FOR SAMPLES FROM SEC CERRO REDONDO, SAN JORGE, la Barda, Huelemolle, Caburgua, Huililco, Pichares and RELICURA 44

FIG. 3.2.1C OXIDE - OXIDE FOR SAMPLES FROM SEC RUCAPILLAN (INCLUDING EL ESTADIO) AND LLIZAN (CONTINUED). 45

FIG. 3.2.1C OXIDE - OXIDE FOR SAMPLES FROM SEC RUCAPILLAN (INCLUDING EL ESTADIO) AND LLIZAN (CONTINUED). 46

FiG. 3.2.1C OXIDE - OXIDE FOR SAMPLES FROM SEC RUCAPILLAN (INCLUDING EL

ESTADIO) AND LLIZAN 47

FIG. 3.2.2 AFM DIAGRAM FOR THE V.VILLARRICA AND SEC BASALTS (IRVINE AND 
Fig. 3.2.3 $\mathrm{K}_{2} \mathrm{O}$ VERSUS $\mathrm{SiO}_{2}$ FOR THE V.VILlaRrica AND SEC BASALTS (SAME SYMBOLS ARE USED AS SHOWN IN FIG.3.2.2) 50

FIG. 3.2.4 $\mathrm{NA}_{2} \mathrm{O}+\mathrm{K}_{2} \mathrm{O}$ VERSUS $\mathrm{SiO}_{2}$ FOR THE V.VILLARRICA AND SEC BASALTS (SAME SYMBOLS ARE USED AS SHOWN IN FIG.3.2.2) (LE BAS ET AL., 1986) 51

FIG.3.3.1 COMPATIBLE ELEMENTS VERSUS SILICA FOR THE V.VILLARRICA AND SEC SAMPLES (CONTINUED) 55

FIG.3.3.1 COMPATIBLE ELEMENTS VERSUS SILICA FOR THE V.VILLARRICA AND SEC SAMPLES (CONTINUED) 56

FIG.3.3.1 COMPATIBLE ELEMENTS VERSUS SILICA FOR THE V.VILLARRICA AND SEC SAMPLES 57

Fig.3.3.2A LILES VERSUS SILICA FOR THE V.VILLARRICA AND SEC SAMPLES (CONTINUED) 60

Fig.3.3.2A LILES VERSUS SILICA FOR THE V.VILLARRICA AND SEC SAMPLES 61

FIG.3.3.2B HFSES VERSUS SILICA FOR THE V.VILLARRICA AND SEC SAMPLES (CONTINUED) 62

FIG.3.3.2B HFSES VERSUS SILICA FOR THE V.VILLARRICA AND SEC SAMPLES (CONTINUED) 63

FIG.3.3.2B HFSES VERSUS SILICA FOR THE V.VILLARRICA AND SEC SAMPLES ........... 64

FIG.3.3.2C REES VERSUS SILICA FOR THE V.VILLARRICA AND SEC SAMPLES ............. 65

FIG.3.3.3.1 (A\&B) REE PATTERNS OF THE V.VILLARRICA (UPPER) AND SAN JORGE +

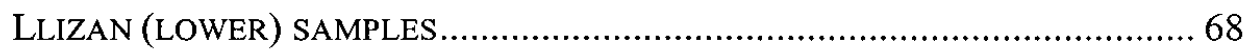

Fig.3.3.3.2 (C\&D) REE PATTERNS OF THE RUCAPILLAN (UPPER) AND OTHER SEC 
(LOWER) SAMPLES

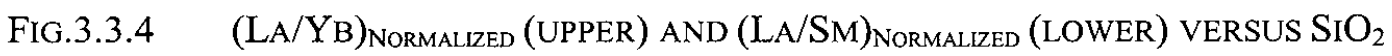
FOR THE V.VILLARRICA AND SEC SAMPLES ............................................ 72

Fig.3.3.5 NORMALIZED TRACE ELEMENT ABUNDANCES IN REPRESENTATIVE

BASALTS FROM V.VILLARRICA, SAN JORGE AND CARBURGUA COMPARED WITH MORB (SUN AND MCDONOUGH, 1989) …...................................... 73

FIG.3.4.1 B VERSUS $\mathrm{SIO}_{2}$ FOR THE V.VILLARRICA AND SEC SAMPLES ....................... 77

Fig.3.4.2 B VERSUS $\mathrm{K}_{2} \mathrm{O}$ FOR THE V.VILLARRICA AND SEC SAMPLES (SAMPLE $110194-02$ IS NOT SHOWN) 78

FIG.3.4.3 (UPPER) B/LA VERSUS $\mathrm{SIO}_{2}$; (LOWER) B/NB VERSUS $\mathrm{SIO}_{2}$ FOR THE V.VILLARRICA AND SEC SAMPLES (SAMPLE 110194 - 02 IS NOT SHOWN) . 79

Fig.3.4.4 BE VERSUS ND FOR THE V.VILLARRICA AND SEC SAMPLES 80

Fig.3.4.5 BE/Nd VERSUS $\mathrm{SIO}_{2}$ FOR THE V.VILlaRRICA AND SEC SAMPLES 81

Fig.3.4.6 B/BE VERSUS $\mathrm{SIO}_{2}$ FOR THE V.VILLARRICA AND SEC SAMPLES (SAMPLE $110194-02$ IS NOT SHOWN) 82

FIG.3.4.7 LI VERSUS YB FOR THE V.VILLARRICA AND SEC SAMPLES (SAMPLE $110194-02$ IS NOT SHOWN). 83

FIG.3.4.8 K/LI VERSUS LA/YB FOR THE V.VILLARRICA AND SEC SAMPLES (SAMPLE $110194-02$ IS NOT SHOWN). 84

FIG.3.5.1 $\quad{ }^{143} \mathrm{ND} /{ }^{144} \mathrm{ND}$ VERSUS ${ }^{87} \mathrm{SR}^{86} \mathrm{SR}$ FOR THE V.VILLARRICA AND SEC SAMPLES 88

FIG.3.5.2 $\quad{ }^{143} \mathrm{ND} /{ }^{144} \mathrm{ND}$ VERSUS ${ }^{87} \mathrm{SR} /{ }^{86} \mathrm{SR}$ FOR THE SAMPLES FROM V.VILLARRICA, SECS AND OTHER GEOLOGIC SETTINGS (HAWKESWORTH ET AL., 1979; 
FREY ET AL., 1984; HiCKEY ET AL., 1986; GERLACH ET AL., 1988; MUNOZ AND STERN, 1989; SUN AND MCDONOUGH, 1989; STERN ET AL., 1990; HICKEY - VARGAS ET AL., 1989; FREY (UNPUBLISHED); DATA FROM THIS WORK) 89

FIG.3.5.3 $\quad{ }^{87} \mathrm{SR}^{86}{ }^{86} \mathrm{SR}$ VERSUS RB/SR FOR THE V.VILLARRICA AND SEC SAMPLES........ 90

FIG.3.5.4 $\quad{ }^{143} \mathrm{ND} /{ }^{144} \mathrm{ND}$ VERSUS SM/ND FOR THE V.VILLARRICA AND SEC SAMPLES .. 91

FIG.3.5.5 $\quad{ }^{207} \mathrm{~PB} /{ }^{204} \mathrm{~PB}$ VERSUS ${ }^{206} \mathrm{~PB} /{ }^{204} \mathrm{~PB}$ FOR THE V.VILLARRICA AND SEC SAMPLES 92

Fig.3.5.6 ${ }^{207} \mathrm{~PB} /{ }^{204} \mathrm{~PB}$ VERSUS ${ }^{206} \mathrm{~PB} /{ }^{204} \mathrm{~PB}$ FOR THE SAMPLES FROM V,VILLARRICA, SECS AND OTHER GEOLOGIC SETTINGS (FROM SUN, 1980; UNRUH AND TATsumoto, 1976; MeiJer, 1976; ChOW AND PATterson, 1962; HARMON ET AL., 1984; Hole ET AL., 1984; GERLACH, 1985; HiCKEY ET AL., 1986; FREY (UNPUBLISHED); DASCH, 1981; HICKEY - VARGAS ET AL., 1989; THIS WORK) 93

FIG.3.5.7 $\quad{ }^{208} \mathrm{~PB} /{ }^{204} \mathrm{~PB}$ VERSUS ${ }^{206} \mathrm{~PB} /{ }^{204} \mathrm{~PB}$ FOR THE V.VILLARRICA AND SEC SAMPLES 94

FIG.3.5.8 $\quad{ }^{208} \mathrm{~PB} /{ }^{204} \mathrm{~PB}$ VERSUS ${ }^{206} \mathrm{~PB} /{ }^{204} \mathrm{~PB}$ FOR THE SAMPLES FROM V.VILLARRICA, SECS AND OTHER GEOLOGIC SETTINGS (SEE FIG.3.5.6 FOR REFERENCES) ... 95

Fig.3.5.9 ${ }^{206} \mathrm{~PB} /{ }^{204} \mathrm{~PB}$ VERSUS U/PB FOR THE V.VILLARRICA AND SEC SAMPLES....... 96 FIG.3.5.10 ${ }^{208} \mathrm{~PB} /{ }^{204} \mathrm{~PB}$ VERSUS TH/PB FOR THE V.VILLARRICA AND SEC SAMPLES ..... 97 Fig.3.5.11 ${ }^{207} \mathrm{~PB} /{ }^{204} \mathrm{~PB}$ VERSUS CE/PB FOR THE V.VIllarRicA AND SEC SAMPLES...... 98 Fig.3.6.1 $\quad\left({ }^{230} \mathrm{TH} /{ }^{232} \mathrm{TH}\right)$ VERSUS $\left({ }^{238} \mathrm{U} /{ }^{232} \mathrm{TH}\right)$ FOR THE V.VILLARRICA AND SEC SAMPLES 101 
FIG.3.6.2 $\left({ }^{210} \mathrm{PO} /{ }^{230} \mathrm{TH}\right)$ VERSUS $\left({ }^{238} \mathrm{U} /{ }^{230} \mathrm{TH}\right)$ FOR THE V.VILLARRICA AND SEC SAMPLES 102

Fig.3.6.3 ${ }^{10} \mathrm{BE} / \mathrm{BE}$ VERSUS ${ }^{10} \mathrm{BE}$ For THE V.VILLARRICA AND SEC SAMPLES ............ 103

Fig.3.6.4 ${ }^{10} \mathrm{BE} / \mathrm{BE}$ VERSUS ${ }^{10} \mathrm{BE}$ FOR THE V.VILlarRICA, SEC AND OTHER ARC VOLCANICS (MORRIS AND TERA, 1989). 104

FIG.3.6.5 $\quad{ }^{10} \mathrm{BE} / \mathrm{BE}$ VERSUS BE FOR SAMPLES FROM V.VILLARRICA AND THE SECS AND OTHER SVZ SAMPLES (MORRIS AND TERA, 1989) 105

FIG.4.2.1A UPPER) THE PSEUDO - TERNARY PROJECTION OF THE V.VILLARRICA AND SEC SAMPLES (Pl to OL - Di - Q) EXCEPT SEC RUCAPILLAN, EL ESTADIO AND LLIZAN. LOWER) THE PSEUDO - TERNARY PROJECTION (Pl to Ol - Di - Q) For SEC RUCAPILlan, El ESTAdio AND LLIZAN. ... 115

FIG.4.2.1B UPPER) THE PSEUDO - TERNARY PROJECTION OF THE V.VILLARRICA AND SEC SAMPLEs (Ol To Pl - DI - Q) EXCEPT SEC RuCAPILlan, El ESTADIO AND LLIZAN. LOWER) THE PSEUDO - TERNARY PROJECTION (Ol to Pl - Di - Q) FOR SEC RucAPILlan, El Estadio AND LLIZAN. ... 116

FIg.4.2.1C UPPER) THE PSEUdo - TERNARY PROJECTION OF THE V.VILLARRICA AND SEC SAMPLES (Di TO Ol - Pl - Q) EXCEPT SEC RUCAPILLAN, EL ESTADIO AND LliZAN. LOWER) THE PSEUDO - TERNARY PROJECTION (Di to Ol - Pl - Q) FOR SEC RUCAPILlan, El ESTAdio AND LLIZAN... 117

Fig.4.2.2A UPPER) PSEUdo - ternary PROJECTION (Pl to Ol - DI - Q) OF THE V.VILLARRICA AND SEC (EXCEPT RUCAPILLAN, EL ESTADIO AND LLIZAN) SAMPLES. LOWER) PSEUdo - TERNARY PROJECTION FOR SEC RUCAPILLAN (OPEN SYMBOLS - ROCK COMPOSITIONS; FILLED SYMBOLS 
- ESTIMATED LIQUID COMPOSITIONS).

Fig. 4.2.2B UPPER) THE PSEUdo - TERNARY PROJECTION (Ol to Pl - Di - Q) OF THE V.VILLARRICA AND SEC SAMPLES EXCEPT SEC RUCAPILLAN, EL ESTADIO AND LLIZAN. LOWER) THE PSEUDO - TERNARY PROJECTION (OL TO PL - Di - Q) FOR SEC RUCAPILLAN. 124

Fig. 4.2.2C UPPER) THE PSEUdo - TERNARY PROJECTION (DI TO Ol - Pl - Q) OF THE V.VILLARRICA AND SEC SAMPLES EXCEPT SEC RUCAPILLAN, EL ESTADIO AND LLIZAN. LOWER) THE PSEUDO - TERNARY PROJECTION (DI TO OL - PL - Q) FOR SEC RUCAPILLAN. 125

FIG.4.2.3 OXIDE VERSUS $\mathrm{SIO}_{2}$ FOR THE LLIZAN ANDESITES, V.VILLARRICA RHYOLITE AND THE UPPER CONTINENTAL CRUST (CONTINUED) 129

FIG.4.2.3 OXIDE VERSUS $\mathrm{SIO}_{2}$ FOR THE LLIZAN ANDESITES, V.VILLARRICA RHYOLITE AND THE UPPER CONTINENTAL CRUST (CONTINUED) 130

Fig.4.2.3 OXIDE VERSUS $\mathrm{SIO}_{2}$ FOR THE LLIZAN ANDESITES, V.VILLARRICA RHYOLITE AND THE UPPER CONTINENTAL CRUST (CONTINUED) 131

FIg.4.2.3 OXIDE VERSUS $\mathrm{SIO}_{2}$ FOR THE LLIZAN ANDESITES, V.VILLARRICA RHYOLITEAND THE UPPER CONTINENTAL CRUST

Fig.4.3.1 THE Pl to Ol - DI - Q PSEUdo - TERNARY PROJECTION OF THE V.VILLARRICA AND SEC SAMPLES WITH THEIR PRIMARY MAGMA COMPOSITIONS (I - Primary MAgMa OF V.VILlaRrRICA; II - PRIMARY Magma of Huelemolle; III - Primary Magma of Caburgua; All THE OTHER SYMBOLS ARE THE SAME AS USED IN FIG.4.2.1) (GROVE AND BAKER, 1984; SISSON AND GROVE, 1993) 140 
Fig.4.3.2 CALCUlATED SOURCE COMPOSITIONS BASED ON A N - MORB SOURCE FROM THE PRIMARY MAGMAS OF THE V.VILLARRICA AND SEC SAMPLES 143

Fig.4.3.3 CALCUlated SOURCE COMPOSITIONS BASED ON AN E - MORB SOURCE FROM THE PRIMARY MAGMAS OF THE V.VILLARRICA AND SEC SAMPLES 145

FIG.4.3.4A (LA/YB) VERSUS LA FOR THE V.VILLARRICA AND SEC SAMPLES.............. 147

Fig.4.3.4B THE (NB/YB) - NB DIAGRAM FOR THE VillaRRICA AND SEC SAMPLES ... 148

FIG.4.3.5 COMPOSITIONS OF THE FLUIDS ADDED TO THE V.VILLARRICA / SEC

SOURCES (N - MORB). 150

FIG.4.3.6 COMPOSITIONS OF THE FLUIDS ADDED TO THE V.VILLARRICA / SEC SOURCES (E - MORB) 152

FIG.4.3.7 SR - ND ISOTOPIC MODELING (MIXING OF SOURCES) CALCULATED FOR THE V.VILLARRICA AND SEC SAMPLES (N - MORB) 155

FIG.4.3.8 SR - ND ISOTOPIC MODELING (MIXING OF SOURCES) CALCULATED FOR THE V.VILLARRICA AND SEC SAMPLES (E - MORB) 156

FIG. 4.3.9 PB ISOTOPES OF V.VILLARRICA AND SEC SAMPLES VERSUS AOC AND SEDIMENT DATA IN THE LITERATURE (MEIJER, 1976; CHURCH, 1976; DASCH, 1981; BARREIRO, 1983; ElliotT ET AL., 1997; HoCHSTAEDTER ET AL., UNPUBLISHED) 160

FIG.4.3.10 LA/NB VERSUS HF/SM FOR THE V.VILLARRICA AND SEC SAMPLES.......... 164

Fig.4.4.1 ${ }^{10} \mathrm{BE} / \mathrm{BE}$ VERSUS $\left({ }^{238} \mathrm{U} /{ }^{230} \mathrm{TH}\right)$ FOR THE V.VILLARRICA AND SEC SAMPLES (V.VILLARRICA SAMPLES: 101275-1 - FROM SIGMARSSON ET AL., 1990; 210281-1 - THIS WORK) 170

Fig.4.4.2 ${ }^{10} \mathrm{BE} / \mathrm{BE}$ VS B/BE FOR THE V.VILLARRICA AND SEC SAMPLES (B - 
LEEMAN ET AL. (UNPUBLISHED); MORRIS ET AL., 1990; BE - THIS WORK;

${ }^{10} \mathrm{BE}-$ MORRIS AND TERA, 1989; MORRIS ET AL., 1990) 171

FIG.4.5.1 SR - ND ISOTOPIC MODELING OF CRUSTAL CONTAMINATION (AFC AND

BINARY MIXING) OF LLIZAN SAMPLES

FIG.4.5.2 $\quad{ }^{87} \mathrm{SR} /{ }^{86} \mathrm{SR}$ VERSUS RB/SR FOR AFC AND BINARY MIXING CALCULATIONS

OF THE LLIZAN SAMPLES ....................................................... 178

FIG.4.5.3 RB/BA VERSUS LA/BA FOR AFC AND BINARY MIXING CALCULATIONS OF

THE LLIZAN SAMPLES

FIG. 4.7.1 OXIDE VERSUS $\mathrm{SIO}_{2}$ FOR CARRAN - LV SEC (RodRIGUEZ Soto, THESIS) (CONTINUED)

FIG. 4.7.1 OXIDE VERSUS $\mathrm{SIO}_{2}$ FOR CARRAN - LV SEC (RODRIGUEZ SOTO, THESIS)

FIG.4.7.2 REE PATTERNS OF 8 SEC SAMPLES FROM CARRAN - LOS VENADOS (THIS WORK) (SAMPLES FROM V.VILLARRICA AND V.VILLARRICA SECS ARE SHOWN FOR COMPARISON) 194

FIG.4.7.3 BA/LA VERSUS LA/NB FOR SAMPLES FROM V.VILLARRICA, V.VILlaRRICA SEC AND CARRAN - LOS VENAdOS SEC (THIS WORK) .... 195

FIG.4.7.4 $\quad{ }^{143} \mathrm{ND} /{ }^{144} \mathrm{ND}$ VERSUS ${ }^{87} \mathrm{SR} /{ }^{86} \mathrm{SR}$ FOR SAMPLES FROM V.VILLARRICA, V.VILLARRICA SEC AND CARRAN - LOS VENADOS SEC (THIS WORK; LOPEZ - ESCOBAR AND MORENO, 1981) 196

FIG.5.2.1 UPPER) DURING VI - VII, RUCAPILLAN MAGMAS ORIGINATED FROM A SEPARATE SOURCE; MidDLE) DURING VII, SEC SUBGROUP I AND SUBGROUP II ORIGINATED (SUBGROUP II PROBABLY FROM THE PERIPHERY 
OF THE V.VILLARRICA MELTING COLUMN); LOWER) DURING VIII + VIV, SAN JORGE WAS FORMED DUE TO EXPANSION OF THE V.VILLARRICA

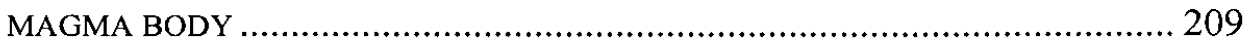




\section{Chapter 1 Introduction}

\subsection{Geochemical processes in subduction zones}

Subduction zones are regions where relatively colder, denser and mechanically stronger lithospheric plates sink into the hotter and weaker asthenospheric mantle. It is well accepted that the subducted slabs play a very important role in driving the motion of plates at trenches due to their negative buoyancy, generally described as the "slab-pull force" (Forsyth and Uyeda, 1975; Carlson, 1981; Carlson et al., 1983). Subduction zones usually comprise the trench, the forearc region including accretionary complexes, the volcanic arc where subduction-related volcanism takes place, and the back arc region (usually associated with extension, faulting, rifting and magmatism).

Magmas generated at subduction zones are geochemically distinct from those produced at mid ocean ridges or oceanic islands by their significant enrichment of LILEs (large ion lithophile elements) relative to HFSEs (high field strength elements). There is a useful link between the chemistry of arc volcanics and the processes of subduction, which continuously recycle crustal materials back into the interior of the Earth.

Many important advances have been made over the past decades in the understanding of subduction zone magmatism. These advances address how elements are transported from their mantle source into the continental crust, how they are recycled by sediment subduction and addition, and how they are incorporated into arc magmas through hydrous fluids or melts. At present, most of the previous work concludes that arc magmas are generated by a three - component (mantle wedge, subducted oceanic crust and sediments) model, i.e., melting of mantle peridotite metasomatized with fluids or 
melts contributed from subducted oceanic slab and/or sediments. At continental arcs such as the Andes, some arc samples may also have been modified by crustal processes such as intra - crustal fractionation and assimilation (Tilton and Barreiro, 1980; James, 1984), MASH (melting, assimilation, storage and homogenization) (Hildreth and Moorbath, 1988) or crustal foundering (Arndt and Goldstein, 1989). However, debate continues because there remain many uncertainties regarding the fundamentals of arc magma genesis, such as:

1) What is the composition of the pre-subduction mantle source of arc magmas?

The mantle wedge overlying the subducted slab is usually considered to be like the mantle source of MORB or OIB, and its compositional variability along or across arc strikes has been extensively investigated using trace element or isotope tracers (Varne, 1985; Hickey et al., 1986; Hickey - Vargas et al., 1989; Hochstaedter et al., 1990; Pearce and Parkinson, 1993). Previous studies pointed out that mantle source heterogeneity is observed in many arc locations, e.g., evidence of sub - Gondwana mantle beneath the Sunda arc (Varne, 1985; Edwards et al., 1993). Studies carried out by Pearce and Parkinson (1993) further concluded that the mantle wedge beneath the South Sandwich Islands is more depleted than the mantle wedge beneath the Lesser Antilles. In the Andean CSVZ, the variations of the chemical compositions of the stratovolcanoes have also been attributed to the heterogeneity of mantle sources across the arc, e.g., volcanic chain Villarrica - Quetrupillan - Lanin (Hickey et al., 1986; Hickey - Vargas et al., 1989). 
2) To what extent does the mantle melt, and by what processes (e.g., the shape of the melting column or zone)?

Although slab melting is possible under some particular circumstances such as a young and hot subducted lithosphere (<25 Ma) (Peacock, 1990; 1991; Defant and Drummond, 1990) and can produce arc magmas of high sodium, aluminum, $\mathrm{La} / \mathrm{Yb}$ and $\mathrm{Sr} / \mathrm{Y}$ (described as "adakites") (Kay, 1978; Defant and Drummond, 1990; Atherton and Petford, 1993), most of the observations on the elemental and isotopic similarity between MORBs and basalts from arc settings suggested that a MORB - type mantle wedge may be ubiquitous (Ewart and Hawkesworth, 1987). Therefore, melting of the hydrated mantle source should be the most important process occurring beneath the arc.

The major difference between the melting process occurring at subduction zones and the melting process occurring at mid ocean ridges is that the former is triggered by sufficient input of slab - released hydrous phases, i.e. fluids or melts ("flux" melting) while the latter is a "decompression" melting without the significant involvement of hydrous phases (Klein and Langmuir, 1987). As a result, the importance and nature of fluid addition processes (into the mantle sources of arc magmas) are also extensively studied (Gill, 1981; Tatsumi et al., 1986; 1991; Peacock, 1990; 1991; Arculus, 1994; Hawkesworth et al., 1997) in order to investigate the possible appearance and breakdown of hydrous minerals such as amphibole, phlogopite, lawsonite, epidote, phengite or serpentine (Tatsumi et al., 1986; Pawley and Holloway, 1993; Melzer and Wunder, 2000; Peacock, 2001) and more importantly, the unique LILE - enriched (relative to 
HFSEs) geochemical patterns of arc basalts. As well accepted now, processes occurring at subduction zones usually include: 1) dehydration of hydrous minerals from the subducted lithosphere at pressure - 2Gpa; 2) hydrated (amphibolized) peridotitic mantle wedge translated down parallel to the dip of the subduction by mantle advection; and 3) partial melting of the metasomatized mantle wedge across solidus (Wyllie and Sekine, 1982; Tatsumi et al., 1986; 1991; Peacock, 1990; Arculus, 1994). However, dehydration of the subducted lithosphere is a much more complicated process than summarized above due to the progressive re-equilibration of the slab minerals to increasing pressures and temperatures (Arculus, 1994). Furthermore, some studies suggest that the sediment portion of the slab melts rather than dehydrates (Plank and Langmuir, 1993; 1998; Johnson and Plank, 1999).

3) How do the primitive melts ascend and evolve before they erupt?

At mid - ocean ridges, melting occurs by decompression due to passive upwelling related to extension. The cross - section of the partial molten regime is typically triangular, with the largest melt production occurring within the central column of the regime (Klein and Langmuir, 1987). At subduction zones, however, melting of the mantle wedge occurs by lowering the solidus due to introduction of water released from the downgoing slab. The mechanism by which magmas ascend was thought to be "diapirism" resulting from gravitational instabilities within the mantle source (Marsh, 1973; Marsh and Carmichael, 1974). However, some recent studies suggest that partial melting could occur within the mantle 
wedge as a column whose height is determined by the thickness of the overlying crust (Plank and Langmuir, 1988) or the upper mantle acts as a permeable chromatographic column (Navon and Stolper, 1987). Studies of Eocene boninites from the Mariana arc (Stern et al., 1991) showed that chromatographic effects could produce trace element fractionation in an ascending melt or subduction fluid. However, it is still possible that even for the arc magmas, the center of the melting column may also have a larger degree of partial melting or be less contaminated (Hickey - Vargas et al., 1989; 1993).

4) What is the composition and amount of slab-derived components added to the magma generation and what is the amount of sediments involved in the subduction?

Evidence from fluid - mobile elements such as $\mathrm{Cs}, \mathrm{Rb}, \mathrm{Ba}, \mathrm{Pb}, \mathrm{Sr}, \mathrm{U}$ (including $\mathrm{U}$ - Series isotopes) and B shows that an agent such as slab - released fluid could be very common in the formation of arc magmas (Gill and Williams, 1990; Morris et al., 1990; Plank and Langmuir, 1992; Leeman et al., 1994; Reagan et al., 1994; Ryan et al., 1995; Elliott et al., 1997; Hawkesworth et al., 1997; Turner et al., 1997; Turner and Hawkesworth, 1997; Bourdon et al., 2000; Hochstaedter et al., unpublished). On the other hand, arc basalts are relatively depleted in $\mathrm{Nd}$ isotopes while enriched in $\mathrm{Sr}$ isotopes relative to MORBs. Additionally, significantly higher concentrations of ${ }^{10} \mathrm{Be}$ in arc basalts than MORBs support the idea that subducted pelagic sediments or sediments from the accretionary complexes are also involved in magmagenesis in most arc settings 
(White and Patchett, 1984; Hickey et al., 1986; Tera et al., 1986; Plank and Langmuir, 1993).

Much work today is focused on modeling and calculating the possible compositions and proportions of "slab - components" using different geochemical indicators (trace elements, isotopes, etc). However, it is very difficult to decipher different processes based only on geochemical features. For example, the decrease of the proportion of slab components from the volcanic front to the back arc area observed in some arc regions could be produced by the progressive decrease of fluid addition with the increase of slab depth (Ryan et al., 1995) or continuous "depletion" of the residual down - going slab in water - soluble elements (Hochstaedter et al., unpublished).

5) How are elements transported in fluids and hydrous melts? And how are trace elements fractionated by these processes?

For a better understanding of the geochemical processes at subduction zones, experimental work and rock data were compiled to explain the transport behaviors of different elements in possible slab - components, that is, the partition coefficients of trace or rare earth elements between fluid and solid, or between melt and solid (Tatsumi and Isoyama, 1988; Brenan et al., 1994; 1995; Keppler, 1996; Kogiso et al., 1997; Stalder et al., 1998; Johnson and Plank, 1999). Results from these experiments revealed that some elements such as $\mathrm{Be}, \mathrm{Rb}$, Th and $\mathrm{Nd}$ are not particularly fluid - mobile, but their mobility increases dramatically at temperatures $-800^{\circ} \mathrm{C}\left(\mathrm{H}_{2} \mathrm{O}\right.$ - saturated basalt solidus at about $\left.2-4 \mathrm{Gpa}\right)$. The 
positive relationship between ${ }^{10} \mathrm{Be} /{ }^{9} \mathrm{Be}$ and ${ }^{238} \mathrm{U} /{ }^{230} \mathrm{Th}$ observed in some arc settings further support that $\mathrm{Be}$ could be transported in hydrous fluids (Hawkesworth et al., 1997). In addition, a large proportion of subducted sediments $(>30 \%)$ could melt (Johnson and Plank, 1999) to provide the needed amount of $\mathrm{Be}$ or Th added to arc lavas.

\section{6) How long does the whole process take?}

Because the formation of arc magmas may not be a single - stage event and magmas developed in different cycles tend to have different geochemical characteristics (Reagan et al., 1994; Hochstaedter et al., unpublished), timing is a basic issue to be addressed. One of the most commonly used tools for determining the timing of a magma event is the short - lived $U$ - series isotopes. Any process inducing a $\mathrm{U}-\mathrm{Th}$ fractionation through slab or sediment dehydration is detectable within $\sim 300,000$ years (six times the half - life of ${ }^{230} \mathrm{Th}$ ) before eruption (Reagan et al., 1994; Hawkesworth et al., 1997). Processes inducing fractionation of $\mathrm{Ra}$ from $\mathrm{Th}$ are detectable within $\sim 6,000$ years (six times the half - life of ${ }^{226} \mathrm{Ra}$ ) (Chabaux et al., 1999; Turner et al., 2000).

The objective of this dissertation is to address these problems, using the unique geologic setting and geochemical characteristics of the small eruptive centers (SEC) surrounding Volcano Villarrica, Southern Volcanic Zone, Chile. 


\subsection{Regional geological background}

\section{2a Volcanic zones of the Andes}

The Andes is a young mountain range extending about $4,000 \mathrm{~km}$ along the west coast of South America. It formed in response to subduction of the Nazca plate beneath the South America plate. In the study area, the Andes are composed of an active volcanic arc about $300-400 \mathrm{~km}$ to the east of the Peru - Chile trench. The widely distributed Andean volcanics are mainly late Tertiary to Recent, indicating that a large amount of magma was generated during this time period. The subducting slab beneath the Andes has variable buoyancies because of features like the Juan Fernandez Ridge and Chile Rise. This variation gives rise to changes in slab dip. The volcanic zones of South America are located where a steeper dipping slab is observed. There are four active segments in the Andean arc: the Northern Volcanic Zone $\left(5^{\circ} \mathrm{N}-2^{\circ} \mathrm{S} ; \mathrm{NVZ}\right)$, the Central Volcanic Zone $\left(16^{\circ} \mathrm{S}-28^{\circ} \mathrm{S} ; \mathrm{CVZ}\right)$, the Southern Volcanic Zone $\left(33^{\circ} \mathrm{S}-46^{\circ} \mathrm{S} ; \mathrm{SVZ}\right)$ and the Austral Volcanic Zone $\left(49^{\circ} \mathrm{S}-55^{\circ} \mathrm{S}\right.$; AVZ). In between the active volcanic zones are shallow - dipping "volcanic gaps" (no active volcanism). Within active segments, the Benioff zone dips at about $30^{\circ}$ towards the east, while in the volcanic gaps such as in Peru $\left(2-15^{\circ} \mathrm{S}\right)$ and central Chile $\left(27-33^{\circ} \mathrm{S}\right)$, the Benioff zone dips at only $5-10^{\circ}$ with relatively focused and abundant shallow seismicity. Because the active volcanoes are located over an asthenospheric mantle zone, it is very possible that their evolution is closely related to the mantle wedge overlying the subducted slabs (Barazangi and Isacks, 1976; 1979; Thorpe et al., 1981). 
The four active volcanic zones, NVZ, CVZ, SVZ and AVZ, are formed on crust of different thickness and age. The NVZ (in Columbia and Ecuador) is located over a $140 \mathrm{~km}$ deep Benioff zone. It is built upon $40-50 \mathrm{~km}$ thick of Paleozoic - Mesozoic age continental crust (Case et al., 1971; Zeil, 1979). NVZ lavas are mostly basaltic andesites and andesites (Pichler et al., 1976). The CVZ, just like the NVZ, is situated above a $140 \mathrm{~km}$ deep Benioff zone $(\sim 300 \mathrm{~km}$ deep at places $)$. The crustal basement beneath the CVZ is, however, much older (Precambrian) and thicker (70km; Shackleton et al., 1979). This segment forms the crest of the modern Andes mountain range with maximum elevations of more than $6 \mathrm{~km}$. The CVZ lavas are dominantly andesites and dacites, enriched in $\mathrm{K}, \mathrm{Rb}$, Th and $\mathrm{U}$, and with elevated $\mathrm{Sr}-\mathrm{Pb}-\mathrm{O}$ isotopes but lower $\mathrm{Nd}$ isotopes compared to many other arc volcanics. These lavas are clearly contaminated by the overlying continental crust (Hawkesworth et al., 1979; 1982). The SVZ has a shallower Benioff zone $(90-120 \mathrm{~km})$, and the thickness of the crustal basement in this segment ranges from $55 \mathrm{~km}$ in the north to $30 \mathrm{~km}$ in the south (Lomnitz, 1962; Barazangi and Isacks, 1976; Hildreth and Moorbath, 1988). Consequently, arc lavas produced in the SVZ vary in chemical composition - andesitic in the north, and basaltic in the south. Different from the above three volcanic zones is the AVZ. It is characterized by oblique convergence and widely spaced volcanoes (Stern et al., 1976; 1984). The minimal volcanism is probably due to the slow subduction rate $(2 \mathrm{~cm} /$ year) (Minster et al., 1974) and relatively young age $(<24 \mathrm{Ma})$ (Forsyth, 1975) of the subducted slab in this area. 


\section{2b The Southern Volcanic Zone of the Andes}

The SVZ of the Andes extends from the intersection of the Juan Fernandez ridge on the Chile Trench $\left(\sim 32^{\circ} \mathrm{S}\right)$ to the Chile Rise triple junction $\left(\sim 47^{\circ} \mathrm{S}\right)$. The SVZ Benioff zone has a shallow dip of approximately $25^{\circ}$ (Stauder, 1973; Barazangi and Isacks, 1976; Hanus and Vanek, 1978). Two major episodes of volcanism are recorded in this area: Miocene volcanism occurring both in the Longitudinal Depression and the crest of the Andes, and Pliocene - Quaternary volcanism distributed only along the Andes (Vergara and Munizaga, 1974; Moreno, 1976; Lopez - Escobar and Frey, 1976; Lopez - Escobar et al., 1976; 1977; Stern et al., 1976; Deruelle, 1977; 1982; Munoz and Niemeyer, 1984). The underlying metasedimentary rocks are Jurassic to Cretaceous, and older basement is exposed to the west of the volcanic front (Drake, 1976; 1983). Lavas erupted at the volcanic front are dominated by calc - alkaline basalts and basaltic andesites. Inland in Argentina occur more alkaline plateau - type basalts (Niemeyer, 1978; Skewes and Stern, 1979; Charrier et al., 1979). In the southmost part $\left(45^{\circ} \mathrm{S}-46^{\circ} \mathrm{S}\right)$ of the SVZ, Mesozoic to recent magmas overlay a metasedimentary basement that is a former accretionary wedge (Forsythe, 1982; Bartholomew and Tarney, 1984).

North of $34.5^{\circ} \mathrm{S}$, the volcanic front is linear (Drake, 1976), and the country rocks are predominantly Paleozoic to Mesozoic. There is no dramatic crustal thickening in this segment compared with the region between $34.5^{\circ} \mathrm{S}$ and $37^{\circ} \mathrm{S}$ (Hildreth and Moorbath, 1988). South of $34.5^{\circ} \mathrm{S}$, the volcanic front migrates westward, and Cenozoic country rocks become dominant. At $37^{\circ} \mathrm{S}$, where the Mocha Fracture Zone on the subducted Nazca plate intersects the trench (Swift and Carr, 1975; Herron, 1981; Hildreth and Moorbath, 1988), is another boundary: subducted oceanic crust is older ( $\sim 40 \mathrm{Ma})$ to the 
north of $37^{\circ} \mathrm{S}$ with a thin veneer of terrigenous sediments, while south of $37^{\circ} \mathrm{S}$ the subducted crust is younger $(\sim 18 \mathrm{Ma})$ and a thicker sediment column is piled in the trench (Herron, 1981). 


\section{2c The volcanic segments of the Andean SVZ}

The Southern Volcanic Zone of Andes can be divided into four segments (Tormey et al., 1991): Northern SVZ $\left(33^{\circ} \mathrm{S}-34.5^{\circ} \mathrm{S}\right)$, Transitional SVZ $\left(34.5^{\circ} \mathrm{S}-37^{\circ} \mathrm{S}\right)$, Central $\operatorname{SVZ}\left(37^{\circ} \mathrm{S}-42^{\circ} \mathrm{S}\right)$ and Southern SVZ $\left(42^{\circ} \mathrm{S}-46^{\circ} \mathrm{S}\right)$ (Map 1.2.1).

The Central part of the Andean SVZ (CSVZ), located between $37-42^{\circ}$ S latitude in Chile, contains predominantly basaltic and basaltic - andesitic lavas, with minor andesites, dacites and rhyolites. Compared to the NSVZ and TSVZ, the crust of CSVZ is much thinner $(30-35 \mathrm{~km})$ and the depth to the Benioff zone is quite uniform $(120 \mathrm{~km})$. The volcanic front of the CSVZ contains eight active late Pleistocene - recent stratovolcanoes aligned from north to south: Lonquimay, Llaima, Villarrica, MochoChoshuenco, Puyehue, Casablanca, Osorno and Calbuco. 


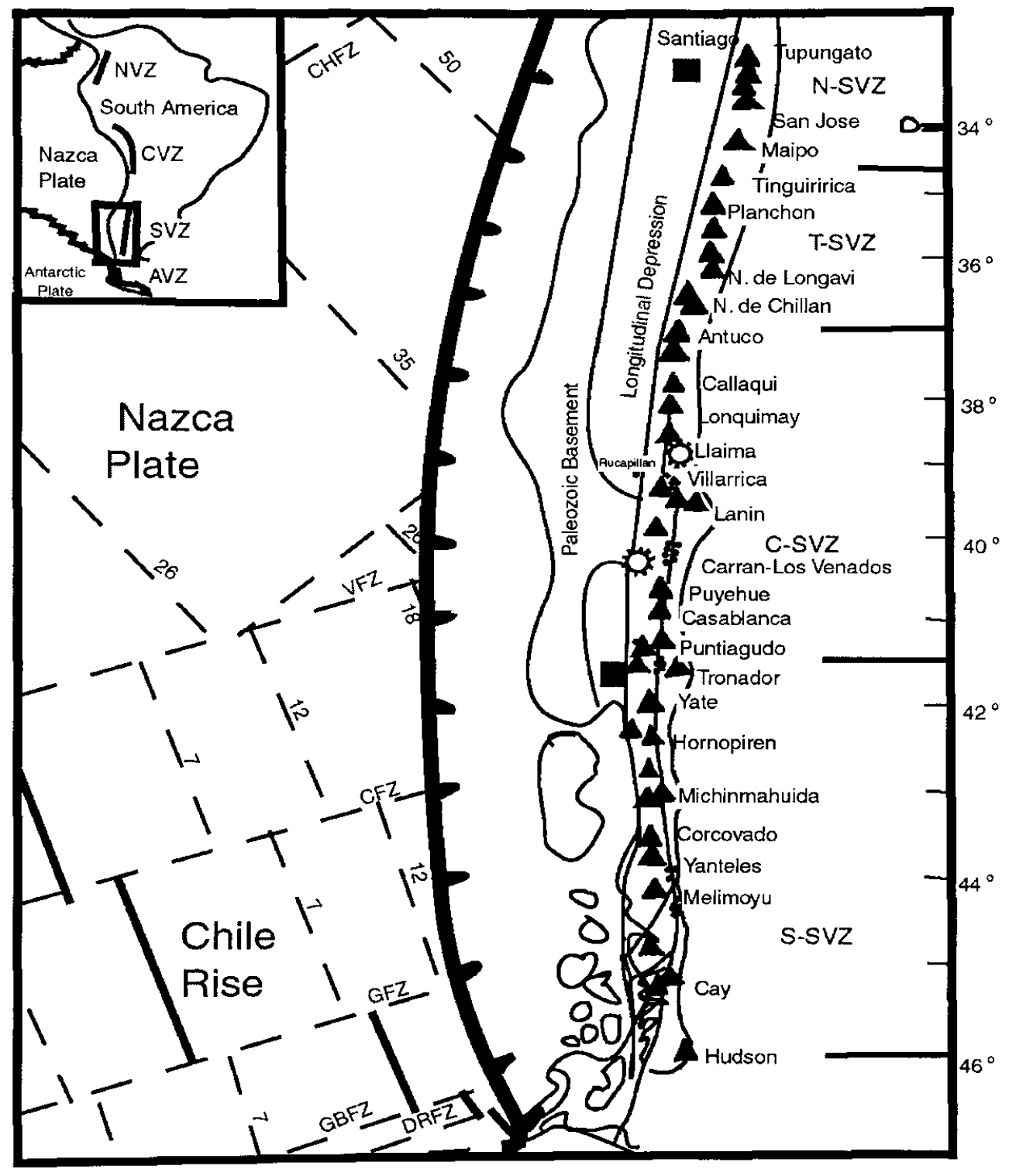

Map 1.2.1 The subduction zone and volcanic front of the Southern Volcanic Zone of Andes $\left(33^{\circ} \mathrm{S}-46^{\circ} \mathrm{S}\right)$ (filled triangles - regular stratovolcanoes; open circles with ticks maar - type volcanic centers) 
Between $38-40^{\circ} \mathrm{S}$ the volcanic front is roughly linear and follows the trace of the dextral Liquine - Ofqui Fault Zone (LOFZ), which strikes N10 - $20^{\circ} \mathrm{E}$ for about $900 \mathrm{~km}$ (Herve et al., 1979). Behind the front are the Volcanoes Quetrupillan and Lanin at $39.5^{\circ} \mathrm{S}$ and Tronador at $40^{\circ} \mathrm{S}$. The NW - SE alignment of the Villarrica - Quetrupillan - Lanin, Tolhuaca - Lonquimay and Puyehue - Cordon Caulle volcanic chains is controlled by a $\mathrm{N} 55-60^{\circ} \mathrm{W}$ transverse fracture. A N50 $-70^{\circ} \mathrm{E}$ transverse fracture controls the NE - SW alignment of the Antuco - Sierra Velluda, Llaima - Sierra Nevada and Osorno Puntiagudo - Cordon Cenizos volcanic chains (Moreno, 1974; 1976; 1977). South of $40.5^{\circ} \mathrm{S}$, the volcanic front marked by Osorno and Calbuco is shifted westward, a potential indication of a steeper subduction angle within this section (Lopez - Escobar, et al., 1992; Lopez - Escobar et al., 1995). All of the stratovolcanoes in the CSVZ are predominantly basaltic, except for Calbuco which shows evidence for significant crustal contamination (Hickey - Vargas et al., 1995; Lopez - Escobar et al., 1995). Small Eruptive Centers (SEC) are found throughout the CSVZ, located north, east and west (trenchward) of the stratovolcanoes. Most are concentrated within four areas: 1) V.Villarrica region; 2) Carran - Los Venados field; 3) field between V.Casablanca and V.Osorno (Cordon Cenizos) and 4) west of V.Osorno and V.Calbuco (Cayutue Pocoihuen). Usually the SECs are aligned along large fault zones (Liquine - Ofqui Fault Zone, for example). It has been suggested that the small eruptive volumes of the SECs require the existence of fractures to get ascending magmas to the surface (Hickey Vargas et al., 1993; Lopez - Escobar et al., 1995). 


\subsection{Geological background and eruption history of V.Villarrica and the SECs \\ 1.3a Volcano Villarrica}

Volcano Villarrica $\left(39^{\circ} 25^{\prime} \mathrm{S}, 71^{\circ} 57^{\prime} \mathrm{W}\right)$, with a summit at $2,847 \mathrm{~m}$ a.s.l. and 2,000 $\mathrm{m}$ above its base, is an active stratovolcano with a large peak displaced toward the southeast. Its huge relief results from a combination of erosion and the accumulation of glacial, volcanic and fluvial materials. Glaciation has developed deep and craggy U shaped valleys in the vicinity of V.Villarrica. Older intrusive and volcanic rocks form a series of mountains, and the majority of valleys (rivers and lakes) are controlled by the EW and NS fracture zones formed during the Quaternary glaciation. The basement of V.Villarrica contains Cretaceous / Miocene plutonic rocks, Triassic / Cretaceous / Miocene sedimentary and volcanogenic series and Plio - Pleistocene volcanic series. There are also some granitic outcrops at its base (Map 1.3.1). Lavas and pyroclastic materials are widespread, covering the older rocks (Moreno, 1980).

Between 1990 and 1995, H. Moreno - Roa and J. Clavero of the University of Chile studied the eruptive history of V.Villarrica in detail. They found (Moreno - Roa et al., 1994; Clavero and Moreno - Roa, 1994) that V.Villarrica is one of the three most active (both fumarolic and eruptive) volcanoes in South America. Since 1558 it has erupted 59 times. Its major active cone is surrounded by several pyroclastic cones.

Volcano Villarrica occupies an area of about $500 \mathrm{~km}^{2}$, with three major superimposed units - V.Villarrica I, II and III (translated from Moreno - Roa et al., 1994): 
1) V.Villarrica I: the oldest unit during the emplacement of which the volcano may have undergone a collapse and generated an elliptic caldera. This unit contains pre - glacial basaltic and andesitic lavas, volcanic breccias, conglomerates and pyroclastics, associated with extensive ignimbrites. The porphyritic basalts are composed of plagioclase phenocrysts and aphanitic matrices, andesites are composed of phenocrysts of plagioclase and olivine, and dacites are composed of plagioclase phenocrysts. The chemical composition of this unit is predominantly andesitic - basaltic $\left(52-56 \% \mathrm{SiO}_{2}\right)$.

2) V.Villarrica II: a composite stratovolcano on the NW side of the caldera, includes intra to post-glacial "aa" - type lavas and pyroclastic flow deposits formed at 14,320 a (ignimbrite Lican $-19 \mathrm{~km}^{3}$ ) and at 3,740 a (ignimbrite Pucon $-5 \mathrm{~km}^{3}$ ). The last pyroclastic flow deposit - Pucon, formed a $2.2 \mathrm{~km}$ wide caldera and built the cone for V.Villarrica III about 3,700 years ago. The chemical composition of this unit is also andesitic - basaltic $\left(53-57 \% \mathrm{SiO}_{2}\right)$. The alternating occurrence of lavas and pyroclastic flows may indicate a dramatic fluctuation of its eruptive behaviors, changing from effusive to highly explosive (Fig.1.3.1a).

3) V.Villarrica III: a young stratovolcano $\sim 400 \mathrm{~m}$ above its base. This unit includes nearly all of the historic products of this volcanic center. Its lower part includes pyroclastics and andesitic - basaltic lavas formed between 3,030 a (PF Refugio) and 1,620 a (PF - C). After that, due to the Hawaiian - type eruption of 
V.Villarrica, the upper part of this unit is mainly composed of interlayered units of lava and lahar (Fig.1.3.1b). 


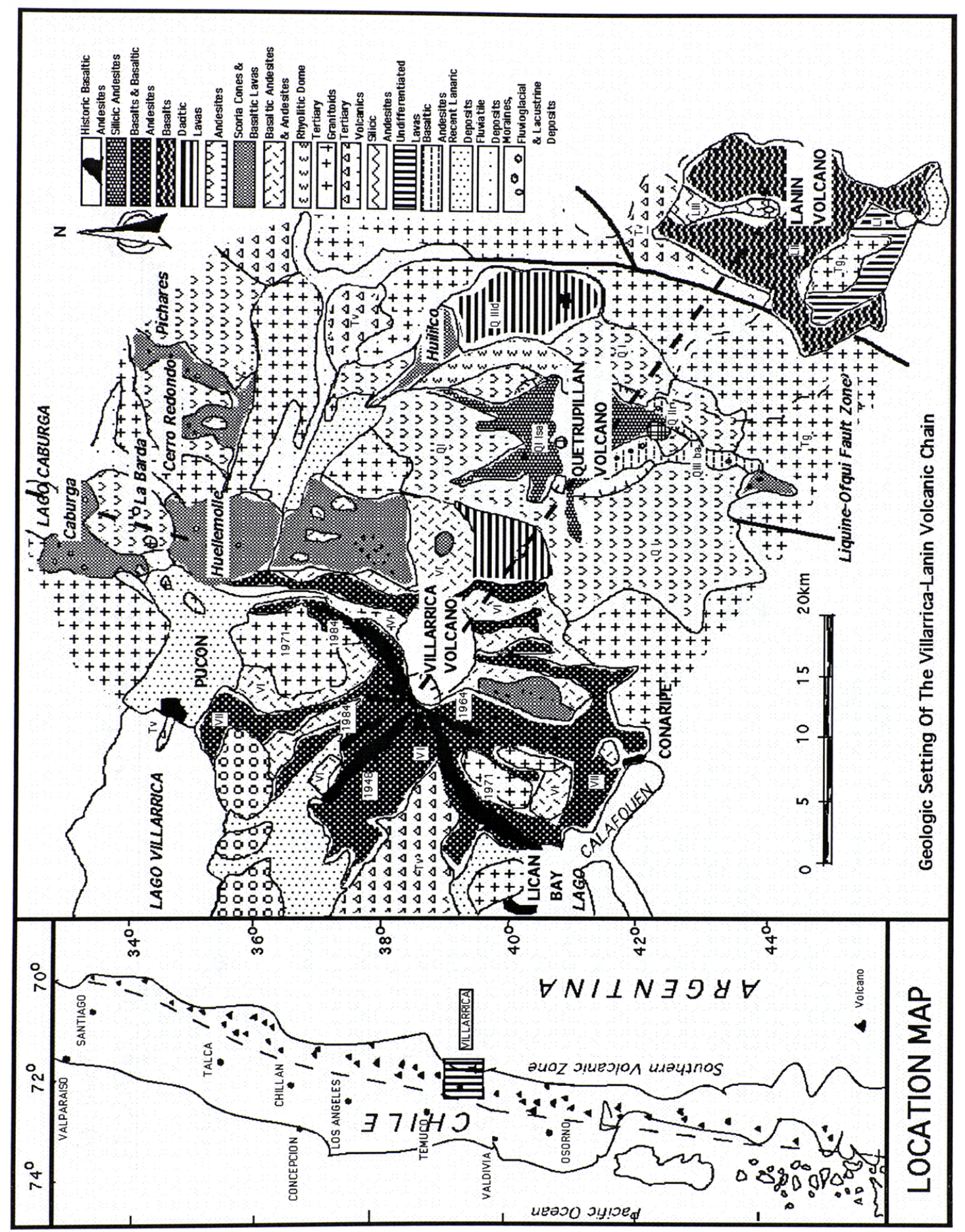

Map 1.3.1 The geologic setting of the Villarrica - Lanin volcanic chain (by Moreno - Roa in Hickey - Vargas et al., 1989) 


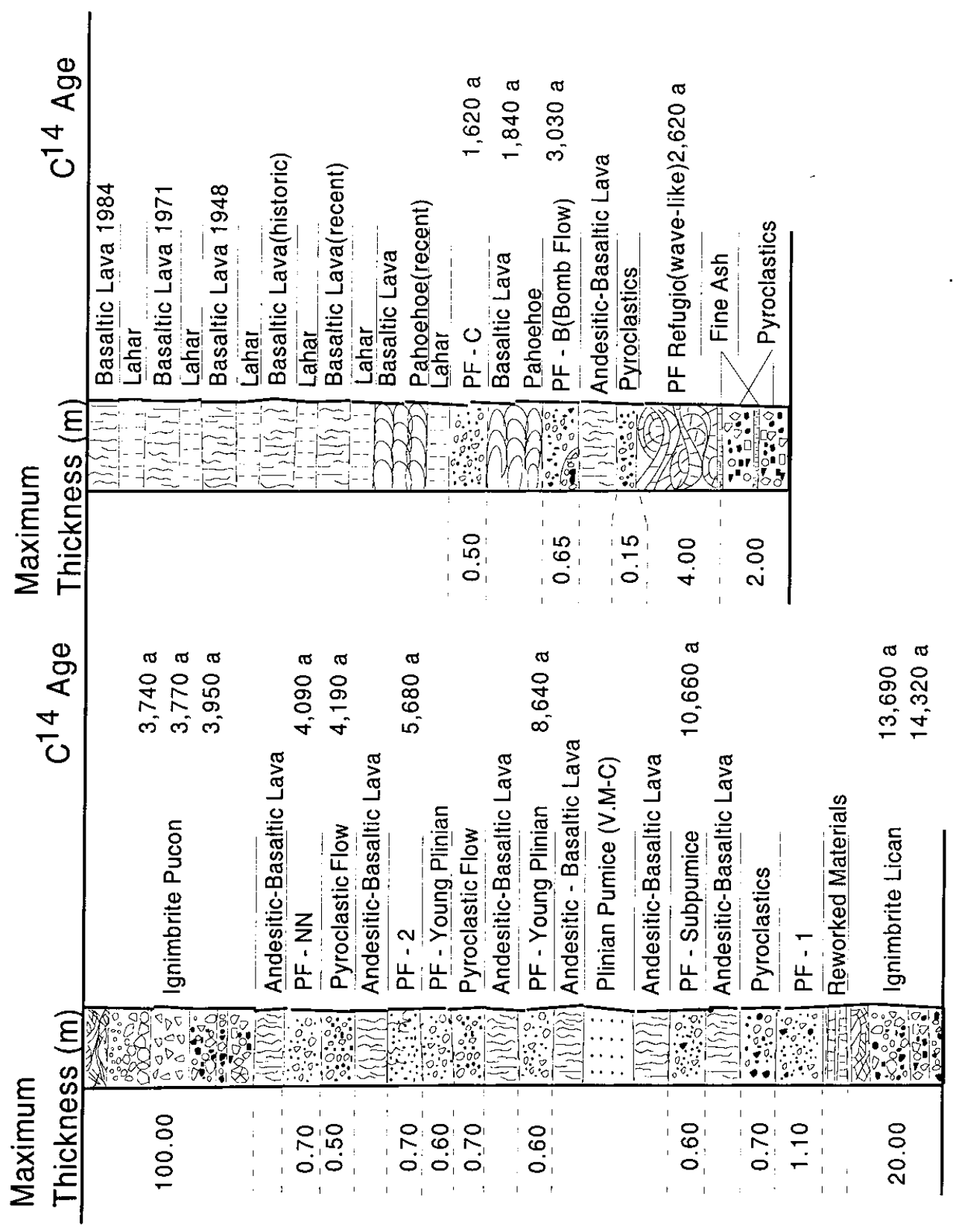

Fig. 1.3.1 a) (left) The V.Villarrica Unit II; b) (right) The V.Villarrica Unit III (from Moreno - Roa et al., 1994) 


\section{3b V.Villarrica SECs}

The Small Eruptive Centers (SEC) surrounding V.Villarrica are mainly to its north and east, aligned along the Liquine - Ofqui Fault Zone, which branches and becomes complex in this area. Most of the SECs are scoria cones with basaltic and basaltic - andesitic lava flows. The sampled area covers about 1,200 mile ${ }^{2}$, located between $39^{\circ} 10^{\prime} \mathrm{S}$ and $39^{\circ} 40^{\prime} \mathrm{S}$ latitude and $71^{\circ} 30^{\prime} \mathrm{W}$ and $72^{\circ} \mathrm{W}$ longitude. SEC Caburgua and La Barda are located to the north of V.Villarrica, and SEC Huelemolle (consisting of three cones) is 3 - 5 mile south of La Barda. SEC Cerro Redondo, Relicura and San Jorge are located east of Huelemolle, and SEC Huililco is to the southeast, along the River Huililco. Llizan, the only SEC in this area that is mainly andesitic, is located south of V.Quetrupillan. The SECs rise to about $500-1,500 \mathrm{~m}$ a.s.l, significantly lower than V.Villarrica $(\sim 2,847 \mathrm{~m})$, and smaller in the volume. Caburgua, La Barda, Huelemolle, and $\mathrm{C}$. Redondo are capped by the dated Pucon ignimbrite. Therefore the age of these SECs is estimated to be $4,000-6,000$ a (Moreno - Roa, personal communication).

To the northwest $\left(39^{\circ} \mathrm{S}\right.$ and $\left.72^{\circ} 10^{\prime} \mathrm{W}\right)$ across the Allipen River lies Rucapillan, an eruptive center composed of two maar - type cones - El Espejo and El Reloj - and one scoria cone - Carilafquen (also named SEC El Estadio in this work) (Moreno - Roa and Lopez - Escobar, 1994). The three cones are aligned approximately NW - SE and stand no higher than $400 \mathrm{~m}$ in altitude. The lower strata on Rucapillan are Plio - Pleistocene volcanics and fluvial - glacial deposits and higher deposits are the Rucapillan pyroclastics and the Curacautin ignimbrites (13,200a). Combined with the southward Ignimbrite Lican (14,000a) around V.Villarrica, the age of Rucapillan is estimated as 15,000a 13,200a (Moreno - Roa and Lopez - Escobar, 1994). 


\subsection{Previous work in this area}

\section{1) Stratovolcanoes}

Hickey et al. (1986) completed an overall investigation on the multiplicity of the mantle source in the CSVZ area. Studies on individual stratovolcanoes in this area include: V.Llaima (Hickey et al., 1986), V.Puyehue (Gerlach et al., 1988), V.Villarrica (Hickey - Vargas et al., 1989), V.Mocho - Choshuenco (McMillan et al., 1989) as well as V.Osorno and V.Calbuco (Lopez - Escobar et al., 1992; 1995; Hickey - Vargas et al., 1995). These results show that samples from the CSVZ stratovolcanoes have less geochemical variation compared with the NSVZ, TSVZ and SSVZ stratovolcano samples. However, across - strike variations exist along the NW - SE oriented volcanic chain Villarrica - Quetrupillan - Lanin (Hickey - Vargas et al., 1989). That is, Volcano Lanin, the farthest stratovolcano from the trench, has highest incompatible element abundances and $\mathrm{La} / \mathrm{Sm}$ but lowest $\mathrm{Ba} / \mathrm{La}$ and alkali - element/La ratios of the three. These differences may result from the smallest contribution from the subducted slab for V.Lanin. Moreover, its geochemical patterns also continue towards the Patagonian highly alkaline plateau basalts (Stern et al., 1990).

Crustal contamination has also been studied in this area. V.Mocho - Choshuenco in the $\operatorname{CSVZ}\left(40^{\circ} \mathrm{S}\right)$ is a basaltic - andesitic to dacitic volcano with elevated $\mathrm{Rb} / \mathrm{Ba}, \mathrm{K} / \mathrm{Ba}$, $\mathrm{Rb} / \mathrm{La}$ and $\mathrm{K} / \mathrm{La}$ ratios, which suggests a $5-15 \%$ contamination by crustal melts from plutonic rocks with modest isotopic contrasts (McMillan et al., 1989). Another contaminated composite volcano - V.Calbuco, is located further south $\left(41^{\circ} 20^{\prime} \mathrm{S}\right)$. Lavas from this volcano are mainly porphyritic andesites with comparatively low $\mathrm{K}_{2} \mathrm{O}, \mathrm{Rb}, \mathrm{Ba}$,

Th and LREE abundances, but higher ${ }^{87} \mathrm{Sr} /{ }^{86} \mathrm{Sr}$, lower ${ }^{143} \mathrm{Nd} /{ }^{144} \mathrm{Nd}$ and higher $\delta^{18} \mathrm{O}$ relative 
to its adjacent volcanoes. These features, together with its high xenolith abundance, suggest that Calbuco magmas have assimilated underlying basement rocks (Deruelle et al., 1983; Lopez - Escobar et al., 1995).

Major, trace element and isotopic studies on the CSVZ stratovolcanoes concur that the dominant sources for magma generation in this region are the peridotitic mantle wedge and subduction - related components, with minor effects by crustal assimilation (Hickey - Vargas et al., 1989; Tormey et al., 1991) (see Appendix 1). Previous studies have also examined the $\mathrm{Sr}-\mathrm{Nd}-\mathrm{Pb}$ isotopic systematics for the CSVZ volcanoes such as V.Villarrica (Hickey - Vargas et al., 1989) (see Appendix 1). Additionally, it is suggested that young pelagic sediments were involved in the mantle source through recent slab / sediment dehydration based on the high ${ }^{10} \mathrm{Be}$ contents $\left(2.1-2.9^{*} 10^{6} \mathrm{a} / \mathrm{g}\right)$ and the postive correlation between ${ }^{10} \mathrm{Be} / \mathrm{Be}$ and $\mathrm{B} / \mathrm{Be}$ (Morris and Tera, 1989; Morris et al., 1990) along with the high $\left({ }^{238} \mathrm{U} /{ }^{230} \mathrm{Th}\right)$ ratios and the positive correlation between $\left({ }^{238} \mathrm{U} /{ }^{230} \mathrm{Th}\right.$ ) and ${ }^{10} \mathrm{Be} / \mathrm{Be}$ (Sigmarsson et al., 1990) of the basaltic lavas from the stratovolcanoes in the CSVZ.

2) $S E C$

Among the large and minor volcanic centers of the CSVZ, there is an overall relationship between the scales of the volcanic edifices and their geochemical signatures (Hickey - Vargas et al., 1989; 1993; 1997; Lopez - Escobar and Moreno, 1981; Lopez Escobar et al., 1995). The geochemical and isotopic characteristics of these SECs, compared to stratovolcanoes such as V.Villarrica in these previous studies, are summarized as: 1) higher $\mathrm{MgO}, \mathrm{Ni}$ and $\mathrm{Cr}$ contents at a similar $\mathrm{SiO}_{2} ; 2$ ) wider range of 
trace element concentrations and isotopic ratios, including lower alkali element contents such as $\mathrm{K}, \mathrm{Rb}$ and $\mathrm{Cs}$, higher $\mathrm{LREE} / \mathrm{HREE}$ ratios such as $\mathrm{La} / \mathrm{Yb}$, higher incompatible element contents such as $\mathrm{Ba}, \mathrm{Th}, \mathrm{Nb}, \mathrm{La}$ and $\mathrm{Zr}$, and lower $\mathrm{Ba} / \mathrm{La}, \mathrm{K} / \mathrm{La}$ and $\mathrm{Rb} / \mathrm{La}$ ratios; 3) slightly lower ${ }^{87} \mathrm{Sr} /{ }^{86} \mathrm{Sr}$ and ${ }^{143} \mathrm{Nd} /{ }^{144} \mathrm{Nd}$ ratios.

The origin of the geochemical characteristics of composite volcanoes in the CSVZ was discussed by Hickey et al. (1986). Based on her geochemical models, variations in their trace element and REE abundances and isotopic ratios can be produced by the heterogeneity of the mantle reservoirs beneath the volcanic front as well as behind it. Further study (Hickey - Vargas et al., 1989; Lopez - Escobar et al., 1995) revealed that the SECs have a larger compositional variation compared with the stratovolcanoes in the CSVZ because of their very low ratios of alkalis ( $\mathrm{K}, \mathrm{Rb}$ and $\mathrm{Cs})$ and $\mathrm{Ba}$ to REEs and HFSEs. These features support a model of smaller contributions from the subduction derived fluids (enriched with LILEs) to the SECs. As a result, a lesser degree of partial melting is induced in the source and this is consistent with the higher LREE/HREE ratios of the SEC samples. And the different amount of fluid addition between V.Villarrica and the SECs can not be explained by the changing stabilities of hydrous minerals in the descending slab since V.Villarrica and the SECs are located within a very small area and the latter are also distributed in a scattered pattern surrounding the former. Based on all these observations, Hickey - Vargas et al. $(1989 ; 1993 ; 1997)$ proposed preliminary hypotheses for explaining the different spatial and geochemical patterns of the stratovolcanoes and SECs: 1) the stratovolcanoes are located at the center of the melting column (more hydrated), and represent the maximum extent of partial melting, while the SECs stand at the periphery of the column where the amount of fluid addition and degree 
of partial melting are both lower; 2) the centers of the melting columns are more chemically uniform, but its peripheral parts may be melts produced within or subject to mixing with the surrounding lithospheric mantle during magma ascending. 


\subsection{Specific objectives of this project}

The purpose of this work was to study the basaltic volcanic rocks from small eruptive centers in the vicinity of V.Villarrica in order to determine the reasons of geochemical differences between these centers and large composite volcanoes. Specifically, in this work I will address:

1. Do the SECs have uniform geochemical characteristics distinctive from those of V.Villarrica?

2. Do they tap smaller amounts of slab - derived fluids, as proposed by Hickey Vargas et al. (1993; 1997), or is a more complicated process required for the formation of the SEC magmas?

3. What are the compositions and proportions of potential endmembers in the sources of V.Villarrica and the SECs, respectively (mantle wedge vs. slab components)?

4. The new ages and time constraints given by the ignimbrites prove that some of the SECs erupted concurrently with V.Villarrica. So an important question here is: how can magmas with large geochemical variations be produced in such a small segment of volcanic arc $(20 \mathrm{~km} \times 20 \mathrm{~km})$ at the same time?

This work was accomplished using a more complete suite of trace elements ( $\mathrm{Sr}$, $\mathrm{Zr}, \mathrm{Nb}, \mathrm{Cs}, \mathrm{Rb}, \mathrm{Ba}, \mathrm{U}, \mathrm{Th}, \mathrm{Pb}, \mathrm{B}, \mathrm{Be}, \mathrm{Li}$ and REEs) determined by ICPMS and DCPES compared with earlier studies. Moreover, isotopic ratios of ${ }^{87} \mathrm{Sr} /{ }^{86} \mathrm{Sr},{ }^{143} \mathrm{Nd} /{ }^{144} \mathrm{Nd}$, ${ }^{208} \mathrm{~Pb} /{ }^{204} \mathrm{~Pb},{ }^{207} \mathrm{~Pb} /{ }^{204} \mathrm{~Pb}$ and ${ }^{206} \mathrm{~Pb} /{ }^{204} \mathrm{~Pb}$ along with time and source - sensitive isotopic tracers such as ${ }^{230} \mathrm{Th} /{ }^{232} \mathrm{Th}$ and ${ }^{10} \mathrm{Be}$ will also be used to determine the potential sources 
and processes that may cause the geochemical differences between the V.Villarrica and SEC lavas.

This work will also compare the geochemical patterns of the Villarrica SECs to those SECs from Carran - Los Venados area. Based on previous studies (Lopez - Escobar and Moreno, 1981), basalts from the latter show geochemical characteristics more like the stratovolcanoes in the CSVZ than the other SECs. SECs from this field usually erupt more violently (maar - type volcanism) compared with SECs near V.Villarrica. Therefore, this work, as collaboration with the thesis of Ana Carolina Rodriguez - Soto, a M.S. student of University of Chile who is studying the petrology, major and trace element geochemistry of the Carran - LV SECs, will also provide useful information for explaining the contrast between SEC and stratovolcano geochemistry. 


\section{Chapter 2 Sample Locations and Descriptions}

\subsection{Sample Locations}

The SEC samples from near V.Villarrica were collected by L. Lopez - Escobar. Attempts were made to sample as many eruptive cones as possible, but many areas were inaccessible due to thick vegetation (Photo 2.1.1). A total of 40 samples were collected from the SECs surrounding V.Villarrica (detailed sample locations are given in Appendix 2).

Most of the SECs are located to the north and northeast of V.Villarrica, controlled by the local fracture system - Liquine - Ofqui Fault Zone (LOFZ). The location of each of the eruptive centers is as follows (Map 2.1.1):

- Caburgua $\left(39.2^{\circ} \mathrm{S} / 71.8^{\circ} \mathrm{W}\right)$ : west of Lago Caburgua, about $550 \mathrm{~m}$ a.s.l. (above sea level).

- Huelemolle $\left(39.3^{\circ} \mathrm{S} / 71.8^{\circ} \mathrm{W}\right)$ : includes three cones aligned North - South, located north of River Pucon and south of River Liucura. The northernmost cone is about $500 \mathrm{~m}$ a.s.l., and the other two are slightly taller.

- La Barda $\left(39.2^{\circ} \mathrm{S} / 71.8^{\circ} \mathrm{W}\right)$ : includes two adjacent cones, and located to the north of River Liucura. Its elevation is slightly higher than $1,000 \mathrm{~m}$ a.s.l. 
- Cerro Redondo $\left(39.2^{\circ} \mathrm{S} / 71.7^{\circ} \mathrm{W}\right)$ : east of Co. La Barda and Huelemolle, with an elevation of about $1,000 \mathrm{~m}$ a.s.l.

- Relicura and Pichares $\left(39.2^{\circ} \mathrm{S} / 71.7^{\circ} \mathrm{W}\right)$ : two cones adjacent to each other, each summit slightly higher than $1,500 \mathrm{~m}$ a.s.l.

- San Jorge $\left(39.3^{\circ} \mathrm{S} / 71.7^{\circ} \mathrm{W}\right)$ : a very inaccessible cone because of heavy vegetation. It is located south of Co. Relicura and north of River Pucon, and reaches about $1,000 \mathrm{~m}$ a.s.1.

- Huililco $\left(39.4^{\circ} \mathrm{S} / 71.6^{\circ} \mathrm{W}\right)$ : about $5 \mathrm{~km}$ east of River Huililco, with a summit slightly higher than $1,000 \mathrm{~m}$ a.s.l.

- Llizan $\left(39.5^{\circ} \mathrm{S} / 71.7^{\circ} \mathrm{W}\right)$ : the southernmost center, southeast of V.Villarrica and south of V.Quetrupillan, less than $4 \mathrm{~km}$ northwest of the Argentina - Chile border. Its summit is relatively high, about $1,600 \mathrm{~m}$ a.s.l.

- Rucapillan / El Estadio $\left(39.0^{\circ} \mathrm{S} / 72.3^{\circ} \mathrm{W}\right)$ : the only eruptive center far to the west of V.Villarrica, across the River Allipen. Rucapillan includes three adjacent cones, aligned northwest - southeast, named El Espejo, El Reloj, and Cono Carilafquen (El Estadio), respectively. The elevations of the three cones average about $300 \mathrm{~m}$ a.s.l., and their volumes average about 2,000,000 $5,000,000 \mathrm{~m}^{3}$. 

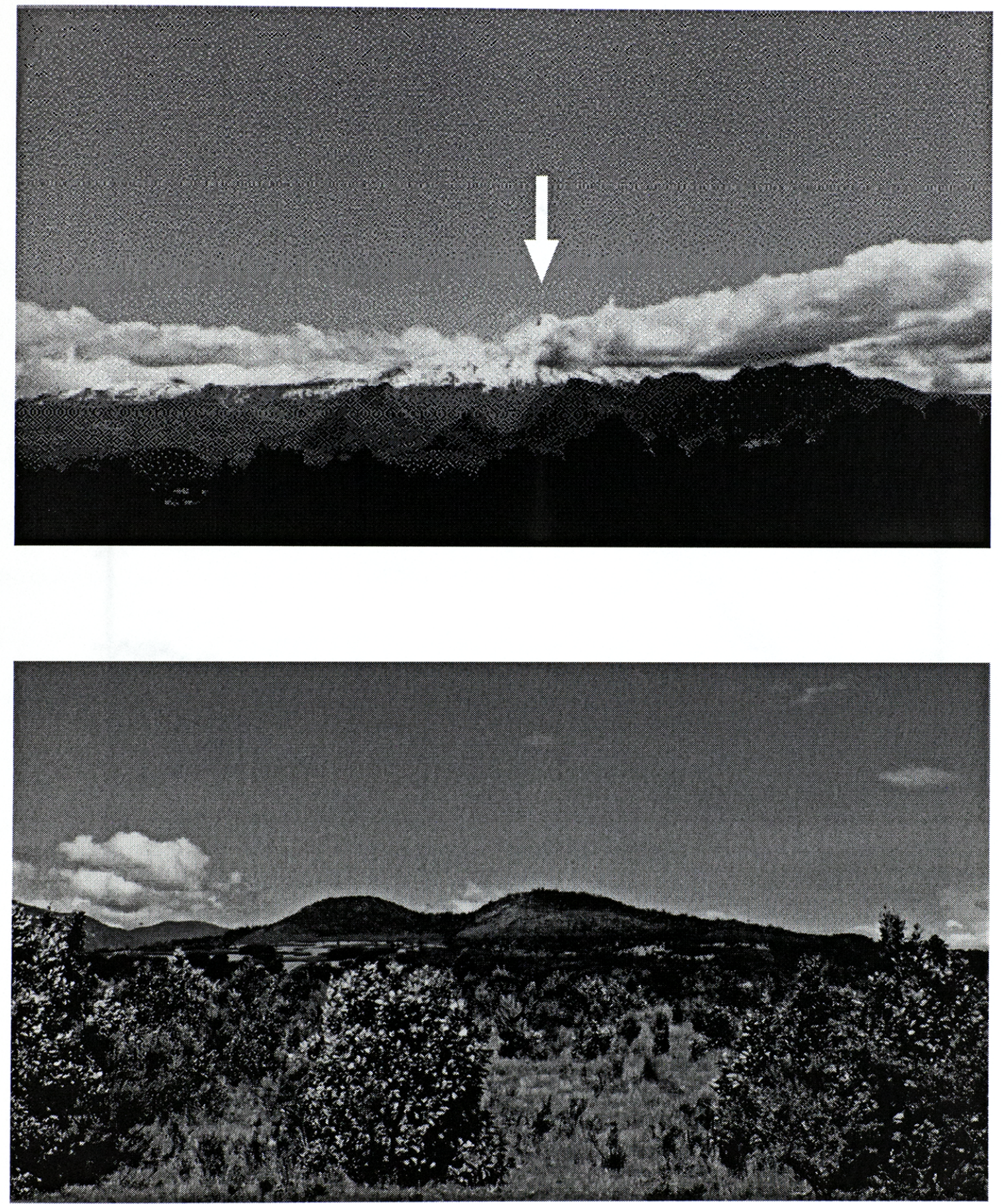

Photo 2.1.1 Upper - V.Villarrica; Lower - SEC Huelemolle (taken by Hickey - Vargas) 


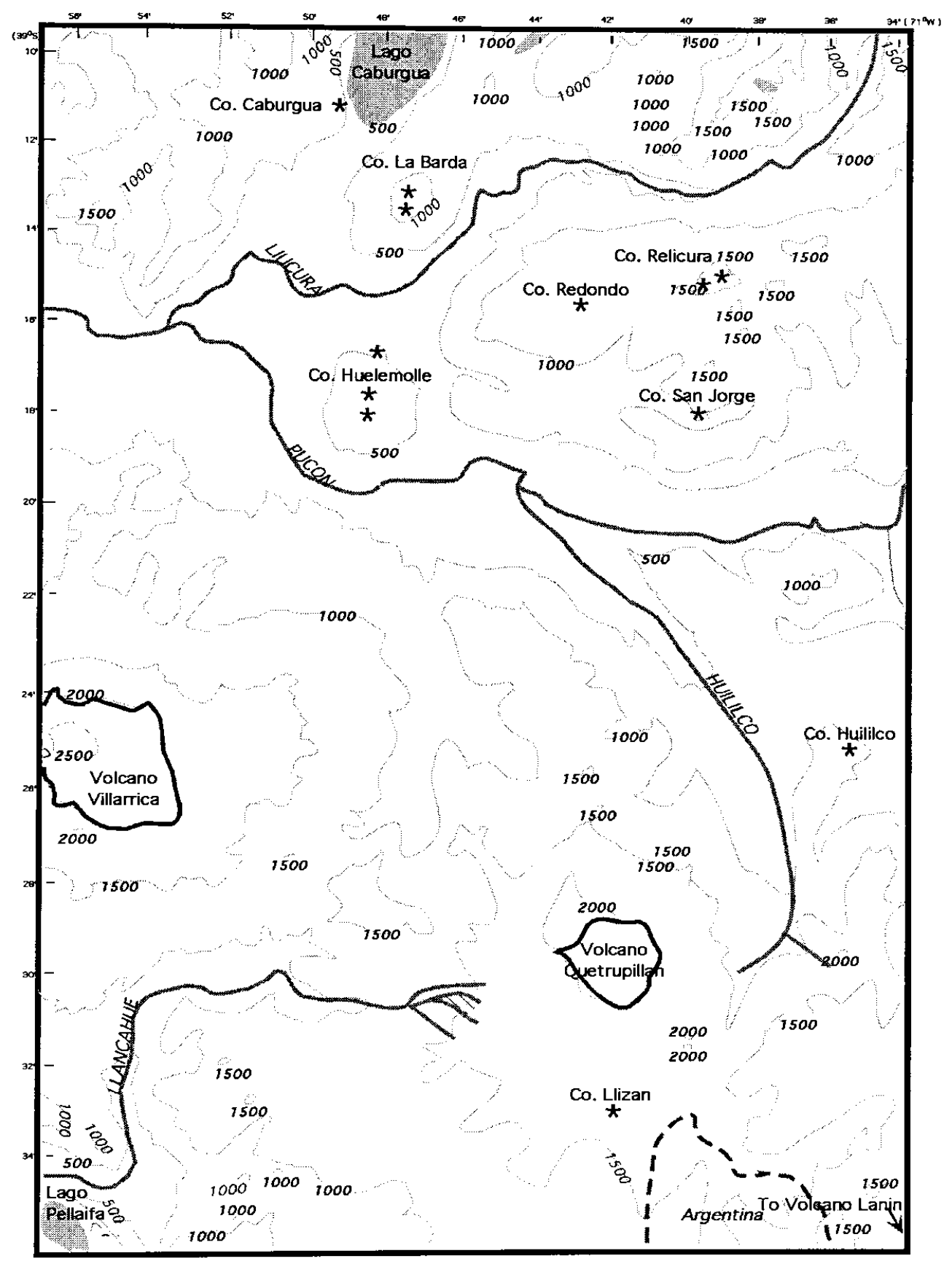

Map 2.1.1 Sampling locations of the SECs surrounding V.Villarrica (star symbols centers / vents; bold grey lines - rivers; thin grey lines - contours; scale - $1: 300,000$ ) 


\subsection{Sample Descriptions and Petrography}

Detailed hand specimen and petrographic descriptions of samples are given in Appendix 2. Table 2-2-1 gives the modal analyses of samples used in modeling calculations.

In general, all samples show porphyritic texture with abundant plagioclase phenocrysts. The groundmass shows diabasic textures, some of which are porphyritic. V.Villarrica basalts $\left(<53 \% \mathrm{SiO}_{2}\right)$ have a larger proportion of phenocrysts (up to $20 \%$ of sample volume) than most of the SEC basalts (Caburgua, Cerro Redondo, Huelemolle, La Barda and Pichares, etc), which contain less than $6 \%$ phenocrysts. In the V.Villarrica - II basalts (191281-1, 180281-1 and L21), plagioclase phenocrysts are the dominant phenocryst phases $(95 \%)$ and are commonly euhedral. Phenocrysts of olivine and cpx also occur. Few plagioclase crystals show resorption textures, and less than 5\% spinel or magnetite crystals are observed. However, the V.Villarrica - III basalt (L23) and the two V.Villarrica - 1971 basalts (L28 and 210281-1) have subhedral to euhedral plagioclases (also the dominating phenocryst phase) which apparently show resorption textures. 
Table 2-2-1 Modal analyses of 21 samples from V.Villarrica and the SECs

\begin{tabular}{|l|r|r|r|r|r|r|}
\hline Sample\# & Vesicles\% & Total Pheno\% & plag.\% & oliv.\% & cpx\% & Groundmass\% \\
\hline $210281-1$ & 1 & 5 & 4.8 & 0.2 & 0 & 94 \\
\hline L28 & 2 & 6 & 5.6 & 0.2 & 0.2 & 92 \\
\hline L23 & 0.5 & 3 & 3 & 0 & 0 & 96.5 \\
\hline L21 & 10 & 20 & 19 & 0.8 & 0.2 & 70 \\
\hline $180281-1$ & 10 & 10 & 9.6 & 0.2 & 0.2 & 80 \\
\hline VII(191281-1) & 1 & 6 & 5.7 & 0 & 0.3 & 93 \\
\hline $151282-3$ & 0 & 0.3 & 0.1 & 0.1 & 0.1 & 99.7 \\
\hline $140194-01$ & 1 & 6 & 0 & 5.4 & 0.6 & 93 \\
\hline L83 & 5 & 1 & 0 & 0.1 & 0.9 & 94 \\
\hline $150194-06$ & 2 & 2 & 0.1 & 1.8 & 0.1 & 96 \\
\hline $120194-02$ & 5 & 2 & 1.9 & 0.1 & 0 & 93 \\
\hline $110194-03$ & 15 & 1 & 0.1 & 0.9 & 0 & 84 \\
\hline L84 & 6 & 1 & 1 & 0 & 0 & 93 \\
\hline L16 & 0 & 2 & 0.7 & 1.2 & 0.1 & 98 \\
\hline $150194-03$ & 5 & 2.5 & 0.9 & 1.5 & 0.1 & 92.5 \\
\hline L82 & 0.3 & 2.5 & 0.4 & 2 & 0.1 & 97.2 \\
\hline L81 & 6 & 0.5 & 0 & 0.2 & 0.3 & 93.5 \\
\hline L24 & 2 & 6 & 3.6 & 2.1 & 0.3 & 92 \\
\hline L20 & 0.3 & 2.5 & 1.5 & 0.8 & 0.2 & 97.2 \\
\hline Ru-porphy & 15 & 5 & 0 & 0.5 & 4.5 & 80 \\
\hline Ru-aphy & 0 & 0.2 & 0.1 & 0 & 0.1 & 99.8 \\
\hline
\end{tabular}


The V.Villarrica II sample $151282-3$ is andesitic $\left(\mathrm{SiO}_{2} \sim 55 \%\right)$, consistent with its lower content of cpx and olivine phenocrysts (nearly aphyric), but a higher proportion of plagioclase crystals.

The SEC basalts may be separated based on their different microscopic characteristics and major element compositions:

1. San Jorge: samples from this center are unusually mafic $\left(\mathrm{SiO}_{2}<50.5 \%\right.$ and $\mathrm{MgO}>9.1 \%$ ). Microscopically, sample 140194 - 01 from this SEC contains a high proportion of olivine phenocrysts ( $\sim 6 \%$ of the total volume). Compared to other SEC samples, San Jorge basalts have much less plagioclase and may contain externally originated olivine (euhedral and sometimes broken grains).

2. Most of the SEC samples - including Caburgua, Cerro Redondo, Huelemolle and Pichares - are composed of a fairly fine groundmass $(\geq 94 \%)$ rich in plagioclase and show nearly diabasic textures. Phenocryst phases are usually olivine and cpx, and in some cases plagioclase is the dominant phenocryst phase. Basalts of SEC Huililco generally have a higher proportion of phenocryst phases and overall a coarser groundmass (intersertal) compared with the other SECs.

3. La Barda: samples from this SEC are slightly more mafic $(\mathrm{MgO} \sim 7.6 \%)$ than most other SEC (except San Jorge and Rucapillan - porphyritic) lavas. Microscopic studies of sample 150194 - 06 reveal that it is mainly composed of plagioclase - rich groundmass $(96 \%)$ with about $2 \%$ of olivine phenocrysts. 
4. Rucapillan: samples from this SEC are characterized by porphyritic and aphyric patches. The porphyritic areas have a higher proportion of large olivine and cpx phenocrysts (up to $1 \mathrm{~mm}$ ). In the aphyric part, less than $0.5 \%$ of the sample volume is composed of $\mathrm{cpx}$ and olivine phenocrysts. Plagioclase - dominanted groundmass comprises more than $99 \%$ of the rock. Scanning Electronic Microscope (backscattered) images of these patches are shown in Appendix 2. 


\section{Chapter 3 Geochemical Results}

\subsection{The procedures and instruments used in this work}

The flow chart on the following page is a simplified description of the geochemical methods and tools used to analyze the V.Villarrica and SEC samples (detailed descriptions of the analytical procedures and data tables are given in Appendix 3): 


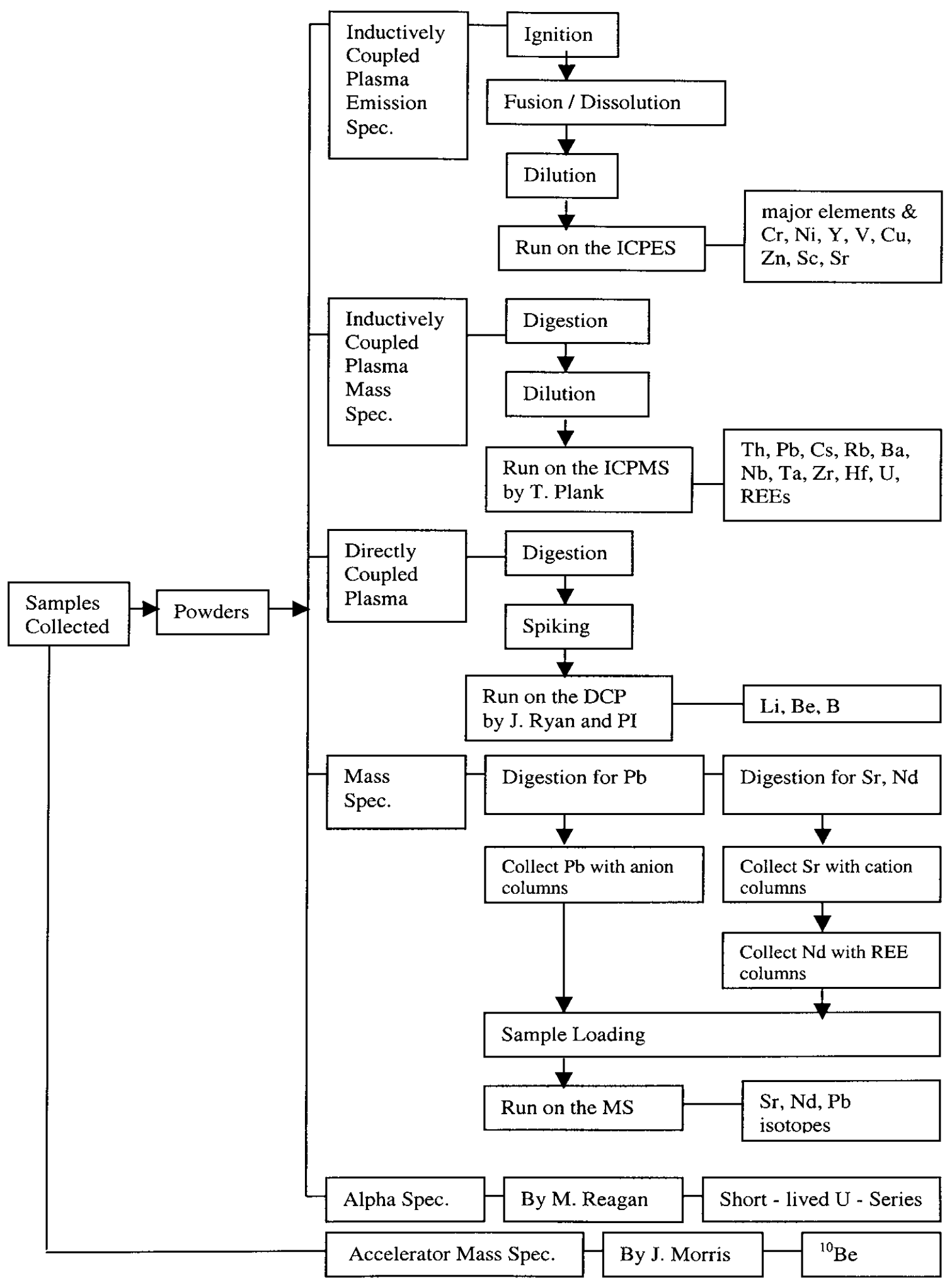




\subsection{Major Element Results}

The ICPES major element data of the SEC basalts and basaltic andesites are listed in Appendix 3. Published data for V.Villarrica (Hickey - Vargas et al., 1989), which are used in some diagrams and calculations in this work, are given in Appendix 1. In order to compare V. Villarrica and the small eruptive centers, several oxide - oxide plots were made for basalts and basaltic andesites from V.Villarrica (Fig.3.2.1a), SECs (Caburgua, Cerro Redondo, Huelemolle, Huililco, La Barda, San Jorge, Pichares and Relicura) (Fig.3.2.1b) and SEC Rucapillan (including El Estadio) + Llizan (Fig.3.2.1c).

V.Villarrica samples exhibit a larger range of $\mathrm{SiO}_{2}$ content, between $51-56 \mathrm{wt} \%$, while the SEC samples are more basaltic $\left(50-53 \mathrm{SiO}_{2} \%\right)$ except for samples from SEC Llizan $\left(54-58 \mathrm{SiO}_{2} \%\right)$ that are andesitic. Relative to the basaltic samples from most SECs, Llizan andesites and andesitic basalts have lower $\mathrm{TiO}_{2}, \mathrm{Fe}_{2} \mathrm{O}_{3}, \mathrm{CaO}$ and $\mathrm{P}_{2} \mathrm{O}_{5}$, but higher $\mathrm{Na}_{2} \mathrm{O}$ and $\mathrm{K}_{2} \mathrm{O}$ contents. The samples from SEC Rucapillan separate into two groups. The porphyritic rocks are more mafic, and the aphyric parts less mafic, due to varying proportions of olivine and cpx contents in the two types of rock samples. The $\mathrm{Ru}$ - porphyritic basalts have lower $\mathrm{TiO}_{2}, \mathrm{Al}_{2} \mathrm{O}_{3}, \mathrm{Na}_{2} \mathrm{O}, \mathrm{K}_{2} \mathrm{O}$ and $\mathrm{P}_{2} \mathrm{O}_{5}$ but higher $\mathrm{MgO}$ and $\mathrm{CaO}$ contents than the $\mathrm{Ru}$ - aphyric basalts. Two samples from El Estadio (one of the Rucapillan cones) have major element compositions that lie between the two Rucapillan endmembers - porphyritic and aphyric, and more close to the former. The most mafic center - San Jorge, is distinguished from V.Villarrica and other SECs in that its basalts have extremely high $\mathrm{MgO}(9.0-10.5 \mathrm{wt} \%)$, together with relatively high $\mathrm{CaO}$ and low $\mathrm{TiO}_{2}, \mathrm{Al}_{2} \mathrm{O}_{3}, \mathrm{Na}_{2} \mathrm{O}, \mathrm{K}_{2} \mathrm{O}$ and $\mathrm{P}_{2} \mathrm{O}_{5}$ contents. One sample from the SEC Huelemolle has major element abundances identical to San Jorge basalts. This sample may be 
misidentified. The averaged composition $\left(\mathrm{SiO}_{2} \sim 50 \%, \mathrm{Al}_{2} \mathrm{O}_{3} \sim 16 \%\right.$ and $\left.\mathrm{MgO} \sim 10 \%\right)$ of the San Jorge samples is comparable to a $10 \%$ partial melt from averaged primitive upper mantle ("primitive arc magma") $\left(\mathrm{SiO}_{2} \sim 50.3 \%, \mathrm{TiO}_{2} \sim 1.15 \%, \mathrm{Al}_{2} \mathrm{O}_{3} \sim 17.1 \%, \mathrm{FeO}^{*} \sim\right.$ 9.4\%, $\mathrm{MgO} \sim 10.6 \%, \mathrm{CaO} \sim 8.4 \%$ and $\mathrm{Na}_{2} \mathrm{O} \sim 3.0 \%$ ) estimated by Plank and Langmuir (1988). 

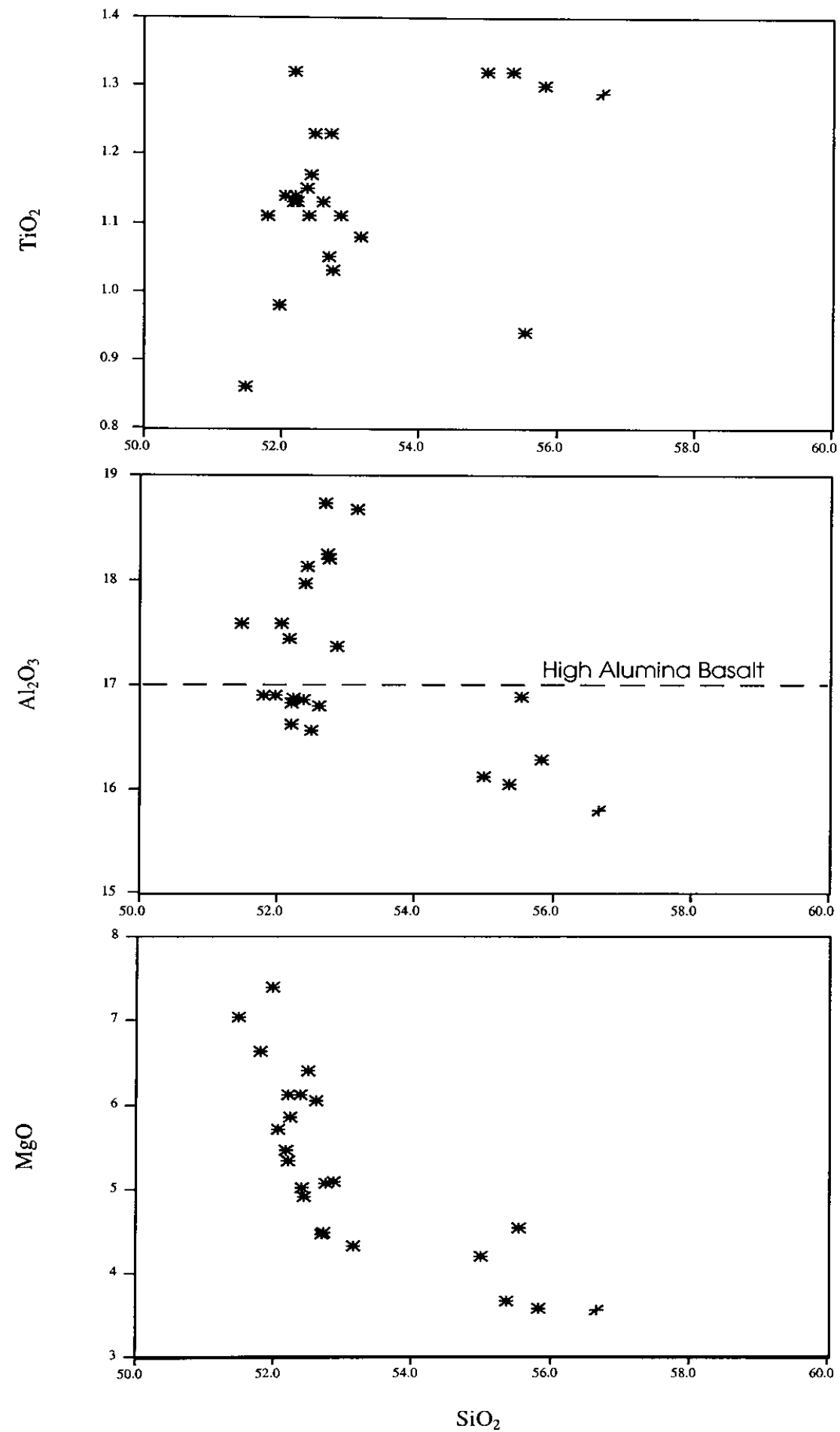

Fig.3.2.1a Oxide - $\mathrm{SiO}_{2}$ for samples from Volcano Villarrica (continued) 

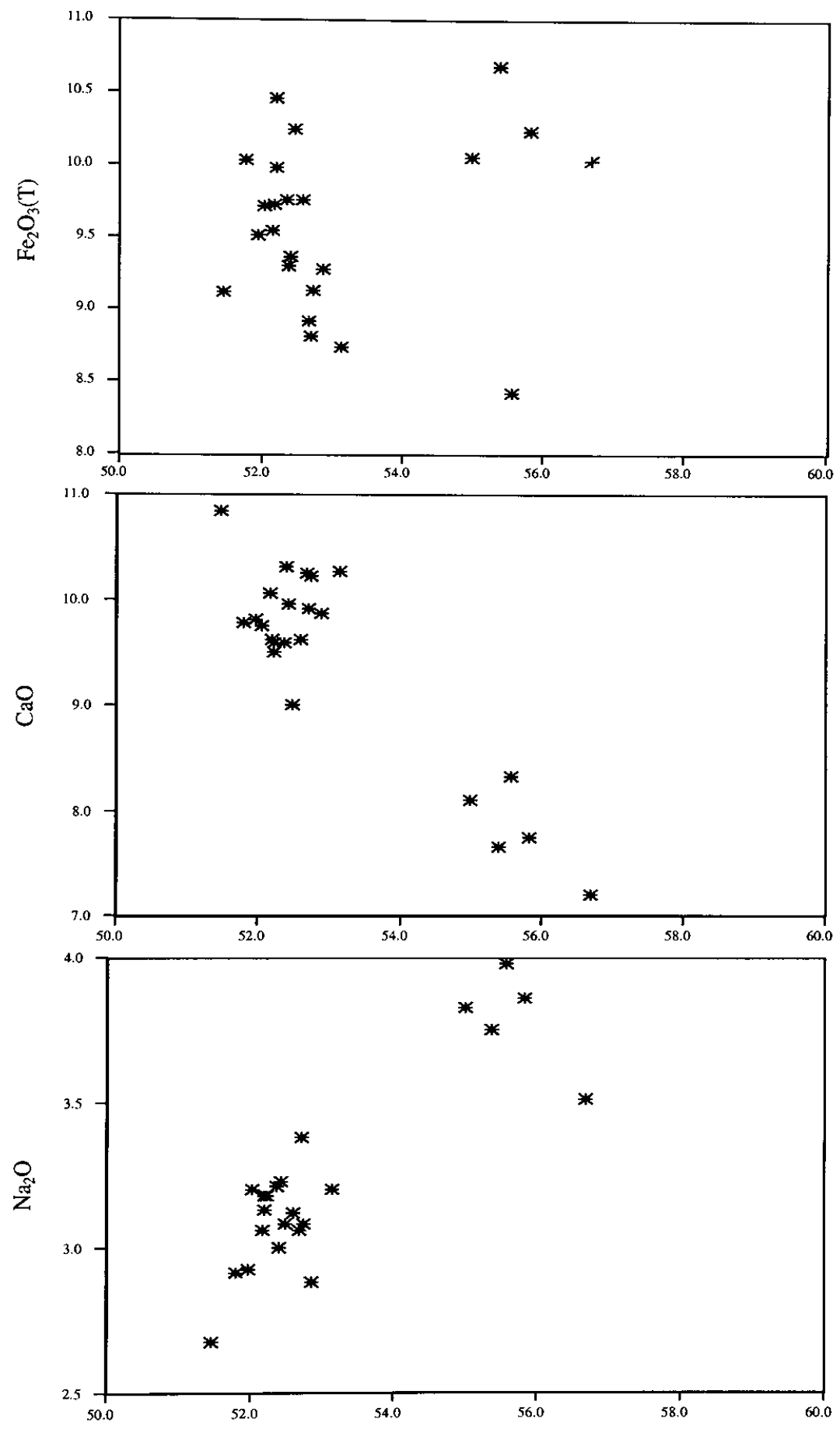

$\mathrm{SiO}_{2}$

Fig.3.2.1a Oxide - $\mathrm{SiO}_{2}$ for samples from Volcano Villarrica (continued) 

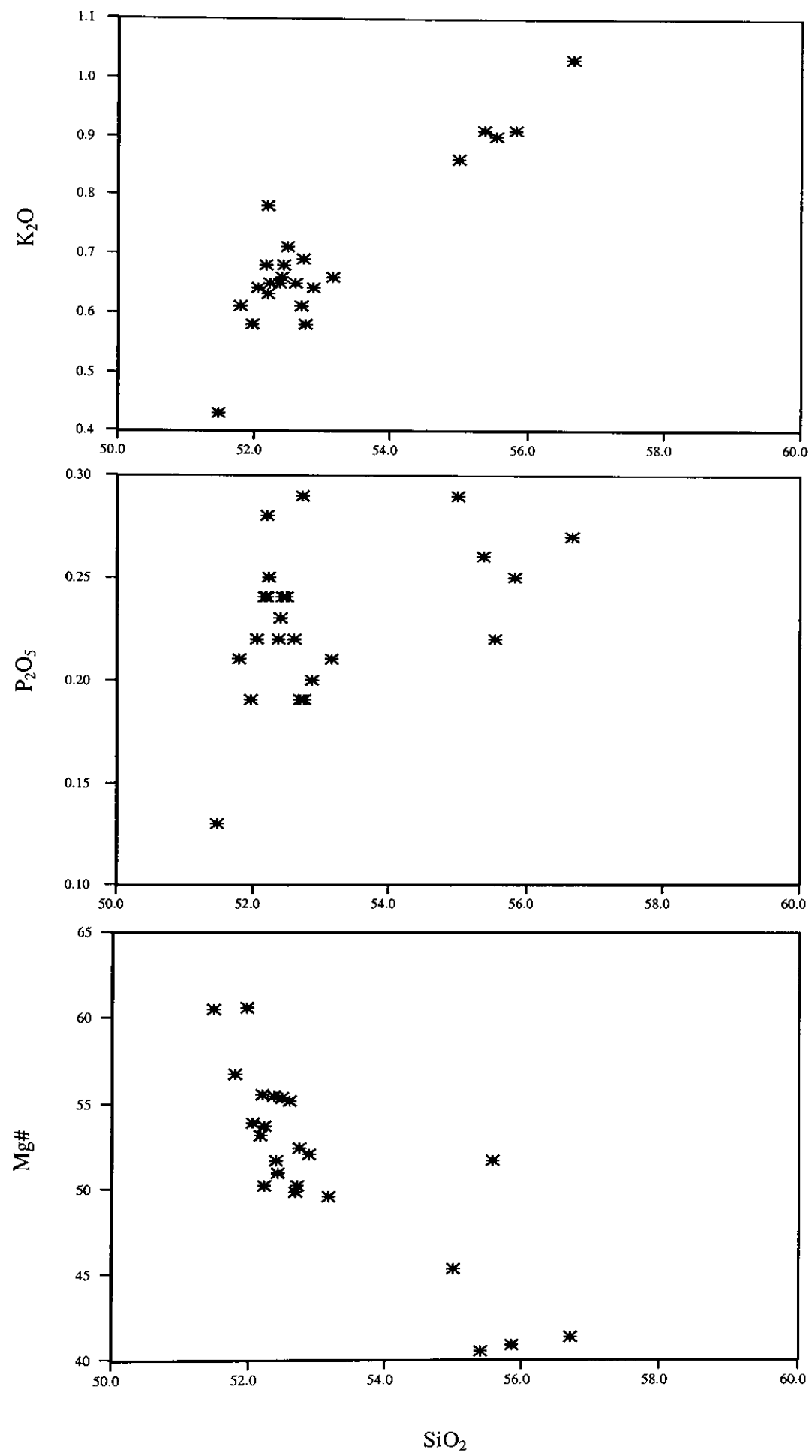

Fig.3.2.1a Oxide - $\mathrm{SiO}_{2}$ for samples from Volcano Villarrica 

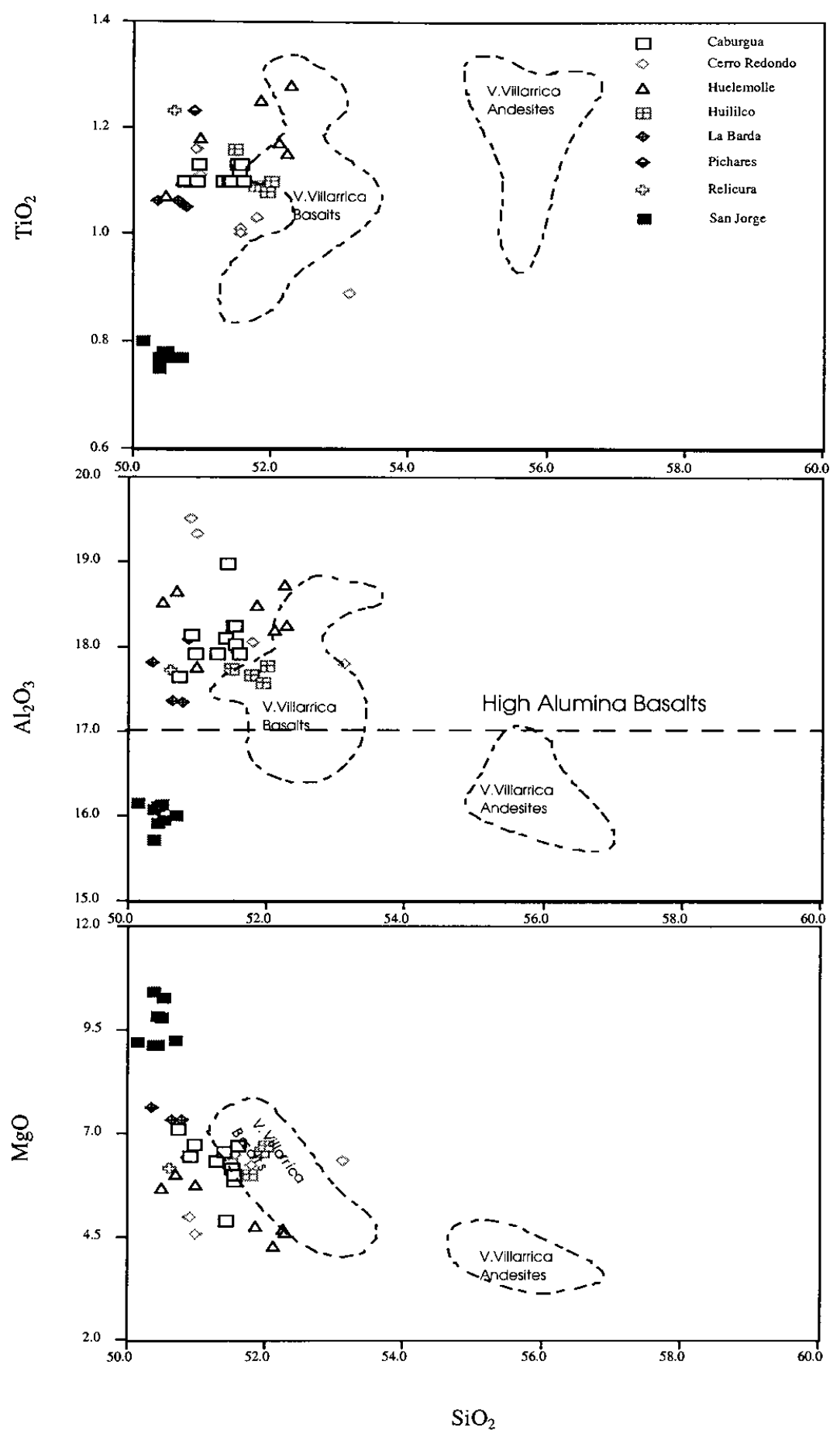

Fig. 3.2.1b Oxide - $\mathrm{SiO}_{2}$ for samples from SEC Cerro Redondo, San Jorge, La Barda, Huelemolle, Caburgua, Huililco, Pichares and Relicura (continued) 

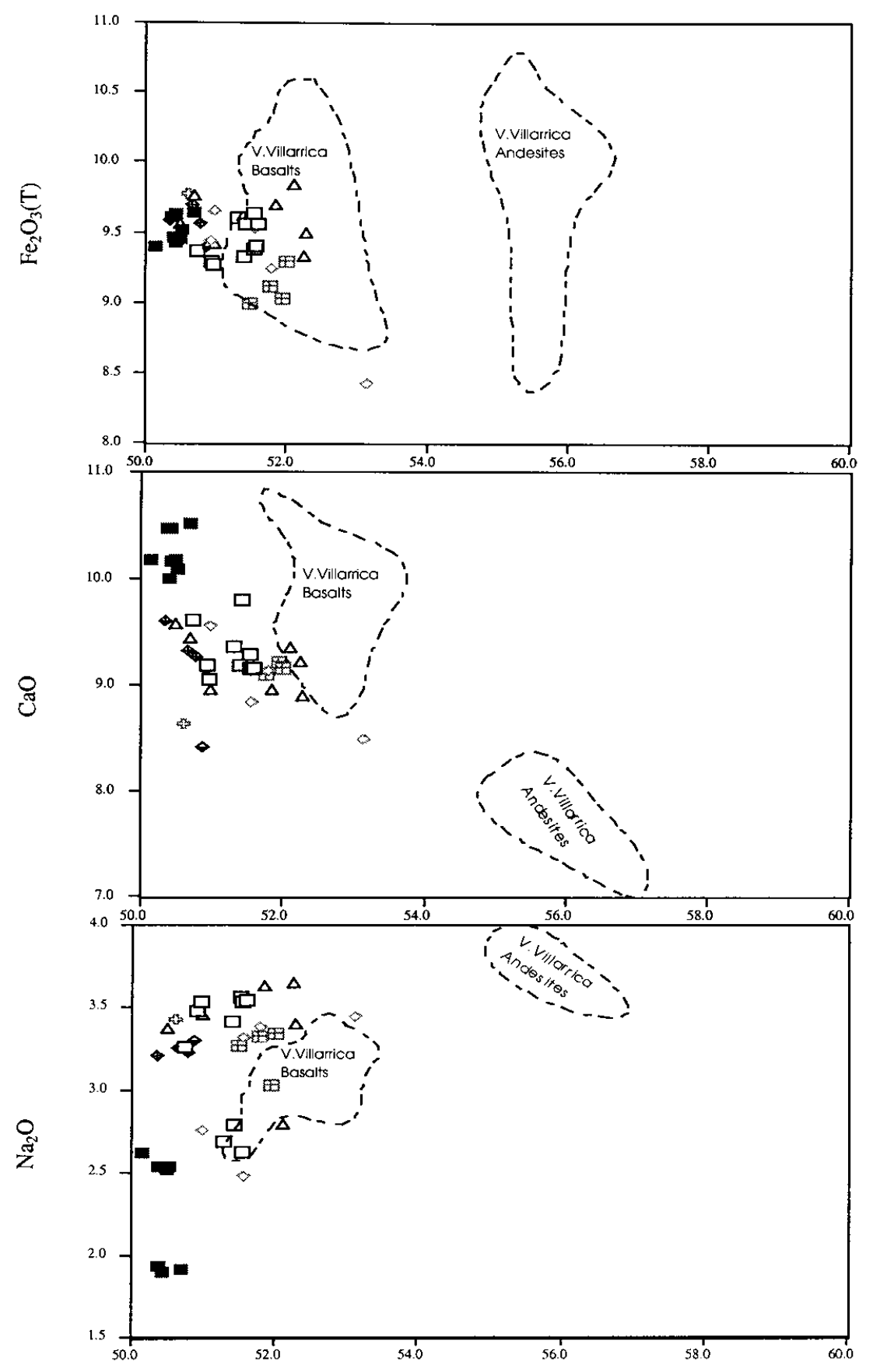

$\mathrm{SiO}_{2}$

Fig. 3.2.1b Oxide - $\mathrm{SiO}_{2}$ for samples from SEC Cerro Redondo, San Jorge, La Barda,

Huelemolle, Caburgua, Huililco, Pichares and Relicura (continued) 


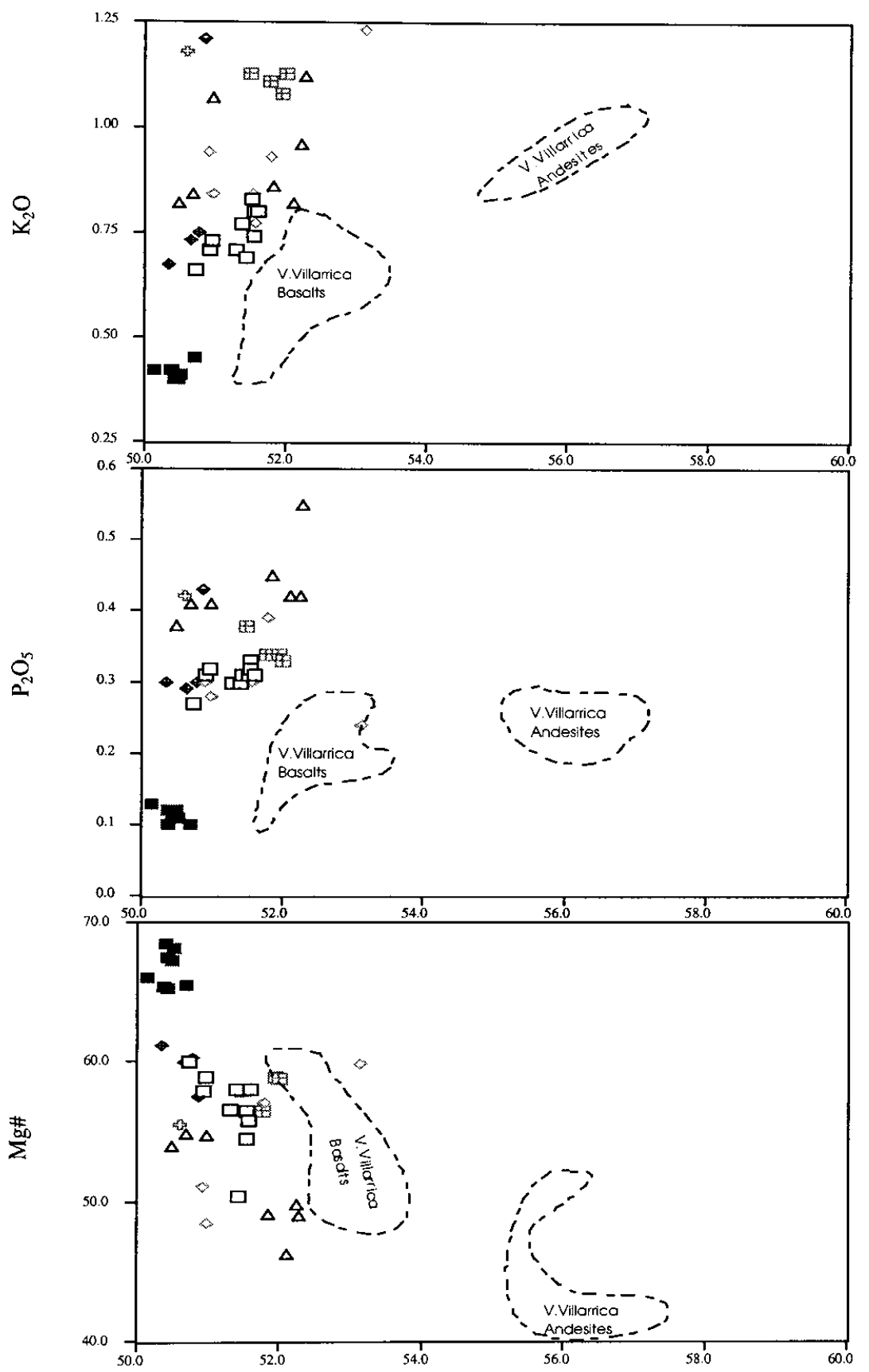

$\mathrm{SiO}_{2}$

Fig. 3.2.1b Oxide $-\mathrm{SiO}_{2}$ for samples from SEC Cerro Redondo, San Jorge, La Barda, Huelemolle, Caburgua, Huililco, Pichares and Relicura 

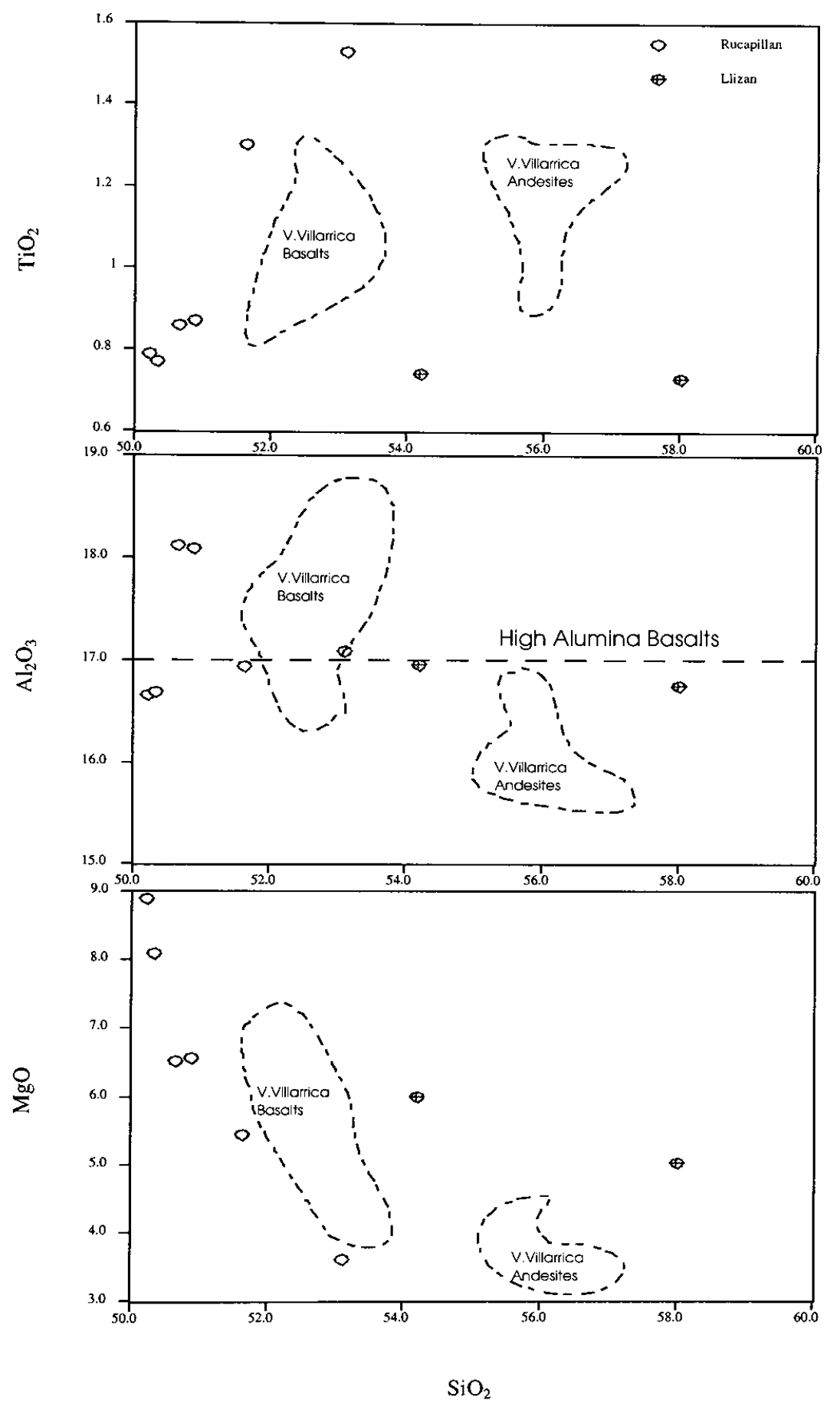

Fig. 3.2.1c Oxide - $\mathrm{SiO}_{2}$ for samples from SEC Rucapillan (including El Estadio) and Llizan (continued) 


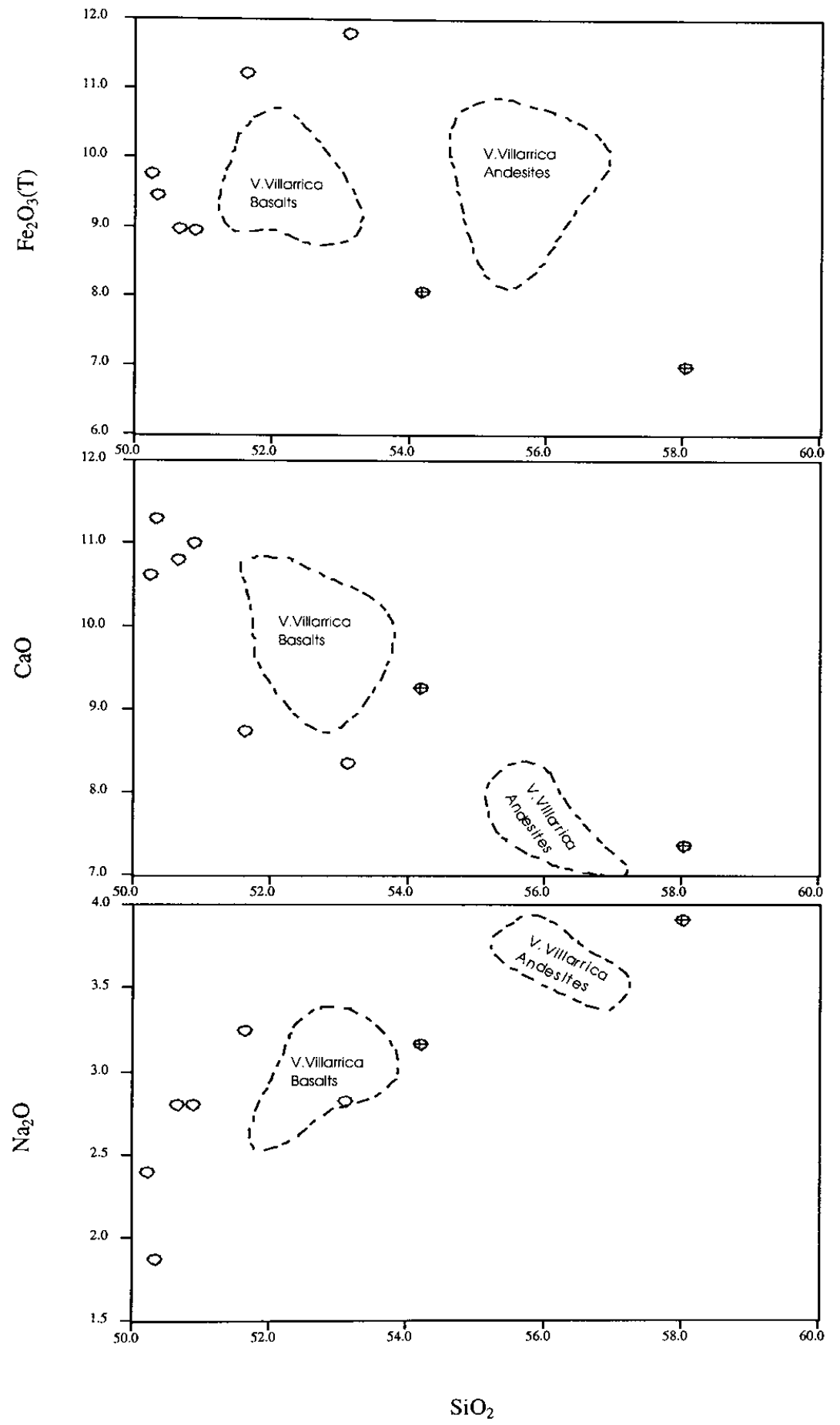

Fig. 3.2.1c Oxide $-\mathrm{SiO}_{2}$ for samples from SEC Rucapillan (including El Estadio) and Llizan (continued) 

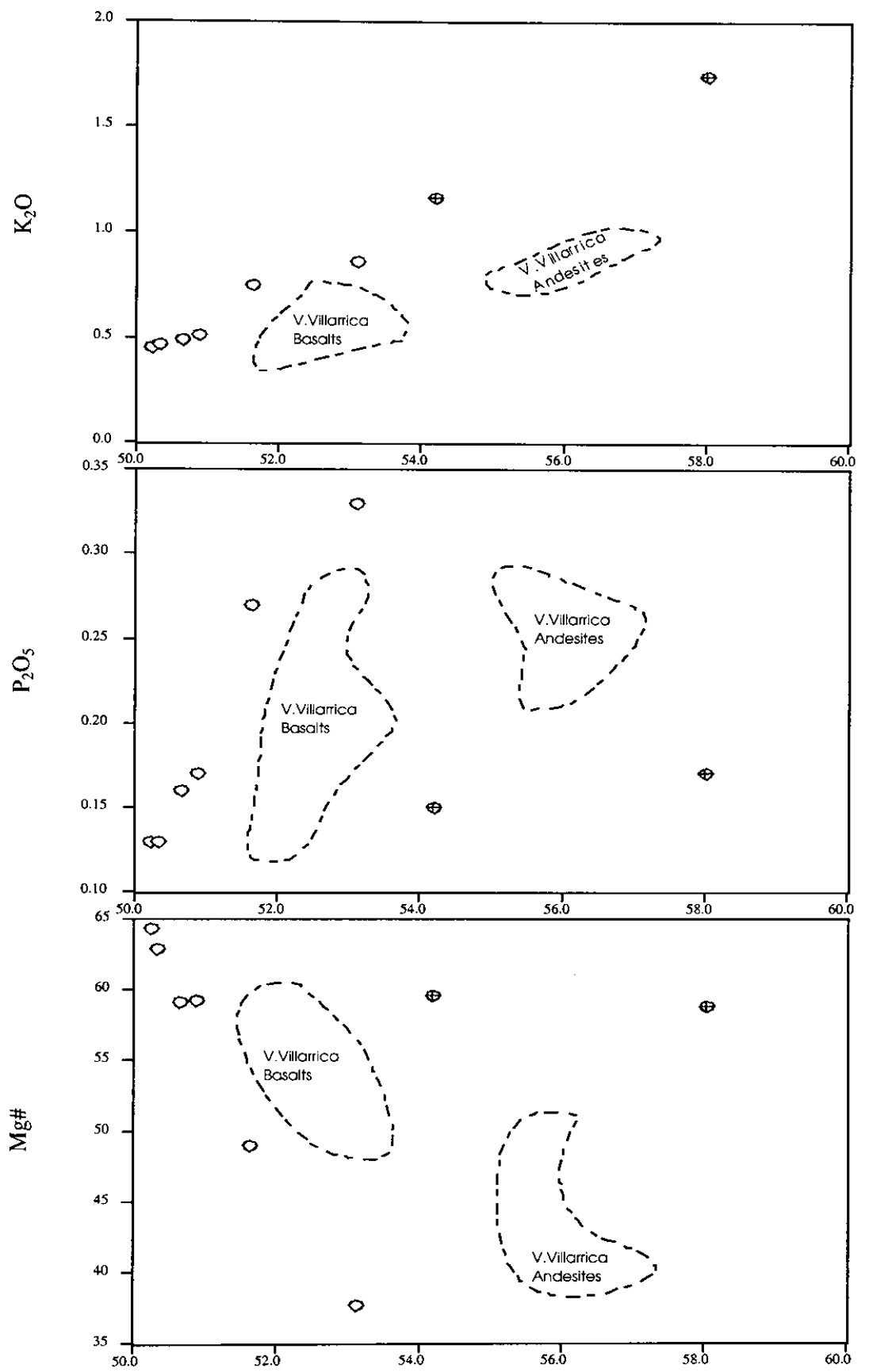

$\mathrm{SiO}_{2}$

Fig. 3.2.1c Oxide - $\mathrm{SiO}_{2}$ for samples from SEC Rucapillan (including El Estadio) and Llizan 
Most SEC and V.Villarrica samples are typical high - alumina basalts $(\geq 17 \mathrm{wt} \%$ $\mathrm{Al}_{2} \mathrm{O}_{3}$ ) (HABs) (Irvine and Baragar, 1971) with an average $\mathrm{Al}_{2} \mathrm{O}_{3}$ of 17.26 wt\% (Fig.3.2.1a, b and c). The SEC samples have higher $\mathrm{Al}_{2} \mathrm{O}_{3}$ than V.Villarrica samples except for the extremely mafic rocks from SEC San Jorge and Rucapillan $(<17 \%)$. More than half of the V.Villarrica basalts have $\mathrm{Al}$ contents as low as the latter. The two samples with the highest $\mathrm{Al}_{2} \mathrm{O}_{3}$ contents are from SEC Cerro Redondo.

Most SEC basalts also show higher $\mathrm{Na}_{2} \mathrm{O}$ and $\mathrm{K}_{2} \mathrm{O}$ but lower $\mathrm{CaO}$ contents than V.Villarrica basalts. In addition to higher $\mathrm{Al}_{2} \mathrm{O}_{3}$ contents, SEC basalts are more enriched with alkalis, probably due to greater plagioclase accumulation or less plagioclase fractionation (plagioclase suppression). In this case, less plagioclase crystallization is favored because microscopic studies (see Chapter 2 and Appendix 2) revealed that the SEC basalts generally have lower abundances of plagioclase phenocrysts compared with V.Villarrica basalts.

All of the SEC and V.Villarrica basalts belong to the calc - alkaline series on the AFM diagram (Irvine and Baragar, 1971) as expected in a continental arc tectonic environment, although the unusually mafic rocks from SEC San Jorge and Rucapillan tend to shift slightly away from the alkali apex (higher proportions of olivine or cpx phenocrysts) (Fig. 3.2.2).

Basaltic rocks from V.Villarrica and the SECs fall mostly in the medium - K series (Fig.3.2.3). The V.Villarrica samples have a slightly lower $\mathrm{K}$ content compared with the SECs at a given $\mathrm{SiO}_{2} \%$, except for the mafic rocks from San Jorge and Rucapillan. 


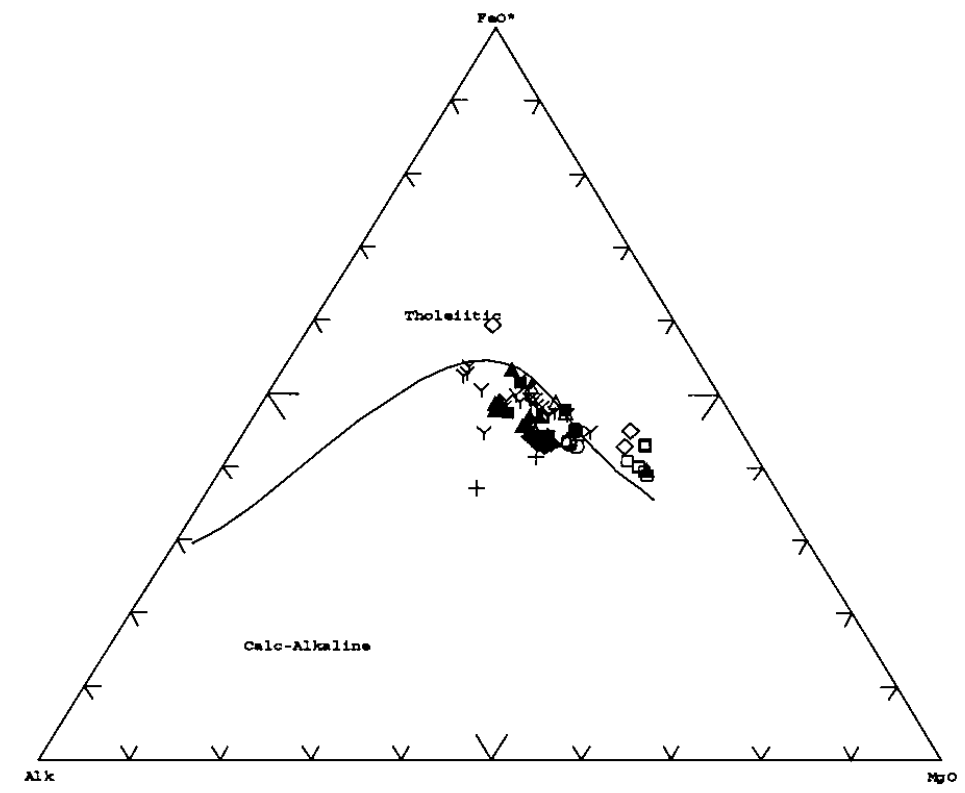

- C. Redondo

$\square$ San Jorge

- El Estadio

O La Barda

A Huelemolle

$\triangle$ Caburgua

- Huililco

$\diamond$ Rucapillan

+ Llizan

* Relicura+

Y Villarrica

Fig. 3.2.2 AFM diagram for the V.Villarrica and SEC basalts (Irvine and Baragar, 1971) 


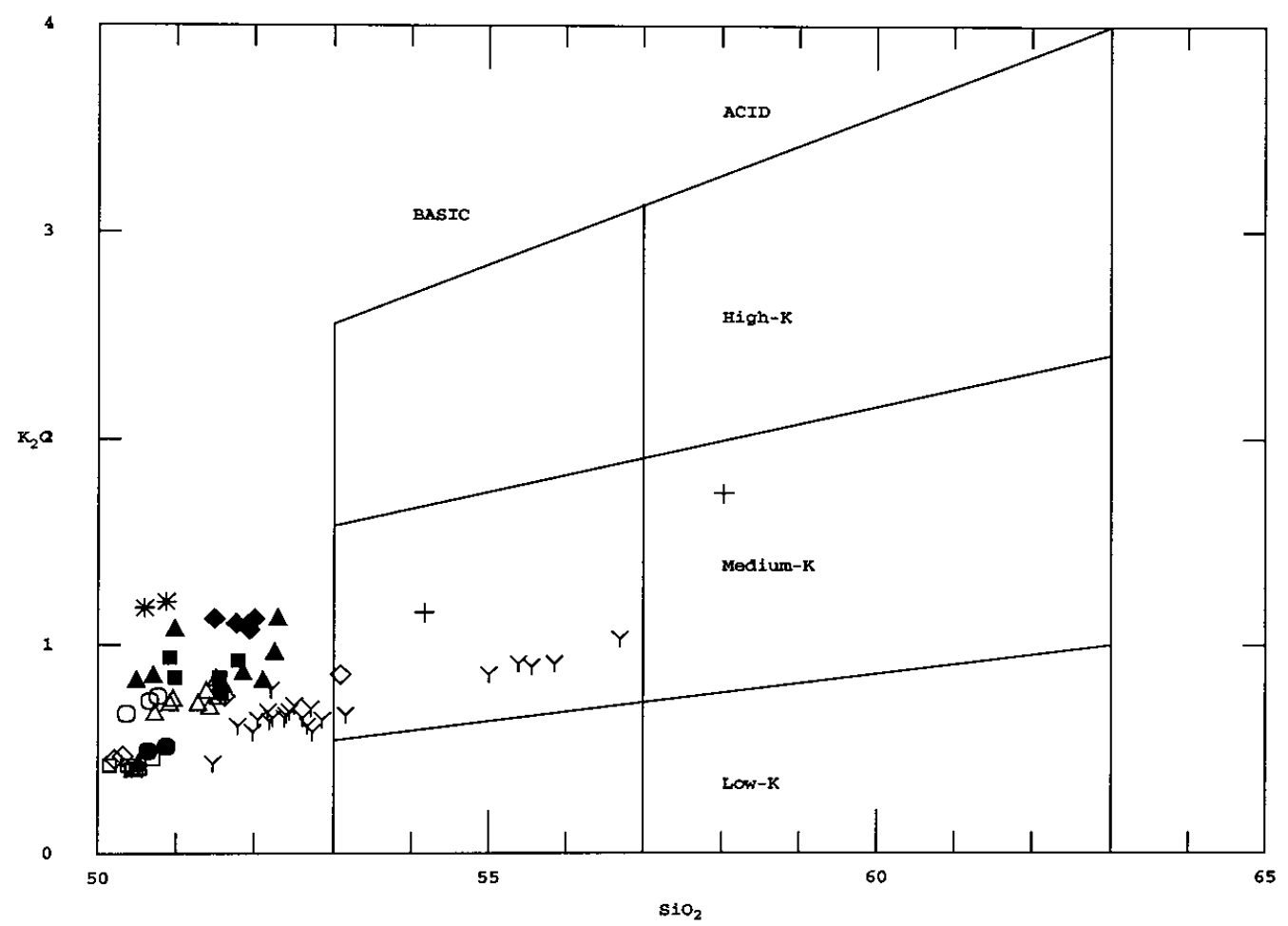

Fig. 3.2.3 $\mathrm{K}_{2} \mathrm{O}$ versus $\mathrm{SiO}_{2}$ for the V.Villarrica and $\mathrm{SEC}$ basalts (same symbols are used as shown in Fig.3.2.2) 


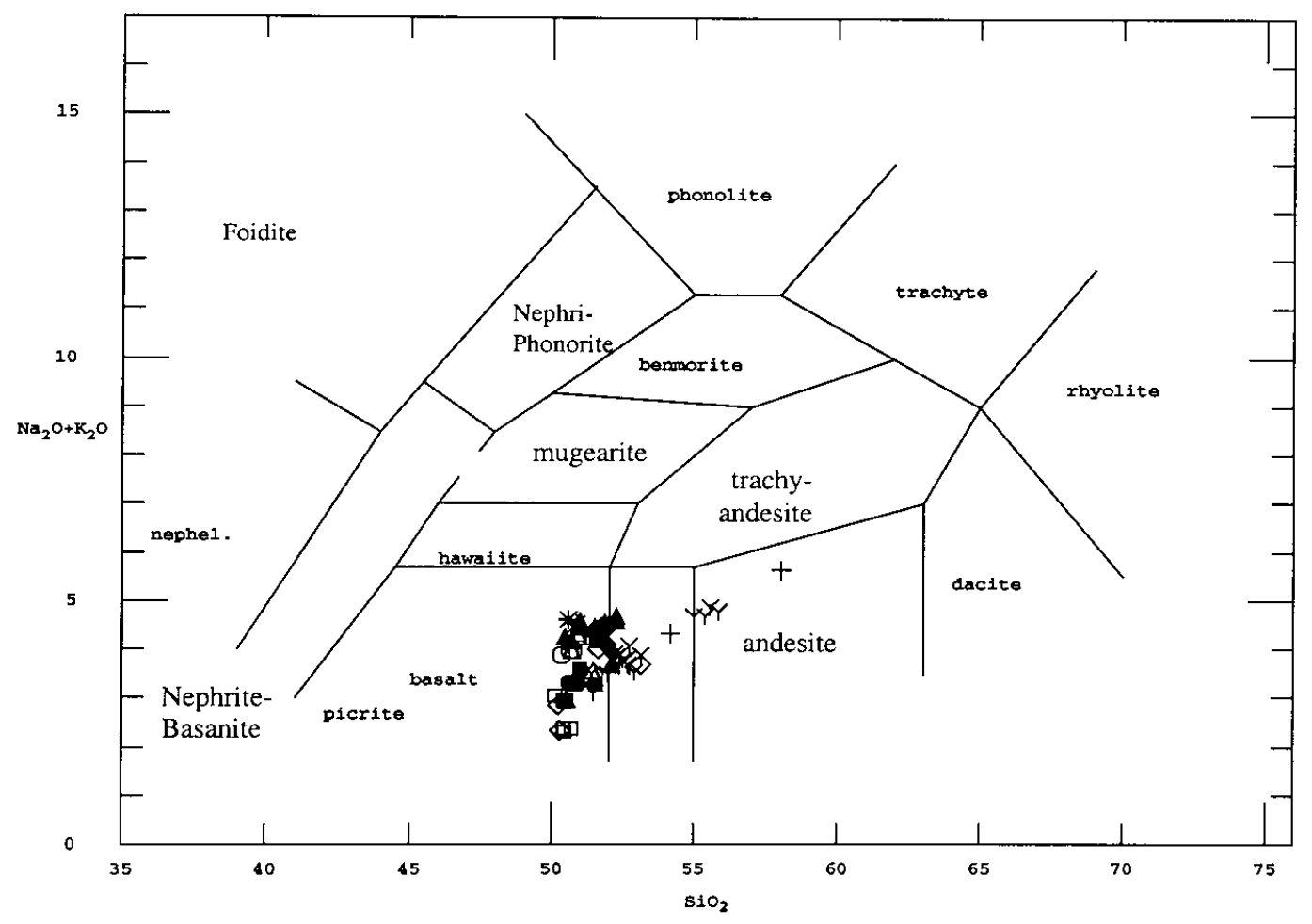

Fig. 3.2.4 $\mathrm{Na}_{2} \mathrm{O}+\mathrm{K}_{2} \mathrm{O}$ versus $\mathrm{SiO}_{2}$ for the V.Villarrica and SEC basalts (same symbols are used as shown in Fig.3.2.2) (Le Bas et al., 1986) 
On the $\mathrm{Na}_{2} \mathrm{O}+\mathrm{K}_{2} \mathrm{O}$ versus $\mathrm{SiO}_{2}$ diagram (Le Bas et al., 1986), these typical basalts and basaltic andesites show a wedge - shaped distribution, meaning that there is a larger variation of the alkali elements at the more mafic instead of the more felsic end of the chemical composition of these samples (Fig.3.2.4). 


\subsection{Trace Element Results}

Based on petrography (Chapter 2 and Appendix 2), the typical phenocryst assemblages in V.Villarrica and the SEC basalts are olivine + plagioclase ( \pm pyroxene). I consider elements compatible (bulk partition coefficient D > =1) (Rollinson, 1983) and incompatible (bulk partition coefficient $\mathrm{D}<1$ ) based on their geochemical behaviors during crystallization of this mineral assemblage. Trace element data (ICPES and ICPMS) are listed in Table $3-2$ and Table 3-5a of Appendix 3. Trace element results of V.Villarrica samples used in this work are from Hickey - Vargas et al. (1989). In the present study, five V.Villarrica samples were reanalyzed by ICPMS and the results are shown in Table $3-5 \mathrm{c}$ of Appendix 3. 


\subsubsection{Compatible elements}

Elements that are compatible for the crystallizing assemblage of olivine clinopyroxene - plagioclase are $\mathrm{Ni}, \mathrm{Cr}, \mathrm{Sc}, \mathrm{Sr}, \mathrm{Zn}$ and $\mathrm{V}$. The variations of the above elements versus $\mathrm{SiO}_{2}$ are shown in Fig. 3.3.1.

The $\mathrm{Ni}$ and $\mathrm{Cr}$ abundances range from $20-380 \mathrm{ppm}$ and $10-900 \mathrm{ppm}$, respectively, in basalts $\left(<52 \% \mathrm{SiO}_{2}\right)$ from V.Villarrica and the SECs. Abundances decrease sharply with increasing $\mathrm{SiO}_{2}$ within this range. Among the more differentiated samples $\left(52-58 \% \mathrm{SiO}_{2}\right), \mathrm{Cr}$ and $\mathrm{Ni}$ contents vary irregularly: in andesites from V.Villarrica, Ni decreases to $\sim 20 \mathrm{ppm}$ and $\mathrm{Cr}$ to $10-20 \mathrm{ppm}$, whereas andesites from the SEC Llizan have higher contents of $\mathrm{Ni}(50-80 \mathrm{ppm})$ and $\mathrm{Cr}(\sim 300 \mathrm{ppm})$. 

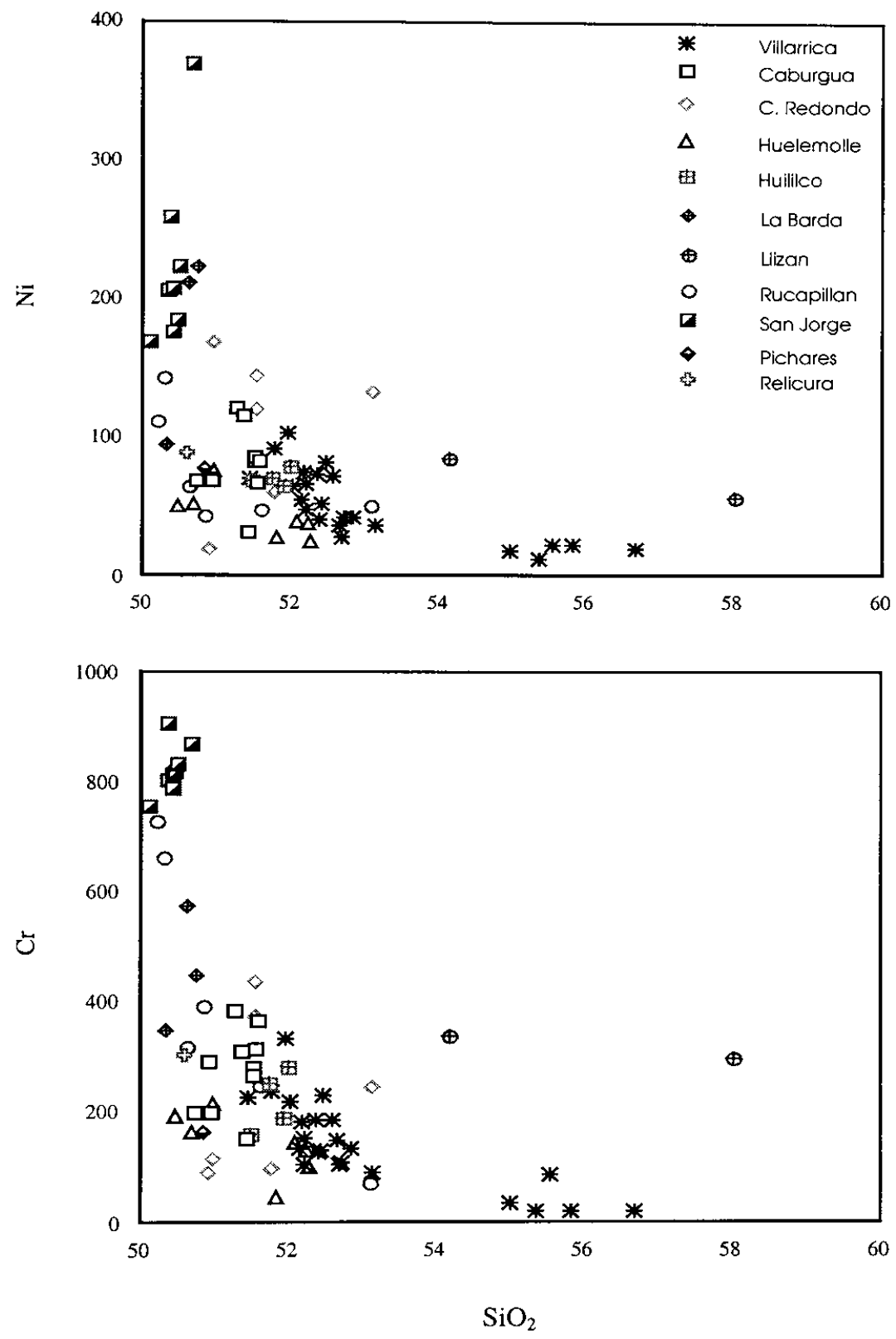

Fig.3.3.1 Compatible elements versus Silica for the V.Villarrica and SEC samples (continued) 

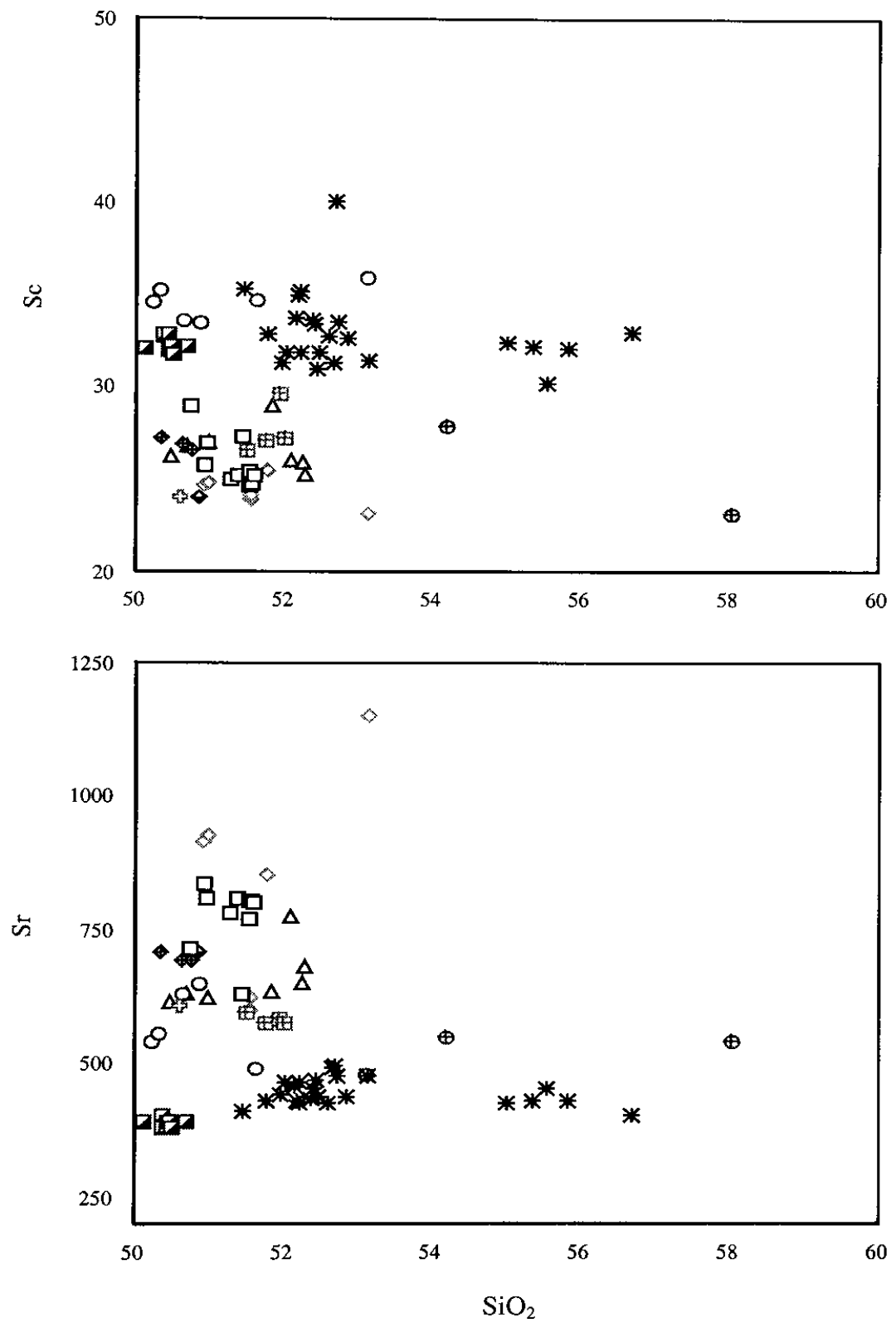

Fig.3.3.1 Compatible elements versus Silica for the V.Villarrica and SEC samples (continued) 

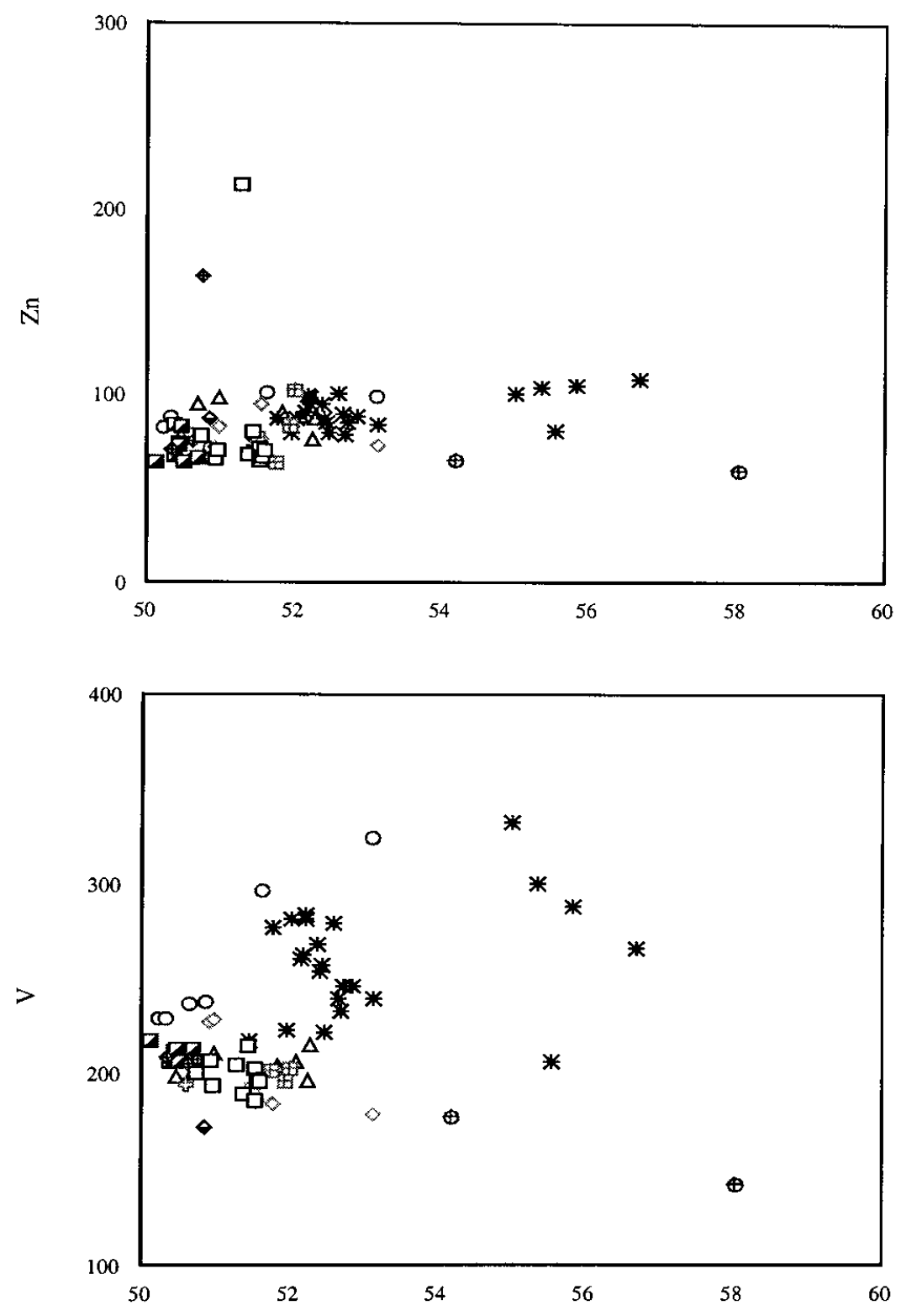

$\mathrm{SiO}_{2}$

Fig.3.3.1 Compatible elements versus Silica for the V.Villarrica and SEC samples 
Sc, Sr, $\mathrm{Zn}$ and $\mathrm{V}$ have relatively uniform abundances in the V.Villarrica suite, through the range from basalts to andesites (Fig. 3.3.1 and Hickey - Vargas et al., 1989). Compared with these trends, most of the SEC basalts (all but Rucapillan and San Jorge) have lower $\mathrm{Sc}$ and $\mathrm{V}$ contents including the differentiated samples. In contrast, $\mathrm{Sr}$ abundances of the SEC samples (except those from San Jorge) are mostly above 500 ppm, higher than the V.Villarrica samples (mostly $400-500$ ppm). Zn abundances show very little variations except one sample from SEC Caburgua that has an extremely high content of $\mathrm{Zn}$.

For the six samples from Rucapillan and El Estadio, contents of $\mathrm{Ni}$ and $\mathrm{Cr}$ decrease while their contents of $\mathrm{V}$ increase along with the increase of $\mathrm{SiO}_{2}$. The contents of $\mathrm{Sc}, \mathrm{Zn}$ and $\mathrm{Sr}$ vary between the basalts and basaltic andesites, but all are higher than those of the V.Villarrica samples. 


\subsubsection{Incompatible elements}

Incompatible elements are generally divided into large ion lithophile elements (LILE) (Fig.3.3.2a), high field strength elements (HFSE) (Fig.3.3.2b) and rare earth elements (REE) (Fig.3.3.2c).

\subsection{2a Large ion lithophile elements (Rb, $C s, B a$ and $P b)$ :}

Cs contents in V.Villarrica basalts range from 1.5 - 1.7 ppm compared with < $1.5 \mathrm{ppm}$ in the $\mathrm{SEC}$ basalts. In contrast, $\mathrm{Rb}, \mathrm{Pb}$ and especially $\mathrm{Ba}$ contents are higher in SEC basalts compared with the V.Villarrica basalts $\left(<52 \% \mathrm{SiO}_{2}\right)$. Mafic rocks from Rucapillan + San Jorge stand out in having the lowest $\mathrm{Ba}, \mathrm{Pb}$ and $\mathrm{Rb}$ contents, but similar Cs to the other SEC samples.

Basaltic andesites and andesites from V.Villarrica have $\mathrm{Cs}, \mathrm{Rb}, \mathrm{Pb}$ and $\mathrm{Ba}$ contents ranging from $1.6-2 \mathrm{ppm}, 18-26 \mathrm{ppm}, 8-10 \mathrm{ppm}$ and $250-290 \mathrm{ppm}$, respectively. Andesitic samples from the most evolved SEC - Llizan, have higher contents of all these elements.

\subsection{2b High field strength elements ( $\mathrm{Nb}, \mathrm{Ta}, \mathrm{Zr}, \mathrm{Hf}, \mathrm{U}$ and $\mathrm{Th})$ :}

All of the HFSE contents are lower in V.Villarrica basalts than in the SEC basalts, except for the samples from San Jorge and Rucapillan. The basaltic andesites from SEC Llizan are more enriched in HFSEs than V.Villarrica basaltic andesites. Enrichment in U and Th is also extremely pronounced in the former. Basaltic samples from San Jorge and Rucapillan have the lowest contents of the HFSEs of all the SECs. 

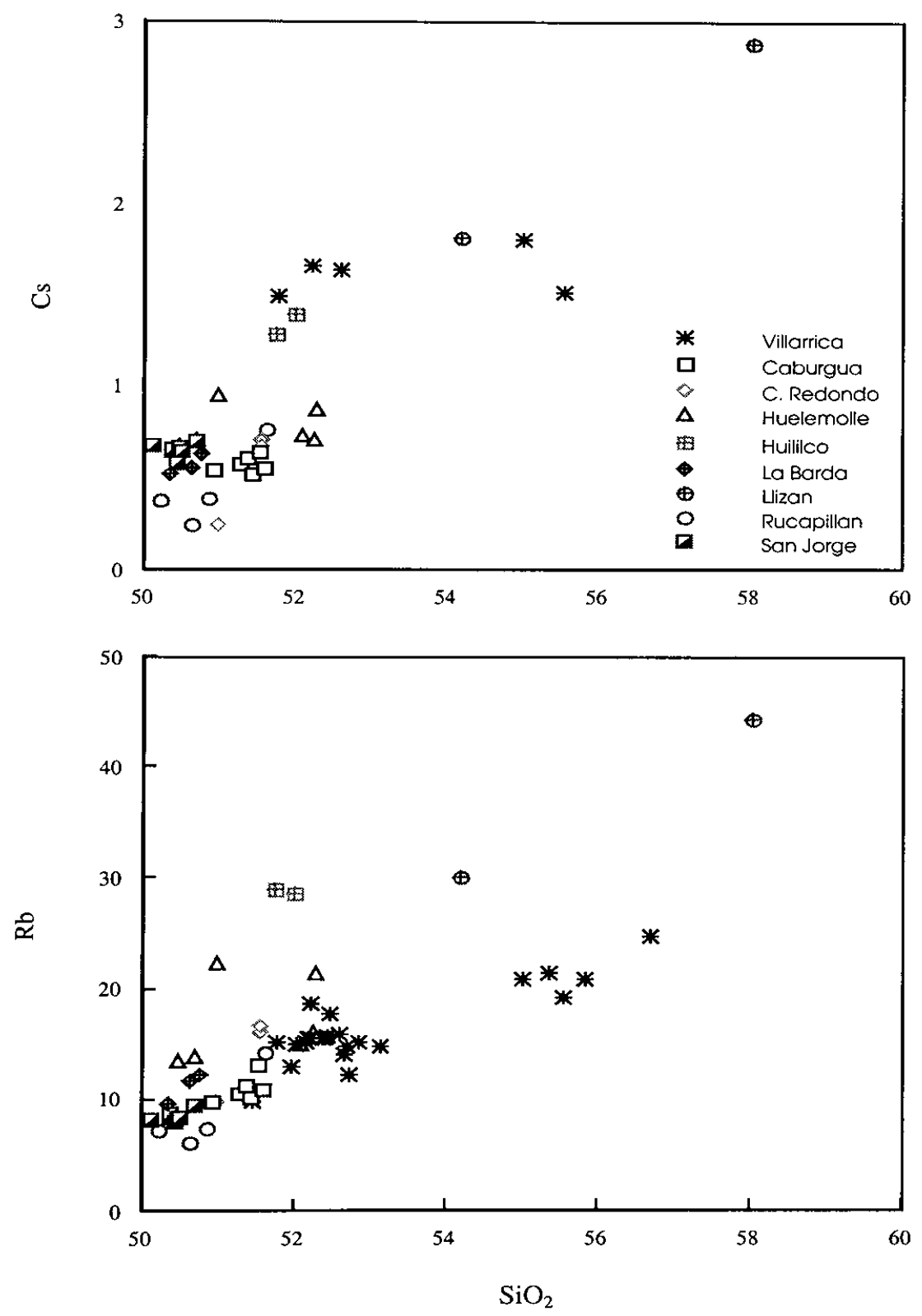

Fig.3.3.2a LILEs versus Silica for the V.Villarrica and SEC samples (continued) 

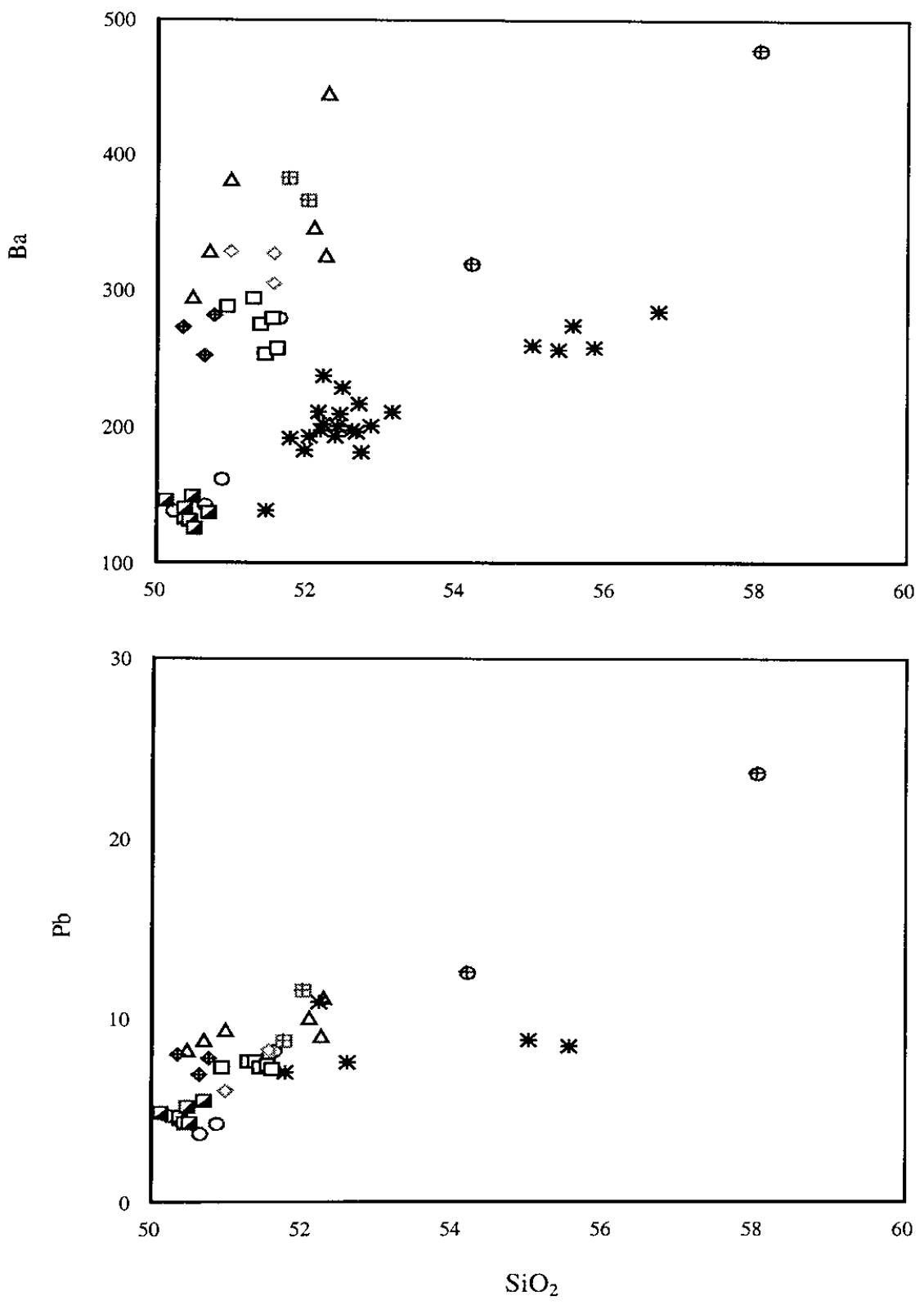

Fig.3.3.2a LILEs versus Silica for the V.Villarrica and SEC samples 

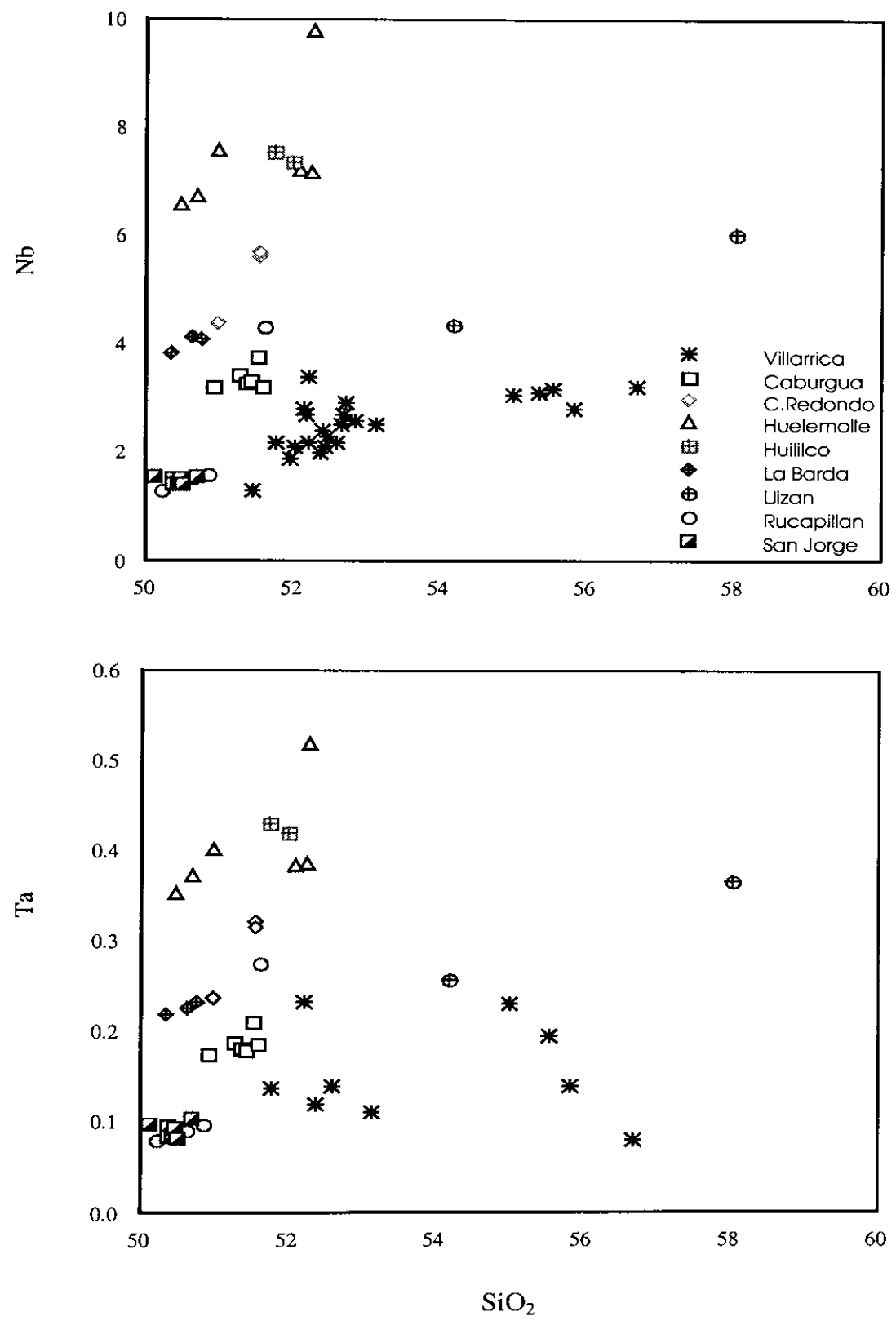

Fig.3.3.2b HFSEs versus Silica for the V.Villarrica and SEC samples (continued) 

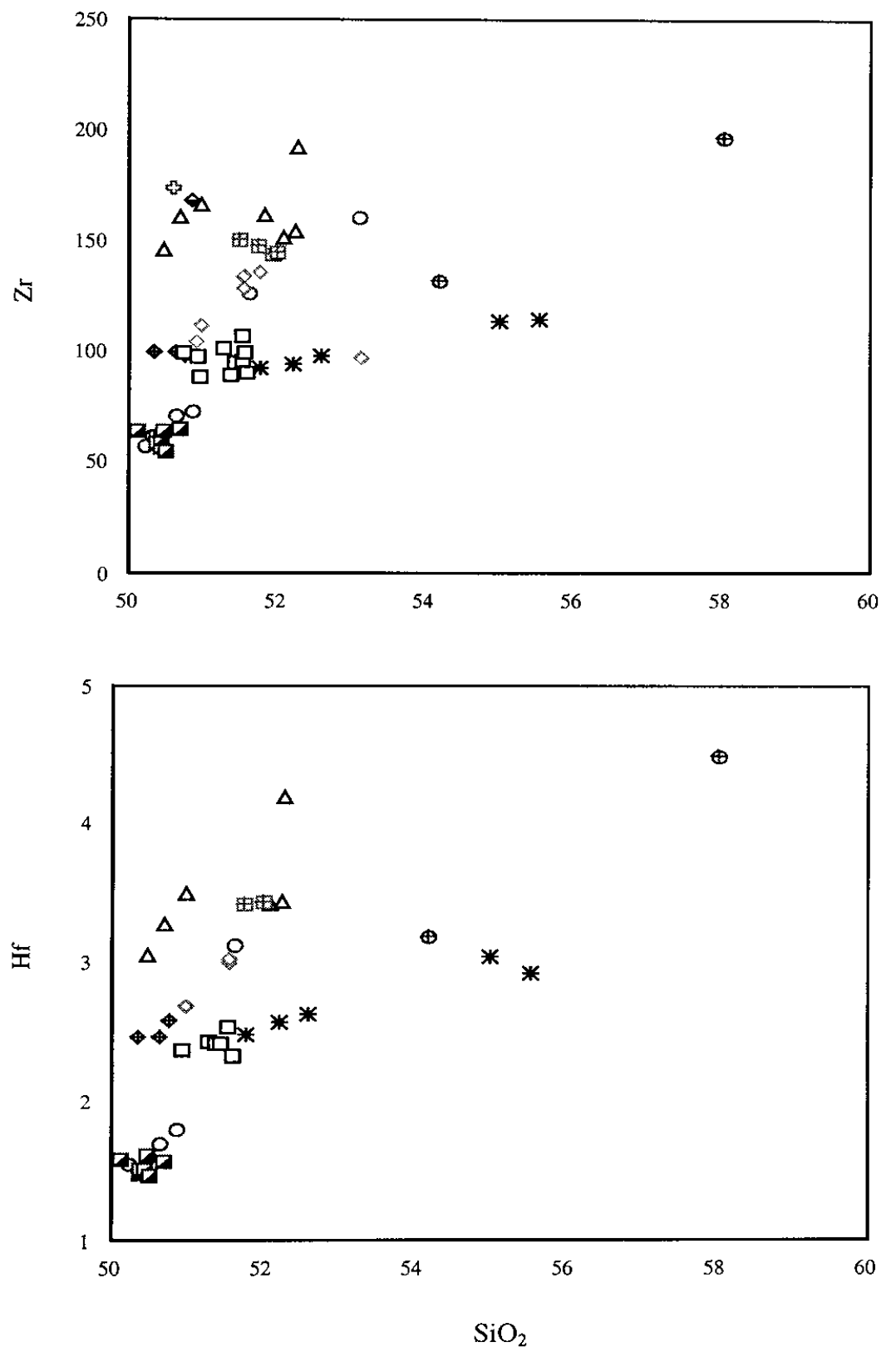

Fig.3.3.2b HFSEs versus Silica for the V.Villarrica and SEC samples (continued) 

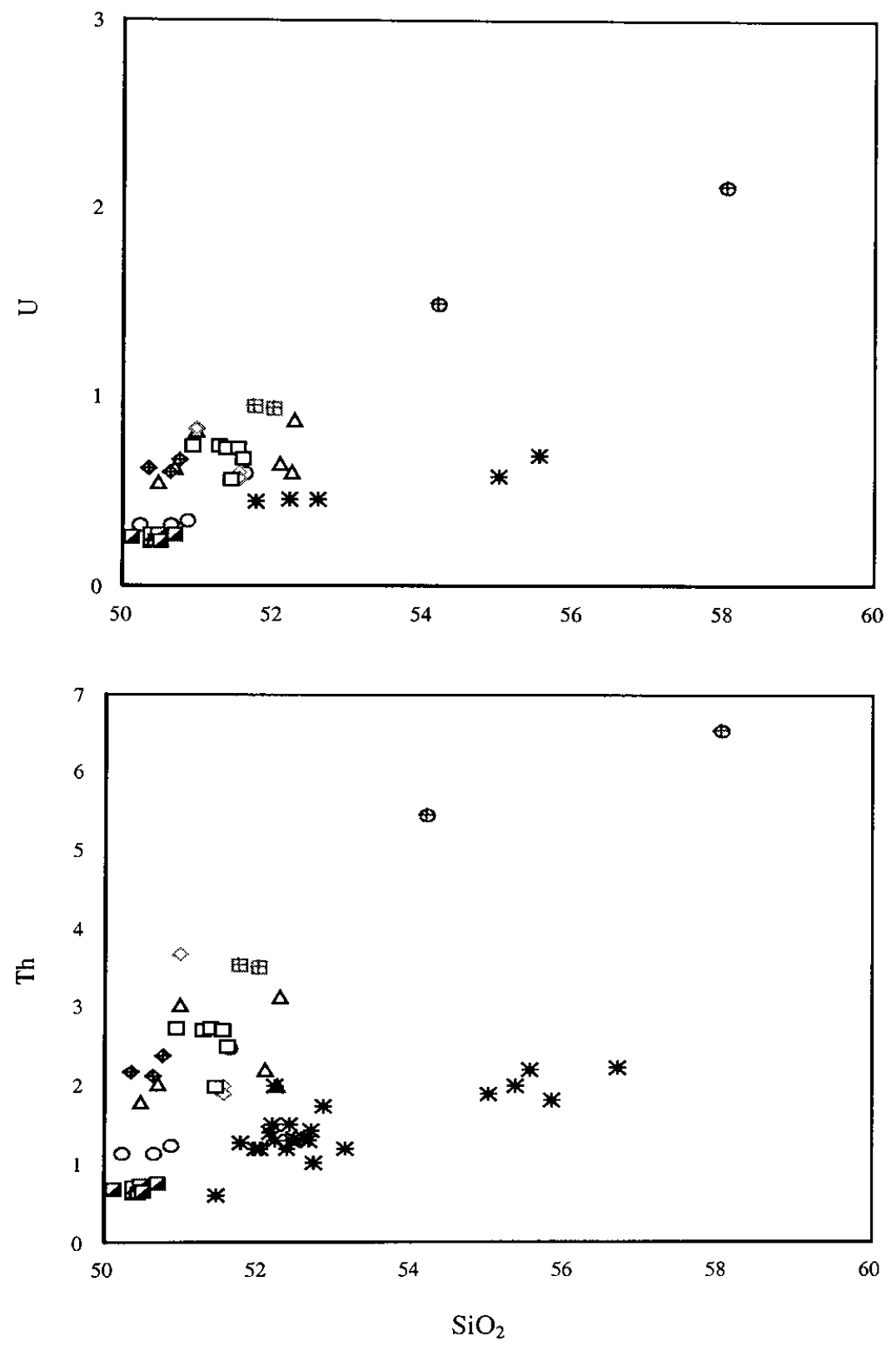

Fig.3.3.2b HFSEs versus Silica for the V.Villarrica and SEC samples 

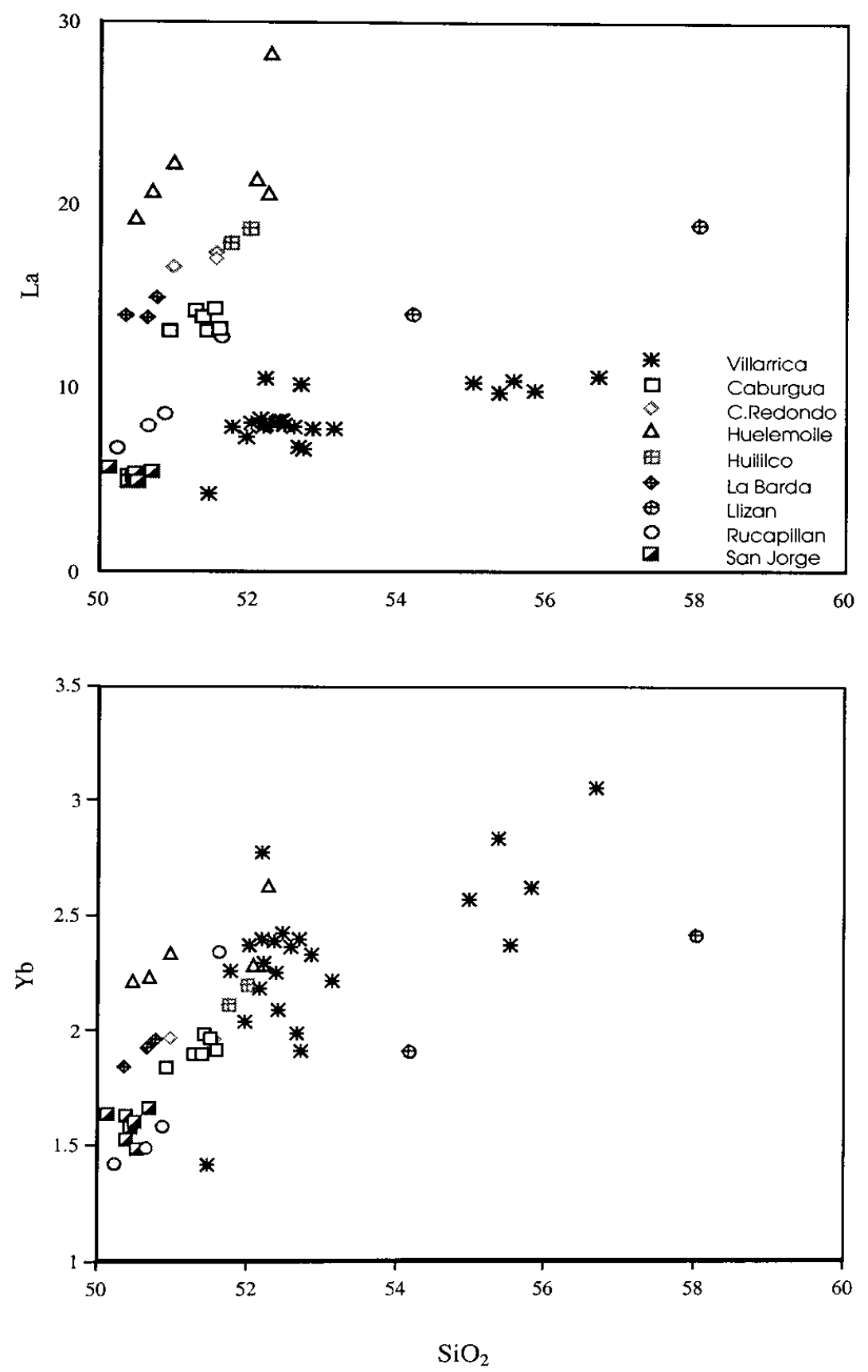

Fig.3.3.2c REEs versus Silica for the V.Villarrica and SEC samples 


\subsection{2c Rare earth elements (La, Yb or Y):}

As shown in Fig.3.3.2c, La (LREE) contents are lower in both V.Villarrica basalts $(<10 \mathrm{ppm})$ and basaltic andesites $(10-11 \mathrm{ppm})$ as compared to the SECs, except for San Jorge and Rucapillan. La contents in Llizan andesites are higher $(10-20 \mathrm{ppm})$ than in V.Villarrica andesites. In contrast, $\mathrm{Yb}$ (HREE) contents of V.Villarrica basalts are similar to the $\mathrm{Yb}$ contents of the SEC basalts. The $\mathrm{Yb}$ or HREE contents of V.Villarrica basaltic andesites are even slightly higher than those of the Llizan andesites. 


\subsubsection{REE - patterns}

Primitive mantle - normalized REE patterns are shown as follows (Fig.3.3.3.1a: V.Villarrica basalts - ICPMS data from this work only; Fig.3.3.3.1b: samples from San Jorge and Llizan; Fig.3.3.3.2c: samples from Rucapillan including El Estadio; Fig.3.3.3.2d: samples from SECs - Caburgua, C. Redondo, Huelemolle, Huililco and La Barda). Reference data of primitive mantle is from Sun and McDonough (1989).

Samples from V.Villarrica have LREE - enriched patterns with slight negative Eu anomalies. Among the five samples measured by ICPMS, three $-280976-1,191284-1$ and $210281-1$ are quite similar, while the andesitic sample $151282-3$ has higher REE, and is more LREE - enriched. Sample 151282 - 2 has La, Ce, Pr and Nd contents similar to the former but all the other rare earth element compositions similar to the latter, so it has the steepest pattern $(\mathrm{La} / \mathrm{Yb})$ of the five. 
a)

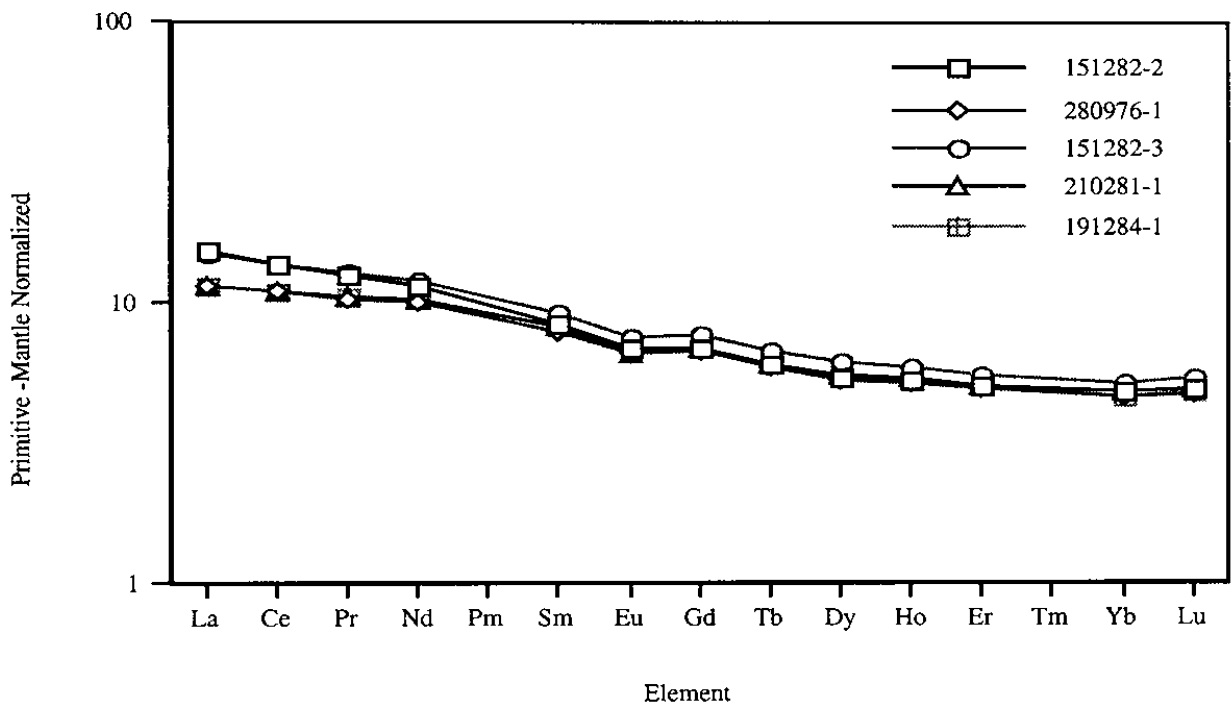

b)

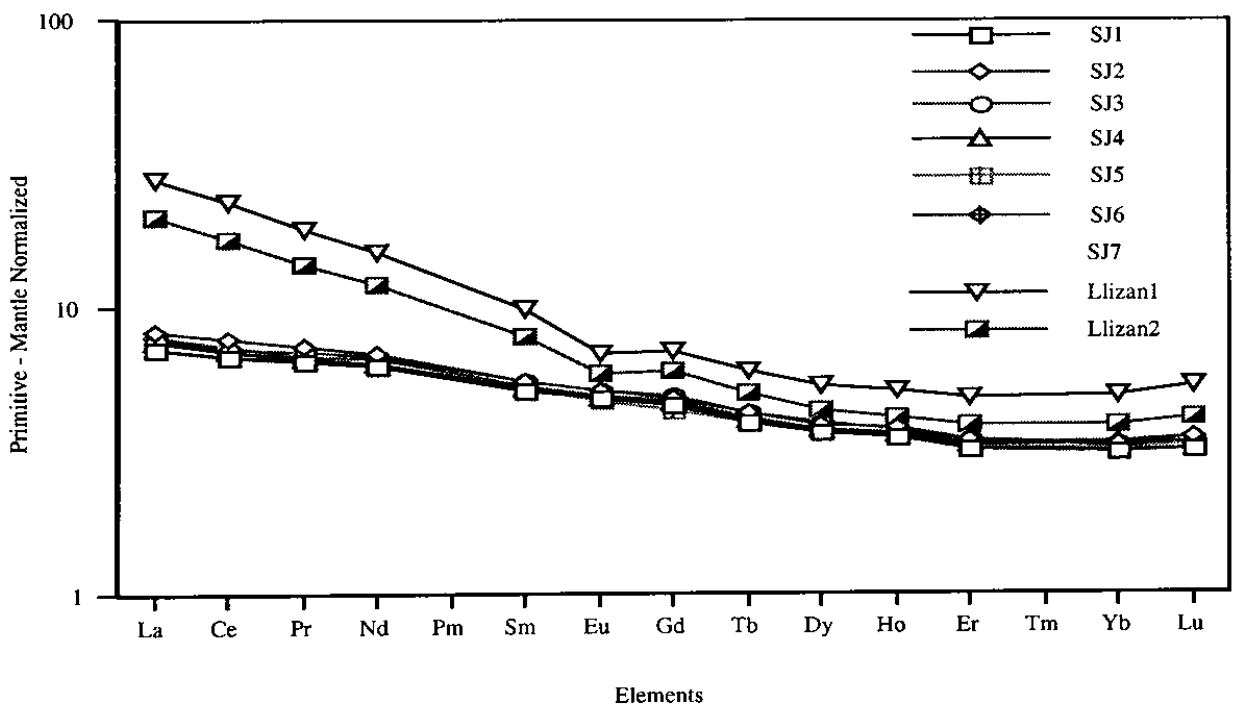

Fig.3.3.3.1 (a\&b) REE patterns of the V.Villarrica (upper) and San Jorge + Llizan (lower) samples 
c)

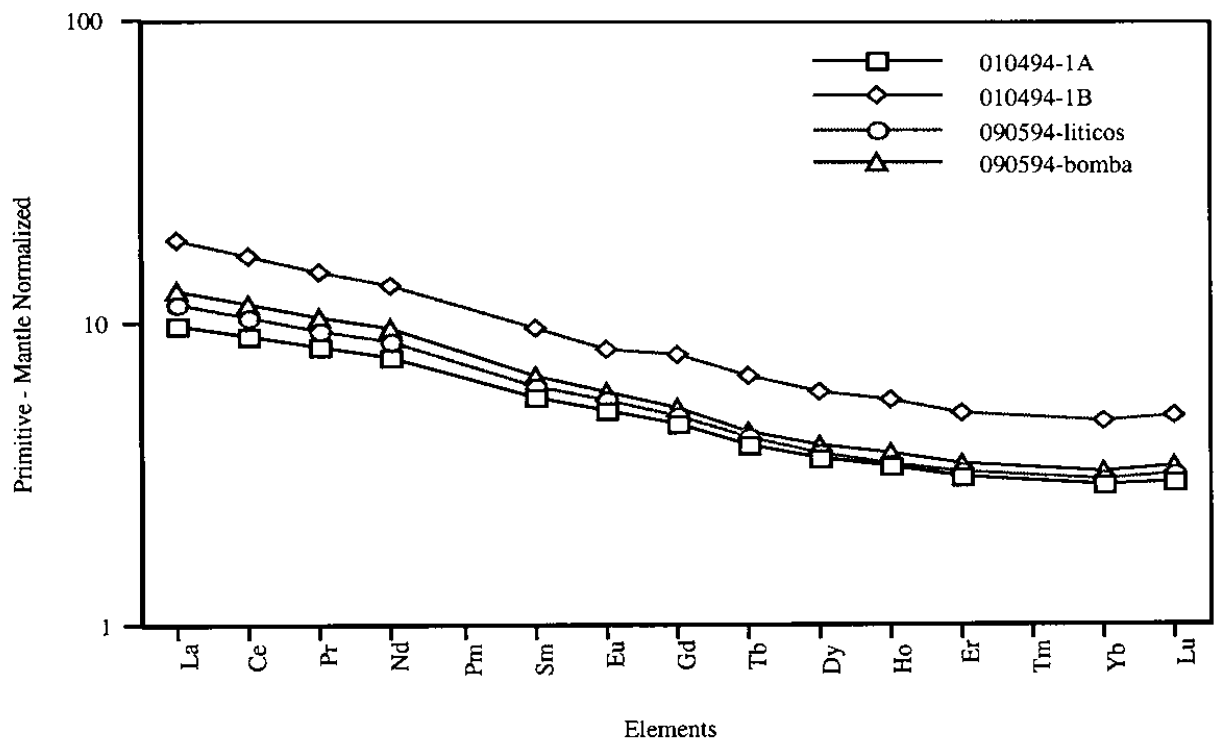

d)

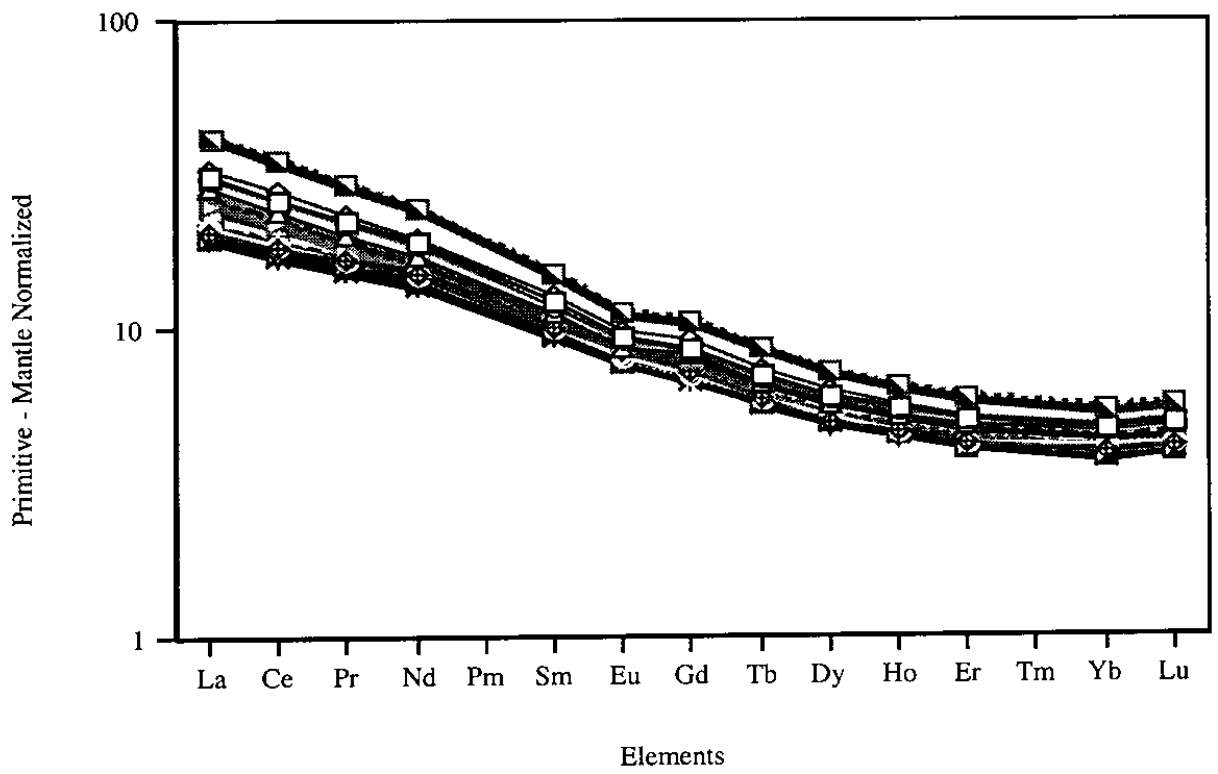

Fig.3.3.3.2 (c\&d) REE patterns of the Rucapillan (upper) and other SEC (lower) samples 
The SEC basalts are much more LREE - enriched than the V.Villarrica samples, with smaller Eu - anomalies (Fig.3.3.3d). Twenty samples from SEC Caburgua, Cerro Redondo, Huelemolle, Huililco and La Barda are plotted, and their REE patterns define a uniform field. Huelemolle basalt - 110194 - 01 (MEC - 1) has unusually high REE and incompatible element abundances.

The seven high - MgO basalts from SEC San Jorge exhibit a REE pattern that is sub - parallel to, but lower than those of the V.Villarrica samples. San Jorge basalts do not show any Eu anomaly.

Three samples from Rucapillan - including two from El Estadio (one of the three Rucapillan cones) and the Rucapillan porphyritic sample 010494 - 1A, have LREE enriched REE patterns with greater LREE enrichment than the V.Villarrica samples, but lower than the other SECs. The most silicic sample from Rucapillan, 010494 - 1B, plots above the other three samples, showing its much higher abundances of all the rare earth elements.

SEC Llizan, which has the most silicic samples of all the SECs, has LREE enriched patterns like other SECs, but with larger negative Eu anomalies.

On the primitive - mantle normalized $\mathrm{La} / \mathrm{Yb}$ and $\mathrm{La} / \mathrm{Sm}$ ratio diagrams (Fig.3.3.4), the SEC basalts other than San Jorge have higher La/Yb (LREE/HREE) ratios (3 - 8), while the V.Villarrica samples mainly have $\mathrm{La} / \mathrm{Yb}$ less than 3 . The $\mathrm{La} / \mathrm{Sm}$ ratio is also relatively higher for the SECs $(1.5-3$ for most of them, with Cerro Redondo the highest - up to 4), but lower for V.Villarrica $(<2)$. Samples from Cerro Redondo, Huelemolle and Huililco have the highest $\mathrm{La} / \mathrm{Yb}$ and $\mathrm{La} / \mathrm{Sm}$ ratios among the SEC 
samples, while samples from Rucapillan (porphyritic) and San Jorge are extremely low on both ratios.

Fig.3.3.5 shows primitive mantle normalized trace element abundances of selected samples of the V.Villarrica and SEC basalts. All these samples have the enrichment of the LILEs, $\mathrm{Sr}$ and $\mathrm{Pb}$ and depletion of $\mathrm{Ta}$ and $\mathrm{Nb}$ compared with the $\mathrm{N}$ type MORB (Sun and McDonough, 1989) that is typical of subduction - related basalts. However, $\mathrm{Nb}$ and $\mathrm{Ta}$ contents are both relatively higher (less depleted) in the SECs compared with V.Villarrica.

In general, the V.Villarrica basalts have higher concentrations of the alkali elements such as $\mathrm{Cs}$ and $\mathrm{Rb}$, and the HREE elements such as $\mathrm{Yb}$ and $\mathrm{Lu}$ compared with the SEC basalts, while the latter are particularly enriched in $\mathrm{Ba}, \mathrm{Th}, \mathrm{U}, \mathrm{Ta}, \mathrm{Nb}, \mathrm{LREE}$ and MREE elements. Patterns for the samples from the mafic SEC San Jorge are basically sub - parallel to the V.Villarrica basalts, but lower in concentration. 

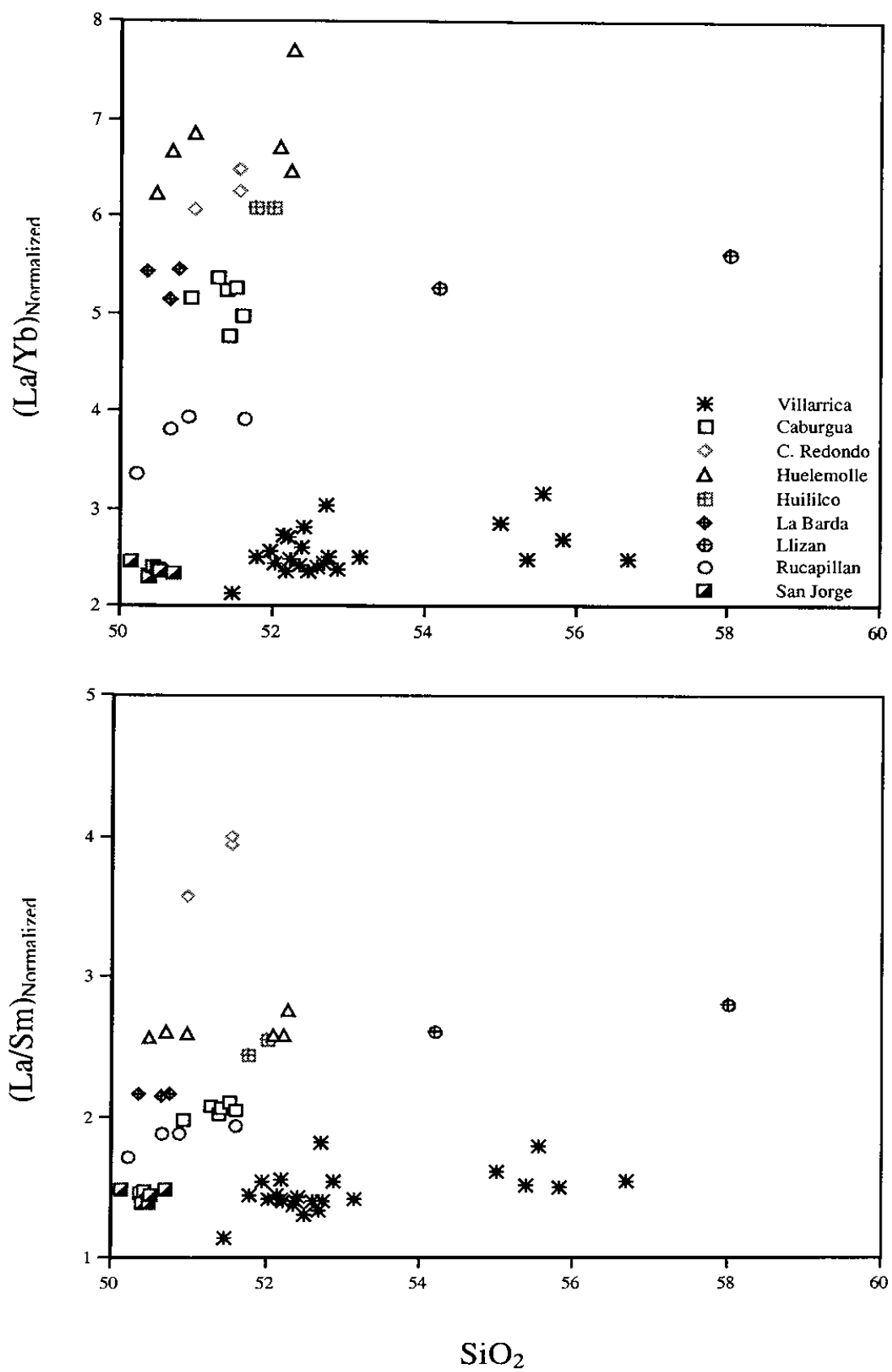

Fig.3.3.4 $(\mathrm{La} / \mathrm{Yb})_{\text {Normalized }}$ (upper) and $(\mathrm{La} / \mathrm{Sm})_{\text {Normalized }}$ (lower) versus $\mathrm{SiO}_{2}$ for the V.Villarrica and SEC samples 


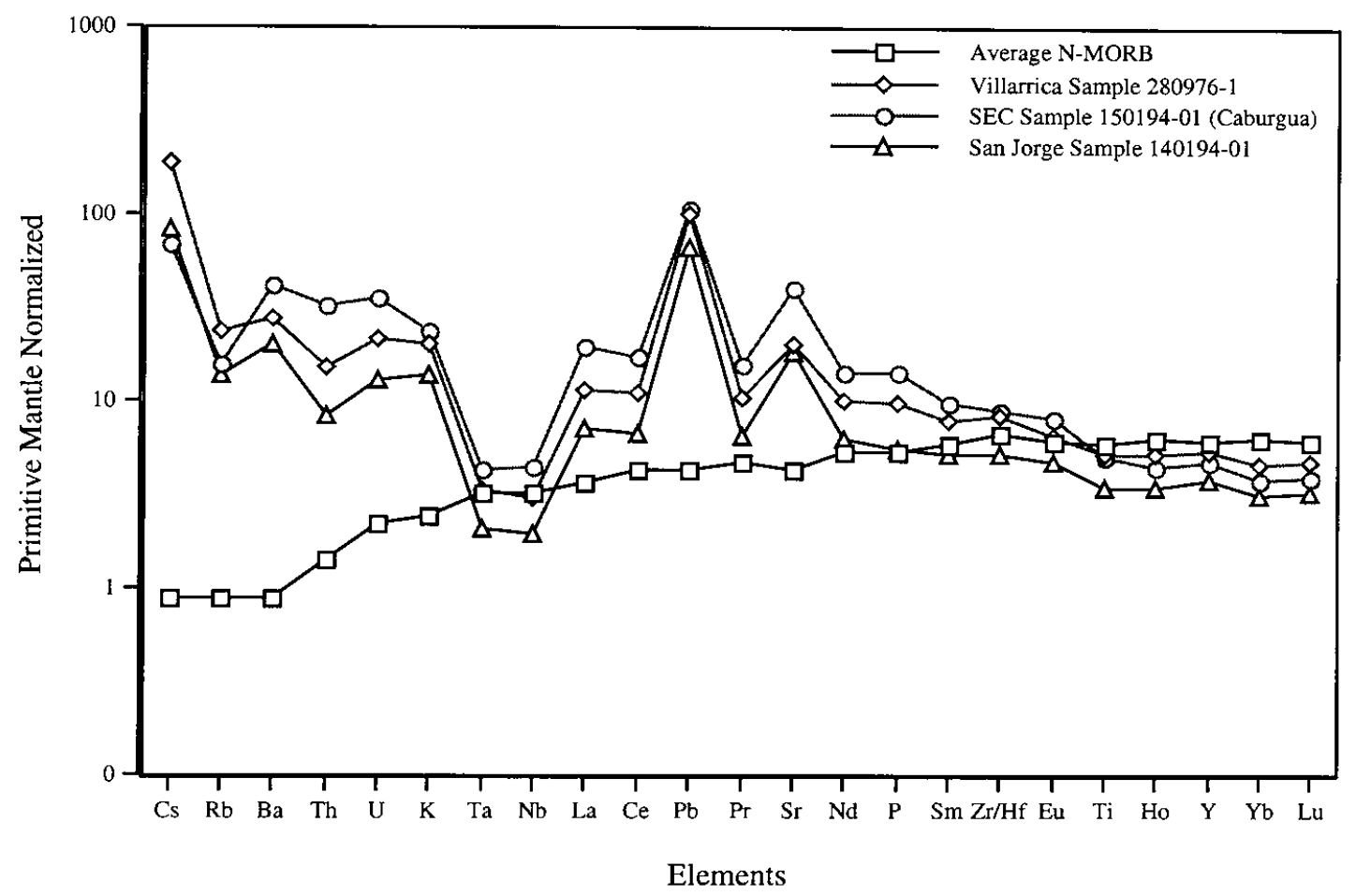

Fig.3.3.5 Normalized trace element abundances in representative basalts from V.Villarrica, San Jorge and Caburgua compared with MORB (Sun and McDonough, 1989) 


\subsection{B - Be - Li variations}

The light elements boron, beryllium and lithium have been used to trace the fluid inputs and the recycling of crustal materials at volcanic arcs (Leeman, 1987; Morris et al., 1990; Ryan and Langmuir, 1993). Data for B, Be and Li contents analyzed in this work are listed in Table $3-7 \mathrm{a}$ (SEC) and Table $3-7 \mathrm{~b}$ (V.Villarrica), Appendix 3. Previous data of B contents for V.Villarrica Basalts (Leeman et al., unpublished; Morris et al., 1990) are listed in Table 1-4, Appendix 1. Samples from V.Villarrica have much higher B contents compared with the SEC basalts (Fig. 3.4.1). Only SEC basalt $110194-02$ from Huelemolle has a B content $(\sim 24 \mathrm{ppm})$ as high as those of the V.Villarrica basalts. All the other SEC basalts have B contents lower than 12ppm, and among them there are no systematic variations of the B contents. The andesitic sample from SEC Llizan has a B content of $\sim 15 \mathrm{ppm}$, higher than the SEC basalts but lower than the V.Villarrica andesitic basalts or andesites.

The V.Villarrica and SEC samples have similar $\mathrm{K}_{2} \mathrm{O}$ contents $(0.4 \%-1.2 \%)$ except the most silicic Llizan sample $(\sim 1.8 \%)$, so their $\mathrm{B} / \mathrm{K}$ (The chemical behavior of $\mathrm{B}$ resembles that of $\mathrm{K}$ ) values are also dramatically different. For the V.Villarrica samples the $\mathrm{B} / \mathrm{K}$ is about 0.003 , while the SECs have their $\mathrm{B} / \mathrm{K}$ ratios of about 0.001 , the average ratio for MORB (Fig.3.4.2).

The ratios of $\mathrm{B}$ to immobile elements $\mathrm{La}$ and $\mathrm{Nb}$ have been used to examine fluid inputs in subduction magmas. The $\mathrm{B} / \mathrm{La}$ variation (Fig.3.4.3) shows the systematic difference between the V.Villarrica and the SEC samples. Despite the large range of the La contents of the SECs, all the SEC samples have a B/La ratio between 0.08 to 1.5 , whereas the V.Villarrica samples show a much higher B/La ratio $~ 3.5$. Similarly, the 
$\mathrm{B} / \mathrm{Nb}$ ratios of the $\mathrm{V}$.Villarrica samples are also significantly higher $(7-13)$ compared to the SEC samples $(\leq 5)$. Within the SECs, basalts from San Jorge have the highest B/Nb ratios $(\sim 5)$.

Beryllium is slightly more compatible than boron, and its chemical behavior resembles that of Nd (Ryan and Langmuir, 1988) (Fig.3.4.4). The Be contents of the V.Villarrica basalts vary from $0.6-0.9 \mathrm{ppm}$, slightly lower than those of the SEC basalts (0.7 - 1.1ppm except the mafic San Jorge and Rucapillan samples). The Be and Nd contents of the SEC basalts vary systematically, with Caburgua and La Barda the lowest, then Cerro Redondo, Huililco and the Huelemolle the highest. Basalts from San Jorge and Rucapillan contain $0.3-0.4 \mathrm{ppm}$ Be. The andesitic sample from Llizan has a higher Be content $(\sim 1.15 \mathrm{ppm})$ than the V.Villarrica andesites $(\sim 0.8 \mathrm{ppm}) . \mathrm{Be} / \mathrm{Nd}$ ratios of the V.Villarrica basalts range between $0.042-0.052$. SEC basalts show a larger variation of $\mathrm{Be} / \mathrm{Nd}(0.034-0.051)$, with most of them $<0.042$ (Fig.3.4.5).

Consequently, because of their higher contents of $\mathrm{B}$ and lower contents of $\mathrm{Be}$ compared to the SEC samples, the V.Villarrica samples have much higher $\mathrm{B} / \mathrm{Be}$ ratios $(25-40)$ than those of the SECs $(2-25)$ (Fig.3.4.6).

The lithium contents (Fig.3.4.7) of the V.Villarrica samples are also slightly higher $(13-16 \mathrm{ppm})$ compared with those of the SEC samples $(7-16 \mathrm{ppm}$ except sample 110194 - 02). Because of the similar chemical behaviors between $\mathrm{Li}$ and $\mathrm{Yb}$ (Ryan and Langmuir, 1985), the Li versus $\mathrm{Yb}$ correlations for V.Villarrica and SEC samples are both linear, except for sample $110194-02$ which has usually high Li of 23.18ppm. Along with its unusually high B content, this basaltic sample from SEC Huelemolle might be contaminated by some material enriched with $\mathrm{B}$ and $\mathrm{Li}$. The $\mathrm{Li}$ 
contents for the SEC samples again vary systematically, with San Jorge the lowest, then La Barda, Cerro Redondo, Carburgua, Huililco, Huelemolle and Llizan the highest. In addition, the two samples from Rucapillan, one porphyritic and one aphyric, have a dramatic difference on their $\mathrm{Li}$ as well as Be contents.

$\mathrm{K} / \mathrm{Li}$ versus $\mathrm{La} / \mathrm{Yb}$ (Fig.3.4.8) shows similar correlation between $\mathrm{K}$ and $\mathrm{Li}$, as the Be - Nd systematics observed on Fig.3.4.5. V.Villarrica varies between $300-600$ along with most of the SECs, except for Huililco and Llizan (600 - 900). 


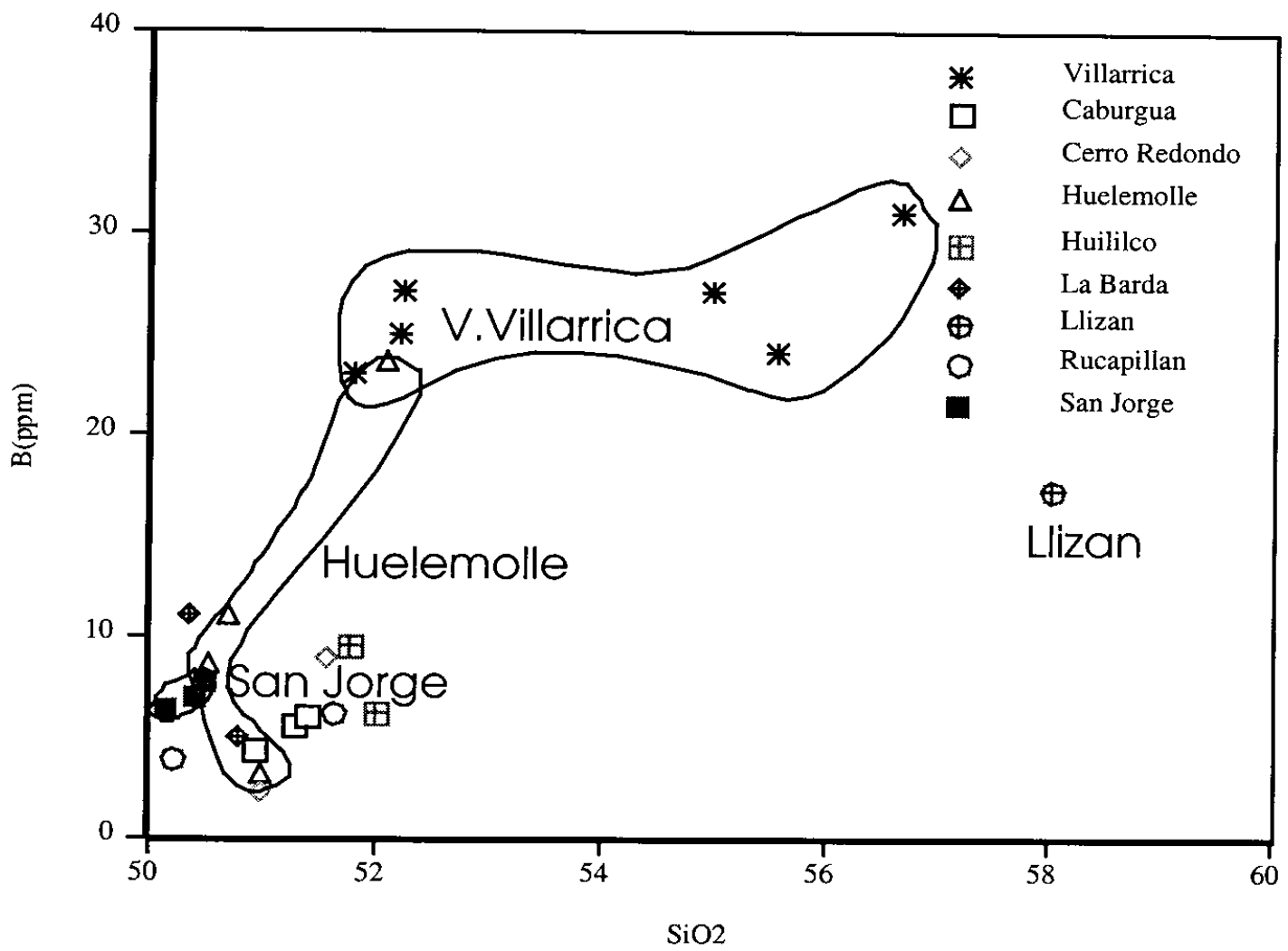

Fig.3.4.1 B versus $\mathrm{SiO}_{2}$ for the V.Villarrica and SEC samples 


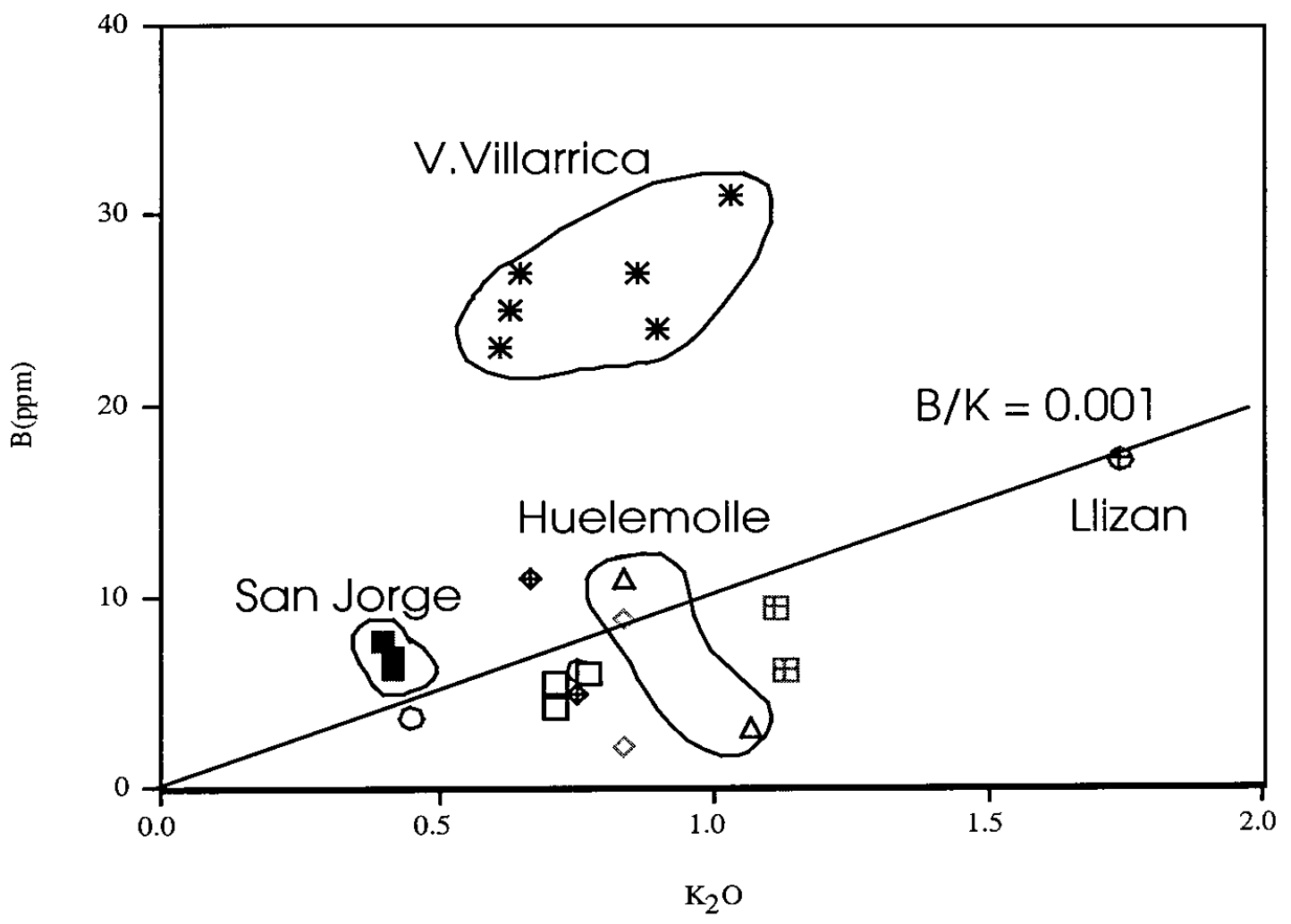

Fig.3.4.2 B versus $\mathrm{K}_{2} \mathrm{O}$ for the V.Villarrica and SEC samples (sample 110194-02 is not shown) 

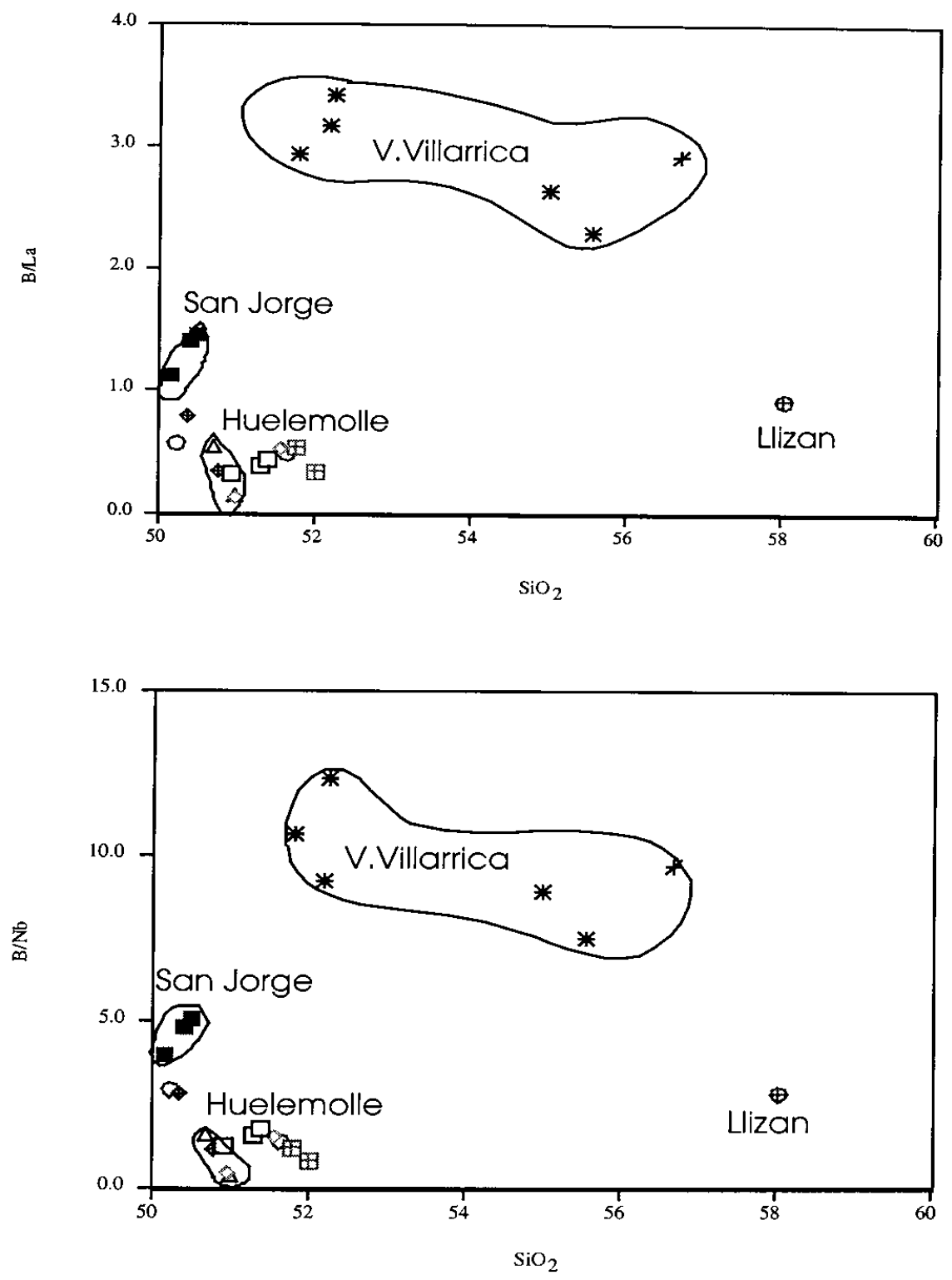

Fig.3.4.3 (upper) B/La versus $\mathrm{SiO}_{2}$; (lower) $\mathrm{B} / \mathrm{Nb}$ versus $\mathrm{SiO}_{2}$ for the V.Villarrica and SEC samples (sample $110194-02$ is not shown) 


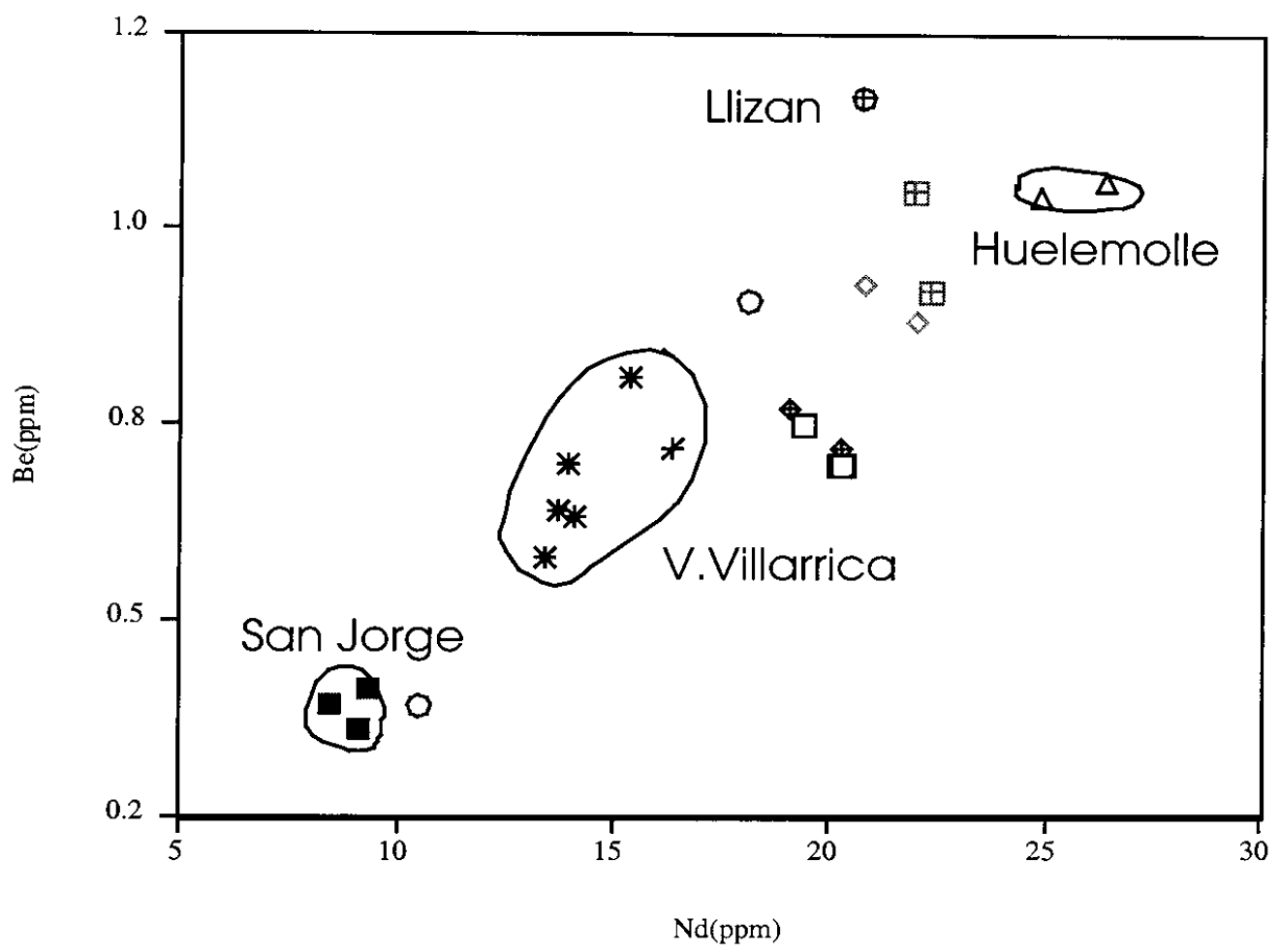

Fig.3.4.4 Be versus Nd for the V.Villarrica and SEC samples 


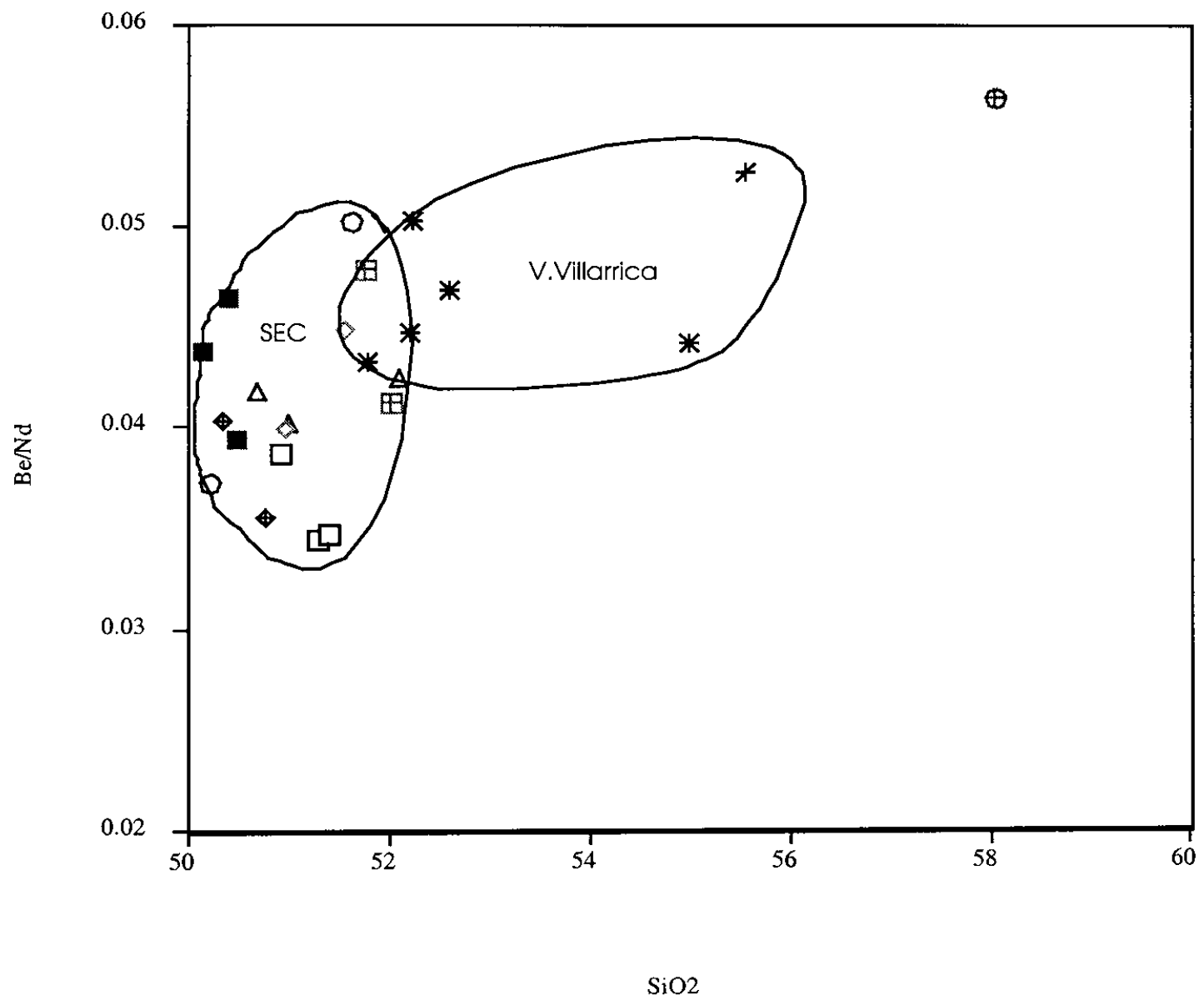

Fig.3.4.5 Be/Nd versus $\mathrm{SiO}_{2}$ for the V.Villarrica and SEC samples 


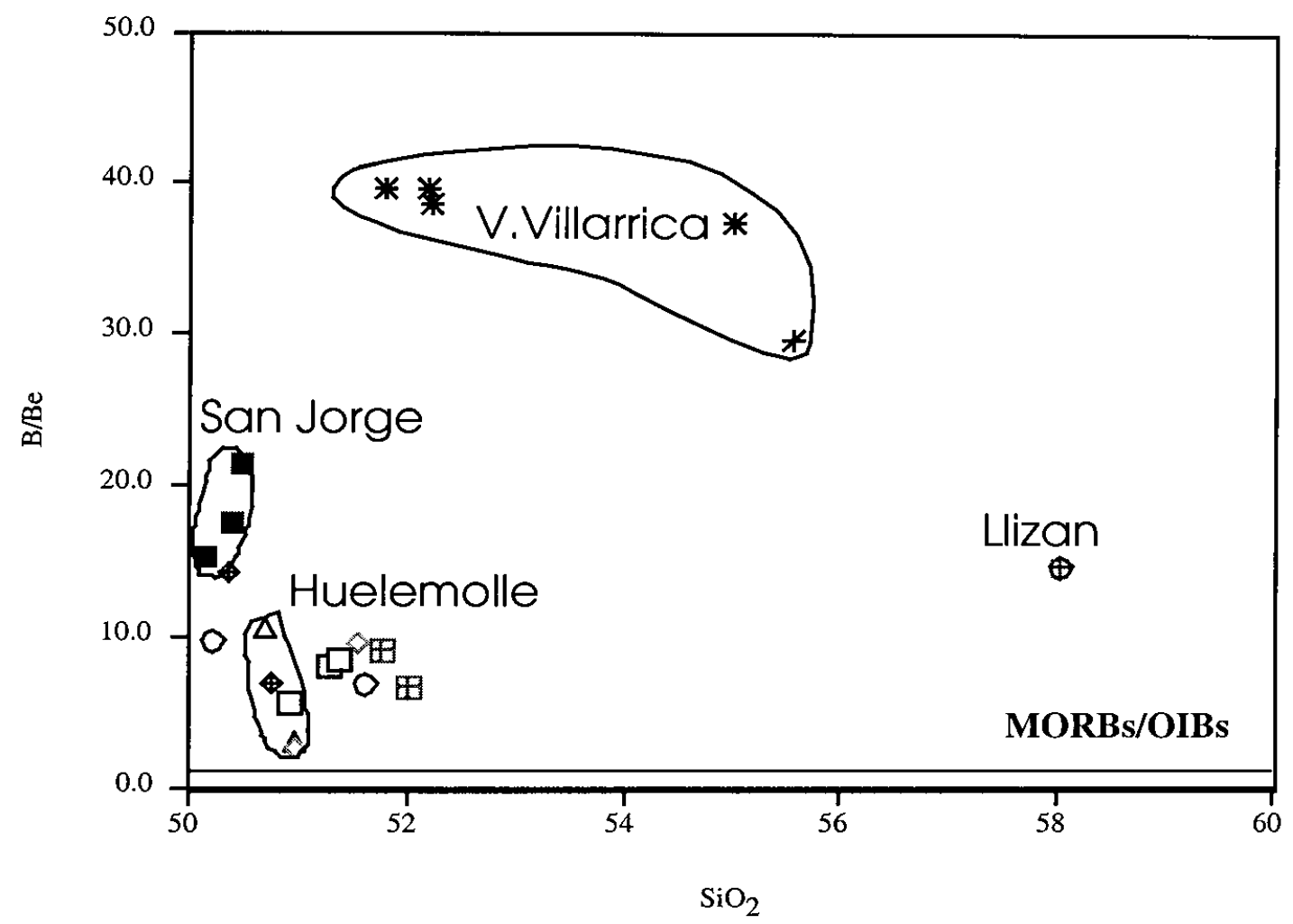

Fig.3.4.6 B/Be versus $\mathrm{SiO}_{2}$ for the V.Villarrica and SEC samples (sample $110194-$ 02 is not shown) 


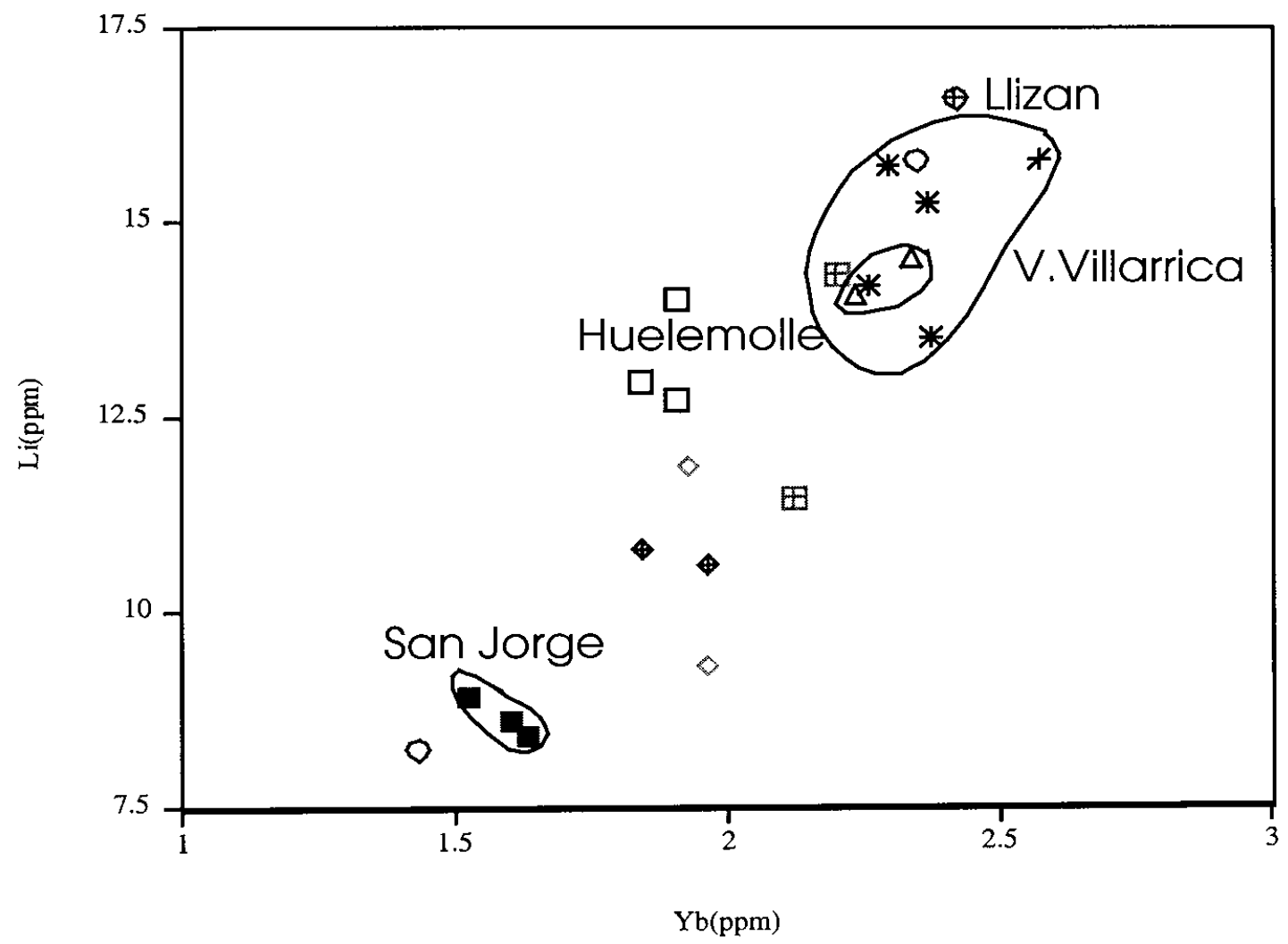

Fig.3.4.7 Li versus $\mathrm{Yb}$ for the V.Villarrica and SEC samples (sample 110194-02 is not shown) 


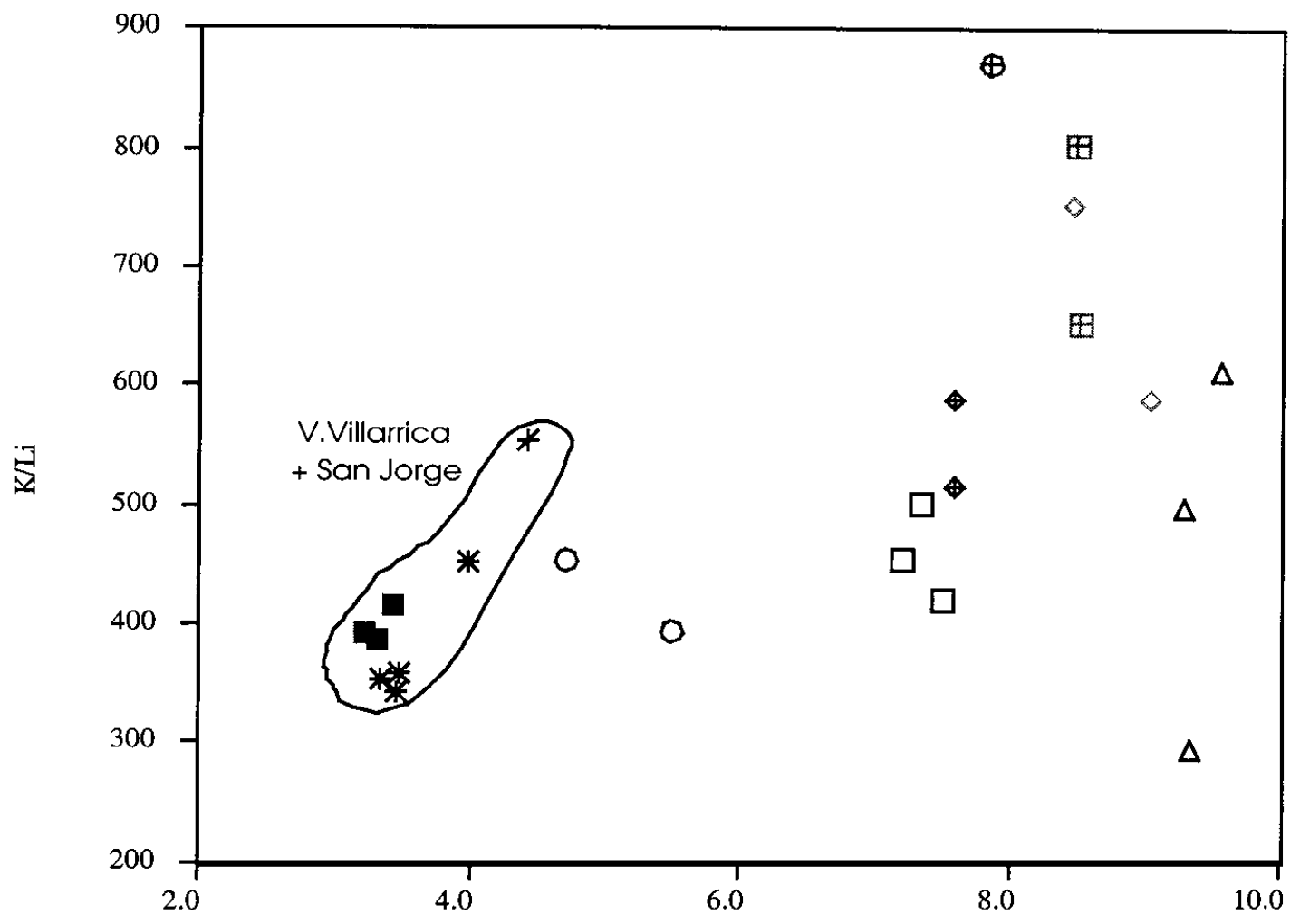

$\mathrm{La} / \mathrm{Yb}$

Fig.3.4.8 $\quad \mathrm{K} / \mathrm{Li}$ versus $\mathrm{La} / \mathrm{Yb}$ for the V.Villarrica and SEC samples (sample 110194 -02 is not shown) 


\subsection{Radiogenic Isotopes}

$\mathrm{Sr}, \mathrm{Nd}$ and $\mathrm{Pb}$ isotope data from this work are listed in Table 3-9 of Appendix 3. Data from Hickey - Vargas et al. (1989) for samples from V.Villarrica (Table 1 - 1, Appendix 1) and the SECs (Table 1 - 3, Appendix 1) are also used in plots and calculations.

$\mathrm{Sr}$ isotopic ratios in basaltic lavas from V.Villarrica and surrounding SECs range from 0.7034 to 0.7042 , with the lowest ratios $(0.70340-0.70342)$ in basaltic sample 010494 - 1A (porphyritic), 090594 - liticos and 090594 - bomba from SEC Rucapillan including El Estadio. The SEC basalts have lower Sr isotopic ratios, mainly $<0.7040$, whereas most of the V.Villarrica basalts have ${ }^{87} \mathrm{Sr} /{ }^{86} \mathrm{Sr}$ higher than 0.7040 (Fig.3.5.1).

$\mathrm{Nd}$ isotopes vary from 0.51281 to 0.51297 and are not well - correlated with $\mathrm{Sr}$ isotopic ratios (Fig. 3.5.1). V.Villarrica basalts have higher $\mathrm{Nd}$ isotopic ratios than the SEC samples ( $\leq 0.512875$ except San Jorge, El Estadio and Rucapillan - porphyritic), typically $>0.51287$. The Rucapillan porphyritic sample and the two samples from El Estadio (of Rucapillan) have the highest Nd isotopic ratios $(0.512950-0.512967)$ and the lowest $\mathrm{Sr}$ isotopic ratios of the SEC sample suites, and are among the lowest ${ }^{87} \mathrm{Sr} /{ }^{86} \mathrm{Sr}$ and highest ${ }^{143} \mathrm{Nd} /{ }^{144} \mathrm{Nd}$ ever reported in SVZ basaltic lavas. The more silicic Rucapillan aphyric sample 010494 - 1B, has significantly higher ${ }^{87} \mathrm{Sr} /{ }^{86} \mathrm{Sr}(0.70369)$ and lower ${ }^{143} \mathrm{Nd} /{ }^{144} \mathrm{Nd}(0.512873)$ ratios. Samples from San Jorge have $\mathrm{Sr}-\mathrm{Nd}$ isotopic ratios quite similar to those of the V.Villarrica samples, just slightly higher in ${ }^{143} \mathrm{Nd} /{ }^{144} \mathrm{Nd}(\sim 0.5129)$ and lower in ${ }^{87} \mathrm{Sr} /{ }^{86} \mathrm{Sr}(\sim 0.7039)$. 
The ${ }^{87} \mathrm{Sr} /{ }^{86} \mathrm{Sr}$ and ${ }^{143} \mathrm{Nd} /{ }^{144} \mathrm{Nd}$ ratios in V.Villarrica region lavas are typical of the CSVZ arc lavas and also within the range of oceanic island basalts, except SEC Rucapillan (Fig.3.5.2).

On a plot of ${ }^{87} \mathrm{Sr} /{ }^{86} \mathrm{Sr}$ versus $\mathrm{Rb} / \mathrm{Sr}$ (Fig.3.5.3), the SECs define a positive correlation, with $\mathrm{Rb} / \mathrm{Sr}$ values increasing from 0.012 to 0.050 , and $\mathrm{Sr}$ isotopic ratios increasing from 0.7034 to 0.7040 . Sr isotope ratios of V.Villarrica basalts do not vary significantly despite $\mathrm{Rb} / \mathrm{Sr}$ values ranging from $0.015-0.062$.

The SEC basalts do not show a clear correlation between their Nd isotopic ratios $(0.51278-0.51292)$ and $\mathrm{Sm} / \mathrm{Nd}$ ratios (0.20 - 0.274) (Fig.3.5.4). Most are clustered at lower $\mathrm{Sm} / \mathrm{Nd}(<0.23)$, with the Rucapillan samples at higher $\mathrm{Sm} / \mathrm{Nd}(0.23-0.24)$. V.Villarrica basalts fall within a narrow range of ${ }^{143} \mathrm{Nd} /{ }^{144} \mathrm{Nd}(0.51286-0.51290)$, and their $\mathrm{Sm} / \mathrm{Nd}$ ratios are the highest $(0.24-0.27)$, clustering with the San Jorge samples.

$\mathrm{Pb}$ isotopic ratios of SEC basalts range from 18.52 to $18.66\left({ }^{206} \mathrm{~Pb} /{ }^{204} \mathrm{~Pb}\right), 15.58$ $15.63\left({ }^{207} \mathrm{~Pb} /{ }^{204} \mathrm{~Pb}\right)$ and $38.40-38.56\left({ }^{208} \mathrm{~Pb} /{ }^{204} \mathrm{~Pb}\right)$, compared with $18.58,15.59$ and $38.46-$ 38.47, respectively, in the V.Villarrica basaltic samples (Fig.3.5.5; Fig.3.5.7). The total range of the ${ }^{207} \mathrm{~Pb} /{ }^{204} \mathrm{~Pb}$ isotopic ratios is within the analytical error $(\sigma)$, and ${ }^{208} \mathrm{~Pb} /{ }^{204} \mathrm{~Pb}$ about $2 \sigma$ and ${ }^{206} \mathrm{~Pb} /{ }^{204} \mathrm{~Pb}$ about $4 \sigma$. So overall the $\mathrm{Pb}$ isotopic variations among the V.Villarrica and SEC samples are very small.

On a plot of ${ }^{208} \mathrm{~Pb} /{ }^{204} \mathrm{~Pb}$ versus ${ }^{206} \mathrm{~Pb} /{ }^{204} \mathrm{~Pb}$, all the measured samples from V.Villarrica and the SECs cluster, except Llizan. All the samples of V.Villarrica and SECs have $\mathrm{Pb}$ isotopic compositions similar to the Nazca or Pacific sediments (Fig.3.5.6 and Fig.3.5.8). 
The andesitic SEC sample from Llizan, as shown on the diagrams, has unusually low ${ }^{206} \mathrm{~Pb} /{ }^{204} \mathrm{~Pb}(18.29)$ and ${ }^{208} \mathrm{~Pb} /{ }^{204} \mathrm{~Pb}(38.14)$ ratios but is not different in ${ }^{207} \mathrm{~Pb} /{ }^{204} \mathrm{~Pb}$ (15.59).

The four Rucapillan samples do not stand out in the $\mathrm{Pb}$ - isotope diagrams as they do in the $\mathrm{Sr}$ and $\mathrm{Nd}$ isotope variations.

Both the ${ }^{206} \mathrm{~Pb} /{ }^{204} \mathrm{~Pb}-\mathrm{U} / \mathrm{Pb}$ (Fig.3.5.9) and ${ }^{208} \mathrm{~Pb} /{ }^{204} \mathrm{~Pb}-\mathrm{Th} / \mathrm{Pb}$ (Fig.3.5.10) diagrams show no or little variation of the $\mathrm{Pb}$ isotopic ratios with the increase of $\mathrm{U} / \mathrm{Pb}$ or $\mathrm{Th} / \mathrm{Pb}$ ratios. The $\mathrm{U} / \mathrm{Pb}$ ratio of the SEC and V.Villarrica basalts ranges between 0.04 and 0.12 , and $\mathrm{Th} / \mathrm{Pb} 0.1-0.5$. Samples from San Jorge and V.Villarrica have much lower $\mathrm{U} / \mathrm{Pb}$ $(<0.065)$ and $\mathrm{Th} / \mathrm{Pb}(<0.2)$ ratios compared with other SEC samples.

Similarly, the ${ }^{207} \mathrm{~Pb} /{ }^{204} \mathrm{~Pb}$ vs $\mathrm{Ce} / \mathrm{Pb}$ diagram (Fig.3.5.11) also shows that the V.Villarrica and San Jorge samples are much lower in $\mathrm{Ce} / \mathrm{Pb}(<3)$ compared with other SEC samples (>3) except Llizan. The sample from Llizan, despite its medium ${ }^{207} \mathrm{~Pb} /{ }^{204} \mathrm{~Pb}$ value, has the lowest $\mathrm{Ce} / \mathrm{Pb}$ ratio $(\sim 1.7)$ of all the V.Villarrica and SEC samples. 


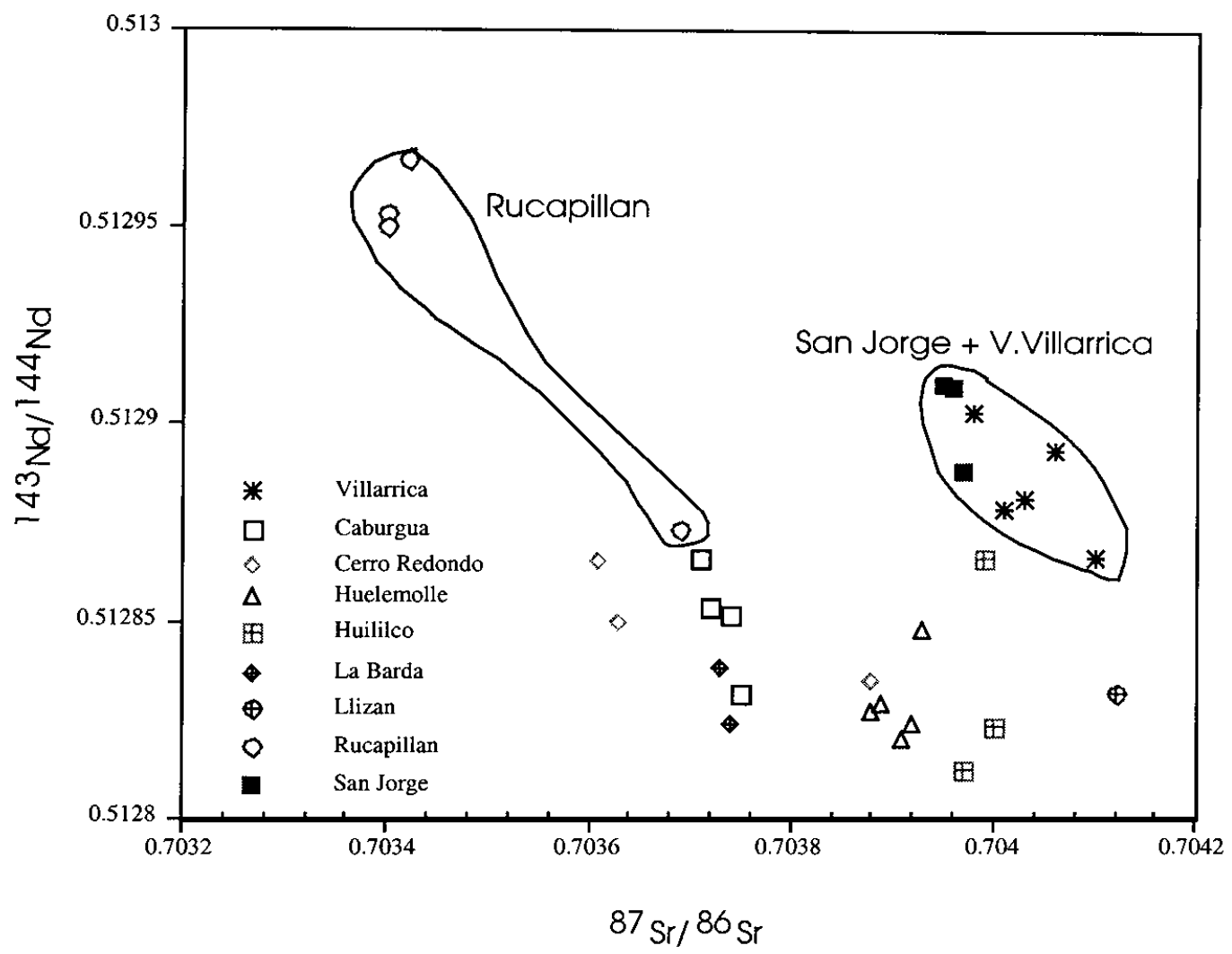

Fig.3.5.1 $\quad{ }^{143} \mathrm{Nd} /{ }^{144} \mathrm{Nd}$ versus ${ }^{87} \mathrm{Sr} /{ }^{86} \mathrm{Sr}$ for the V.Villarrica and SEC samples 


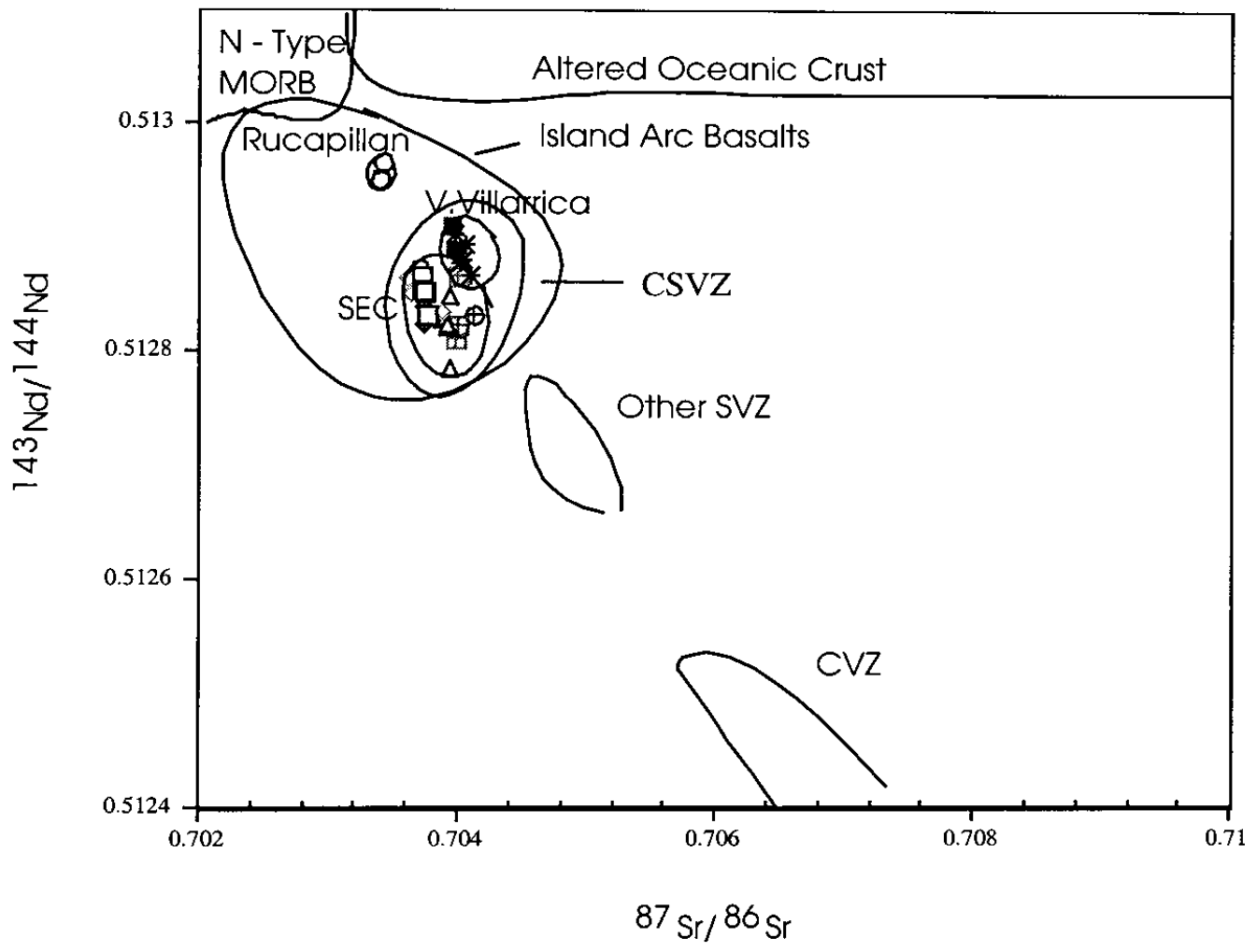

Fig.3.5.2 ${ }^{143} \mathrm{Nd} /{ }^{144} \mathrm{Nd}$ versus ${ }^{87} \mathrm{Sr} /{ }^{86} \mathrm{Sr}$ for the samples from V.Villarrica, SECs and other geologic settings (Hawkesworth et al., 1979; Sun and McDonough, 1989; Frey et al., 1984; Hickey et al., 1986; Gerlach et al., 1988; Munoz and Stern, 1989; Stern et al., 1990; Hickey - Vargas et al., 1989; Frey (unpublished); Data from this work) 


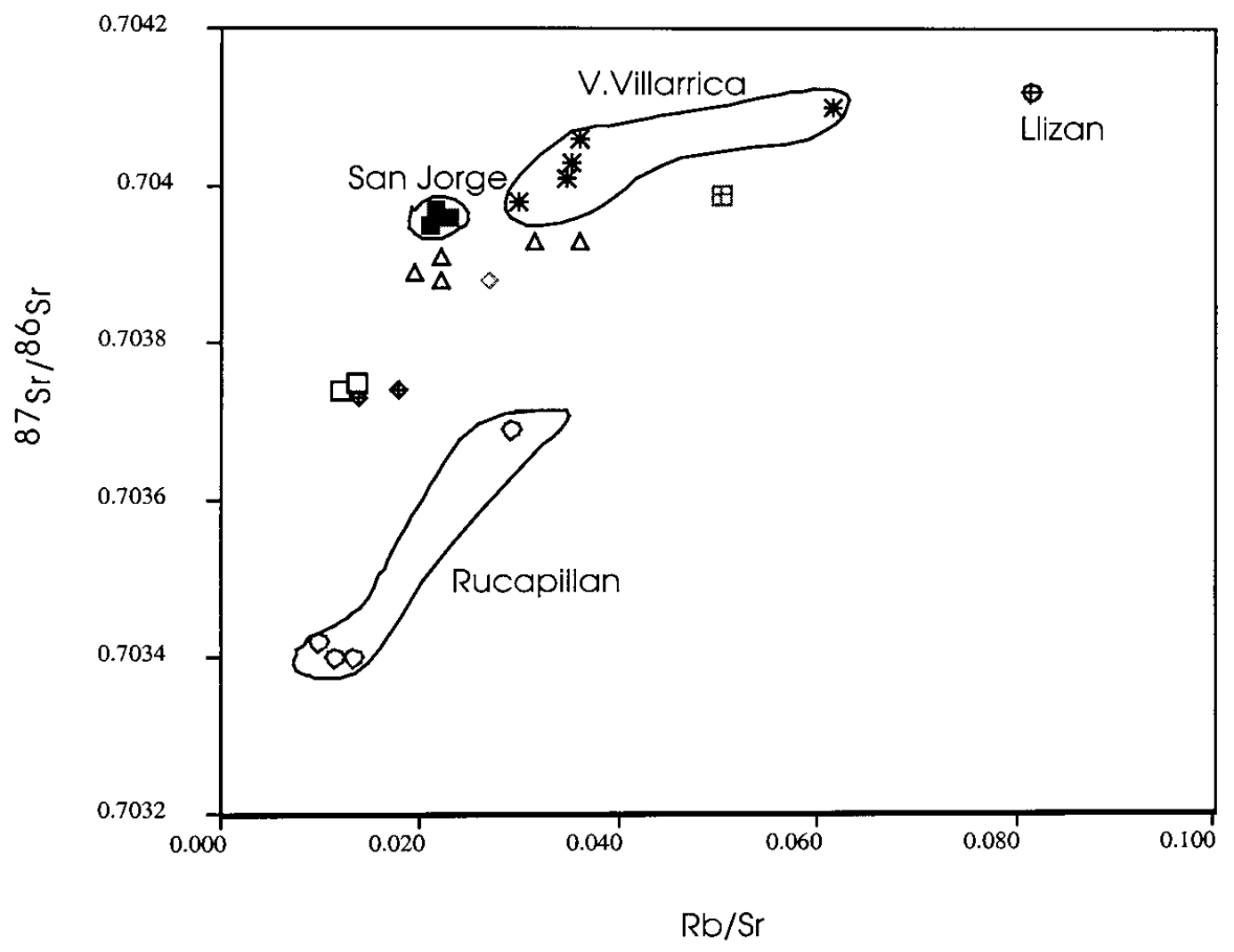

Fig.3.5.3 $\quad{ }^{87} \mathrm{Sr} /{ }^{86} \mathrm{Sr}$ versus $\mathrm{Rb} / \mathrm{Sr}$ for the V.Villarrica and SEC samples 


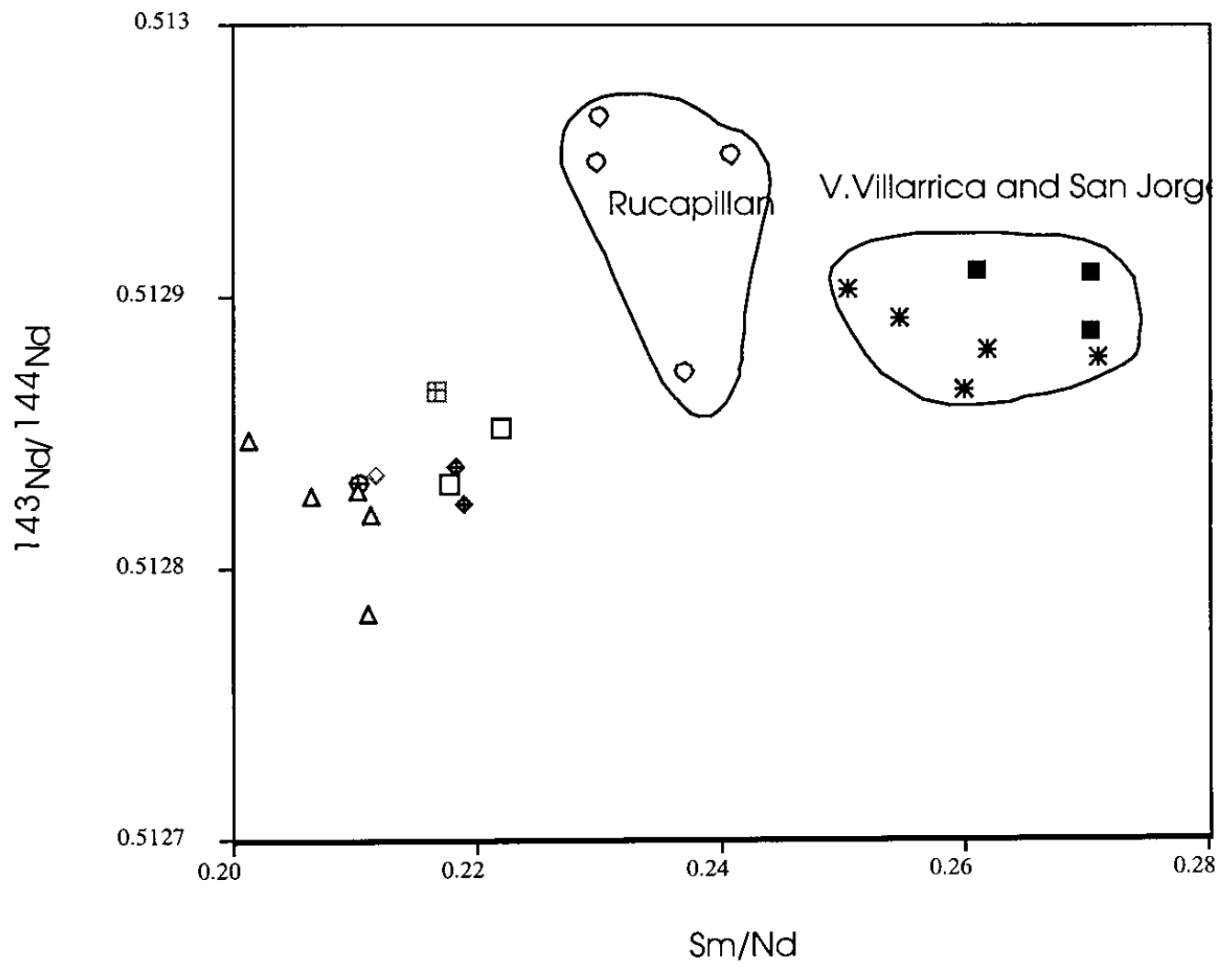

Fig.3.5.4 ${ }^{143} \mathrm{Nd} /{ }^{144} \mathrm{Nd}$ versus $\mathrm{Sm} / \mathrm{Nd}$ for the V.Villarrica and SEC samples 


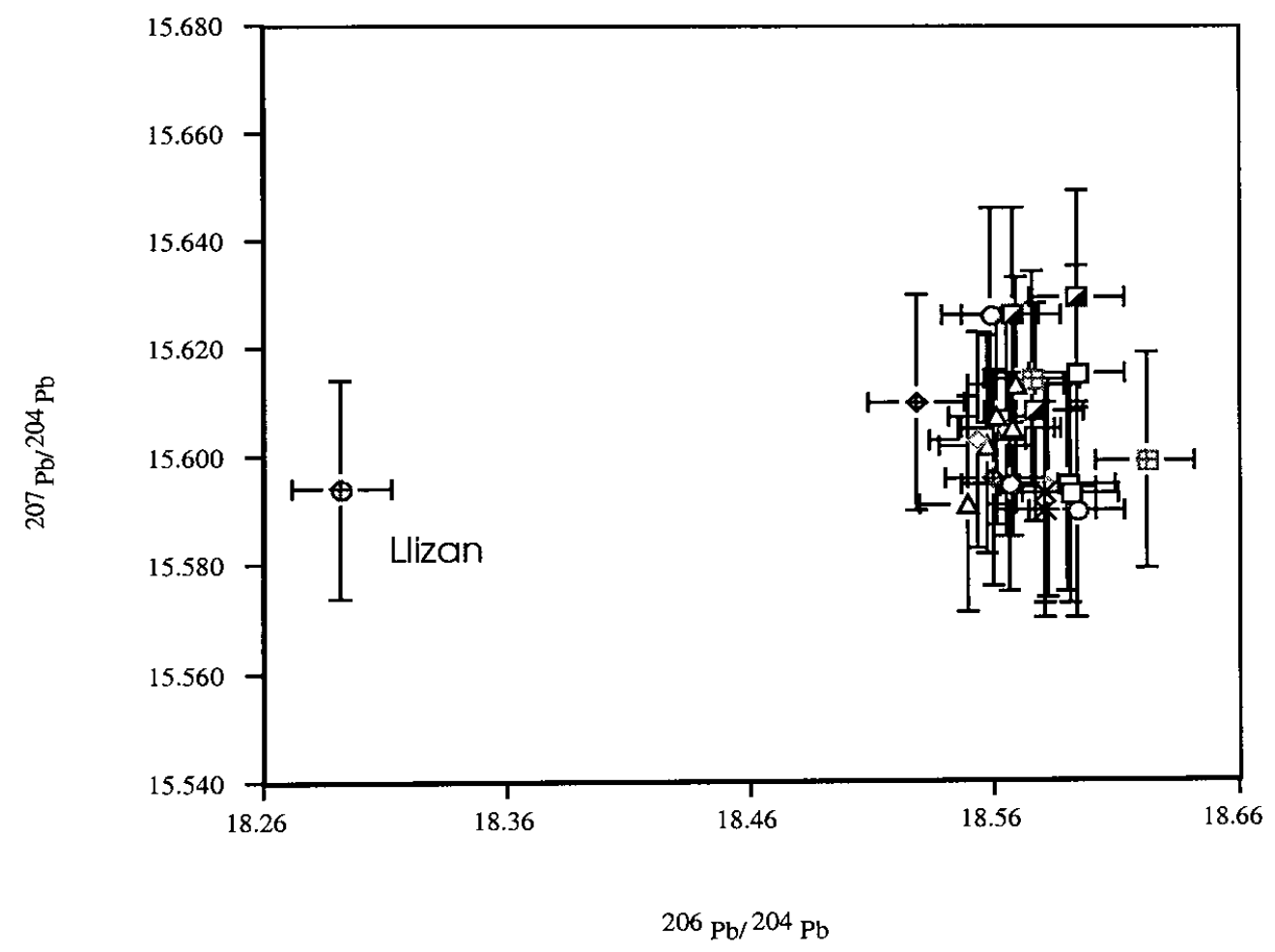

Fig.3.5.5 ${ }^{207} \mathrm{~Pb} /{ }^{204} \mathrm{~Pb}$ versus ${ }^{206} \mathrm{~Pb} /{ }^{204} \mathrm{~Pb}$ for the V.Villarrica and SEC samples 


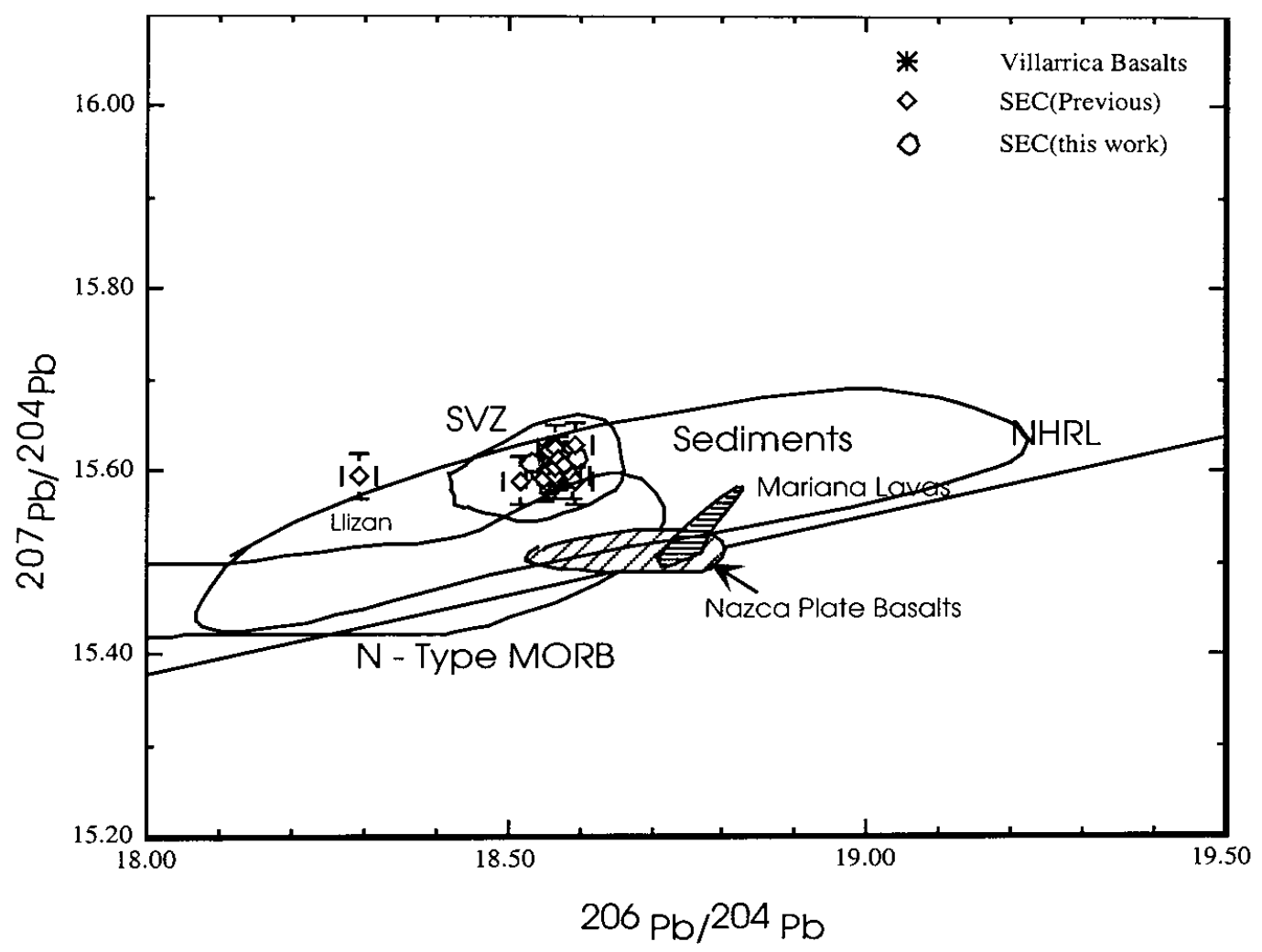

Fig.3.5.6 ${ }^{207} \mathrm{~Pb} /{ }^{204} \mathrm{~Pb}$ versus ${ }^{206} \mathrm{~Pb} /{ }^{204} \mathrm{~Pb}$ for the samples from $\mathrm{V}$, Villarrica, SECs and other geologic settings (from Sun, 1980; Unruh and Tatsumoto, 1976; Meijer, 1976; Chow and Patterson, 1962; Harmon et al., 1984; Hole et al., 1984; Gerlach, 1985; Hickey et al., 1986; Frey (unpublished); Dasch, 1981; Hickey - Vargas et al., 1989; this work) 


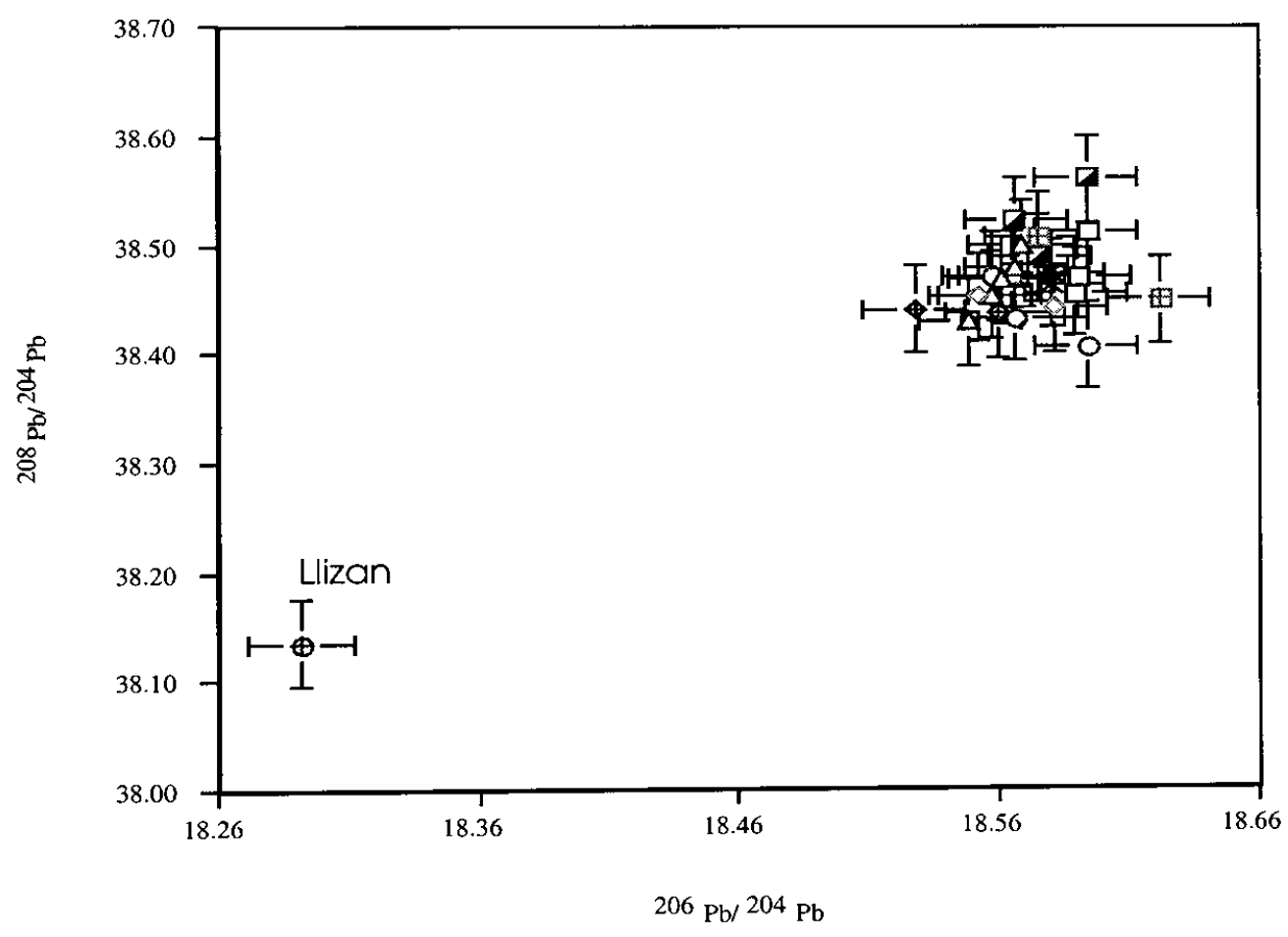

Fig.3.5.7 $\quad{ }^{208} \mathrm{~Pb} /{ }^{204} \mathrm{~Pb}$ versus ${ }^{206} \mathrm{~Pb} /{ }^{204} \mathrm{~Pb}$ for the V.Villarrica and SEC samples 


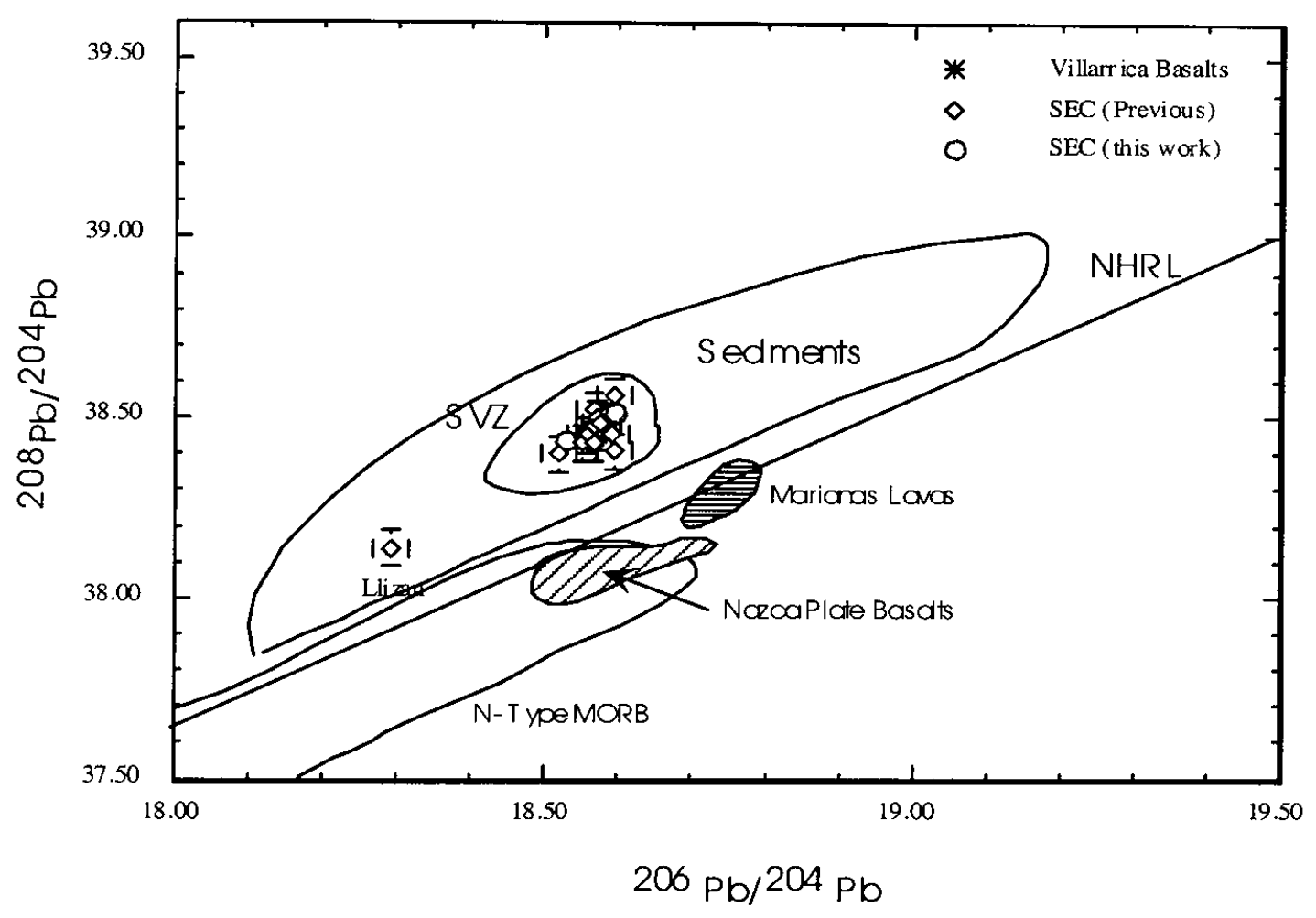

Fig.3.5.8 ${ }^{208} \mathrm{~Pb} /{ }^{204} \mathrm{~Pb}$ versus ${ }^{206} \mathrm{~Pb} /{ }^{204} \mathrm{~Pb}$ for the samples from V.Villarrica, SECs and other geologic settings (see Fig.3.5.6 for references) 


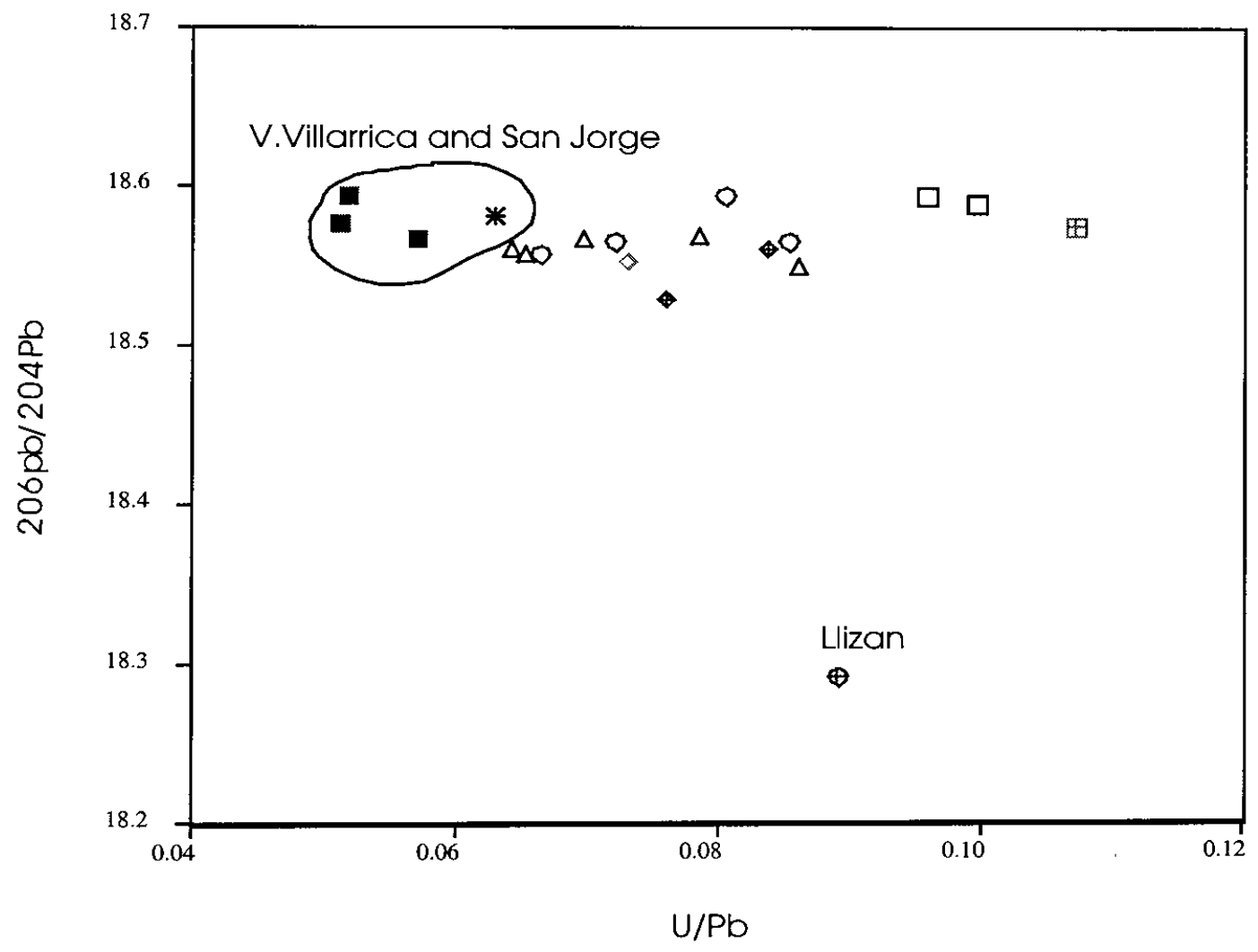

Fig.3.5.9 ${ }^{206} \mathrm{~Pb} /{ }^{204} \mathrm{~Pb}$ versus $\mathrm{U} / \mathrm{Pb}$ for the V.Villarrica and SEC samples 


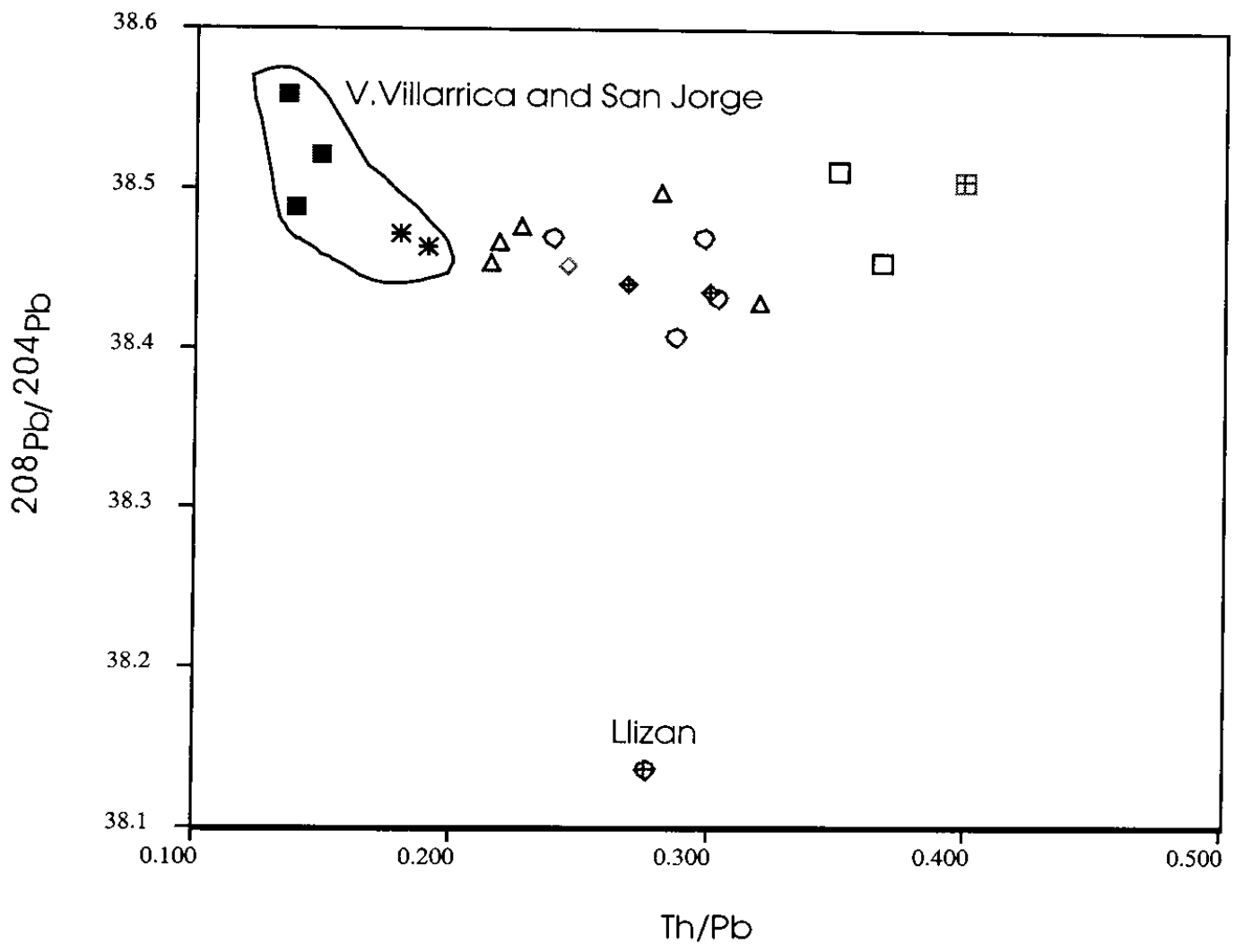

Fig.3.5.10 $\quad{ }^{208} \mathrm{~Pb} /{ }^{204} \mathrm{~Pb}$ versus $\mathrm{Th} / \mathrm{Pb}$ for the V.Villarrica and SEC samples 


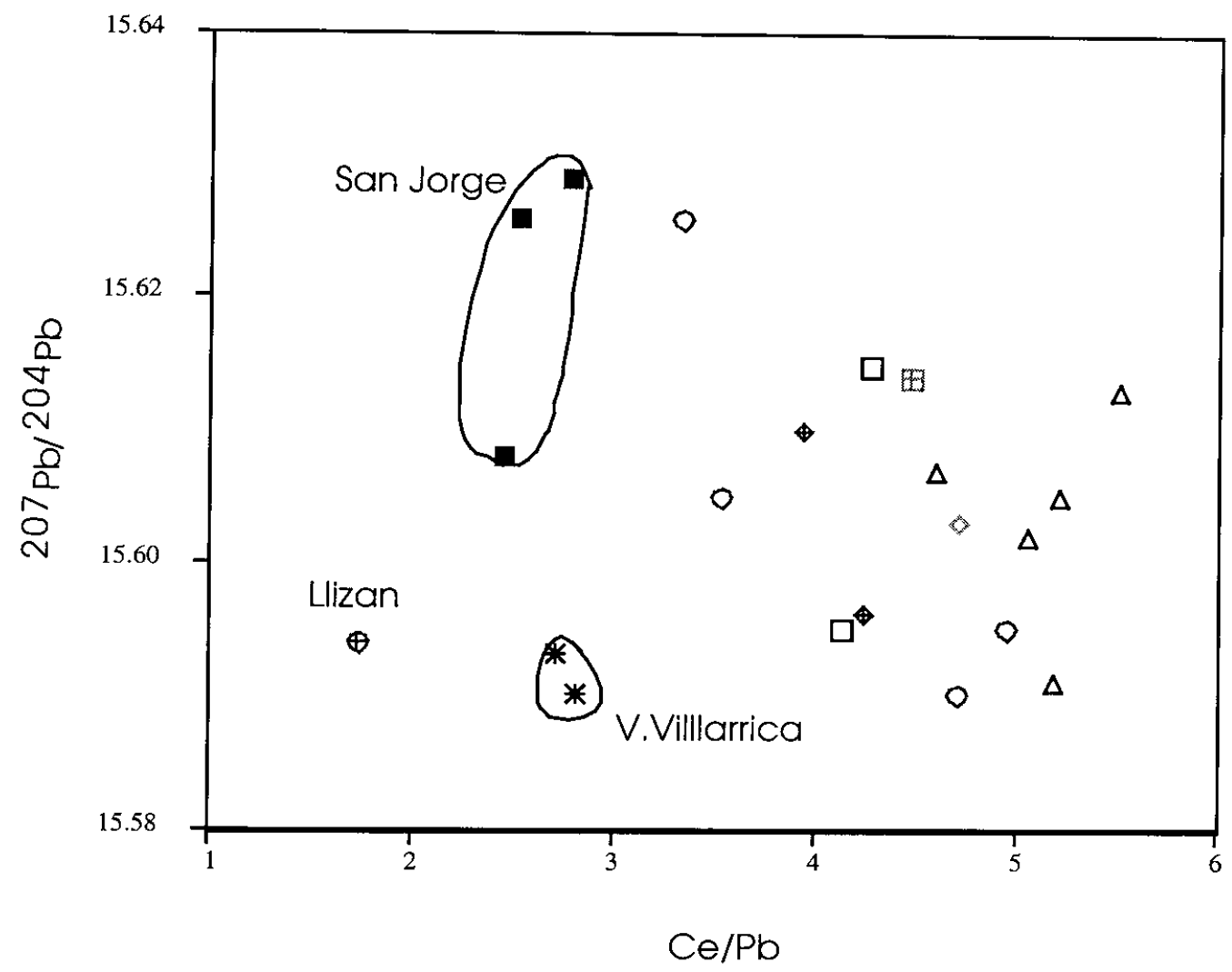

Fig.3.5.11 $\quad{ }^{207} \mathrm{~Pb} /{ }^{204} \mathrm{~Pb}$ versus $\mathrm{Ce} / \mathrm{Pb}$ for the $\mathrm{V}$.Villarrica and SEC samples 


\subsection{Short - lived isotopes}

\subsubsection{U-Series isotopes}

$\mathrm{U}$ - Series activity data from this work are given in Table 3 - 11a, Appendix 3. Other published data for samples from V.Villarrica are listed in Table 1-4, Appendix 1.

On Fig.3.6.1, the basaltic sample 210281-1 from Volcano Villarrica shows a distinctive excess of ${ }^{238} \mathrm{U}$ over ${ }^{230} \mathrm{Th}$, as does the sample from SEC San Jorge. Other SEC basalts plot on or to the left of the equiline $\left({ }^{230} \mathrm{Th}={ }^{238} \mathrm{U}\right.$; nuclides on the same decay series all have the same activities), showing that they have all reached secular equilibrium. Andesitic V.Villarrica samples 151282 - 2 and 151282 - 3, and the andesitic sample from Llizan plot on or slightly to the right of the equiline.

The $\left({ }^{230} \mathrm{Th} /{ }^{232} \mathrm{Th}\right)$ activity ratios of all the V.Villarrica and SEC basalts are lower than unity, ranging between 0.7 - 1.0. The samples from San Jorge and V.Villarrica (210281-1 - 1971 flow) are the lowest. The samples define a good negative correlation between their $\left({ }^{230} \mathrm{Th} /{ }^{232} \mathrm{Th}\right)$ and $\left({ }^{238} \mathrm{U} /{ }^{232} \mathrm{Th}\right)$ values.

On a plot of $\left({ }^{210} \mathrm{Po} /{ }^{230} \mathrm{Th}\right)$ versus $\left({ }^{238} \mathrm{U} /{ }^{230} \mathrm{Th}\right)($ Fig.3.6.2), the samples from San Jorge and 210281-1 of V.Villarrica with ${ }^{238} \mathrm{U}$ excesses also have an excess of ${ }^{210} \mathrm{Po}$ over ${ }^{230} \mathrm{Th}$. Most other SEC samples as well as the andesitic samples $151282-2$ and 151282 3 from V.Villarrica are very close to the equiline with respect to ${ }^{210} \mathrm{Po}$ and ${ }^{230} \mathrm{Th}$.

The $\left({ }^{210} \mathrm{Po} /{ }^{230} \mathrm{Th}\right)$ and $\left({ }^{238} \mathrm{U} /{ }^{230} \mathrm{Th}\right)$ activity ratios of all the V.Villarrica and SEC samples define a good positive correlation. V.Villarrica (1971 flow) and San Jorge have the highest $\left({ }^{210} \mathrm{Po} /{ }^{230} \mathrm{Th}\right)$ ratios $(>1.5)$. Other samples all have their $\left({ }^{210} \mathrm{Po} /{ }^{230} \mathrm{Th}\right)$ between $1.0-1.3$. 


\section{$\underline{3.6 .2{ }^{10} \mathrm{Be}}$}

${ }^{10} \mathrm{Be}$ data from this work are given in Table $3-11 \mathrm{~b}$, Appendix 3. Other published ${ }^{10} \mathrm{Be}$ data for samples from V.Villarrica are listed in Table $1-4$, Appendix 1.

V.Villarrica (1971 flow) and San Jorge, which show the greatest U/Th disequilibrium, also stand out on the ${ }^{10} \mathrm{Be} /{ }^{9} \mathrm{Be}$ versus ${ }^{10} \mathrm{Be}$ diagram (Fig.3.6.3). Both of them have much higher ${ }^{10} \mathrm{Be} /{ }^{9} \mathrm{Be}$ ratios and ${ }^{10} \mathrm{Be}$ concentrations than the other $\mathrm{SEC}$ samples. ${ }^{10} \mathrm{Be}$ and $\mathrm{Be}$ concentrations of samples from SEC Caburgua and La Barda are almost identical, and the sample from Huelemolle is slightly lower.

${ }^{10} \mathrm{Be}$ and ${ }^{10} \mathrm{Be} /{ }^{9} \mathrm{Be}$ results of the five measured samples match the positive correlation established with 47 global volcanic arc samples (Morris and Tera, 1989) and are all clustered at the lower - concentration end of the compositional range (Fig.3.6.4). On the other hand, the ${ }^{10} \mathrm{Be} / \mathrm{Be}$ versus $\mathrm{Be}$ diagram shows a negative trend (Fig.3.6.5) for the samples from V.Villarrica, SECs and other parts of the SVZ (33-42 ${ }^{\circ} \mathrm{S}$ ) (Morris and Tera, 1989). 


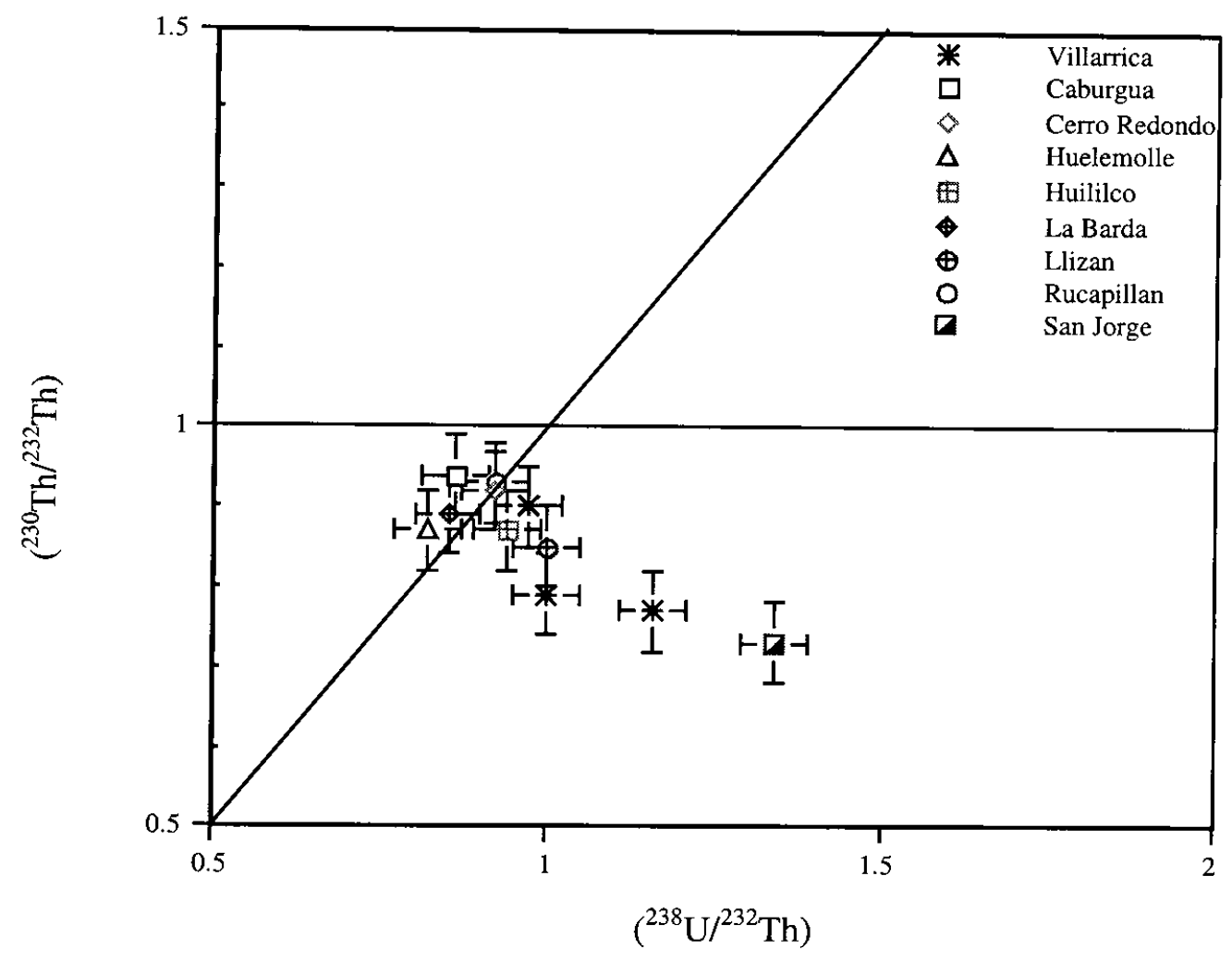

Fig.3.6.1 $\left({ }^{230} \mathrm{Th} /{ }^{232} \mathrm{Th}\right)$ versus $\left({ }^{238} \mathrm{U} /{ }^{232} \mathrm{Th}\right)$ for the V.Villarrica and SEC samples 


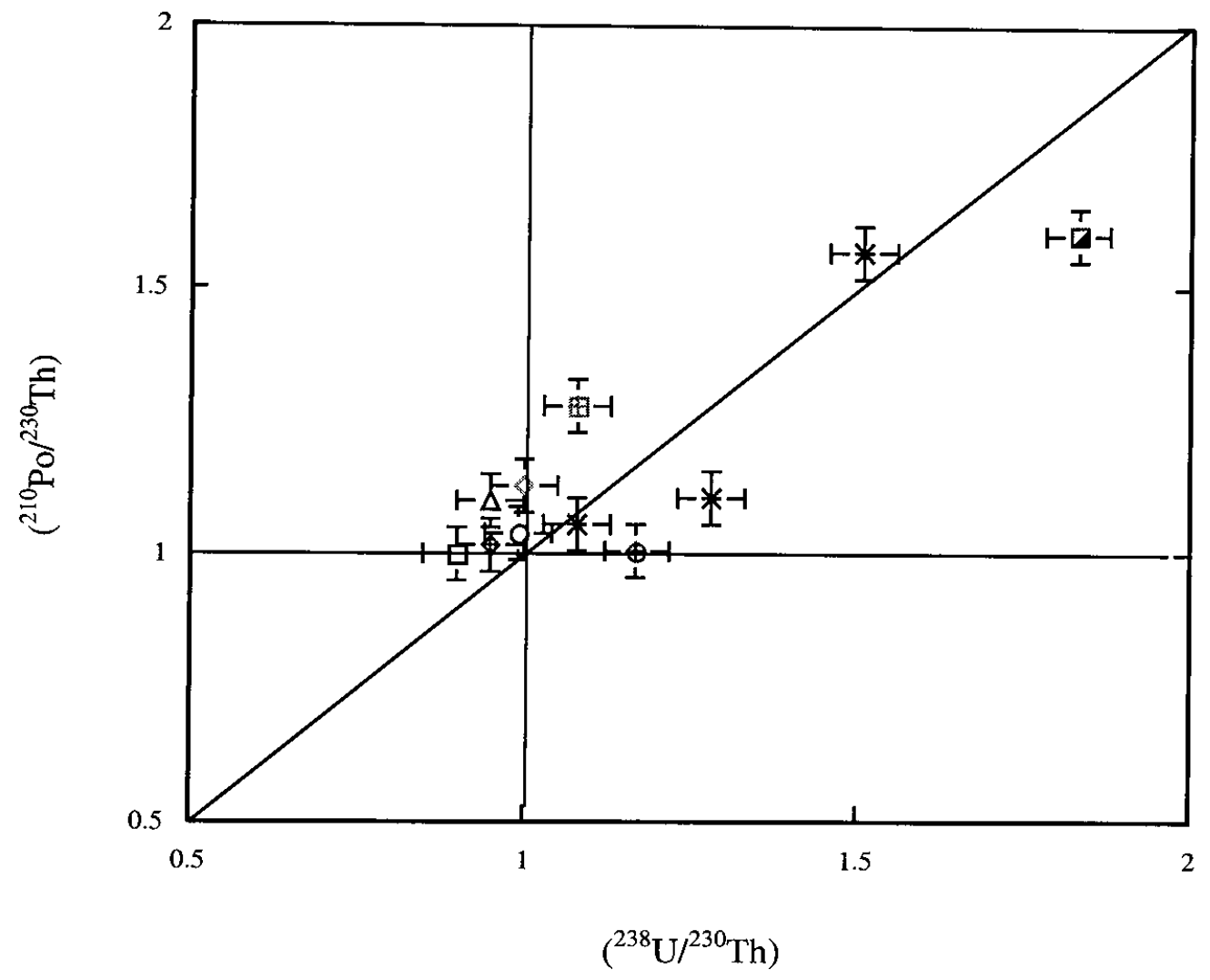

Fig.3.6.2 $\left.\quad{ }^{210} \mathrm{Po} /{ }^{230} \mathrm{Th}\right)$ versus $\left({ }^{238} \mathrm{U} /{ }^{230} \mathrm{Th}\right)$ for the V.Villarrica and SEC samples 


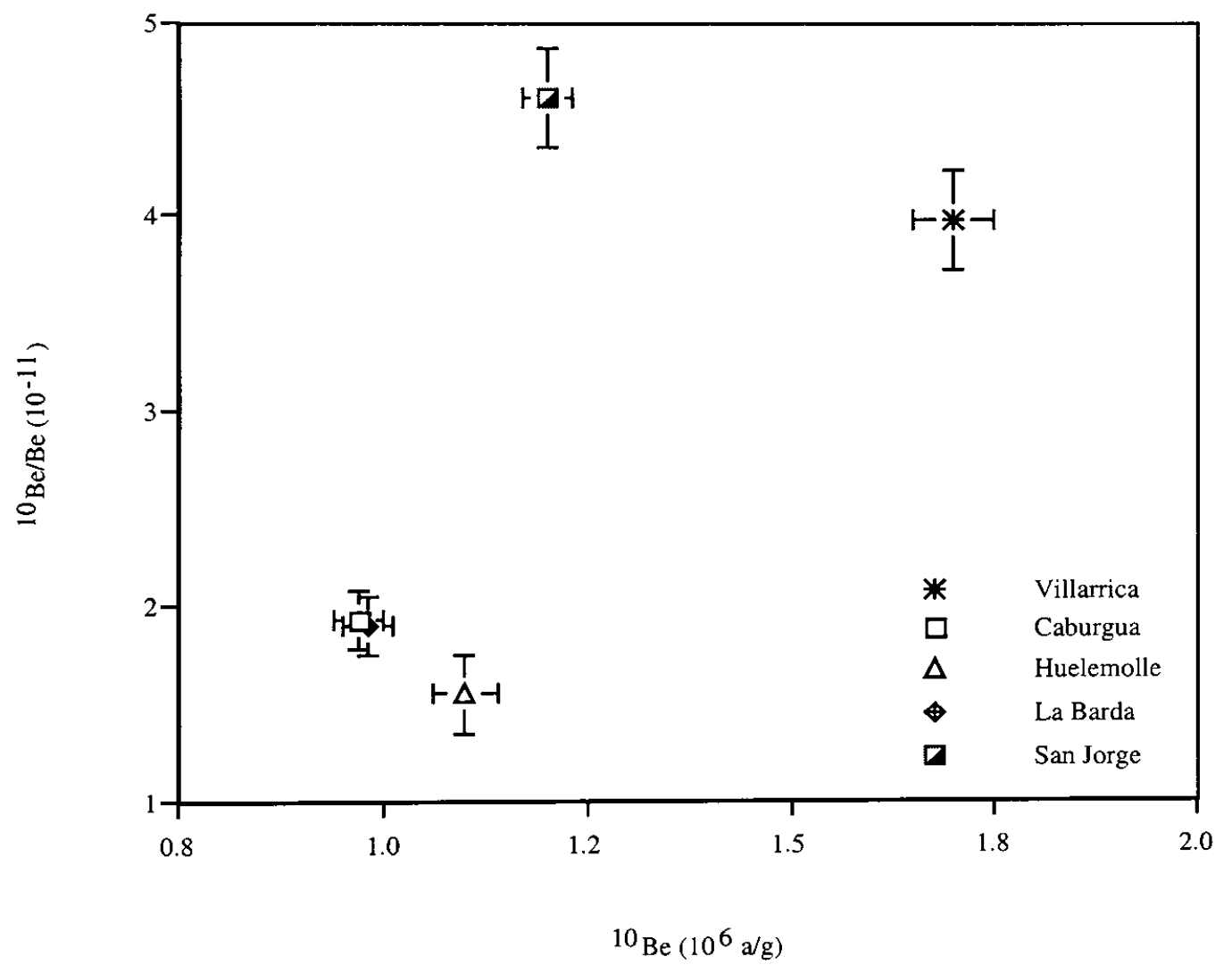

Fig.3.6.3 ${ }^{10} \mathrm{Be} / \mathrm{Be}$ versus ${ }^{10} \mathrm{Be}$ for the V.Villarrica and SEC samples 


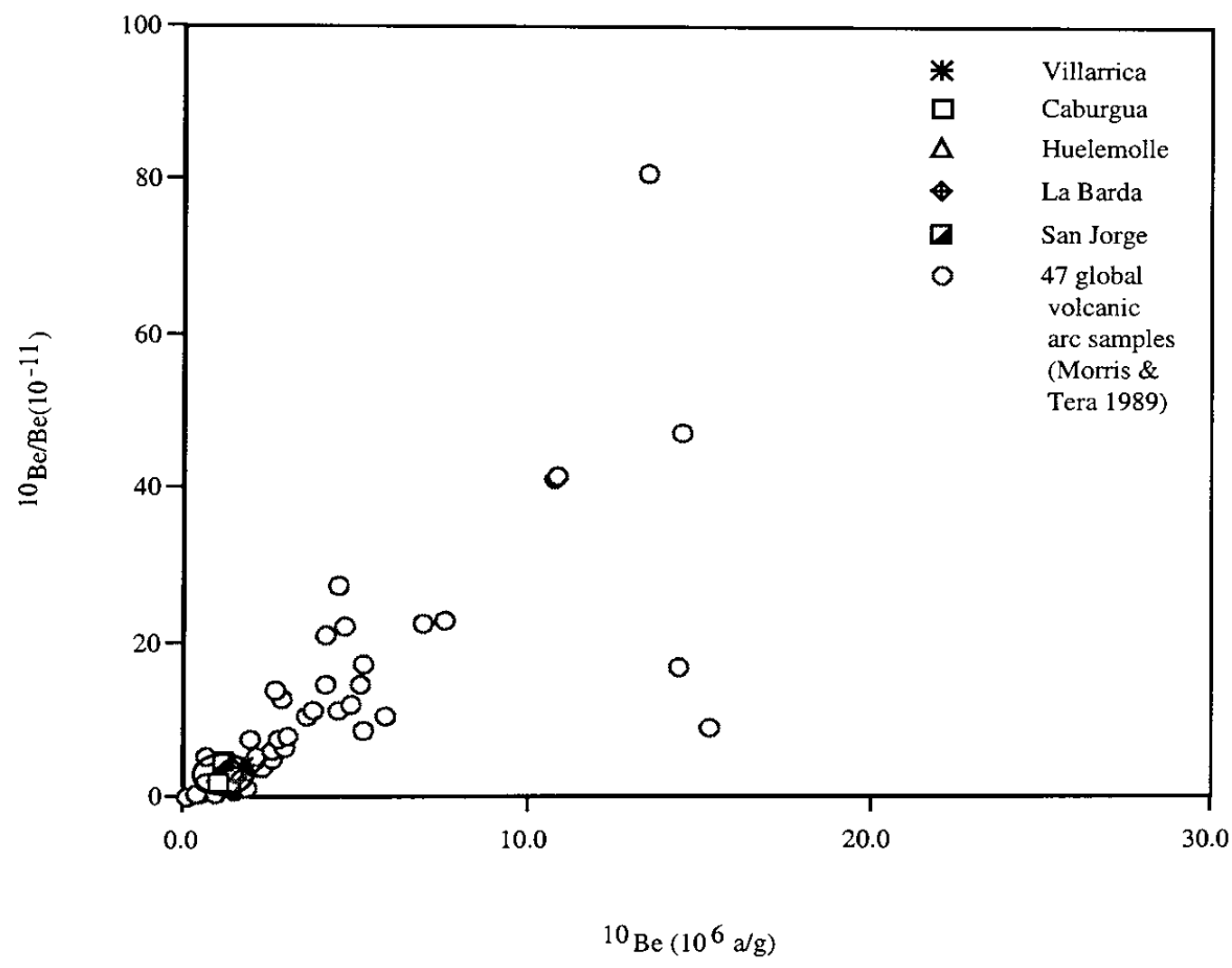

Fig.3.6.4 ${ }^{10} \mathrm{Be} / \mathrm{Be}$ versus ${ }^{10} \mathrm{Be}$ for the V.Villarrica, SEC and other arc volcanics (Morris and Tera, 1989) 


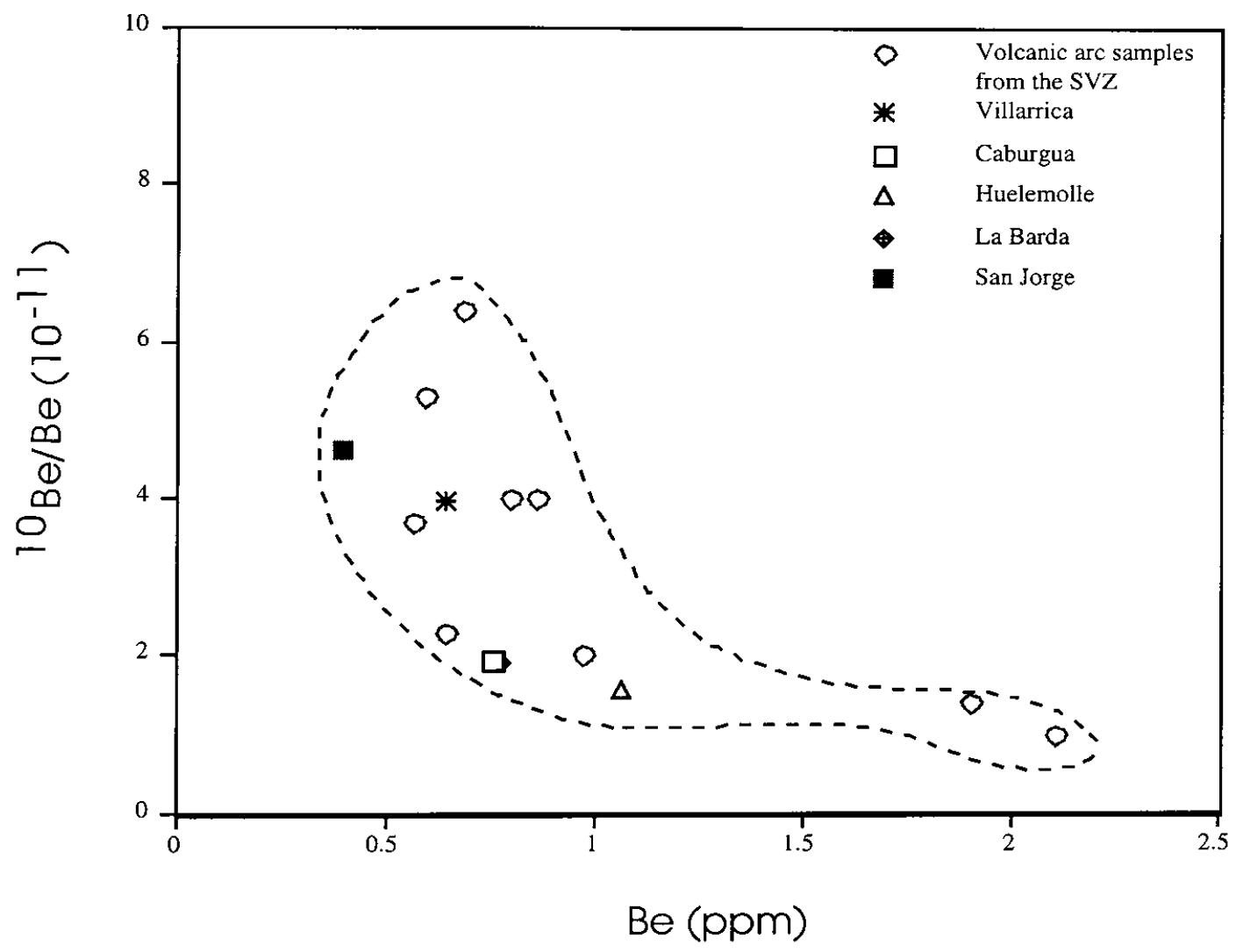

Fig.3.6.5 $\quad{ }^{10} \mathrm{Be} / \mathrm{Be}$ versus Be for samples from V.Villarrica and the SECs and other SVZ samples (Morris and Tera, 1989) 


\title{
Chapter 4 Origin of the Geochemical Features of the Small Eruptive
}

\author{
Centers
}

\subsection{Potential sources and processes for the generation of arc magma}

\subsubsection{Introduction}

Examination of the major and trace element and isotopic data (Chapter 3) reveals significant differences between the SEC and V.Villarrica samples and among the SEC samples themselves. In this chapter, the differences will be interpreted in terms of: 1) mixing of materials from the subducted lithosphere and mantle wedge; 2) partial melting; 3) magmatic differentiation and crustal assimilation.

Based on geologic (Chapter 2) and geochemical (Chapter 3) distinctions, this discussion is divided into sections grouping related centers: 1) V.Villarrica and basaltic SECs associated with it in time and space (i.e., Caburgua, Cerro Redondo, Huelemolle, Huililco, La Barda and San Jorge); 2) Llizan, the only andesitic SEC; 3) Rucapillan centers (including El Estadio) which predate V.Villarrica. In the last section, the V.Villarrica region SECs are compared with those from Carran - Los Venados region. 


\subsubsection{Sources and processes - a brief summary}

The most commonly proposed models of magma genesis at subduction zones are all based on mixing among the following endmembers:

- Pre - subduction mantle wedge

- Hydrous fluids or melts from subducted lithosphere including: 1) altered oceanic crust (AOC); and 2) sediments

- Crust

\subsubsection{Evidence for slab dehydration:}

A lot of research in recent decades has focused on slab dehydration (Gill, 1981; Wyllie and Sekine, 1982; Tatsumi, 1986; 1989; Peacock, 1990; 1991; 2001; Arculus, 1994; Reagan et al., 1994; Ryan et al., 1995; Elliott et al., 1997; Hawkesworth et al., 1997; Melzer and Wunder, 2000; Turner et al., 2000). Based on these studies, arc magmas are believed to be generated from the interaction between the mantle wedge and hydrous fluids derived from subducting slabs by dehydration. $\mathrm{H}_{2} \mathrm{O}$ can be released from decomposition of clay minerals, amphiboles and serpentines at a depth around or shallower than $120 \mathrm{~km}$ (Gill, 1981) and react with wedge peridotites to form amphiboles, phlogopite, and clinohumite or chondrodite under the fore - arc region. Later partial melting of the metasomatized "arc - source" produces a large ionic incompatible elementenriched initial melt for arc magmas which then migrate obliquely to the volcanic front with a downgoing material flow along the slab. Magma is produced because the geotherm of $1000^{\circ} \mathrm{C} / 40 \mathrm{kbar}$ (Peacock, 1990) crosses the $\mathrm{H}_{2} \mathrm{O}$ - saturated solidus of peridotite above the surface of subducted slabs beneath the volcanic arc front. 
In the "hybridization" model of Wyllie and Sekine (1982), phlogopite - pyroxenite is formed by the interaction of slab - derived hydrous fluids and the mantle. Usually alkaline lavas behind volcanic fronts are formed by deeper melting of the preexisting phlogopite - pyroxenite, and continental arc magmatism with a clear signature of crust is formed when arc magmas ascend and reside in the continental lithosphere over a long time period.

\subsubsection{Slab versus mantle wedge melting:}

Arc magmas have generally been modeled as originating by melting of the mantle wedge, but a few are believed to be melts of subducted lithosphere (Wyllie and Sekine, 1982; Tatsumi et al., 1986; 1991; Peacock, 1990; 1991; Defant and Drummond, 1990; Atherton and Petford, 1993; Arculus, 1994). The reason earlier proposals favored the direct melting of the subducted oceanic crust (Green and Ringwood, 1968) rather than the overlying mantle wedge is that most arc lavas are calc - alkaline, not like the melt compositions produced by equilibrium partial fusion of a lherzolite parent in the upper mantle. However, Peacock (1990) pointed out that slabs $>25 \mathrm{Ma}$ are too old to satisfy the conditions of partial melting of slabs before dehydration can occur. Therefore, partial melting of subducted slabs can only occur in young and hot oceanic crust $(<25 \mathrm{Ma})$, when the subducted oceanic crust is infiltrated by substantial amounts of $\mathrm{H}_{2} \mathrm{O}$ released by dehydration reactions. In some modern arcs (e.g., North Kamchatka and Austral Andes) where the subducted slabs are younger than $25 \mathrm{Ma}$, the trace element geochemistry of "adakite" lavas is consistent with partial melting of the subducted oceanic lithosphere (Defant and Drummond, 1990). 
Peacock (1990) first investigated the process of hydrous melting of the mantle peridotite at high pressures. He concluded that at least some of the fluids released from the subducting slabs migrate upward into the overlying mantle wedge, and 1) form phlogopite at temperatures below $1200^{\circ} \mathrm{C}$; 2) trigger fluid - present partial melting at temperatures greater than the wet solidus $\left(>900^{\circ} \mathrm{C}\right)$. At temperatures lower than $900^{\circ} \mathrm{C}$ no melting occurs and fluids may continue to migrate until they reach the $\mathrm{P}-\mathrm{T}$ conditions for the formation of serpentine, talc, phlogopite or hornblende. In subduction zones which are cooler, it is more likely that released fluids with geochemical signatures from the slab trigger partial melting of the mantle wedge instead of the slab itself.

\subsubsection{Evidence for involvement of subducted sediments:}

Plank and Langmuir (1993) calculated that there is a positive linear relationship between the sediment input fluxes and the Na-normalized concentrations of some incompatible elements, including $\mathrm{Ba}, \mathrm{K}, \mathrm{Sr}$ and $\mathrm{Th}$ (especially $\mathrm{Ba}$ and $\mathrm{Th}$ ) in volcanic arc samples on a global basis. They calculated best-fit lines for each of those elements. The sodium content of arc suites at $\mathrm{MgO}=6 \mathrm{wt} \%, \mathrm{Na}_{6.0}$, was chosen for normalization because the average $\mathrm{MgO}$ content for most primitive arc basalts is about $6 \%$, rather low compared to MORBs. They argued that at oceanic trenches, sea-floor sediments might be scraped off the subducted slab or recycled into the mantle to be involved in the generation of arc magmas later. The volcanic outputs are direct indicators of the sediment inputs. Although there are exceptions like the South Sandwich Island (SSI) basalts (Pearce et al., 1995), the linear correlation between $\mathrm{Ba}_{6.0} / \mathrm{Na}_{6.0}$ and $\mathrm{Ba}$ sediment flux is strong $\left(R^{2}=0.924\right)$ for eight of the arc systems. However, this approach can not be taken 
for the SVZ volcanics because there is no reference core for sediments on the subducting Nazca plate (Plank and Langmuir, 1998).

Other evidence of sediment involvement in arc magma genesis comes from the enrichment in $\mathrm{Pb}$ and $\mathrm{Pb}$ isotopic ratios. $\mathrm{Ce}$ and $\mathrm{Pb}$ are a pair of elements which have similar melt / crystal partition coefficients, such that the $\mathrm{Ce} / \mathrm{Pb}$ ratio can be used to infer source enrichment / melting processes since it is largely unaffected by shallow - level differentiation. For instance, the source of Aleutian magmas has been modeled by mixing between a mantle - derived fluid (low ${ }^{207} \mathrm{~Pb} /{ }^{204} \mathrm{~Pb}$, low $\mathrm{Ce} / \mathrm{Pb}$ ) and a small fraction (1-3\%) of subducted sediments (high ${ }^{207} \mathrm{~Pb} /{ }^{204} \mathrm{~Pb}$, very low $\mathrm{Ce} / \mathrm{Pb}$ ) that created the $\mathrm{Pb}$ - enriched source (Miller et al, 1994).

The investigation of the short-lived $\left(\mathrm{T}_{12}=1.5 \mathrm{Ma}\right)$ cosmogenic ${ }^{10} \mathrm{Be}$ (produced by spallation of oxygen and nitrogen in the atmosphere) also provides important constraints on defining the contribution of subducted sediments. For example, lavas from Japan, Peru, Central America and the Aleutians all show high ${ }^{10} \mathrm{Be}$ concentrations while samples from Sunda, Halmahera, Philippine, Taiwan, Cascade and Mexico arcs have little ${ }^{10} \mathrm{Be}$ enrichment $\left(<1^{*} 10^{6} \mathrm{a} / \mathrm{g}\right)$. Because ${ }^{10} \mathrm{Be}$ decays rapidly $(\sim 10 \mathrm{Ma}$ after it is formed there is almost no ${ }^{10} \mathrm{Be}$ left), its higher content may indicate younger sediments involved, while lower content indicates older sediments. It is the fraction of young (Plio - Pleistocene) sediments in the total sediment column not the total amount of sediments subducted that controls the concentrations of ${ }^{10} \mathrm{Be}$ in arc basalts (Tera et al., 1986). A better indicator-the ratio of ${ }^{10} \mathrm{Be} /{ }^{9} \mathrm{Be}$, is more frequently used because it is not affected by fractionation (Tera et al., 1986; Morris and Tera, 1989). 


\subsubsection{Three - component mixing:}

Ringwood (1974) is among the earliest work that proposed the model of mixing of three components at subduction zones: asthenospheric mantle wedge, altered oceanic crust and sediments of the subducting slab. Hole et al. (1984) and Ellam and Hawkesworth (1988) also demonstrated that subduction related basalts are derived from a three - component mixed source: a high $\mathrm{Sr} / \mathrm{Nd}$ component from dehydration of subducted oceanic crust, a low $\mathrm{Sr} / \mathrm{Nd}$ component from subducted terrigenous sediment and the mantle wedge with an isotopic composition similar to MORB.

Later work has refined and developed this idea. Geochemical evidence from the SSI (South Sandwich Island) arc samples (Pearce et al, 1995) suggests the involvement of three components: the depleted mantle source, altered oceanic crust and pelagic sediment (contributed less). Similarly, Kamchatka lavas are derived from a mixed source of a MORB-like depleted mantle source and two slab components (hydrous fluid and slab melt). Trace element ratios such as $\mathrm{Nb} / \mathrm{Zr}$ vs. $\mathrm{Th} / \mathrm{Zr}$ and $\mathrm{Rb} / \mathrm{Y}$ vs. $\mathrm{Nb} / \mathrm{Y}$ are leveraged by different extents of mixing between the mantle wedge and 1) sediment melts (higher $\mathrm{Th} / \mathrm{Zr}$ and $\mathrm{Nb} / \mathrm{Y}$ ); or 2) fluids (higher $\mathrm{Nb} / \mathrm{Zr}$ and $\mathrm{Rb} / \mathrm{Y}$ ) (Kepezhinskas et al, 1997). For the Mariana arc, Elliott et al (1997) proposed also a three - component mixing model: addition of a rutile - fractionated sedimentary melt (higher $\mathrm{Th} / \mathrm{Nb}$ ) and a slab - derived fluid phase (higher U and LILE/HFSE) to the subarc mantle source.

The M - series samples in Grenada (Thirlwall et al, 1996) are unique because of the relatively thick sequence of sediments in the crust in this area. They can be considered to be derived from the mixing of four components: the depleted mantle wedge, slab fluids, sediments and the overlying crust. 


\subsubsection{Influence of the crust:}

Plank and Langmuir (1988) have proposed that varying extents of partial melting in the mantle beneath an arc volcano can account for variations of major element geochemistry of lavas. Where the overlying crust is thicker, the effective melting column in the mantle should be shorter, and should lead to a smaller extent of melting. In the SVZ, Tormey et al. (1991) used this reasoning to explain, in part, the higher LREE / HREE in the NSVZ and TSVZ of the Andes.

The interaction between a melt and the wall rock, often called the AFC (Assimilation and Fractionation Crystallization), is frequently used to explain the trace element characteristics of continental volcanic arc samples. DePaolo (1981) demonstrated that crystallization and assimilation should be "coupled" processes because of the heat balance. The larger the amount of wallrock assimilation, the greater the degree of enrichment of incompatible elements such as $\mathrm{Rb}, \mathrm{K}, \mathrm{U}$ and Th. Hildreth and Moorbath (1988) presented arguments that all the geochemical variations along the volcanic arc of central Chile (NSVZ and TSVZ) are derived from crustal contributions rather than subduction processes. They suggested that the origin of the most primitive basaltic magmas can be attributed to the base - level contribution of the lowermost crust (MASH zone), and the ascending silicic - alkalic magmas can be further modified by the mid upper crustal materials. More recent studies of magmatic evolution in these arcs recognize mantle and crustal contributions of varying importance but do not support the existence of MASH zones (Feeley et al., 1998).

Geochemical parameters that have been used to infer crustal assimilation in CSVZ lavas include $\delta^{18} \mathrm{O}, \mathrm{Sr}$ and $\mathrm{Nd}$ isotopes, and trace element ratios such as $\mathrm{La} / \mathrm{Yb}$, 
$\mathrm{Rb} / \mathrm{Ba}$ and $\mathrm{K} / \mathrm{Rb}$. Results from Harmon and Hoefs (1984) show that $\delta^{18} \mathrm{O}$ values of lavas from the $S V Z$ range between +5.2 to +6.7 per mil, indicating a more mantle - like source as opposed significant crustal inputs. Hickey - Vargas et al. (1989) pointed out that as there are no elevated $\mathrm{Rb}$ contents and $\mathrm{Rb} / \mathrm{Ba}$ ratios in rhyolites from V.Villarrica compared to the basaltic lavas, crustal contamination is not a major influence on the geochemical features of the samples from V.Villarrica vicinity. However, studies of Volcano Mocho - Choshuenco (40 S) (McMillan et al., 1989) revealed that a crustal component with small isotopic contrasts but enriched in $\mathrm{Rb}$ and $\mathrm{K}$ relative to $\mathrm{Ba}$ and $\mathrm{La}$ is assimilated, resulting in small $\mathrm{Sr}-\mathrm{Nd}$ isotopic changes and elevated $\mathrm{K} / \mathrm{Ba}, \mathrm{Rb} / \mathrm{Ba}, \mathrm{Rb} / \mathrm{La}$ and $\mathrm{K} / \mathrm{La}$ ratios in the basaltic andesites and dacites from this area. Similarly, V.Calbuco $\left(41^{\circ} 20^{\prime} S\right)$ in the southern CSVZ, is also thought to be contaminated by metasedimentary crustal rocks based on the abundance of crustal xenoliths in the lavas from this region and the higher ${ }^{87} \mathrm{Sr} /{ }^{86} \mathrm{Sr}$ and lower ${ }^{143} \mathrm{Nd} /{ }^{144} \mathrm{Nd}$ ratios of the V.Calbuco samples compared with other CSVZ volcanics (Lopez - Escobar, et al., 1995). 


\subsection{Crystallization behavior of V.Villarrica and SEC lavas based on petrologic and major element constraints}

\subsubsection{V.Villarrica and associated SECs}

In this section, I will discuss the differentiation trends of V.Villarrica and its associated SEC basalts and basaltic andesites based on phase relations and try to establish possible fractionation paths for the above rock samples.

Experiments on $\mathrm{H}_{2} \mathrm{O}$ - saturated arc high - alumina basalts reveal a multiple saturation of olivine, high - Ca pyroxene, calcic plagioclase and spinel or magnetite together with a high - alumina basaltic or basaltic - andesitic liquid (Helz, 1973, 1976; Baker and Eggler, 1987; Sisson and Grove, 1993). On the following diagrams all the V.Villarrica and SEC samples are plotted (Fig.4.2.1). On this and similar diagrams, abbreviations are:

On fields: $\quad$ oliv = olivine; aug = augite; pig = pigeonite; ens = enstatite;

$$
\text { opx }=\text { orthopyroxene (enstatite) }
$$

On apices: $\quad \mathrm{Ol}=$ olivine $; \mathrm{Di}=$ diopside $; \mathrm{Q}=$ quartz; $\mathrm{Pl}=$ plagioclase 
Fig.4.2.1a Upper) The pseudo - ternary projection of the V.Villarrica and SEC samples (Pl to Ol - Di - Q) except SEC Rucapillan, El Estadio and Llizan. Lower) The pseudo ternary projection (Pl to Ol - Di - Q) for SEC Rucapillan, El Estadio and Llizan.
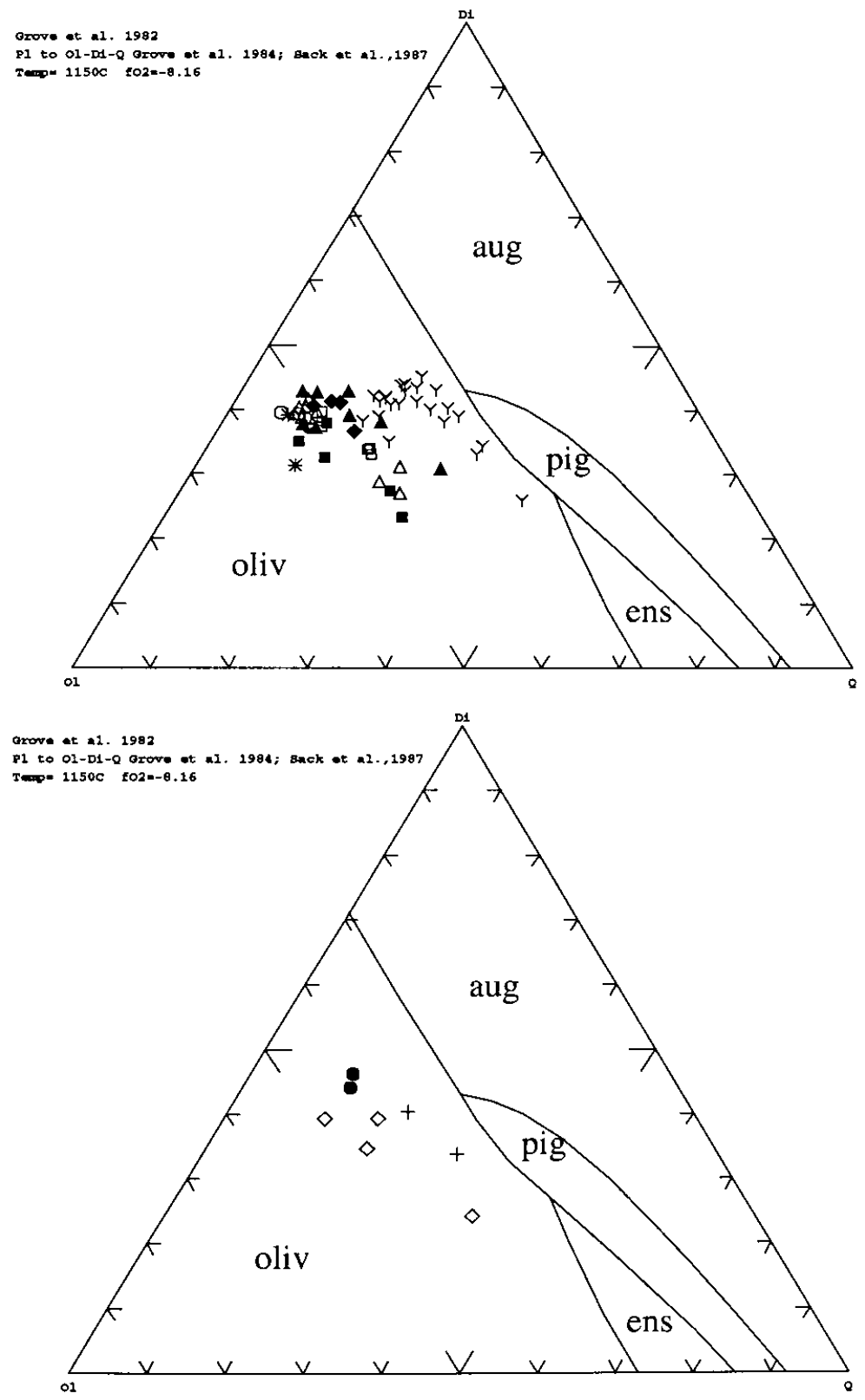

C. Redondo

San Jorge

$Y$ Villarrica

O La Barda

$\Delta$ Huelemolle

$\triangle$ Caburgua

$\checkmark$ Huililco

* Relicura +

Pichares

$\diamond$ Rucapillan

+ Llizan

- El Estadio 
Fig.4.2.1b Upper) The pseudo - ternary projection of the V.Villarrica and SEC samples (Ol to Pl - Di - Q) except SEC Rucapillan, El Estadio and Llizan. Lower) The pseudo ternary projection (Ol to Pl - Di - Q) for SEC Rucapillan, El Estadio and Llizan.

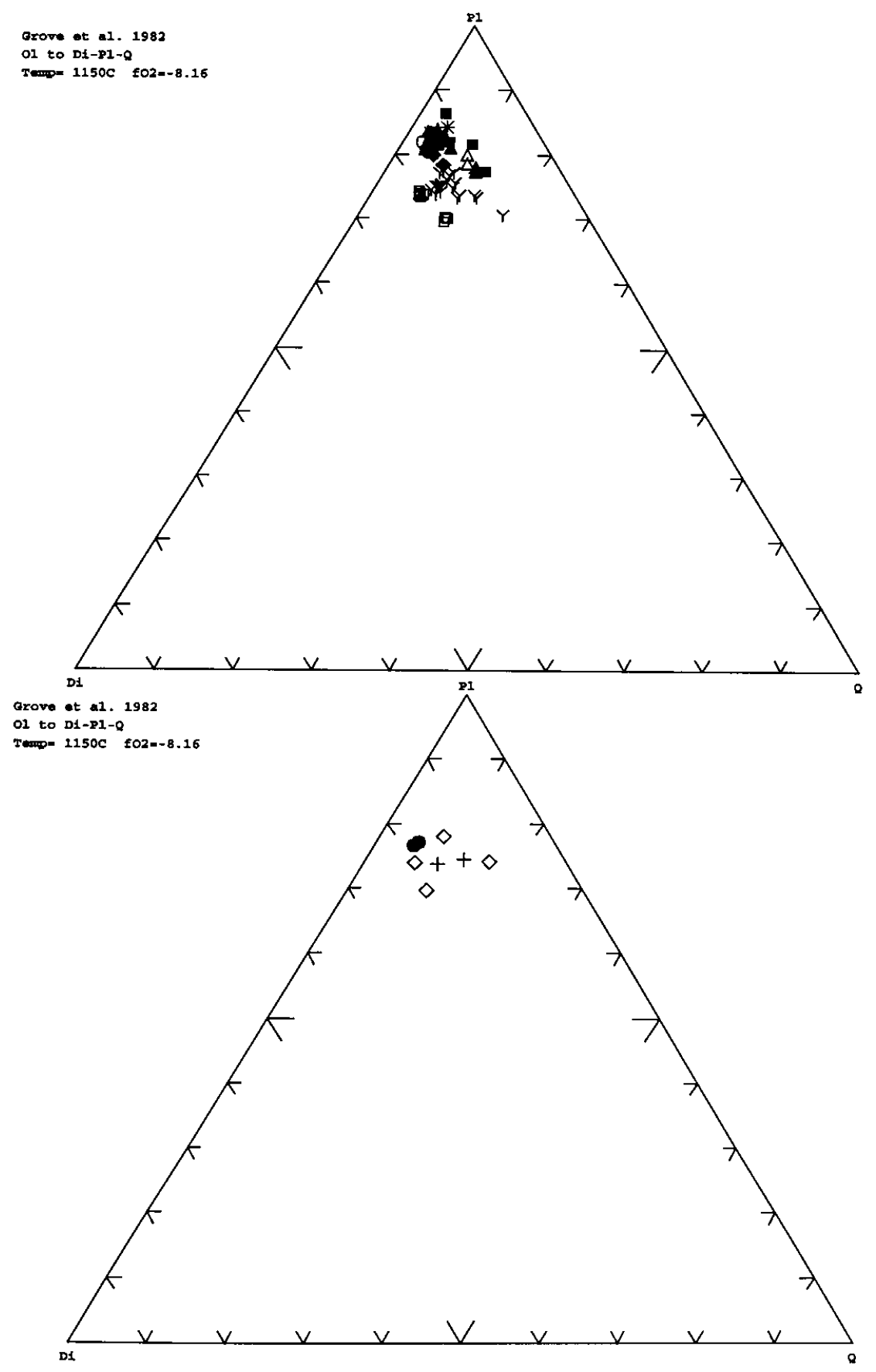


Fig.4.2.1c Upper) The pseudo - ternary projection of the V.Villarrica and SEC samples (Di to OI - Pl - Q) except SEC Rucapillan, El Estadio and Llizan. Lower) The pseudo ternary projection (Di to Ol - Pl - Q) for SEC Rucapillan, El Estadio and Llizan.

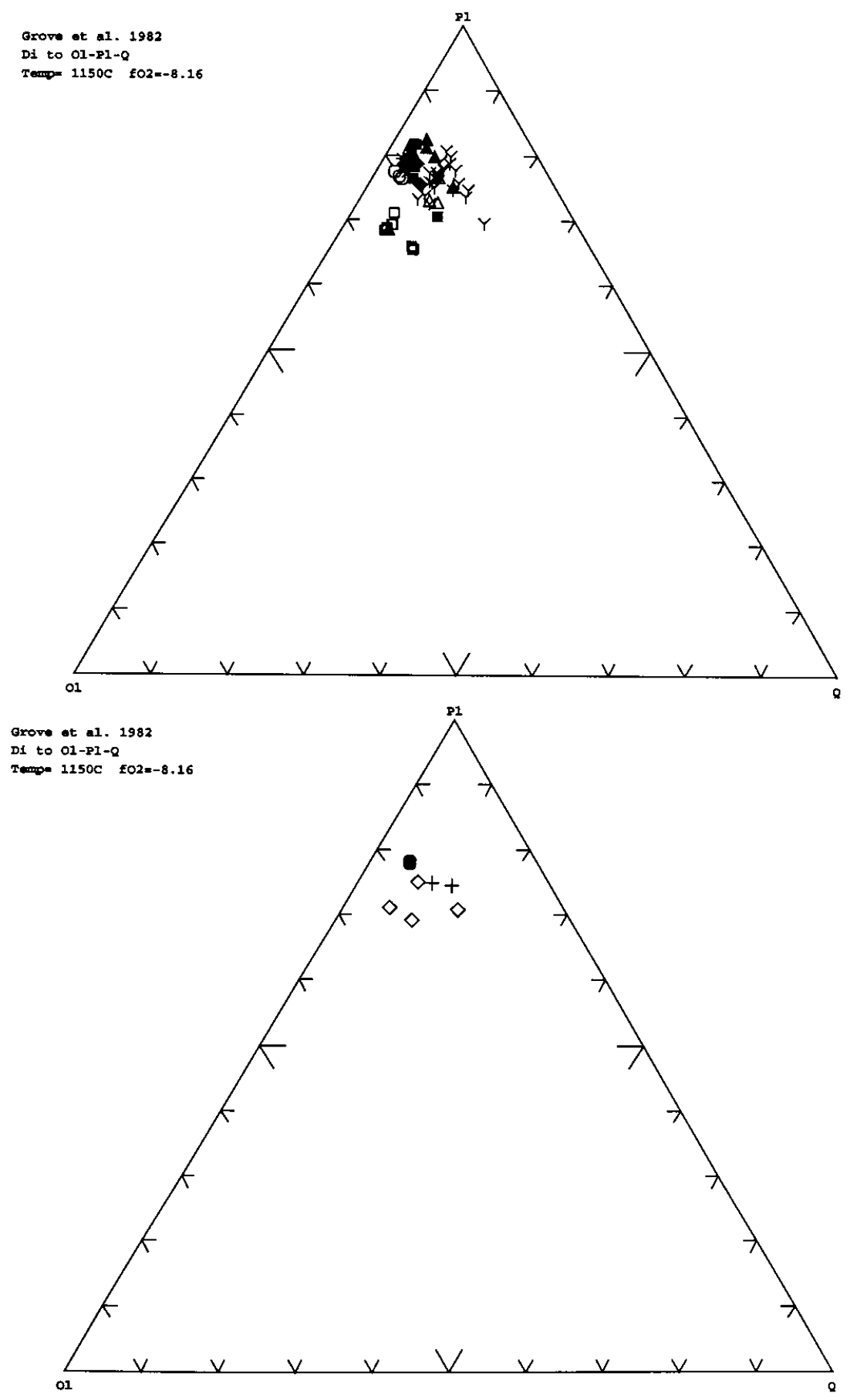


Most of the samples, except two from Huelemolle (120194-02 and 110194-03), contain clinopyroxene in addition to olivine and plagioclase as a phenocryst phase (Table 2-2-1). For some samples (L83, L81 and Rucapillan), cpx is the dominant phenocryst phase $(\geq 70 \%)$. These rocks are unlikely to represent liquids that crystallized at atmospheric pressure because they do not plot along the 1 atm olivine + diopside + plagioclase anhydrous pseudocotectic (Fig.4.2.1a). In fact, all samples fall inside the olivine + plagioclase liquidus field. The reason for this offset might be: 1) they evolved at pressures substantially greater than $1 \mathrm{~atm}$; or 2) the role of $\mathrm{H}_{2} \mathrm{O}$.

Subduction zone magmatism is characterized by the influence of water, therefore, only hydrous phase diagrams should be used to interpret the evolution of arc lavas. Previous studies indicate that increases in pressure under anhydrous conditions should shrink the olivine primary phase volume and shift the olivine - augite cotectic towards the olivine apex (Kushiro, 1969, 1974; Stolper, 1980; Grove and Baker, 1984), which is consistent with the distribution of samples in Fig.4.2.1. Addition of $\mathrm{H}_{2} \mathrm{O}$ to silicate melts also lowers the temperatures of first appearance of near - liquidus silicate minerals, and moves the cotectics towards the plagioclase apex (i.e., destabilizes plagioclase as a crystallizing phase). This allows crystallization of more high $\mathrm{Fe}-\mathrm{Mg}$ silicates relative to $\mathrm{Ca}$ - rich plagioclase. The residual liquids are more depleted in $\mathrm{FeO}$ and $\mathrm{MgO}$ and enriched in silica, alumina and alkalis, producing the calc - alkaline high - alumina basalts and andesites characteristic of arc volcanics (Yoder, 1965; Grove and Baker, 1984; Gill, 1981; Baker and Eggler, 1983; Sisson and Grove, 1993).

In order to eliminate the possible influence of crystal accumulation (especially for San Jorge), chemical compositions of the groundmass $(\approx$ liquid composition) were 
recalculated by subtracting the phenocrysts from the bulk composition. Twenty - one samples with microscopically determined modal analyses (see Table 2-2-1) were plotted together with their bulk compositions to define a possible liquid line of descent (Fig.4.2.2). Compositions of the phenocrysts were taken (or averaged) (Table 4-2-1) from the results in the dissertation of Gerlach (1985) and the calculated liquid (groundmass) compositions are shown in Table 4-2-2.

Rock compositions cluster more tightly on Fig.4.2.2., since the above calculation largely removes the effect of phenocryst (e.g., olivine) accumulation and shallow crystallization processes on the compositions of the V.Villarrica and SEC lavas. However, the difference of compositions between whole rock samples and their groundmass is not significant in many cases. 
Table 4-2-1 Averaged compositions of the phenocrysts in the V.Villarrica and SEC samples (used for calculating the LLDs)

\begin{tabular}{|c|c|c|c|}
\hline \multicolumn{4}{|c|}{ Reference: Dissertation of D. C. Gerlach (1985) } \\
\hline Oxides & Plagioclase & Olivine & Cpx \\
\hline $\mathrm{SiO} 2$ & 47.31 & 39.41 & 51.11 \\
\hline $\mathrm{Al} 2 \mathrm{O} 3$ & 33.13 & 0.015 & 1.64 \\
\hline$\overline{\mathrm{CiO} 2}$ & 0 & 0 & 0.42 \\
\hline $\mathrm{FeO}$ & 0.62 & 16.72 & 16.86 \\
\hline $\mathrm{MgO}$ & 0.14 & 43.73 & 12.39 \\
\hline $\mathrm{CaO}$ & 16.85 & 0.21 & 16.79 \\
\hline $\mathrm{MnO}$ & 0 & 0.19 & 0.68 \\
\hline $\mathrm{Na} 2 \mathrm{O}$ & 1.84 & 0.07 & 0.14 \\
\hline $\mathrm{K} 2 \mathrm{O}$ & 0.08 & 0 & 0.01 \\
\hline
\end{tabular}


Table 4-2-2 The original rock sample composition (Part I) and the calculated liquid composition (Part II) for the chosen V.Villarrica and SEC samples

\section{Part I}

\begin{tabular}{|c|c|c|c|c|c|}
\hline Sample\# & $\mathrm{SiO}_{2}$ & $\mathrm{Al}_{2} \mathrm{O}_{3}$ & $\mathrm{TiO}_{2}$ & $\mathrm{Fe}_{2} \mathrm{O}_{3}(\mathrm{~T})$ & $\mathrm{FeO}(\mathrm{T})$ \\
\hline $210281-1$ & 52.6 & 16.79 & 1.15 & 9.76 & 8.78 \\
\hline L28 & 52.19 & 16.82 & 1.14 & 9.73 & 8.76 \\
\hline L23 & 52.71 & 18.25 & 1.23 & 8.81 & 7.93 \\
\hline $\mathrm{L} 21$ & 51.79 & 16.89 & 1.14 & 10.03 & 9.03 \\
\hline $151282-3$ & 55 & 16.11 & 1.37 & 10.06 & 9.05 \\
\hline 140194-01 & 50.39 & 15.7 & 0.75 & 9.46 & 8.51 \\
\hline L83 & 50.87 & 18.08 & 1.23 & 9.4 & 8.46 \\
\hline 150194-06 & 50.35 & 17.82 & 1.06 & 9.59 & 8.63 \\
\hline $120194-02$ & 50.69 & 18.65 & 1.1 & 9.76 & 8.78 \\
\hline 110194-03 & 50.98 & 17.76 & 1.18 & 9.42 & 8.48 \\
\hline L84 & 51.84 & 18.48 & 1.25 & 9.7 & 8.73 \\
\hline L16 & 51.79 & 18.05 & 1.03 & 9.24 & 8.31 \\
\hline $150194-03$ & 51.28 & 17.92 & 1.1 & 9.61 & 8.65 \\
\hline L82 & 50.95 & 17.92 & 1.13 & 9.28 & 8.35 \\
\hline L81 & 50.72 & 17.66 & 1.1 & 9.38 & 8.44 \\
\hline$\llcorner 24$ & 51.93 & 17.57 & 1.08 & 9.03 & 8.13 \\
\hline$\lcm{20}$ & 51.48 & 17.75 & 1.16 & 9 & 8.10 \\
\hline Ru-porphy & 50.31 & 16.69 & 0.77 & 9.46 & 8.51 \\
\hline Ru-Aphy & 53.1 & 17.09 & 1.53 & 11.8 & 10.62 \\
\hline
\end{tabular}

\begin{tabular}{|c|c|c|c|c|c|}
\hline Sample\# & $\mathrm{MgO}$ & $\mathrm{CaO}$ & $\mathrm{MnO}$ & $\mathrm{Na}_{2} \mathrm{O}$ & $\mathrm{K}_{2} \mathrm{O}$ \\
\hline $210281-1$ & 6.05 & 9.62 & 0.16 & 3.12 & 0.65 \\
\hline $\mathrm{L} 28$ & 6.12 & 9.61 & 0.16 & 3.18 & 0.63 \\
\hline L23 & 4.48 & 9.91 & 0.17 & 3.38 & 0.69 \\
\hline L21 & 6.63 & 9.77 & 0.16 & 2.91 & 0.61 \\
\hline $151282 \cdot 3$ & 4.2 & 8.1 & 0.16 & 3.83 & 0.86 \\
\hline 140194-01 & 10.4 & 10 & 0.16 & 2.54 & 0.42 \\
\hline $\mathrm{L} 83$ & 6.41 & 8.4 & 0.15 & 3.3 & 1.21 \\
\hline $150194-06$ & 7.62 & 9.6 & 0.16 & 3.21 & 0.67 \\
\hline 120194-02 & 5.99 & 9.44 & 0.16 & 3.26 & 0.84 \\
\hline 110194-03 & 5.74 & 8.95 & 0.16 & 3.46 & 1.07 \\
\hline L84 & 4.73 & 8.95 & 0.17 & 3.63 & 0.86 \\
\hline L16 & 6.21 & 9.13 & 0.15 & 3.38 & 0.93 \\
\hline 150194-03 & 6.32 & 9.36 & 0.16 & 2.69 & 0.71 \\
\hline L82 & 6.72 & 9.05 & 0.14 & 3.54 & 0.73 \\
\hline L81 & 7.1 & 9.61 & 0.14 & 3.26 & 0.66 \\
\hline L24 & 6.56 & 9.21 & 0.16 & 3.03 & 1.08 \\
\hline $\mathrm{L} 20$ & 6.24 & 9.18 & 0.16 & 3.27 & 1.13 \\
\hline Ru-porphy & 8.1 & 11.29 & 0.16 & 1.87 & 0.47 \\
\hline Ru-Aphy & 3.6 & 8.36 & 0.19 & 2.82 & 0.86 \\
\hline
\end{tabular}




\section{$\underline{\text { Part II }}$}

\begin{tabular}{|l|r|r|r|r|r|}
\hline Sample\# & \multicolumn{1}{|c|}{$\mathrm{SiO}_{2}(\mathrm{~L})$} & $\mathrm{Al}_{2} \mathrm{O}_{3}(\mathrm{~L})$ & $\mathrm{TiO}_{2}(\mathrm{~L})$ & $\mathrm{Fe}_{2} \mathrm{O}_{3}(\mathrm{~T})(\mathrm{L})$ & $\mathrm{FeO}(\mathrm{T})(\mathrm{L})$ \\
\hline $210281-1$ & 52.89 & 16.02 & 1.21 & & 9.17 \\
\hline $\mathrm{L} 28$ & 52.51 & 15.88 & 1.21 & & 9.22 \\
\hline $\mathrm{L} 23$ & 52.88 & 17.80 & 1.27 & 8.15 \\
\hline $\mathrm{L} 21$ & 52.98 & 13.24 & 1.42 & 10.92 \\
\hline $151282-3$ & 55.02 & 16.12 & 1.37 & & 9.05 \\
\hline $140194-01$ & 51.02 & 16.69 & 0.80 & 7.99 \\
\hline $\mathrm{L} 83$ & 50.88 & 18.25 & 1.24 & 8.37 \\
\hline $150194-06$ & 50.56 & 18.17 & 1.08 & 8.47 \\
\hline $120194-02$ & 50.77 & 18.39 & 1.12 & 8.93 \\
\hline $110194-03$ & 51.09 & 17.92 & 1.19 & 8.40 \\
\hline $\mathrm{L} 84$ & 51.89 & 18.34 & 1.26 & 8.81 \\
\hline $\mathrm{L} 16$ & 51.97 & 18.18 & 1.05 & 8.26 \\
\hline $150194-03$ & 51.50 & 18.08 & 1.13 & 8.58 \\
\hline $\mathrm{L} 82$ & 51.20 & 18.25 & 1.16 & 8.20 \\
\hline $\mathrm{L} 81$ & 50.74 & 17.74 & 1.10 & 8.40 \\
\hline $\mathrm{L} 24$ & 52.39 & 17.42 & 1.15 & 8.19 \\
\hline $\mathrm{L} 20$ & 51.64 & 17.69 & 1.19 & & 8.12 \\
\hline Ru-porphy & 50.33 & 17.49 & 0.79 & & 8.07 \\
\hline Ru-Aphy & 53.11 & 17.09 & 1.53 & & 10.62 \\
\hline
\end{tabular}

\begin{tabular}{|l|r|r|r|r|r|}
\hline Sample\# & $\mathrm{MgO}(\mathrm{L})$ & $\mathrm{CaO}(\mathrm{L})$ & $\mathrm{MnO}(\mathrm{L})$ & & \\
\hline $210281-1$ & 6.27 & 9.27 & 0.17 & 3.19 & $\mathrm{Ka}_{2} \mathrm{O}(\mathrm{L})$ \\
\hline $\mathrm{L} 28$ & 6.41 & 9.17 & 0.17 & 3.27 & 0.68 \\
\hline $\mathrm{L} 23$ & 4.61 & 9.70 & 0.18 & 3.43 & 0.67 \\
\hline $\mathrm{L} 21$ & 7.79 & 8.17 & 0.20 & 3.20 & 0.71 \\
\hline $151282-3$ & 4.17 & 8.09 & 0.16 & 3.84 & 0.74 \\
\hline $140194-01$ & 8.47 & 10.52 & 0.15 & 2.70 & 0.86 \\
\hline $\mathrm{L} 83$ & 6.32 & 8.33 & 0.15 & 3.33 & 0.45 \\
\hline $150194-06$ & 6.92 & 9.77 & 0.16 & 3.27 & 0.22 \\
\hline $120194-02$ & 6.06 & 9.31 & 0.16 & 3.29 & 0.86 \\
\hline $110194-03$ & 5.38 & 9.03 & 0.16 & 3.49 & 1.08 \\
\hline $\mathrm{L} 84$ & 4.77 & 8.87 & 0.17 & 3.65 & 0.87 \\
\hline $\mathrm{L} 16$ & 5.79 & 9.18 & 0.15 & 3.43 & 0.95 \\
\hline $150194-03$ & 5.79 & 9.42 & 0.16 & 2.74 & 0.73 \\
\hline L82 & 5.98 & 9.19 & 0.14 & 3.62 & 0.75 \\
\hline L81 & 7.03 & 9.60 & 0.14 & 3.28 & 0.66 \\
\hline $\mathrm{L} 24$ & 5.96 & 9.09 & 0.16 & 3.15 & 1.15 \\
\hline L20 & 6.03 & 9.11 & 0.16 & 3.32 & 1.16 \\
\hline Ru-porphy & 7.71 & 11.09 & 0.14 & 1.96 & 0.49 \\
\hline Ru-Aphy & 3.59 & 8.34 & 0.19 & 2.82 & 0.86 \\
\hline
\end{tabular}


Fig.4.2.2a Upper) Pseudo - ternary projection ( $\mathrm{Pl}$ to $\mathrm{Ol}$ - Di - Q) of the V.Villarrica and SEC (except Rucapillan, El Estadio and Llizan) samples. Lower) Pseudo - ternary projection for SEC Rucapillan (open symbols - rock compositions; filled symbols estimated liquid compositions).

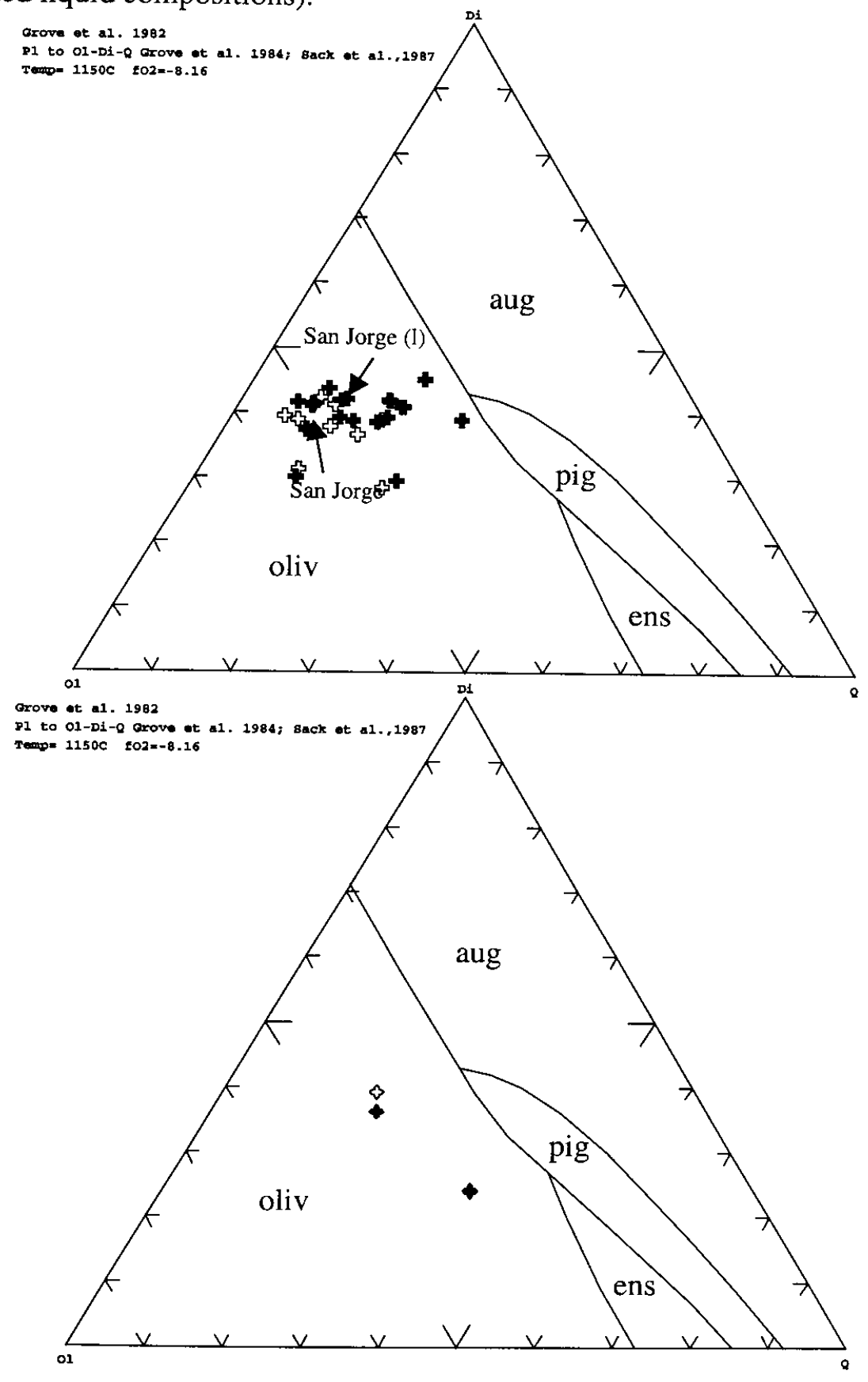


Fig. 4.2.2b Upper) The pseudo - ternary projection ( $\mathrm{Ol}$ to $\mathrm{Pl}$ - $\mathrm{Di}$ - Q) of the V.Villarrica and SEC samples except SEC Rucapillan, El Estadio and Llizan. Lower) The pseudo ternary projection (Ol to Pl - Di - Q) for SEC Rucapillan.

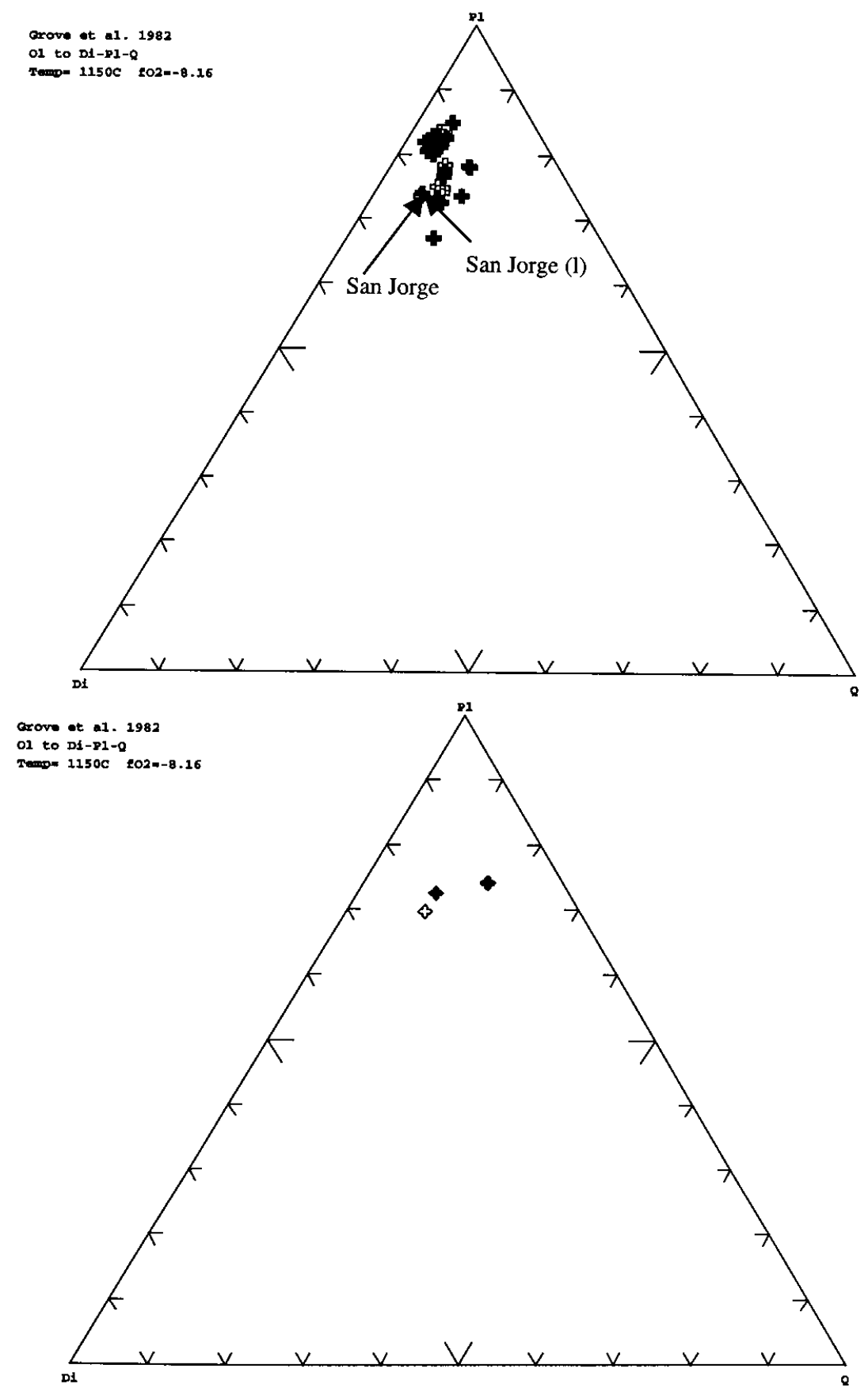


Fig. 4.2.2c Upper) The pseudo - ternary projection (Di to Ol - $\mathrm{Pl}-\mathrm{Q}$ ) of the V.Villarrica and SEC samples except SEC Rucapillan, El Estadio and Llizan. Lower) The pseudo ternary projection (Di to Ol - $\mathrm{Pl}$ - Q) for SEC Rucapillan.

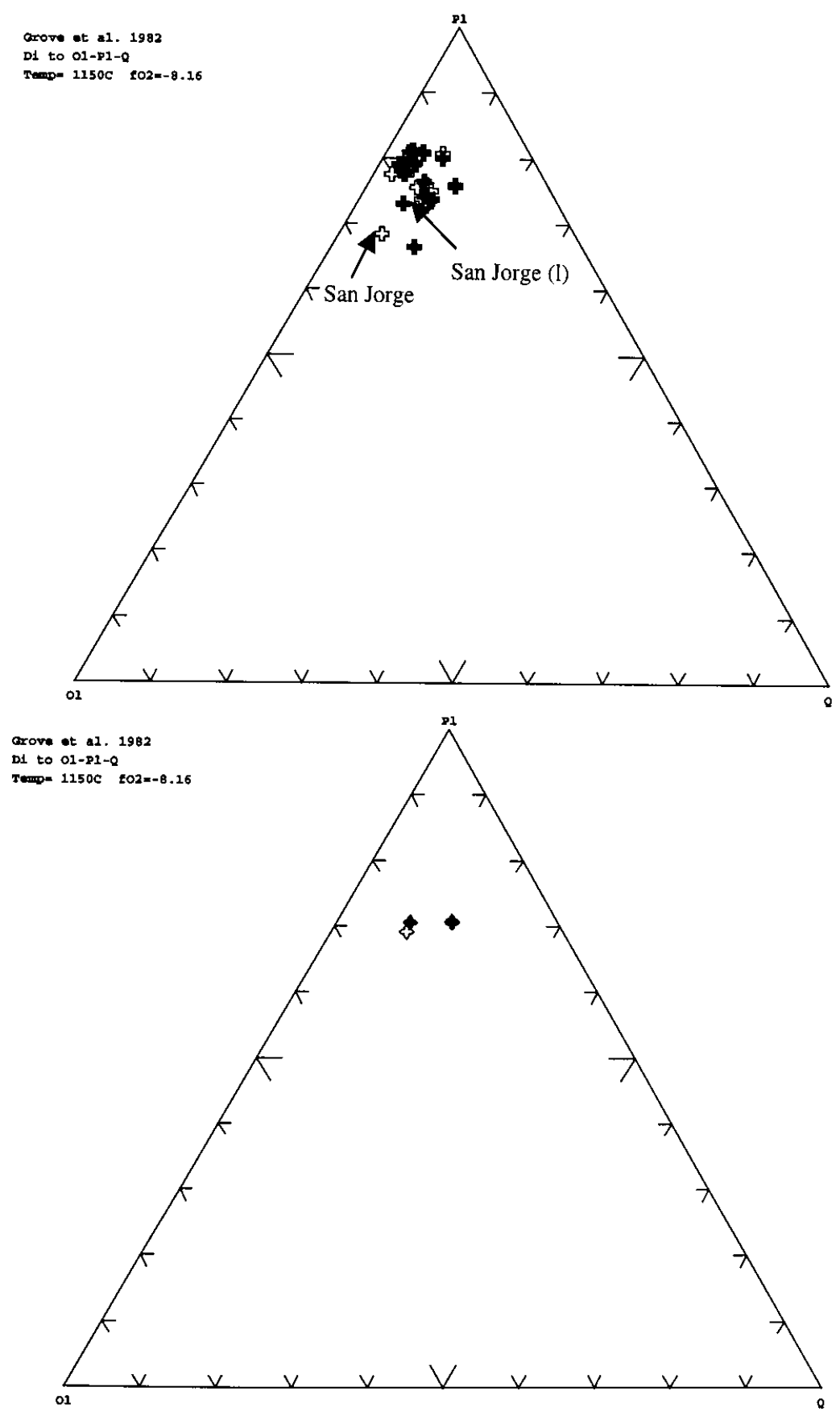


The SEC basalts are both more enriched in olivine component (Fig.4.2.1a; 4.2.2a) and plagioclase component (Fig.4.2.1b; 4.2.2b) compared to basalts from V.Villarrica. This may result from less olivine fractionation for the SECs, as shown on the oxide - $\mathrm{SiO}_{2}$ diagrams (Fig.3.2.1). The same increase of $\mathrm{SiO}_{2}$ causes more $\mathrm{MgO}$ depletion for the V.Villarrica samples, because they fractionate more high $\mathrm{Fe}-\mathrm{Mg}$ mineral phases such as olivine. On the contrary, the SEC basalts may have fractionated a larger proportion of clinopyroxene, causing an increase in plagioclase component in the low - pressure liquids. This is also consistent with the lower $\mathrm{SiO}_{2}$ for a given $\mathrm{MgO}$ in the $\mathrm{SEC}$ basalts. These results suggest that SEC magmas underwent fractional crystallization under higher pressure relative to V.Villarrica magmas (Grove and Baker, 1984; Sisson and Grove, 1993). 


\subsubsection{San Jorge}

Basalts from the most mafic SEC, San Jorge, located $18 \mathrm{~km}$ to the ENE of V.Villarrica, are distinctive because of their extremely high $\mathrm{MgO}$ contents $(\sim 10 \mathrm{wt} \%)$. This appears to have resulted from substantial olivine accumulation in the samples ( $10 \%$ of the total volume, see the sample $140194-01$ from Table 2-2-1). Consequently, when the olivine phenocrysts are subtracted, San Jorge sample 140194 - 01 shows the largest shift away from the olivine apex, while no significant change on the $\mathrm{Ol}$ to $\mathrm{Di}-\mathrm{Pl}$ - Q projections (Fig.4.2.1b; Fig.4.2.2b).

On projections from the plagioclase apex (Fig. 4.2.1a; 4.2.2a), the basalts of San Jorge do not stand out from other SEC basalts and basaltic andesites. Why are the most $\mathrm{MgO}$ - rich samples not particularly olivine - rich from the projection? In addition, on the diagrams from olivine apex (Fig.4.2.1b; 4.2.2b) and diopside apex (Fig.4.2.1c; 4.2.2c), San Jorge basalts are less plagioclase - rich, similar to V.Villarrica basalts, but not comparable to lavas from the other SECs. 


\subsubsection{Llizan}

SEC Llizan, the most evolved SEC, has erupted basaltic andesites and andesites with $\mathrm{SiO}_{2}>54 \%$. The sample with highest $\mathrm{SiO}_{2}(58 \%)$ also has unusually high ${ }^{87} \mathrm{Sr} /{ }^{86} \mathrm{Sr}$ (0.70412) and low ${ }^{206} \mathrm{~Pb} /{ }^{204} \mathrm{~Pb}$ (18.29) compared with basaltic SECs. These are all suggestive of crustal assimilation (Tilton and Barreiro, 1980; Lopez - Escobar et al., 1995) as an origin for the andesites.

Fig.4.2.3 shows major element features of Llizan samples (the two "+" symbols) compared with the V.Villarrica and SEC basalts, a representative of rhyolites from V.Villarrica (VR) (Hickey - Vargas et al., 1989) and the average upper continental crust (CC) (Rudnick and Fountain, 1995). The arrows on the diagram are trajectories that pass directly through the two analyzed Llizan samples.

Llizan samples show a possible evolution trend of mixing the average compositions of the SEC (or V.Villarrica) basalts with a silicic endmember, which has lower $\mathrm{Al}_{2} \mathrm{O}_{3}, \mathrm{Fe}_{2} \mathrm{O}_{3}, \mathrm{MgO}$ and $\mathrm{CaO}$ and higher $\mathrm{Na}_{2} \mathrm{O}$ and $\mathrm{K}_{2} \mathrm{O}$ contents than the basaltic V.Villarrica and SEC samples. This potential endmember could be the upper continental crust, V.Villarrica rhyolites or other crustal materials from the Coastal Cordillera (especially the CVZ) used for modeling by other people, such as the Charcani Gneisses (James, 1984), Arequipa Massif (Barreiro, 1984) and Patagonian Batholith (Lopez Escobar et al., 1995). 

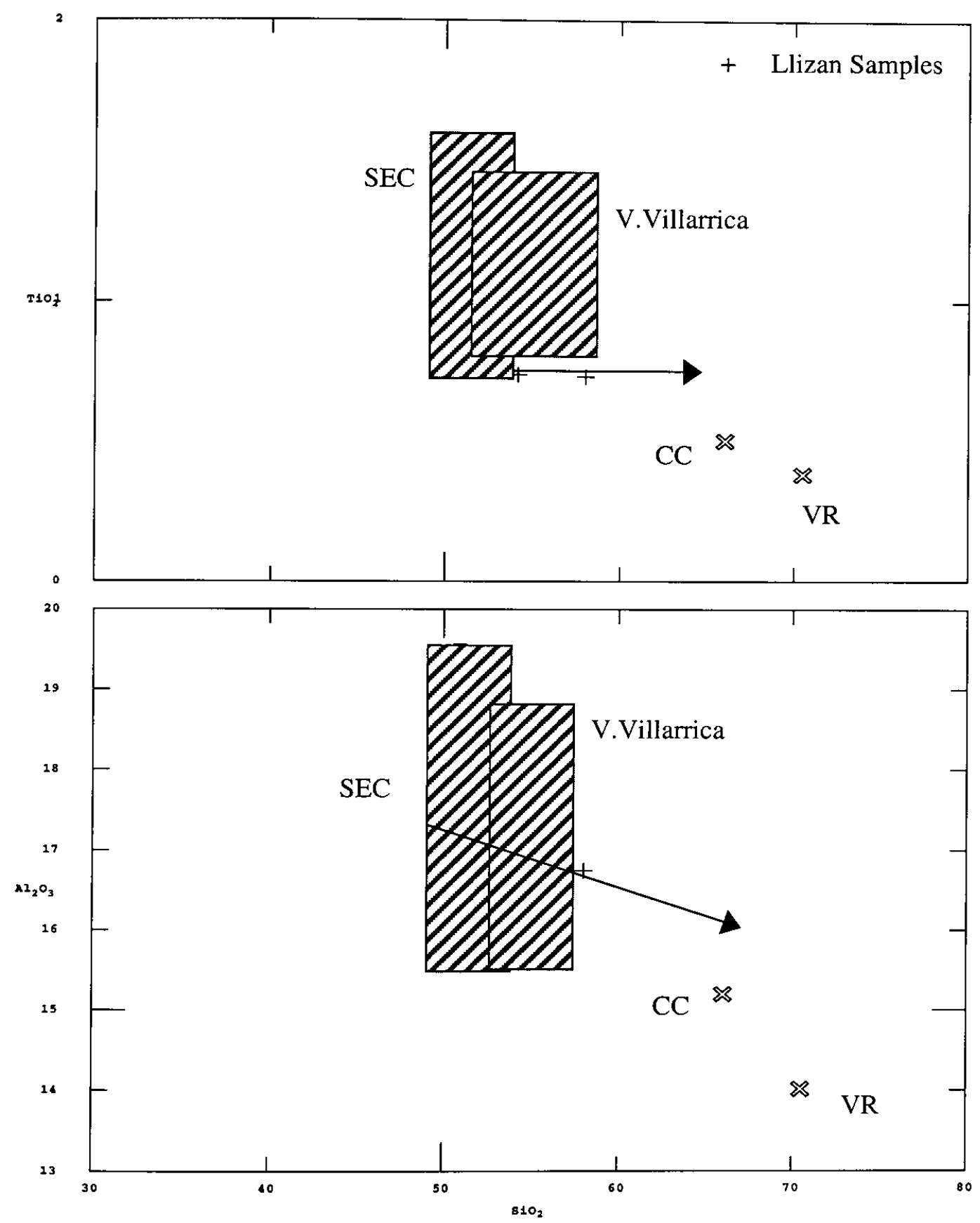

Fig.4.2.3 Oxide versus $\mathrm{SiO}_{2}$ for the Llizan andesites, V.Villarrica rhyolite and the upper continental crust (continued) 

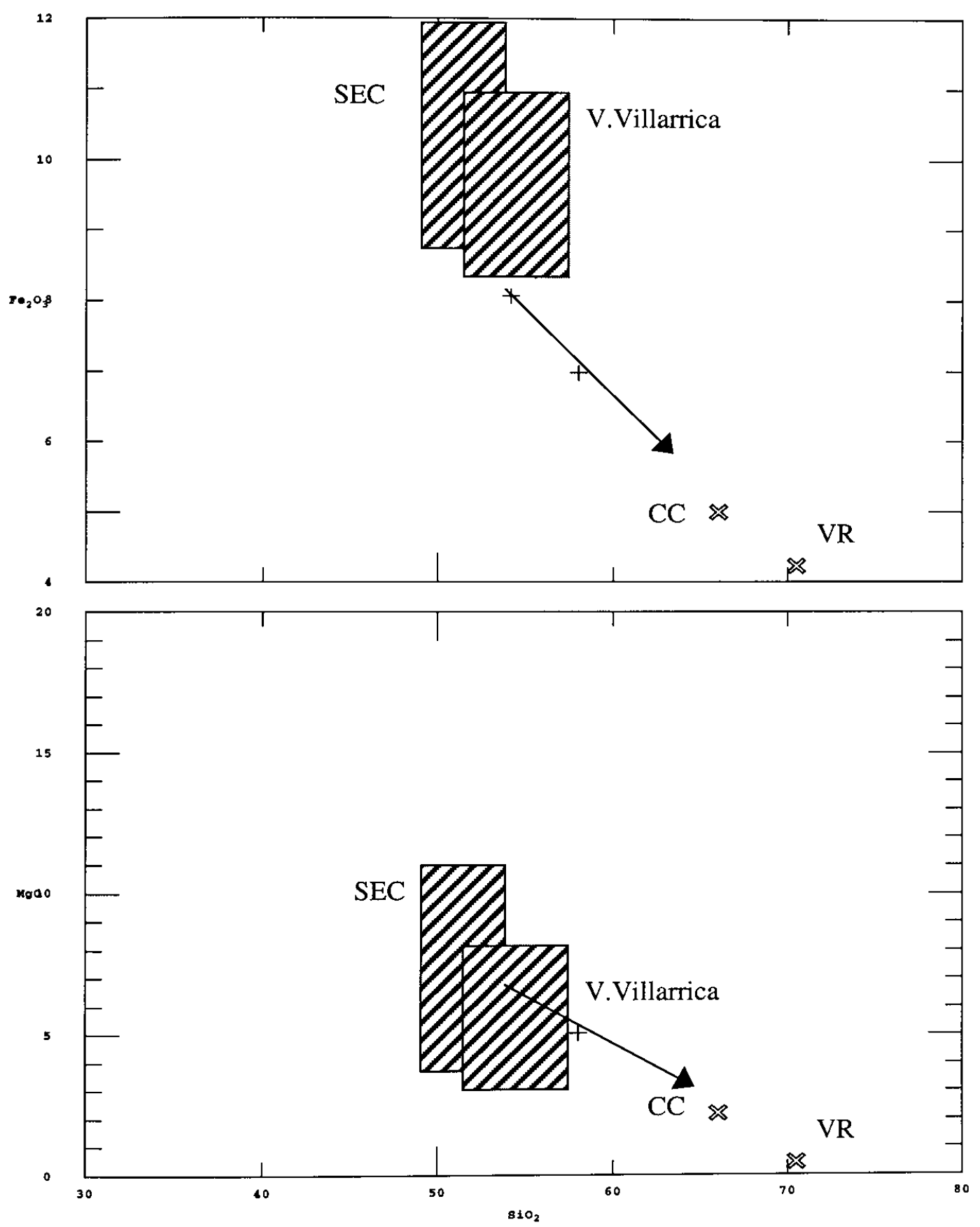

Fig.4.2.3 Oxide versus $\mathrm{SiO}_{2}$ for the Llizan andesites, V.Villarrica rhyolite and the upper continental crust (continued) 

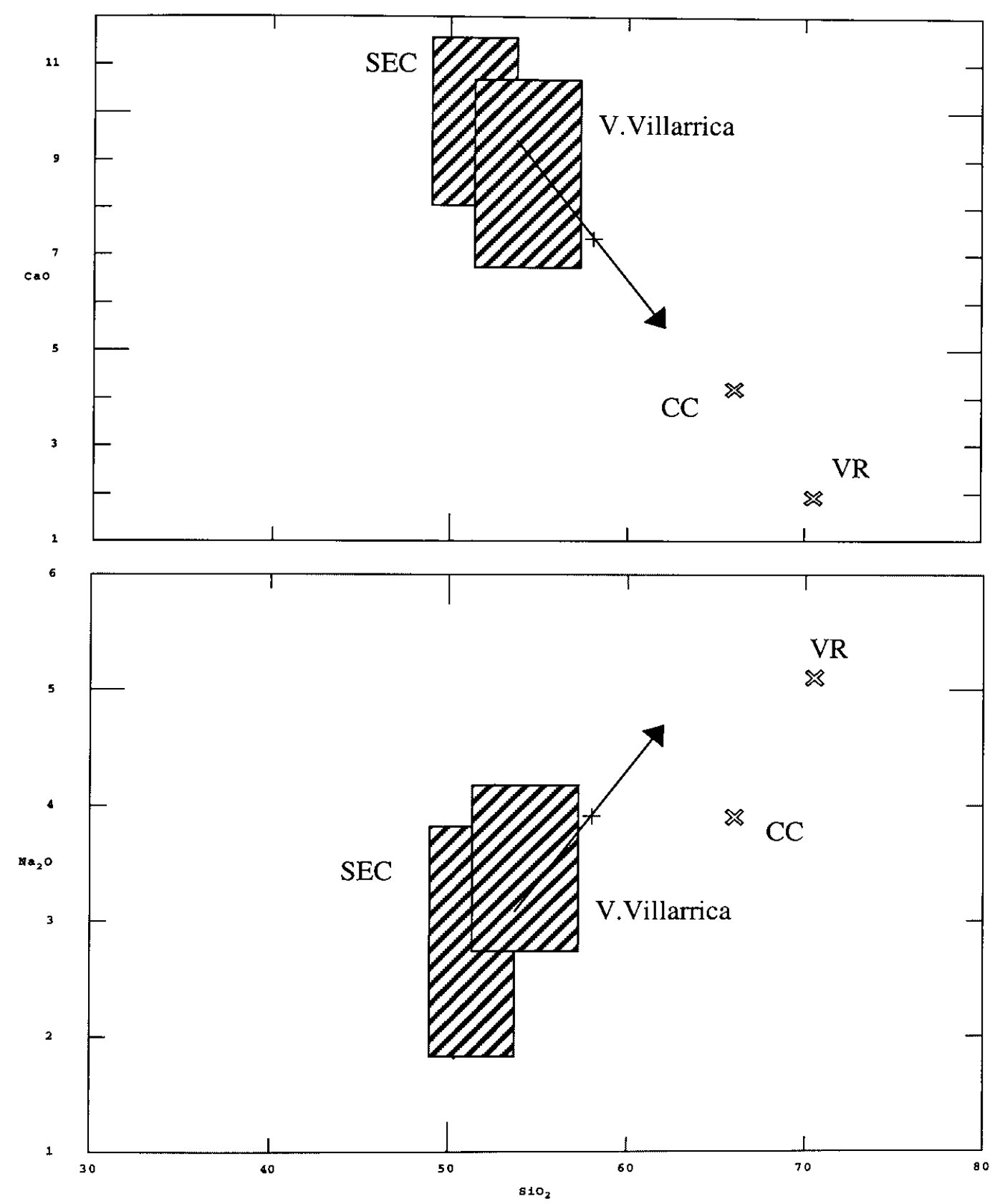

Fig.4.2.3 Oxide versus $\mathrm{SiO}_{2}$ for the Llizan andesites, V.Villarrica rhyolite and the upper continental crust (continued) 

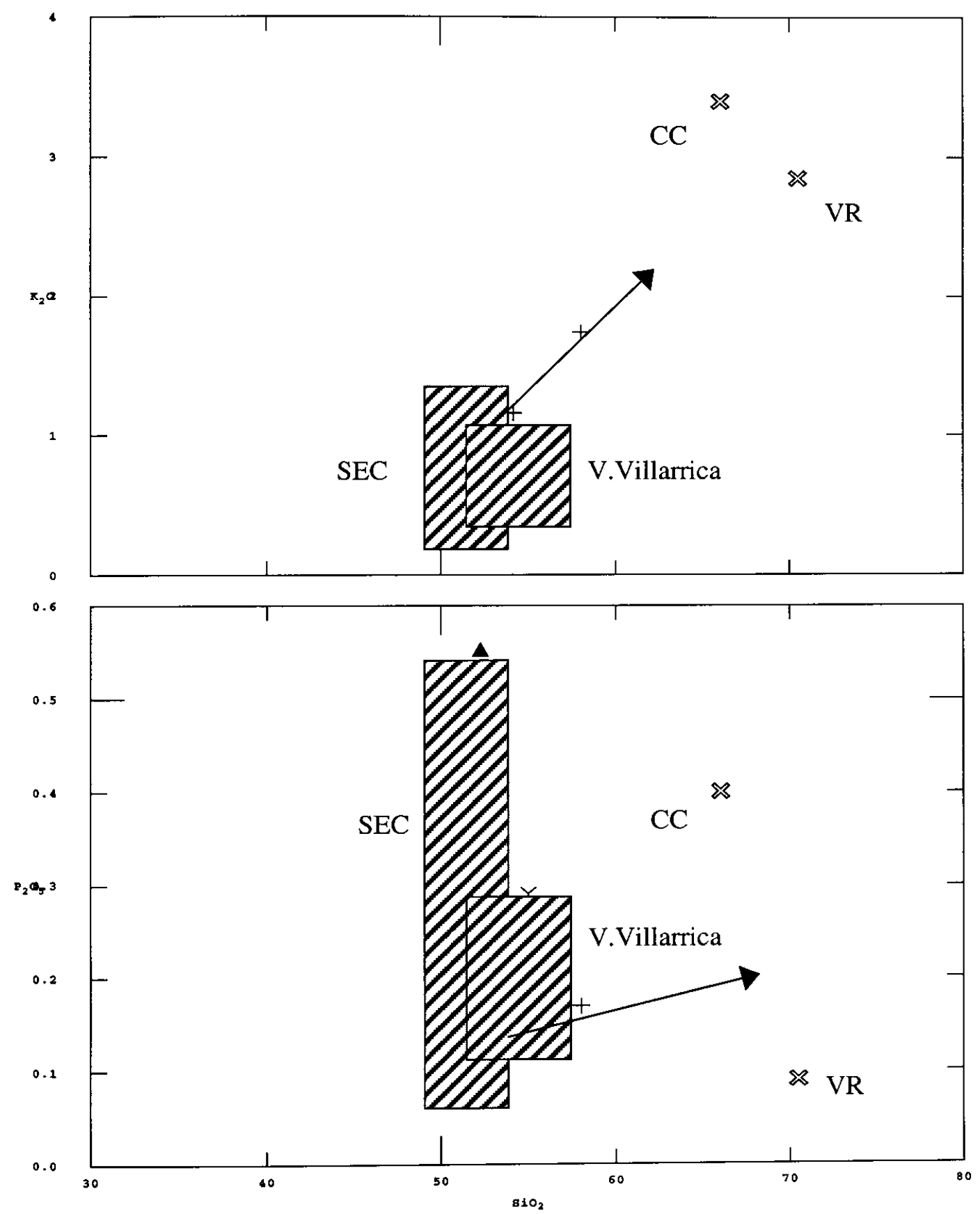

Fig.4.2.3 Oxide versus $\mathrm{SiO}_{2}$ for the Llizan andesites, V.Villarrica rhyolite and the upper continental crust 


\subsubsection{Rucapillan and El Estadio}

Samples (4 from Rucapillan - 2 porphyritic and 2 aphyric - and 2 from El Estadio) of SEC Rucapillan and El Estadio, the volcanic center to the west side of the volcanic front in this area, have distinct chemical compositions and textures. The Rucapillan specimen is a mixture of two rock components - a porphyritic part with abundant cpx and olivine phenocrysts and an aphyric one with tiny amounts of small cpx and olivine crystals. Analyses (Ru - Porphyritic and 010494 - 1A) of the porphyritic part show much more mafic compositions than the other two analyses ( $\mathrm{Ru}$ - Aphyric and 010494 - 1B) from the aphyric part. Two samples from El Estadio have intermediate $\mathrm{SiO}_{2}$ contents. A possible explanation for the increase of $\mathrm{TiO}_{2}, \mathrm{Al}_{2} \mathrm{O}_{3}$ (slightly), $\mathrm{Fe}_{2} \mathrm{O}_{3}, \mathrm{MnO}, \mathrm{Na}_{2} \mathrm{O}, \mathrm{K}_{2} \mathrm{O}$ and $\mathrm{P}_{2} \mathrm{O}_{5}$ contents and the decrease of $\mathrm{CaO}$ and $\mathrm{MgO}$ contents between the $\mathrm{Ru}$ Porphyritic and the Ru - Aphyric samples (Fig.3.2.1c) is crystallization of cpx and olivine with the possible plagioclase suppression or accumulation to elevate $\mathrm{Al}_{2} \mathrm{O}_{3}$. The two $\mathrm{El}$ Estadio basalts show a different path of differentiation. Compared with the same Ru Porphyritic sample, they contain more $\mathrm{TiO}_{2}, \mathrm{Al}_{2} \mathrm{O}_{3}$ (largely), $\mathrm{Na}_{2} \mathrm{O}, \mathrm{K}_{2} \mathrm{O}$ and $\mathrm{P}_{2} \mathrm{O}_{5}$ and less $\mathrm{Fe}_{2} \mathrm{O}_{3}, \mathrm{MnO}, \mathrm{MgO}$, and an almost unchanged $\mathrm{CaO}$. This is consistent with crystallizing olivine, less cpx and probably a larger extent of plagioclase suppression or accumulation. These paths could also be observed on the above projections (Fig.4.2.1a; Fig.4.2.1b; Fig.4.2.1c). The parental magmas may also have been different, either as a result of source differences or crustal effects. This will be further discussed in section 4.6.

The Rucapillan samples are physical mixtures of two magmas - the original "porphyritic" magma and the more differentiated "aphyric" magma derived either from the former or from separate sources. Since the "aphyric" magma is more differentiated, 
its near - liquidus temperature is relatively low. When it was entrained by the hotter mafic "porphyritic" magma it was superheated and the previously - crystallized phenocrysts were resorbed and remelted. Under the microscope (Appendix 2), we can observe very clearly that the Ru - aphyric part appears to be like a long and narrow strip "sandwiched" by the both vesicle - rich and phenocryst - rich $\mathrm{Ru}$ - porphyritic part. Therefore, it is possible that the Rucapillan basalts were generated by multiple injections of basaltic magma into a chamber of differentiating magma. 


\subsubsection{Summary}

Based on petrographic and major element results I conclude that the V.Villarrica and SEC basalts have probably evolved along somewhat different liquid lines of descent. Magmas of V.Villarrica crystallized more plagioclase, probably as the result of fast ascent and shallow level crystallization. Other SEC underwent crystallization of olivine + cpx + plagioclase at moderate depths, resulting in lower $\mathrm{MgO}$ and higher $\mathrm{Al}_{2} \mathrm{O}_{3}$ contents at a given $\mathrm{SiO}_{2}$. However, the inferred differences in the LLDs for V.Villarrica and the SECs are insufficient to explain their trace element and isotopic differences. As discussed by Hickey - Vargas et al. (1989), crustal contamination is also unlikely for both the V.Villarrica and SEC lavas because: 1) their overall composition is basaltic; 2) their $\delta^{18} \mathrm{O}$ values are the same; 3) trace element and isotopic indicators of crustal contamination show conflicting results, i.e., high alkali abundances are correlated with low LREE / HREE ratios and high ${ }^{143} \mathrm{Nd} /{ }^{144} \mathrm{Nd}$ values (V.Villarrrica).

However, andesitic lavas from SEC Llizan may have evolved by crustal assimilation and fractional crystallization as well based on their elevated $\mathrm{SiO}_{2}, \mathrm{Na}_{2} \mathrm{O}, \mathrm{K}_{2} \mathrm{O}$ and lowered $\mathrm{MgO}, \mathrm{CaO}$ and $\mathrm{Fe}_{2} \mathrm{O}_{3}$ contents. $\mathrm{Pb}$ and $\mathrm{Sr}$ isotopic ratios also support the involvement of a crustal component in the Llizan magma genesis.

Basaltic samples from Rucapillan are mixed liquids of a mafic and a more evolved magma endmember. The possible origin for this SEC is the change of compositions in the magma chamber and the entrainment and simultaneous ascent of two different types of magmas. 


\subsection{Geochemical Modeling of Source Mixing, Fluid Addition and Partial Melting Processes for V.Villarrica and associated SECs}

\subsubsection{Calculation of primary magmas by olivine addition}

V.Villarrica and associated SECs have trace element and isotopic differences that cannot be explained by intracrustal processes. In order to model source mixing and partial melting, concentrations of trace and major elements in the primary magma must be estimated. The method of olivine addition is used here based on a major assumption that olivine is the only mineral phase that is fractionated from the primary magma. This assumption, strictly speaking, is not true because the distribution of the V.Villarrica and SEC samples on the Pl to Ol - Cpx - Qz pseudoternary diagram (Fig.4.3.1) shows that they have all undergone some extent of clinopyroxene fractionation. As a result, leaving out cpx could cause some deviations of the major element compositions in the calculated primary magmas such as higher $\mathrm{MgO}$ and $\mathrm{FeO}$ and lower $\mathrm{CaO}$. This effect can be limited to some extent if samples chosen for calculation fall before those big cusps (Fig.4.3.1) because the basaltic magmas fractionated much more olivine than cpx at the beginning of their ascent (crystallization mainly takes the rock compositions away from the olivine apex). In addition, the above assumption does not affect the compositions of those highly incompatible elements very much because their $\mathrm{D}$ values in olivine and cpx are both very low $(\approx 0)$.

By adding a small proportion (for example, $2 \%$ at each step) of olivine crystals in chemical equilibrium with the liquid, until the liquid composition reaches equilibrium with an average upper mantle peridotite $(\mathrm{Mg} /(\mathrm{Mg}+\mathrm{Fe})=0.76)$ (Falloon and Green, 
1988)., Primary magma compositions were calculated from 250884 - 4 (representative of V.Villarrica lavas), 120194 - 04C (representative of SEC Caburgua lavas) and 120194 02 (representative of SEC Huelemolle lavas) and shown in Table 4-3-1. A $\mathrm{K}_{\mathrm{D}}$ $\left((\mathrm{Fe} / \mathrm{Mg})_{\text {olivine }} /(\mathrm{Fe} / \mathrm{Mg})_{\text {magma }}\right)$ value of 0.3 for olivine was used in the calculations (Grove et al., 1982; Grove and Baker, 1984).

The amounts of olivine added to each chosen sample to reach its primary magma composition (i.e., the amount of olivine fractionated from the primary magma to form the studied sample) are as follows: $21 \mathrm{wt} \%$ (of the weight of the original magma body) for V.Villarrica, $24 \mathrm{wt} \%$ for Caburgua and $27 \mathrm{wt} \%$ for Huelemolle. Kd (partition coefficient) values from Table 4-3-3 are used in the modeling ( 0 is used for highly incompatible elements to simplify the calculations).

On Fig.4.3.1, the primary magma for V.Villarrica samples has more $\mathrm{SiO}_{2}$ than the SEC primary magmas. It also contains less $\mathrm{MgO}$ (less olivine component) and more $\mathrm{CaO}$ (more diopside component). The shallow crystallization paths of both V.Villarrica and the SEC primary magmas involve crystallization of olivine and plagioclase, followed by later crystallization of the $c p x+$ olivine + plagioclase assemblage under different physical conditions (pressure dominantly). The primary magma of the Huelemolle samples, compared with the primary magma of the Caburgua samples, is more mafic (higher $\mathrm{MgO} \%$ and lower $\mathrm{SiO}_{2} \%$ ) and therefore closer to the olivine endmember.

The calculated primary magmas of V.Villarrica and the SECs are consistent with the $10-20 \%$ "primary" melts from the averaged primitive upper mantle calculated by Plank and Langmuir (1988) (Table 4-3-2), except relatively higher $\mathrm{MgO}$ and $\mathrm{FeO}$ and lower $\mathrm{CaO}$ due to cpx fractionation as discussed earlier in this section. 
Table 4-3-1 Primary magma calculations for the samples from V.Villarrica and the SECs.

Part I Major Elements (PM - Primary Magma Calculated) (wt\%)

\begin{tabular}{|l|l|l|l|l|l|l|l|l|l|l|}
\hline $\mathrm{SiO}_{2}$ & $\mathrm{TiO}_{2}$ & $\mathrm{Al}_{2} \mathrm{O}_{3}$ & $\mathrm{MgO}$ & $\mathrm{Fe}_{2} \mathrm{O}_{3}$ & $\mathrm{CaO}$ & $\mathrm{Na}_{2} \mathrm{O}$ & $\mathrm{K}_{2} \mathrm{O}$ & $\mathrm{MnO}$ & $\mathrm{P}_{2} \mathrm{O}_{5}$ & Sample \# \\
\hline 50.69 & 1.10 & 18.65 & 5.99 & 9.76 & 9.44 & 3.26 & 0.84 & 0.16 & 0.41 & Hue 120194-02 \\
\hline 51.59 & 1.10 & 17.93 & 6.68 & 9.56 & 9.16 & 3.55 & 0.80 & 0.15 & 0.31 & CA 120194-04C \\
\hline 51.97 & 0.98 & 16.90 & 7.40 & 9.51 & 9.81 & 2.92 & 0.58 & 0.16 & 0.19 & Vi 250884-4 \\
\hline 47.59 & 0.80 & 13.49 & 17.12 & 10.80 & 6.83 & 2.36 & 0.61 & 0.12 & 0.30 & Huelemolle (PM) \\
\hline 48.42 & 0.82 & 13.43 & 16.51 & 10.36 & 6.86 & 2.66 & 0.60 & 0.11 & 0.23 & Caburgua (PM) \\
\hline 49.24 & 0.77 & 13.23 & 15.90 & 10.17 & 7.68 & 2.29 & 0.45 & 0.13 & 0.15 & Villarrica (PM) \\
\hline
\end{tabular}

Part II Trace Elements (PM - Primary Magma Calculated) (ppm)

\begin{tabular}{|l|l|l|l|l|l|l|l|l|}
\hline $\mathrm{Rb}$ & $\mathrm{Nb}$ & $\mathrm{Cs}$ & $\mathrm{Ba}$ & $\mathrm{La}$ & $\mathrm{Ce}$ & $\mathrm{Hf}$ & $\mathrm{Pb}$ & Sample \# \\
\hline 13.9 & 6.7 & 0.707 & 329 & 20.8 & 46.4 & 3.28 & 8.89 & Huelemolle \\
\hline 11.0 & 3.2 & 0.557 & 257 & 13.3 & 30.2 & 2.33 & 7.36 & Caburgua \\
\hline 13.0 & 1.9 & 1.100 & 182 & 7.3 & 18.7 & 2.00 & 9.80 & Villarrica \\
\hline 10.1 & 4.9 & 0.515 & 239 & 15.1 & 33.8 & 2.39 & 6.47 & Hue (PM) \\
\hline 8.3 & 2.4 & 0.422 & 195 & 10.1 & 22.9 & 1.77 & 5.58 & Ca (PM) \\
\hline 10.2 & 1.5 & 0.867 & 144 & 5.8 & 14.7 & 1.58 & 7.73 & Vi (PM) \\
\hline $\mathrm{Th}$ & $\mathrm{Ta}$ & $\mathrm{U}$ & $\mathrm{Sr}$ & $\mathrm{Nd}$ & $\mathrm{Li}$ & $\mathrm{Be}$ & $\mathrm{B}$ & Sample \# \\
\hline 2.01 & 0.373 & 0.619 & 628 & 24.9 & 14.1 & 1.04 & 11.0 & Huelemolle \\
\hline 2.51 & 0.185 & 0.680 & 800 & 18.8 & 12.7 & 0.70 & 6.0 & Caburgua \\
\hline 1.20 & 0.185 & 0.450 & 439 & 11.9 & 15.0 & 0.64 & 25.0 & Villarrica \\
\hline 1.46 & 0.272 & 0.451 & 458 & 18.2 & 11.6 & 0.76 & 8.1 & Hue (PM) \\
\hline 1.90 & 0.140 & 0.515 & 606 & 14.2 & 10.8 & 0.53 & 4.6 & Ca (PM) \\
\hline 0.95 & 0.146 & 0.354 & 346 & 9.4 & 13.0 & 0.51 & 19.8 & Vi (PM) \\
\hline
\end{tabular}


Table 4-3-2 Primary melts from the averaged primitive upper mantle (Plank and Langmuir, 1988) (wt\%)

\begin{tabular}{|l|l|l|l|}
\hline Elements & Mantle & $25 \%$ Melt & $10 \%$ Melt \\
\hline $\mathrm{SiO}_{2}$ & 45.4 & 49.8 & 50.3 \\
\hline $\mathrm{TiO}_{2}$ & 0.18 & 0.65 & 1.15 \\
\hline $\mathrm{Al}_{2} \mathrm{O}_{3}$ & 4.0 & 13.3 & 17.1 \\
\hline $\mathrm{FeO} *$ & 7.9 & 9.4 & 9.4 \\
\hline $\mathrm{MgO}$ & 38.0 & 13.6 & 10.6 \\
\hline $\mathrm{CaO}$ & 3.4 & 12.0 & 8.4 \\
\hline $\mathrm{Na}_{2} \mathrm{O}$ & 0.32 & 1.3 & 3.0 \\
\hline
\end{tabular}




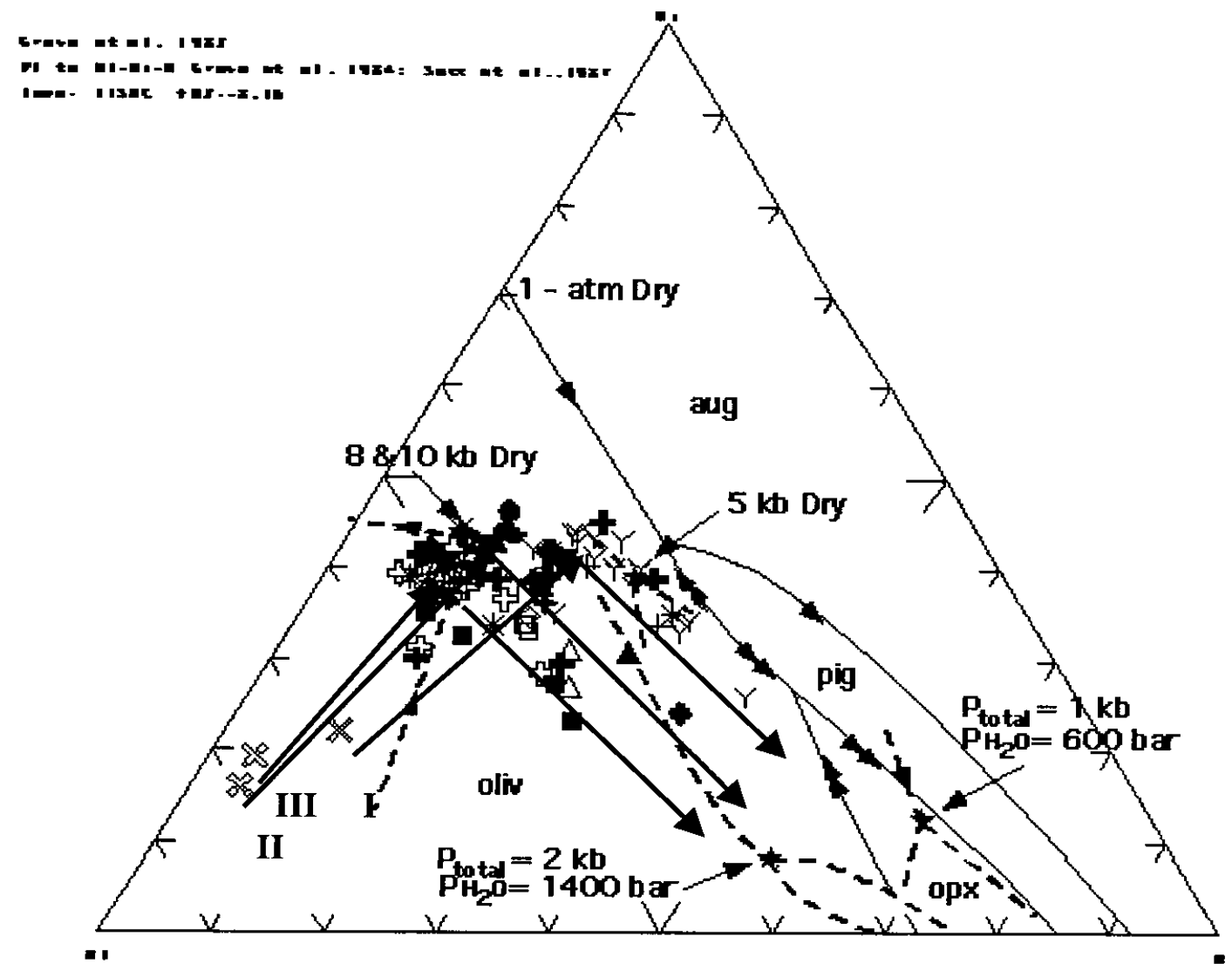

Fig.4.3.1 The Pl to Ol - Di - Q pseudo - ternary projection of the V.Villarrica and SEC samples with their primary magma compositions (I - Primary Magma of V.Villarrrica; II - Primary Magma of Huelemolle; III - Primary Magma of Caburgua; All the other symbols are the same as used in Fig.4.2.1) (Grove and Baker, 1984; Sisson and Grove, 1993) 


\subsubsection{Calculation of the source compositions}

Based on the assumption that relatively immobile elements such as $\mathrm{Nb}$, Ti and the HREEs remain unchanged during subduction modification processes and a $\mathrm{N}-$ MORB source (depleted in highly incompatible elements; Wood, 1979) and an E - MORB source (enriched in highly incompatible elements; Wood, 1979), respectively, for V.Villarrica and the SECs, mantle source compositions were calculated in this study from the abundances of the trace elements and REEs in the primary magmas (calculated in 4.3.1) by changing $\mathrm{F}$ (degree of partial melting). A non - modal equilibrium (batch) melting model (Shaw, 1970; Hofmann and Feigenson, 1983) was used. The mode of the mineral assemblage is olivine : opx : $\mathrm{cpx}=0.5: 0.25: 0.25$ (mantle lherzolite) in the source and olivine : opx : $\mathrm{cpx}=0.2: 0.4: 0.4$ in the residue (more olivine melted than pyroxene at the studied depth) (Feigenson et al., 1996).

As shown on Fig.4.3.2 (N - MORB source), the primary magmas of V.Villarrica may have undergone larger extents of partial melting, up to $F=0.2$, than those of the SECs. This large amount of melt extraction is consistent with the large volume of V.Villarrica relative to the SEC, and with the extent of partial melting suggested for arc basalts $(10-25 \%)$ (Plank and Langmuir, 1988) and MORBs $(8-20 \%)$ (Klein and Langmuir, 1987). By contrast, SEC Caburgua may have undergone much smaller extents of partial melting, $\sim \mathrm{F}=0.1$. Another SEC, Huelemolle, has distinctly higher HFSE ( $\mathrm{Nb}$ and $\mathrm{Zr}$ ) and REE contents compared with the other SECs. The possible origin of this particular SEC is either:

- Its source has the same $\mathrm{Nb}$ content as the sources of the other centers, and it has undergone an extremely low extent of partial melting (about $\mathrm{F}=0.025$ ). 
Table 4-3-3 The partition coefficients used to calculate the partial melting process of the V.Villarrica and SEC samples (From GERM web site: http://Earthref.org/GERM)

\begin{tabular}{|l|l|l|l|l|l|l|}
\hline Element & Kd (oliv) & Kd (opx) & Kd (cpx) & Kd $(\overline{G T})$ & Do & P \\
\hline $\mathrm{Cs}$ & 0.01 & 0.01 & 0.0025 & 0 & 0.00813 & 0.007 \\
\hline $\mathrm{Rb}$ & 0.011 & 0.011 & 0.0026 & 0 & 0.0089 & 0.00764 \\
\hline $\mathrm{Ba}$ & 0.0099 & 0.013 & 0.026 & 0.023 & 0.0147 & 0.01758 \\
\hline $\mathrm{Th}$ & 0 & 0 & 0.03 & 0 & 0.0075 & 0.012 \\
\hline $\mathrm{U}$ & 0.002 & 0 & 0.04 & 0 & 0.011 & 0.0164 \\
\hline $\mathrm{K}$ & 0.0068 & 0.014 & 0.038 & 0.015 & 0.0164 & 0.02216 \\
\hline $\mathrm{Nb}$ & 0.01 & 0.15 & 0.005 & 0.02 & 0.04375 & 0.064 \\
\hline $\mathrm{La}$ & 0.0067 & 0.002 & 0.056 & 0.01 & 0.01785 & 0.02454 \\
\hline $\mathrm{Ce}$ & 0.006 & 0.02 & 0.1 & 0.03 & 0.033 & 0.0492 \\
\hline $\mathrm{Pb}$ & 0.011 & 0.0013 & 0.01 & 0.0001 & 0.00833 & 0.00672 \\
\hline $\mathrm{Sr}$ & 0.014 & 0.04 & 0.06 & 0.012 & 0.032 & 0.0428 \\
\hline $\mathrm{Nd}$ & 0.006 & 0.03 & 0.27 & 0.05 & 0.078 & 0.1212 \\
\hline $\mathrm{Sm}$ & 0.0068 & 0.05 & 0.47 & 0.3 & 0.1334 & 0.20936 \\
\hline $\mathrm{Eu}$ & 0.0071 & 0.05 & 0.49 & 0.5 & 0.13855 & 0.21742 \\
\hline $\mathrm{Zr}$ & 0.012 & 0.18 & 0.1 & 0.65 & 0.076 & 0.1144 \\
\hline $\mathrm{Hf}$ & 0.012 & 0.18 & 0.1 & 0.65 & 0.076 & 0.1144 \\
\hline $\mathrm{Ti}$ & 0.02 & 0.1 & 0.4 & 0.3 & 0.135 & 0.204 \\
\hline $\mathrm{Tb}$ & 0.01 & 0.24 & 0.57 & 0.705 & 0.2075 & 0.326 \\
\hline $\mathrm{Y}$ & 0.01 & 0.18 & 0.9 & 9 & 0.275 & 0.434 \\
\hline $\mathrm{Yb}$ & 0.03 & 0.34 & 0.58 & 11.5 & 0.245 & 0.374 \\
\hline $\mathrm{Lu}$ & 0.03 & 0.42 & 0.53 & 11.9 & 0.2525 & 0.386 \\
\hline & & & & & & \\
\hline
\end{tabular}




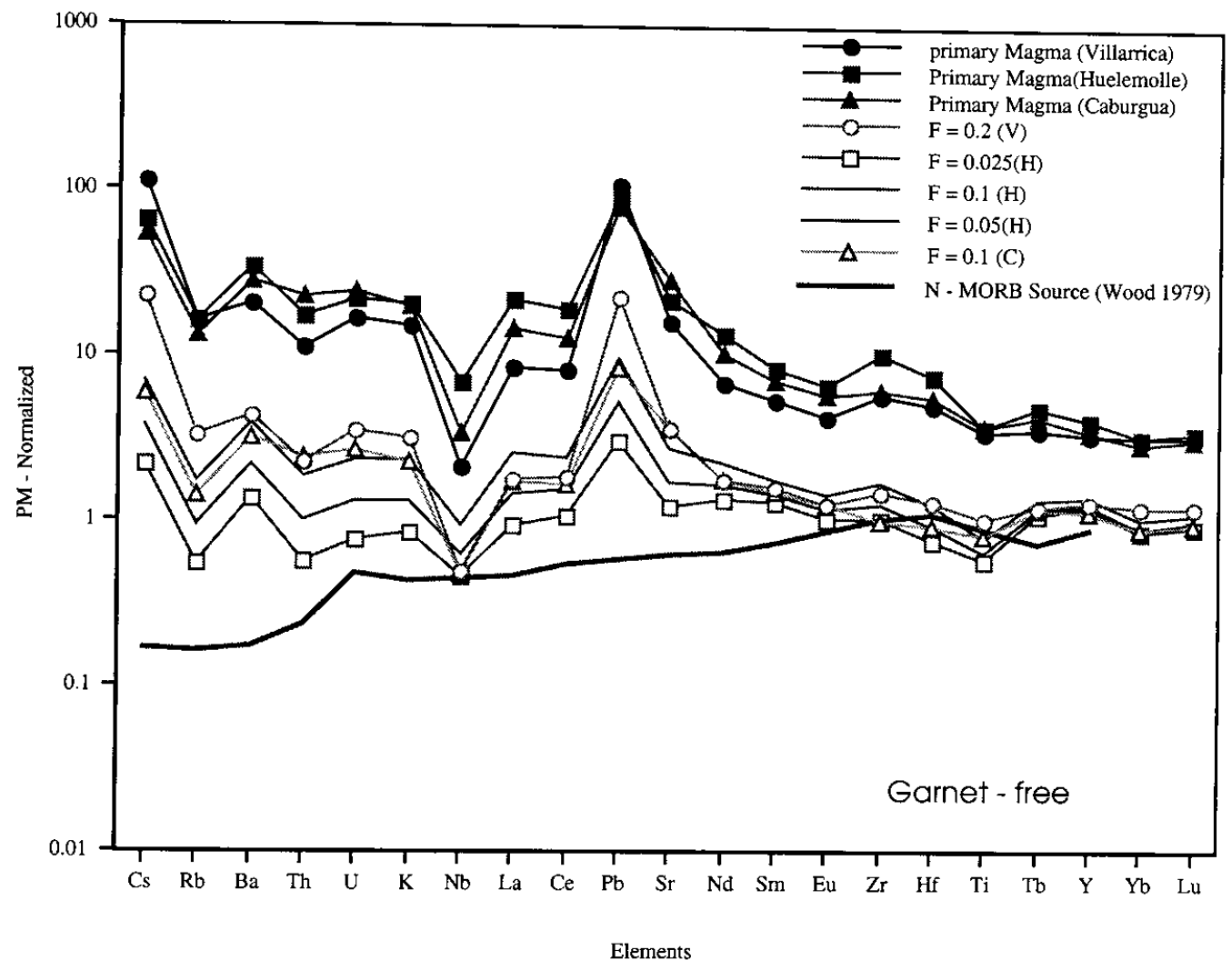

Fig.4.3.2 Calculated source compositions based on a N - MORB source from the primary magmas of the V.Villarrica and SEC samples 
- It undergoes a similar extent of partial melting (about $F=0.05-0.10$ ) as SEC Carburgua, and its much higher $\mathrm{Nb}, \mathrm{La}$ and $\mathrm{Ce}$ contents can be related to some additional processes. For example, an E - MORB or enriched mantle source, or transportation of these elements to the source of this particular SEC by a subduction component.

Fig.4.3.3 summarizes the results calculated from an E - MORB source. With the elevated incompatible element concentrations, the E - MORB source displays a much more flattened trace element and REE pattern (Wood, 1979) compared with the N MORB source shown in Fig.4.3.2. Consequently, the degrees of partial melting (F) for all the three samples become larger: $F=0.5$ for V.Villarrica, 0.25 for Caburgua and 0.1 for Huelemolle. However, the relative extent of partial melting remains unchanged - the mantle source of V.Villarrica was melted about twice as much as the source of SEC Caburgua and SEC Huelemolle underwent the smallest amount of partial melting. The calculated $\mathrm{F}$ values for V.Villarrica and Carburgua based on an E - MORB source may be too high to be true, while $\mathrm{F}=0.1$ for Huelemolle is a reasonable degree of partial melting (much better than $\mathrm{F}=0.025$ because this small melt fraction may require an extremely - low - viscosity magma to be separated from its source residue). 


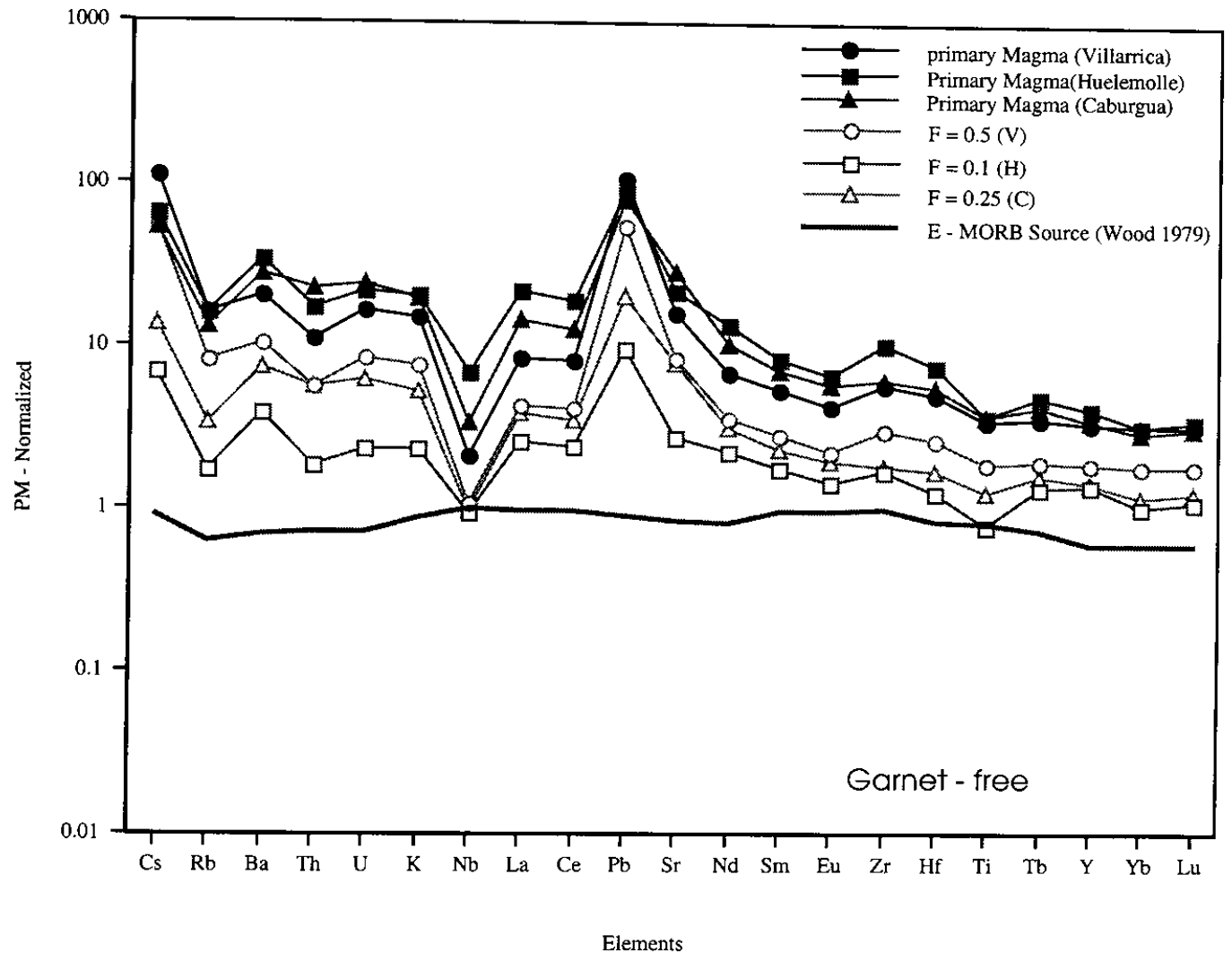

Fig.4.3.3 Calculated source compositions based on an E - MORB source from the primary magmas of the V.Villarrica and SEC samples 
In both cases Huelemolle shows a smaller extent of partial melting compared with other SEC samples. This is a reasonable conclusion drawn both from the above calculations and from the following diagrams: I) $\mathrm{La}-\mathrm{La} / \mathrm{Yb}$ (Fig.4.3.4a); II) $\mathrm{Nb}-\mathrm{Nb} / \mathrm{Yb}$ (Fig.4.3.4b). Surprisingly, the La - La/Yb relationship seems to favor an E - type MORB source while the $\mathrm{Nb}-\mathrm{Nb} / \mathrm{Yb}$ strongly suggests a $\mathrm{N}$ - MORB mantle source. This relationship suggests that $\mathrm{La}$ and the LREEs may be enriched by subduction processes, while $\mathrm{Nb}$ is not. Therefore, in both cases I used $\mathrm{Nb}$ contents as references - the $\mathrm{F}$ values that provide the best match between the $\mathrm{Nb}$ contents calculated in the mantle source in this study and the estimated $\mathrm{Nb}$ contents of the $\mathrm{N}$ - MORB or E - MORB source (Wood, 1979) are used to represent the degrees of partial melting for V.Villarrica and the SECs as well. 


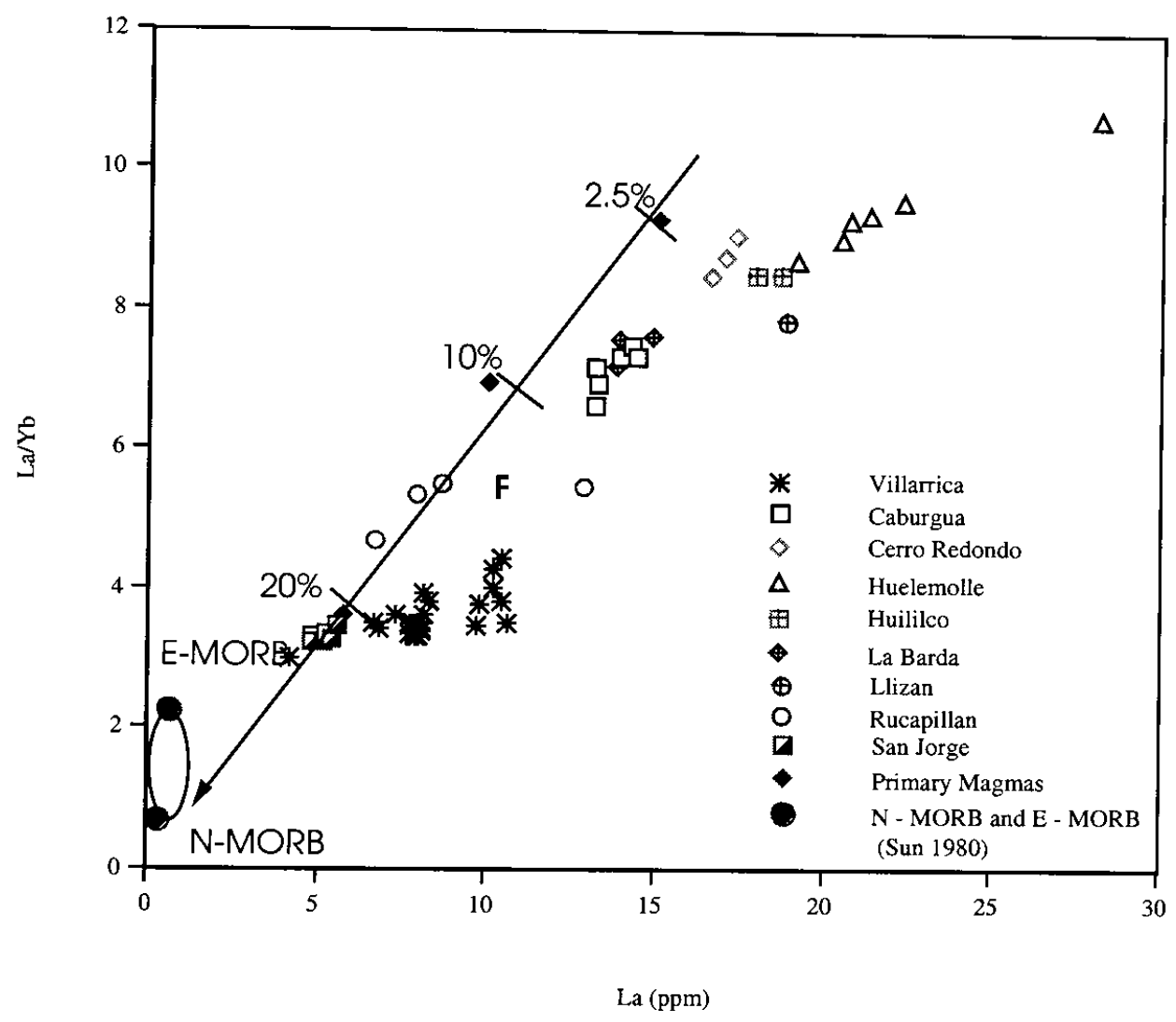

Fig.4.3.4a $(\mathrm{La} / \mathrm{Yb})$ versus La for the V.Villarrica and SEC samples 


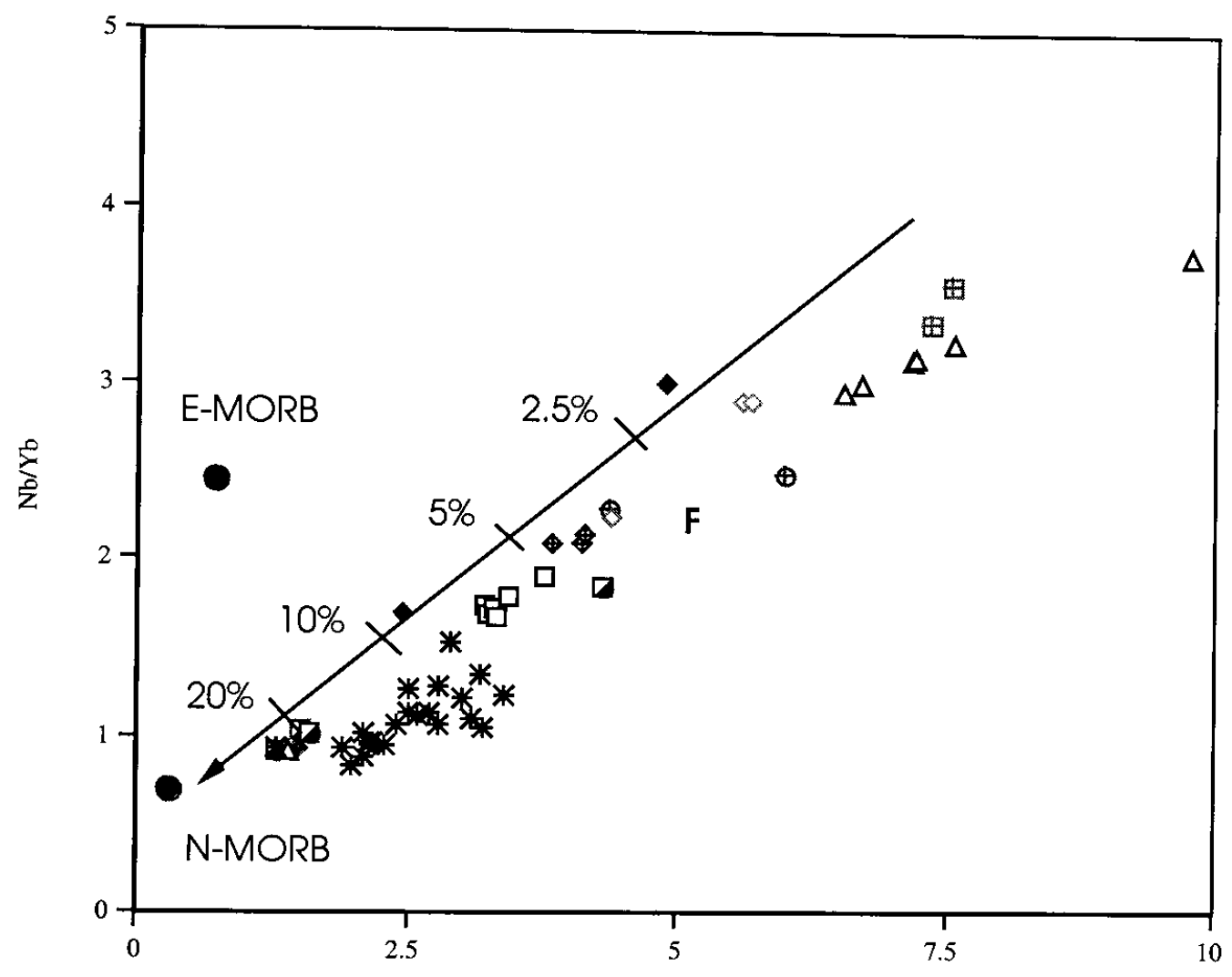

$\mathrm{Nb}$ (ppm)

Fig.4.3.4b The $(\mathrm{Nb} / \mathrm{Yb})$ - $\mathrm{Nb}$ diagram for the Villarrica and SEC samples 


\subsubsection{Modeling of the amount and compositions of the subduction component}

Assuming that $\mathrm{Nb} / \mathrm{Yb}$ variations in the V.Villarrica and SEC samples result from partial melting processes alone, I calculated the inputs of incompatible elements that would have to be added to the N - MORB source via subduction (Table 4-3-4). This approach is common in the literature of subduction magma geochemistry (see Ellam and Hawkesworth, 1988; Pearce et al., 1993). The concentrations of these elements in the slab - derived fluid phase depend on the amount added, and the specific fluid compositions, which are not well known. Table 4-3-4 shows the range of fluid compositions calculated based on the experimental results that under about $30 \mathrm{kbar}$, the solubility of the fluid is close to 5\% of the weight of the original "dry magma" (Holtz et al., 1992). It is assumed that the magma produced in this case is water - saturated under the above conditions and no water exsolvation occurs during its ascent. The percentages of $\mathrm{Nb}$ contents of both V.Villarrica and the SEC samples added from subduction - derived fluids are very low $(<10 \%)$, mainly reflecting calculation uncertainties (should be zero ideally).

The comparison of fluid compositions added to the V.Villarrica and SEC samples is illustrated in Fig.4.3.5. For most trace and REE elements fluids added to the source of V.Villarrica are chemically similar to those added to the source of the SECs. 
Table 4-3-4 Subduction - derived fluid compositions and the proportions of elements added to the source of V.Villarrica and SEC (N - MORB) (in ppm)

\begin{tabular}{|c|c|c|c|c|c|c|}
\hline \multirow[t]{2}{*}{ Element } & \multicolumn{2}{|c|}{ Villarrica $(\mathrm{F}=0.2)$} & \multicolumn{2}{|c|}{ Huelemolle $(\mathrm{F}=0.025)$} & \multicolumn{2}{|c|}{ Caburgua $(\mathrm{F}=0.1)$} \\
\hline & Fluid Conc. & added & Fluid Conc. & added & Fluid Conc. & added \\
\hline $\mathrm{Cs}$ & 17 & $99 \%$ & 10 & $92 \%$ & 8 & $97 \%$ \\
\hline $\mathrm{Rb}$ & 194 & 95\% & 146 & $71 \%$ & 149 & $89 \%$ \\
\hline $\mathrm{Ba}$ & 2762 & $96 \%$ & 4209 & $87 \%$ & 3697 & $95 \%$ \\
\hline $\mathrm{Th}$ & 17 & $90 \%$ & 17 & $58 \%$ & 34 & $90 \%$ \\
\hline $\mathrm{U}$ & 6 & $86 \%$ & 4 & $38 \%$ & 9 & $82 \%$ \\
\hline $\mathrm{K}$ & 65211 & $87 \%$ & 51970 & $49 \%$ & 81979 & $81 \%$ \\
\hline $\mathrm{Nb}$ & 4 & $10 \%$ & 10 & $6 \%$ & 6 & $8 \%$ \\
\hline $\mathrm{La}$ & 88 & $75 \%$ & 163 & $51 \%$ & 150 & $73 \%$ \\
\hline $\mathrm{Ce}$ & 213 & $71 \%$ & 358 & $51 \%$ & 317 & $68 \%$ \\
\hline $\mathrm{Yb}$ & 9 & $25 \%$ & 0 & $0 \%$ & 2 & $0 \%$ \\
\hline $\mathrm{Pb}$ & 151 & $97 \%$ & 106 & $81 \%$ & 104 & $93 \%$ \\
\hline $\mathrm{Sr}$ & 5791 & $83 \%$ & 4687 & $49 \%$ & 10152 & $83 \%$ \\
\hline $\mathrm{Nd}$ & 123 & $64 \%$ & 200 & $53 \%$ & 186 & $64 \%$ \\
\hline $\mathrm{Sm}$ & 27 & $54 \%$ & 35 & $44 \%$ & 34 & $52 \%$ \\
\hline
\end{tabular}

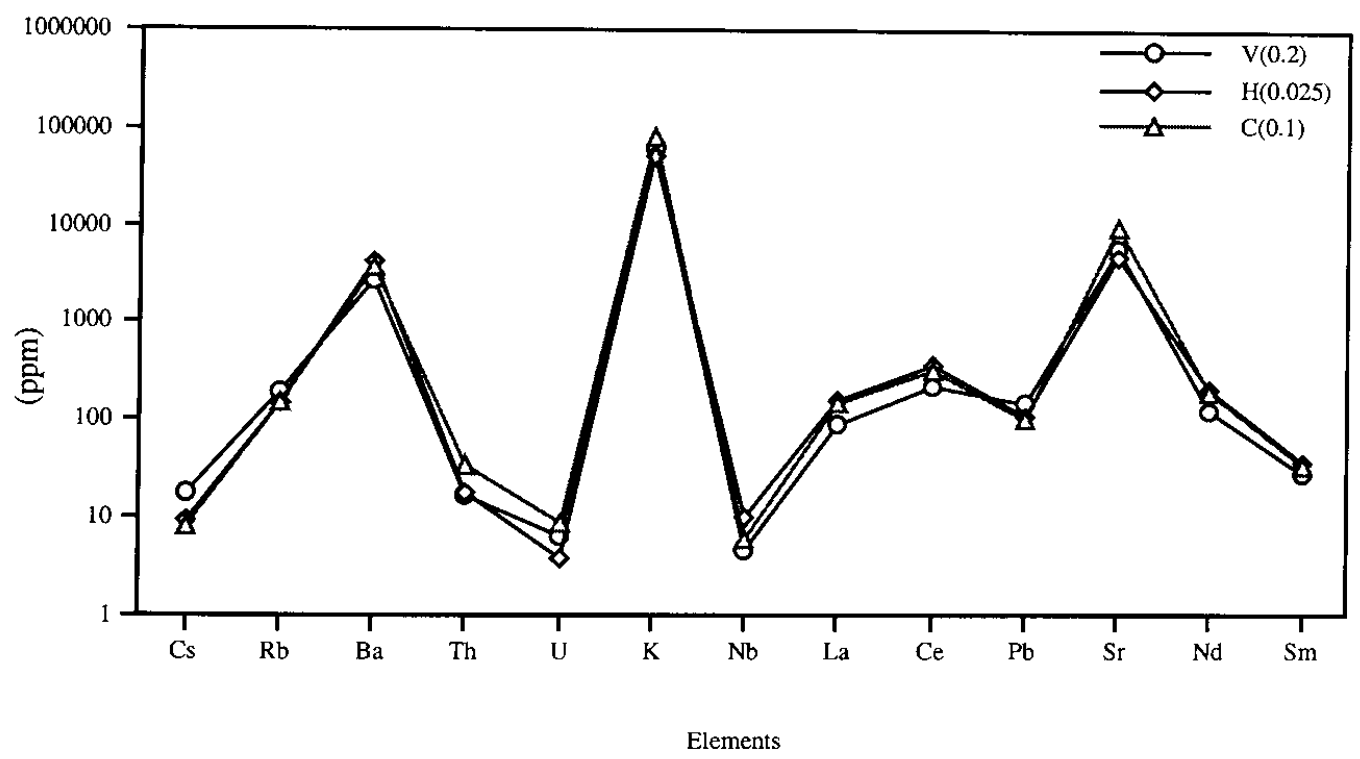

Fig.4.3.5 Compositions of the fluids added to the V.Villarrica / SEC sources (N - MORB) 
A different set of fluid compositions for the above elements were calculated using an E-MORB source (Table 4-3-5; Fig.4.3.6).

Small differences between the chemical compositions of the fluids added to the source of V.Villarrica and the SECs in the two cases (N - MORB source and E - MORB source respectively) need to be pointed out here. That is, the fluids added to the V.Villarrica source have relatively higher contents of $\mathrm{Cs}, \mathrm{Rb}$ and $\mathrm{Pb}$, similar $\mathrm{Ba}, \mathrm{Th}, \mathrm{U}$, $\mathrm{K}, \mathrm{Nb}$, Nd and Sm, and apparently lower La and Ce concentrations compared with those added to the SEC source. For Carburgua, the fluid is especially enriched in Th, U, K and Sr. However, it is important to note that the differences in the compositions of the fluids are very small compared to the total abundances of these elements contributed from the subducting slab. 
Table 4-3-5 Fluid compositions calculated with an E - MORB source (in ppm)

\begin{tabular}{|c|c|c|c|c|c|c|}
\hline \multirow{2}{*}{ Element } & \multicolumn{2}{|c|}{ Villarrica $(\mathrm{F}=0.5)$} & \multicolumn{2}{|c|}{ Huelemolle $(\overline{\mathrm{F}}=0.1)$} & \multicolumn{2}{|c|}{ Caburgua $(\mathrm{F}=0 . \overline{25})$} \\
\hline & Fluid Conc. & added & Fluid Conc. & added & Fluid Conc. & added \\
\hline $\mathrm{Cs}$ & 17 & $98 \%$ & 9 & $87 \%$ & 8 & $94 \%$ \\
\hline $\mathrm{Rb}$ & 189 & $92 \%$ & 1349 & $64 \%$ & 137 & $82 \%$ \\
\hline $\mathrm{Ba}$ & 2691 & $93 \%$ & 3988 & $82 \%$ & 3550 & $91 \%$ \\
\hline $\mathrm{Th}$ & 17 & $87 \%$ & 18 & $61 \%$ & 34 & $88 \%$ \\
\hline $\mathrm{U}$ & 6 & $92 \%$ & 6 & $70 \%$ & 9 & $89 \%$ \\
\hline $\mathrm{K}$ & 66591 & $89 \%$ & 65335 & $63 \%$ & 83884 & $83 \%$ \\
\hline $\mathrm{Nb}$ & 3 & $6 \%$ & $\mathrm{~N} / \mathrm{A}$ & $0 \%$ & N/A & $0 \%$ \\
\hline $\mathrm{La}$ & 91 & $77 \%$ & 194 & $62 \%$ & 153 & $75 \%$ \\
\hline $\mathrm{Ce}$ & 231 & $78 \%$ & 427 & $61 \%$ & 340 & $73 \%$ \\
\hline $\mathrm{Yb}$ & 22 & $67 \%$ & 14 & $42 \%$ & 15 & $50 \%$ \\
\hline $\mathrm{Pb}$ & 152 & $98 \%$ & 118 & $91 \%$ & 107 & $96 \%$ \\
\hline $\mathrm{Sr}$ & 6247 & $90 \%$ & 6508 & $69 \%$ & 10862 & $89 \%$ \\
\hline $\mathrm{Nd}$ & 147 & $77 \%$ & 236 & $63 \%$ & 214 & $74 \%$ \\
\hline $\mathrm{Sm}$ & 33 & $67 \%$ & 37 & $47 \%$ & 39 & $60 \%$ \\
\hline
\end{tabular}

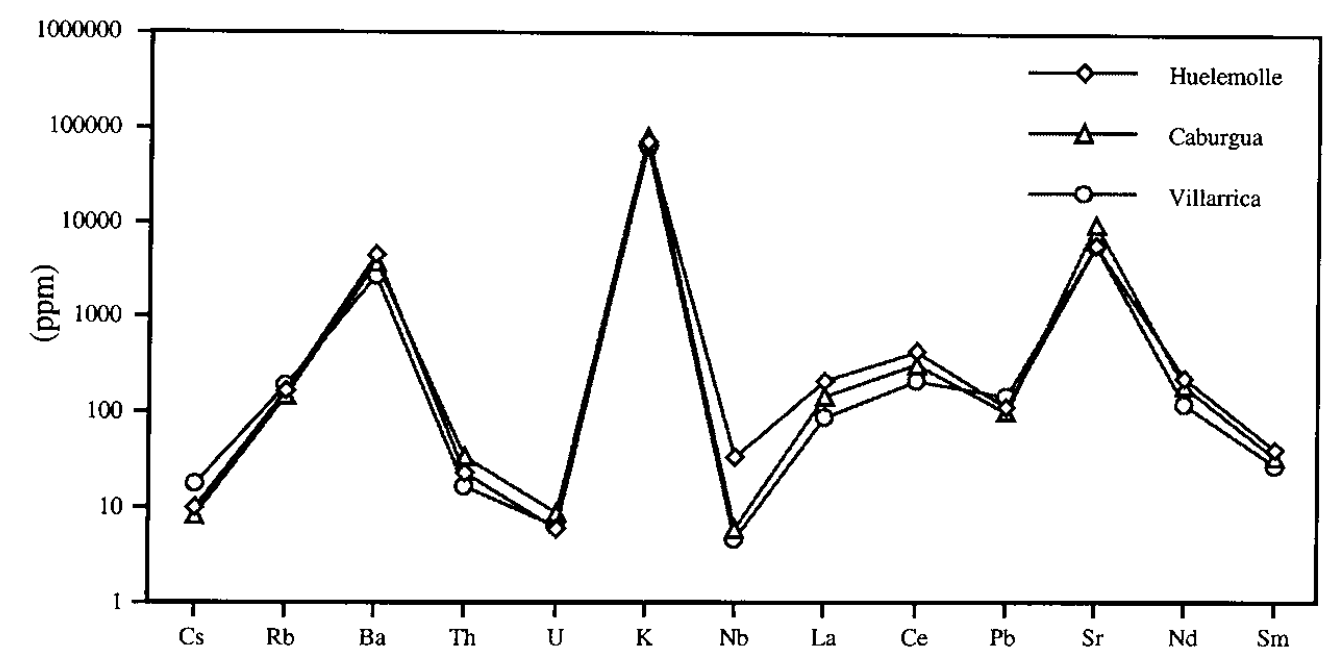

Elements

Fig.4.3.6 Compositions of the fluids added to the V.Villarrica / SEC sources (E - MORB) 


\subsubsection{Radiogenic isotopes $\mathrm{Sr}-\mathrm{Nd}$ - Pb systematics}

Using $\mathrm{Sr}-\mathrm{Nd}$ isotope results for the V.Villarrica and SEC basalts (Fig.3.5.2), I calculated mixing trajectories between the pre - subduction $\mathrm{N}-\mathrm{MORB}\left({ }^{87} \mathrm{Sr} /{ }^{86} \mathrm{Sr}=\right.$ 0.7025 and $\left.{ }^{143} \mathrm{Nd} /{ }^{144} \mathrm{Nd}=0.51315\right)$ or $\mathrm{E}-\mathrm{MORB}\left({ }^{87} \mathrm{Sr} /{ }^{86} \mathrm{Sr}=0.703\right.$ and ${ }^{143} \mathrm{Nd} /{ }^{144} \mathrm{Nd}=$ 0.513) mantle wedge (Wood, 1979), subducted sediments (average Izu sediments, 50\% clay and $50 \%$ chalk; $\left.{ }^{87} \mathrm{Sr} /{ }^{86} \mathrm{Sr}=0.709597,{ }^{143} \mathrm{Nd} /{ }^{144} \mathrm{Nd}=0.51187-0.51196\right)$ and the altered oceanic crust $(\mathrm{AOC})\left({ }^{87} \mathrm{Sr} /{ }^{86} \mathrm{Sr}=0.7035-0.704,{ }^{143} \mathrm{Nd} /{ }^{144} \mathrm{Nd}=0.513077\right)$ (Hochstaedter et al., unpublished). Since Nd is moderately immobile in aqueous fluids under subduction conditions (Brenan et al., 1994; 1995), its $\mathrm{D}^{\text {(mineraffluid) }}$ value is set to 1.0. In this model, fluids derived from sediments and AOC first mix, and then enter the overlying mantle where they metasomatize it and later trigger melting. The calculated mixing trends are shown on the following diagrams (Fig.4.3.7 and Fig.4.3.8). Table 4-3-6 displays abundances and isotope ratios of AOC and sediments used to model the isotopic ratios of the V.Villarrica and SEC samples in this study and the calculated results. Sr/Nd ratios used to calculate mixing trends, and the calculated $\mathrm{Sr} / \mathrm{Nd}$ ratios of the V.Villarrica and SEC primary magmas (with both mantle sources) are shown in Table 4-3-7.

As shown in Fig.4.3.7. and Fig.4.3.8, the fluids metasomatizing SEC Huelemolle source may incorporate a smaller proportion of AOC component than fluids metasomatizing SEC Caburgua source and especially V.Villarrica source. The calculated total amounts of fluids added to the mantle source of V.Villarrica are greater for both $\mathrm{N}-$ type and $\mathrm{E}$ - type MORB sources. This is consistent with higher ${ }^{87} \mathrm{Sr} /{ }^{86} \mathrm{Sr}$ and ${ }^{143} \mathrm{Nd} /{ }^{144} \mathrm{Nd}$ in V.Villarrica basalts compared with the SECs, and is quite reasonable since the composite volcano might be located in the center of the melting column and receive a 
larger proportion of the subduction component from the oceanic crust. The SECs, receive less of slab - derived fluids with a slightly larger contribution from subducted sediments. In addition, it is also consistent with the largest degree of partial melting of V.Villarrica that was concluded earlier in this section (a larger amount of fluid addition triggers a larger extent of partial melting in the metasomatized overlying mantle wedge).

The modeled chemical and isotopic compositions of the slab - released fluids beneath the different SECs are variable, especially for Caburgua. The fluids added to the source of Carburgua must have significantly lower ${ }^{87} \mathrm{Sr} /{ }^{86} \mathrm{Sr}$, indicating that AOC beneath the melting column of this SEC may be less altered than that beneath Huelemolle and V.Villarrica. Between the two SECs, the amount of fluid addition for Caburgua is relatively larger and as a result, the extent of partial melting (F) at Caburgua is also larger. Because V.Villarrica and all the SECs are located within a relatively small area, it is not clear at this stage whether the heterogeneity of the subducted slab at such a small scale is a localized phenomenon or it is caused by certain unknown factors at the subduction zone. 


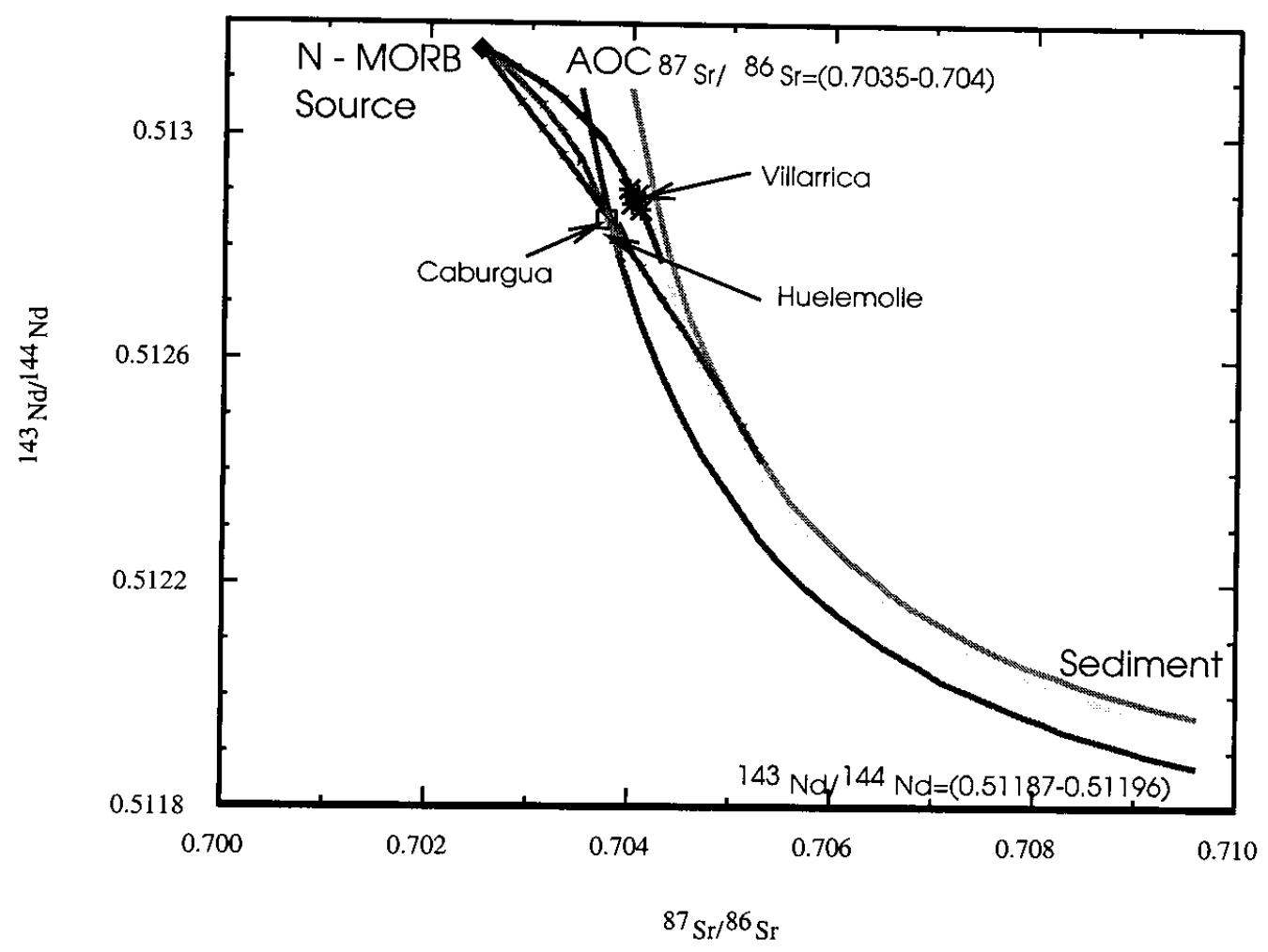

Fig.4.3.7 Sr - Nd isotopic modeling (mixing of sources) calculated for the V.Villarrica and SEC samples $(\mathrm{N}-\mathrm{MORB})$ 


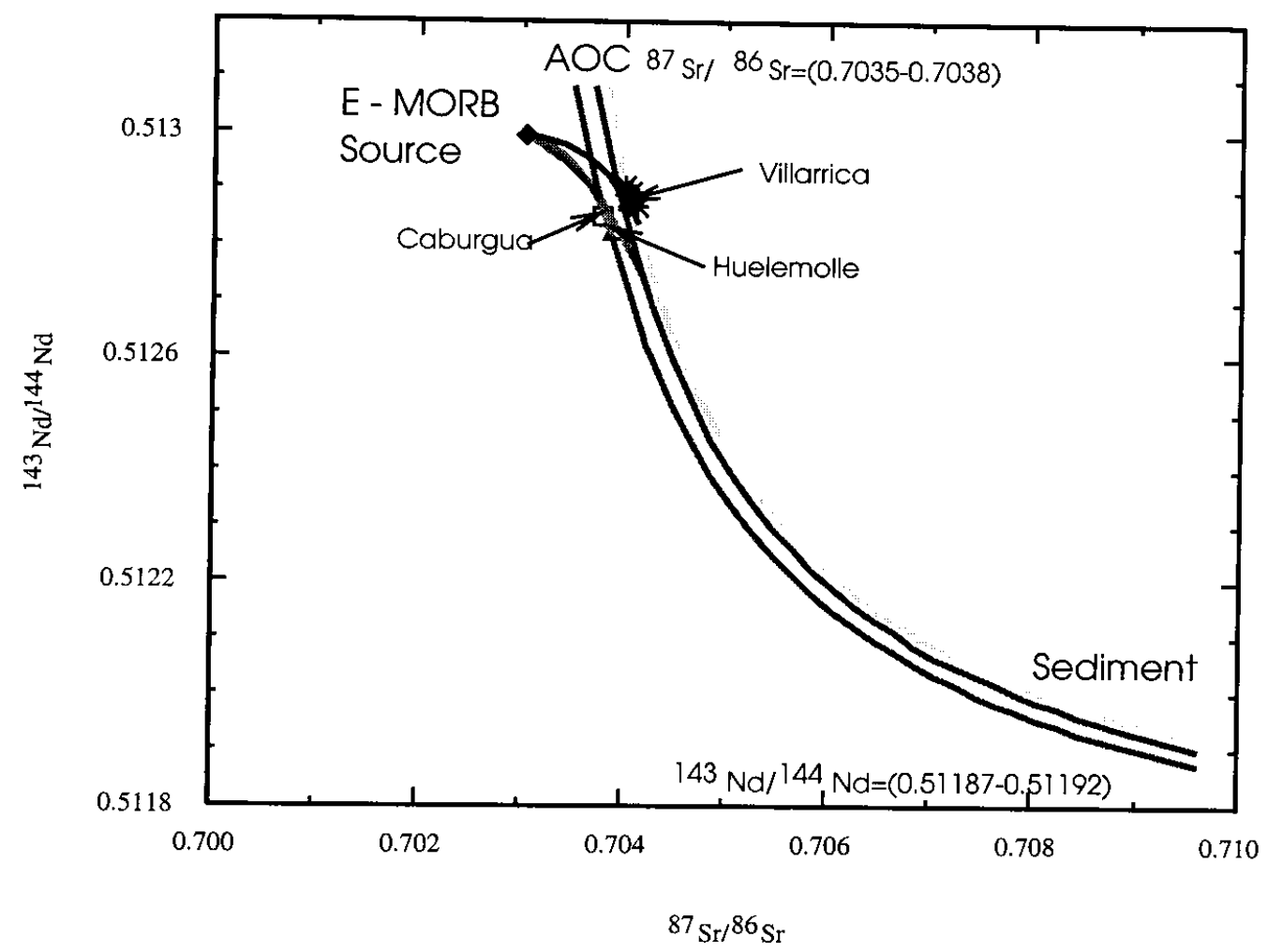

Fig.4.3.8 $\mathrm{Sr}$ - Nd isotopic modeling (mixing of sources) calculated for the V.Villarrica and SEC samples (E-MORB) 
Table 4-3-6 Modeled compositions of slab - derived fluids added to potential N MORB and E - MORB sources (in ppm)

\begin{tabular}{|l|l|l|l|l|}
\hline Elements & In sediments & In Fluids from Sediments & In AOC & In Fluids from AOC \\
\hline $\mathrm{Sr}$ & 216.0 & 280.8 & 115.0 & 400.0 \\
\hline $\mathrm{Nd}$ & 21.8 & 21.8 & 6.6 & 6.6 \\
\hline $\begin{array}{l}\text { References: } \\
\text { Hochstaedter et al. (unpublished); Kogiso et al. (1997); Plank and Langmuir (1998) }\end{array}$ \\
\hline
\end{tabular}

\begin{tabular}{|l|l|l|l|l|}
\hline N - MORB Source & \begin{tabular}{l} 
Fluid (AOC $\begin{array}{l}\text { lu Sediment } \\
\text { isotopes }\end{array}$ \\
\cline { 2 - 4 }
\end{tabular} & $\begin{array}{l}\text { AOC in } \\
\text { the Fluid }\end{array}$ & $\begin{array}{l}\text { Fluid added to } \\
\text { the mantle } \\
\text { source }\end{array}$ \\
\hline Villarrica & 0.7043 & 0.512779 & $90.3 \%$ & $0.97 \%$ \\
\hline Huelemolle & 0.7053 & 0.512421 & $69.9 \%$ & $0.12 \%$ \\
\hline Caburgua & 0.70397 & 0.512736 & $89.4 \%$ & $0.52 \%$ \\
\hline
\end{tabular}

\begin{tabular}{|l|l|l|l|l|}
\hline E - MORB Source & \multicolumn{2}{|l|}{\begin{tabular}{l} 
Fluid (AOC $\begin{array}{l}\text { AOC Sediment) } \\
\text { isotopes }\end{array}$ \\
\cline { 2 - 3 }
\end{tabular}} & $\begin{array}{l}\text { AOC in } \\
\text { the Fluid }\end{array}$ & $\begin{array}{l}\text { Fluid added } \\
\text { To the mantle } \\
\text { source }\end{array}$ \\
\hline Villarrica & 0.7041 & 0.512841 & $92.8 \%$ & $2.66 \%$ \\
\hline Huelemolle & 0.70425 & 0.512693 & $87.2 \%$ & $0.49 \%$ \\
\hline Caburgua & 0.70383 & 0.512821 & $92.5 \%$ & $1.19 \%$ \\
\hline
\end{tabular}


Table 4-3-7 The comparison between the measured and calculated $\mathrm{Sr} / \mathrm{Nd}$ ratios in the Villarrica and SEC samples

\begin{tabular}{|l|l|l|l|l|l|}
\hline Sample & $\begin{array}{l}\text { (Sr/Nd)- } \\
\text { Primary } \\
\text { Magma }\end{array}$ & $\begin{array}{l}\text { (Sr/Nd)- } \\
\text { Dry } \\
\text { Magma }\end{array}$ & $\begin{array}{l}\text { (Sr/Nd)- } \\
\text { Fluid }\end{array}$ & (Sr/Nd)Cal. & N MORB \\
\hline Villarrica & 36.9 & 17.4 & 48.1 & 36.7 & \\
\cline { 1 - 5 } Huelemolle & 25.2 & 27.4 & 32.6 & 29.8 & \\
\hline Caburgua & 42.5 & 20.0 & 47.1 & 38.8 & \\
\hline Villarrica & 36.9 & 16.3 & 50.9 & 42.7 & E - MORB \\
\hline Huelemolle & 25.2 & 20.9 & 45.0 & 33.6 & \\
\hline Caburgua & 42.5 & 17.7 & 50.5 & 42.0 & \\
\hline
\end{tabular}


Based on the calculations in this section, more than $80 \%$ of the $\mathrm{Pb}$ in the primary magmas of the SECs and more than $95 \%$ of the $\mathrm{Pb}$ in the primary magma of V.Villarrica was contributed by subduction (subducted slab and sediments). The lack of difference in their $\mathrm{Pb}$ isotopic compositions indicates that either:

- Most of the $\mathrm{Pb}$ contributed by the subduction components (subducted sediments) comes from one single source with its $\mathrm{Pb}$ isotopes constrained within a narrow compositional range, or melting and dehydration of subducted sediments and slab homogenize their $\mathrm{Pb}$ isotopes, i.e., the slab component is isotopically homogeneous (Edwards et al., 1993).

or

- The $\mathrm{AOC}$ and sediments may have similar $\mathrm{Pb}$ isotope ratios because $\mathrm{Pb}$ could be exchanged between them during hydrothermal alteration due to its high mobility in the hydrothermal solutions (Peucker-Ehrenbrink et al., 1994).

Fig.4.3.9 shows $\mathrm{Pb}$ isotopic ratios of basaltic samples from V.Villarrica, the SECs (previous work and this study), average Izu sediment and AOC results from Hochstaedter et al. (unpublished), Mariana sediments from Elliott et al. (1997) and Meijer (1976), South Atlantic pelagic sediment results from Barreiro (1983), open - ocean, Mn - nodule and DSDP measurements of sediments from Church (1976) and the metalliferous Nazca plate sediment results from Dasch (1981). Although under most circumstances the $\mathrm{Pb}$ isotopic ratios of AOC are not affected by hydrothermal solutions and sediments (Tatsumoto, 1978; Chen and Pallister, 1981), metalliferous sediments ("non - lithic") receive their $\mathrm{Pb}$ from hydrothermal solutions dominated by mantle $\mathrm{Pb}$ signatures. 


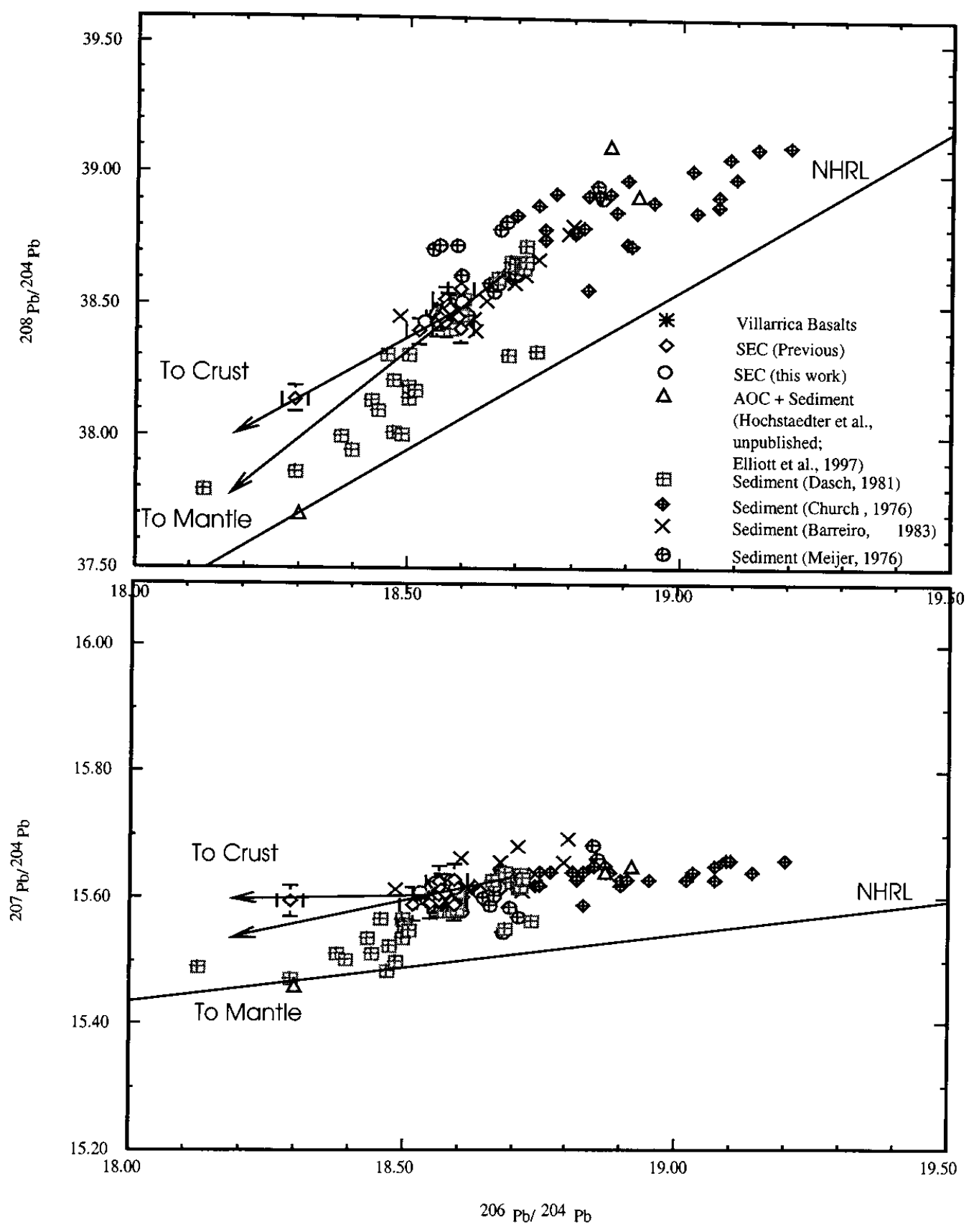

Fig. 4.3.9 Pb isotopes of V.Villarrica and SEC samples versus AOC and sediment data in the literature (Meijer, 1976; Church, 1976; Dasch, 1981; Barreiro, 1983; Elliott et al., 1997; Hochstaedter et al., unpublished) 
The clustering of the $\mathrm{Pb}$ isotopes for the V.Villarrica and SEC samples may suggest that they are getting their $\mathrm{Pb}$ from either metalliferous sediments with less mantle signature or sediments mixed by metalliferous sediments and detrital sediments shed from the continent.

$\mathrm{Pb}$ isotopic ratios of lavas from SEC Llizan suggest crustal contamination, and the crustal material Llizan magmas may assimilate are expected to have much lower ${ }^{208} \mathrm{~Pb} /{ }^{204} \mathrm{~Pb}$ and ${ }^{206} \mathrm{~Pb} /{ }^{204} \mathrm{~Pb}$ than the V.Villarrica and SEC lavas, as pointed out by the arrows on Fig.4.3.9. Therefore, the contaminant should be relatively old basement metamorphic or metasedimentary rocks. Detailed discussions and modeling on the crustal processes occurring at this SEC are in Section 4.5. 


\subsubsection{A possible $\mathrm{Nb}$ - bearing component from the subducted slab}

Although the above modeling based on addition of the slab - derived fluids alone explains most of the geochemical characteristics of the V.Villarrica and SEC samples, there is still one important problem unsolved - why do calculated fluids added to different SEC, like Huelemolle and Caburgua, differ significantly in La/Nb ratios? Partial melting of the mantle does not produce big contrasts in $\mathrm{La}$ or $\mathrm{Nb}$ concentrations in basaltic magmas. An assumption of these calculations is that $\mathrm{Nb}$ is not mobile in subduction fluids, so the amount of fluid added is proportional to certain trace element ratios in the samples, such as $\mathrm{Ba} / \mathrm{Nb}, \mathrm{Rb} / \mathrm{Nb}$ and $\mathrm{La} / \mathrm{Nb}$. However, the variations of $\mathrm{La} / \mathrm{Nb}$ suggest that $\mathrm{Nb}$ may be carried by a subduction component. As shown in Fig.4.3.10, there is a well - defined negative correlation between the $\mathrm{La} / \mathrm{Nb}$ and $\mathrm{Hf} / \mathrm{Sm}$ ratios among the SECs, which suggests that ratios are affected by fractionation of HFSE, i.e., $\mathrm{Nb}$ and Hf, relative to REEs such as La and Sm. Although HFSEs and REEs could be fractionated by fluid transport processes, it is more likely that this is the result of partial melting in the presence of a HFSE retaining mineral like rutile or ilmenite. Because both subducted sediments and basaltic oceanic crust may contain a certain amount of rutile, the $D_{\mathrm{Nb}}$ value of the crust / melt will vary with the proportion of rutile (Johnson and Plank, 1999). It is thus possible that hydrous melts from subducted crust with variable $\mathrm{La} / \mathrm{Nb}$ ratios may be mixed into the mantle sources of V.Villarrica and the SECs during or before the formation of the arc magmas in this area.

Since substantial $\mathrm{Nb}$ could be added to the mantle by melts, an alternative interpretation of elevated $\mathrm{Nb}$ contents in the primary magma of Huelemolle is addition of a melt phase. In other words, $\mathrm{Nb}$ may be enriched via a slab melt, rather than an 
unusually small degree of melting. Evidence in support of this idea is that the $\mathrm{La} / \mathrm{Nb}$ ratios in Huelemolle samples are close to the lowest end $(\sim 3.0)$, indicating a larger amount of $\mathrm{Nb}$ is added to the source of Huelemolle relative to other SECs and V.Villarrica. As an alternative, Huelemolle is modeled based on a higher F of 0.1 (the same as the F of Caburgua), and the calculated fluid / melt compositions are shown in Table 4-3-8 (N-MORB as example).

If in sediments $\mathrm{La}=57.0 \mathrm{ppm}, \mathrm{Nb}=6.9 \mathrm{ppm}$ and in $\mathrm{AOC} \mathrm{La}=1.84 \mathrm{ppm}, \mathrm{Nb}=$ $1.22 \mathrm{ppm}$ (Hochstaedter et al., unpublished), then to derive a hydrous melt with $\mathrm{La} / \mathrm{Nb}$ ratio of 4.6 for Huelemolle, 19.6 for V.Villarrica and 25.0 for Caburgua (see Table 4-38), under a constant extent of melting $F=0.3$ (Johnson and Plank, 1999), the bulk $D_{\mathrm{Nb}}$ value will need to vary between 0 (little rutile - for Huelemolle) and 2.0 (more rutile, for Caburgua) if this melt is derived from the subducted sediments and between 1.0 and 7.0 if this melt is derived from the $\mathrm{AOC}\left(\mathrm{D}_{\mathrm{La}}=0.02\right.$, from GERM Website). 


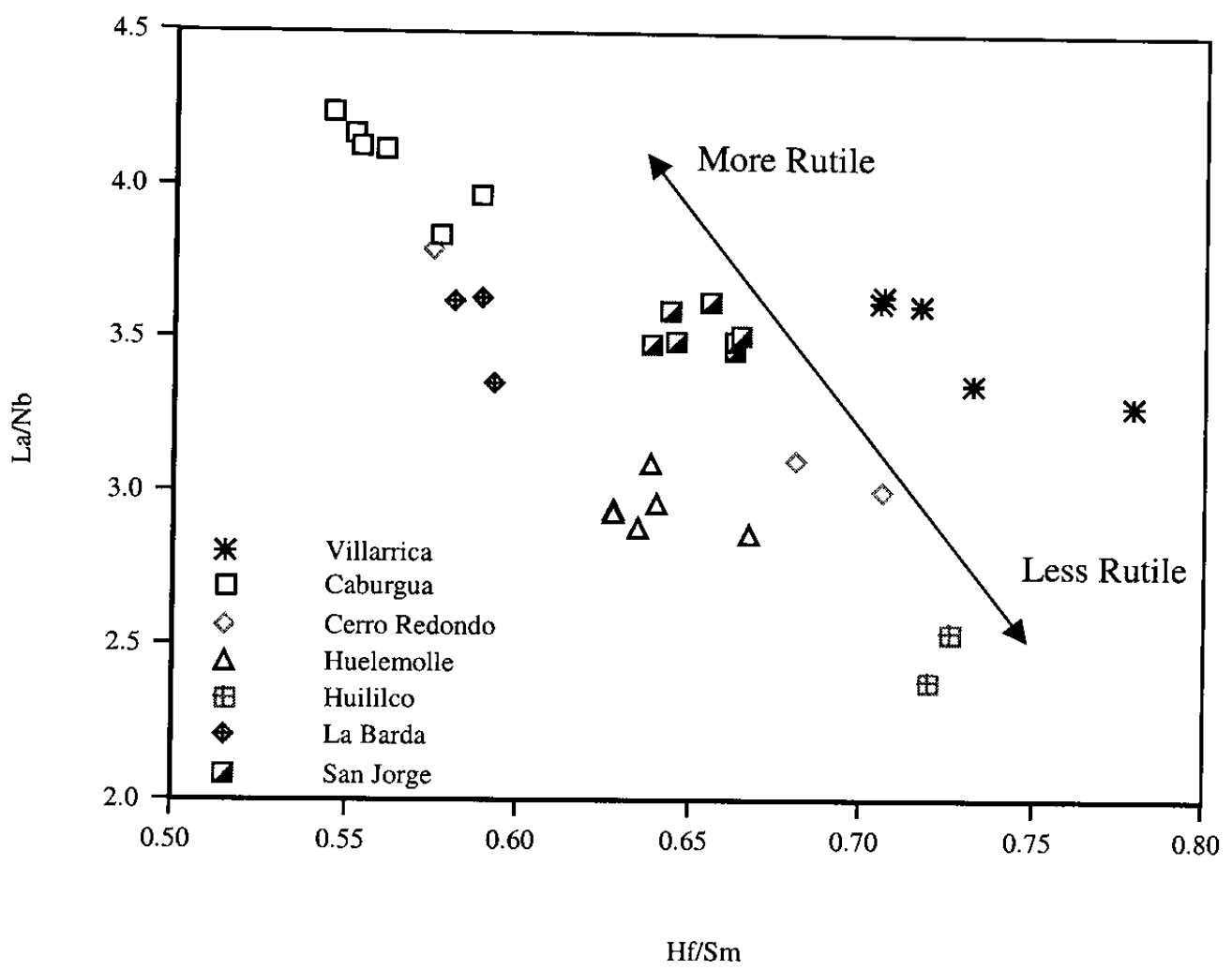

Fig.4.3.10 La/ $\mathrm{Nb}$ versus $\mathrm{Hf} / \mathrm{Sm}$ for the V.Villarrica and SEC samples 
Table 4-3-8 Subduction - derived fluid / melt compositions and the proportions of elements added to the source of V.Villarrica and SEC (N - MORB) (in ppm)

\begin{tabular}{|r|r|r|r|r|r|r|}
\hline Element & \multicolumn{2}{|l|}{ Villarrica (F=0.2) } & \multicolumn{2}{|l|}{ Huelemolle (F=0.1) } & \multicolumn{2}{|l|}{ Caburgua (F=0.1) } \\
\cline { 2 - 7 } & Fluid Conc. & added & Fluid Conc. & added & Fluid Conc. & added \\
\hline $\mathrm{Cs}$ & 17 & $99 \%$ & 10 & $98 \%$ & 8 & $97 \%$ \\
\hline $\mathrm{Rb}$ & 194 & $95 \%$ & 185 & $91 \%$ & 149 & $89 \%$ \\
\hline $\mathrm{Ba}$ & 2762 & $96 \%$ & 4588 & $96 \%$ & 3697 & $95 \%$ \\
\hline $\mathrm{Th}$ & 17 & $90 \%$ & 26 & $87 \%$ & 34 & $90 \%$ \\
\hline $\mathrm{U}$ & 6 & $86 \%$ & 7 & $80 \%$ & 9 & $82 \%$ \\
\hline $\mathrm{K}$ & 65211 & $87 \%$ & 83639 & $82 \%$ & 81979 & $81 \%$ \\
\hline $\mathrm{Nb}$ & 4 & $10 \%$ & 55 & $54 \%$ & 6 & $8 \%$ \\
\hline $\mathrm{La}$ & 88 & $75 \%$ & 251 & $82 \%$ & 150 & $73 \%$ \\
\hline $\mathrm{Ce}$ & 213 & $71 \%$ & 535 & $78 \%$ & 317 & $68 \%$ \\
\hline $\mathrm{Yb}$ & 9 & $25 \%$ & 122 & $94 \%$ & 2 & $0 \%$ \\
\hline $\mathrm{Pb}$ & 151 & $97 \%$ & 7207 & $77 \%$ & 104 & $93 \%$ \\
\hline $\mathrm{Sr}$ & 5791 & $83 \%$ & 265 & $71 \%$ & 10152 & $83 \%$ \\
\hline $\mathrm{Nd}$ & 123 & $64 \%$ & 46 & $60 \%$ & 186 & $64 \%$ \\
\hline $\mathrm{Sm}$ & 27 & $54 \%$ & 10 & $98 \%$ & 34 & $52 \%$ \\
\hline
\end{tabular}




\subsection{Some important constraints from ${ }^{10} \mathrm{Be}$ and the $\mathrm{U}$ - Series}

The short - lived cosmogenic isotope ${ }^{10} \mathrm{Be}\left(\mathrm{T}_{12}=1.5 \mathrm{Ma}\right)$ is used to constrain the nature and timescale of subduction zone magmatism. Both ${ }^{10} \mathrm{Be}$ and the element $\mathrm{B}$ are enriched in some arc lavas relative to MORBs and OIBs (Table 4-4-1).

At some subduction zones such as the Sunda arc, ${ }^{10} \mathrm{Be}$ concentrations in volcanic samples are very low $\left(<1 * 10^{6} \mathrm{a} / \mathrm{g}\right)$, maybe due to a minimal amount of subducted young sediments beneath the arc, or the ${ }^{10} \mathrm{Be}$ formed originally has decayed away over a fairly long time (>10Ma). Other arc lavas have much higher ${ }^{10} \mathrm{Be}$ concentrations, typically from subducted sediments within the upper layers of the sediment column on the slab (Tera et al., 1986).

Disequilibrium among isotopes of the ${ }^{238} \mathrm{U}$ decay series $\left({ }^{230} \mathrm{Th},{ }^{226} \mathrm{Ra}\right.$ and $\left.{ }^{210} \mathrm{Po}\right)$ occurs when two nuclides in a decay series are fractionated and do not have time to reach secular equilibrium (proportional to the ratio of their decay constants). U - series disequilibrium in young volcanic rocks generally reflects fractionation of $U$ relative to $T h$ (or Ra relative to Th) during partial melting or crystallization processes (Gill and Condomines, 1992; Chabaux et al., 1999; Turner et al., 2000). U excesses over Th, as observed in most basaltic and andesitic arc lavas, can be explained by $U$ addition through slab dehydration and mantle metasomatism, higher oxygen fugacity, or due to Th retention (relative to $U$ ) in residual minerals (Gill and Williams, 1990).

In samples from V.Villarrica and the surrounding SECs, ${ }^{238} \mathrm{U} /{ }^{232} \mathrm{Th}(\leq 1.2)$ and ${ }^{230} \mathrm{Th} /{ }^{232} \mathrm{Th}(\leq 1.0)$ values lie between the $\mathrm{U}$ and $\mathrm{Th}$ isotopic ratios of the mantle and the altered oceanic crust / sediments (see Section 3.6), indicating some contributions from a subducted sedimentary component. This is consistent with the fact that in the Andean 
CSVZ, the subducted oceanic crust is relatively young ( 18Ma) at the trench axis and the trench is sediment - rich (Herron, 1981). In addition, ${ }^{10} \mathrm{Be}$ ranges between $0.97-1.7\left({ }^{*} 10^{6}\right.$ $\mathrm{a} / \mathrm{g}$ ), with V.Villarrica the highest (see Section 3.6). The ${ }^{10} \mathrm{Be}$ values in the V.Villarrica and SEC samples are significantly higher than those of MORBs or the mantle (usually $<<1 * 10^{6} \mathrm{a} / \mathrm{g}$ ), reflecting incorporation of relatively young ( $\left.<10 \mathrm{Ma}\right)$ subducted pelagic sediments before or during the formation of the arc magmas in this area.

In Fig.4.4.1, ${ }^{10} \mathrm{Be} /{ }^{3} \mathrm{Be}$ shows a positive correlation with $\left({ }^{238} \mathrm{U} /{ }^{230} \mathrm{Th}\right)$. The two samples with high $\left({ }^{238} \mathrm{U} /{ }^{230} \mathrm{Th}\right)$ ratios (V.Villarrica (1971) and San Jorge) also have high ${ }^{10} \mathrm{Be} / \mathrm{Be}$, while those samples (Caburgua, Huelemolle and $\mathrm{La} \mathrm{Barda}$ ) with low $\left({ }^{238} \mathrm{U} /{ }^{230} \mathrm{Th}\right.$ ) have low ${ }^{10} \mathrm{Be} /{ }^{9} \mathrm{Be}$. The high $\left({ }^{238} \mathrm{U} /{ }^{230} \mathrm{Th}\right.$ ) ratios $(\geq 1.7)$ (i.e., ${ }^{238} \mathrm{U}$ excess over ${ }^{230} \mathrm{Th}$ ) of samples from V.Villarrica and San Jorge are most likely caused by the preferential partitioning of $U(U / T h=0.339-0.385)$ in the fluids derived from subducted crust, which is consistent with their apparent ${ }^{10} \mathrm{Be}$ enrichment. The three low SEC samples $(\mathrm{U} / \mathrm{Th}=0.27-0.284)$ indicate less sediment inputs from the slab, due either to 1$)$ lesser amounts of fluids derived from subducted sediments; or 2) older sediments being involved. Their ${ }^{10} \mathrm{Be} /{ }^{9} \mathrm{Be}$ ratios are all less than $2 * 10^{-11}$ and $\left.{ }^{238} \mathrm{U} /{ }^{230} \mathrm{Th}\right)$ are all less than 1 , showing that their $\mathrm{U}, \mathrm{Th}$ and Be budgets are either dominated by the MORB or OIB - like mantle source, or that their sources are older.

A positive correlation also exists between ${ }^{10} \mathrm{Be} /{ }^{\beta} \mathrm{Be}$ and $\mathrm{B} / \mathrm{Be}$ (Fig.4.4.2), which supports the idea that subducted sediments were involved into the arc magmas in the V.Villarrica vicinity, mainly through the recent slab or sediment dehydration. Since the V.Villarrica and San Jorge samples with excess $U$ lie along an almost horizontal line on Fig.3.6.1, according to the reasoning of Sigmarsson et al. (1990), the dehydration process 
has to have occurred within a very short time period, most likely less than $\sim 30,000$ years ago.

In addition, the strong ${ }^{226} \mathrm{Ra}$ excess of the V.Villarrica (1971) and San Jorge samples indicated by their high ${ }^{210} \mathrm{Po} /{ }^{230} \mathrm{Th}$ ratios suggests that SEC San Jorge may have been developed within the past 5,000 years (stratigraphic age of San Jorge has not been reported), along with the latest V.Villarrica units (III and IV) (age both analyzed by ${ }^{14} \mathrm{C}$ dating and inferred from the above work). The lack of such excesses in the other SECs may be due to their age $\left(4,000-6,000\right.$ a) or they may not have had ${ }^{226} \mathrm{Ra}$ excesses initially. 
Table 4-4-1 Be - B concentrations measured in different geologic settings on a global basis

\begin{tabular}{|l|l|l|l|l|l|}
\hline $\begin{array}{l}\text { Morris \& Tera (1989); } \\
\text { Morris et al. (1990) }\end{array}$ & $\begin{array}{l}{ }^{10} \mathrm{Be} \\
\left(10^{6} \mathrm{a} / \mathrm{g}\right)\end{array}$ & $\mathrm{Be}(\mathrm{ppm})$ & $\begin{array}{l}{ }^{10} \mathrm{Be} / \mathrm{Be} \\
\left(10^{-11}\right)\end{array}$ & $\mathrm{B}(\mathrm{ppm})$ & $\mathrm{B} / \mathrm{Be}$ \\
\hline MORB & $<1$ & $0.3-1.5$ & $<1$ & $\sim 1$ & $\sim 2$ \\
\hline OIB & $<1$ & $0.3-1.5$ & $<1$ & $2-3$ & $1-2$ \\
\hline Sediments & $\sim 5000$ & $0.3-1.5$ & $\sim 5000$ & $50-150$ & $\sim 100$ \\
\hline Arc Lavas & $0.1-24$ & $0.3-1.5$ & $0.1-81$ & $4-94$ & $3-190$ \\
\hline
\end{tabular}




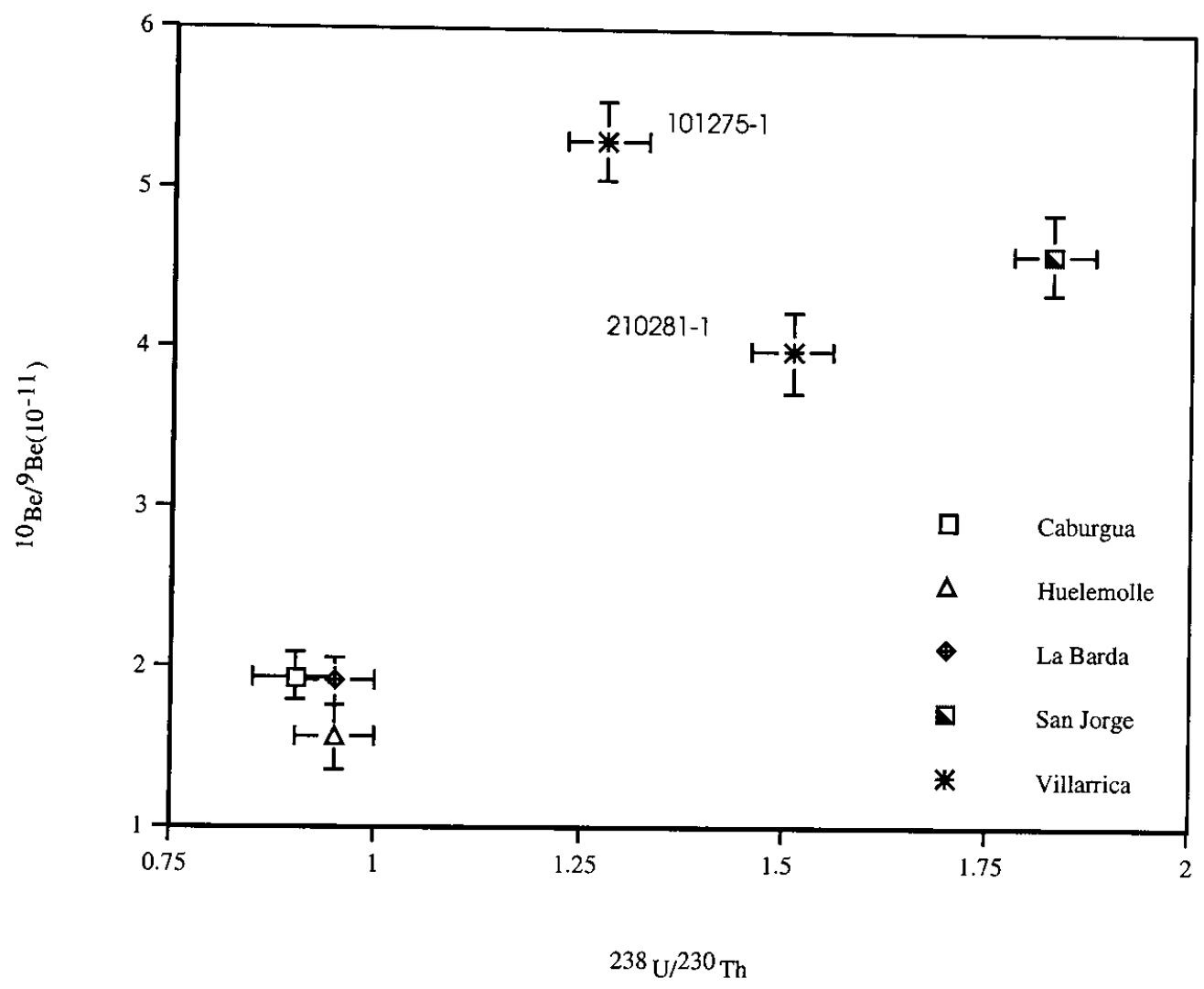

Fig.4.4.1 ${ }^{10} \mathrm{Be} / \mathrm{Be}$ versus $\left({ }^{238} \mathrm{U} /{ }^{230} \mathrm{Th}\right)$ for the V.Villarrica and SEC samples (V.Villarrica samples: 101275-1 - from Sigmarsson et al., 1990; 210281-1 - this work) 


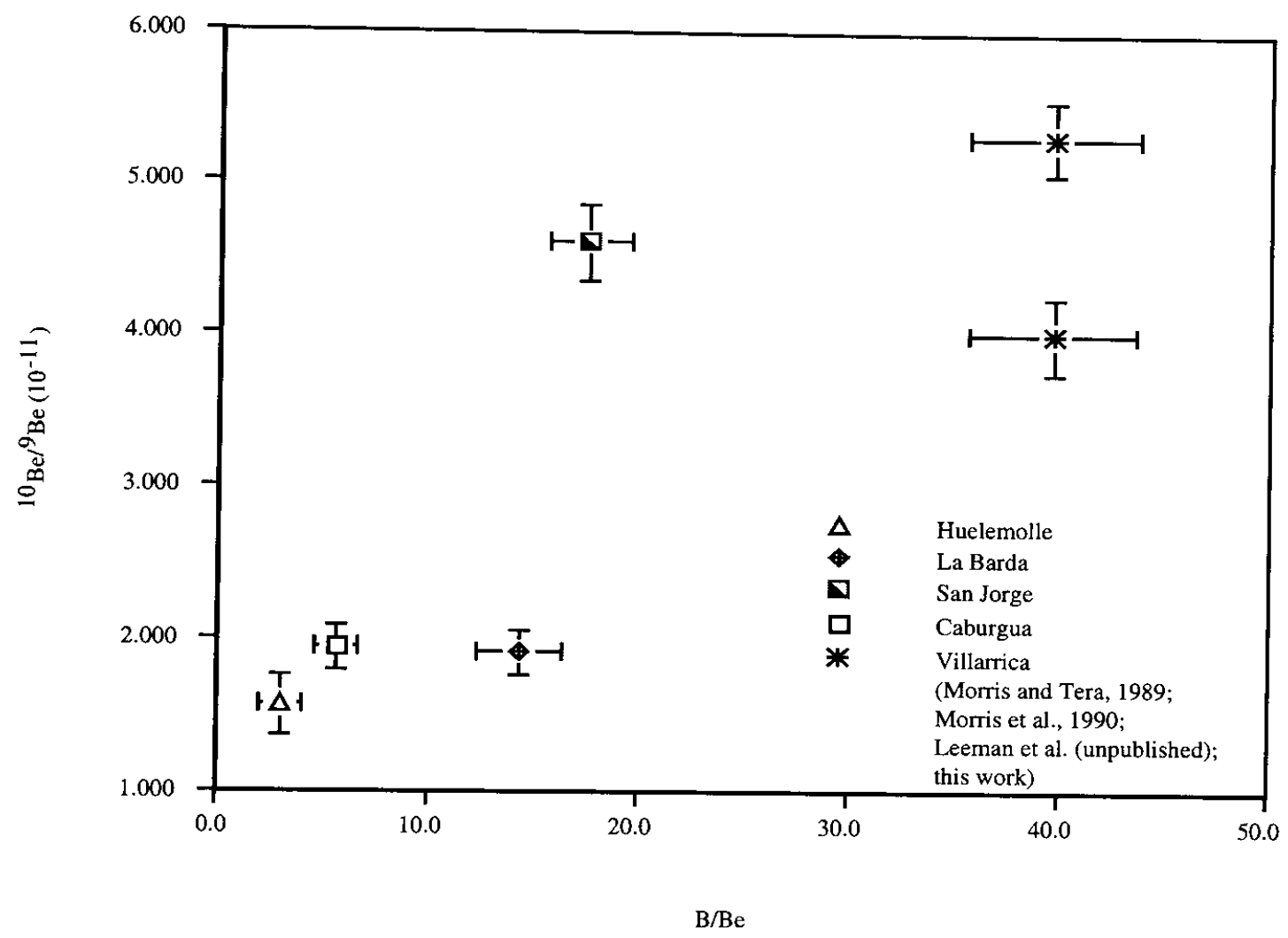

Fig.4.4.2 ${ }^{10} \mathrm{Be} / \mathrm{Be}$ vs $\mathrm{B} / \mathrm{Be}$ for the V.Villarrica and SEC samples (B - Leeman et al. (unpublished); Morris et al., 1990; $\mathrm{Be}$ - this work; ${ }^{10} \mathrm{Be}$ - Morris and Tera, 1989; Morris et al., 1990) 


\subsection{Modeling of Llizan basaltic andesites and andesites - upper crust contamination, binary mixing and AFC processes}

In section 4.2, a series of major element $-\mathrm{SiO}_{2}$ diagrams were plotted and crustal contamination was suggested for the origins of the basaltic andesites and andesites from SEC Llizan. Based on their $\mathrm{La} / \mathrm{Yb}$ and $\mathrm{Nb} / \mathrm{Yb}$ values (Fig.4.3.4), the Llizan samples are more similar to the SEC suite than to V.Villarrica samples. Therefore, it is likely that SEC - type basaltic magma was contaminated to produce the andesites of Llizan. However, it is still unclear: 1) whether Llizan lavas originated from the magma body of another SEC or from the primary magma of that SEC (i.e., did contamination occur just prior to eruption or at depth in the crust?); 2) whether the process of contamination is a simple mixture of contaminant and starting magma, or it is an AFC (assimilation and fractionation crystallization) - like process; and 3) which contaminant will produce the best fit in this case, is its composition similar to the average upper continental crust, the Villarrica silicic samples, or other basement metamorphic rocks? Table 4-5-1 - Table 45-3 and Fig.4.5.1 - Fig.4.5.3 present trace element and $\mathrm{Sr}-\mathrm{Nd}$ isotopic constraints on the possible origin of the andesitic samples from SEC Llizan.

In Fig.4.5.1, a plot of ${ }^{143} \mathrm{Nd} /{ }^{144} \mathrm{Nd}$ versus ${ }^{87} \mathrm{Sr} /{ }^{86} \mathrm{Sr}$, the Llizan sample $130194-02$ $(\mathrm{MEC}-3)$ has the highest ${ }^{87} \mathrm{Sr} /{ }^{86} \mathrm{Sr}$ ratio (0.70412) among the SECs, but an intermediate ${ }^{143} \mathrm{Nd} /{ }^{144} \mathrm{Nd}$ ratio $(0.512832)$. Its $\mathrm{Sr} / \mathrm{Nd}$ ratio is $\approx 26.2$. The basaltic $\mathrm{SECs}$ in this region, can be divided into 3 subgroups based on their $\mathrm{Sr} / \mathrm{Nd}$ ratios and $\mathrm{Sr}$ isotopic values. Subgroup I, which includes SEC Caburgua, Cerro Redondo and La Barda, is lower in ${ }^{87} \mathrm{Sr} /{ }^{86} \mathrm{Sr}(<0.7038)$ and higher in $\mathrm{Sr} / \mathrm{Nd}(>40)$. Subgroup II, which includes SEC Huelemolle and Huililco, is higher in ${ }^{87} \mathrm{Sr} /{ }^{86} \mathrm{Sr}(>0.7038)$ and lower in $\mathrm{Sr} / \mathrm{Nd}(<30)$. 
Subgroup III is the mafic SEC San Jorge, with a ${ }^{87} \mathrm{Sr} /{ }^{86} \mathrm{Sr}$ of 0.70396 (averaged) and $\mathrm{Sr} / \mathrm{Nd}$ of 43.8 (averaged). These groups represent three potential starting magma compositions for binary mixing and/or AFC.

\section{1) Binary Mixing:}

For binary mixing from Subgroup I, as there is basically no diffrence between Llizan and these SEC lavas in ${ }^{143} \mathrm{Nd} /{ }^{144} \mathrm{Nd}$ compared to ${ }^{87} \mathrm{Sr} /{ }^{86} \mathrm{Sr}$, the potential contaminant must have extremely high $\mathrm{Sr} / \mathrm{Nd}$, which conflicts with the lower $\mathrm{Sr} / \mathrm{Nd}$ seen in Llizan samples. Subgroup II is also not suitable as a starting composition because the required Nd content in the contaminant is too low $(\mathrm{Nd} \approx 5.6 \mathrm{ppm})$ based on calculations. Subgroup $I I I$, on the other hand, may satisfy all these criteria because the contrast of ${ }^{143} \mathrm{Nd} /{ }^{144} \mathrm{Nd}$ relative to ${ }^{87} \mathrm{Sr} /{ }^{86} \mathrm{Sr}$ ratios between Llizan and this group is relatively large, and therefore a larger decrease of ${ }^{143} \mathrm{Nd} /{ }^{144} \mathrm{Nd}$ versus ${ }^{87} \mathrm{Sr} /{ }^{86} \mathrm{Sr}(\mathrm{r}<1)$ for the mixing path and a much lower $\mathrm{Sr} / \mathrm{Nd}$ ratio in the contaminant can be accommodated. This indicates that mixing may have occurred close to the surface where plagioclase fractionation greatly decreases the $\mathrm{St} / \mathrm{Nd}$ ratio in the contaminant $\left(\mathrm{Sr}\right.$ is compatible in plagioclase; $\left.\mathrm{D}_{\mathrm{S}_{r}}^{\text {Plag Melt }}=1.0-2.0\right)$ (from GERM website). Therefore, the actual compositions measured for San Jorge samples may not be used directly for the calculation. As discussed in Section 4.2, San Jorge is much more mafic and less fractionated especially in olivine compared with other SECs so samples from this SEC do not reflect the compositions of evolved magmas at shallow depths. Since there is no olivine accumulation observed in Llizan samples, it is more likely that Llizan was derived by contamination of a magma body that was chemically similar to the San Jorge magma but underwent more shallow level 
crystallization. Using constraints from the isotopic ratios and $\mathrm{Sr}$ and $\mathrm{Nd}$ abundances in both San Jorge and Llizan samples, an estimate of about $30 \%$ (comparable to the extent of olivine fractionation calculated for the SECs and V.Villarrica, see Section 4.3) olivine fractionation is required in San Jorge magmas to produce an approximate starting composition. As a result, the highly incompatible element contents $\left(D^{\text {olivineliquid }} \approx 0\right)$ in the estimated "original" Llizan magma can be calculated by multiplying the measured concentrations (averaged) of these elements of San Jorge samples with a factor of 1.45.

The chosen model contaminant is silicic melt of upper crustal materials ${ }^{87} \mathrm{Sr} /{ }^{86} \mathrm{Sr}$ $=0.712$ and $\left.{ }^{143} \mathrm{Nd} /{ }^{144} \mathrm{Nd}=0.5126\right)$ whose trace element and REE contents are similar to V.Villarrica rhyolites in Hickey - Vargas et al. (1989). This contaminant component is favored because: 1) major element compositions of Llizan samples, especially $\mathrm{Fe}_{2} \mathrm{O}_{3}$, $\mathrm{MgO}, \mathrm{CaO}, \mathrm{Na}_{2} \mathrm{O}$ and $\mathrm{K}_{2} \mathrm{O}$ indicate V.Villarrica rhyolites could be a possible contaminant; 2) Villarrica rhyolite $(\mathrm{Sr} / \mathrm{Nd} \approx 5.0)$ suits the $\mathrm{Sr} / \mathrm{Nd}$ ratio required for the mixing $(\sim 3.0)$ better than the average upper continental crust $(\mathrm{Sr} / \mathrm{Nd} \approx 13.5)$. This choice is also supported by the widespread occurrence of granites in the basement in this region (see Map1.3.1), although these rocks have never been analyzed.

A melt $(\mathrm{F} \approx 0.14)$ derived from this wallrock with bulk $\mathrm{D}_{\mathrm{sr}}$ close to 1.0 and $\mathrm{D}_{\mathrm{Nd}}$ about 0.5 in the presence of plagioclase would have $\mathrm{Sr} / \mathrm{Nd}$ as low as 3.0, and the $\mathrm{Sr}$ and $\mathrm{Nd}$ contents of $160 \mathrm{ppm}$ and $53.3 \mathrm{ppm}$, respectively. Similarly, incompatible element contents of the melt can be calculated (Table 4-5-3) using $\mathrm{D}_{\mathrm{Sm}}=0.2, \mathrm{D}_{\mathrm{zr}}=0.05, \mathrm{D}_{\mathrm{Hf}}=$ $0.05, \mathrm{D}_{\mathrm{Yb}}=1.0$ and $\mathrm{D}$ values of 0 for more incompatible elements. The Th content of the Llizan sample is relatively high $(\sim 6.5 \mathrm{ppm})$ compared with the calculated result $(\sim$ $4.0 \mathrm{ppm})$ from simple mixing if the Th content of the V.Villarrica rhyolite $(=6.6 \mathrm{ppm})$ is 
used. If binary mixing takes place, the Th content of the contaminant must be higher. For example, with $\mathrm{Th}=11.9 \mathrm{ppm}$, similar to silicic rocks from other parts of the SVZ (Stern et al., 1984), the calculated result is 6.5ppm, which matches the Th content of the Llizan sample (Table 4-5-2). Using the $\mathrm{Pb}$ concentrations in Table 4-5-2, $\mathrm{Pb}$ isotopic ratios of ${ }^{208} \mathrm{~Pb} /{ }^{204} \mathrm{~Pb}=38.00,{ }^{207} \mathrm{~Pb} /{ }^{204} \mathrm{~Pb}=15.58$ and ${ }^{206} \mathrm{~Pb} /{ }^{204} \mathrm{~Pb}=18.19$ can be inferred for this potential contaminant. Based on a binary mixing model, the degree of crustal contamination on Llizan magma is estimated to be about $6.7 \%$.

2) $A F C$ :

AFC processes are controlled by the combined effect of fractionation and assimilation, that is, the $\mathrm{r}$ ratio $(\mathrm{Ma} / \mathrm{Mc})$ and the $\mathrm{D}$ values of $\mathrm{Sr}$ and $\mathrm{Nd}$ (Depaolo, 1981). As a result, three possibilities need to be considered: AFC starting from Subgroup I, Subgroup II and Subgroup III.

At shallow depths, because the dominant mineral phase fractionated is plagioclase, $D_{\mathrm{Sr}}$ tends to be larger than 1.0 , and $D_{\mathrm{Nd}}$ is usually $\ll<1.0$. As a result, the $\mathrm{Sr}$ content in the magma body decreases while Nd increases with decreasing F, and the $\mathrm{Sr} / \mathrm{Nd}$ ratio in the derived magma decreases faster than during simple mixing. As a result, higher concentrations of incompatible elements are required for the contaminant in the AFC model. Samples from Subgroup II, are more enriched in both $\mathrm{Sr}$ and Nd relative to the Llizan sample, so this group is not suitable as a starting magma for Llizan. Subgroup I is also ruled out because the calculated $\mathrm{Nd}$ content in the contaminant is too low $(\mathrm{Nd} \approx$ $8.5 \mathrm{ppm})$. 
The AFC path calculated using the same starting magma (Subgroup III) match the compositions of Llizan well (Table 4-5-2). I propose therefore that an AFC - like contamination from a San Jorge - like but more evolved magma body an alternative origin for the Llizan lavas. In the AFC calculations, the required $\mathrm{Sr} / \mathrm{Nd}$ of the assimilant (rhyolitic or granitic melt) is slightly lower $(\sim 2.5)$ than in the binary mixing case, which may indicate a more plagioclase - enriched mineral assemblage. On the other hand, a smaller extent of partial meting of the wallrock $(\mathrm{F} \approx 0.08)$ is necessary to produce higher incompatible element abundances in the resulting assimilant. The required assimilant also needs to be much older than the Tertiary, based on the chosen $\mathrm{Sr}$ and $\mathrm{Nd}$ isotope values. Using the $\mathrm{Pb}$ concentrations in Table 4-5-3, $\mathrm{Pb}$ isotopic ratios of ${ }^{208} \mathrm{~Pb} /{ }^{204} \mathrm{~Pb}=37.90$, ${ }^{207} \mathrm{~Pb} /{ }^{204} \mathrm{~Pb}=15.58$ and ${ }^{206} \mathrm{~Pb} /{ }^{204} \mathrm{~Pb}=18.12$ can be inferred for this potential assimilant. These ratios also match the compositions of relatively old Andean basement granites / gneisses (Barreiro, 1984). A Th content of 11.9ppm in the assimilant is also used in the calculations and the calculated result matches the Th content in Llizan (Table 4-5-3). In AFC model, the degree of crustal contamination in Llizan magmas is about $3.4 \%$.

The ${ }^{87} \mathrm{Sr} /{ }^{86} \mathrm{Sr}$ versus $\mathrm{Rb} / \mathrm{Sr}$ relationship (Fig.4.5.2) favors AFC over a simple mixing process, which echoes our observations from the major element systematics of Llizan (see Section 4.2), however, $\mathrm{Rb} / \mathrm{Ba}$ versus $\mathrm{La} / \mathrm{Ba}$ (Fig.4.5.3) shows similar mixing path for both simple mixing and AFC. Neither of these two possibilities can be ruled out at this stage based on our limited geochemical data from Llizan. The unusually high incompatible element concentrations (but normal elemental ratios) in the calculated contaminant may be reduced if the chosen contaminant is less $\mathrm{Sr}$ - radiogenic (lower ${ }^{87} \mathrm{Sr}{ }^{86} \mathrm{Sr}$ ) because a larger amount of a more dilute contaminant will be permissible. 


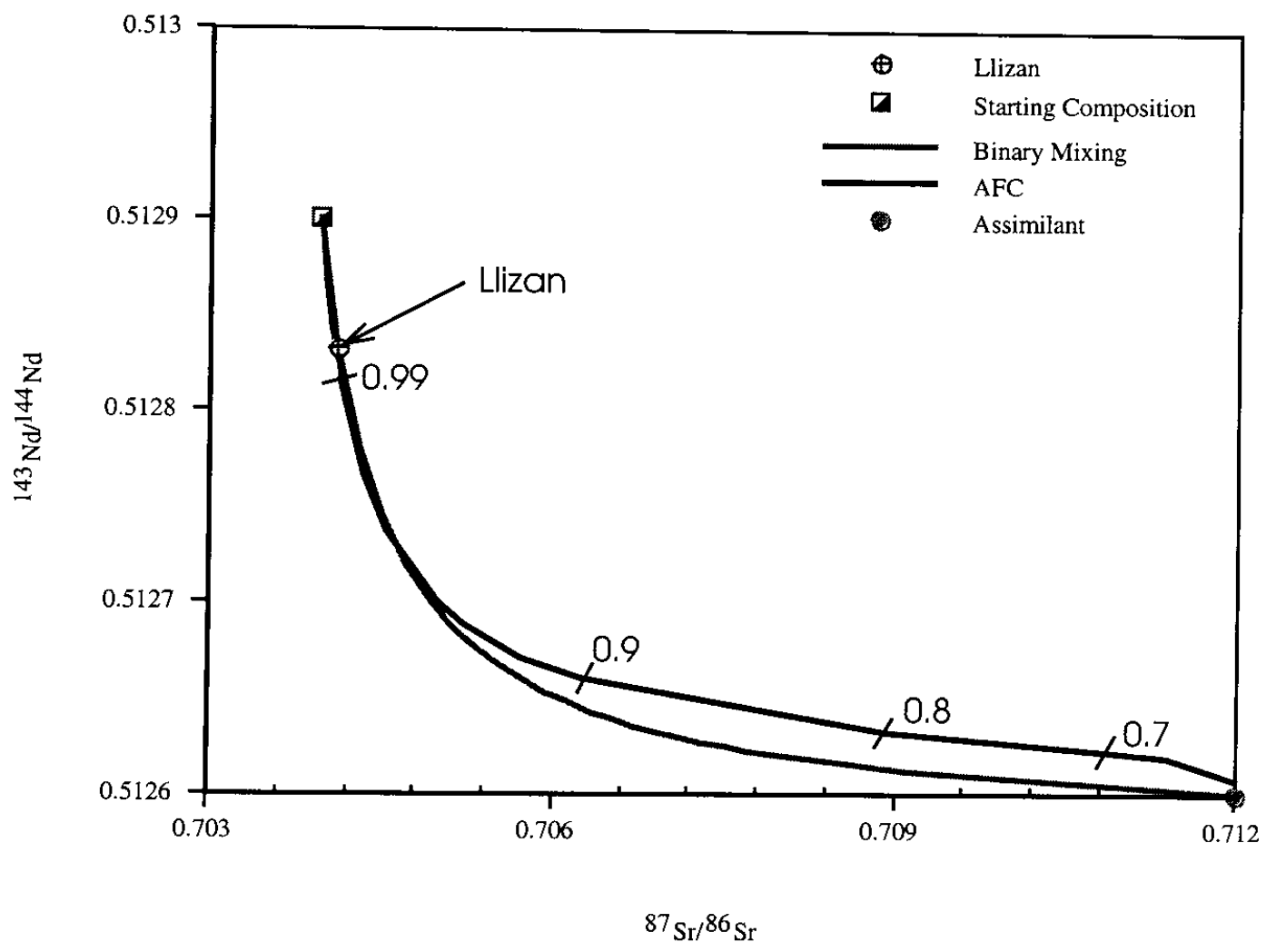

Fig.4.5.1 $\mathrm{Sr}-\mathrm{Nd}$ isotopic modeling of crustal contamination (AFC and Binary Mixing) of Llizan samples 


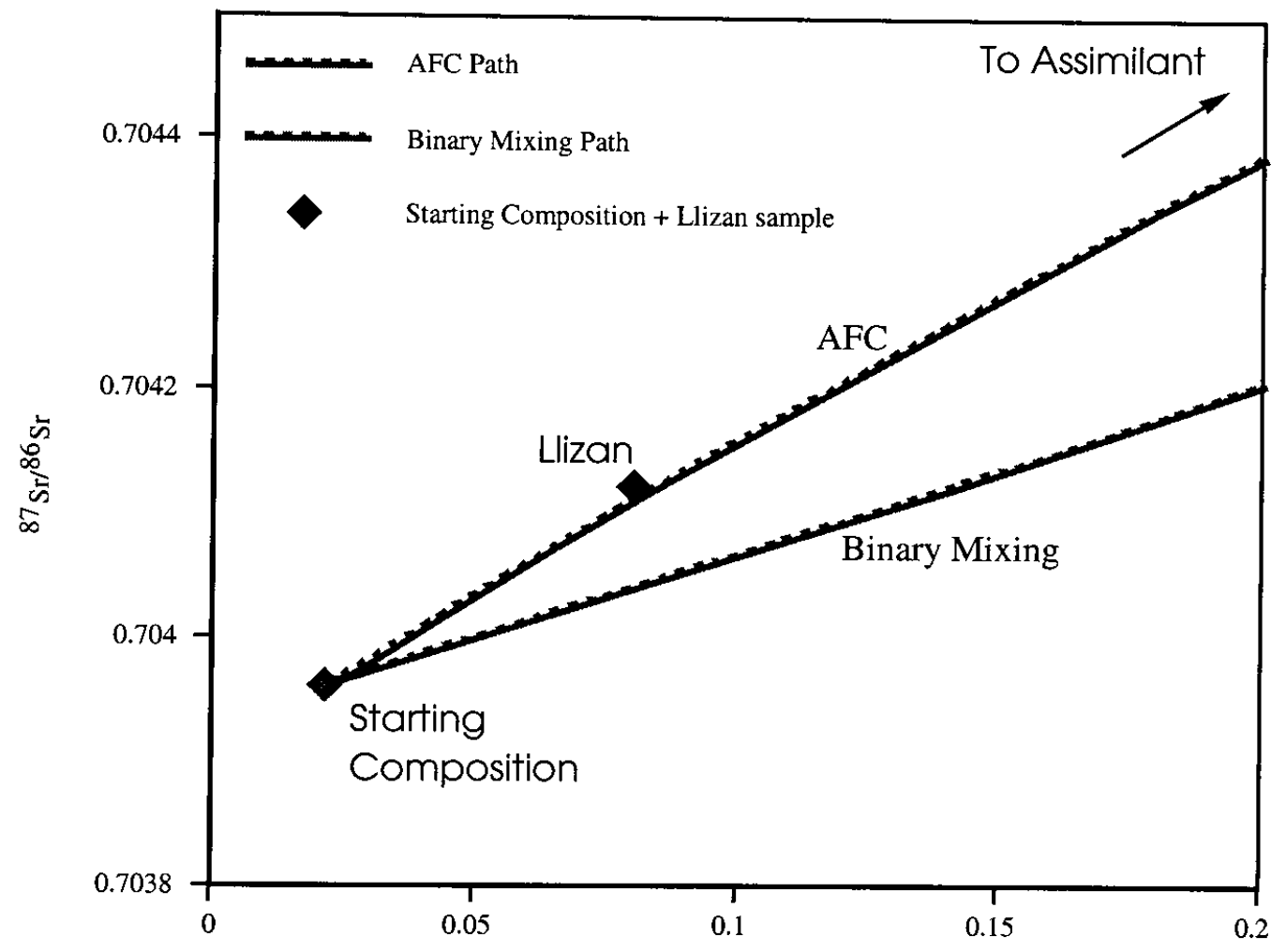

$\mathrm{Rb} / \mathrm{Sr}$

Fig.4.5.2 $\quad{ }^{87} \mathrm{Sr} /{ }^{86} \mathrm{Sr}$ versus $\mathrm{Rb} / \mathrm{Sr}$ for $\mathrm{AFC}$ and binary mixing calculations of the Llizan samples 


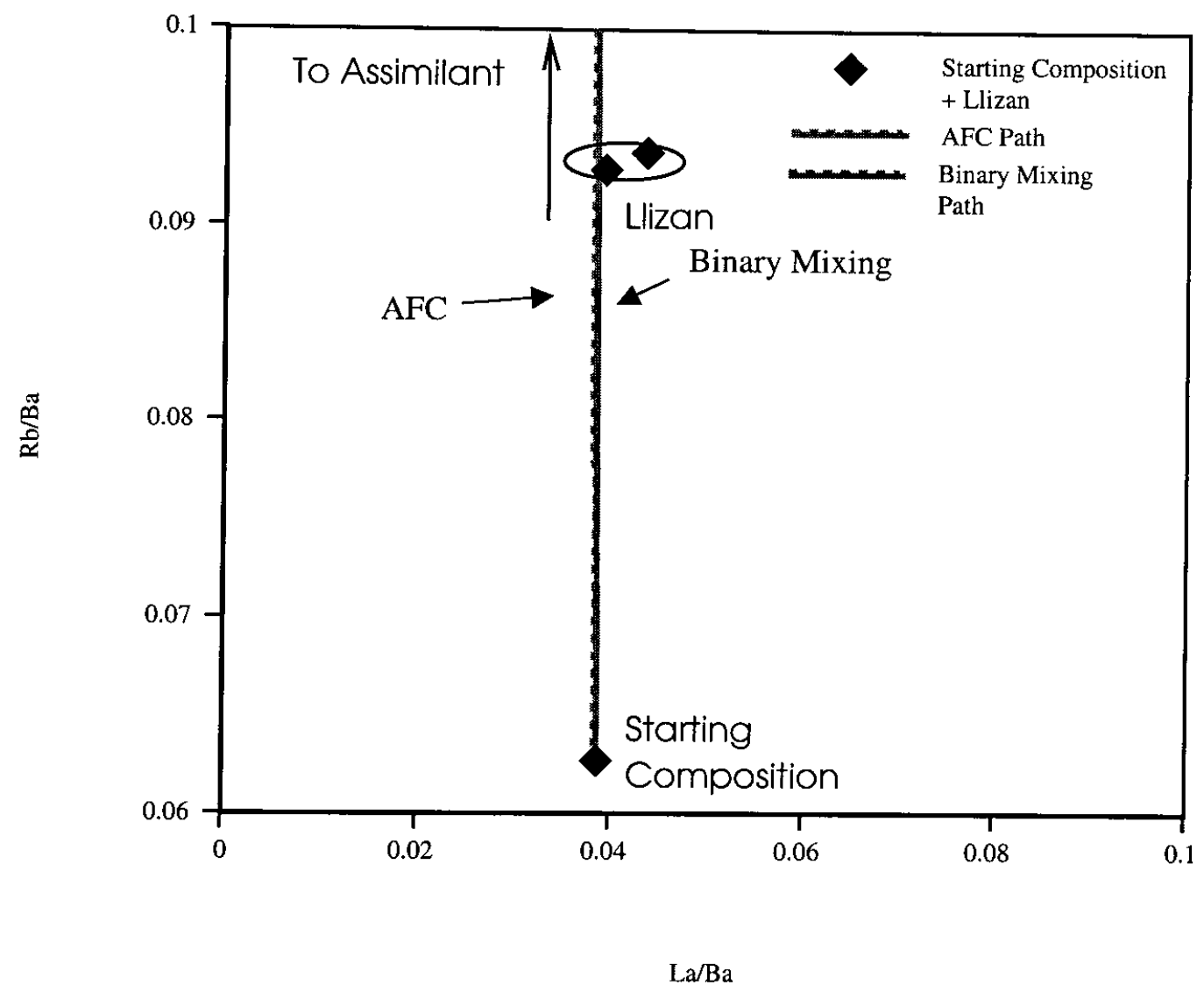

Fig.4.5.3 $\mathrm{Rb} / \mathrm{Ba}$ versus $\mathrm{La} / \mathrm{Ba}$ for $\mathrm{AFC}$ and binary mixing calculations of the Llizan samples 
Table 4-5-1 Compositions of the contaminants and the starting magma and parameters and coefficients used to calculate the AFC / Binary Mixing trends of the Llizan samples

\begin{tabular}{|l|l|}
\hline \multicolumn{2}{|l|}{ Binary Mixing } \\
\hline Contaminant & Starting Composition \\
\hline${ }^{87} \mathrm{Sr} /{ }^{86} \mathrm{Sr}=0.712$ & ${ }^{87} \mathrm{Sr}{ }^{86} \mathrm{Sr}=0.70396$ \\
${ }^{143} \mathrm{Nd} /{ }^{144} \mathrm{Nd}=0.5126$ & ${ }^{143} \mathrm{Nd} /{ }^{144} \mathrm{Nd}=0.5129$ \\
$\mathrm{Sr}=160 \mathrm{ppm}$ & $\mathrm{Sr}=565.5 \mathrm{ppm}$ \\
$\mathrm{Nd}=53.3 \mathrm{ppm}$ & $\mathrm{Nd}=12.9 \mathrm{ppm}$ \\
\hline
\end{tabular}

\begin{tabular}{|c|c|c|c|c|}
\hline \multicolumn{5}{|l|}{$\mathrm{AFC}$} \\
\hline Contaminant & Starting Composition & $\mathrm{r}$ & $\mathrm{D}_{\mathrm{Sr}}$ & $\mathrm{D}_{\mathrm{Nd}}$ \\
\hline${ }^{87} \mathrm{Sr} /{ }^{86} \mathrm{Sr}=0.712$ & ${ }^{87} \mathrm{Sr}{ }^{86} \mathrm{Sr}=0.70396$ & 0.8 & 2 & 0.05 \\
\hline${ }^{143} \mathrm{Nd} /{ }^{144} \mathrm{Nd}=0.5126$ & ${ }^{143} \mathrm{Nd} /{ }^{144} \mathrm{Nd}=0.5129$ & & & \\
\hline $\mathrm{Sr}=320 \mathrm{ppm}$ & $\mathrm{Sr}=565.5 \mathrm{ppm}$ & & & \\
\hline $\mathrm{Nd}=130 \mathrm{ppm}$ & $\mathrm{Nd}=12.9 \mathrm{ppm}$ & & & \\
\hline
\end{tabular}


Table 4-5-2 Calculated elemental and isotopic compositions for SEC Llizan by Binary Mixing model (From Subroup III)

\begin{tabular}{|l|l|l|l|}
\hline $\begin{array}{l}\text { Element and } \\
\text { Isotope ratios }\end{array}$ & $\begin{array}{l}\text { Contaminant } \\
\text { (ppm for conc.) }\end{array}$ & $\begin{array}{l}\text { (Llizan) } \\
\text { Calculated By Bingary }\end{array}$ & $\begin{array}{l}\text { Llizan (Measured) } \\
\text { (ppm for conc.) }\end{array}$ \\
\hline $\mathrm{La}$ & 178.6 & 19.0 & 18.877 \\
\hline $\mathrm{Nb}$ & 52.1 & 5.5 & 6.007 \\
\hline $\mathrm{Ce}$ & 425.7 & 45.4 & 40.916 \\
\hline $\mathrm{Sm}$ & 24.2 & 4.7 & 4.36 \\
\hline $\mathrm{Yb}$ & 5.8 & 2.4 & 2.412 \\
\hline $\mathrm{Zr}$ & 1896.2 & 208.2 & 196.7 \\
\hline $\mathrm{Hf}$ & 37.4 & 4.5 & 4.482 \\
\hline $\mathrm{Th}$ & 85.7 & 6.6 & 6.531 \\
\hline $\mathrm{Sr} / \mathrm{Nd}$ & 3.0 & 34.5 & 26.17 \\
\hline $\mathrm{Pb}$ & 192.9 & 19.6 & 23.713 \\
\hline $\mathrm{Rb}$ & 535.7 & 47.5 & 44.258 \\
\hline $\mathrm{Cs}$ & 40.7 & 3.5 & 2.882 \\
\hline $\mathrm{Ba}$ & 4692.9 & 490.3 & 477.284 \\
\hline${ }^{206} \mathrm{~Pb} /{ }^{204} \mathrm{~Pb}$ & 18.19 & 18.292 & 18.292 \\
\hline${ }^{207} \mathrm{~Pb} /{ }^{204} \mathrm{~Pb}$ & 15.58 & 38.190 & 38.136 \\
\hline${ }^{208} \mathrm{~Pb} /{ }^{204} \mathrm{~Pb}$ & 38.00 & & \\
\hline
\end{tabular}


Table 4-5-3 Calculated elemental and isotopic compositions for SEC Llizan by AFC model (From Subgroup III)

\begin{tabular}{|c|c|c|c|}
\hline $\begin{array}{l}\text { Elements and } \\
\text { Isotope ratios }\end{array}$ & $\begin{array}{l}\text { Contaminant } \\
\text { (ppm for conc.) }\end{array}$ & $\begin{array}{l}\text { (Llizan) })_{\text {Calculated }} \text { By AFC } \\
\text { Model (ppm for conc.) }\end{array}$ & $\begin{array}{l}\text { Llizan (Measured) } \\
\text { (ppm for conc.) }\end{array}$ \\
\hline $\mathrm{La}$ & 312.5 & 18.9 & 18.877 \\
\hline $\mathrm{Nb}$ & 91.2 & 5.5 & 6.007 \\
\hline $\mathrm{Ce}$ & 745.0 & 45.3 & 40.916 \\
\hline $\mathrm{Sm}$ & 28.4 & 4.4 & 4.36 \\
\hline $\mathrm{Yb}$ & 5.8 & 2.4 & 2.412 \\
\hline $\mathrm{Zr}$ & 2754.0 & 187.5 & 196.7 \\
\hline $\mathrm{Hf}$ & 68.3 & 4.7 & 4.482 \\
\hline Th & 150 & 6.3 & 6.531 \\
\hline $\mathrm{Sr} / \mathrm{Nd}$ & 2.5 & 30.1 & 26.17 \\
\hline $\mathrm{Pb}$ & 337.5 & 19.5 & 23.713 \\
\hline$\overline{\mathrm{Rb}}$ & 937.5 & 46.4 & 44.258 \\
\hline Cs & 71.2 & 3.5 & 2.882 \\
\hline $\mathrm{Ba}$ & 8212.5 & 495.1 & 477.284 \\
\hline${ }^{206} \mathrm{~Pb} /{ }^{204} \mathrm{~Pb}$ & 18.12 & 18.290 & 18.292 \\
\hline${ }^{207} \mathrm{~Pb} /{ }^{204} \mathrm{~Pb}$ & 15.58 & 15.597 & 15.594 \\
\hline${ }^{208} \mathrm{~Pb} /{ }^{204} \mathrm{~Pb}$ & 37.90 & 38.131 & 38.136 \\
\hline
\end{tabular}




\subsection{Rucapillan}

As described in section 1.2, SEC Rucapillan (including El Estadio) is located $20 \mathrm{~km}$ west $\left(72^{\circ} 10^{\prime} \mathrm{W}\right)$ of V.Villarrica. It was originally chosen for this study because it was trenchward and might therefore reveal depth - related geochemical changes. However, it is much older $(13,000-15,000 \mathrm{yr})$ than the other satellite cones and V.Villarrica. Consequently, samples from Rucapillan can not be used to interpret contemporaneous processes affecting V.Villarrica and the SECs. On the other hand, the Rucapillan group is important geochemically because it does have some relationship to the CSVZ volcanic centers.

As noted earlier, our three Rucapillan basalts - the porphyritic one and the two from El Estadio, have extremely low ${ }^{87} \mathrm{Sr} /{ }^{86} \mathrm{Sr}(0.70340-0.70342)$ and high ${ }^{143} \mathrm{Nd} /{ }^{144} \mathrm{Nd}$ $(0.512950-0.512967)$ ratios, lower and higher respectively than samples from any other volcanic centers in the SVZ of the Andes. In terms of the fluid mixing model discussed earlier for V.Villarrica and the SECs, these samples must have either less subduction component or a greater contribution from the AOC than V.Villarrica, San Jorge or the other SEC basalts. The aphyric sample of Rucapillan, on the other hand, shows no difference in $\mathrm{Sr}$ and $\mathrm{Nd}$ isotopic ratios from other SEC samples. In contrast, $\mathrm{Pb}$ isotopic ratios for all the Rucapillan samples are similar to those of all the other centers.

Several observations can be made regarding the formation of the Rucapillan basalts:

1) The Rucapillan samples are produced by mixing two magmas - a more mafic "porphyritic" one and a differentiated "aphyric" one that was entrained and 
probably remelted in the "porphyritic" magma. The El Estadio samples of Rucapillan were originally derived from a magma body similar to the mafic "porphyritic" one but by a lesser extent of crystallization and probably a shallower depth (less cpx crystallization) compared with the Rucapillan "aphyric" magma.

2) The original "porphyritic" magma is very mafic ( 50\% $\left.\mathrm{SiO}_{2}\right)$, exhibiting similar major and trace element concentrations to those of the San Jorge samples. The fairly flat LREE enrichment pattern of the Rucapillan porphyritic samples is similar to that of the V.Villarrica as well as San Jorge basalts, possibly due to a similar degree of partial melting (F) for the three volcanic units. The "aphyric" one, on the contrary, is geochemically more comparable to most of the SEC samples.

3) The $\mathrm{Sr}$ - Nd isotopic ratios indicate that the Rucapillan - "porphyritic" magma has a different source from those of the V.Villarrica and other SECs. It is much closer to the mantle wedge or the AOC endmember. Since its $\mathrm{La} / \mathrm{Nb}$ ratio is extremely high $(\geq 5)$, indicating probably the highest input of subduction components, its low ${ }^{87} \mathrm{Sr} /{ }^{86} \mathrm{Sr}$ and high ${ }^{143} \mathrm{Nd} /{ }^{144} \mathrm{Nd}$ isotopic ratios are most likely resulted from the greatest input from the AOC and subsequently the least input from sediment - derived fluids or melts. In contrast, the "aphyric" magma of Rucapillan is much higher in ${ }^{87} \mathrm{Sr} /{ }^{86} \mathrm{Sr}$ and lower in ${ }^{143} \mathrm{Nd} /{ }^{144} \mathrm{Nd}$ just like the other SECs. It is possible that there was an 
alternation of magma type in this area that produced the "aphyric" and "porphyritic" types of magma at different times. 


\subsection{Small Eruptive Centers (SEC) from Carran - Los Venados Region}

\subsubsection{Geologic background}

\subsubsection{Eruptive Centers - Carran (Holocene):}

Carran consists of a series of mixed pyroclastic, crater and maar - type eruptive centers which are aligned $\mathrm{N} 60-70^{\circ} \mathrm{E}$ and cover an area of about $25 \mathrm{~km}^{2}$ (Rodriguez Soto, thesis). There are four different morphological units in Carran:

- Carran I: This unit is formed by lava flows coming from the valleys of the Nilahue and Rininahue rivers. Eruptive centers align along the $\mathrm{N} 60^{\circ}-70^{\circ} \mathrm{E}$ fracture and extend for $2-3 \mathrm{~km}$.

- Carran II: This unit partially covers previous formations and consists mainly of lava flows and some maars. These lavas are found in the east and northwest part of the Carran groups, mainly in the river valley south of Lago Maihue rellenando, partially in the glacial valleys between the lagos Huishue and Maihue, and also in small river valleys such as Yolye.

- Carran III: This unit is composed of small pyroclastic, crater and maar-type cones, forming a strip which extends $\mathrm{N} 60^{\circ}-70^{\circ} \mathrm{E}$ for about $6 \mathrm{~km}$, overlying the Carran I and II units. Materials produced from these centers are mainly lavas and pyroclastic deposits.

- Carran IV: This unit is composed of pyroclastic deposits associated with the 1955 eruption of the maar - type SEC Carran, and accumulated up to $\sim 3 \mathrm{~m}$ thick around the vent. The products from the 1979 eruption of the SEC Mirador (Moreno, 1980), the latest eruption event of this group recorded, are also 
considered part of this unit, spatially and temporally. These lavas and pyroclastics from the Mirador eruption partially cover the pyroclastic deposits from the 1955 eruption of Carran.

\subsubsection{Eruptive Centers - Los Venados (Holocene):}

Los Venados is another series of mixed pyroclastic, crater and maar - type eruptive centers aligning $N 60^{\circ}-70^{\circ} \mathrm{E}$, covering about $30 \mathrm{~km}^{2}$, between the River Rininahue and Los Venados. These volcanics form Cerro Negro, a mountain peak higher than $1,055 \mathrm{~m}$, and consist of two morphological units (Rodriguez Soto, thesis):

- Los Venados I: This unit is composed of lava flows that are from Cerro Negro and come along River Rininahue and Los Venados.

- Los Venados II: This unit partially covers previous formations and is composed of lavas and pyroclastic materials, some of which have been partially eroded. This unit is contemporaneous with Carran III.

In the Carran - Los Venados area, SECs are devided into three subgroups based on petrology and chemistry (Rodriguez Soto, thesis). Subgroup I: along the fracture N60$70^{\circ} \mathrm{E}$, mainly composed of the volcanic units Los Venados I and Carran I (Moreno, 1977). Subgroup II: similar orientation as the former, and composed of Los Venados II, Carran II and Carran III (Moreno, 1977). Satellite Center Group: along the fracture LOFZ $\left(\mathrm{N} 10^{\circ} \mathrm{E}\right)$ and the stratovolcanoes Los Guindos and Media Luna. 


\subsubsection{Geochemical features of the Carran - LV SEC samples}

As discussed in the M.S. thesis by Rodriguez Soto, major element compositions of the C-LV SECs are summarized as follows (Fig.4.7.1):

- Similar to the V.Villarrica SECs, they are mainly medium - K, calc - alkaline and sub - alkaline basalts as well as basaltic andesites.

- Samples from Subgroup I have low $\mathrm{Al}_{2} \mathrm{O}_{3}(<16 \%)$ but high $\mathrm{FeO}^{*}(>11 \%)$, $\mathrm{TiO}_{2}(>2 \%), \mathrm{K}_{2} \mathrm{O}(\sim 1 \%)$ and $\mathrm{P}_{2} \mathrm{O}_{5}(>0.5 \%)$. Samples from Subgroup II have higher $\mathrm{Al}_{2} \mathrm{O}_{3}(>17 \%)$, lower $\mathrm{FeO}^{*}(<10.5 \%), \mathrm{TiO}_{2}(<1.5 \%), \mathrm{K}_{2} \mathrm{O}(<1 \%)$ and $\mathrm{P}_{2} \mathrm{O}_{5}(<0.5 \%)$. Their $\mathrm{MgO}, \mathrm{Na}_{2} \mathrm{O}$ and $\mathrm{CaO}$ contents are quite similar to Subgroup I, but show a larger range of variations with $\mathrm{SiO}_{2}(3-5.5 \%, 3-5 \%$ and $6.5-9.5 \%$, respectively). Samples from the Satellite Center Group have higher $\mathrm{MgO}(6.5-8 \%)$ and their $\mathrm{Na}_{2} \mathrm{O}$ contents are very low $(3.0-3.3 \%)$.

Samples from Subgroup I are more enriched in $\mathrm{Cr}, \mathrm{Sc}, \mathrm{Rb}$ and $\mathrm{Ba}$ and depleted in Sr compared with samples from Subgroup II. The Satellite Center Group, because of their more mafic compositions, are particularly high in $\mathrm{Cr}(>250 \mathrm{ppm})$ and $\mathrm{Ni}(\geq 75 \mathrm{ppm})$ contents (Rodriguez Soto, thesis). 


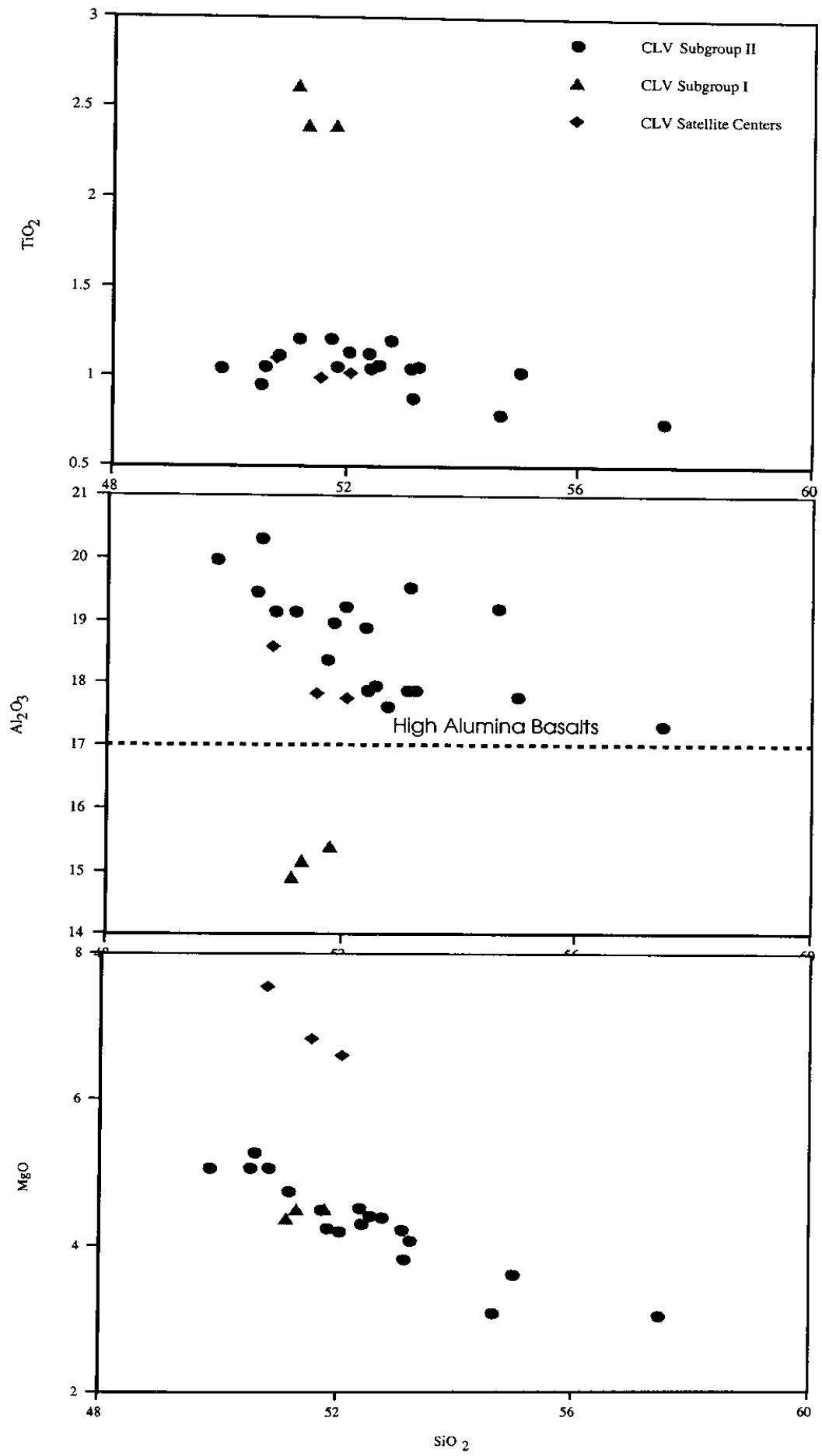

Fig. 4.7.1 Oxide versus $\mathrm{SiO}_{2}$ for Carran - LV SEC (Rodriguez Soto, thesis) (continued) 


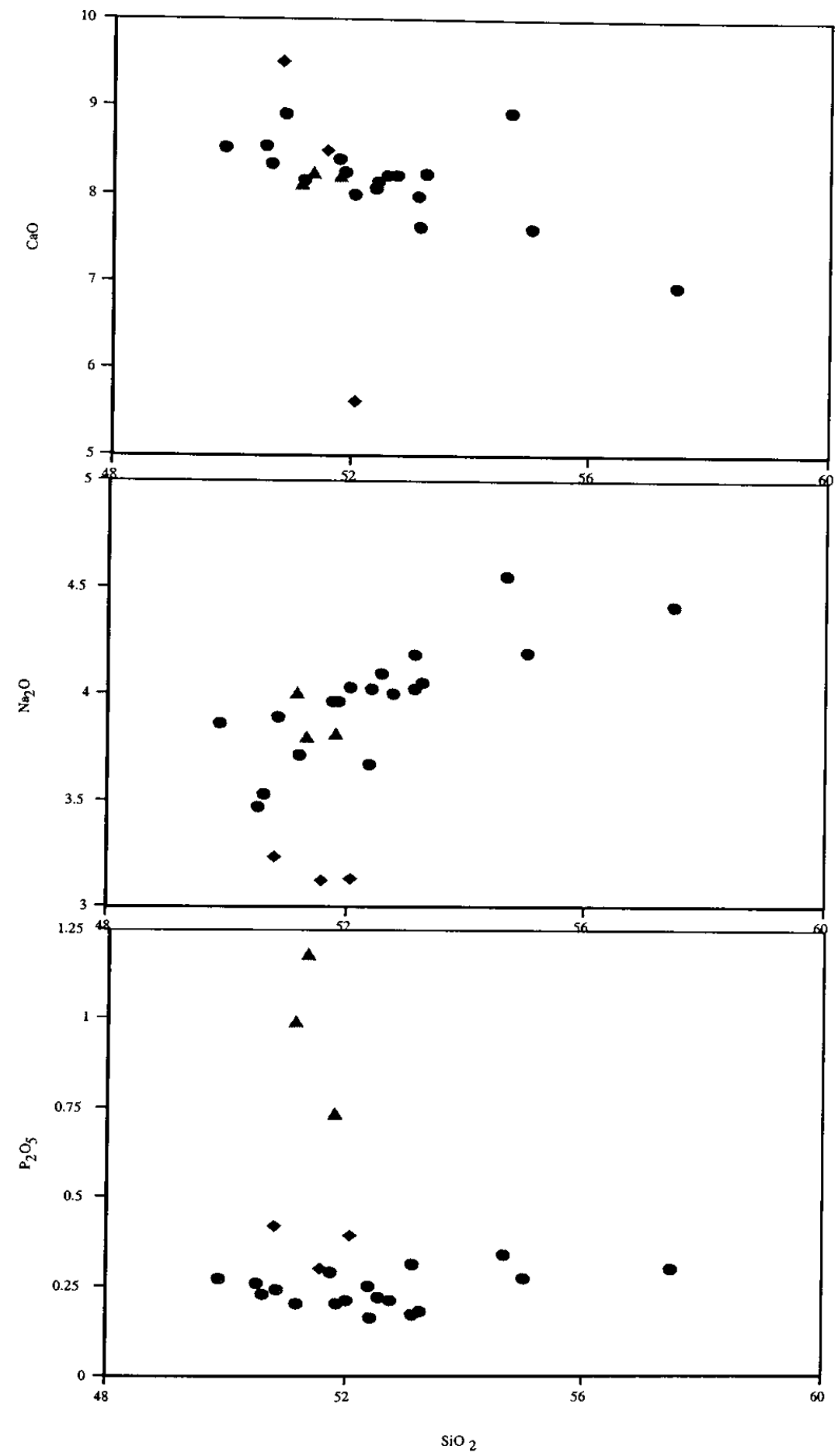

Fig. 4.7.1 Oxide versus $\mathrm{SiO}_{2}$ for Carran - LV SEC (Rodriguez Soto, thesis) 
REE patterns of 8 samples from Carran - LV (2 from Subgroup I, 4 from Subgroup II and 2 from the Satellite Center Group) are plotted in Fig.4.7.2. Subgroup II is comparable to the V.Villarrica basalts, the Satellite Center Group is similar to most of the V.Villarrica SEC basalts (higher LREE - enrichment). Subgroup I is much more REE and incompatible element - enriched than the other two groups; basalts with such REE patterns and high $\mathrm{TiO}_{2}$ and $\mathrm{P}_{2} \mathrm{O}_{5}$ contents are not found in the V.Villarrica region. Considering the much higher $\mathrm{TiO}_{2}$ and $\mathrm{P}_{2} \mathrm{O}_{5}$ contents of samples from CLV Subgroup I, Rodriguez Soto concluded in her thesis that samples from Subgroup I may have resulted from a lower degree of partial melting (F) than samples from Subgroup II and the Satellite Center Group. To produce the higher LREE - enriched pattern, the F of the Satellite Center Group is also needed to be smaller than that of Subgroup II. REE results from this work (Table $3-5 b$, Appendix 3 ) are consistent with the above observations and conclusions, and the similarities of REE patterns between the CLV Subgroup II and V.Villarrica as well as the CLV Satellite Center Group and Villarica SECs provide further information for understanding the mechanism of magma generation at subduction zones as discussed below.

Based on Ba/La of Carran - LV SEC, V.Villarrica and V.Villarrica SEC basalts (Fig.4.7.3), it further appears that CLV Subgroup II is more subduction component enriched (higher $\mathrm{Ba} / \mathrm{La}$ ) and has undergone a larger degree of partial melting similar to V.Villarrica. The Satellite Center Group is similar to the regular V.Villarrica SECs (e.g., Caburgua), and the lowest fluid addition (low $\mathrm{Ba} / \mathrm{La}$ ) and consequently the lowest degree of partial melting has occurred for the Carran - LV Subgroup I, similar to the unusual V.Villarrica region SEC - Huelemolle. On the other hand, the La/ $\mathrm{Nb}$ of all the measured 
volcanic samples are much higher than that of the mantle source $(\sim 1.0)$, indicating subduction - related fluid addition is ubiquitous for all the arc settings - V.Villarrica, V.Villarrica SECs and Carran - LV SECs. Furthermore, since the highest amount of fluid addition indicated by $\mathrm{Ba} / \mathrm{La}$ does not necessarily produce samples with the highest $\mathrm{La} / \mathrm{Nb}$ ratios, it is also concluded, similar to the V.Villarrica and V.Villarrica SEC samples, that the slab - derived fluids added are not uniform. Either their $\mathrm{La} / \mathrm{Nb}$ may vary as the result of partial melting, as argued for V.Villarrica region SECs (fluids added to Caburgua samples have a La/ $\mathrm{Nb}$ ratio of 25.0 , but 19.6 for V.Villarrica and 4.6 for Huelemolle, see section 4.3), or Ba/La may vary as the result of "drier" or "wetter" (fluid soluble element rich) fluids. The latter interpretation is most applicable to the Carran - LV volcanics.

Generally speaking, the chemical compositions of the Carran - LV samples are much more homogeneous than the V.Villarrica and V.Villarrica SEC basalts, probably due to the similar compositions of their mantle sources and the subduction components added from the underlying slab. For example, the range of variation of the alkali elements $(\mathrm{Ba} / \mathrm{La}, \mathrm{K} / \mathrm{La}, \mathrm{B} / \mathrm{La}, \mathrm{Ba} / \mathrm{Nb}, \mathrm{K} / \mathrm{Nb}$, etc) for the Carran - LV SECs are smaller, and so are their $\mathrm{Sr}$ and $\mathrm{Nd}$ isotopic ratios (Fig.4.7.4; Table 3-9, Appendix 3).

Sr isotope ratios vary from $0.70400-0.70415$, and ${ }^{143} \mathrm{Nd} /{ }^{144} \mathrm{Nd}$ and ${ }^{87} \mathrm{Sr} /{ }^{86} \mathrm{Sr}$ do not vary significantly among different volcanic units. The ${ }^{87} \mathrm{Sr} /{ }^{86} \mathrm{Sr}$ of the measured Carran LV samples are higher than those of most V.Villarrica SECs, and some are higher than those of the V.Villarrica samples.

Both the V.Villarrica SECs and the Carran - LV SECs are mainly clustered along faults but there is no major stratovolcano in the Carran - LV area. Because of the more violent eruption style (maar - type and volatile - rich) of the Carran - LV SECs, Lopez - 
Escobar and Moreno (1981) suggested that this group "could represent the initial step in the formation of a magma chamber that could develop a polygenetic composite stratovolcano". The new data neither refute nor confirm this idea. They do demonstrate, however, that SECs tend to have greater geochemical diversity than established larger volcanic centers. 


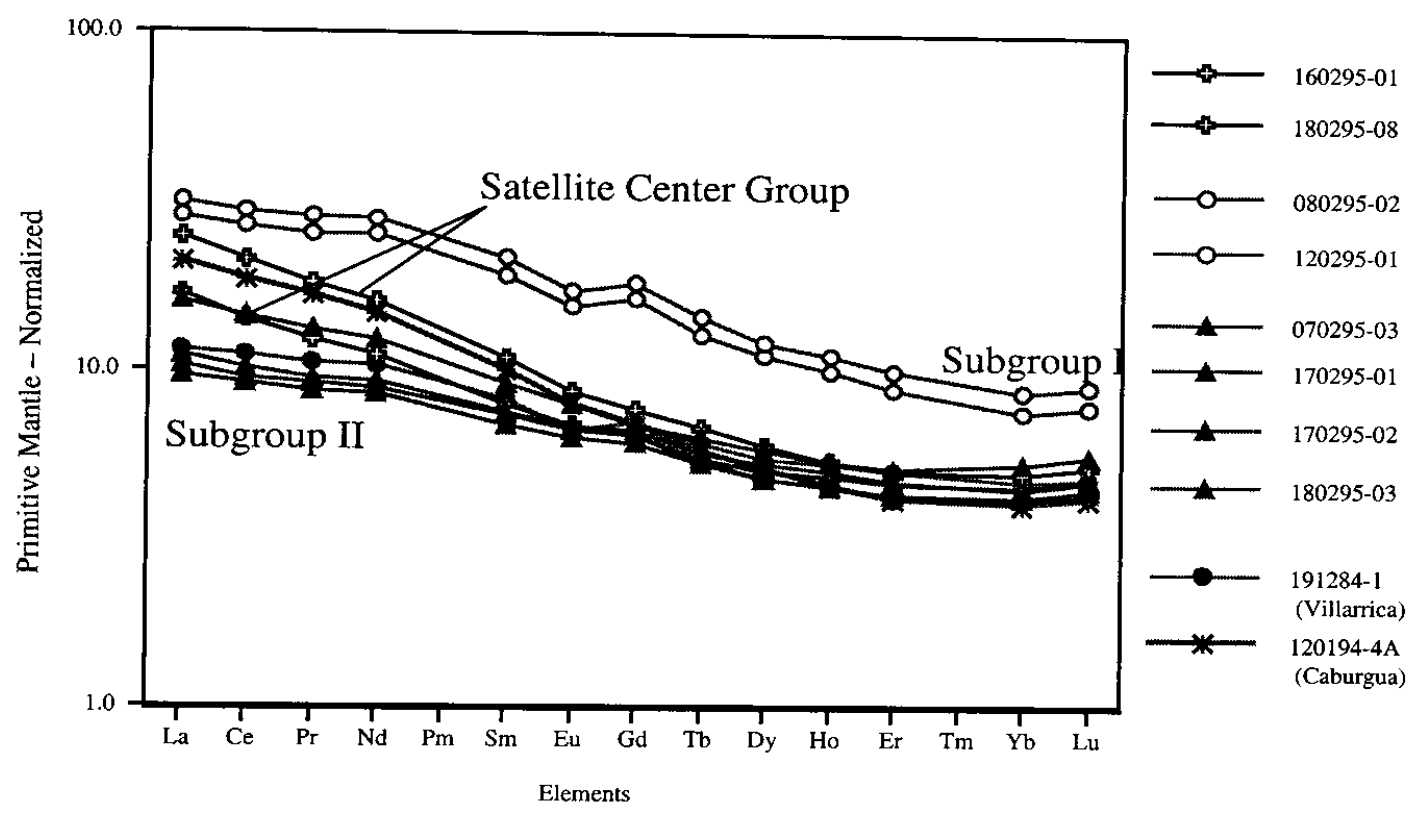

Fig.4.7.2 REE patterns of 8 SEC samples from Carran - Los Venados (this work) (samples from V.Villarrica and V.Villarrica SECs are shown for comparison) 


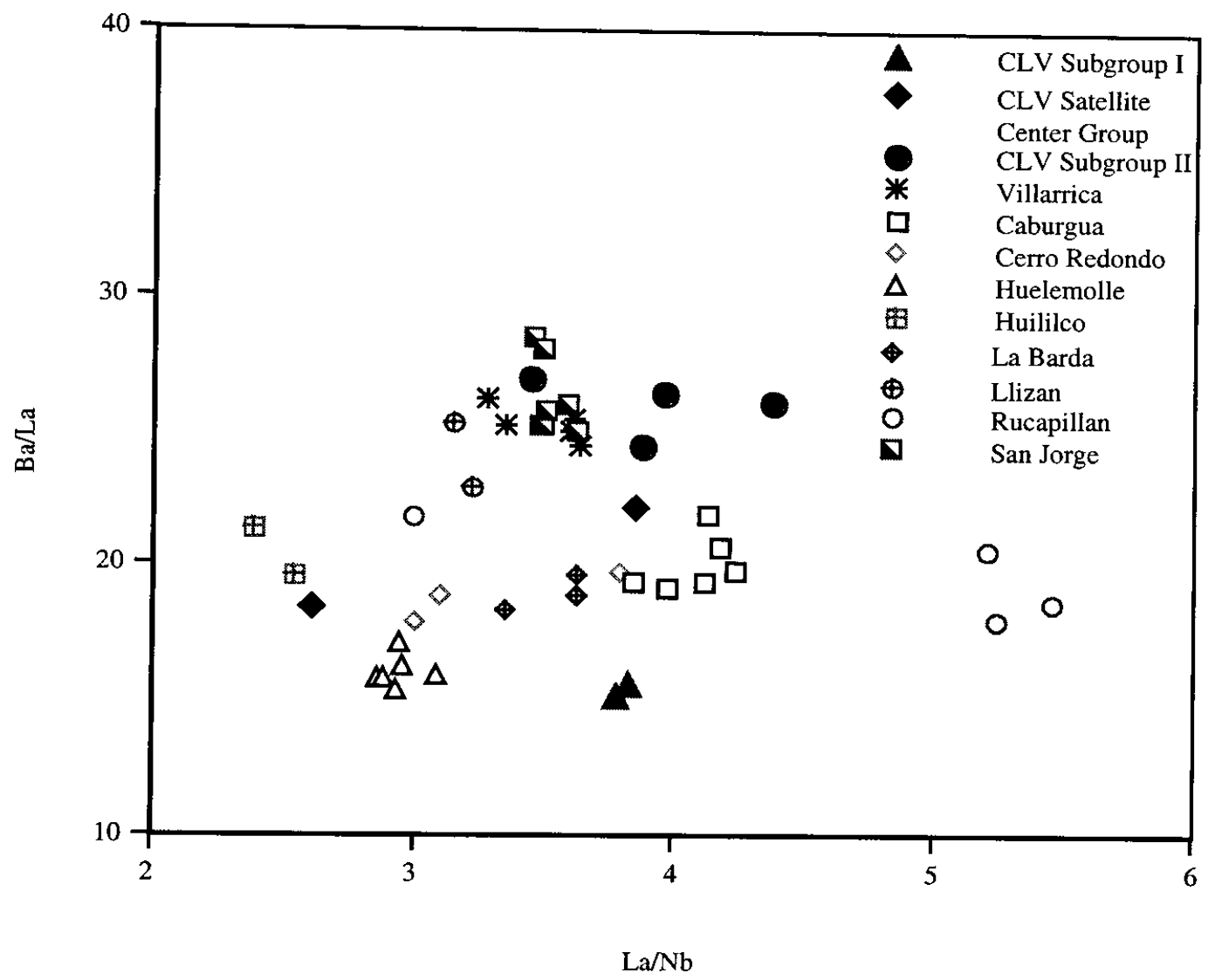

Fig.4.7.3 $\mathrm{Ba} / \mathrm{La}$ versus $\mathrm{La} / \mathrm{Nb}$ for samples from V.Villarrica, V.Villarrica SEC and Carran - Los Venados SEC (this work) 


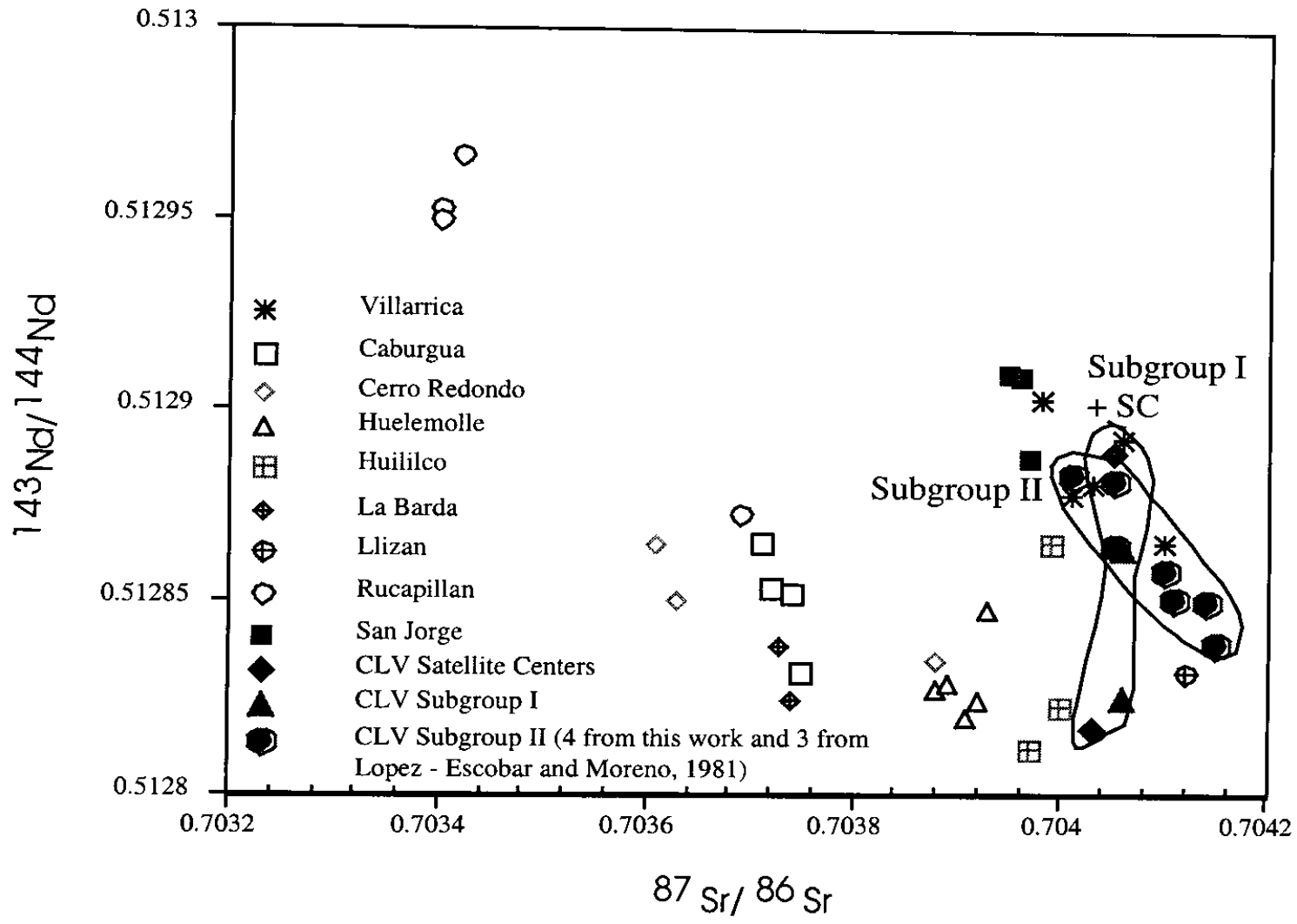

Fig.4.7.4 ${ }^{143} \mathrm{Nd} /{ }^{144} \mathrm{Nd}$ versus ${ }^{87} \mathrm{Sr} /{ }^{86} \mathrm{Sr}$ for samples from V.Villarrica, V.Villarrica SEC and Carran - Los Venados SEC (this work; Lopez - Escobar and Moreno, 1981) 


\section{Chapter 5 Summary and Conclusions}

\subsection{A summary of the findings about the V.Villarrica, SEC (type I) and SEC (type II) basalts and basaltic andesites}

\section{i) V.Villarrica}

V.Villarrica lavas are generally calc - alkaline, medium - $\mathrm{K}$ and high - alumina $(16-19 \%)$ continental arc basalts or basaltic andesites (Hickey - Vargas et al., 1989; this study). Their major element contents suggest an origin by fractional crystallization of an olivine + plagioclase + clinopyroxene assemblage at a pressure greater than 1 atm or by mixing between basaltic and rhyolitic magmas. Their $\mathrm{Ni}$ and $\mathrm{Cr}$ contents decrease and $\mathrm{V}$ contents increase with increasing $\mathrm{SiO}_{2}$, and are systematically higher in $\mathrm{Sc}$ and $\mathrm{V}$ and lower in Sr compared with the SEC samples. Abundances of LREE, Ba, Nb, La, Th and $\mathrm{U}$ in the V.Villarrica samples are lower than those in the basalts from the SECs. As a result, the $\mathrm{La} / \mathrm{Sm}$ and $\mathrm{La} / \mathrm{Yb}$ ratios are lower and $\mathrm{Zr} / \mathrm{Nb}, \mathrm{Ba} / \mathrm{La}, \mathrm{Ba} / \mathrm{Nb}$ and $\mathrm{Ba} / \mathrm{Th}$ ratios are higher in lavas from V.Villarrica relative to the SECs. On the other hand, alkali elements are especially enriched in V.Villarrica samples, and as a result, their $\mathrm{K} / \mathrm{La}$, $\mathrm{Rb} / \mathrm{La}$ and $\mathrm{Cs} / \mathrm{La}$ ratios are all significantly higher than those of the SEC samples.

$\mathrm{Sr}$ isotopic ratios of V.Villarrica samples are higher $(>0.7040)$ than related SEC lavas, and so are their Nd isotopes, but there is no clear correlation between their ${ }^{87} \mathrm{Sr} /{ }^{86} \mathrm{Sr}$ and ${ }^{143} \mathrm{Nd} /{ }^{144} \mathrm{Nd}$ ratios. However, $\mathrm{Pb}$ isotopic ratios of V.Villarrica samples are quite uniform, varying only within the range of $\sim 2$ to 4 times of the analytical errors. Previous analyses (Leeman, unpublished; Morris and Tera, 1989; Morris et al, 1990) and results from this work on the concentrations of $\mathrm{B}, \mathrm{Be}$ and $\mathrm{Li}$ indicate that V.Villarrica samples 
have significantly higher $\mathrm{B}$ contents and $\mathrm{B} / \mathrm{K}, \mathrm{B} / \mathrm{La}, \mathrm{B} / \mathrm{Nb}$ and $\mathrm{B} / \mathrm{Be}$ ratios compared with the SEC samples. ${ }^{10} \mathrm{Be}$ concentrations and ${ }^{10} \mathrm{Be} / \mathrm{Be}$ of selected V.Villarrica samples are relatively high $\left(1.7 * 10^{6} \mathrm{a} / \mathrm{g}\right)$ compared with the SEC samples, and high ${ }^{10} \mathrm{Be}$ concentrations are well correlated with high ${ }^{238} \mathrm{U} /{ }^{230} \mathrm{Th}$ ratios (U excess).

Based on the above observations and the assumption that the source of the V.Villarrica basalts and basaltic andesites is a mixture of the overlying mantle wedge and the subduction - derived fluids (released from dehydration of the altered oceanic crust and the subducted sediments) or melts, the major conclusions of V.Villarrica from this work are:

1) The amount of slab - derived fluids added to the source of the V.Villarrica samples is significantly greater than that added to the source of the SEC samples for both mantle types (the N-MORB and E-MORB, respectively).

2) The estimated (weight) percentage of fluid added to the mantle source of V.Villarrica is $0.97 \%$ for a $\mathrm{N}-\mathrm{MORB}$ and $2.66 \%$ for an $\mathrm{E}-\mathrm{MORB}$ mantle. This is consistent with the higher ratios of the water - soluble elements (Cs, $\mathrm{Rb}, \mathrm{Pb}, \mathrm{Ba}, \mathrm{B}, \mathrm{K}$ and $\mathrm{U}$ ) to the non - mobile incompatible elements ( $\mathrm{La}, \mathrm{Ce}$ and $\mathrm{Nb}$ ) measured in the V.Villarrica samples. However, other factors may also influence the abundances of these elements such as the composition of the fluid itself.

3) The larger amount of fluid / melt addition to the source of V.Villarrica triggered a greater degree of partial melting in it, about $F=0.2$ calculated based on a $\mathrm{N}-\mathrm{MORB}$ and $\mathrm{F}=0.5$ based on an $\mathrm{E}-\mathrm{MORB}$ mantle source. The larger degree of partial melting in the source of V.Villarrica results in 
their lower concentrations of highly incompatible elements such as the LREEs, which is consistent with the flatter REE pattern (less LREE enriched) of the V.Villarrica samples compared with the majority of the SEC basalts and basaltic andesites.

4) For the source of V.Villarrica, the percentage of the slab - derived fluids contributed from the altered oceanic crust is higher compared with the AOC\% in the fluids added into the SEC sources (for both the N - MORB and E MORB mantle).

5) Relatively young subducted pelagic sediments were involved in the formation of the SEC and especially V.Villarrica samples. This conclusion is derived from: 1) a larger amount of fluids / melts from the slab added to the source of V.Villarrica; 2) higher ${ }^{10} \mathrm{Be}$ and ${ }^{238} \mathrm{U} /{ }^{230} \mathrm{Th}$ values of the V.Villarrica samples compared with the SEC samples.

6) From their primary magma body, the samples from V.Villarrica have undergone a crystallization path of first olivine + plagioclase and then olivine + plagioclase + clinopyroxene at pressure $>1$ atm. The fractionation assemblage is similar to that of the SEC samples, but with a higher proportion of plagioclase (shallower depth) and potentially olivine, but less clinopyroxene. This is consistent with the petrography of the samples from V.Villarrica (more plagioclase phenocrysts) and the LLDs derived from the oxide - oxide diagrams. It is also consistent with the conclusions from Hickey - Vargas et al. (1989) that the magma body of V.Villarrica ascended fairly 
slowly and was probably pooled within the upper crust or just beneath the base of the stratovolcano before it erupted to the surface. 


\section{ii) $\quad \underline{\text { SEC }}$}

The majority of the SECs can be divided into 3 subgroups: Subgroup I (Caburgua, C. Redondo and La Barda), Subgroup II (Huelemolle and Huililco) and Subgroup III (San Jorge) (Hickey - Vargas et al., 1989; this study). The geochemical features of Subgroup I and Subgroup II are:

\section{a) Subgroup I:}

The geochemical features of SEC Subgroup I samples (including Caburgua, Cerro Redondo and La Barda) are:

- The SEC Subgroup I samples are calc - alkaline, medium - K and high alumina basalts (or basaltic andesites) similar to V.Villarrica samples. Their $\mathrm{Al}_{2} \mathrm{O}_{3}, \mathrm{~K}_{2} \mathrm{O}$ and $\mathrm{P}_{2} \mathrm{O}_{5}$ contents are higher (especially two of the samples from Cerro Redondo), $\mathrm{CaO} \%$ is lower than those from V.Villarrica. Compared with the SEC Subgroup II samples, they are slightly depleted in $\mathrm{TiO}_{2}, \mathrm{~K}_{2} \mathrm{O}$ and $\mathrm{P}_{2} \mathrm{O}_{5}$ contents.

- The SEC Subgroup I samples are slightly higher in Ni and Cr (especially La Barda) and $\mathrm{Sr}$ and lower in $\mathrm{TiO}_{2}, \mathrm{~K}_{2} \mathrm{O}$ and $\mathrm{P}_{2} \mathrm{O}_{5}$ than samples from SEC Subgroup II. They also have relatively low concentrations of the alkali and alkali earth elements such as $\mathrm{Cs}, \mathrm{Rb}, \mathrm{Ba}$ and $\mathrm{Pb}$, and HFSEs $(\mathrm{Nb}, \mathrm{Ta}, \mathrm{Zr}$ and Hf) as well. The Th and U concentrations of the SEC Subgroup I and Subgroup II samples are not distinguishable (samples from SEC Huililco are slightly higher). The SEC Subgroup I lavas have flatter REE patterns than 
those of the SEC Subgroup II samples, although both are more LREE enriched than the V.Villarrica samples.

- The SEC Subgroup I samples have higher La/Nb but lower Hf/Sm ratios (probably more rutile in the subducting slab) than the SEC Subgroup II and V.Villarrica samples.

- The B and Li concentrations of the SEC Subgroup I and Subgroup II samples are not distinguishable, but Subgroup I lavas have lower Be (larger degree of partial melting).

- The most important difference between SEC Subgroup I and Subgroup II is that ${ }^{87} \mathrm{Sr} /{ }^{86} \mathrm{Sr}$ ratios in Subgroup I samples are lower $(<0.7038)$, and their $\mathrm{Sr} / \mathrm{Nd}$ ratios are higher $(>40)$. On the contrary, Subgroup II lavas have higher ${ }^{87} \mathrm{Sr} /{ }^{86} \mathrm{Sr}(>0.7038)$ and significantly lower $\mathrm{Sr} / \mathrm{Nd}(<30) . \mathrm{Nd}$ and $\mathrm{Pb}$ isotopic ratios of samples from the two subgroups are not distinguishable.

- $\left({ }^{238} \mathrm{U} /{ }^{230} \mathrm{Th}\right)$ and $\left({ }^{210} \mathrm{Po} /{ }^{230} \mathrm{Th}\right)$ ratios of the SEC Subgroup I samples are similar to those of the SEC Subgroup II samples (only the sample from Huililco is higher in $\left.\left({ }^{210} \mathrm{Po} /{ }^{230} \mathrm{Th}\right)\right)$, both close to secular disequilibrium. Also, ${ }^{10} \mathrm{Be}$ concentrations of SEC Subgroup $I$ are lower, but their ${ }^{10} \mathrm{Be} /{ }^{9} \mathrm{Be}$ ratios are higher (lower Be due to a larger degree of partial melting) than SEC Subgroup II.

b) Subgroup II:

SEC Subgroup II samples have the following geochemical characteristics (compared with Subgroup I): 
- Calc - alkaline, medium - K and high - alumina basalts and basaltic andesites

- $\quad \mathrm{TiO}_{2}, \mathrm{~K}_{2} \mathrm{O}$ and $\mathrm{P}_{2} \mathrm{O}_{5}$ slightly higher

- $\mathrm{Ni}, \mathrm{Cr}$ and $\mathrm{Sr}$ slightly lower

- Water - soluble alkali elements, HFSEs and LREEs higher

- Very low La/Nb but fairly low $\mathrm{Hf} / \mathrm{Sm}$ ratios

- higher ${ }^{87} \mathrm{Sr} /{ }^{86} \mathrm{Sr}$ and lower $\mathrm{Sr} / \mathrm{Nd}$

- ${ }^{10} \mathrm{Be}$ and $\mathrm{Be}$ higher and ${ }^{10} \mathrm{Be} / \mathrm{Be}$ lower

Based on comparisons of the geochemical characteristics of samples from SEC Subgroup I, Subgroup II and V.Villarrica, I conclude that:

1) The source regions of the SEC samples are the mantle wedge with addition of subduction - derived fluids or melts.

2) The magnitude of fluids added to the source of Subgroup $I$ lavas is significantly higher $(0.52 \%$ for a $\mathrm{N}-$ MORB and $1.19 \%$ for an $\mathrm{E}-\mathrm{MORB}$ mantle) than the amount of fluids added to the source of Subgroup II lavas $(0.12 \%$ for a $\mathrm{N}-\mathrm{MORB}$ and $0.49 \%$ for an $\mathrm{E}-\mathrm{MORB}$ mantle).

3) SEC Subgroup I lavas reflect a higher degree of partial melting (i.e., for a N MORB mantle, $F=0.1$ and for an $E-M O R B$ mantle, $F=0.25$ ) than $S E C$ Subgroup II samples (i.e., $\mathrm{F}=0.025$ for a $\mathrm{N}-\mathrm{MORB}$ mantle and $\mathrm{F}=0.1$ for an E - MORB mantle). Alternatively, Subgroup II may have undergone a similar degree of partial melting as Subgroup I, with differences in trace element and REE contents between the two groups resulting from differences 
in mineralogy on the subducting slab - a lower proportion of titanates for SEC Subgroup II compared with V.Villarrica and especially SEC Subgroup I.

4) The probable contribution of the fluids from altered oceanic crust is lower for SEC Subgroup II, and a larger portion of its slab flux may come from dehydration of subducted sediments. Greater sediment involvement in SEC Subgroup II genesis is largely offset by the much lower amount of fluids / melts added to the source of these centers, causing relatively lower ${ }^{10} \mathrm{Be} /{ }^{9} \mathrm{Be}$ concentrations measured in the Huelemolle sample compared with the Caburgua and La Barda samples.

5) The AOC subducted beneath the source of the SEC Subgroup I is slightly less altered (lower ${ }^{87} \mathrm{Sr}{ }^{86} \mathrm{Sr}$ ) compared with the AOC contributing to the source of the SEC Subgroup II as well as V.Villarrica.

6) Both Subgroup I and Subgroup II samples have undergone greater clinopyroxene crystallization at higher pressure (greater depth) than V.Villarrica lavas. In addition, samples from the SEC Subgroup I, starting from a less mafic primary magma composition, fractionated less olivine and more cpx (plenty of cpx phenocrysts observed under microscope) than samples from the SEC Subgroup II.

\section{c) Subgroup III:}

The mafic samples from SEC San Jorge are very depleted in $\mathrm{TiO}_{2}, \mathrm{Al}_{2} \mathrm{O}_{3}, \mathrm{Na}_{2} \mathrm{O}$ and $\mathrm{P}_{2} \mathrm{O}_{5}$ and enriched in $\mathrm{MgO}$ and $\mathrm{CaO}$ contents. They also have extremely high $\mathrm{Ni}$ and Cr contents. Like the V.Villarrica samples, they are incompatible element, HFSE and 
LREE - depleted but have higher alkali and alkali earth element contents than the other SEC samples. Their $\mathrm{Sr}-\mathrm{Nd}-\mathrm{Pb}$ isotopes, ${ }^{10} \mathrm{Be}$ concentration and $\mathrm{U}-$ Series isotopic ratios are all very similar to the V.Villarrica samples. Therefore, it can be concluded that:

1) Samples from San Jorge were derived from a chemically similar source to that of the V.Villarrica samples. The F (degree of partial melting) of the source region of this SEC is comparable to the F of the V.Villarrica source, and significantly higher than that of the other SECs.

2) Samples from San Jorge have abundant accumulated olivine phenocrysts (5 10\%). The San Jorge samples thus have high $\mathrm{MgO}$, Ni and $\mathrm{Cr}$ contents. On the other hand, they are fairly poor in plagioclase component (Fig.4.2.1b; Fig.4.2.1c) but their olivine/cpx component ratios (Fig.4.2.1a) are similar to the other SEC and V.Villarrica samples. This may indicate that, unlike the V.Villarrica magma that is pooled in the crust (Hickey - Vargas et al., 1989), San Jorge magmas ascend quickly to the surface through preexisting fractures.

3) The ${ }^{210} \mathrm{Po} /{ }^{230} \mathrm{Th}$ ratio of the measured San Jorge sample is relatively high, indicating an age of less than 5,000 years for the formation of San Jorge. So, it could be concluded that SEC San Jorge is younger than most of the Villarrica SECs, potentially evolving together with the V.Villarrica magma body that produced V.Villarrica units III and IV.

d) Llizan:

The andesitic samples from SEC Llizan have lower $\mathrm{TiO}_{2}, \mathrm{Al}_{2} \mathrm{O}_{3}, \mathrm{Fe}_{2} \mathrm{O}_{3}, \mathrm{CaO}$ and $\mathrm{P}_{2} \mathrm{O}_{5}$ and higher $\mathrm{K}_{2} \mathrm{O}$ and $\mathrm{Mg} \#$ than the other SEC samples. Their trace element contents 
also stand out from other SECs in several respects, e.g., lower $\mathrm{Zn}$ and V, higher Cs, Rb, $\mathrm{Ba}, \mathrm{Pb}$, Th and $\mathrm{U}$ concentrations. Their $\mathrm{B}, \mathrm{Be}$ and $\mathrm{Li}$ concentrations and trace element ratios such as $\mathrm{Cs} / \mathrm{Rb}$ and $\mathrm{Rb} / \mathrm{Ba}$ are also significantly higher. Llizan has higher ${ }^{87} \mathrm{Sr} /{ }^{86} \mathrm{Sr}$ and lower ${ }^{208} \mathrm{~Pb}^{204} \mathrm{~Pb}$ and ${ }^{206} \mathrm{~Pb} /{ }^{204} \mathrm{~Pb}$, along with lower $\left({ }^{238} \mathrm{U} /{ }^{230} \mathrm{Th}\right)$ than V.Villarrica / San Jorge, and may have thus revealed the most convincing evidence in any SEC for crustal contamination.

The Llizan samples could be produced from an "original" magma body similar to the San Jorge magma (with more shallow depth - fractionation) by either simple mixing or AFC with a crustal contaminant. The potential contaminant could be silicic melts derived from a country rock chemically similar to V.Villarrica rhyolites (mostly like granite / gneiss basement).

e) Rucapillan:

SEC Rucapillan is a unique mixture between a mafic "porphyritic" magma derived from a mantle source affected by AOC - derived fluids or melts to the largest extent, and a differentiated "aphyric" magma with a chemically similar source to the other SECs. El Estadio lavas are derived from the same source as the "porphyritic" magma but show evidence of greater olivine (rather than cpx and plagioclase) fractionation than the "porphyritic" magma itself. 


\subsection{A Proposed Physical Model}

Fig.5.2.1 is a series of horizontal - section (North - South) diagrams depicting the alignment of different centers, the distance between V.Villarrica and each SEC group (Rucapillan, Subgroup I, Subgroup II and San Jorge), the relationships among source regions and melting columns of the stratovolcano as well as SECs and the extents of partial melting (size of the arrows) based on the conclusions from both this work and related previous studies (Hickey - Vargas et al., 1989; 1993; 1997).

Rucapillan is the farthest of the SECs from V.Villarrica, located closer to V.Llaima, and lies within the Chilean Longitudinal Depression (see Map 1.2.1). It is the oldest SEC, erupted between V.Villarrica Unit I and Unit II. The source of Rucapillan is different from that of V.Villarrica. In addition, extensively - developed fractures throughout the central graben could act to induce more decompression melting and therefore a relatively high $\mathrm{F}$ (it is inferred from the LREE/HREE ratios of the Rucapillan samples that the degree of partial melting for this SEC is lower than V.Villarrica but higher than most other SECs except San Jorge) or to allow the Rucapillan magma to ascend without much pooling prior to eruption. This may explain why Rucapillan erupted less magma mass and consequently formed a smaller volcanic center compared with the composite volcanoes such as V.Villarrica despite the fairly high degree of partial melting occurring in the source of this SEC.

The Subgroup II centers, are located closer to V.Villarrica than the Subgroup I centers. Groups I and II erupted about the same time as V.Villarrica Unit II. I conclude that their sources apparently differ from each other, and also from the source of V.Villarrica by the incorporation of different subduction components. Subgroup III - San 
Jorge, by contrast, is much younger and erupted together with V.Villarrica Unit III and Unit IV. This SEC is located northeast of V.Villarrica and almost as close to it as the SEC Subgroup II. Both the source and the degree of partial melting of San Jorge are similar to V.Villarrica, so I conclude that San Jorge is derived from the same magma body that produced V.Villarrica III and IV. It may indicate an expansion of the magmatic regime of V.Villarrica (III + IV), unlike the previous two episodes (V.Villarrica I + II) when the V.Villarrica magmas were derived independently without significantly interfering with the magmas of Rucapillan and the SEC Subgroup I and Subgroup II. Due to lack of evidence, it is not clear at this stage whether this is caused by changes of the thermal structure or other physical properties of the mantle wedge during that time period ( 4,000a to present). However, the extremely fast ascent of the magma of San Jorge compared with V.Villarrica as well as the SECs may indicate the existence of some large but unrecognized fractures in the vicinity of this SEC. 


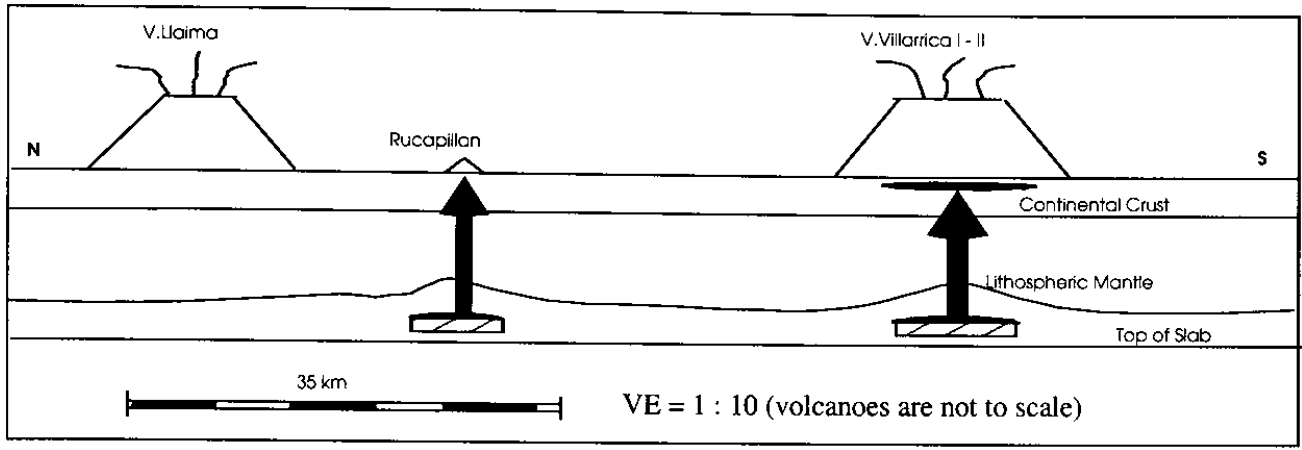

$6.000-4.0000$

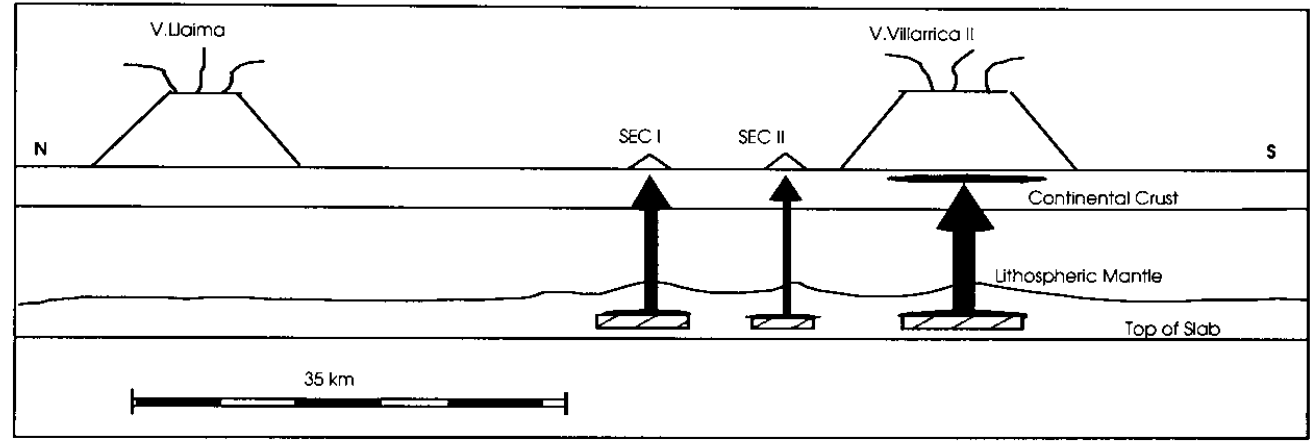

4,000 a - Present

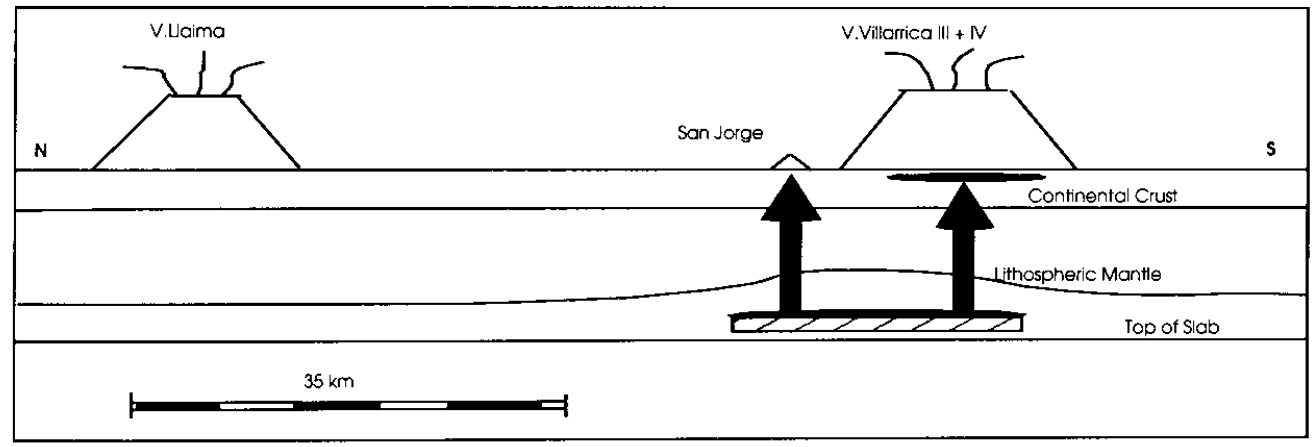

Fig.5.2.1 Upper) During VI - VII, Rucapillan magmas originated from a separate source; Middle) During VII, SEC Subgroup I and Subgroup II originated (Subgroup II probably from the periphery of the V.Villarrica melting column); Lower) During VIII + VIV, San Jorge was formed due to expansion of the V.Villarrica magma body 


\subsection{Implications of the model for the other parts of the CSVZ and SVZ}

Tormey et al. (1991) concluded that basaltic samples from the Andean CSVZ are more $\mathrm{CaO}$ and $\mathrm{HREE}$ - enriched while lower in $\mathrm{Na}_{2} \mathrm{O}$ and incompatible elements as well as $\mathrm{La} / \mathrm{Yb}$ and $\mathrm{Rb} / \mathrm{Cs}$ ratios compared with TSVZ basalts. This is reportedly caused by a higher degree of partial melting of a garnet lherzolitic mantle source of the CSVZ, due to a greater amount of slab flux added into the CSVZ mantle, or a thicker or warmer overlying asthenospheric mantle wedge. The depth of the subducted oceanic crust is also potentially shallower in the CSVZ, due to a relatively warmer and younger subducted slab.

Tormey et al. (1991) also concluded that $37^{\circ} \mathrm{S}$ separates series of geochemically distinct volcanic units. North of $37^{\circ} \mathrm{S}$, on thicker continental crust, magmas ascending undergo more high - pressure crystallization, presumably dominated by clinopyroxene or amphibole phases. In addition, crustal contamination plays a greater role in controlling the trace element compositions and isotopic ratios (e.g., higher ${ }^{87} \mathrm{Sr} /{ }^{86} \mathrm{Sr}$ and $\delta^{18} \mathrm{O}$ ) of the lavas erupted north of $37^{\circ} \mathrm{S}$, especially between $33-36^{\circ} \mathrm{S}$ where the continental crust is thickest. South of $37^{\circ} \mathrm{S}$, crustal contamination is minimal (Hickey et al., 1986; Hickey Vargas et al., 1989) and the magmas reflect low - pressure crystallization, dominated by plagioclase. In the transitional area between $36-37^{\circ} \mathrm{S}$, lavas range from basalts to dacites / rhyolites, showing the most complete eruption series observed in the whole Andean SVZ.

Tormey et al. (1991) proposed that crustal contamination was caused either by a partial melt (higher $\mathrm{La} / \mathrm{Yb}$ ) derived from a lower crustal garnet - granulite protolith composed of subduction - related materials, so that the concentrations of the most water 
- soluble incompatible elements such as $\mathrm{Rb}$, $\mathrm{Cs}$ and Th were enhanced; or an upper crustal material with enhanced $\mathrm{Rb}, \mathrm{Cs}$ and Th concentrations.

Our work, focusing mainly on the SECs surrounding V.Villarrica, combined with the previous results from V.Villarrica samples by Hickey - Vargas et al. (1989), supports the observations and conclusions (as summarized above) by Tormey et al. (1991). Microscopic studies of V.Villarrica samples show that they are less enriched in plagioclase phenocrysts than the SEC samples. It can be inferred that the SEC samples fractionated more cpx than V.Villarrica samples at high pressure, and the reason for this is that the magmas of the SECs were stored deeper in the crust than those of V.Villarrica prior to eruption. This may also be the reason that the V.Villarrica samples are less mafic compared with the SECs especially San Jorge. Trace element compositions combined with the $\mathrm{Sr}-\mathrm{Nd}-\mathrm{Pb}$ isotopic ratios of the Villarrica and SEC samples again show no clear evidence for crustal contamination, aside from the andesitic samples from SEC Llizan. The Llizan samples, enriched in $\mathrm{Rb}, \mathrm{Cs}, \mathrm{Ba}$, Th and $\mathrm{U}$, higher in ${ }^{87} \mathrm{Sr} /{ }^{86} \mathrm{Sr}$ and lower in ${ }^{206} \mathrm{~Pb} /{ }^{204} \mathrm{~Pb}$ and ${ }^{208} \mathrm{~Pb} /{ }^{204} \mathrm{~Pb}$, could be contaminated by an upper crustal material (see calculations in Section 4.5). However, why the Llizan samples should be contaminated by crustal materials in the Andean CSVZ area while most of the others are not remains unclear. According to the MASH model of Hildreth and Moorbath (1988), only thick crust such as that of the NSVZ or TSVZ induces higher temperature in the lower crust and can trigger large - scale lower crustal melting, so as to impose crustal signatures onto the derived lava samples. Therefore it is more reasonable to assume a shallow level AFC contamination model for the Llizan samples as shown in this work, which is again consistent with the conclusions by Tormey et al. (1991) "apparently a 
partially molten lower crust does not exist to intercept them (magmas of the CSVZ samples) and these lavas are contaminated during rise through the lower and upper crust". 


\subsection{Implications of the model for arc magmatism}

As to the arc magmatism globally, the importance of the modeling in this work can be seen regarding the following aspects:

\section{1) The source multiplicity:}

Compared with island arcs, continental arcs such as the Andes are special because of the contributions of the continental crust that is absent at oceanic subduction zones. Therefore, crustal contamination and its related processes (mixing, AFC, MASH, etc) have to be considered. On the other hand, the amount of crustal material added to ascending magmas may be related to the crustal thickness. At the Andean Central Volcanic Zone (CVZ), because of its very high crustal thickness (up to $70 \mathrm{~km}$ ), large - scale of partial melting of the lower crust has to be taken into account for the formation of the erupted lavas in this area. In contrast, the studied area between $37-42^{\circ} \mathrm{S}$, the CSVZ of the Andes, has a thinner continental crust $(\sim 35 \mathrm{~km})$. A localized crustal contamination signature was observed in the volcanics collected and analyzed in this work.

Another important subduction component is subducted sediments. According to the observations made in our study area, this part of the trench is extremely sediment - rich (Herron, 1981). Therefore, clear evidence should be seen for the involvement of sediments in the formation of the lavas erupted in this area. In our work, by modeling the $\mathrm{Sr}-\mathrm{Nd}$ isotope variations of samples from V.Villarrica and the SECs, all three components were considered: mantle wedge, altered oceanic crust with a similar Nd isotopic ratio as the MORB but a higher ${ }^{87} \mathrm{Sr} /{ }^{86} \mathrm{Sr}$ ratio, and a sediment endmember with low ${ }^{143} \mathrm{Nd} /{ }^{144} \mathrm{Nd}$ and high ${ }^{87} \mathrm{Sr} /{ }^{86} \mathrm{Sr}$. 
Sedimentary materials were mixed into the mantle source basically by slab dehydration, supported by positive correlations between the ${ }^{10} \mathrm{Be}$ concentrations and U - Th isotopic ratios of the V.Villarrica and SEC samples. The calculated results indicate that the proportions of the contributing sediment / oceanic crust could be different for different volcanic units, and the amount of these fluids added to the mantle wedge is also highly variable. However, higher slab inputs do induce higher extents of partial melting, and the center of the magma column tends to have more oceanic crust contribution, a higher amount of total fluid addition and a higher degree of partial melting, such as in V.Villarrica. In addition, the subducted slab may also melt, which can affect $\mathrm{Nb}$ and $\mathrm{Th}$ concentrations of the magmas.

\section{2) Nb problems:}

Negative $\mathrm{Nb}$ anomalies are a common phenomenon observed in arc lavas globally. They can be generated via addition of slab - released fluids, which are preferentially enriched in LILEs compared with HFSEs. They can also be derived by melting of the subducted basaltic crust or sediments in the presence of residual titanates. Therefore, $\mathrm{Nb}$ concentrations can be used to indicate different sources involved in the formation of arc samples.

In this work, $\mathrm{Nb}$ concentrations in the V.Villarrica and SEC samples are low $(1-9 \mathrm{ppm})$. However, an elevated $\mathrm{La} / \mathrm{Nb}$ ratio correlated with $\mathrm{Sm} / \mathrm{Hf}$ reveals the possibility of melt involvement in addition to sediment or oceanic crust dehydration. Moreover, $\mathrm{La} / \mathrm{Nb}$ and $\mathrm{Ba} / \mathrm{La}$ ratios are decoupled in both the 
V.Villarrica vicinity samples and the Carran - Los Venados SEC samples, suggesting that the mobility of LILEs, REEs and HFSEs is controlled by different processes.

\section{3) Th problems:}

Th is known not to be as mobile in fluids as U. On the other hand, it is highly enriched in sediments. Therefore, its origin in arc samples is highly controversial:

i. Not very soluble, from subducted sediments (McDermott et al., 1993)

ii. From mantle (Morris and Hart, 1983; McCulloch and Gamble, 1991; Hawkesworth et al., 1993; Pearce and Peate, 1995)

iii. Sediment melting (Plank and Langmuir, 1993; Elliott et al., 1997; Johnson and Plank, 1999)

However, Th recycling between sediments and evolved arc lavas is very efficient $(\sim 30 \%)$ (Hawkesworth et al., 1997). He estimated that $\sim 90 \%$ of the Th in arc samples should be from sediments and the amount of total sediment addition is $\sim 2 \%$. Vroon et al. (1995) and Zheng et al. (1994) concluded that Nd and $\mathrm{Be}$ inputs from sediments to arc samples are similar, both very efficient. Because all the above elements and the HFSEs (such as $\mathrm{Zr}, \mathrm{Nb}$ and $\mathrm{Ta}$ ) are not mobile in subduction - related fluids, it is required that subducted sediments be input into the mantle source of arc lavas by melt or a more $\mathrm{SiO}_{2}$ - rich phase 
(Plank and Langmuir, 1993; Ryan et al., 1995; Turner et al., 1996; Elliott et al., 1997; Johnson and Plank, 1999).

In this work, $[\mathrm{Th}]_{\mathrm{PM}}$ concentrations in the V.Villarrica and SEC samples are lower than $\mathrm{Ba}$ or $\mathrm{U}$, indicating a certain amount of fluid addition $(<1 \%)$ (see calculations in Section 4.3) were added to metasomatize the overlying mantle wedge in the study area. $\mathrm{Ba} / \mathrm{Th}$ ratios are $\sim 100$ in samples from the SEC Subgroup I, but $\sim 150$ in V.Villarrica and the SEC Subgroup II samples. Since the averaged $\mathrm{Ba} / \mathrm{Th}$ ratio in the altered oceanic crust is $\sim 300$ or higher (Hochstaedter et al., unpublished), Th contents are relatively high in the studied samples (SEC samples are even higher compared with V.Villarrica). So it is probable that sediment melting plays a role in the formation of the arc magmas in this area, especially for SEC Subgroup $I$.

$\mathrm{U}$ - Th isotopes of V.Villarrica and the SECs show U fractionation from Th that supports slab dehydration, and this $U$ excess is positively correlated with the ${ }^{10} \mathrm{Be} / \mathrm{Be}$ ratios of the measued V.Villarrica and SEC samples. Although it is strongly supported in this work that the mantle source of V.Villarica may have incorporated more slab - derived fluids and potentially melts than the SECs, the possibility still remains that the lower ${ }^{10} \mathrm{Be} / \mathrm{Be}$ ratios measured in the SEC Subgroup I and Subgroup II samples reflect relatively older sediments involved into the source of the SECs compared with V.Villarrica. However, if Th does move into the slab component with melts as indicated in this study, U/Th in the subduction component is expected to be changed but not dramatically (U/Th) $)_{\text {fluds }}$ $\left.>(\mathrm{U} / \mathrm{Th})_{\text {mels }}\right)$. 


\section{Chapter 6 Future Work}

This work, as an important part of the NSF - funded project "Production and Ascend of Magma at Convergent Margins: Information from Small Eruptive Centers in the Central Southern Volcanic Zone, Chile" by Dr. Hickey - Vargas, has successfully completed the following objectives stated in the original proposal (by Hickey - Vargas): whether magmas rise from the subducted plate as zoned columns and whether the composite stratovolcanoes contain the maximum amount of hydrous subduction - related fluids; whether magmas rising above the subduction zone are geochemicallly homogeneous; whether geochemical variations are also resulted from melting of the surrounding mantle lithosphere; what controls the edifice size of different volcanic centers and what sources and processes are involved in the formation of the arc magmas at the Andes and other convergent margin geologic settings.

However, even after this comprehensive geochemical study of the Villarrica and SEC samples including their major and trace elements, $\mathrm{REEs}, \mathrm{Sr}-\mathrm{Nd}-\mathrm{Pb}$ isotopes, $\mathrm{U}-$ series isotopes, $\mathrm{B}-\mathrm{Be}-\mathrm{Li}$ concentrations plus ${ }^{10} \mathrm{Be}$ isotopic ratios, some questions regarding subduction and related magmagenesis in this area still remain unclear or elusive such as:

1) What cause the geochemical differences between the SEC Subgroup I and Subgroup II samples? Especially, since Subgroup I may be derived from a different AOC source, how is this AOC heterogeneity originated and how common is this phenomenon on a global basis? 
2) The mechanism for the mixing between the Rucapillan "porphyritic" and"aphyric" magma and the role of the fracture zone (LOFZ) for the transportation of magmas through the SECs at different sites.

3) What causes the crustal contamination of SEC Llizan (previous results show no apparent crustal contamination of CSVZ basalts because of the thin continental crust in this area)? Additional $\delta^{18} \mathrm{O}$ analyses may provide more useful information on the origin of the Llizan andesitic samples.

4) For the Carran - LV samples, the analyzed isotopic results need to be further investigated in order to discover any difference of subduction components and processes between the two areas.

5) Some work should be done on the individual mineral phases (or any melt inclusion if identified) particularly in the phenocryst - rich V.Villarrica and San Jorge samples in order to get more information about intra - crustal processes related to the ascending and evolving of magmas derived at continental arc regions.

6) What is the actual composition of the crust in this region? 


\section{List of References}

Arculus R.J. (1994) Aspects of magma genesis in arcs. Lithos, 33, 189-208

Arndt N.T. and Goldstein S.L. (1989) An open boundary between lower continental crust and mantle; its role in crust formation and crustal recycling. Tectonophysics, vol.161, no.3-4, pp.201-212

Atherton M.P. and Petford N. (1993) Generation of sodium-rich magmas from newly underplated basaltic crust. Nature $362,144-146$

Baker D.R. and Eggler D.H. (1987) compositions of anhydrous and hydrous melts coexisting with plagioclase, augite, and olivine or low $-\mathrm{Ca}$ pyroxene from 1 atm to 8 kbar: application to the Aleutian volcanic center of Atka. Am. Mineral. 72: 12-28

Barazangi M. and Isacks B.L. (1976) Spatial distribution of earthquakes and subduction of the Nazca Plate beneath South America. Geology (Boulder). 4; 11, Pages 686-692

Barazangi M. and Isacks B.L. (1979) Subduction of the Nazca Plate beneath Peru; evidence from spatial distribution of earthquakes. Geophysical Journal of the Royal Astronomical Society. 57; 3, Pages 537-555

Barreiro B.A. (1983) Lead isotopic compositions of South Sandwich Island volcanic rocks and their bearing on magmagenesis in intra-oceanic island arcs. Geochimica et Cosmochimica Acta, vol.47, no.4, pp.817-822

Barreiro B.A. (1984) Lead isotopes and Andean magmagenesis. Andean magmatism (chemical and isotopic constraints), Editors: Harmon R.S. and Barreiro B.A., pp.21-30

Bartholomew D.S. and Tarney J. (1984) Geochemical characteristics of magmatism in the Southern Andes $\left(45-46^{\circ} \mathrm{S}\right)$. Andean magmatism (chemical and isotopic constraints), Editors: Harmon R.S. and Barreiro B.A., PP 220 - 229

Bourdon B., Wörner G. and Zindler A. (2000) U-series evidence for crustal involvement and magma residence times in the petrogenesis of Parinacota volcano, Chile. Contributions to Mineralogy and Petrology, Volume 139 Issue 4 (2000) pp 458-469

Brenan J.M., Shaw H.F., Phinney D.L. and Ryerson F.J. (1994) Rutile-aqueous fluid partitioning of $\mathrm{Nb}, \mathrm{Ta}, \mathrm{Hf}, \mathrm{Zr}, \mathrm{U}$ and $\mathrm{Th}$; implications for high field strength element depletions in island-arc basalts. Earth and Planetary Science Letters, vol.128, no.3-4, 327 $-339$

Brenan J.M., Shaw H.F., Ryerson F.J. and Phinney D.L. (1995) Mineral-aqueous fluid partitioning of trace elements at 900 degrees $\mathrm{C}$ and $2.0 \mathrm{GPa}$; constraints on the trace 
element chemistry of mantle and deep crustal fluids. Geochimica et Cosmochimica Acta, vol.59, no.16, pp.3331-3350

Carlson R.L. (1981) Boundary forces and plate velocities. Geophysical Research Letters, vol.8, no.9, pp.958-961

Carlson R.L., Hilde T.W.C. and Uyeda S. (1983) The driving mechanism of plate tectonics; relation to age of the lithosphere at trenches. Geophysical Research Letters, vol.10, no.4, 297-300

Case J.E., Barnes J. and Gabriel P.Q. (1971) Trans-Andean geophysical profile, southern Colombia. Eos, Transactions, American Geophysical Union, vol.52, no.4, pp.183

Chabaux F., Hemond C. and Allegre C.J. (1999) ${ }^{238} \mathrm{U}-{ }^{230} \mathrm{Th}-{ }^{226} \mathrm{Ra}$ disequilibria in the Lesser Antilles arc; implications for mantle metasomatism. Chemical Geology, vol.153, no.1-4, 171-185

Charrier R., Linares E., Niemeyer H. and Skarmeta J. (1979) K-Ar ages of basalt flows of the Meseta Buenos Aires in southern Chile and their relation to the Southeast Pacific triple junction. Geology (Boulder), vol.7, no.9, 436-439

Chen J.H. and Pallister J.S. (1981) Lead isotopic studies of the Samail ophiolite, Oman. JGR. Journal of Geophysical Research. B, vol.86, no.4, pp.2699-2708

Chow T.J.and Patterson C.C. (1962) The occurrence and significance of lead isotopes in pelagic sediments. Geochimica et Cosmochimica Acta, vol.26, pp.263-308

Church S.E. (1976) The Cascade Mountains revisited; a re-evaluation in light of new lead isotopic data. Earth and Planetary Science Letters, vol.29, no.1, pp.175-188

Clavero R.J. and Moreno - Roa H. (1994) Ignimbritas Lican y Pucon: Evidencias de erupciones explosives andesitico - basalticas postglaciales del volcan Villarrica, Andes del sur, $39^{\circ} 25^{\prime}$ S. $7^{\circ}$ Congreso Geologico Chileno 1994, Actas Vol. I, pp. 250-254

Dasch E.J. (1981) Lead isotopic composition of metalliferous sediments from the Nazca Plate. Memoir - Geological Society of America, no.154, pp.199-209

Defant M.J. and Drummond M.S. (1990) Derivation of some modern arc magmas by melting of young subducted lithosphere. Nature 347, 662

DePaolo D.J. (1981) Trace element and isotopic effects of combined wallrock assimilation and fractional crystallization. Earth and Planet. Sci. Lett., 53, 189-202

Deruelle B. (1977) Sur l'activite recente des Nevados de Chillan (Chili central). New activity of the Nevados de Chillan, central Chile. Comptes Rendus Hebdomadaires des 
Seances de l'Academie des Sciences, Serie D: Sciences Naturelles, vol.284, no.17, 16511654

Deruelle B. (1982) Petrology of the Plio-Quaternary volcanism of the south-central and meridional Andes. Journal of Volcanology and Geothermal Research, vol.14, no.1-2, 77 124

Deruelle B., Harmon R.S. and Moorbath S. (1983) Combined Sr - O isotope relationships and petrogenesis of Andean Volcanics of South America. Nature, 302: 814 - 816

Drake R.E. (1976) Chronology of Cenozoic igneous and tectonic events in the central Chilean Andes; latitudes 35 degrees 30' to 36 degrees S. Journal of Volcanology and Geothermal Research, vol.1, no.3, pp.265-284

Drake R. (1983) Geochronological relationships between magmatism and tectonics in the Andes of central Chile. Eos, Transactions, American Geophysical Union, vol.64, no.18, pp.327

Edwards C.M.H., Morris J.D., Thirlwall M.F. (1993) Separating mantle from slab signatures in arc lavas using $\mathrm{B} / \mathrm{Be}$ and radiogenic isotope systematics. Nature (London), vol.362, no.6420, pp.530-533

Ellam R.M. and Hawkesworth C.J. (1988) Elemental and isotopic variations in subduction related basalts: evidence for a three component model. Contrib. Mineral. Petrol. 98., 72-80

Elliott T., Plank T, Zindler A and White W. (1997) Element transport from slab to volcanic front at the Mariana arc. J. of Geophys. Res. 102 (B7) 14991-15019

Ewart A. and Hawkesworth C.J. (1987) The Pleistocene-Recent Tonga-Kermadec Arc lavas; interpretation of new isotopic and rare earth data in terms of a depleted mantle source model. Journal of Petrology, vol.28, no.3, pp 495-530

Falloon T.J. and Green D.H. (1988) Anhydrous partial melting of peridotite from 8 to 35 $\mathrm{kb}$ and the petrogenesis of MORB. Journal of Petrology, vol.1988, pp.379-414

Feeley T.C., Dungan M.A. and Frey F.A. (1998) Geochemical constraints on the origin of mafic and silicic magmas at Cordon El Guadal, Tatara - San Pedro complex, central Chile. Contri. to Min. and Petrol., 131; 4, 393 - 411

Feigenson M.D., Patino L.C. and Carr, M.J. (1996) Constraints on partial melting imposed by rare earth element variations in Mauna Kea basalts. Journal of Geophysical Research, B, Solid Earth and Planets, vol.101, no.5, pp.11,815-11,829

Forsyth D.W. (1975) Fault plane solutions and tectonics of the south Atlantic and Scotia Sea. Journal of Geophysical Research, vol.80, no.11, pp.1429-1443 
Forsyth D.W. and Uyeda S. (1975) On the relative importance of the driving forces of plate motion. The Geophysical Journal of the Royal Astronomical Society, vol.43, no.1, pp.163-200

Forsythe R. (1982) The late Paleozoic to early Mesozoic evolution of southern South America: a plate tectonic interpretation. J. geol. Soc. London, Vol. 139, 671-682

Frey F.A., Gerlach D.C., Hickey R.L., Lopez-Escobar L., Munizaga-Villavicencio F. (1984) Petrogenesis of the Laguna del Maule volcanic complex, Chile (36 degrees S). Contributions to Mineralogy and Petrology, vol.88, no.1-2, pp.133-149

Gerlach D.C. (1985) Geochemistry and Petrology of recent volcanics of the Puyehue Cordon Caulle area, Chile $\left(40.5^{\circ} \mathrm{S}\right)$. Ph.D. Dissertation, Department of Earth, Atmospheric and Planetary Sciences, Massachusetts Institute of Technology

Gerlach D.C., Frey F.A., Moreno H. and Lopez - Escobar L. (1988) Recent volcanism in the Puyehue - Cordon Caulle region, Southern Andes, Chile $\left(40.5^{\circ} \mathrm{S}\right)$ : Petrogenesis of evolved lavas. Journal of Petrology, 29, 333 - 382

Germ Website: http://earthref.org/GERM/main.htm

Gill JB (1981) Orogenic Andesites and Plate Tectonics. Springer - Verlag. Berlin. Heidelberg. New York

Gill J.B. and Williams R.W. (1990) Th isotope and U-series studies of subduction-related volcanic rocks. Geochim. Cosmochim. Acta, vol.54, no.5, pp.1427-1442

Gill JB and Condomines M. (1992) Short-lived radioactivity and magma genesis. Science, vol.257, no.5075, pp.1368-1376

Green T.H. and Ringwood A.E. (1968) Genesis of calc-alkaline igneous rock suite. Contrib. Mineral Petrol 18: 105-162

Grove T.L., Gerlach D.C. and Thomas W.S. (1982) Origin of calc-alkaline series lavas at medicine lake volcano by fractionation, assimilation and mixing. Contrib. Mineral Petrol. 80, 160-182

Grove T.L. and Baker M.B. (1984) Phase equilibrium controls on the tholeiitic versus calc-alkaline differentiation trends. J. Geophys. Res. 89 (B5) 3253-327

Hanus V. and Vanek J. (1978) Morphology of the Andean Wadati-Benioff zone, andesitic volcanism, and tectonic features of the Nazca Plate. Tectonophysics, vol.44, no.1-4, pp.65-77

Harmon R.S., Barreiro B.A., Moorbath S., Hoefs J., Francis P.W., Thorpe R.S., Deruelle B., McHugh J. and Viglino J.A. (1984) Reginal O-, Sr-, and Pb-isotope relationships in 
late Cenozoic calc-alkaline lavas of the Andean Cordillera. Journal of the Geological Society of London, vol.141, no.5, pp.803-822

Harmon R.S. and Hoefs J. (1984) Oxygen isotope ratios in Late Cenozoic Andean volcanics. In: Andean magmatism: chemical and isotopic constraints (editor: Harmon R.S. and Barreiro B.A.), Shiva Geology Series, pp. 9 - 20

Hawkesworth C.J., Norry M.J., Roddick J.C., Baker P.E., Francis P.W. and Thorpe R.S. (1979) ${ }^{143} \mathrm{Nd} /{ }^{144} \mathrm{Nd},{ }^{87} \mathrm{Sr} /{ }^{86} \mathrm{Sr}$, and incompatible element variations in calc-alkaline andesites and plateau lavas from South America. Earth and Planetary Science Letters, vol.42, no.1, 45-57

Hawkesworth C.J., Hammill M., Gledhill A.R., van Calsteren P. and Rogers G. (1982) Isotope and trace element evidence for late-stage intra-crustal melting in the High Andes. Earth and Planetary Science Letters, vol.58, no.2, pp.240-254

Hawkesworth C.J., Gallagher K., Hergt J.M. and McDermott F. (1993) Mantle and slab contributions in arc magmas. Annual Review of Earth and Planetary Sciences, vol.21, pp.175-204

Hawkesworth, C. J., Turner S.P., McDermott F., Peate D. W., and Van-Calsteren P. (1997) U-Th isotopes in arc magmas: Implications for element transfer from the subducted crust. Science, 276, 551-555

Herve F., Araya E., Fuenzalida J.L. and Solano A. (1979) Edades radiometricas u tectonica neogena en el sector costero de Chiloe continental, X Region. In Congreso Geologico Chileno, No2, Actas, v.1, p.F1-F18

Helz R.T. (1973) Phase Relations of Basalts in their Melting Range at $P_{\mathrm{H} 2 \mathrm{O}}=5 \mathrm{~kb}$ as a Function of Oxygen Fugacity; Part I, Mafic Phases. Journal of Petrology, vol.14, no.2, pp.249-302

Helz R.T. (1976) Phase relations of basalts in their melting ranges at $\mathrm{P}_{\mathrm{H} 2 \mathrm{O}}=5 \mathrm{~kb}$; Part II, Melt compositions. Journal of Petrology, vol.17, no.2, pp.139-193

Herron EM (1981) Chile margin near lat 38 degrees S; evidence for a genetic relationship between continental and marine geologic features or a case of curious coincidences? Memoir - Geological Society of America, no.154, pp.755-760

Hickey R.L., Frey F.A., Gerlach D.C., Lopez-Escobar L. (1986) Multiple sources for basaltic arc rocks from the Southern Volcanic Zone of the Andes $\left(34-42^{\circ} \mathrm{S}\right)$ : Trace element and isotopic evidence for contributions from subducted oceanic crust, mantle and continental crust. J. Geophys. Res. 91, 5963-5983

Hickey - Vargas R., Moreno H., Lopez-Escobar L., Frey F.A. (1989) Geochemical variations in Andean basaltic and silicic lavas from the Villarrica-Lanin volcanic chain 
$\left(39.5^{\circ} \mathrm{S}\right)$ : an evaluation of source heterogeneity, fractional crystallization and crustal assimilation, Contrib. Mineral. Petrol. 103, 361-386

Hickey - Vargas R.L., Lopez-Escobar L., Parada M.A., Frey F.A. (1993) Subduction controls on magma production in the Southern SVZ: evidence from major and minor eruptive centers. EOS TransAm Geophys Union 74: 663

Hickey - Vargas R.L., Abdollahi M.J., Parada M.A., Lopez-Escobar L., Frey F.A. (1995) Crustal xenoliths from Calbuco Volcano, Andean Southern Volcanic Zone: implications for crustal composition and magma-crust interaction. Contrib. Mineral Petrol. 119: 331344

Hickey - Vargas R., Lopez - Escobar L. and Moreno H. (1997) Isotopic characteristics of volcanic rocks from minor eruptive centers (MEC) in the area of Villarrica Volcano ( $39^{\circ}$ - 39 $30^{\circ}$ 'S). Actas 8th Congreso Geologico Chileno, 1997

Hildreth W., Moorbath S. (1988) Crustal Contribution to arc magmatism in the Andes of Central Chile. Contrib. Mineral. Petrol. 98, 455-489

Hochstaedter A., Ryan J.G., Luhr J.F. and Hasenake T. (1996) On B/Be ratios in the Mexican Volcanic Belt, Geochim. Cosmochim. Acta 60, 613-628

Hochstaedter A., Gill J.B., Peters R., Broughton P., Holden P. and Taylor B. (unpublished) Across - arc geochemical trends in the Izu - Bonin arc: contributions from the subducting slab. In prep.

Hofmann A.W. and Feigenson M.D. (1983) Case studies on the origin of basalt; I, Theory and reassessment of Grenada basalts. Contributions to Mineralogy and Petrology, vol.84, no.4, pp.382-389

Hole M.J., Saunders A.D., Marriner G.F. and Tarney J. (1984) Subduction of pelagic sediments: implications for the origin of $\mathrm{Ce}$ - anomalous basalts from the Mariana Islands. J. geol. Soc., London, 141, 453-472

Holtz F., Behrens H., Dingwell D.B. and Taylor R.P. (1992) Water solubility in aluminosilicate melts of haplogranitic composition at 2 kbar. Chem. Geology 96, 289-302

Irvine T.N. and Baragar W.R.A. (1971) A guide to the chemical classification of the common volcanic rocks. Canad. J. Earth Sci., v.8, p.523 - 548

James D.E. (1984) Quantitative models for crustal contamination in the Central and Northern Andes. Andean magmatism (chemical and isotopic constraints), Editors: Harmon R.S. and Barreiro B.A., PP $124-138$ 
Johnson M.C. and Plank T. (1999) Dehydration and melting experiments constrain the fate of subducted sediments. Geochemistry / Geophysics / Geosystems (http://www.agu.org), Volume 1

Kay R.W. (1978) Aleutian magnesian andesites; melts from subducted Pacific Ocean crust. Journal of Volcanology and Geothermal Research, vol.4, no.1-2, pp 117-132

Kepezhinskas P., McDermott F., Defant M.J., Hochstaedter A., Drummond M.S., Hawkersworth C.J., Koloskov A., Maury R.C and Bellon H. (1997) Trace element and $\mathrm{Sr}-\mathrm{Nd}-\mathrm{Pb}$ isotopic constraints on a three-component model of Kamchatka arc petrogenesis. Geochim. Cosmochim. Acta 61(3), 577-600

Keppler H. (1996) Constraints from partitioning experiments on the composition of subduction-zone fluids. Nature (London), vol.380, no.6571, pp.237-240

Klein E.M. and Langmuir C.H. (1987) Global correlations of ocean ridge basalt chemistry with axial depth and crustal thickness. J. Geophys. Res. 92, 8089-8115

Kogiso T., Tatsumi Y. and Nakano S. (1997) Trace element transport during dehydration processes in the subducted oceanic crust: Experiments and implications for the origin of ocean island basalts. Earth Planet. Sci. Lett. 148, 193-205

Kushiro I. (1969) The system forsterite - diopside - silica with and without water at high pressures. Am. J. Sci., 267A, 269 - 294

Kushiro I. (1974) On the nature of silicate melt and its significance in magma genesis: Regularities in the shift of the liquidus boundaries involving olivine, pyroxene, and silica minerals. Am. J. Sci., 275, 411 - 431

Le Bas M.J., Le Maitre R.W., Streckeisen A. and Zanettin B. (1986) A chemical classification of volcanic rocks based on the total alkali - silica diagram. J. Petrol., v.27, p.745 - 750

Leeman W.P. (1987) Boron geochemistry of volcanic arc magmas: evidence for recycling of subducted oceanic lithosphere. $\operatorname{EOS} 68, p .462$

Leeman WP, Carr MJ and Morris JD (1994) Boron geochemistry of the Central American Volcanic Arc: constraints on the genesis of subduction-related magmas. Geochim. Cosmochim. Acta 58, 149-168

Lloyd F.E. and Bailey D.K. (1975) Light element metasomatism of the continental mantle: the evidence and consequence. Phys. Chem. Earth, 9, 389 - 416

Lomnitz C. (1962) On Andean structure. Journal of Geophysical Research, vol.67, no.1, pp.351-363 
Lopez - Escobar L. and Frey F.A. (1976) Rocas volcanicas cuaternarias de Chile central - sur $\left(33-41^{\circ} \mathrm{S}\right)$ : Modelos petrogeneticos sugeridos por las Tierras Raras, Actas I Congreso Geologico Chileno, 2, F223 - F255

Lopez - Escobar L., Frey F.A. and Vergara M. (1976) Andesites from central-south Chile; trace element abundances and petrogenesis. In: IAVCEI Proc. Symp. on Andean and Antarctic Volcanology Problems (Editor: O. Gonzalez F.), 725 - 761; Santiago Chile

Lopez - Escobar L. and Moreno H. (1981) Erupcion de 1979 del volcan Mirador, Andes del sur $41^{\circ} 21$ 'S: Caracteristicas geoquimicas de las lavas y xenolitos graniticos. Revista Geologica de Chile, $N^{\circ} 13-14$, P $17-33$

Lopez-Escobar L., Parada M.A., Moreno H., Frey F.A., Hickey - Vargas R.L. (1992) A contribution to the petrogenesis of Osorno and Calbuco volcanoes, Southern Andes (41 degrees 00'-41 degrees 30'S); comparative study. Revista Geologica de Chile, vol.19, no.2, pp.211-226

Lopez-Escobar L., Parada M.A, Hickey-Vargas R., Frey F.A., Kempton P.D. and Moreno H. (1995) Calbuco volcano and minor eruptive centers distributed along the LiquineOfqui Fault Zone, Chile $\left(41-42^{\circ} \mathrm{S}\right)$ : contrasting origin of andesitic and basaltic magma in the Southern Volcanic Zone of the Andes, Contrib. Mineral. Petrol. 119, 345-361

Marsh B.D. (1973) Island Arc Magmatism. Eos, Transactions, American Geophysical Union, vol.54, no.11, pp.1205

Marsh B.D. and Carmichael I.S.E. (1974) Benioff Zone Magmatism. Journal of Geophysical Research, vol.79, no.8, pp.1196-1206

McCulloch M.T. and Gamble A.J. (1991) Geochemical and geodynamical constraints on subduction zone magmatism. Earth and Planetary Science Letters, vol.102, no.3-4, pp.358-374

McMillan N.J., Harmon R.S., Moorbath S., Lopez-Escobar L. and Strong D.F. (1989) Crustal sources involved in continental arc magmatism: A case study of volcan MochoChoshuenco, southern Chile Geology. 17, 1152-1156

Meijer A. (1976) $\mathrm{Pb}$ and $\mathrm{Sr}$ isotopic data bearing on the origin of volcanic rocks from the Mariana island-arc system. Geological Society of America Bulletin, vol.87, no.9, pp.1358-1369

Melzer S. and Wunder B. (2000) Island-arc basalt alkali ratios; constraints from phengitefluid partitioning experiments. Geology (Boulder), vol.28, no.7, pp.583-586

Miller, D.M., Goldstein S.L., and Langmuir C.H. (1994) Cerium/lead and lead isotopic ratios in arc magmas and the enrichment of lead in the continents. Nature, 368, 514-520 
Minster J.B., Jordan T.H., Molnar P. and Haines E. (1974) Numerical Modelling of Instantaneous Plate Tectonics. The Geophysical Journal of the Royal Astronomical Society, vol.36, no.3, pp.541-576

Moreno H. (1974) Airplane flight over active volcanoes of central - south Chile. In: IAVCEI Proc. Symp. on Andean and Antarctic Volcanology Problems (Editor: O. Gonzalez F.), Santiago - Chile

Moreno H. (1976) The upper Cenozoic volcanism in the Andes of Southern Chile. In: IAVCEI Proc. Symp. on Andean and Antarctic Volcanology Problems (Editor: O. Gonzalez F.), 143 - 171, Santiago - Chile

Moreno H. (1977) Geologia del ara volcanica Puyehue - Carran en los Andes del Sur de Chile. Tesis de Grado, Departamento de Geologia, Universidad de Chile, 181p

Moreno H. (1980) La erupcion del volcan Mirador en Abril - Mayo de 1979, Lago Ranco - Rininahue, Andes del Sur. Universidad de Chile, Departamento de Geologia, Comunicaciones, $N^{\circ} 28$, p. $1-23$

Moreno - Roa H. and Lopez - Escobar L. (1994) Los centros eruptivos de Rucapillan: actividad volcanica reciente en la depression central de los Andes del sur $\left(39^{\circ} \mathrm{S}\right) .7^{\circ}$ Congreso Geologico Chileno 1994, Actas Vol. I, pp 334-338

Moreno - Roa H., Lopez - Escobar L. and Cembrano J. (1994) The Villarrica Quetrupillan - Lanin volcanic chain: a review and probable significance in the southern Andes, 39.4oS, Chile. $7^{\circ}$ Congreso Geologico Chileno 1994, Actas Vol. I, pp. 339-341

Morris JD and Hart SR (1983) Isotopic and incompatible element constraints on the genesis of island arc volcanics from Cold Bay and Amak Island, Aleutians, and implications for mantle structure. Geochimica et Cosmochimica Acta, vol.47, no.11, pp.2015-2030

Morris J.D and Tera F. (1989) $10 \mathrm{Be}$ and 9Be in mineral separates and whole rocks from volcanic arcs: Implications for sediment subduction. Geochim. Cosmochim. Acta 53, 3197-3205

Morris J.D., Leeman W.P. and Tera F. (1990) The subducted component in island arc lavas: constraints from $\mathrm{Be}$ isotopes and B-Be systematics. Nature 344, 31-36

Munoz B.J. and Stern C.R. (1989) Alkaline magmatism within the segment 38 degrees 39 degrees $S$ of the Plio-Quaternary volcanic belt of the southern South American continental margin. Journal of Geophysical Research, B. Solid Earth and Planets, vol.94, no.4, pp.4545-4560

Navon O. and Stolper E. (1987) Geochemical consequences of melt percolation; the upper mantle as a chromatographic column. Journal of Geology, vol.95, no.3, pp.285-307 
Niemeyer F.H. (1978) The Rio Pedregoso Cave with indigenous paintings; Chile Chico, Aysen, Chile. Monograph - Notas del Museo - Museo de Historia Natural de San Rafael, no.19, p. 339-364

Pawley A.R. and Holloway J.R. (1993) Water sources for subduction zone volcanism; new experimental constraints. Science, vol.260, no.5108, pp.664-667

Peacock S. (1990) Fluid processes in subduction zones. Science 248, 329-337

Peacock S.M. (1991) Numerical simulation of subduction zone pressure-temperaturetime paths; constraints on fluid production and arc magmatism. Philosophical Transactions of the Royal Society of London, Series A: Mathematical and Physical Sciences, vol.335, no.1638, pp 341-353

Peacock S.M. (2001) Are the lower planes of double seismic zones caused by serpentine dehydration in subducting oceanic mantle? Geology (Boulder), vol.29, no.4, pp.299-302

Pearce J.A and Parkinson I.J. (1993) Trace element models for mantle melting; application to volcanic arc petrogenesis. Geological Society Special Publications, vol.76, pp 373-403

Pearce J.A., Baker P.E., Harvey P.K. and Luff I.W. (1995) Geochemical evidence for subduction fluxes, mantle melting and fractional crystallization beneath the South Sandwich island arc, J. Petrol. 36, 1073-1109

Pearce J.A. and Peate D.W. (1995) Tectonic implications of the composition of volcanic arc magmas. Annual Review of Earth and Planetary Sciences, vol.23, pp.251-285

Peucker - Ehrenbrink B., Hofmann A.W. and Hart S.R. (1994) Hydrothermal lead transfer from mantle to continental crust: the role of metalliferous sediments. Earth and Planetary Science Letters, vol. 125, no. 1-4, pp.129-142

Pichler H., Hoermann P.K. and Braun A.F. (1976) First petrologic data on lavas of the volcano El Reventador (eastern Ecuador). Muenstersche Forschungen zur Geologie und Palaeontologie, no.38-39, 129-141

Plank T. and Langmuir C.H. (1988) An evaluation of the global variations in the major element chemistry of arc basalts. Earth Planet. Sci. Lett. 90, 349-370

Plank T. and Langmuir C.H. (1992) Effects of the melting regime on the composition of the oceanic crust. Journal of Geophysical Research, B, Solid Earth and Planets, vol.97, no.13, pp.19,749 - 19,770

Plank T. and Langmuir C.H. (1993) Tracing trace elements from sediment input to volcanic output at subduction zones. Nature 362, 739-742 
Plank T. and Langmuir C.H. (1998) The chemical composition of subducting sediment and its consequences for the crust and mantle. Chemical Geology, vol.145, no.3-4, pp.325-394

Reagan M.K., Morris J.D., Herrstrom E.A. and Murrell M.T. (1994) Uranium series and beryllium isotope evidence for an extended history of subduction modification of the mantle below Nicaragua. Geochim. Cosmochim. Acta.58, 4199-4212

Ringwood A.E. (1974) The petrological evolution of island arc systems. J. of Geol. Soc. of London, Vol.130, No.3, pp183-204

Rollinson H.R. (1983) The geochemistry of mafic and ultramafic rocks from the Archaean greenstone belts of Sierra Leone. Mineralogical Magazine, vol.47, no.3, pp.267-280

Rodriguez Soto A.C. (1998) Geoquimica del grupo volcanico Carran - Los Venados, Andes del sur, $\mathrm{x}$ region. (Thesis) Dept. of Geology, University of Chile

Rudnick R.L. and Fountain D.M. (1995) Nature and composition of the continental crust; a lower crustal perspective. Reviews of Geophysics, vol.33, no.3, pp.267-309

Ryan J.G. and Langmuir C.H. (1988) Beryllium systematics in young volcanic rocks: Implications for 10Be. Geochim. Cosmochim. Acta 52, 237-244

Ryan J.G. and Langmuir C.H. (1993) The systematics of boron abundances in young volcanic rocks. Geochim. Cosmochim. Acta 57, 1489-1498

Ryan J.G., Morris J., Tera F., Leeman W.P. and Tsvetkov A. (1995) Cross - arc geochemical variations in the Kurile arc as a function of slab depth. Science, Vol. 270, $625-627$

Ryan, J.G., Leeman, W.P., Morris, J.D. and Langmuir, C.H. (1996) The boron systematics of intraplate lavas: implications for crust and mantle evolution. Geochimica et Cosmochimica Acta, vol. 60, pp. 415-422

Shackleton R.M, Ries A.C., Coward M.P. and Cobbold P.R. (1979) Structure, metamorphism and geochronology of the Arequipa Massif of coastal Peru. Journal of the Geological Society of London, vol.136, Part 2, pp.195-214

Shaw D.M. (1970) Trace element fractionation during anatexis. Geochimica et Cosmochimica Acta, vol.34, no.2, pp.237-243

Sigmarsson O., Condomines M., Morris J.D. and Harmon R.S. (1990) Uranium and ${ }^{10} \mathrm{Be}$ enrichments by fluids in Andean arc magmas, Nature 346, 163-165 
Sisson T.W. and Grove T.L. (1993) Experimental investigations of the role of $\mathrm{H} 2 \mathrm{O}$ in calc-alkaline differentiation and subduction zone magmatism. Contrib. Mineral Petrol. $113,143-166$

Skewes MA and Stern CR (1979) Petrology and geochemistry of alkali basalts and ultramafic inclusions from the Palei-Aike volcanic field in southern Chile and the origin of the Patagonian plateau lavas. Journal of Volcanology and Geothermal Research, vol.6, no.1-2, pp.3-25

Stalder R., Foley S.F., Brey G.P. and Horn I. (1998) Mineral-aqueous fluid partitioning of trace elements at 900-1200 degrees $\mathrm{C}$ and 3.0-5.7 GPa; new experimental data for garnet, clinopyroxene, and rutile, and implications for mantle metasomatism. Geochimi. Cosmochimi. Acta, vol.62, no.10, pp.1781-1801

Stauder W. (1973) Mechanism and Spatial Distribution of Chilean Earthquakes with Relation to Subduction of the Oceanic Plate. Journal of Geophysical Research, vol.78, no.23, 5033-5061

Stern C.R., Skewes M.A. and Duran M. (1976) Volcanismo calc - alkaline en Chile austral. Actas Primer Congreso Geologico Chileno, 2, 195 - 212

Stern C.R., Futa K. and Muehlenbachs K. (1984) Isotope and trace element data for orogenic andesites from the Austral Andes. Andean magmatism (chemical and isotopic constraints), Editors: Harmon R.S. and Barreiro B.A., PP 31 - 46

Stern C.R., Frey F.A., Futa K., Zartman R.E., Peng Z. and Kyser T.K. (1990) Traceelement and $\mathrm{Sr}, \mathrm{Nd}, \mathrm{Pb}$ and $\mathrm{O}$ isotopic composition of Pliocene and Quaternary alkali basalts of the Patagonian plateau lavas of southernmost South America. Contributions to Mineralogy and Petrology, vol.104, no.3, 294-308

Stern R.J., Morris J., Bloomer S.H. and Hawkins J.W. Jr. (1991) The source of the subduction component in convergent margin magmas: Trace element and radiogenic isotope evidence from Eocene boninites, Mariana forearc. Geochimi. Cosmochimi. Acta, vol.55, pp1467-1481

Stolper E. (1980) A phase diagram for mid - ocean ridge basalts: preliminary results and implications for petrogenesis. Contrib. Mineral Petrol. 74, 13 - 27

Sun S.S. (1980) Lead isotopic study of young volcanic rocks from mid-ocean ridges, ocean islands and island arcs. Philosophical Transactions of the Royal Society of London, Series A: Mathematical and Physical Sciences, vol.297, no.1431, pp.409-445

Sun S.S. and McDonough W.F. (1989) Chemical and isotopic systematics of oceanic basalts: implications for mantle composition and processes. From Saunders, A.D. \& Norry, M.J. (eds), Magmatism in the Ocean Basins, Geological Society Special Publication No.42, 313-345 
Swift S. and Carr M. (1975) The segmented nature of the Chilean seismic zone. Phys. Earth Plan. Int., 9, $183-191$

Tatsumi Y., Hamilton D.L. and Nesbitt R.W. (1986) Chemical characteristics of fluid phase released from a subducted lithosphere and origin of arc magmas: Evidence from high-pressure experiments and natural rocks, J. Volc. Geoth. Res. 29, 293-309

Tatsumi Y. and Isoyama H. (1988) Transportation of beryllium with $\mathrm{H}$ (sub 2) O at high pressures; implication for magma genesis in subduction zones. Geophysical Research Letters, vol.15, no.2, pp.180-183

Tatsumi Y., Murasaki M., Arsadi E.M. and Nohda S. (1991) Geochemistry of Quarternary lavas from NE Sulawesi: transfer of subduction components into the mantle wedge. Contrib. Mineral. Petrol., 107, 137-149

Tatsumoto M. (1978) Isotopic composition of lead in oceanic basalt and its implication to mantle evolution. Earth and Planetary Science Letters, vol.38, no.1, pp.63-87

Tera F., Brown L., Morris J., Selwyn Sacks I., J. Klein and R. Middleton (1986) Sediment incorporation in island - arc magmas: Inferences from 10Be. Geochim. Cosmochim Acta 50, 535-550

Thirlwall M.F., Graham A.M., Arculus R.J., Harmon R.S. and Mccpherson C.G. (1996) Resolution of the effects of crustal assimilation, sediment subduction, and fluid transport in island arc magmas: $\mathrm{Pb}-\mathrm{Sr}-\mathrm{Nd}-\mathrm{O}$ isotope geochemistry of Grenada, Lesser Antilles. Geochim. Cosmochim Acta 60, 4785-4810

Thorpe R.S., Francis P.W. and Harmon R.S. (1981) Andean andesites and crustal growth. Philosophical Transactions of the Royal Society of London, Series A: Mathematical and Physical Sciences. 301; 1461, Pages 305-320. 1981. .

Tilton G.R. and Barreiro B.A. (1980) Origin of lead in Andean calc-alkaline lavas, southern Peru. Science, vol.210, no.4475, pp.1245-1247

Toksoz M.N. and Hasui A.T. (1978) Numerical studies of back - arc convection and the formation of marginal basins. Tectonophysics, 50, $177-196$

Tormey D.R., Hickey-Vargas R. Frey F.A. and Lopez Escobar L. (1991) Recent lavas from the Andean volcanic front (33 to 42oS); Interpretations of along-arc compositional variations. GSA Special Paper 265: Andean Magmatism and its Tectonic Setting. pp. 5777

Turner S. and Hawkesworth C. (1997) Constraints on flux rates and mantle dynamics beneath island arcs from Tonga - Kermadec lava geochemistry. Nature (London), vol.389, no.6651, pp.568-573 
Turner S., Hawkesworth C., Roger N., Barlett J., Worthington T., Hergt J., Pearce J. and Smith I. (1997) ${ }^{238} \mathrm{U}^{230}$ Th disequilibria, magma petrogenesis and flux rates beneath the depleted Tonga-Kermadec island arc. Geochim. Cosmochim Acta 61, 4855-4884

Turner S., Bourdon B., Hawkesworth C. and Evans P. (2000) ${ }^{226} \mathrm{Ra}-{ }^{230} \mathrm{Th}$ evidence for multiple dehydration events, rapid melt ascent and the time scales of differentiation beneath the Tonga - Kermadec island arc. Earth and Planetary Science Letters, vol.179, no.3-4, 581-593

Unruh D.M. and Tatsumoto M. (1976) Lead isotopic composition and uranium, thorium, and lead concentrations in sediments and basalts from the Nazca Plate. Initial Reports of the Deep Sea Drilling Project, vol.34, Papeete, Tahiti to Callao, Peru; Dec. 1973-Feb. 1974, pp.341-347

Uyeda S. and Kanamori H. (1979) Back-arc opening and the mode of subduction. Journal of Geophysical Research, vol.84, no.B3, pp.1049-1061

Varne R. (1985) Ancient subcontinental mantle; a source for K-rich orogenic volcanics. Geology (Boulder), vol.13, no.6, pp 405-408

Vergara M. and Munizaga F. (1974) Age and Evolution of the Upper Cenozoic Andesitic Volcanism in Central-South Chile. Geological Society of America Bulletin, vol.85, no.4, pp.603-606

Vroon P.Z., van Bergen M.J., Klaver G.J. and White W.M. (1995) Strontium, neodymium, and lead isotopic and trace-element signatures of the East Indonesian sediments: provenance and implications for Banda Arc magma genesis. Geochimica et Cosmochimica Acta, vol.59, no.12, pp.2573-2598

White W.M. and Patchett J. (1984) Hf-Nd-Sr isotopes and incompatible element abundances in island arcs; implications for magma origins and crust-mantle evolution. Earth and Planetary Science Letters, vol.67, no.2, pp.167-185

Wood D.A. (1979) A variably veined suboceanic upper mantle - Genetic significance for mid - ocean ridge basalts from geochemical evidence. Geology, V.7, pp. 499 - 503

Wyllie P.J. and Sekine T. (1982) The formation of mantle phlogopite in subduction zone hybridization. Contrib. Mineral Petrol. 79: 375-380

Yamamoto K. and Akimoto S. (1977) The system $\mathrm{MgO}-\mathrm{SiO}_{2}-\mathrm{H}_{2} \mathrm{O}$ at high pressures and temperatures; stability field for hydroxyl-chondrodite, hydroxyl-clinohumite and $10 \mathrm{~A}^{\circ}-$ phase. American Journal of Science, vol.277, no.3, pp.288-312

Yoder H.S., Jr (1965) Diopside-anorthite-water at five and ten kilobars and its bearing on explosive volcanism. Year Book - Carnegie Institution of Washington, pp.82-89 
Zartman R.E. and Doe B.R. (1981) Plumbotectonics - The Model. Tectonophysics, 75: 135-162

Zeil W. (1979) The Andes; a geological review. Monograph - Beitraege zur Regionalen Geologie der Erde, vol.13, 260

Zheng S.H., Morris J., Tera F., klein J. and Middleton R. (1994) Beryllium isotopic investigation of sedimentary columns outboard of subduction zones. ICOG Abstracts, 8, 366 


\section{Appendices}

Appendix 1 Previous data for Volcano Villarrica and SEC samples used for plots and calculations in this work

1. Villarrica samples analyzed by Dr. Rosemary Hickey - Vargas (Hickey - Vargas et al., 1989) (Table 1 - 1): 
Table 1-1

\begin{tabular}{|l|l|l|l|l|l|l|l|l|}
\hline $\begin{array}{l}\text { Sample } \\
\text { Number }\end{array}$ & $\begin{array}{l}\text { Lab } \\
\text { Code }\end{array}$ & $\begin{array}{l}\text { Paper } \\
\text { Code }\end{array}$ & Unit/Age & ${ }^{87} \mathrm{Sr} /{ }^{86} \mathrm{Sr}$ & ${ }^{143} \mathrm{Nd} /{ }^{144} \mathrm{Nd}$ & ${ }^{206} \mathrm{~Pb} /{ }^{204} \mathrm{~Pb}$ & ${ }^{207} \mathrm{~Pb} /{ }^{204} \mathrm{~Pb}$ & ${ }^{208} \mathrm{~Pb} /{ }^{204} \mathrm{~Pb}$ \\
\hline $101275-3$ & L-25 & V1-1 & I & $0.70410 \pm 3$ & $0.512866 \pm 22$ & & & \\
\hline $270976-3$ & L-18 & V2-1 & II & $0.70401 \pm 3$ & $0.512878 \pm 18$ & & & \\
\hline $280976-1$ & L-21 & V2-2 & II & $0.70403 \pm 3$ & $0.512881 \pm 14$ & 18.581 & 15.593 & 38.472 \\
\hline $300976-5$ & L-23 & V3-1 & III & $0.70398 \pm 3$ & $0.512903 \pm 18$ & & & \\
\hline $101275-1$ & L-28 & V3-5 & 1971 & $0.70406 \pm 3$ & $0.512893 \pm 18$ & 18.581 & 15.590 & 38.464 \\
\hline $290884-2$ & & & Rhyolite* & $0.70398 \pm 3$ & $0.512873 \pm 18$ & & & \\
\hline
\end{tabular}

(CONTINUED)

\begin{tabular}{|l|l|l|l|l|l|l|l|l|l|l|}
\hline Sample Numbers & $\mathrm{SiO}_{2}$ & $\mathrm{TiO}_{2}$ & $\mathrm{Al}_{2} \mathrm{O}_{3}$ & $\mathrm{MgO}$ & $\mathrm{Fe}_{2} \mathrm{O}_{3}(\mathrm{~T})$ & $\mathrm{CaO}$ & $\mathrm{Na}_{2} \mathrm{O}$ & $\mathrm{K}_{2} \mathrm{O}$ & $\mathrm{MnO}$ & $\mathrm{P}_{2} \mathrm{O}_{5}$ \\
\hline $101275-3$ & 56.69 & 1.29 & 15.79 & 3.56 & 10.03 & 7.20 & 3.51 & 1.03 & 0.18 & 0.27 \\
\hline $151282-2$ & 55.56 & 1.02 & 16.88 & 4.53 & 8.42 & 8.32 & 3.98 & 0.90 & 0.17 & 0.22 \\
\hline $270884-3$ & 52.49 & 1.23 & 16.55 & 6.40 & 10.25 & 9.00 & 3.08 & 0.71 & 0.16 & 0.24 \\
\hline $270976-3$ & 52.87 & 1.11 & 17.37 & 5.08 & 9.28 & 9.86 & 2.88 & 0.64 & 0.15 & 0.20 \\
\hline $280976-1$ & 51.79 & 1.14 & 16.89 & 6.63 & 10.03 & 9.77 & 2.91 & 0.61 & 0.16 & 0.21 \\
\hline $151282-3$ & 55.00 & 1.37 & 16.11 & 4.20 & 10.06 & 8.10 & 3.83 & 0.86 & 0.16 & 0.29 \\
\hline $250884-4$ & 51.97 & 0.98 & 16.90 & 7.40 & 9.51 & 9.81 & 2.92 & 0.58 & 0.16 & 0.19 \\
\hline $270884-4$ & 55.38 & 1.32 & 16.04 & 3.67 & 10.68 & 7.65 & 3.75 & 0.91 & 0.17 & 0.26 \\
\hline $270884-11$ & 52.40 & 1.11 & 17.97 & 5.01 & 9.30 & 10.31 & 3.00 & 0.66 & 0.15 & 0.23 \\
\hline $240884-1$ & 52.68 & 1.05 & 18.74 & 4.47 & 8.92 & 10.25 & 3.06 & 0.61 & 0.15 & 0.19 \\
\hline $280884-9$ & 51.47 & 0.86 & 17.58 & 7.04 & 9.12 & 10.84 & 2.67 & 0.43 & 0.15 & 0.13 \\
\hline $101283-1$ & 52.74 & 1.03 & 18.20 & 5.07 & 9.13 & 10.22 & 3.08 & 0.58 & 0.15 & 0.19 \\
\hline $300976-5$ & 52.71 & 1.23 & 18.25 & 4.48 & 8.81 & 9.91 & 3.38 & 0.69 & 0.17 & 0.29 \\
\hline $250884-1$ & 52.04 & 1.14 & 17.59 & 5.71 & 9.71 & 9.74 & 3.20 & 0.64 & 0.15 & 0.22 \\
\hline $270884-5$ & 52.21 & 1.32 & 16.62 & 5.33 & 10.46 & 9.59 & 3.13 & 0.78 & 0.17 & 0.28 \\
\hline $290884-4$ & 52.43 & 1.17 & 18.13 & 4.90 & 9.36 & 9.95 & 3.23 & 0.68 & 0.15 & 0.24 \\
\hline $101275-1$ & 52.19 & 1.14 & 16.82 & 6.12 & 9.73 & 9.61 & 3.18 & 0.63 & 0.16 & 0.24 \\
\hline $151282-1$ & 52.37 & 1.15 & 16.85 & 6.11 & 9.76 & 9.58 & 3.21 & 0.65 & 0.16 & 0.22 \\
\hline $210281-1$ & 52.60 & 1.15 & 16.79 & 6.05 & 9.76 & 9.62 & 3.12 & 0.65 & 0.16 & 0.22 \\
\hline $191284-1$ & 52.23 & 1.16 & 16.86 & 5.85 & 9.98 & 9.49 & 3.18 & 0.65 & 0.16 & 0.25 \\
\hline $29076-2$ & 52.16 & 1.13 & 17.44 & 5.46 & 9.54 & 10.06 & 3.06 & 0.68 & 0.16 & 0.24 \\
\hline $240884-3$ & 55.84 & 1.30 & 16.28 & 3.58 & 10.24 & 7.74 & 3.86 & 0.91 & 0.17 & 0.25 \\
\hline $260884-8$ & 53.15 & 1.08 & 18.68 & 4.32 & 8.74 & 10.26 & 3.20 & 0.66 & 0.15 & 0.21 \\
\hline $290884-2$ & 70.47 & 0.38 & 14.02 & 0.45 & 4.22 & 1.92 & 5.11 & 2.85 & 0.10 & 0.09 \\
\hline
\end{tabular}

(CONTINUED)

\begin{tabular}{|l|l|l|l|l|l|l|l|}
\hline Sample Numbers & $\mathrm{H}_{2} \mathrm{O}$ & Total & $\mathrm{Ni}$ & $\mathrm{Cr}$ & $\mathrm{Sc}$ & $\mathrm{Y}$ & $\mathrm{Sr}$ \\
\hline $101275-3$ & 0.53 & 99.55 & 18.6 & 20 & 32.9 & 27.6 & 402 \\
\hline $151282-2$ & 0.17 & 100.01 & 21.0 & 86 & 30.9 & 23.1 & 463 \\
\hline $270884-3$ & & 100.00 & 81.0 & 228 & 31.9 & 24.4 & 437 \\
\hline $270976-3$ & 0.23 & 99.44 & 41.8 & 134 & 32.6 & 21.7 & 437 \\
\hline $280976-1$ & 0.15 & 100.14 & 85.4 & 248 & 33.3 & 21.9 & 429 \\
\hline $151282-3$ & 0.35 & 99.98 & 22.0 & 35 & 32.4 & 25.2 & 428 \\
\hline
\end{tabular}


(CONTINUED)

\begin{tabular}{|l|l|l|l|l|l|l|l|}
\hline Sample Numbers & $\mathrm{H}_{2} \mathrm{O}$ & Total & $\mathrm{Ni}$ & $\mathrm{Cr}$ & $\mathrm{Sc}$ & $\mathrm{Y}$ & $\mathrm{Sr}$ \\
\hline $250884-4$ & & & 102.0 & 333 & 31.3 & 19.5 & 439 \\
\hline $270884-4$ & & & 12.0 & 17 & 32.2 & 27.1 & 428 \\
\hline $270884-11$ & & & 40.0 & 126 & 33.4 & 22.6 & 453 \\
\hline $240884-1$ & & & 36.0 & 147 & 31.3 & 20.7 & 491 \\
\hline $280884-9$ & & & 70.0 & 225 & 35.3 & 17.0 & 410 \\
\hline $101283-1$ & & & 42.0 & 108 & 33.5 & 19.9 & 474 \\
\hline $300976-5$ & 0.20 & 99.92 & 27.8 & 105 & 40.0 & 22.5 & 493 \\
\hline $250884-1$ & & & 64.0 & 219 & 31.8 & 22.3 & 465 \\
\hline $270884-5$ & & & 47.0 & 104 & 35.2 & 26.4 & 426 \\
\hline $290884-4$ & & & 52.0 & 129 & 31.0 & 23.5 & 469 \\
\hline $101275-1$ & 0.13 & 99.82 & 74.3 & 180 & 34.9 & 23.1 & 429 \\
\hline $151282-1$ & & & 73.0 & 185 & 33.6 & 23.3 & 432 \\
\hline $210281-1$ & & & 74.0 & 183 & 33.7 & 23.2 & 433 \\
\hline $191284-1$ & & & 67.0 & 161 & 33.0 & 23.0 & 473 \\
\hline $29076-2$ & & 54.0 & 133 & 33.7 & 22.7 & 457 \\
\hline $240884-3$ & & & 21.0 & 17 & 32.1 & 26.4 & 428 \\
\hline $260884-8$ & & & 35.0 & 88 & 31.4 & 21.1 & 477 \\
\hline $290884-2$ & & & 10.0 & 81 & 11.2 & 50.8 & 160 \\
\hline
\end{tabular}

(CONTINUED)

\begin{tabular}{|l|l|l|l|l|l|}
\hline Sample Numbers & $\mathrm{Zn}$ & $\mathrm{Zr}$ & $\mathrm{V}$ & $\mathrm{Co}$ & $\mathrm{Ga}$ \\
\hline $101275-3$ & 108.1 & 124.0 & 266.0 & 25.6 & 19.2 \\
\hline $151282-2$ & 81.0 & 118.0 & 192.0 & 24.6 & 19.3 \\
\hline $270884-3$ & 80.0 & 106.0 & 222.0 & 35.2 & 19.6 \\
\hline $270976-3$ & 89.1 & 95.1 & 246.0 & 25.0 & 18.6 \\
\hline $280976-1$ & 87.2 & 91.9 & 246.0 & 37.0 & 18.3 \\
\hline $151282-3$ & 101.0 & 114.0 & 312.0 & 26.9 & 19.5 \\
\hline $250884-4$ & 80.0 & 84.0 & 223.0 & 34.9 & 18.7 \\
\hline $270884-4$ & 104.0 & 118.0 & 300.0 & 25.3 & 20.2 \\
\hline $270884-11$ & 88.0 & 97.0 & 254.0 & 28.3 & 18.6 \\
\hline $240884-1$ & 90.0 & 89.0 & 239.0 & 26.6 & 19.6 \\
\hline $280884-9$ & 73.0 & 62.0 & 217.0 & 35.6 & 16.9 \\
\hline $101283-1$ & 85.0 & 84.0 & 246.0 & 28.7 & 19.0 \\
\hline $300976-5$ & 78.7 & 110.0 & 233.0 & 26.8 & 19.8 \\
\hline $250884-1$ & 87.0 & 94.0 & 282.0 & 32.6 & 19.0 \\
\hline $270884-5$ & 99.0 & 119.0 & 282.0 & 31.9 & 19.0 \\
\hline $290884-4$ & 85.0 & 100.0 & 257.0 & 29.2 & 18.9 \\
\hline $101275-1$ & 100.0 & 100.0 & 263.0 & 34.1 & 19.0 \\
\hline $151282-1$ & 95.0 & 99.0 & 268.0 & 33.6 & 19.0 \\
\hline $210281-1$ & 101.0 & 102.0 & 269.0 & 33.8 & 18.7 \\
\hline $191284-1$ & 95.0 & 103.0 & 279.0 & & 18.5 \\
\hline $29076-2$ & 91.0 & 103.0 & 260.0 & 30.9 & 18.9 \\
\hline $240884-3$ & 105.0 & 118.0 & 288.0 & 24.9 & 19.8 \\
\hline $260884-8$ & 84.0 & 96.0 & 239.0 & 25.5 & 19.0 \\
\hline & & & & & \\
\hline
\end{tabular}


(CONTINUED)

\begin{tabular}{|l|l|l|l|l|l|}
\hline Sample Numbers & $\mathrm{Zn}$ & $\mathrm{Zr}$ & $\mathrm{V}$ & Co & Ga \\
\hline $290884-2$ & 101.0 & 347.0 & 12.5 & 2.6 & 18.4 \\
\hline
\end{tabular}

(CONTINUED)

\begin{tabular}{|l|l|l|l|l|l|l|l|}
\hline Sample Numbers & $\mathrm{Rb}$ & $\mathrm{Nb}$ & $\mathrm{Cs}$ & $\mathrm{Ba}$ & $\mathrm{La}$ & $\mathrm{Ce}$ & $\mathrm{Nd}$ \\
\hline $101275-3$ & 24.7 & 3.2 & 2.22 & 285 & 10.60 & 27.8 & 17.0 \\
\hline $151282-2$ & 19.4 & 3.6 & 1.30 & 287 & 10.60 & 25.9 & 15.5 \\
\hline $270884-3$ & 17.8 & 2.3 & 1.70 & 229 & 7.96 & 22.3 & 15.1 \\
\hline $270976-3$ & 15.1 & 2.6 & 1.62 & 200 & 7.74 & 19.5 & 12.0 \\
\hline $280976-1$ & 14.6 & 2.4 & 1.60 & 191 & 7.80 & 19.8 & 12.2 \\
\hline $151282-3$ & 20.4 & 2.8 & 1.40 & 255 & 10.10 & 25.8 & 16.3 \\
\hline $250884-4$ & 12.9 & 1.9 & 1.10 & 182 & 7.32 & 18.7 & 11.9 \\
\hline $270884-4$ & 21.4 & 3.1 & 2.00 & 256 & 9.76 & 26.3 & 16.6 \\
\hline $270884-11$ & 15.5 & 2.4 & 1.30 & 200 & 8.15 & 21.5 & 13.6 \\
\hline $240884-1$ & 14.0 & 2.5 & 1.20 & 196 & 6.80 & 19.0 & 12.1 \\
\hline $280884-9$ & 9.7 & 1.3 & 1.00 & 138 & 4.21 & 12.9 & 8.9 \\
\hline $101283-1$ & 12.2 & 2.9 & 0.90 & 181 & 6.68 & 18.2 & 12.0 \\
\hline $300976-5$ & 14.7 & 2.7 & 1.92 & 217 & 10.20 & 25.3 & 14.5 \\
\hline $250884-1$ & 14.9 & 2.1 & 1.60 & 193 & 8.07 & 21.0 & 13.4 \\
\hline $270884-5$ & 18.7 & 3.4 & 1.60 & 238 & 10.50 & 27.0 & 16.7 \\
\hline $290884-4$ & 15.6 & 2.1 & 1.40 & 209 & 8.18 & 22.2 & 14.3 \\
\hline $101275-1$ & 15.5 & 2.7 & 1.70 & 198 & 7.91 & 22.3 & 14.1 \\
\hline $151282-1$ & 15.5 & 2.0 & & 193 & 8.04 & 21.0 & 14.2 \\
\hline $210281-1$ & 15.7 & 2.6 & 1.30 & 206 & 8.02 & 22.2 & 13.2 \\
\hline $191284-1$ & 15.3 & 3.1 & 1.60 & 202 & 7.77 & 22.4 & 13.9 \\
\hline $29076-2$ & 15.1 & 2.8 & 1.40 & 210 & 8.31 & 21.9 & 13.7 \\
\hline $240884-3$ & 20.8 & 2.8 & 1.70 & 258 & 9.80 & 26.6 & 16.0 \\
\hline $260884-8$ & 14.8 & 2.5 & 1.30 & 211 & 7.74 & 21.2 & 12.8 \\
\hline $290884-2$ & 75.0 & 7.3 & 5.70 & 657 & 25.00 & 59.6 & 31.9 \\
\hline & & & & & & & \\
\hline
\end{tabular}

\section{(CONTINUED)}

\begin{tabular}{|l|l|l|l|l|l|l|l|l|l|}
\hline Sample Numbers & Sm & Eu & Tb & Yb & Lu & Hf & Ta & Pb & Th \\
\hline $101275-3$ & 4.42 & 1.31 & 0.77 & 3.05 & 0.42 & 3.20 & 0.08 & 10.0 & 2.23 \\
\hline $151282-2$ & 3.95 & 1.20 & 0.60 & 2.50 & 0.37 & 2.90 & 0.17 & 12.0 & 1.80 \\
\hline $270884-3$ & 3.92 & 1.21 & 0.55 & 2.42 & 0.36 & 2.90 & & 9.5 & 1.32 \\
\hline $270976-3$ & 3.25 & 1.21 & 0.66 & 2.33 & 0.36 & 2.25 & & 7.0 & 1.74 \\
\hline $280976-1$ & 3.29 & 1.15 & 0.68 & 2.35 & 0.36 & 2.47 & & 8.8 & 1.51 \\
\hline $151282-3$ & 4.32 & 1.28 & 0.72 & 2.66 & 0.36 & 2.80 & 0.16 & 11.0 & 1.70 \\
\hline $250884-4$ & 3.05 & 0.92 & 0.49 & 2.04 & 0.31 & 2.00 & & 9.8 & 1.20 \\
\hline $270884-4$ & 4.14 & 1.26 & 0.56 & 2.83 & 0.40 & 3.10 & & 11.7 & 2.00 \\
\hline $270884-11$ & 3.75 & 1.16 & 0.55 & 2.25 & 0.34 & 2.50 & & 9.3 & 1.50 \\
\hline $240884-1$ & 3.28 & 1.06 & 0.57 & 1.99 & 0.31 & 2.20 & & 11.8 & 1.30 \\
\hline $280884-9$ & 2.38 & 0.85 & 0.40 & 1.41 & 0.22 & 1.70 & & 5.4 & 0.60 \\
\hline $101283-1$ & 3.06 & 1.07 & 0.47 & 1.91 & 0.30 & 2.10 & & 8.0 & 1.00 \\
\hline
\end{tabular}


(CONTINUED)

\begin{tabular}{|l|l|l|l|l|l|l|l|l|l|}
\hline Sample Numbers & Sm & Eu & Tb & Yb & Lu & Hf & Ta & Pb & Th \\
\hline $300976-5$ & 3.63 & 1.24 & 0.65 & 2.40 & 0.35 & 2.60 & & 9.9 & 1.42 \\
\hline $250884-1$ & 3.68 & 1.13 & 0.78 & 2.37 & 0.36 & 2.60 & & 10.3 & 1.20 \\
\hline $270884-5$ & 4.35 & 1.27 & 0.63 & 2.77 & 0.40 & 2.90 & & 12.4 & 2.00 \\
\hline $290884-4$ & 3.69 & 1.15 & 0.54 & 2.09 & 0.34 & 2.50 & & 9.7 & 1.30 \\
\hline $101275-1$ & 3.59 & 1.14 & 0.66 & 2.40 & 0.36 & 2.55 & & 7.9 & 1.50 \\
\hline $151282-1$ & 3.78 & 1.14 & 0.69 & 2.39 & 0.37 & 2.60 & 0.12 & 10.2 & 1.20 \\
\hline $210281-1$ & 3.68 & 1.15 & 0.50 & 2.41 & 0.37 & 2.60 & 0.15 & 10.8 & 1.10 \\
\hline $191284-1$ & 3.70 & 1.16 & 0.51 & 2.25 & 0.34 & 2.50 & 0.11 & 13.7 & 1.10 \\
\hline $29076-2$ & 3.71 & 1.17 & 0.66 & 2.18 & 0.31 & 2.40 & & 11.0 & 1.40 \\
\hline $240884-3$ & 4.22 & 1.30 & 0.75 & 2.62 & 0.41 & 3.30 & 0.14 & 9.5 & 1.80 \\
\hline $260884-8$ & 3.51 & 1.06 & 0.66 & 2.22 & 0.34 & 2.30 & 0.11 & 9.4 & 1.20 \\
\hline $290884-2$ & 7.51 & 1.34 & 1.26 & 5.84 & 0.88 & 8.60 & & 27.0 & 6.60 \\
\hline
\end{tabular}


2. The previous results of the major and trace element compositions of the basaltic cones (SEC) around Villarrica (Hickey - Vargas et al., 1989) (Table 1 - 2): 
Table 1-2

\begin{tabular}{|l|l|l|l|l|l|l|l|l|}
\hline Cones & CR-1 & CR-2 & CA-1 & CA-2 & PI -1 & HM-1 & HL-1 & HL-2 \\
\hline $\mathrm{SiO}_{2}$ & 51.79 & 50.91 & 50.72 & 50.95 & 50.87 & 51.84 & 51.48 & 51.93 \\
\hline $\mathrm{TiO}_{2}$ & 1.03 & 1.16 & 1.10 & 1.13 & 1.23 & 1.25 & 1.16 & 1.08 \\
\hline $\mathrm{Al}_{2} \mathrm{O}_{3}$ & 18.05 & 19.50 & 17.66 & 17.92 & 18.08 & 18.48 & 17.75 & 17.57 \\
\hline $\mathrm{Fe}, \mathrm{O}_{3}$ & 9.24 & 9.44 & 9.38 & 9.28 & 9.40 & 9.70 & 9.00 & 9.03 \\
\hline $\mathrm{MnO}$ & 0.15 & 0.15 & 0.14 & 0.14 & 0.15 & 0.17 & 0.16 & 0.16 \\
\hline $\mathrm{MgO}$ & 6.21 & 4.98 & 7.10 & 6.72 & 6.41 & 4.73 & 6.24 & 6.56 \\
\hline $\mathrm{CaO}$ & 9.13 & 9.15 & 9.61 & 9.05 & 8.40 & 8.95 & 9.18 & 9.21 \\
\hline $\mathrm{Na}, \mathrm{O}$ & 3.38 & 3.48 & 3.26 & 3.54 & 3.30 & 3.63 & 3.27 & 3.03 \\
\hline $\mathrm{K}_{2} \mathrm{O}$ & 0.93 & 0.94 & 0.66 & 0.73 & 1.21 & 0.86 & 1.13 & 1.08 \\
\hline $\mathrm{P}_{2} \mathrm{O}_{5}$ & 0.39 & 0.30 & 0.27 & 0.32 & 0.43 & 0.45 & 0.38 & 0.34 \\
\hline $\mathrm{H}_{2} \mathrm{O}+$ & 0.21 & 0.25 & 0.26 & 0.26 & 0.30 & 0.60 & 0.19 & 0.24 \\
\hline
\end{tabular}

(CONTINUED)

\begin{tabular}{|l|l|l|l|l|l|l|l|l|}
\hline Cones & CR-1 & CR-2 & CA-1 & CA-2 & PI -1 & HM-1 & HL-1 & HL-2 \\
\hline $\mathrm{Sc}$ & 25.4 & 24.6 & 29.0 & 27.0 & 24.0 & 29.0 & 26.5 & 29.6 \\
\hline $\mathrm{V}$ & 184.0 & 227.0 & 201.0 & 194.0 & 172.0 & 204.0 & 192.0 & 196.0 \\
\hline $\mathrm{Cr}$ & 96 & 88 & 199 & 198 & 161 & 46 & 157 & 189 \\
\hline $\mathrm{Co}$ & 31.3 & 27.7 & 36.0 & 34.0 & 34.0 & 29.0 & 30.5 & 34.7 \\
\hline $\mathrm{Ni}$ & 60.0 & 18.0 & 68.0 & 68.0 & 77.0 & 27.0 & 69.0 & 64.0 \\
\hline $\mathrm{Zn}$ & 88.0 & 72.0 & 79.0 & 71.0 & 88.0 & 91.0 & 78.0 & 84.0 \\
\hline $\mathrm{Ga}$ & 20.1 & 19.8 & 17.7 & 18.4 & 18.6 & 20.0 & 17.8 & 18.7 \\
\hline $\mathrm{K}$ & 7792 & 7880 & 5540 & 6350 & 10202 & 7122 & 9594 & 9815 \\
\hline $\mathrm{Rb}$ & 11.0 & 9.1 & 9.1 & 10.1 & 23.0 & 13.5 & 28.2 & 27.6 \\
\hline $\mathrm{Cs}$ & 0.52 & 0.29 & 0.75 & 0.68 & 0.95 & 0.73 & 1.43 & 1.46 \\
\hline $\mathrm{Sr}$ & 851 & 911 & 715 & 810 & 706 & 633 & 594 & 583 \\
\hline $\mathrm{Ba}$ & 382 & 300 & 255 & 259 & 430 & 322 & 362 & 358 \\
\hline $\mathrm{Y}$ & 21.3 & 19.3 & 18.6 & 18.2 & 22.8 & 23.8 & 21.4 & 21.9 \\
\hline $\mathrm{Zr}$ & 136.0 & 104.0 & 100.0 & 89.0 & 168.0 & 161.0 & 150.0 & 144.0 \\
\hline $\mathrm{Nb}$ & 5.5 & 4.1 & 4.3 & 3.3 & 10.0 & 7.4 & 8.7 & 7.3 \\
\hline $\mathrm{Hf}$ & 2.90 & 2.40 & 2.50 & 2.30 & 3.70 & 3.50 & 3.10 & 3.20 \\
\hline $\mathrm{Th}$ & 4.40 & 3.50 & 2.10 & 2.60 & 3.10 & 2.30 & 3.50 & 3.30 \\
\hline $\mathrm{La}$ & 22.30 & 15.80 & 13.70 & 13.40 & 21.90 & 21.50 & 18.00 & 17.00 \\
\hline $\mathrm{Ce}$ & 51.5 & 38.6 & & & & & 42.4 & 37.1 \\
\hline $\mathrm{Nd}$ & 26.5 & 21.0 & 18.4 & 18.6 & 25.9 & 25.2 & 21.1 & 18.8 \\
\hline $\mathrm{Sm}$ & 5.29 & 4.48 & 4.08 & 4.14 & 5.42 & 5.34 & 4.36 & 4.23 \\
\hline $\mathrm{Eu}$ & 1.49 & 1.48 & 1.36 & 1.41 & 1.72 & 1.70 & 1.37 & 1.46 \\
\hline $\mathrm{Tb}$ & 0.69 & 0.68 & 0.61 & 0.55 & 0.67 & 0.78 & 0.66 & 0.72 \\
\hline $\mathrm{Yb}$ & 2.20 & 1.96 & 1.90 & 2.00 & 2.20 & 2.40 & 2.19 & 2.13 \\
\hline $\mathrm{Lu}$ & 0.32 & 0.29 & 0.29 & 0.30 & 0.33 & 0.38 & 0.32 & 0.35 \\
\hline
\end{tabular}


3. Previous results of the radiogenic isotopes of the SEC samples. Samples marked with a "*" were reported in Hickey - Vargas et al. 1989, and other samples were analyzed at DTM, Carnegie Institute of Washington by Dr. Rosemary Hickey - Vargas (Table 1-3): 
Table 1 -3

\begin{tabular}{|c|c|c|c|c|c|c|}
\hline Sample Number & Location & ${ }^{87} \mathrm{Sr} /{ }^{86} \mathrm{Sr}$ & ${ }^{143} \mathrm{Nd} / /^{144} \mathrm{Nd}$ & ${ }^{206} \mathrm{~Pb} / /^{204} \mathrm{~Pb}$ & ${ }^{207} \mathrm{~Pb} /{ }^{204} \mathrm{~Pb}$ & ${ }^{208} \mathrm{~Pb} /{ }^{204} \mathrm{~Pb}$ \\
\hline 090594-liticos & El Estadio & 0.70342 & 0.512967 & 18.566 & 15.595 & 38.432 \\
\hline 090594-Bomba & El Estadio & 0.70340 & 0.512950 & 18.594 & 15.590 & 38.407 \\
\hline 110194-01 & Huelemolle & 0.70393 & 0.512848 & 18.569 & 15.613 & 38.499 \\
\hline $110194-03$ & Huelemolle & 0.70393 & 0.512784 & 18.549 & 15.591 & 38.429 \\
\hline $120194-01$ & Huelemolle & 0.70391 & 0.512820 & 18.557 & 15.602 & 38.453 \\
\hline 120194-02 & Huelemolle & 0.70388 & 0.512827 & 18.567 & 15.605 & 38.477 \\
\hline * L84 ( HM -1) & Huelemolle & $0.70392 \pm 3$ & $0.512824 \pm 18$ & & & \\
\hline *L81 ( CA -1) & Caburgua & $0.70372 \pm 3$ & $0.512854 \pm 18$ & & & \\
\hline${ }^{*} \mathrm{~L} 82(\mathrm{CA}-2)$ & Caburgua & $0.70371 \pm 3$ & $0.512866 \pm 18$ & 18.591 & 15.593 & 38.471 \\
\hline 150194-01 & Caburgua & 0.70374 & 0.512852 & 18.590 & 15.595 & 38.456 \\
\hline 130194-02 & Llizan & 0.70412 & 0.512832 & 18.292 & 15.594 & 38.136 \\
\hline 140194-01 & San Jorge & 0.70396 & 0.512909 & 18.567 & 15.626 & 38.522 \\
\hline 140194-04 & San Jorge & 0.70395 & 0.512910 & 18.594 & 15.629 & 38.560 \\
\hline 140194-07 & San Jorge & 0.70397 & 0.512888 & 18.576 & 15.608 & 38.488 \\
\hline${ }^{*} \mathrm{~L} 16(\mathrm{CR}-1)$ & Cerro Redondo & $0.70363 \pm 3$ & $0.512850 \pm 18$ & & & \\
\hline${ }^{*} \mathrm{~L} 17(\mathrm{CR}-2)$ & Cerro Redondo & $0.70361 \pm 3$ & $0.512865 \pm 18$ & 18.582 & 15.594 & 38.441 \\
\hline${ }^{*} \mathrm{~L} 20(\mathrm{HL}-1)$ & Huililco & $0.70400 \pm 3$ & $0.512823 \pm 15$ & & & \\
\hline${ }^{*} \mathrm{~L} 24(\mathrm{HL}-2)$ & Huililco & $0.70397 \pm 3$ & $0.512812 \mathrm{v} 18$ & 18.622 & 15.599 & 38.449 \\
\hline 220194-03L & C. Pirocl. & 0.70401 & 0.512836 & 18.519 & 15.590 & 38.398 \\
\hline * L83 ( PI - 1) & Pichares & $0.70391 \pm 3$ & $0.512815 \pm 19$ & & & \\
\hline
\end{tabular}


4. Previous published $\mathrm{B}-\mathrm{Be}-\mathrm{Li}$ and $\mathrm{U}$ - Series results in this area (Table $1-4$ ): 
Table 1-4

\begin{tabular}{|c|c|c|c|}
\hline Sample Numbers & Location & Boron (ppm) & References \\
\hline $260186-2$ & Villarrica & 32.0 & \multirow{13}{*}{$\begin{array}{l}\text { Leeman et al. } \\
\text { (unpublished) }\end{array}$} \\
\hline $151282-2$ & Villarrica & 24.0 & \\
\hline $151282-3$ & Viilarrica & 27.0 & \\
\hline $101275-3(\mathrm{~L} 25)$ & Villarrica & $34.0,29.0$ & \\
\hline $101275-1$ & Villarrica & 25.0 & \\
\hline 280976-1 (L21) & Villarrica & 23.0 & \\
\hline 191284-1 & Villarrica & 27.0 & \\
\hline CA1 & Caburgua & 10.0 & \\
\hline PI-1 & Pichares & 8.2 & \\
\hline HM-1 & Huelemolle & 11.0 & \\
\hline HL-1 & Huililco & 10.0 & \\
\hline CR-1 & Cerro Redondo & 9.0 & \\
\hline CR-2 & Cerro Redondo & 7.1 & \\
\hline
\end{tabular}

(CONTINUED)

\begin{tabular}{|c|c|c|c|c|c|c|}
\hline $\begin{array}{l}\text { Sample } \\
\text { Numbers }\end{array}$ & Location & $\mathrm{U}(\mathrm{ppm})$ & $\mathrm{Th}(\mathrm{ppm})$ & ${ }^{238} \mathrm{U} / /^{232} \mathrm{Th}$ & ${ }^{238} \mathrm{U} / /^{230} \mathrm{Th}$ & $\mathrm{SiO}_{2}$ \\
\hline $101275-1$ & $\begin{array}{l}\text { Villarrica } \\
(1971)\end{array}$ & 0.447 & 1.24 & 1.09 & 1.28 & 52.5 \\
\hline $191284-1$ & $\begin{array}{l}\text { Villarrica } \\
(1984)\end{array}$ & 0.429 & 1.19 & 1.09 & 1.24 & 52.3 \\
\hline $\begin{array}{l}\text { Sample } \\
\text { Numbers }\end{array}$ & \multicolumn{2}{|l|}{${ }^{10} \mathrm{Be}\left({ }^{*} 10^{6} \mathrm{a} / \mathrm{g}\right)$} & ${ }^{10} \mathrm{Be} /{ }^{\prime} \mathrm{Be}\left({ }^{*} 10^{-11}\right)$ & ${ }^{87} \mathrm{Sr} /{ }^{86} \mathrm{Sr}$ & \multicolumn{2}{|c|}{ References } \\
\hline $101275-1$ & \multicolumn{2}{|l|}{2.1} & 5.3 & $0.70404 \pm 2$ & \multirow{2}{*}{\begin{tabular}{|l|} 
Sigmarsson \\
$(1990)$
\end{tabular}} & \multirow{2}{*}{ et al. } \\
\hline $191284-1$ & & & & $0.70403 \pm 2$ & & \\
\hline
\end{tabular}

\section{(CONTINUED)}

\begin{tabular}{|c|c|c|c|c|}
\hline Location & $\begin{array}{l}\text { Sample } \\
\text { Numbers }\end{array}$ & ${ }^{10} \mathrm{Be}\left({ }^{*} 10^{6} \mathrm{a} / \mathrm{g}\right)$ & ${ }^{10} \mathrm{Be} /{ }^{\beta} \mathrm{Be}\left({ }^{*} 10^{-11}\right)$ & References \\
\hline Villarrica (Prehistoric) & $280976-1$ & 2.1 & 4.0 & \multirow{4}{*}{$\begin{array}{l}\text { Morris and Tera } \\
\text { (1989) / } \\
\text { Morris et al. } \\
(1990)\end{array}$} \\
\hline Villarrica (1948) & $261185-2$ & 2.9 & 6.4 & \\
\hline Villarrica (1971) & $101275-1$ & 2.1 & 5.3 & \\
\hline Villarrica (1985) & $241185-3$ & 2.3 & 4.0 & \\
\hline
\end{tabular}




\section{Appendix 2 Sample locations and detailed sample descriptions}

1. Sample locations

The following descriptions of sample locations were translated by PI from the notes taken originally in Spanish by Dr. Lopez - Escobar (Table 2-1): 
Table 2 - 1

\begin{tabular}{|c|c|c|c|}
\hline Sample & Lab Code & Cone & Places of Collection \\
\hline $010494-1 \mathrm{~A}$ & & RUCAPILLAN & \\
\hline $010494-1 \mathrm{~B}$ & & RUCAPILLAN & \\
\hline $\begin{array}{l}090594- \\
\text { LITICOS }\end{array}$ & MEC-12 & EL ESTADIO & \\
\hline $\begin{array}{l}090594- \\
\text { BOMBA } \\
\end{array}$ & MEC-9 & EL ESTADIO & \\
\hline $110194-01$ & MEC-1 & HUELEMOLLE & Near the River Pucon, Southern Huelemolle or Los Nevados? \\
\hline $110194-02$ & & HUELEMOLLE & At Farm Tomas Pollak, Central Huelemolle \\
\hline $110194-03$ & MEC-10 & HUELEMOLLE & At Farm Tomas Pollak, Central Huelemolle \\
\hline $120194-01$ & MEC-2 & HUELEMOLLE & $\begin{array}{l}3 \mathrm{~km} \text { from the intersection of Road Pichares and Caburgua, } \\
\text { Northern Huelemolle }\end{array}$ \\
\hline $120194-02$ & MEC-8 & HUELEMOLLE & $\begin{array}{l}100 \mathrm{~m} \text { before the west entrance of Pichares, Northern or } \\
\text { Central Huelemolle }\end{array}$ \\
\hline $120194-03$ & & HUELEMOLLE & \begin{tabular}{|l}
$\begin{array}{l}\text { Westmost of the stream front, Northern or Central } \\
\text { Huelemolle }\end{array}$ \\
\end{tabular} \\
\hline $120194-4 \mathrm{~A}$ & & CABURGUA & $\begin{array}{l}\text { Cone at the west shore of Lake Caburgua, Juvenile bombs in } \\
\text { Pyroclastic materials }\end{array}$ \\
\hline 120194-4B & & CABURGUA & $\begin{array}{l}\text { Cone at the west shore of Lake Caburgua, Juvenile bombs in } \\
\text { Pyroclastic materials }\end{array}$ \\
\hline $120194-4 \mathrm{C}$ & & CABURGUA & $\begin{array}{l}\text { Cone at the west shore of Lake Caburgua, Juvenile bombs in } \\
\text { Pyroclastic materials }\end{array}$ \\
\hline $120194-05$ & & CABURGUA & $600 \mathrm{~m}$ north of the previous cone, shore of Lake Caburgua \\
\hline $130194-02$ & MEC-3 & LLIZAN & Southern slope of Volcano Quetrupillan \\
\hline $130194-03$ & & LLIZAN & Southern slope of Volcano Quetrupillan \\
\hline 140194-01 & MEC-4 & SAN JORGE & $1 \mathrm{~km}$ west of Lake San Jorge \\
\hline 140194-02 & & SAN JORGE & $2.5 \mathrm{~km}$ west of Lake San Jorge, probably the same lava \\
\hline 140194-03 & & SAN JORGE & $3 \mathrm{~km}$ west of Lake San Jorge, probably the same lava \\
\hline 140194-04 & MEC-11 & SAN JORGE & $4 \mathrm{~km}$ west of Lake San Jorge, probably the same lava \\
\hline $140194-5 A$ & & SAN JORGE & $\begin{array}{l}\text { At the same level, } 1 \mathrm{~km} \text { west of the intersection of Road } \\
\text { Relicura and San Jorge }\end{array}$ \\
\hline 140194-5B & & \begin{tabular}{|l|} 
SAN JORGE?- \\
RELICURA?
\end{tabular} & $\begin{array}{l}\text { Shore of the River Relicura or San Jorge, the same location as } \\
\text { the previous sample }\end{array}$ \\
\hline $140194-06$ & & RELICURA & Road Relicura \\
\hline 140194-07 & MEC-7 & $\begin{array}{l}\text { SAN JORGE?- } \\
\text { RELICURA? }\end{array}$ & $1 \mathrm{~km}$ west of the intersection of Road Relicura and San Jorge \\
\hline $140194-7 \mathrm{~B}$ & & $\begin{array}{l}\text { SAN JORGE?- } \\
\text { RELICURA? }\end{array}$ & $3 \mathrm{~km}$ west of the intersection of Road Relicura and San Jorge \\
\hline 140194-08 & & $\begin{array}{l}\text { LAVAS MAS } \\
\text { ANTIGUAS }\end{array}$ & $4 \mathrm{~km}$ west of the intersection of Road Relicura and San Jorge \\
\hline 140194-09 & & $\begin{array}{l}\text { CERRO } \\
\text { REDONDO }\end{array}$ & $5 \mathrm{~km}$ west of the intersection of Road Relicura and San Jorge \\
\hline 140194-10 & & $\begin{array}{l}\text { CERRO } \\
\text { REDONDO }\end{array}$ & $7 \mathrm{~km}$ west of the intersection of Road Relicura and San Jorge \\
\hline 140194-11 & & $\begin{array}{l}\text { L. } \quad+\quad \text { ANT. } \\
\text { C.REDONDO }\end{array}$ & $8 \mathrm{~km}$ west of the intersection of Road Relicura and San Jorge \\
\hline 150194-01 & MEC-5 & CABURGA & Playa Blanca \\
\hline $150194-02$ & & CABURGA & Interior of the cone (second cone) \\
\hline 150194-03 & & CABURGA & Interior of the cone (third cone, Caballo Blanco) \\
\hline
\end{tabular}


(CONTINUED)

\begin{tabular}{|l|l|l|l|}
\hline Sample & Lab Code & Cone & Places of Collection \\
\hline $150194-04$ & & CABURGA & Final cone, taken at the outcrop located at the sidewalk \\
\hline $150194-5 \mathrm{~A}$ & & $\begin{array}{l}\text { LA BARDA } \\
\text { (BOMBA) }\end{array}$ & \\
\hline $150194-5 \mathrm{~B}$ & & $\begin{array}{l}\text { LA BARDA } \\
\text { (BOMBA) }\end{array}$ & \\
\hline $150194-06$ & & $\begin{array}{l}\text { LA BARDA } \\
\text { (LAVA) }\end{array}$ & \\
\hline $150194-07$ & & $\begin{array}{l}\text { HUELEMOLLE } \\
\text { CTR CATA }\end{array}$ & \\
\hline
\end{tabular}




\section{Hand species descriptions}

\subsection{The SEC samples collected from different eruptive centers:}

120194-02 (Huelemolle) is a mixed white - dark gray and black - colored, porphyritic basalt with about $5 \%$ vesicles. The light (white) - colored minerals are dominantly plagioclase (1-2mm), occupying about $15-20 \%$ of the total volume. The dark - colored part is mainly composed of matrix, with scattered olivine phenocrysts $(1-2 \mathrm{~mm})$.

140194-01 (San Jorge) is dark gray to black - colored, porphyritic with $<5 \%$ vesicles. The color of the fine - grained part is darker, occupying about $60 \%$ of the total volume. In the phenocryst phase, olivine (1-3mm, yellowish green) is the dominant component $(>90 \%)$.

150194-03 (Caburga) is dark - gray to black - colored, porphyritic, and vesicle abundant. Those vesicles are big (up to $5 \mathrm{~mm}$ ), and consisting of about $20-30 \%$ of the total volume. The major part of the rock is dark - colored groundmass (fine - grained), and phenocrysts are mainly olivine (yellowish green), plagioclase (white) and cpx.

150194-06 (La Barda) is dark gray- colored, fine - grained basalt with $<5 \%$ vesicles. The $80-85 \%$ of the total volume is plain groundmass, with $10-15 \%$ of phenocrysts $(<1 \mathrm{~mm})$ that are mainly olivine $(>90 \%)$.

110194-03 (Huelemolle) is black - colored, vesicle - abundant (20-30\%), and porphyritic. Fine - grained groundmass comprises about $50 \%$ of the total volume, and the phenocrysts are olivine (up to several $\mathrm{mm}$ ), and plagioclase.

279765 (L20) (Huililco) is dark gray to black - colored, porphyritic and with 5\% vesicles. The fine - grained groundmass comprises $80 \%$ of the total volume, and the phenocrysts (1-3mm) are mainly plagioclase, olivine and cpx.

269762 (L16) (Cerro Redondo) is badly - weathered on the surface. The sample is gray colored, porphyritic and almost vesicle - free. The phenocrysts are $<20 \%$, including olivine, cpx and plagioclase.

(10)1275-1(L24) (Huililco 1971 flow) is dark gray to black - colored, porphyritic and with about 5\% vesicles. The surface of the rock is severely weathered. Plain matrix comprises the darker part, occupying about $60 \%$ of the total volume. Phenocrysts are up to $3 \mathrm{~mm}$ long, with plagioclase dominant (light colored) and some amount of olivine / cpx.

127515 ( $L 81$ ) (Caburga) is brown - colored, fine - grained basalt with little amount of vesicles. More than $90 \%$ of the total volume is composed of plain groundmass, and the surface of the rock is pretty much weathered. Phenocrysts are almost invisible, with livine dominant and minor amount of plagioclase (light colored). 
$R u-1$ (Rucapillan) is a mixed porphyritic / aphyric basalt which was severely weathered. Its porphyritic part is dark gray - colored, and contains about $15-20 \%$ vesicles, $20-30 \%$ phenocrysts and plain matrix. Phenocrysts $(1-3 \mathrm{~mm})$ are mainly composed of cpx and olivine. The aphyric part of the rock is darker - colored (black), very fine - grained and vesicle - free. The groundmass occupys more than $95 \%$ of the total volume, and the rest of the rock is cpx and olivine phenocrysts (up to 1-2mm).

192811 (?) is mixed white - and - dark gray - colored, porphyritic and contains about 5\% vesicles. About $50-60 \%$ of the total volume is plain groundmass (dark colored). Phenocrysts are big (up to several $\mathrm{mm}$ ), which are mainly composed of plagioclase (light - colored) and some amount of olivine / cpx.

\subsection{V.Villarrica samples:}

18281-1 (V3-9) is well - preserved, very porphyritic and vesicle - abundant. The vesicles of it are up to $1 \mathrm{~cm}$ in diameter and comprise about $50 \%$ of the total volume. The rock is black - and - white - colored, the darker part is the very - fined groundmass and the lighter - colored part is composed of mainly plagioclase (mineral crystals are up to $1 \mathrm{~cm}$ in length).

151282-2 (VI-2) is dark - gray colored, fine - grained and almost vesicle - free. The 70$80 \%$ of the total volume is composed of matrix, and the phenocrysts are mainly plagioclase (1-2mm), olivine and cpx.

$151282-3(V 2-3)$ is black - colored, fine - grained and with little amount of vesicles. The major part of the rock is dark - colored groundmass, with scattered plagioclase and olivine and cpx crystals $(5 \%, 1-2 \mathrm{~mm})$. The surface of the rock is weathered to some extent (yellow and earthy).

12759 ( $L 28)$ is very - black colored, porphyritic and contains about $10 \%$ vesicles. The darker - colored part of the rock is fine - grained groundmass (70\%), and the phenocrysts (up to several $\mathrm{mm}$ ) are plagioclase, olivine and cpx.

12753 (L25) is black - colored, fine - grained and almost vexsicle - free. Less than 5\% of the total volume is composed of lighter - colored phenocrysts $(<1 \mathrm{~mm})$, dominantly plagioclase. The rest of the rock is darker - colored plain matrix.

289761 ( $L 21$ ) is dark gray to black - colored, porphyritic and consists of 10-15\% vesicles. Matrix occupys about $50 \%$ of the total volume, and the phenocrysts are mainly plagioclase, olivine and cpx.

309765 (L23) is dark gray to black - colored, porphyritic and with very little amount of vesicles. Very fine - grained groundmass occupys about $50-60 \%$ of the total volume, and the phenocrysts $(0.5-1 \mathrm{~mm})$ are plagioclase, olivine and cpx. 


\title{
3. Microscopic descriptions of the V.Villarrica and SEC samples
}

\author{
3.1 V. Villarrica:
}

\section{V.Villlrrica VII:}

$191281-1$ contains about $93 \%$ of groundmass, $1 \%$ of vesicles and $6 \%$ of phenocrysts. The groundmass is composed of microcrystals, with plagioclase dominant $(60 \%)$. Plagioclase has the diabasic intersertal texture and is randomly oriented. The phenocrysts are plagioclase dominant $(95 \%)$, euhedral and rarely broken. The rest of the phenocrysts are olivine and cpx, which are subhedral and relatively smaller. In some cases the big plagioclase crystals (up to $2 \mathrm{~mm}$ ) form in clusters and poikilitically entrain the cpx and olivine crystals.

$180281-1$ is porphyritic, with about $80 \%$ of groundmass, $10 \%$ of phenocrysts and $10 \%$ of vesicles. Among the phenocrysts, plagioclase is the dominant component (95\%), which is euhedral, ranges between $0.2 \mathrm{~mm}-2.5 \mathrm{~mm}$ and often forms in clusters or twinnings. The rest is cpx + olivine (5\%), and minor magnetite / spinel. The groundmass is fairly black and fine, plagioclase dominant and forms diabasic texture.

L21 contains $10 \%$ of vesicles, $70 \%$ of groundmass and $20 \%$ of phenocrysts. The groundmass is plagioclase dominant and forms diabasic textures. The phenocrysts have a variety of grain size (up to several $\mathrm{mm}$ ), among which the plagioclase is occupying about $95 \%$ of the total volume, cpx and olivine combine for $5 \%$ (ol > cpx), and magnetite / spinel is less than $0.5 \%$. The plagioclases are very euhedral, with some of them are clean while the other of them are resorbed.

$151282-3$ contains only few vesicles, $99-100 \%$ of groundmass and $0.25 \%$ of phenocrysts (almost aphyric). The groundmass is fine, black and comprises trachytic micro - crystals of plagioclase. The phenocrysts are mainly $(\sim 40 \%)$ plagioclase $(0.2-0.5 \mathrm{~mm})$, olivine $(\sim$ $30 \%)(<3 \mathrm{~mm})$ and cpx $(\sim 30 \%)$.

\section{V.Villarrica VIII:}

$L 23$ is composed of about $96-97 \%$ of groundmass, with plagioclase: cpx + olivine $\approx 2: 1$ and forms the diabasic textures. The phenocrysts are mainly plagioclase $(\sim 99 \%)$, with minor cpx, a little olivine and tiny amount of spinel. The plagioclase phenocrysts are subhedral, range between $0.5-2.5 \mathrm{~mm}$, and show clear resorption textures.

\section{V.Villarrica 1971:}

L28 contains about $92 \%$ of the groundmass, which is dominantly plagioclase, forms trychatically. The phenocrysts are not equal - sized $(0.2-2.5 \mathrm{~mm})$, with plagioclase: olivine: $\mathrm{cpx} \approx 10: 1: 1$, and $<1 \%$ magnetite or spinel. The phenocrysts are euhedral subhedral, and plagioclase crystals have resorption textures and sometimes form in 
clusters / twinnings. In some cases plagioclase and cpx crystals form contacted to each
other.

$210281-1$ contains about $1 \%$ of vesicles, $94-95 \%$ of groundmass and $5 \%$ of phenocrysts. The groundmass is mainly plagioclase which is very trachytic, with minor olivine and cpx (diabasic). The phenocrysts are euhedral to subhedral, range between $0.2-2.5 \mathrm{~mm}$, with plagioclase: olivine: $\mathrm{cpx} \approx 10: 2: 1$, and spinel $<0.5 \%$. The plagioclases are resorbed and sometimes occur in clusters.

\subsection{SEC:}

\section{$\underline{\text { San Jorge: }}$}

$140194-01$ contains $1 \%$ of vesicles, $93 \%$ of groundmass and $6 \%$ of phenocrysts. In the groundmass the micro - crystals of plagioclase: plain matrix $\approx 4: 6$, and the plagioclase shows very trachytic textures. The phenocrysts are mainly olivine $(90 \%)$, cpx $(10 \%)$, and spinel $(<0.5 \%)$. The phenocryts are basically subhedral to euhedral and some of them are in clusters. Some large crystals are broken.

\section{Rucapillan and El Estadio:}

Rucapillan $(R u-1)$ is a sample which is composed of two parts (SEM photo 2.3.1):

1. The porphyritic part: Vesicles are small and occupy about $15 \%$ of the total volume, and the rest of the sample is composed of $80 \%$ of groundmass and $5 \%$ of phenocrysts. The groundmass contains mainly micro - crystals of plagioclase (70-80\%), with diabasic textures. Cpx and minor olivine comprise the majority of the phenocrysts, about $0.5-$ $1 \mathrm{~mm}$, euhedral and some of them are broken. Spinel / magnetite occupys $<5 \%$ of the total phenocryst volume, and are always included in olivine or cpx crystals. There is also a xenolith with reaction rim of quartz + glass surrounded by cpx. 


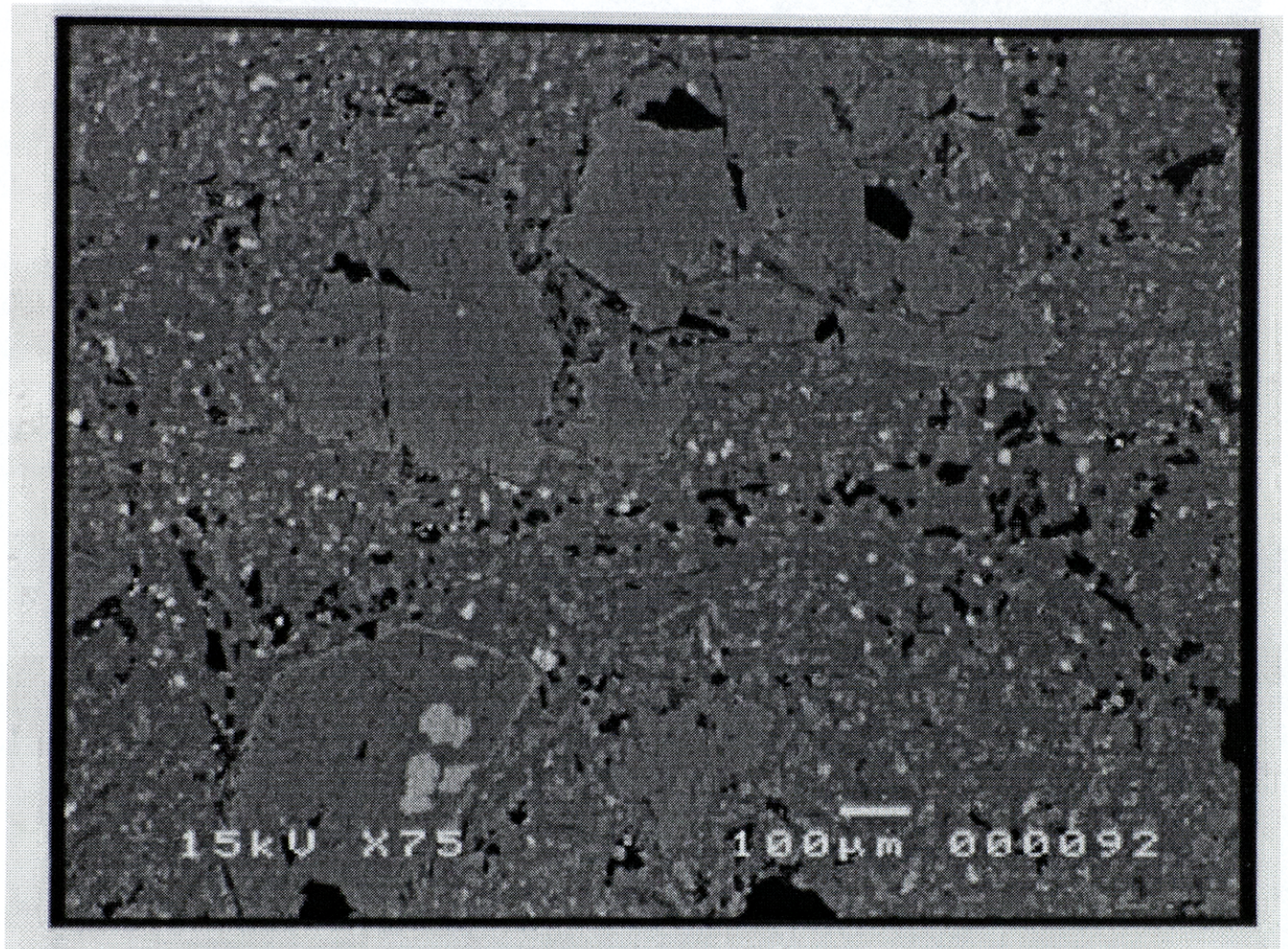

Photo 2 - 1a The porphyritic part of the Rucapillan sample (x 75) (taken by the Scanning Electronic Microprobe of FIU Geology) 

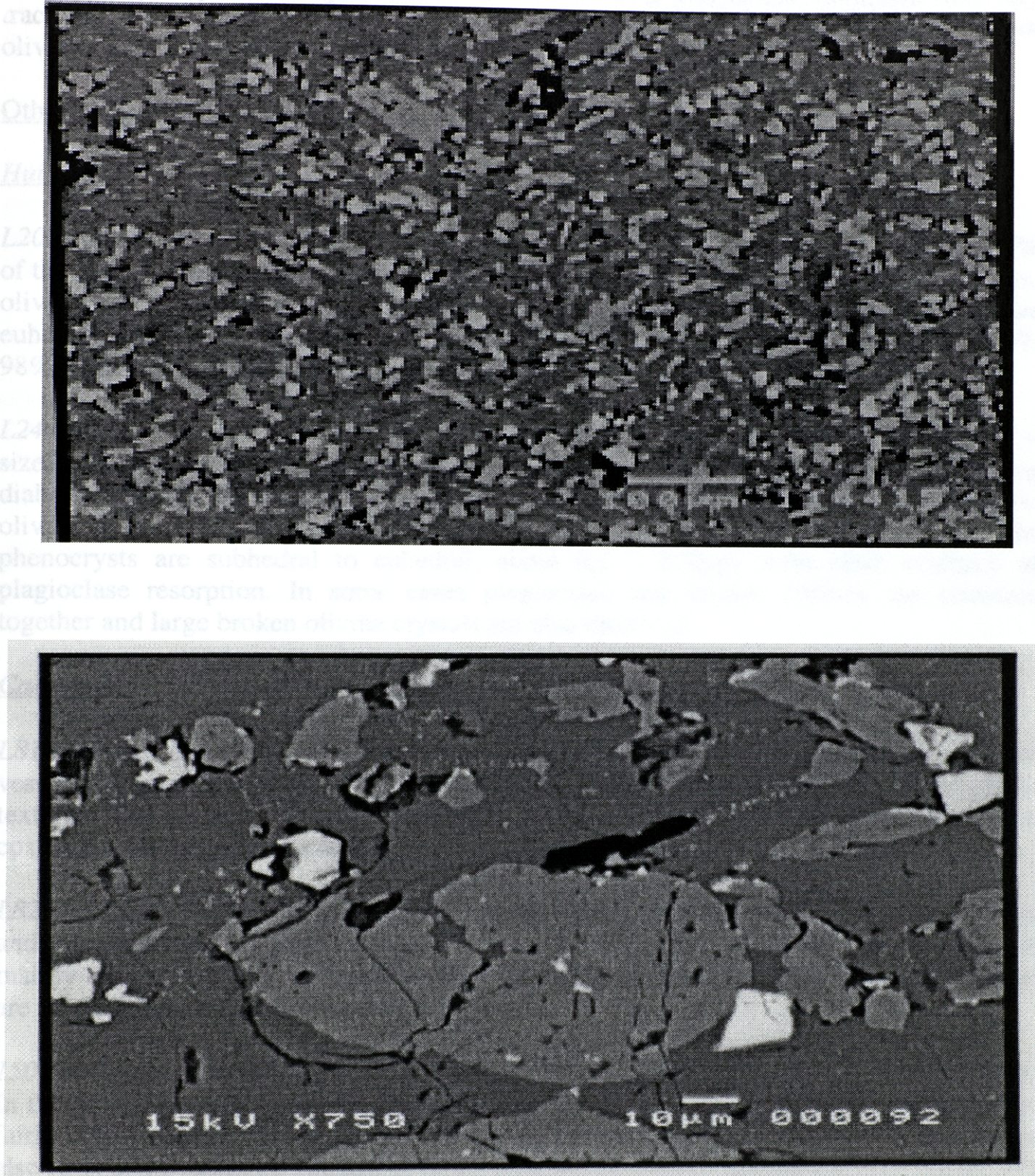

Photo 2 - 1b The aphyric part of the Rucapillan sample (Upper - x 150; Lower - x 750) (taken by the Scanning Electronic Microprobe of FIU Geology) 
2. The aphyric part: The groundmass is $>99 \%$, with plagioclase dominant and very trachytic. No vesicles. The phenocrysts are $\sim 0.25 \%$, with mainly scattered cpx, minor olivine (not equal - sized) and little amount of spinel / magnetite.

Other SECs (Huelemolle, Caburgua, Huililco, La Barda, etc):

\section{Huililco:}

L20 is composed of all visible crystals (no plain matrix). Phenocrysts occupy about $2.5 \%$ of the total volume, among which the proportion of different mineral crystals is plag: cpx: olivine $\approx 6: 1: 3$, with a little magnetite / spinel in olivine crystals. The phenocrysts are euhedral, and show clear evidence of plagioclase resorption. The groundmass is about $97-$ $98 \%$, with very trachytic plagioclase dominant.

$L 24$ contains $2 \%$ of vesicles, $92 \%$ of groundmass and $6 \%$ of phenocrysts (not equal sized). The groundmass is fairly coarse $(\sim 0.1 \mathrm{~mm})$, with plagioclase $>70 \%$ and forming diabasic textures. In the phenocrysts, the proportion of different minerals is plag: cpx: olivine $\approx 6: 1: 3$, with a little amount of magnetite / spinel in olivine crystals. The phenocrysts are subhedral to euhedral, about $0.2-2.5 \mathrm{~mm}$, with clear evidence of plagioclase resorption. In some cases plagioclase and olivine crystals are clustered together and large broken olivine crystals are also observed.

\section{Caburgua:}

L81 contains almost $93-94 \%$ of the groundmass, about $0.5 \%$ of phenocrysts and $6 \%$ of vesicles. The groundmass is trachytic plagioclase dominant $(>80 \%)$, forming diabasic textures. The phenocrysts are up to $1 \mathrm{~mm}$, subhedral, mainly composed of olivine and cpx, and $<1 \%$ spinel / magnetite.

$L 82$ contains $\sim 97-98 \%$ of groundmass, which is very diabasic (fairly coarse, $\sim 0.1 \mathrm{~mm}$ ), and the proportion of plagioclase: olivine $+\mathrm{cpx} \approx 2: 1$. The phenocrysts $(>0.5 \mathrm{~mm})$ are mainly olivine and cpx, with minor plagioclase and $1 \%$ spinel or magnetite. Phenocrysts are subhedral and sometimes occur in clusters.

150194-03 contains about $5 \%$ of vesicles, $92-93 \%$ of groundmass and $2.5 \%$ phenocrysts. In the groundmass, plagioclase: olivine $+\mathrm{cpx} \approx 6: 4$. The plagioclase micro - crystals are fairly coarse (up to $0.2 \mathrm{~mm}$ ) and the texture of the groundmass is clearly diabasic. There also exist some radiating clusters of larger plagioclase micro - phases (up to $0.5 \mathrm{~mm}$ ). The phenocrysts have a combination of olivine and plagioclase?(7:3), euhedral to subhedral, and their grain size is between $0.5-3.5 \mathrm{~mm}$ with apparent plagioclase twinning. $\mathrm{Cpx}$ is $\approx$ $5 \%$.

\section{Cerro Redondo:}

L16 contains about $98 \%$ of groundmass (fairly coarse, up to $0.2 \mathrm{~mm}$ ) and $2 \%$ of phenocrysts. In the groundmass the dominant component is plagioclase $(>80 \%)$, and 


\section{Appendix 3 Analytical Techniques and Results}

\section{Inductively Coupled Plasma-Atomic Emission Spectrometry (ICPES)}

ICPES is a designed emission spectrometer with a plasma (an electronically excited discharge) source. Its source contains a glass torch and a copper coil surrounding it. The torch is usually composed of three concentric glass tubes, so it is able to maintain a stable argon plasma at its open end. The work coil consists of two or three turns of copper tube, and connects to a radiofrequency power generator to produce an oscillating magnetic field, within which the "seeded" (from a Tesla coil) free electrons and the argon atoms collide each other, form more charged particles and increase the temperature of the plasma up to $10,000^{\circ} \mathrm{K}$. Liquid samples are nebulized through the spray chamber by a pump and a (usually concentric glass) nebulizer, under the low argon injector flow rate of about 1 liter/min. In the spray chamber, larger - sized sample aerosols are thrown again the chamber walls and condensed to be drained away while the smallest droplets can go through the sharp changes in direction of flow path and finally injected into the plasma. The high excitation temperature in ICPES effectively prevents chemical interferences and makes ICPES a widely - used instrument in geochemistry for quantitative measurements.

The major (Table 3 - 1) and trace (Table 3 - 2) elements were measured on the JY - 70 III ICPES at the Geochemistry Laboratory, Dept. of Geology, Florida International University, under the tutelage of Dr. Rosemary Hickey-Vargas. Sample preparation procedures are as follows:

- Sample ignition: Weigh $\sim 0.6 \mathrm{~g}$ sample powders on a weighing paper, weigh a $\mathrm{DD}-\mathrm{H}_{2} \mathrm{O}$ - cleaned and dry crucible, and transfer the sample into the crucible and weigh the crucible+sample. At $950^{\circ} \mathrm{C}$ ignite samples $(4-6 / \mathrm{batch})$ in the furnace for $30 \mathrm{~min}$, cool them to the room temperature and store them in a dessicator. After $30 \mathrm{~min}$, reweigh the cruicible + sample and the loss is the amount of escaped volatiles $\left(\mathrm{CO}_{2}, \mathrm{H}_{2} \mathrm{O}\right.$ etc $)$.

- Sample fusion: Weigh $1.0000 \pm 0.0010 \mathrm{LiBO}_{2}$, and $0.2000 \pm 0.0002$ ignited sample, mix them together in a pre-conditioned graphite crucible, and fuse the sample $(1 / \mathrm{batch})$ in the furnace at $1090^{\circ} \mathrm{C}$ for $7 \mathrm{~min}$, take the crucible out and swirl it to ensure that all the sample powders are picked up and put the sample back to be fused for another $7 \mathrm{~min}$. Weigh a $50 \mathrm{ml}$ wide - mouth bottle, transfer $50 \mathrm{ml} 1.5 \mathrm{~N}$ trace - metal grade $\mathrm{HNO}_{3}$ (20ppm $\mathrm{Pd}$ - spiked) solution into it (using a pippet), and reweigh the bottle + solution. Pour the fused redhot sample bean directly into the solution, cap it tightly and shake it for more than 1 hour.

- Sample filtering: Filter the solutions from step 2) to get rid of the graphite powders from them. Solutions collected after filtering are ready for the trace element measurement.

- Dilution: Weigh a $50 \mathrm{ml}$ narrow-mouth bottle, transfer $2.5 \mathrm{ml}$ of the trace element solution from step 3 ) into it (using a pippet), reweigh the bottle + solution, then transfer $47.5 \mathrm{ml} 1.5 \mathrm{~N}$ trace - metal grade $\mathrm{HNO}_{3}(20 \mathrm{ppm} \mathrm{Pd}$, $10 \mathrm{ppm} \mathrm{Sc}$ - spiked) solution into the bottle (using a pippet), and reweigh the bottle + solution. Cap the bottle and shake it for $\sim 2 \mathrm{~min}$, and this diluted sample solution is now ready for the major element measurement. 
Three or Four USGS rock standards and at least one blank $\left(\mathrm{LiBO}_{2}\right.$ only) were prepared along with the samples under the same conditions. To calibrate the ICPES, 2 standards (AGV-1 + BHV0-1) and one blank were analyzed first for the major element measurement and BHV0-1 + blank for the trace element measurement. The resulted precision (\%RSD) was $<0.3 \%$ for $\mathrm{SiO}_{2}$ and $<3 \%$ for $\mathrm{K}_{2} \mathrm{O}$. Drifting errors were corrected by analyzing one certain sample both at the beginning and at the end of the measurement. AGV-1 and a TESTD (Trace Element Standard) were both analyzed along with the samples to check the analytical accuracy and reproducibility. Major elements and some of the trace elements $(\mathrm{Cr}, \mathrm{Ni}, \mathrm{Ba}, \mathrm{Sc}, \mathrm{Y}$ and $\mathrm{Sr}$ ) were measured by the simultaneous spectrometer, while some trace elements such as $\mathrm{La}, \mathrm{Nb}, \mathrm{Zr}, \mathrm{Cu}, \mathrm{Zn}$ and $\mathrm{V}$ were measured by the sequential spectrometer. $\mathrm{Ti}, \mathrm{Ni}, \mathrm{Cr}, \mathrm{Sc}, \mathrm{Y}, \mathrm{Sr}, \mathrm{Cu}, \mathrm{Zr}$ and $\mathrm{V}$ contents for sample 110194-01 (marked with a "*") are replaced with their ICPMS results measured in May, 2000 along with the five samples from V.Villarrica (see the ICPMS section). 
Table 3 - 1 Major Elements (oxides in wt\%)

\begin{tabular}{|c|c|c|c|c|c|c|}
\hline Sample Number & Sample Location & $\mathrm{SiO}_{2}$ & $\mathrm{TiO}_{2}$ & $\mathrm{Al}_{2} \mathrm{O}_{3}$ & $\mathrm{MgO}$ & $\mathrm{Fe}_{2} \mathrm{O}_{3}(\mathrm{~T})$ \\
\hline $010494-1 \mathrm{~A}$ & RUCAPILLAN & 50.21 & 0.79 & 16.65 & 8.88 & 9.77 \\
\hline 010494-1B & RUCAPILLAN & 51.61 & 1.30 & 16.94 & 5.45 & 11.23 \\
\hline Aphyric & RUCAPILLAN & 53.10 & 1.53 & 17.09 & 3.60 & 11.80 \\
\hline Porphyritic & RUCAPILLAN & 50.31 & 0.77 & 16.69 & 8.10 & 9.46 \\
\hline 090594-liticos & EL ESTADIO & 50.64 & 0.86 & 18.12 & 6.53 & 8.97 \\
\hline 090594-Bomba & EL ESTADIO & 50.87 & 0.87 & 18.09 & 6.56 & 8.96 \\
\hline 110194-01 & HUELEMOLLE & 52.28 & $1.28 *$ & 18.26 & 4.60 & 9.50 \\
\hline 110194-02 & HUELEMOLLE & 52.10 & 1.17 & 18.19 & 4.26 & 9.84 \\
\hline 110194-03 & HUELEMOLLE & 50.98 & 1.18 & 17.76 & 5.74 & 9.42 \\
\hline 120194-01 & HUELEMOLLE & 50.48 & 1.07 & 18.53 & 5.67 & 9.56 \\
\hline $120194-02$ & HUELEMOLLE & 50.69 & 1.10 & 18.65 & 5.99 & 9.76 \\
\hline 120194-03 & HUELEMOLLE & 50.51 & 0.77 & 15.85 & 10.31 & 9.47 \\
\hline 150194-07 & HUELEMOLLE Ctr. & 52.24 & 1.15 & 18.72 & 4.67 & 9.33 \\
\hline 120194-4A & CABURGUA & 51.51 & 1.13 & 18.25 & 6.15 & 9.39 \\
\hline $120194-4 \mathrm{~B}$ & CABURGUA & 51.54 & 1.13 & 18.25 & 5.99 & 9.41 \\
\hline $120194-4 \mathrm{C}$ & CABURGUA & 51.59 & 1.10 & 17.93 & 6.68 & 9.56 \\
\hline $120194-05$ & CABURGUA & 51.38 & 1.10 & 18.10 & 6.54 & 9.33 \\
\hline 150194-01 & CABURGUA & 50.91 & 1.10 & 18.15 & 6.45 & 9.30 \\
\hline $150194-02$ & CABURGUA & 51.42 & 1.10 & 18.97 & 4.90 & 9.56 \\
\hline $150194-03$ & CABURGUA & 51.28 & 1.10 & 17.92 & 6.32 & 9.61 \\
\hline 150194-04 & CABURGUA & 51.53 & 1.12 & 18.03 & 5.84 & 9.64 \\
\hline $130194-02$ & LLIZAN & 58.02 & $0.7 \overline{3}$ & 16.75 & 5.03 & 6.99 \\
\hline 130194-03 & LLIZAN & 54.18 & 0.74 & 16.95 & 6.00 & 8.07 \\
\hline 140194-01 & SAN JORGE & 50.39 & $0 . \overline{75}$ & 15.70 & 10.40 & 9.46 \\
\hline $140194-02$ & SAN JORGE & 50.52 & 0.77 & 15.94 & 10.25 & 9.52 \\
\hline 140194-03 & SAN JORGE & 50.43 & 0.78 & 15.91 & 9.84 & 9.43 \\
\hline $140194-04$ & SAN JORGE & 50.14 & 0.80 & 16.15 & 9.20 & 9.40 \\
\hline $140194-5 \mathrm{~A}$ & SAN JORGE & 50.38 & 0.77 & 16.08 & 9.14 & 9.61 \\
\hline 140194-5B & SAN JORGE & 50.44 & 0.77 & 16.11 & 9.12 & 9.63 \\
\hline $140194-07$ & SAN JORGE & 50.49 & 0.78 & 16.12 & 9.78 & 9.45 \\
\hline 140194-7B & SAN JORGE & 50.70 & 0.77 & 15.99 & 9.23 & 9.64 \\
\hline $140194-09$ & CERRO REDONDO & 51.55 & 1.01 & 17.96 & 6.49 & 9.37 \\
\hline $140194-10$ & CERRO REDONDO & 51.56 & 1.00 & 17.93 & 6.10 & 9.53 \\
\hline $140194-11$ & CERRO REDONDO & 50.97 & 1.11 & 19.33 & 4.57 & 9.65 \\
\hline 150194-5B & LA BARDA & 50.77 & 1.05 & 17.34 & 7.33 & 9.56 \\
\hline $150194-5 \mathrm{~A}$ & LA BARDA & 50.65 & 1.06 & 17.37 & 7.32 & 9.70 \\
\hline $150194-06$ & LA BARDA & 50.35 & 1.06 & 17.82 & 7.62 & 9.59 \\
\hline 240394-6A & HUILILCO & 51.76 & 1.09 & 17.67 & 5.98 & 9.12 \\
\hline 240394-6B & HUILILCO & 52.00 & 1.10 & 17.78 & 6.70 & 9.30 \\
\hline $140194-06$ & RELICURA & 50.60 & 1.23 & 17.72 & 6.14 & 9.77 \\
\hline 140194-08 & MAS ANTIGUAS & 53.13 & 0.89 & 17.79 & 6.33 & 8.43 \\
\hline 220194-03L & C.PIROCL. & 51.74 & 1.08 & 17.64 & 6.32 & 9.18 \\
\hline 300594-01 & ANTICURA-1 & 50.29 & 0.85 & 18.15 & 7.38 & 9.37 \\
\hline
\end{tabular}


(CONTINUED)

\begin{tabular}{|l|l|l|l|l|l|l|}
\hline Sample Number & Sample Location & $\mathrm{SiO}_{2}$ & $\mathrm{TiO}_{2}$ & $\mathrm{Al}_{2} \mathrm{O}_{3}$ & $\mathrm{MgO}$ & $\mathrm{Fe}_{2} \mathrm{O}_{3}(\mathrm{~T})$ \\
\hline $300594-02$ & ANTICURA-2 & 55.87 & 0.84 & 17.71 & 4.44 & 7.68 \\
\hline
\end{tabular}

(CONTINUED)

\begin{tabular}{|c|c|c|c|c|c|c|c|c|}
\hline Sample Number & Sample Location & $\mathrm{CaO}$ & $\mathrm{Na}_{2} \mathrm{O}$ & $\mathrm{K}_{2} \mathrm{O}$ & $\mathrm{MnO}$ & $\mathrm{P}_{2} \mathrm{O}_{5}$ & $\mathrm{H}_{2} \mathrm{O}$ & Total \\
\hline $010494-1 \mathrm{~A}$ & RUCAPILLAN & 10.62 & 2.40 & 0.45 & 0.16 & 0.13 & 0.00 & 100.06 \\
\hline 010494-1B & RUCAPILLAN & 8.74 & 3.24 & 0.75 & 0.18 & 0.27 & 1.15 & 99.71 \\
\hline Aphyric & RUCAPILLAN & 8.36 & 2.82 & 0.86 & 0.19 & 0.33 & 0.75 & 99.68 \\
\hline Porphyritic & RUCAPILLAN & 11.29 & 1.87 & 0.47 & 0.16 & 0.13 & 0.30 & 99.25 \\
\hline 090594-liticos & EL ESTADIO & 10.81 & 2.80 & 0.49 & 0.15 & 0.16 & 1.15 & 99.53 \\
\hline 090594-Bomba & EL ESTADIO & 11.00 & 2.80 & 0.51 & 0.15 & 0.17 & 0.63 & 99.98 \\
\hline 110194-01 & HUELEMOLLE & 8.90 & 3.40 & 1.12 & 0.16 & 0.55 & 0.05 & 100.06 \\
\hline 110194-02 & HUELEMOLLE & 9.35 & 2.79 & 0.82 & 0.16 & 0.42 & 0.15 & 99.10 \\
\hline 110194-03 & HUELEMOLLE & 8.95 & 3.46 & 1.07 & 0.16 & 0.41 & 0.00 & 99.13 \\
\hline 120194-01 & HUELEMOLLE & 9.57 & 3.37 & 0.82 & 0.16 & 0.38 & 0.00 & 99.61 \\
\hline 120194-02 & HUELEMOLLE & 9.44 & 3.26 & 0.84 & 0.16 & 0.41 & 0.17 & 100.30 \\
\hline 120194-03 & HUELEMOLLE & 10.10 & 2.48 & 0.42 & 0.16 & 0.12 & 0.00 & 100.19 \\
\hline 150194-07 & HUELEMOLLE Ctr. & 9.22 & 3.65 & 0.96 & 0.16 & 0.42 & 0.12 & 100.52 \\
\hline $120194-4 \mathrm{~A}$ & CABURGUA & 9.16 & 3.57 & 0.83 & 0.15 & 0.31 & 0.15 & 100.45 \\
\hline 120194-4B & CABURGUA & 9.16 & 3.54 & 0.80 & 0.15 & 0.32 & 0.00 & 100.29 \\
\hline $120194-4 \mathrm{C}$ & CABURGUA & 9.16 & 3.55 & 0.80 & 0.15 & 0.31 & 0.02 & 100.83 \\
\hline 120194-05 & CABURGUA & 9.19 & 3.42 & 0.77 & 0.15 & 0.30 & 0.00 & 100.28 \\
\hline 150194-01 & CABURGUA & 9.18 & 3.48 & 0.71 & 0.15 & 0.31 & 0.00 & 99.74 \\
\hline $150194-02$ & CABURGUA & 9.80 & 2.79 & 0.69 & 0.16 & 0.31 & 0.00 & 99.70 \\
\hline 150194-03 & CABURGUA & 9.36 & 2.69 & 0.71 & 0.16 & 0.30 & 0.02 & 99.45 \\
\hline \begin{tabular}{|l|}
$150194-04$ \\
\end{tabular} & CABURGUA & 9.29 & 2.63 & 0.74 & 0.16 & 0.33 & 0.18 & 99.31 \\
\hline 130194-02 & LLIZAN & 7.36 & 3.91 & 1.74 & 0.13 & 0.17 & 0.58 & 100.83 \\
\hline $130194-03$ & LLIZAN & 9.26 & 3.16 & 1.16 & 0.14 & 0.15 & 0.45 & 99.81 \\
\hline 140194-01 & SAN JORGE & 10.00 & 2.54 & 0.42 & 0.16 & 0.12 & 0.00 & 99.94 \\
\hline 140194-02 & SAN JORGE & 10.09 & 2.54 & 0.41 & 0.16 & 0.11 & 0.00 & 100.31 \\
\hline 140194-03 & SAN JORGE & 10.16 & 2.54 & 0.40 & 0.16 & 0.11 & 0.00 & 99.76 \\
\hline 140194-04 & SAN JORGE & 10.17 & 2.62 & 0.42 & 0.16 & 0.13 & 0.00 & 99.19 \\
\hline $140194-5 \mathrm{~A}$ & SAN JORGE & 10.47 & 1.94 & 0.42 & 0.16 & 0.10 & 0.00 & 99.07 \\
\hline 140194-5B & SAN JORGE & 10.47 & 1.90 & 0.41 & 0.16 & 0.11 & 0.00 & 99.12 \\
\hline 140194-07 & SAN JORGE & 10.18 & 2.52 & 0.40 & 0.16 & 0.12 & 0.00 & 100.00 \\
\hline 140194-7B & SAN JORGE & 10.51 & 1.92 & 0.45 & 0.16 & 0.10 & 0.00 & 99.47 \\
\hline $140194-09$ & CERRO REDONDO & 8.83 & 3.32 & 0.84 & 0.15 & 0.31 & 0.13 & 99.83 \\
\hline 140194-10 & CERRO REDONDO & 9.13 & 2.48 & 0.77 & 0.15 & 0.30 & 0.08 & 98.95 \\
\hline $140194-11$ & CERRO REDONDO & 9.56 & 2.76 & 0.84 & 0.16 & 0.28 & 0.02 & 99.23 \\
\hline 150194-5B & LA BARDA & 9.26 & 3.23 & 0.75 & 0.16 & 0.30 & 0.08 & 99.75 \\
\hline 150194-5A & LA BARDA & 9.32 & 3.25 & 0.73 & 0.16 & 0.29 & 0.12 & 99.85 \\
\hline 150194-06 & LA BARDA & 9.60 & 3.21 & 0.67 & 0.16 & 0.30 & 0.00 & 100.38 \\
\hline $240394-6 A$ & HUILILCO & 9.10 & 3.33 & 1.11 & 0.15 & 0.34 & 0.00 & 99.65 \\
\hline $240394-6 \mathrm{~B}$ & HUILILCO & 9.16 & 3.35 & 1.13 & 0.16 & 0.33 & 0.00 & 101.01 \\
\hline $140194-06$ & RELICURA & 8.63 & 3.43 & 1.18 & 0.16 & 0.42 & 0.00 & 99.28 \\
\hline
\end{tabular}


(CONTINUED)

\begin{tabular}{|l|l|l|l|l|l|l|l|l|}
\hline Sample Number & Sample Location & $\mathrm{CaO}$ & $\mathrm{Na}_{2} \mathrm{O}$ & $\mathrm{K}_{2} \mathrm{O}$ & $\mathrm{MnO}$ & $\mathrm{P}_{2} \mathrm{O}_{5}$ & $\mathrm{H}_{2} \mathrm{O}$ & Total \\
\hline $140194-08$ & MAS ANTIGUAS & 8.48 & 3.45 & 1.23 & 0.14 & 0.24 & 0.12 & 100.11 \\
\hline $220194-03 \mathrm{~L}$ & C.PIROCL. & 8.88 & 3.45 & 1.10 & 0.15 & 0.35 & 0.00 & 99.89 \\
\hline $300594-01$ & ANTICURA-1 & 11.05 & 2.61 & 0.63 & 0.16 & 0.16 & 0.00 & 100.65 \\
\hline $300594-02$ & ANTICURA-2 & 8.73 & 3.37 & 1.28 & 0.13 & 0.23 & 0.38 & 100.28 \\
\hline
\end{tabular}


Table 3 - 2 Trace Elements (in ppm )

\begin{tabular}{|c|c|c|c|c|c|c|c|}
\hline Sample Number & Sample Location & $\mathrm{Ni}$ & $\mathrm{Ba}$ & $\mathrm{Cr}$ & $\mathrm{Sc}$ & $\mathrm{Y}$ & $\mathrm{Nb}$ \\
\hline $010494-1 \mathrm{~A}$ & RUCAPILLAN & 111.2 & 119 & 725 & 34.6 & 15.8 & 2.2 \\
\hline 010494-1B & RUCAPILLAN & 46.5 & 250 & 248 & 34.7 & 26.4 & 4.4 \\
\hline Aphyric & RUCAPILLAN & 50.5 & 330 & 68 & 35.9 & 32.0 & 4.7 \\
\hline Porphyritic & RUCAPILLAN & 143.0 & 129 & 662 & 35.3 & 16.1 & 0.8 \\
\hline 090594-liticos & EL ESTADIO & 63.7 & 143 & 318 & 33.6 & 17.1 & 3.8 \\
\hline 090594-Bomba & EL ESTADIO & 42.9 & 147 & 391 & 33.5 & 17.4 & 5.9 \\
\hline 110194-01 & HUELEMOLLE & $24.1 *$ & 420 & $99.16^{*}$ & $25.18^{*}$ & $29.02 *$ & 10.2 \\
\hline 110194-02 & HUELEMOLLE & 38.5 & 254 & 142 & 26.0 & 22.1 & 7.0 \\
\hline 110194-03 & HUELEMOLLE & 75.1 & 360 & 213 & 27.0 & 27.0 & 9.8 \\
\hline \begin{tabular}{|l|}
$120194-01$ \\
\end{tabular} & HUELLEMOLLE & 50.1 & 287 & 191 & 26.2 & 24.3 & 7.1 \\
\hline 120194-02 & HUELEMOLLE & 50.8 & 307 & 161 & 26.8 & 26.0 & 8.7 \\
\hline \begin{tabular}{|l|}
$120194-03$ \\
\end{tabular} & HUELEMOLLE & 192.1 & 121 & 792 & 32.3 & 16.6 & 0.4 \\
\hline \begin{tabular}{|l|}
$150194-07$ \\
\end{tabular} & HUELEMOLLE Ctr. & 36.5 & 312 & 127 & 25.9 & 25.5 & 7.3 \\
\hline 120194-4A & CABURGUA & 83.2 & 365 & 281 & 24.6 & 21.6 & 3.9 \\
\hline \begin{tabular}{|l|} 
120194-4B \\
\end{tabular} & CABURGUA & 67.1 & 269 & 313 & 24.8 & 21.7 & 4.3 \\
\hline $120194-4 \mathrm{C}$ & CABURGUA & 82.7 & 247 & 364 & 25.2 & 20.9 & 3.0 \\
\hline \begin{tabular}{|l|}
$120194-05$ \\
\end{tabular} & CABURGUA & 114.7 & 246 & 308 & 25.2 & 20.9 & 3.2 \\
\hline 150194-01 & CABURGUA & 70.1 & 265 & 293 & 25.8 & 21.6 & 5.6 \\
\hline 150194-02 & CABURGUA & 31.1 & 334 & 151 & 27.3 & 26.5 & 3.2 \\
\hline 150194-03 & CABURGUA & 120.9 & 263 & 384 & 25.0 & 21.4 & 2.9 \\
\hline 150194-04 & CABURGUA & 85.6 & 283 & 266 & 25.4 & 22.3 & 3.2 \\
\hline $130194-02$ & LLIZAN & 54.9 & 460 & 296 & 23.1 & 26.1 & 7.3 \\
\hline $130194-03$ & LLIZAN & 83.4 & 321 & 335 & 27.9 & 20.8 & 5.0 \\
\hline $140194-01$ & SAN JORGE & 257.4 & 130 & 905 & 32.8 & 17.0 & 3.7 \\
\hline $140194-02$ & SAN JORGE & 221.9 & 124 & 831 & 31.7 & 16.8 & 3.1 \\
\hline 140194-03 & SAN JORGE & 175.5 & 124 & 786 & 32.0 & 16.8 & 2.2 \\
\hline 140194-04 & SAN JORGE & 168.5 & 135 & 752 & 32.1 & 17.6 & 3.7 \\
\hline 140194-5A & SAN JORGE & 204.2 & 129 & 799 & 32.7 & 16.8 & 1.2 \\
\hline 140194-5B & SAN JORGE & 205.8 & 130 & 810 & 32.8 & 17.2 & 1.3 \\
\hline 140194-07 & SAN JORGE & 183.9 & 132 & 816 & 32.2 & 17.2 & 11.9 \\
\hline 140194-7B & SAN JORGE & 368.8 & 127 & 868 & 32.2 & 17.1 & 0.8 \\
\hline 140194-09 & CERRO REDONDO & 144.0 & 292 & 434 & 23.9 & 21.5 & 5.8 \\
\hline $140194-10$ & CERRO REDONDO & 119.4 & 309 & 373 & 24.1 & 22.1 & 4.3 \\
\hline 140194-11 & CERRO REDONDO & 168.1 & 303 & 115 & 24.8 & 22.9 & 3.4 \\
\hline 150194-5B & LA BARDA & 222.3 & 246 & 447 & 26.5 & 20.7 & 4.3 \\
\hline $150194-5 \mathrm{~A}$ & LA BARDA & 210.1 & 244 & 572 & 26.9 & 21.0 & 4.2 \\
\hline 150194-06 & LA BARDA & 93.7 & 248 & 348 & 27.2 & 21.0 & 4.1 \\
\hline $240394-6 \mathrm{~A}$ & HUILILCO & 69.7 & 348 & 252 & 27.1 & 24.8 & 7.1 \\
\hline 240394-6B & HUILILCO & 79.0 & 345 & 280 & 27.2 & 25.0 & 7.2 \\
\hline 140194-06 & RELICURA & 88.5 & 387 & 303 & 24.0 & 25.5 & 10.6 \\
\hline 140194-08 & MAS ANTIGUAS & 132.6 & 495 & 245 & 23.1 & 18.1 & 3.2 \\
\hline 220194-03L & C.PIROCL. & 89.6 & 365 & 270 & 27.3 & 25.9 & 9.8 \\
\hline 300594-01 & ANTICURA-1 & 86.5 & 169 & 313 & 32.8 & 18.1 & 1.5 \\
\hline
\end{tabular}


(CONTINUED)

\begin{tabular}{|l|l|l|l|l|l|l|l|}
\hline Sample Number & Sample Location & $\mathrm{Ni}$ & $\mathrm{Ba}$ & $\mathrm{Cr}$ & $\mathrm{Sc}$ & $\mathrm{Y}$ & $\mathrm{Nb}$ \\
\hline $300594-02$ & ANTICURA-2 & 38.4 & 355 & 230 & 23.9 & 18.7 & 2.8 \\
\hline
\end{tabular}

(CONTINUED)

\begin{tabular}{|c|c|c|c|c|c|c|c|}
\hline \begin{tabular}{|l|} 
Sample Number \\
\end{tabular} & Sample Location & $\mathrm{Sr}$ & $\mathrm{Cu}$ & $\mathrm{Zn}$ & $\mathrm{Zr}$ & $\mathrm{La}$ & $\mathrm{V}$ \\
\hline 010494-1A & RUCAPILLAN & 539 & 92.2 & 83.4 & 57.2 & 7.9 & 230 \\
\hline 010494-1B & RUCAPILLAN & 490 & 78.9 & 101.6 & 126.6 & 14.1 & 297 \\
\hline Aphyric & RUCAPILLAN & 479 & 46.8 & 99.4 & 160.9 & 18.3 & 324 \\
\hline Porphyritic & RUCAPILLAN & 557 & 84.9 & 89.0 & 62.2 & 8.7 & 230 \\
\hline 090594-liticos & EL ESTADIO & 630 & 76.1 & 66.2 & 71.3 & 9.7 & 238 \\
\hline 090594-Bomba & EL ESTADIO & 649 & 94.9 & 71.7 & 72.8 & 9.8 & 238 \\
\hline 110194-01 & HUELEMOLLE & $680^{*}$ & $73.23^{*}$ & 87.6 & $191.69^{*}$ & 31.0 & $215^{*}$ \\
\hline \begin{tabular}{|l|}
$110194-02$ \\
\end{tabular} & HUELEMOLLE & 773 & 81.6 & 88.2 & 151.5 & 24.0 & 206 \\
\hline 110194-03 & HUELEMOLLE & 621 & 81.7 & 98.0 & 165.9 & 24.9 & 211 \\
\hline \begin{tabular}{|l|}
$120194-01$ \\
\end{tabular} & HUELEMOLLE & 616 & 76.8 & 78.7 & 146.1 & 20.8 & 198 \\
\hline \begin{tabular}{|l|}
$120194-02$ \\
\end{tabular} & HUELEMOLLE & 628 & 86.5 & 95.1 & 160.5 & 25.6 & 200 \\
\hline 120194-03 & HUELEMOLLE & 380 & 87.8 & 69.9 & 55.3 & 5.0 & 198 \\
\hline \begin{tabular}{|l|}
$150194-07$ \\
\end{tabular} & HUELEMOLLE Ctr. & 651 & 77.6 & 76.8 & 154.4 & 23.4 & 196 \\
\hline 120194-4A & CABURGUA & 803 & 79.9 & 65.7 & 96.3 & 15.1 & 186 \\
\hline 120194-4B & CABBURGUA & 806 & 78.2 & 67.7 & 99.7 & 14.4 & 198 \\
\hline $120194-4 \mathrm{C}$ & CABURGUA & 800 & 82.3 & 70.5 & 90.8 & 14.2 & 196 \\
\hline 120194-05 & CABURGUA & 807 & 78.5 & 68.4 & 89.2 & 13.7 & 190 \\
\hline 150194-01 & CABURGUA & 837 & 85.2 & 66.2 & 97.4 & 14.7 & 207 \\
\hline 150194-02 & CABURGUA & 629 & 77.3 & 80.9 & 95.4 & 14.5 & 215 \\
\hline 150194-03 & CABURGUA & 781 & 86.0 & 213.3 & 101.6 & 17.2 & 206 \\
\hline 150194-04 & CABURGUA & 770 & 77.4 & 72.0 & 106.7 & 17.1 & 203 \\
\hline 130194-02 & LLIZAN & 543 & 60.4 & 59.7 & 196.7 & 19.8 & 142 \\
\hline 130194-03 & LLIZAN & 547 & 76.1 & 65.0 & 132.3 & 16.2 & 177 \\
\hline 140194-01 & SAN JORGE & 379 & 88.6 & 67.6 & 58.3 & 5.4 & 206 \\
\hline 140194-02 & SAN JORGE & 377 & 85.0 & 64.6 & 54.3 & 4.9 & 207 \\
\hline 140194-03 & SAN JORGE & 377 & 89.1 & 74.3 & 56.2 & 5.1 & 209 \\
\hline 140194-04 & SAN JORGE & 391 & 93.1 & 64.1 & 64.1 & 6.8 & 218 \\
\hline 140194-5A & SAN JORGE & 401 & 85.4 & 84.1 & 60.9 & 6.9 & 206 \\
\hline 140194-5B & SAN JORGE & 390 & 53.5 & 73.2 & 60.0 & 6.4 & 212 \\
\hline 140194-07 & SAN JORGE & 388 & 87.2 & 83.3 & 63.9 & 3.5 & 212 \\
\hline 140194-7B & SAN JORGE & 388 & 86.1 & 66.9 & 64.7 & 7.9 & 213 \\
\hline 140194-09 & CERRO REDONDO & 598 & 74.2 & 75.9 & 128.4 & 18.7 & 186 \\
\hline $140194-10$ & CERRO REDONDO & 623 & 76.8 & 95.0 & 134.2 & 20.0 & 187 \\
\hline $140194-11$ & CERRO REDONDO & 924 & 49.7 & 82.8 & 111.9 & 20.5 & 228 \\
\hline 150194-5B & LA BARDA & 690 & 75.3 & 163.5 & 97.7 & 14.9 & 208 \\
\hline 150194-5A & LA BARDA & 694 & 77.6 & 75.2 & 99.3 & 14.8 & 205 \\
\hline 150194-06 & LA BARDA & 709 & 91.7 & 70.7 & 99.6 & 14.0 & 208 \\
\hline 240394-6A & HUILILCO & 576 & 69.9 & 64.6 & 147.2 & 20.2 & 202 \\
\hline 240394-6B & HUILILCO & 577 & 70.9 & 103.1 & 145.2 & 20.1 & 203 \\
\hline 140194-06 & RELICURA & 608 & 59.0 & 78.6 & \begin{tabular}{|l|l}
173.0 \\
\end{tabular} & 26.5 & \begin{tabular}{|l|}
194 \\
\end{tabular} \\
\hline
\end{tabular}


(CONTINUED)

Sample Number Sample Location

\begin{tabular}{|l|l}
\hline 140194-08 & MAS ANTIGUAS \\
\hline
\end{tabular}

220194-03L

C.PIROCL.

300594-01

ANTICUR

ANTICURA-1

300594-02 ANTICURA-2

\begin{tabular}{|l|l|}
\hline $\mathrm{Sr}$ \\
\hline 1148 \\
\hline 581 \\
\hline 477 \\
\hline 701 \\
\hline
\end{tabular}

\begin{tabular}{|l|l|}
\hline $\mathrm{Cu}$ & $\mathrm{Zn}$ \\
\hline 72.1 & 73.5 \\
\hline
\end{tabular}

\begin{tabular}{l|l|l}
71.8 & 129.3
\end{tabular}

\begin{tabular}{l|l}
71.8 & 129.3
\end{tabular}

69.3

\begin{tabular}{|l|l|}
\hline 67.6 & 73.1 \\
\hline
\end{tabular}

99.5

18.3

\begin{tabular}{|l|l|}
\hline La & V \\
\hline 24.2 & 179 \\
\hline 18.0 & 202 \\
\hline 8.3 & 213 \\
\hline 18.3 & 178 \\
\hline
\end{tabular}


The results of the standards measured from three batches of analyses (July 97, Nov. 97 and Jan. 98, respectively) are shown in the following tables (Table $3-3 \mathrm{a}$; Table $3-3 \mathrm{~b}$; Table $3-3 c)$. In addition, sample 110194-01 was analyzed twice to check the reproducibility of the measurement. Table $3-4$ shows the results of the replicates and the corresponding errors. The variations of $\mathrm{Na}_{2} \mathrm{O} \%$ between the two runs are uncharacteristically high, and this sample may need to be run in the future. Another problem of this sample needs to be pointed out is its " $\mathrm{Zr}$ mystery". $\mathrm{Zr}$ contents of this sample were too low in both of the two runs $(<66 \mathrm{ppm})$ by ICPES, however by ICPMS the $\mathrm{Zr}$ content of this sample goes up as high as $191.69 \mathrm{ppm}$. Therefore there must be some "mysterious" mineral phase in this sample that does not dissolve using the fusion techniques mentioned earlier in this section, or $\mathrm{Zr}$ precipitates quickly after it is originally dissolved. 
Table 3 - 3a (07/97)

\begin{tabular}{|l|l|l|l|l|l|l|l|l|l|l|}
\hline \hline Standards(\%) & $\mathrm{SiO}_{2}$ & $\mathrm{MnO}$ & $\mathrm{Fe}_{2} \mathrm{O}_{3}$ & $\mathrm{MgO}$ & $\mathrm{CaO}$ & $\mathrm{TiO}_{2}$ & $\mathrm{Al}_{2} \mathrm{O}_{3}$ & $\mathrm{Na}_{2} \mathrm{O}$ & $\mathrm{K}, \mathrm{O}$ & $\mathrm{P}_{2} \mathrm{O}_{5}$ \\
\hline AGV-1 & 60.20 & 0.10 & 6.87 & 1.55 & 5.02 & 1.08 & 17.43 & 4.32 & 2.95 & 0.48 \\
\hline BHV0-1 & 49.75 & 0.17 & 12.16 & 7.12 & 11.37 & 2.64 & 13.76 & 2.20 & 0.55 & 0.28 \\
\hline
\end{tabular}

(CONTINUED)

\begin{tabular}{|l|l|l|l|l|l|l|}
\hline Stds(ppm) & $\mathrm{Ni}$ & $\mathrm{Ba}$ & $\mathrm{Cr}$ & $\mathrm{Sc}$ & $\mathrm{Y}$ & $\mathrm{Sr}$ \\
\hline AGV-1 & 54.5 & 1229 & 35.6 & 11.9 & 21.3 & 675 \\
\hline BHV0-1 & 117.0 & 128 & 300.0 & 30.0 & 28.0 & 390 \\
\hline TESTD & 118.3 & 265 & 272.3 & 52.2 & 30.7 & 518 \\
\hline Stds(ppm) & $\mathrm{Zn}$ & $\mathrm{V}$ & $\mathrm{Nb}$ & $\mathrm{Cu}$ & $\mathrm{Zr}$ & $\mathrm{La}$ \\
\hline AGV-1 & 93.6 & 116 & 14.6 & 60.2 & 247 & 44.4 \\
\hline BHV0-1 & 102.0 & 286 & 19.0 & 137.0 & 180 & 16.7 \\
\hline TESTD & 103.7 & 244 & 27.2 & 127.7 & 270 & 31.0 \\
\hline
\end{tabular}

Table 3 - 3b (11/97)

\begin{tabular}{|l|l|l|l|l|l|l|l|l|l|l|}
\hline \hline Standards(\%) & $\mathrm{SiO}_{2}$ & $\mathrm{MnO}$ & $\mathrm{Fe}_{2} \mathrm{O}_{3}$ & $\mathrm{MgO}$ & $\mathrm{CaO}$ & $\mathrm{TiO}_{2}$ & $\mathrm{Al}_{2} \mathrm{O}_{3}$ & $\mathrm{Na}_{2} \mathrm{O}$ & $\mathrm{K}_{2} \mathrm{O}$ & $\mathrm{P}_{2} \mathrm{O}_{5}$ \\
\hline AGV-1 & 60.20 & 0.10 & 6.87 & 1.55 & 5.02 & 1.08 & 17.43 & 4.32 & 2.95 & 0.49 \\
\hline BHV0-1 & 49.75 & 0.17 & 12.16 & 7.12 & 11.37 & 2.64 & 13.76 & 2.20 & 0.55 & 0.28 \\
\hline
\end{tabular}

(CONTINUED)

\begin{tabular}{|l|l|l|l|l|l|l|}
\hline Stds(ppm) & $\mathrm{Ni}$ & $\mathrm{Ba}$ & $\mathrm{Cr}$ & $\mathrm{Sc}$ & $\mathrm{Y}$ & $\mathrm{Sr}$ \\
\hline AGV-1 & 30.6 & 1222 & 19.9 & 11.9 & 21.4 & 672 \\
\hline BHV0-1 & 117.0 & 128 & 300 & 30.0 & 28.0 & 390 \\
\hline TESTD & 135.9 & 280 & 304 & 53.5 & 30.8 & 519 \\
\hline Stds(ppm) & $\mathrm{Zn}$ & $\mathrm{V}$ & $\mathrm{Nb}$ & $\mathrm{Cu}$ & $\mathrm{Zr}$ & $\mathrm{La}$ \\
\hline AGV-1 & 82.7 & 119 & 12.5 & 58.0 & 79.9 & 47.3 \\
\hline BHV0-1 & 102.0 & 286 & 19.0 & 137.0 & 180.0 & 16.7 \\
\hline TESTD & 115.8 & 250 & 27.4 & 127.7 & 269.0 & 31.7 \\
\hline
\end{tabular}

Table 3 - 3c (01/98)

\begin{tabular}{|l|l|l|l|l|l|l|l|l|l|l|}
\hline \hline Standards(\%) & $\mathrm{SiO}_{2}$ & $\mathrm{MnO}$ & $\mathrm{Fe}_{2} \mathrm{O}_{3}$ & $\mathrm{MgO}$ & $\mathrm{CaO}$ & $\mathrm{TiO}_{2}$ & $\mathrm{Al}_{2} \mathrm{O}_{3}$ & $\mathrm{Na}_{2} \mathrm{O}$ & $\mathrm{K}_{2} \mathrm{O}$ & $\mathrm{P}_{2} \mathrm{O}_{5}$ \\
\hline AGV-1 & 60.20 & 0.10 & 6.87 & 1.55 & 5.02 & 1.08 & 17.43 & 4.32 & 2.95 & 0.47 \\
\hline BHV0-1 & 49.75 & 0.17 & 12.16 & 7.12 & 11.37 & 2.64 & 13.76 & 2.20 & 0.55 & 0.28 \\
\hline
\end{tabular}

(CONTINUED)

\begin{tabular}{|l|l|l|l|l|l|l|}
\hline Stds(ppm) & $\mathrm{Ni}$ & $\mathrm{Ba}$ & $\mathrm{Cr}$ & $\mathrm{Sc}$ & $\mathrm{Y}$ & $\mathrm{Sr}$ \\
\hline AGV-1 & 81.5 & 1192 & 20.9 & 12.0 & 21.2 & 675 \\
\hline BHV0-1 & 117.0 & 128 & 300 & 30.0 & 28.0 & 390 \\
\hline TESTD & 133.1 & 273 & 291 & 53.2 & 30.9 & 528 \\
\hline Stds(ppm) & $\mathrm{Zn}$ & $\mathrm{V}$ & $\mathrm{Nb}$ & $\mathrm{Cu}$ & $\mathrm{Zr}$ & $\mathrm{La}$ \\
\hline AGV-1 & 88.6 & 110 & 15.1 & 58.2 & 171 & 43.8 \\
\hline BHV0-1 & 102.0 & 286 & 19.0 & 137.0 & 180 & 16.7 \\
\hline TESTD & 109.5 & 232 & 26.2 & 124.8 & 267 & 28.8 \\
\hline
\end{tabular}


Table 3 - 4 Replicates of 110194-01 and Errors

\begin{tabular}{|l|l|l|l|l|l|l|l|l|l|l|}
\hline Rep.(\%) & $\mathrm{SiO}_{2}$ & $\mathrm{MnO}$ & $\mathrm{Fe}_{2} \mathrm{O}_{3}$ & $\mathrm{MgO}$ & $\mathrm{CaO}$ & $\mathrm{TiO}_{2}$ & $\mathrm{Al}_{2} \mathrm{O}_{3}$ & $\mathrm{Na}_{2} \mathrm{O}$ & $\mathrm{K}_{2} \mathrm{O}$ & $\mathrm{P}_{2} \mathrm{O}_{5}$ \\
\hline Run1 & 52.35 & 0.16 & 9.61 & 4.35 & 9.10 & 1.29 & 18.25 & 2.92 & 1.03 & 0.57 \\
\hline Run2 & 52.21 & 0.16 & 9.39 & 4.85 & 8.70 & 1.29 & 18.27 & 3.88 & 1.21 & 0.53 \\
\hline \%RSD & 0.3 & 0.0 & 2.3 & 11.5 & 4.4 & 0.0 & 0.1 & 32.9 & 17.5 & 7.0 \\
\hline
\end{tabular}

(CONTINUED)

\begin{tabular}{|l|l|l|l|l|l|l|}
\hline Rep.(ppm) & $\mathrm{Ni}$ & $\mathrm{Ba}$ & $\mathrm{Cr}$ & $\mathrm{Sc}$ & $\mathrm{Y}$ & $\mathrm{Sr}$ \\
\hline Run1 & 83.8 & 420 & 150 & 25.0 & 30.9 & 671 \\
\hline Run2 & 70.2 & 419 & 121 & 24.8 & 30.7 & \\
\hline \%RSD & 16.2 & 0.3 & 19.4 & 1.2 & 0.8 & 1.5 \\
\hline Rep.(ppm) & $\mathrm{Zn}$ & $\mathrm{V}$ & $\mathrm{Nb}$ & $\mathrm{Cu}$ & $\mathrm{Zr}$ & $\mathrm{La}$ \\
\hline Run1 & 80.9 & 205 & 9.5 & 75.0 & 65.5 & 32.4 \\
\hline Run2 & 94.3 & 201 & 10.9 & 74.0 & 49.1 & 29.6 \\
\hline \%RSD & 16.5 & 1.9 & 15.6 & 1.3 & 25.1 & 8.9 \\
\hline
\end{tabular}




\section{Inductively Coupled Plasma-Mass Spectrometry (ICPMS)}

In an ICPMS, similarly to the ICPES, samples are ionized by injecting a stream of small particles into the plasma, and the mass separation of different ions in the instrument is performed by a electrostatically driven quadrupole mass spectrometer. This technique, therefore, combines the freedom of matrix interferences of the inductively coupled argon plasma with the "signal - background ratios" which is one of the most favorable characteristics of the mass spectrometry, and provides a strong potential for the highly quantitative multi - element analysis. ICPMS can be used to measure the concentrations of a wide range of trace and rare earth elements in the rock samples on a precision of $\sim 3 \%$ or less, as well as some certain individual isotope ratios. In general, a ICPMS consists of three major components:

- The source: an inductively coupled argon plasma as ion source, including the torch, work coils, nebulizer and cloud chamber, and the associated power supplies. Instead of the vertical alignment as in the ICPES, the torch in the ICPMS is configured horizontally so that the tail of the plasma flame can be directed to the sampling orifice.

- The collector: a quadrupole mass spectrometer and the associated data collection device which can perform quick scanning of the selected mass ranges between $0-300 \mathrm{amu}$.

- The interface: a unit that permits the transfering of the high - temperature (6000 - 7500K) plasma gases into the cold, vacated mass spectrometer. Plasma gases pass through a $400-800 \mu \mathrm{m}$ aperture to enter a small expansion chamber, and the resulting ion beams whose size is strictly constrained by a skimmer positioned about $100 \mathrm{~mm}$ behind the sampling aperture are then discharged into the mass spectrometer for analysis.

The trace and REE elements were measured at a Fisons / VG PlasmaQuad IIXS ICPMS by Dr. Terry Plank at the University of Kansas and Boston University (Table 3 - 5a; Table 3 - 5b; Table $3-5 \mathrm{c}$ ). Samples were prepared at FIU, following the procedures of sample dissolution at UK-PAL:

1) Sample digestion: weigh $0.100 \mathrm{~g}$ of sample powders $(0.150 \mathrm{~g}$ for drift correcting sample) and put them in $23 \mathrm{ml}$ savillex capsule. Add $6 \mathrm{ml} 8 \mathrm{~N}$ $\mathrm{HNO}_{3}$ and $2 \mathrm{ml} \mathrm{HF}$, and tilt the capsules to wash off the samples on the wall of the beakers. Place the sample beakers on hot plate and heat at $150-200^{\circ} \mathrm{C}$. If sample is not dissolved (dark bits still present) after 6-8 hours, sonicate them for 1 hour and heat for another 6-8 hours. Repeat as necessary until dissolved. If brown bits cannot be dissolved, uncap the capsules and heat the samples to dryness. Add $1 \mathrm{ml} 6 \mathrm{~N} \mathrm{HCl}$ and dry down, then add $1 \mathrm{ml} 8 \mathrm{~N} \mathrm{HNO}_{3}$ and dry down.

2) Drying down samples: when samples are clear, remove the cap carefully and return samples to hot plate without cap until sample has dried down.

3) Picking up samples: Add $6 \mathrm{ml} 8 \mathrm{~N} \mathrm{HNO}_{3}$ per $0.1 \mathrm{~g}$ of sample, cap, and place them back on hot plate for $\sim 8$ hours. Then remove the caps carefully and add about $10 \mathrm{ml}$ of double-distilled water, cap, and heat them on hot plate for at least $20 \mathrm{~min}$. 
4) Sample transfer: Get some clean $250 \mathrm{ml}$ Nalgene bottles and label them with the sample names. Wiegh the bottle, carefully transfer samples from capsules into the $250 \mathrm{ml}$ bottles and rinse capsules and lids three times with doubledistilled water, pouring rinse water also into the corresponding bottles.

5) Sample dilution: dilute sample by 1500 times the original weight to make a $2 \% \mathrm{HNO}_{3}$ solution. If sample was $0.1 \mathrm{~g}$, the final total solution weight should be about $150 \mathrm{~g}$. Blanks were prepared under the same conditions to ensure the measurement accuracy.

Rock standards (BHV0, AGV, W-2, DNC and BIR) were prepared into solutions and measured on the ICPMS along with the samples and one sample (Drifting Correction Solution) was also measured repeatedly (once in each run) to constrain the accuracy and reproducibility of the measurements (Table 3 - 6a; Table $3-6 \mathrm{~b}$ ). Altogether three sample batches were analyzed (07/98, 11/98 and 05/00 respectively) in this work. 
Table 3 - 5a ICPMS results (in ppm) from Villarrica SEC samples

\begin{tabular}{|c|c|c|c|c|c|c|}
\hline Sample Number & Sample Location & $\mathrm{Rb}$ & $\mathrm{Nb}$ & $\mathrm{Cs}$ & $\mathrm{Ba}$ & $\mathrm{La}$ \\
\hline 010494-1A & RUCAPILLAN & 7.11 & 1.29 & 0.378 & 138 & 6.70 \\
\hline 010494-1B & RUCAPILLAN & 14.3 & 4.29 & 0.762 & 280 & 12.8 \\
\hline 090594-liticos & EL ESTADIO & 6.12 & 1.52 & 0.241 & 142 & 7.95 \\
\hline 090594-Bomba & EL ESTADIO & 7.33 & 1.60 & 0.386 & 162 & 8.69 \\
\hline $110194-01$ & HUELEMOLLE & 21.8 & 9.71 & 0.879 & 461 & 28.9 \\
\hline 110194-02 & HUELEMOLLE & 15.0 & 7.21 & 0.736 & 346 & 21.3 \\
\hline 110194-03 & HUELEMOLLE & 22.3 & 7.57 & 0.951 & 382 & 22.3 \\
\hline 120194-01 & HUELEMOLLE & 13.5 & 6.55 & 0.675 & 295 & 19.2 \\
\hline 120194-02 & HUELEMOLLE & 13.9 & 6.72 & 0.707 & 329 & 20.8 \\
\hline 120194-03 & HUELEMOLLE & 8.29 & 1.42 & 0.691 & 137 & 5.08 \\
\hline 150194-07 & HUELEMOLLE Ctr. & 16.1 & 7.17 & 0.712 & 325 & 20.6 \\
\hline 120194-4A & CABURGUA & 13.2 & 3.76 & 0.646 & 280 & 14.4 \\
\hline $120194-4 \mathrm{C}$ & CABURGUA & 11.0 & 3.23 & 0.557 & 257 & 13.3 \\
\hline 120194-05 & CABURGUA & 11.2 & 3.29 & 0.612 & 276 & 13.9 \\
\hline $150194-01$ & CABURGUA & 9.81 & 3.20 & 0.537 & 288 & 13.2 \\
\hline 150194-02 & CABURGUA & 10.2 & 3.32 & 0.521 & 253 & 13.2 \\
\hline 150194-03 & CABURGUA & 10.5 & 3.42 & 0.575 & 295 & 14.3 \\
\hline 130194-02 & LLIZAN & 44.3 & 6.01 & 2.882 & 477 & 18.9 \\
\hline 130194-03 & LLIZAN & 30.0 & 4.36 & 1.815 & 320 & 14.0 \\
\hline 140194-01 & SAN JORGE & 8.61 & 1.42 & 0.658 & 139 & 4.90 \\
\hline 140194-02 & SAN JORGE & 8.25 & 1.39 & 0.640 & 125 & 4.88 \\
\hline 140194-04 & SAN JORGE & 8.17 & 1.56 & 0.673 & 146 & 5.62 \\
\hline $140194-5 \mathrm{~A}$ & SAN JORGE & 8.29 & 1.50 & 0.642 & 132 & 5.23 \\
\hline 140194-5B & SAN JORGE & 7.86 & 1.45 & 0.571 & 131 & 5.25 \\
\hline $140194-07$ & SAN JORGE & 8.32 & 1.52 & 0.668 & 149 & 5.30 \\
\hline 140194-7B & SAN JORGE & 9.44 & 1.56 & 0.700 & 137 & 5.43 \\
\hline $140194-09$ & CERRO REDONDO & 16.1 & 5.59 & 0.712 & 327 & 17.4 \\
\hline 140194-10 & CERRO REDONDO & 16.7 & 5.68 & 0.675 & 305 & 17.1 \\
\hline 140194-11 & CERRO REDONDO & 9.71 & 4.39 & 0.249 & 329 & 16.6 \\
\hline 150194-5B & LA BARDA & 12.2 & 4.11 & 0.628 & 281 & 14.9 \\
\hline $150194-5 \mathrm{~A}$ & LA BARDA & 11.7 & 4.13 & 0.554 & 253 & 13.8 \\
\hline 150194-06 & LA BARDA & 9.64 & 3.85 & 0.524 & 273 & 13.9 \\
\hline 240394-6A & HUILILCO & 29.0 & 7.54 & 1.279 & 384 & 18.0 \\
\hline 240394-6B & HUILILCO & 28.5 & 7.35 & 1.390 & 367 & 18.7 \\
\hline 220194-03L & C.PIROCL. & 27.3 & 7.07 & 1.190 & 360 & 18.6 \\
\hline
\end{tabular}

(CONTINUED)

\begin{tabular}{|l|l|l|l|l|l|l|}
\hline Sample Number & Sample Location & Ce & Pr & Nd & Sm & Eu \\
\hline 010494-1A & RUCAPILLAN & 16.0 & 2.29 & 10.5 & 2.52 & 0.86 \\
\hline $010494-1 B$ & RUCAPILLAN & 29.5 & 4.05 & 18.1 & 4.29 & 1.36 \\
\hline $090594-l i t i c o s$ & EL ESTADIO & 18.5 & 2.62 & 11.8 & 2.71 & 0.92 \\
\hline $090594-B o m b a$ & EL ESTADIO & 20.3 & 2.89 & 12.9 & 2.97 & 1.00 \\
\hline $110194-01$ & HUELEMOLLE & 63.1 & 8.14 & 33.5 & 6.73 & 1.89 \\
\hline
\end{tabular}


(CONTINUED)

\begin{tabular}{|c|c|c|c|c|c|c|}
\hline Sample Number & Sample Location & $\mathrm{Ce}$ & $\operatorname{Pr}$ & Nd & Sm & $\mathrm{Eu}$ \\
\hline $110194-02$ & HUELEMOLLE & 46.4 & 6.14 & 25.5 & 5.35 & 1.57 \\
\hline 110194-03 & HUELEMOLLE & 49.1 & 6.36 & 26.4 & 5.57 & 1.62 \\
\hline $120194-01$ & HUELLEMOLLE & 42.1 & 5.52 & 23.0 & 4.86 & 1.42 \\
\hline 120194-02 & HUELEMOLLE & 46.4 & 5.94 & 24.9 & 5.13 & 1.52 \\
\hline 120194-03 & HUELEMOLLE & 12.3 & 1.82 & 8.6 & 2.29 & 0.81 \\
\hline 150194-07 & HUELEMOLLE Ctr. & 45.0 & 5.91 & 24.6 & 5.15 & 1.50 \\
\hline $120194-4 \mathrm{~A}$ & CABURGUA & 32.8 & 4.56 & 19.9 & 4.41 & 1.34 \\
\hline $120194-4 \mathrm{C}$ & CABURGUA & 30.2 & 4.24 & 18.8 & 4.16 & 1.30 \\
\hline 120194-05 & CABURGUA & 31.8 & 4.52 & 20.2 & 4.44 & 1.39 \\
\hline 150194-01 & CABURGUA & 30.9 & 4.33 & 19.4 & 4.30 & 1.35 \\
\hline 150194-02 & CABURGUA & 29.8 & 4.16 & 18.3 & 4.11 & 1.27 \\
\hline 150194-03 & CABURGUA & 33.1 & 4.56 & 20.3 & 4.42 & 1.38 \\
\hline 130194-02 & LLIZAN & 40.9 & 5.10 & 20.7 & 4.36 & 1.17 \\
\hline 130194-03 & LLIZAN & 30.0 & 3.84 & 16.0 & 3.47 & 1.00 \\
\hline \begin{tabular}{|l|}
$140194-01$ \\
\end{tabular} & SAN JORGE & 11.9 & 1.79 & 8.4 & 2.27 & 0.80 \\
\hline 140194-02 & SAN JORGE & 11.7 & 1.71 & 8.1 & 2.19 & 0.76 \\
\hline \begin{tabular}{|l|}
$140194-04$ \\
\end{tabular} & SAN JORGE & 13.6 & 2.00 & 9.4 & 2.45 & 0.86 \\
\hline $140194-5 \mathrm{~A}$ & SAN JORGE & 12.5 & 1.83 & 8.7 & 2.31 & 0.80 \\
\hline 140194-5B & SAN JORGE & 12.5 & 1.82 & 8.5 & 2.29 & 0.79 \\
\hline 140194-07 & SAN JORGE & 12.8 & 1.94 & 9.1 & 2.47 & 0.86 \\
\hline 140194-7B & SAN JORGE & 12.9 & 1.88 & 8.9 & 2.36 & 0.82 \\
\hline 140194-09 & CERRO REDONDO & 38.4 & 4.93 & 20.8 & 4.40 & 1.35 \\
\hline $140194-10$ & CERRO REDONDO & 37.1 & 4.85 & 20.0 & 4.27 & 1.30 \\
\hline $140194-11$ & CERRO REDONDO & 37.7 & 5.06 & 22.0 & 4.67 & 1.46 \\
\hline 150194-5B & LA BARDA & 33.6 & 4.63 & 20.3 & 4.44 & 1.37 \\
\hline $150194-5 \mathrm{~A}$ & LA BARDA & 31.2 & 4.31 & 18.9 & 4.16 & 1.27 \\
\hline 150194-06 & LA BARDA & 32.1 & 4.32 & 19.1 & 4.17 & 1.29 \\
\hline $240394-6 \mathrm{~A}$ & HUILILCO & 39.7 & 5.18 & 21.9 & 4.75 & 1.39 \\
\hline 240394-6B & HUILILCO & 40.5 & 5.32 & 22.3 & 4.73 & 1.42 \\
\hline 220194-03L & C.PIROCL. & 40.4 & 5.29 & 22.2 & 4.75 & 1.38 \\
\hline
\end{tabular}

\section{(CONTINUED)}

\begin{tabular}{|l|l|l|l|l|l|l|}
\hline Sample Number & Sample Location & Gd & Tb & Dy & Ho & Er \\
\hline $010494-1 \mathrm{~A}$ & RUCAPILLAN & 2.74 & 0.426 & 2.62 & 0.548 & 1.47 \\
\hline $010494-1 \mathrm{~B}$ & RUCAPILLAN & 4.64 & 0.714 & 4.36 & 0.904 & 2.41 \\
\hline $090594-$ liticos & EL ESTADIO & 2.96 & 0.447 & 2.74 & 0.563 & 1.55 \\
\hline $090594-$ Bomba & EL ESTADIO & 3.12 & 0.474 & 2.90 & 0.611 & 1.64 \\
\hline $110194-01$ & HUELEMOLLE & 6.25 & 0.913 & 5.21 & 1.039 & 2.77 \\
\hline $110194-02$ & HUELEMOLLE & 4.99 & 0.754 & 4.34 & 0.879 & 2.36 \\
\hline $110194-03$ & HUELEMOLLE & 5.36 & 0.786 & 4.52 & 0.906 & 2.41 \\
\hline $120194-01$ & HUELEMOLLE & 4.82 & 0.705 & 4.11 & 0.828 & 2.26 \\
\hline $120194-02$ & HUELEMOLLE & 4.96 & 0.733 & 4.31 & 0.877 & 2.36 \\
\hline $120194-03$ & HUELEMOLLE & 2.69 & 0.428 & 2.69 & 0.583 & 1.59 \\
\hline $150194-07$ & HUELEMOLLE Ctr. & 4.75 & 0.734 & 4.35 & 0.863 & 2.32 \\
\hline
\end{tabular}




\section{(CONTINUED)}

\begin{tabular}{|l|l|l|l|l|l|l|}
\hline Sample Number & Sample Location & Gd & Tb & Dy & Ho & Er \\
\hline $120194-4 \mathrm{~A}$ & CABURGUA & 4.13 & 0.625 & 3.74 & 0.74 & 1.99 \\
\hline $120194-4 \mathrm{C}$ & CABURGUA & 4.17 & 0.606 & 3.51 & 0.714 & 1.95 \\
\hline $120194-05$ & CABURGUA & 4.26 & 0.626 & 3.56 & 0.743 & 1.97 \\
\hline $150194-01$ & CABURGUA & 4.19 & 0.612 & 3.59 & 0.72 & 1.90 \\
\hline $150194-02$ & CABURGUA & 3.94 & 0.607 & 3.64 & 0.734 & 2.00 \\
\hline $150194-03$ & CABURGUA & 4.24 & 0.624 & 3.61 & 0.744 & 2.01 \\
\hline $130194-02$ & LLIZAN & 4.20 & 0.646 & 3.95 & 0.836 & 2.31 \\
\hline $130194-03$ & LLIZAN & 3.55 & 0.537 & 3.24 & 0.672 & 1.87 \\
\hline $140194-01$ & SAN JORGE & 2.69 & 0.429 & 2.69 & 0.571 & 1.53 \\
\hline $140194-02$ & SAN JORGE & 2.63 & 0.415 & 2.60 & 0.551 & 1.51 \\
\hline $140194-04$ & SAN JORGE & 2.89 & 0.459 & 2.84 & 0.618 & 1.66 \\
\hline $140194-5 \mathrm{~A}$ & SAN JORGE & 2.78 & 0.436 & 2.75 & 0.582 & 1.58 \\
\hline $140194-5 \mathrm{~B}$ & SAN JORGE & 2.58 & 0.426 & 2.71 & 0.573 & 1.56 \\
\hline $140194-07$ & SAN JORGE & 2.91 & 0.46 & 2.88 & 0.614 & 1.65 \\
\hline $140194-7 \mathrm{~B}$ & SAN JORGE & 2.84 & 0.441 & 2.77 & 0.597 & 1.63 \\
\hline $140194-09$ & CERRO REDONDO & 4.25 & 0.632 & 3.69 & 0.747 & 2.02 \\
\hline $140194-10$ & CERRO REDONDO & 4.06 & 0.622 & 3.68 & 0.732 & 1.99 \\
\hline $140194-11$ & CERRO REDONDO & 4.43 & 0.654 & 3.84 & 0.77 & 2.07 \\
\hline $150194-5 \mathrm{~B}$ & LA BARDA & 4.31 & 0.645 & 3.76 & 0.745 & 2.00 \\
\hline $150194-5 \mathrm{~A}$ & LA BARDA & 4.19 & 0.601 & 3.61 & 0.729 & 1.98 \\
\hline $150194-06$ & LA BARDA & 4.09 & 0.6 & 3.55 & 0.725 & 1.94 \\
\hline $240394-6 \mathrm{~A}$ & HUILILCO & 4.66 & 0.695 & 4.12 & 0.832 & 2.21 \\
\hline $240394-6 \mathrm{~B}$ & HUILILCO & 4.67 & 0.707 & 4.06 & 0.839 & 2.27 \\
\hline $220194-03 \mathrm{~L}$ & C.PIROCL. & 4.72 & 0.709 & 4.21 & 0.851 & 2.31 \\
\hline & & & & & & \\
\hline
\end{tabular}

\section{(CONTINUED)}

\begin{tabular}{|l|l|l|l|l|l|l|l|l|}
\hline Sample Number & Sample Location & Yb & Lu & Hf & Ta & Pb & Th & U \\
\hline $010494-1 \mathrm{~A}$ & RUCAPILLAN & 1.43 & 0.221 & 1.55 & 0.08 & 4.81 & 1.14 & 0.319 \\
\hline $010494-1 \mathrm{~B}$ & RUCAPILLAN & 2.34 & 0.361 & 3.13 & 0.274 & 8.34 & 2.48 & 0.6 \\
\hline $090594-1 \mathrm{tic}$ S & EL ESTADIO & 1.49 & 0.234 & 1.69 & 0.09 & 3.75 & 1.13 & 0.319 \\
\hline $090594-$ Bomba & EL ESTADIO & 1.58 & 0.249 & 1.80 & 0.097 & 4.33 & 1.24 & 0.348 \\
\hline $110194-01$ & HUELEMOLLE & 2.63 & 0.414 & 4.25 & 0.516 & 11.49 & 3.18 & 0.89 \\
\hline $110194-02$ & HUELEMOLLE & 2.28 & 0.357 & 3.42 & 0.384 & 10.08 & 2.19 & 0.646 \\
\hline $110194-03$ & HUELEMOLLE & 2.34 & 0.366 & 3.50 & 0.401 & 9.45 & 3.01 & 0.814 \\
\hline $120194-01$ & HUELEMOLLE & 2.22 & 0.348 & 3.05 & 0.352 & 8.33 & 1.79 & 0.544 \\
\hline $120194-02$ & HUELEMOLLE & 2.24 & 0.355 & 3.28 & 0.373 & 8.89 & 2.01 & 0.619 \\
\hline $120194-03$ & HUELEMOLLE & 1.55 & 0.244 & 1.50 & 0.086 & 5.52 & 0.67 & 0.248 \\
\hline $150194-07$ & HUELEMOLLE Ctr. & 2.29 & 0.356 & 3.44 & 0.385 & 9.13 & 1.99 & 0.602 \\
\hline $120194-4 \mathrm{~A}$ & CABURGUA & 1.97 & 0.307 & 2.54 & 0.211 & 7.56 & 2.72 & 0.736 \\
\hline $120194-4 \mathrm{C}$ & CABURGUA & 1.91 & 0.303 & 2.33 & 0.185 & 7.36 & 2.51 & 0.68 \\
\hline $120194-05$ & CABURGUA & 1.90 & 0.302 & 2.42 & 0.182 & 7.73 & 2.74 & 0.735 \\
\hline $150194-01$ & CABURGUA & 1.84 & 0.285 & 2.38 & 0.175 & 7.46 & 2.73 & 0.743 \\
\hline $150194-02$ & CABURGUA & 1.99 & 0.311 & 2.42 & 0.18 & 7.44 & 1.99 & 0.565 \\
\hline $150194-03$ & CABURGUA & 1.90 & 0.301 & 2.43 & 0.189 & 7.74 & 2.70 & 0.741 \\
\hline
\end{tabular}


(CONTINUED)

\begin{tabular}{|l|l|l|l|l|l|l|l|l|}
\hline Sample Number & Sample Location & Yb & Lu & Hf & Ta & Pb & Th & U \\
\hline $130194-02$ & LLIZAN & 2.41 & 0.391 & 4.48 & 0.366 & 23.71 & 6.53 & 2.113 \\
\hline $130194-03$ & LLIZAN & 1.91 & 0.305 & 3.18 & 0.257 & 12.67 & 5.45 & 1.492 \\
\hline $140194-01$ & SAN JORGE & 1.52 & 0.235 & 1.51 & 0.085 & 4.70 & 0.70 & 0.268 \\
\hline $140194-02$ & SAN JORGE & 1.48 & 0.233 & 1.46 & 0.083 & 4.31 & 0.64 & 0.236 \\
\hline $140194-04$ & SAN JORGE & 1.63 & 0.262 & 1.58 & 0.097 & 4.90 & 0.66 & 0.254 \\
\hline $140194-5 A$ & SAN JORGE & 1.62 & 0.25 & 1.47 & 0.095 & 4.55 & 0.62 & 0.227 \\
\hline $140194-5 B$ & SAN JORGE & 1.57 & 0.246 & 1.50 & 0.087 & 4.31 & 0.61 & 0.229 \\
\hline $140194-07$ & SAN JORGE & 1.60 & 0.248 & 1.60 & 0.093 & 5.19 & 0.72 & 0.265 \\
\hline $140194-7 \mathrm{~B}$ & SAN JORGE & 1.66 & 0.257 & 1.56 & 0.103 & 5.51 & 0.74 & 0.264 \\
\hline $140194-09$ & CERRO REDONDO & 1.92 & 0.302 & 2.99 & 0.32 & 8.12 & 1.98 & 0.593 \\
\hline $140194-10$ & CERRO REDONDO & 1.96 & 0.305 & 3.02 & 0.314 & 8.30 & 1.88 & 0.562 \\
\hline $140194-11$ & CERRO REDONDO & 1.97 & 0.305 & 2.68 & 0.236 & 6.13 & 3.67 & 0.825 \\
\hline $150194-5 B$ & LA BARDA & 1.96 & 0.302 & 2.58 & 0.232 & 7.90 & 2.37 & 0.663 \\
\hline $150194-5 \mathrm{~A}$ & LA BARDA & 1.93 & 0.309 & 2.47 & 0.225 & 7.02 & 2.13 & 0.595 \\
\hline $150194-06$ & LA BARDA & 1.84 & 0.293 & 2.46 & 0.219 & 8.11 & 2.17 & 0.617 \\
\hline $240394-6 \mathrm{~A}$ & HUILILCO & 2.12 & 0.329 & 3.42 & 0.429 & 8.86 & 3.53 & 0.95 \\
\hline $240394-6 \mathrm{~B}$ & HUILILCO & 2.20 & 0.349 & 3.43 & 0.419 & 11.65 & 3.51 & 0.942 \\
\hline $220194-03 \mathrm{~L}$ & C.PIROCL. & 2.28 & 0.358 & 3.45 & 0.4 & 8.38 & 3.27 & 0.857 \\
\hline
\end{tabular}


Table 3 - 5b ICPMS results (in ppm) from Carran - LV SEC samples

\begin{tabular}{|l|l|l|l|l|l|l|l|l|}
\hline Sample Numbers & Sample Locations & $\mathrm{Rb}$ & $\mathrm{Nb}$ & $\mathrm{Cs}$ & $\mathrm{Ba}$ & $\mathrm{La}$ & $\mathrm{Ce}$ & $\mathrm{Pr}$ \\
\hline $060295-03$ & Vn. Quene & 13.8 & 2.82 & 1.10 & 267 & 10.9 & 25.4 & 3.61 \\
\hline $070295-04$ & Aserradero Alto & 23.2 & 5.76 & 1.40 & 330 & 21.8 & 52.8 & 7.92 \\
\hline $100295-02$ & Vn. Pichi Negro & 21.9 & 5.10 & 1.35 & 304 & 19.5 & 47.6 & 7.04 \\
\hline $150295-042$ & Cntros Quilicura & 18.6 & 6.47 & 0.82 & 313 & 16.9 & 37.4 & 5.01 \\
\hline $160295-01$ & Vn. Media Luna & 8.87 & 1.75 & 0.77 & 199 & 7.65 & 17.8 & 2.62 \\
\hline $170295-01$ & Chascon Sur lava & 9.29 & 1.80 & 0.91 & 188 & 7.11 & 16.7 & 2.50 \\
\hline $180295-02$ & Vn Mirador block & 7.25 & 1.92 & 0.71 & 179 & 6.63 & 16.1 & 2.39 \\
\hline $180295-06$ & Los Guindos I & 12.1 & 3.02 & 0.66 & 257 & 11.6 & 25.1 & 3.42 \\
\hline
\end{tabular}

\begin{tabular}{|l|l|l|l|l|l|l|l|l|}
\hline Sample Numbers & Sample Locations & $\mathrm{Nd}$ & $\mathrm{Sm}$ & $\mathrm{Eu}$ & $\mathrm{Gd}$ & $\mathrm{Tb}$ & Dy & Ho \\
\hline $060295-03$ & Vn. Quene & 16.6 & 4.07 & 1.33 & 4.09 & 0.684 & 4.21 & 0.883 \\
\hline $070295-04$ & Aserradero Alto & 38.4 & 9.65 & 2.90 & 10.8 & 1.545 & 8.98 & 1.816 \\
\hline $100295-02$ & Vn. Pichi Negro & 34.3 & 8.52 & 2.60 & 9.68 & 1.384 & 8.13 & 1.642 \\
\hline $150295-042$ & Cntros Quilicura & 21.7 & 4.80 & 1.46 & 4.56 & 0.736 & 4.40 & 0.882 \\
\hline $160295-01$ & Vn. Media Luna & 12.6 & 3.32 & 1.14 & 3.96 & 0.614 & 3.88 & 0.819 \\
\hline $170295-01$ & Chascon Sur lava & 12.0 & 3.26 & 1.12 & 3.81 & 0.592 & 3.68 & 0.788 \\
\hline $180295-02$ & Vn Mirador block & 11.4 & 3.06 & 1.0 & 3.61 & 0.566 & 3.52 & 0.744 \\
\hline $180295-06$ & Los Guindos I & 15.1 & 3.54 & 1.16 & 3.83 & 0.580 & 3.50 & 0.740 \\
\hline
\end{tabular}

\begin{tabular}{|l|l|l|l|l|l|l|l|l|l|}
\hline Sample Numbers & Sample Locations & Er & Yb & Lu & Hf & Ta & Pb & Th & U \\
\hline $060295-03$ & Vn. Quene & 2.45 & 2.59 & 0.414 & 2.80 & 0.165 & 7.91 & 1.18 & 0.414 \\
\hline $070295-04$ & Aserradero Alto & 4.77 & 4.29 & 0.667 & 3.59 & 0.351 & 8.78 & 2.76 & 0.749 \\
\hline $100295-02$ & Vn. Pichi Negro & 4.24 & 3.73 & 0.577 & 3.26 & 0.306 & 8.27 & 2.62 & 0.712 \\
\hline $150295-042$ & Cntros Quilicura & 2.41 & 2.42 & 0.381 & 3.33 & 0.362 & 6.71 & 2.00 & 0.527 \\
\hline $160295-01$ & Vn. Media Luna & 2.24 & 2.20 & 0.348 & 1.93 & 0.102 & 5.83 & 1.20 & 0.329 \\
\hline $170295-01$ & Chascon Sur lava & 2.19 & 2.21 & 0.351 & 1.98 & 0.107 & 5.83 & 0.80 & 0.261 \\
\hline $180295-02$ & Vn Mirador block & 2.06 & 2.06 & 0.327 & 2.10 & 0.106 & 5.55 & 0.44 & 0.175 \\
\hline $180295-06$ & Los Guindos I & 2.02 & 2.04 & 0.316 & 2.07 & 0.171 & 6.36 & 2.19 & 0.491 \\
\hline
\end{tabular}


Table 3-5c ICPMS results (in ppm) from V.Villarrica samples

\begin{tabular}{|l|l|l|l|l|l|l|l|l|}
\hline Sample Number & Sc & TiO2 & V & Cr & Co & Ni & Cu & Sr \\
\hline $289761-L 21$ & 32.8 & 1.11 & 278 & 236 & 36.0 & 91.1 & 133 & 420 \\
\hline $210281-1$ & 32.7 & 1.11 & 279 & 185 & 33.4 & 71.1 & 134 & 426 \\
\hline $151282-2$ & 30.2 & 0.94 & 207 & 84.4 & 25.0 & 21.4 & 71.1 & 451 \\
\hline $191284-1$ & 31.9 & 1.13 & 284 & 152 & 32.8 & 65.3 & 155 & 463 \\
\hline $151282-3$ & 32.4 & 1.33 & 333 & 34.5 & 27.2 & 17.5 & 138 & 425 \\
\hline
\end{tabular}

\begin{tabular}{|l|l|l|l|l|l|l|l|l|}
\hline Sample Number & $\mathrm{Y}$ & $\mathrm{Zr}$ & $\mathrm{Nb}$ & $\mathrm{Ba}$ & $\mathrm{Rb}$ & $\mathrm{Cs}$ & $\mathrm{La}$ & $\mathrm{Ce}$ \\
\hline $289761-\mathrm{L} 21$ & 24.2 & 92.5 & 2.16 & 192 & 15.1 & 1.499 & 7.86 & 19.3 \\
\hline $210281-1$ & 24.6 & 95.7 & 2.19 & 198 & 15.9 & 1.601 & 7.90 & 19.4 \\
\hline $151282-2$ & 24.3 & 114 & 3.19 & 274 & 19.2 & 1.519 & 10.5 & 24.3 \\
\hline $191284-1$ & 24.2 & 93.9 & 2.19 & 202 & 15.5 & 1.663 & 7.92 & 19.5 \\
\hline $151282-3$ & 26.9 & 114 & 3.08 & 260 & 20.8 & 1.757 & 10.32 & 24.6 \\
\hline
\end{tabular}

\begin{tabular}{|l|l|l|l|l|l|l|l|l|}
\hline Sample Number & Pr & Nd & Sm & Eu & Tb & Gd & Dy & Ho \\
\hline $289761-L 21$ & 2.84 & 13.40 & 3.51 & 1.10 & 0.633 & 3.99 & 3.93 & 0.855 \\
\hline $210281-1$ & 2.88 & 13.57 & 2.58 & 1.10 & 0.643 & 4.08 & 4.02 & 0.869 \\
\hline $151282-2$ & 3.42 & 15.38 & 3.76 & 1.16 & 0.646 & 4.11 & 4.00 & 0.857 \\
\hline $191284-1$ & 2.92 & 13.94 & 3.65 & 1.12 & 0.651 & 4.14 & 4.04 & 0.870 \\
\hline $151282-3$ & 3.52 & 16.12 & 4.05 & 1.26 & 0.712 & 4.54 & 4.43 & 0.951 \\
\hline
\end{tabular}

\begin{tabular}{|l|l|l|l|l|l|l|l|l|}
\hline Sample Number & Er & Yb & Lu & Hf & Ta & Pb & Th & U \\
\hline $289761-$ L21 & 2.35 & 2.26 & 0.348 & 2.48 & 0.137 & 7.08 & 1.27 & 0.446 \\
\hline $210281-1$ & 2.41 & 2.33 & 0.357 & 2.56 & 0.140 & 7.33 & 1.32 & 0.458 \\
\hline $151282-2$ & 2.42 & 2.37 & 0.368 & 2.93 & 0.195 & 8.48 & 2.20 & 0.683 \\
\hline $191284-1$ & 2.40 & 2.29 & 0.354 & 2.57 & 0.233 & 10.9 & 1.29 & 0.450 \\
\hline $151282-3$ & 2.62 & 2.53 & 0.394 & 2.96 & 0.230 & 8.54 & 1.88 & 0.571 \\
\hline
\end{tabular}


Table 3 - 6a (07/98) (The MEC1 results marked with a "*" were measured in 05/00)

\begin{tabular}{|l|l|l|l|l|l|l|l|l|l|l|l|}
\hline Replicates & $\mathrm{Rb}$ & $\mathrm{Nb}$ & $\mathrm{Cs}$ & $\mathrm{Ba}$ & $\mathrm{La}$ & $\mathrm{Ce}$ & $\mathrm{Pr}$ & $\mathrm{Nd}$ & $\mathrm{Sm}$ & Eu \\
\hline MEC1 & FIU-1 & 21.9 & 9.70 & 0.839 & 471 & 28.2 & 61.5 & 8.06 & 33.2 & 6.70 & 1.87 \\
\hline MEC1 & FIU-3 & 21.7 & 9.63 & 0.904 & 464 & 29.3 & 64.0 & 8.20 & 33.7 & 6.70 & 1.88 \\
\hline MEC1 & FIU-2 & 21.7 & 9.80 & 0.893 & 447 & 29.2 & 63.7 & 8.15 & 33.5 & 6.78 & 1.91 \\
\hline MEC1 & Ave. & 21.8 & 9.71 & 0.879 & 461 & 28.9 & 63.1 & 8.14 & 33.5 & 6.73 & 1.88 \\
\hline \% RSD & \%RSD & 0.4 & 0.9 & 3.9 & 2.7 & 2.0 & 2.1 & 0.9 & 0.7 & 0.7 & 1.1 \\
\hline \multirow{2}{*}{ MEC1* } & $05 / 00$ & 21.0 & 9.86 & 0.870 & 430 & 27.5 & 60.2 & 7.83 & 32.1 & 6.48 & 1.86 \\
\hline \multirow{3}{*}{ Stds } & W-2 & 22.0 & 7.70 & 0.902 & 172 & 10.1 & 22.8 & 3.04 & 12.9 & 3.24 & 1.10 \\
\cline { 2 - 11 } & BHVO & 9.20 & 19.7 & 0.967 & 133 & 15.7 & 37.8 & 5.40 & 24.8 & 6.10 & 1.98 \\
\cline { 2 - 11 } & AGV & 68.0 & 14.9 & 1.260 & 1226 & 38.7 & 69.0 & 8.50 & 32.3 & 5.82 & 1.73 \\
\hline
\end{tabular}

(CONTINUED)

\begin{tabular}{|l|l|l|l|l|l|l|l|l|l|l|l|l|}
\hline Rep. & Gd & Tb & Dy & Ho & Er & Yb & Lu & Hf & Ta & Pb & Th & U \\
\hline FIU-1 & 6.24 & 0.908 & 5.25 & 1.033 & 2.74 & 2.59 & 0.401 & 4.23 & 0.516 & 11.5 & 3.21 & 0.900 \\
\hline FIU-3 & 6.23 & 0.907 & 5.22 & 1.049 & 2.80 & 2.64 & 0.419 & 4.23 & 0.517 & 11.3 & 3.15 & 0.890 \\
\hline FIU-2 & 6.28 & 0.925 & 5.17 & 1.034 & 2.77 & 2.66 & 0.421 & 4.28 & 0.516 & 11.6 & 3.17 & 0.881 \\
\hline Ave. & 6.25 & 0.913 & 5.21 & 1.039 & 2.77 & 2.63 & 0.414 & 4.25 & 0.516 & 11.5 & 3.18 & 0.890 \\
\hline \%RSD & 0.4 & 1.1 & 0.7 & 0.8 & 1.0 & 1.3 & 2.6 & 0.6 & 0.2 & 1.3 & 0.9 & 1.0 \\
\hline MEC1* & 6.16 & 0.905 & 5.20 & 1.038 & 2.82 & 2.63 & 0.409 & 4.14 & 0.520 & 10.8 & 3.08 & 0.861 \\
\hline W-2 & 3.73 & 0.632 & 3.83 & 0.800 & 2.17 & 1.98 & 0.300 & 2.48 & 0.500 & 7.70 & 2.10 & 0.490 \\
\hline BHV0 & 6.56 & 0.948 & 5.37 & 1.010 & 2.38 & 2.01 & 0.290 & 4.49 & 1.210 & 2.06 & 1.25 & 0.408 \\
\hline AGV & 4.90 & 0.706 & 3.78 & 0.698 & 1.87 & 1.70 & 0.262 & 5.17 & 0.900 & 37.0 & 6.50 & 1.920 \\
\hline
\end{tabular}


Table 3 - 6b (11/98)

\begin{tabular}{|c|c|c|c|c|c|c|c|c|c|c|c|c|}
\hline \multicolumn{2}{|l|}{ Rep. } & $\mathrm{Rb}$ & $\mathrm{Nb}$ & Cs & $\mathrm{Ba}$ & $\mathrm{La}$ & $\mathrm{Ce}$ & $\mathrm{Pr}$ & $\mathrm{Nd}$ & $\mathrm{Sm}$ & Eu & $\mathrm{Gd}$ \\
\hline MEC6 & Batch-A & 27.2 & 7.01 & 1.18 & 361 & 18.8 & 40.7 & 5.32 & 22.1 & 4.74 & 1.36 & 4.52 \\
\hline MEC6 & Batch-B & 27.2 & 6.90 & 1.18 & 354 & 18.1 & 39.3 & 5.13 & 21.6 & 4.62 & 1.34 & 4.69 \\
\hline MEC6 & Batch-C & 27.5 & 7.30 & 1.20 & 366 & 19.0 & 41.3 & 5.41 & 22.8 & 4.88 & 1.44 & 4.95 \\
\hline MEC6 & Ave. & 27.3 & 7.07 & 1.19 & 360 & 18.6 & 40.4 & 5.29 & 22.2 & 4.75 & 1.38 & 4.72 \\
\hline MEC6 & $\% \mathrm{RSD}$ & $0.6 \%$ & $2.9 \%$ & $1.0 \%$ & $1.6 \%$ & $2.7 \%$ & $2.5 \%$ & $2.7 \%$ & $2.7 \%$ & $2.7 \%$ & $3.6 \%$ & $4.6 \%$ \\
\hline \multirow{3}{*}{\multicolumn{2}{|c|}{ Stds. }} & $\mathrm{W} 2$ & $\mathrm{~W} 2$ & $\mathrm{~W} 2$ & W2 & BIR & BIR & $\overline{B I R}$ & BIR & BIR & BIR & BIR \\
\hline & & DNC & DNC & $\mathrm{DNC}$ & DNC & DNC & DNC & DNC & DNC & DNC & DNC & DNC \\
\hline & & & $\mathrm{BHV}$ & $\mathrm{BHV}$ & $\mathrm{BHV}$ & $\mathrm{BHV}$ & $\mathrm{BHV}$ & BHV & BHV & BHV & BHV & $\mathrm{BHV}$ \\
\hline
\end{tabular}

(CONTINUED)

\begin{tabular}{|l|l|l|l|l|l|l|l|l|l|l|l|}
\hline Rep. & Tb & Dy & Ho & Er & Yb & Lu & Hf & Ta & Pb & Th & U \\
\hline Batch-A & 0.701 & 4.20 & 0.841 & 2.29 & 2.27 & 0.355 & 3.43 & 0.390 & 8.33 & 3.20 & 0.839 \\
\hline Rep. & Tb & Dy & Ho & Er & Yb & Lu & Hf & Ta & Pb & Th & U \\
\hline Batch-B & 0.690 & 4.09 & 0.827 & 2.24 & 2.18 & 0.344 & 3.38 & 0.391 & 8.24 & 3.29 & 0.865 \\
\hline Batch-C & 0.736 & 4.33 & 0.884 & 2.41 & 2.40 & 0.375 & 3.54 & 0.418 & 8.56 & 3.32 & 0.866 \\
\hline Ave & 0.709 & 4.21 & 0.851 & 2.31 & 2.28 & 0.358 & 3.45 & 0.400 & 8.38 & 3.27 & 0.857 \\
\hline \%RSD & $3.4 \%$ & $2.8 \%$ & $3.5 \%$ & $3.9 \%$ & $4.7 \%$ & $4.5 \%$ & $2.4 \%$ & $4.0 \%$ & $2.0 \%$ & $1.9 \%$ & $1.8 \%$ \\
\hline Stds. & BIR & BIR & BIR & BIR & BIR & BIR & W2 & W2 & W2 & W2 & W2 \\
\cline { 2 - 11 } & DNC & DNC & DNC & DNC & DNC & DNC & DNC & DNC & DNC & DNC & DNC \\
\cline { 2 - 4 } & BHV & BHV & BHV & BHV & BHV & BHV & BHV & BHV & BHV & BHV \\
\hline
\end{tabular}




\section{Direct Current Plasmas (DCP)}

Today a commonly - used DCP contains a pair of graphite anodes and a tungsten cathode, to replace its original two-electrode design because of the improving of stability. Argon flows through the electrodes and plasma created in DCP is a DC electric arc (not torch like as in ICP but in an inverted Y-shape). Samples are pumped and nebulized (with a much longer nebulizer than that of ICP) into the spray chamber between the anodes and excited, and can be observed at the center of the Y-shape when the emitted sample ions interact with the plasmas. Comparing with ICP, DCP is relatively cheaper, simpler to be used, less consumation of argon, and can be applied to a larger range of sample types such as organic materials. Most importantly, because of its much lower excitation temperature $\left(\mathrm{T} \approx 6000^{\circ} \mathrm{C}\right), \mathrm{DCP}$ is considered to have better sensitivity in measuring those easily ionizable elements -- alkalis and alkali earths while ICP is usually more intereference - free on refractories. In addition, it is a glassware - free instrument that is considered to be most suitable for B analyses (less B contamination from glass). The detection limits and precision for both ICP and DCP are very similar, while DCP may be slightly worse on the ionization interferences due to its lower excitation temperature.

The Li-Be-B measurements were all completed using the ARL model SpectraSpan (SS) 7 DCP at the University of South Florida, Tampa, under the tutelage of Dr. Jeffery Ryan and Ph.D. Student Ivan Sanov. The following procedures of samples preparation are from the B-Be-Li cookbook of the DCP lab of USF (also see Ryan et al. (1996) for details):

1) Accurately weigh $0.5-1 \mathrm{~g}$ of sample into Pt crucible. In terms of the fusions $\pm 10 \%$ on the weight is not a problem, as long as it is known accurately.

2) Precisely weigh $2-4 \mathrm{~g}$ of $\mathrm{Na}_{2} \mathrm{CO}_{3}$ flux into crucibles with samples. The amount of $\mathrm{Na}_{2} \mathrm{CO}_{3}$ added should be about 4 times the amount of sample (ex: $0.5 \mathrm{~g}$ sample requires $2.000 \mathrm{~g}$ flux). The flux does contain a small, but measurable amount of B. For arc volcanic samples, this added B presents no problems for the quality of analysis, but it does present difficulties measuring $B$ in ocean ridge basalts and ultramafic samples, where B contents of the samples are very low. The standard procedure is to replicate all measurements on samples with B contents below 2 ppm to insure accuracy.

3) Mix sample and flux thoroughly with metal spatula, until homogeneous. $\mathrm{Na}$ carbonate is not a particularly corrosive flux, so it will not digest large grains in the sample powder. Be certain that the powders will pass a $100 \mu \mathrm{m}$ mesh sieve before fusing.

4) Cover crucibles, and place in a COLD muffle furnace. Then GRADUALLY heat the furnace up to $1000-1050^{\circ} \mathrm{C}$. IF heated too fast, the $\mathrm{Na}$ carbonate will decarbonate before it melts, so the slower, the better. Typically bring the samples up over a 60-90 minute period. Even this slowly, some $\mathrm{CO}_{2}$ will be generated, so covers are needed for the crucibles to prevent sample loss from spattering.

5) When the temperature is reached, turn the furnace off, and allow the crucibles to cool to room temperature. Slower cooling of the fusions makes them easier to extract from the crucibles.

6) Immerse the cooled crucibles, with covers, in approx. $80 \mathrm{ml}$ of $\mathrm{B}$-free $\mathrm{H}_{2} \mathrm{O}$ in the $180 \mathrm{ml}$ Savillex jars. Seal tightly, place on a hotplate at about $100-120^{\circ} \mathrm{C}$, and 
leave them overnight. It is in this step that B is separated: in carbonate form in alkaline solutions, B and Si are water soluble, along with all the alkali metals such as $\mathrm{Li}$. All other species in the rock either form insoluble carbonates, or are scavenged by the $\mathrm{CaCO}_{3}$ formed in the fusion. Be produces an insoluble carbonate, and is quantitatively retained in the water-insoluble fraction.

7) The next morning, take the beakers, cool them to handling temperature, and extract the insolubles from the crucible. At this stage the fusion cake will have been softened due to the dissolution of $\mathrm{Na} 2 \mathrm{CO} 3$, but all the water solubles within the cake are typically not dissolved. Remove the crucibles from the beakers, rinse their exteriors thoroughly into the beakers, scrape out the insoluble portion of the fusion cake, and place that in the beaker as well. Use the teflon policemen and plastic clips as extraction tools, as these will not damage the crucibles, or contaminate the samples. Large, hard chunks of the fusion cake will have to be broken up, which can easily be done with the plastic implements. Rinse EVERYTHING from the crucible into the beaker, and then place the beaker on a hotplate at approx. $150^{\circ} \mathrm{C}$ to evaporate down to about $40 \mathrm{ml}$. THIS STEP WILL TAKE A WHILE, BECAUSE YOU WILL HAVE USED A LOT OF B-FREE WATER IN THE EXTRACTION STEP.

8) Take the scraped and cleaned crucibles, and fill each with about $3 \mathrm{ml}$ of Trace Metal Grade $\mathrm{HCl}$, and the rest regular deionized water. This procedure both digests any remaining insoluble carbonates, which you will need for quantitative $\mathrm{Be}$ measurement, and it leaches $\mathrm{Fe}$ off the crucible and prevents its alloying with the Pt the next time you heat it up. The solution need only sit in the crucibles for about two hours, so once this time is past, pour the solutions off into a centrifuge tube and save them. The crucibles are now ready for HF immersion, and to be reused.

9) Once the solutions in the Savillex jars have evaporated down to $40 \mathrm{ml}$, pour them off into $50 \mathrm{ml}$ centrifuge tubes, and centrifuge them for 10-20 minutes. The insolubles will stick nicely at the bottom, so the solutions will pour off cleanly. CAREFULLY decant the supernates back into the Savillex jars -- it is very important at this stage that ALL insolubles remain in the centrifuge tubes! Rinse the residues in the tubes 3 times with about $20 \mathrm{ml}$ of B-free water each time, centrifuge and decant the rinse solutions into the Savillex jars. As an added precaution, Vortex the rinses to mix them thoroughly with the residues before centifuging and decanting them, just to be sure all the solubles are dissolved. Keep the residues, but set them aside for the moment.

10) Evaporate the supernates and rinses down hard, to dryness. The solution at this stage contains all $\mathrm{B}$, and much of $\mathrm{Si}$ of the sample. Resuspend the dried supernates in $20 \mathrm{ml}$ of B-free water. Then, CAREFULLY add to each sample 5$10 \mathrm{ml}$ of Ultrapure, concentrated $\mathrm{HNO}_{3}$ (proportioned to the amount of $\mathrm{Na}_{2} \mathrm{CO}_{3}$ ), or enough to react all the carbonate. Use Fisher's Optima Grade acid for this step. The solutions will fizz and pop violently, so the top of the jar should not be left off. The best way to do this step is to add 1-2 mls of acid at a time, and let it fizz and die down before adding more acid.

11) Once the solutions have been neutralized in acid, allow them to sit, covered, at room temperature for several hours to allow $\mathrm{SiO}_{2}$ to precipitate. DO NOT HEAT 
THE SOLUTIONS AT THIS STAGE! Boron in $\mathrm{HNO}_{3}$ solutions can volatilize at temperatures above $100^{\circ} \mathrm{C}$. Sit them in a cool place at this stage, as lowering the temperature encourages the silica to precipitate.

12) What happens next with the samples depends on the amount of precipitated $\mathrm{SiO}_{2}$ : If there is very little, the solutions can be brought to volume and filtered with no hassle. If there is a lot of $\mathrm{SiO}_{2}$, you will have to centrifuge it off. Care should be taken not to generate too much sample solution at this stage, as you can't evaporate it away. For siliceous samples, centrifuge off silica, and rinse 2-3 times with $5-10 \mathrm{ml}$ of $\mathrm{B}$-free water that was acidified slightly with $\mathrm{HNO}_{3}$ for not to redissolve the silica.

13) Dilute the samples to a known volume. Use 50ml PMP volumetric flasks, which gives a 50:1 dilution factor. If a lower degree of dilution is needed, weigh the solutions instead of using the $50 \mathrm{ml}$ flasks.

14) Filter the solutions into storage bottles. Silica will clog even a DCP nebulizer, so it must be removed for successful analysis.

At this stage, B solutions are complete and ready to go on the DCP for measurement. Now return to the insoluble residues and crucible washes for Be solution preparation:

1) Add to each centrifuge tube with residues, in this order: $10 \mathrm{ml}$ of deionized $\mathrm{H}_{2} \mathrm{O}$, $5 \mathrm{ml}$ of Trace Metal Grade $\mathrm{HCl}$, and sufficient deionized $\mathrm{H}_{2} \mathrm{O}$ to bring the total volume up to approx. $35 \mathrm{ml}$. Be sure to use ONLY untreated deionized water for this and all following steps. Beryllium solubility is a strong function of $\mathrm{pH}$ : at $\mathrm{pH}$ $>4$, Be precipitates as $\mathrm{Be}(\mathrm{OH})_{2}$ (water treated for boron extraction has a $\mathrm{pH}>8$ ).

2) Allow the residues to digest. You may want to loosen the tops of the tubes to permit $\mathrm{CO}_{2}$ to escape. Shaking or vortexing the tubes expedites this process.

3) Pour both the dissolved residues, and the crucible washes, into $180 \mathrm{ml}$ Savillex jars. Place the jars on a hotplate, and evaporate them to dryness at $150^{\circ} \mathrm{C}$.

4) Resuspend the dried solutions as follows: add $5 \mathrm{ml}$ of concentrated Trace Metal $\mathrm{HCl}$ to each sample, then add $15 \mathrm{ml}$ of deionized water to each sample. Then you will end up with a yellow solution with clots of a clear (mostly silica) precipitate. Adding the $\mathrm{HCl}$ after the water slows the resuspension significantly -- the dried samples seem to need the "kick start" of the strong acid -- and it may result in a rust-red precipitate due to the complexation of some of the iron. The effect on $\mathrm{Be}$ dissolution of changing the above order is variable: some samples work $\mathrm{OK}$, some show Be losses.

5) After adding the acid and water, seal the samples in their jars, and place on a hotplate for $2-6$ hours at $100^{\circ} \mathrm{C}$. What this step does is to dissolve the solubles, and allow the silica (which will consist of clotted granules) to partly gelatinize, making it easier to separate.

6) Pour these heated solutions into centrifuge tubes, and centrifuge them to separate the silica. Decant solutions back into the Savillex jars, and rinse the residues 2-3 times with $10-15 \mathrm{ml} \mathrm{H}_{2} \mathrm{O}$, until the yellow color disappears. If some of the finer grained silica happens to get out of the tubes, no problem.

7) At this stage you will have anywhere from $50-80 \mathrm{ml}$ of solution for Be analysis. Typically evaporate the solutions to about $40 \mathrm{ml}$, and bring them to $50 \mathrm{ml}$ in volumetric flasks (glass flasks are $\mathrm{OK}$ here). For rocks with $>=0.2 \mathrm{ppm} \mathrm{Be}$, this 
solution is concentrated enough to be analyzed. Again, filter the solutions into storage bottles to prevent silica from getting into the DCP nebulizer.

$\mathrm{Li}$ and $\mathrm{Be}$ solutions can also be prepared by an alternative procedure - the $\mathrm{HF}-\mathrm{HClO}_{4}$ digestion (necessary for $100 \%$ extraction because $\mathrm{Li}$ - fluorides are highly insoluble):

1) Weigh samples into $60 \mathrm{ml}$ Savillex jars. The exact amount weighed will determine the final volume of solution you have: $0.5 \mathrm{~g}$ yields $50 \mathrm{ml}, 0.25 \mathrm{~g}$ yields $25 \mathrm{ml}$, etc. It is not crucial that the weight be in round numbers, only that you know it exactly.

2) Take weighed samples in their jars to $255 \mathrm{~A}$, the Acid lab, and place them in the steel $\mathrm{HClO}_{4}$-rated hood. Add enough water to each sample to wet the powders thoroughly, and to cover the bottoms of the beakers.

3) Add $1 \mathrm{ml}$ of $4: 1 \mathrm{HF}_{-} \mathrm{HClO}_{4}$ solution for each $100 \mathrm{mg}$ of sample in the beaker. [Caution! If the sample contains carbonate, it will fizz and spatter, so cover samples quickly after adding the acid!]

4) Seal the jars tightly, place on hotplate at $150^{\circ} \mathrm{C}$ (a bit below 2 on the gauge), and leave to digest overnight.

5) The next day, remove covers from jars (tap sealed jars gently on table to shake drops loose from the top, unscrew carefully, rinse remaining drops off covers and pour them back into the jars). Set the covers aside, and leave the solutions to dry on the hotplate WITH THE HOOD AIR HANDLER ON.

6) About 5-6 hours later, increase hotplate temperature to $180-200^{\circ} \mathrm{C}$ (a bit above 2 on the scale) to dry off the $\mathrm{HClO}_{4}$ : a heavy white vapor should begin to emanate from the jars. This may take a while (overnight) for the samples to be complete dried.

7) Add $10-15 \mathrm{ml}$ clean $\mathrm{H}_{2} \mathrm{O}$, about $2-3 \mathrm{ml}$ each of concentrated $\mathrm{HCl}$ and $\mathrm{HNO}_{3}$, and about 10-12 drops of conc. $\mathrm{HClO}_{4}$ to each sample jar. The solutions should eventually come clear. Evaporate this off as well, at $150-180^{\circ} \mathrm{C}$.

8) Add to each sample $4 \mathrm{ml}$ of $2 \mathrm{M} \mathrm{HNO}_{3}$ for each $100 \mathrm{mg}$ of powder $(10 \mathrm{ml}$ for $250 \mathrm{mg}, 20 \mathrm{ml}$ for $500 \mathrm{mg}$ ). Cover samples and leave them on hotplate at $100^{\circ} \mathrm{C}$ for an hour.

9) Return, open samples, and examine for insolubles: if white phases remain, repeat the conc. $\mathrm{HCl}-\mathrm{HNO}_{3}-\mathrm{HClO}_{4}$ step with more $\mathrm{HClO}_{4}$. If other crystalline insolubles appear, it may be necessary to add more water or acid to increase solution volume.

10) If no insolubles, then: decant sample into appropriate volumetric flasks $(50 \mathrm{ml}$ for $500 \mathrm{mg}, 25 \mathrm{ml}$ for $250 \mathrm{mg}$ ). Rinse beakers with DI water, and pour the rinses into the flasks too (WATCH YOUR VOLUMES!). Fill flasks to the lines with $\mathrm{H}_{2} \mathrm{O}$, cork, and swirl and shake to homogenize. Pour contents of flasks into appropriately labeled sample bottles.

Now the $\mathrm{Be}$ and $\mathrm{Li}$ solutions are ready to go on the $\mathrm{DCP}$ for measurement. And the following tables (Table $3-7 \mathrm{a}$ ) contain the $\mathrm{B}-\mathrm{Be}-\mathrm{Li}$ results of the measured SEC samples. Five samples from V.Villarrica, 1 replicate of SEC sample 110194 - 02 and 1 rock standard were also measured and their $\mathrm{Be}$ and $\mathrm{Li}$ results are in the Table $3-7 \mathrm{~b}$ (B results are still pending - will be rerun in the coming future). The reported results of the 
Be and $\mathrm{Li}$ concentrations of $110194-02$ (marked with a "*" in Table $3-7 \mathrm{a}$ ) are the average calculated from the two measured results. 
Table 3 - 7a Li-Be-B compositions of the SEC samples (in ppm)

Part 1 - Villarrica SEC

\begin{tabular}{|l|l|l|l|l|}
\hline Sample Number & Sample Location & $\mathrm{B}( \pm 10 \%)$ & $\mathrm{Be}( \pm 5 \%)$ & $\mathrm{Li}( \pm 5 \%)$ \\
\hline $010494-1 \mathrm{~A}$ & RUCAPILLAN & 3.8 & 0.39 & 8.2 \\
\hline $010494-1 \mathrm{~B}$ & RUCAPILLAN & 6.2 & 0.91 & 16 \\
\hline $090594-1 \mathrm{iticos}$ & EL ESTADIO & 3.8 & 0.48 & 9.0 \\
\hline $110194-02^{*}$ & HUELEMOLLE & 24 & 1.08 & 23 \\
\hline $110194-03$ & HUELEMOLLE & 3.1 & 1.06 & 14 \\
\hline $120194-02$ & HUELEMOLLE & 11 & 1.04 & 14 \\
\hline $120194-03$ & HUELEMOLLE & 8.5 & 0.49 & 11 \\
\hline $120194-05$ & CABURGUA & 6.0 & 0.70 & 13 \\
\hline $150194-01$ & CABURGUA & 4.2 & 0.75 & 13 \\
\hline $150194-03$ & CABURGUA & 5.6 & 0.70 & 14 \\
\hline $130194-02$ & LLIZAN & 17 & 1.17 & 17 \\
\hline $140194-01$ & SAN JORGE & 6.8 & 0.39 & 8.9 \\
\hline $140194-04$ & SAN JORGE & 6.3 & 0.41 & 8.4 \\
\hline $140194-07$ & SAN JORGE & 7.7 & 0.36 & 8.6 \\
\hline $140194-09$ & CERRO REDONDO & 8.9 & 0.93 & 12 \\
\hline $140194-11$ & CERRO REDONDO & 2.2 & 0.88 & 9.3 \\
\hline $150194-5 B$ & LA BARDA & 5.0 & 0.72 & 11 \\
\hline $150194-06$ & LA BARDA & 11 & 0.77 & 11 \\
\hline $240394-6 \mathrm{~A}$ & HUILILCO & 9.5 & 1.05 & 11 \\
\hline $240394-6 \mathrm{~B}$ & HUILILCO & 6.2 & 0.92 & 14 \\
\hline
\end{tabular}

\section{Part 2 -- Carran-LV SEC}

\begin{tabular}{|l|l|l|l|l|}
\hline Sample Numbers & Sample Locations & $\mathrm{B}( \pm 10 \%)$ & $\mathrm{Be}( \pm 5 \%)$ & $\mathrm{Li}( \pm 5 \%)$ \\
\hline $080295-02$ & Salto del Diablo & 11. & 0.87 & 19 \\
\hline $120295-01$ & Carran I & 10. & 0.97 & 15 \\
\hline $160295-01$ & Vn. Media Luna & 7.8 & 0.85 & 11 \\
\hline $170295-01$ & Chascon Sur lava & 12 & 0.58 & 9.6 \\
\hline $170295-02$ & Chascon Sur bom & 9.4 & 0.59 & 12 \\
\hline $180295-08$ & Los Guindos III & 5.1 & 0.14 & 11 \\
\hline
\end{tabular}


Table 3 - 7b Be and Li results of the V.Villarrica samples, replicate and standard (in ppm)

\begin{tabular}{|l|l|l|}
\hline V.Villarrica Sample & $\mathrm{Be}( \pm 5 \%)$ & $\mathrm{Li}( \pm 5 \%)$ \\
\hline $151282-2$ & 0.81 & 14 \\
\hline $151282-3$ & 0.72 & 16 \\
\hline $191284-1$ & 0.75 & 16 \\
\hline $210281-1$ & 0.64 & 15 \\
\hline L21 $(280976-1)$ & 0.60 & 14 \\
\hline Replicate & $\mathrm{Be}$ & $\mathrm{Li}$ \\
\hline $110194-02(06 / 99)$ & 1.1 & 24 \\
\hline $110194-02(07 / 00)$ & 1.1 & 22 \\
\hline RSD\% & $3 \%$ & $8 \%$ \\
\hline Standard & $\mathrm{Be}$ & $\mathrm{Li}$ \\
\hline Std. JB - 2 & 0.17 & \\
\hline & & \\
\hline
\end{tabular}




\section{Mass Spectrometry and Isotope Analyses}

The isotope analyses were performed at the National High Magnetic Field Laboratory (NHMFL) using a fully automated 9 collector Finnegan mass spectrometer is equipped with an RPQ-system (for increased abundance sensitivity) and a 13 - sample turret, under the tutelage of Dr. Vincent Salters and PhD student Michael Bizimis and Andreas Stracke. The main use of this mass spectrometer is to analyse the radiogenic $\mathrm{Sr}, \mathrm{Nd}$ and $\mathrm{Pb}$, as well as $\mathrm{U}, \mathrm{Re}$ and Os isotopes.

$\mathrm{Sr}$ and $\mathrm{Pb}$ samples were prepared at the clean lab, FIU, by following the procedures of column chemistry at DTM:

1) Sr Chemistry:

- Sample dissolution: $0.1 \mathrm{~g}$ rock powders were weighed, dissolved by $\mathrm{HF}: \mathrm{HNO}_{3}(2 \mathrm{ml}: 1 \mathrm{ml})$ overnight on the hotplate, and evaporated to dryness. Add $0.5-1 \mathrm{ml} \mathrm{HNO}_{3}$ into the samples, swirl and evaporate them to dryness twice. Then redissolve samples in $0.5 \mathrm{ml} 12 \mathrm{~N} \mathrm{HCl}$, after letting them sit for one hour, dilute them to about $8 \mathrm{mI}$ and evaporate them to dryness. Finally, pick up samples by $4 \mathrm{ml} 1.25 \mathrm{~N} \mathrm{HCl}$, let them sit overnight, and centrifuge them for $5 \mathrm{~min}$.

- Cation columns: put half of the sample solutions $(2 \mathrm{ml})$ through the cation columns, add $1 \mathrm{ml} 2.5 \mathrm{~N} \mathrm{HCl}$ twice, and add $12 \mathrm{ml}, 9 \mathrm{ml}, 12 \mathrm{ml} 2.5 \mathrm{~N} \mathrm{HCl}$, separately, and discard the collected aliqouts. Then add $12 \mathrm{ml} 2.5 \mathrm{~N} \mathrm{HCl}$ and collecte the $\mathrm{Sr}$ splits. After finishing collecting $\mathrm{Sr}$, add $12 \mathrm{ml} 4.0 \mathrm{~N} \mathrm{HCl}$ and discard, then add $15 \mathrm{ml} 4.0 \mathrm{~N} \mathrm{HCl}$ and collect the REE splits.

- Evaporate the collected Sr and REE samples on the hotplate.

- Clean the columns by rinsing them three times with $6.0 \mathrm{~N} \mathrm{HCl}$, then load $2.5 \mathrm{~N} \mathrm{HCl} 1-5 \mathrm{ml}$ into them and hold the solutions by parafilms to keep the columns from being dry.

2) Pb Chemistry:

- $0.1 \mathrm{~g}$ rock powders were weighed, dissolved by $\mathrm{HF}: \mathrm{HNO}_{3}(1 \mathrm{ml}: 0.5 \mathrm{ml})$ and dried, redissolved once by $0.5 \mathrm{ml} \mathrm{Conc}$. $\mathrm{HNO} 3,1 \mathrm{ml} \mathrm{Conc}$. $\mathrm{HCl}$ and diluted to about $5 \mathrm{ml}$. Then pick up samples by $1 \mathrm{ml}$ and $3 \mathrm{ml} 0.5 \mathrm{~N} \mathrm{HBr}$ sequentially.

- Pb columns: put $\sim 0.1 \mathrm{ml}$ anion resin + liquid into the $\mathrm{Pb}$ columns, rinse them with $0.5 \mathrm{ml} 0.5 \mathrm{~N} \mathrm{HBr}$, then add samples $3 \mathrm{ml}$ into the columns and rinse them with $0.3 \mathrm{ml}, 0.5 \mathrm{ml}$ and $0.5 \mathrm{ml} 0.5 \mathrm{~N} \mathrm{HBr}$ respectively, and collect $1.0 \mathrm{ml} \mathrm{Pb}$ samples by adding $0.5 \mathrm{~N} \mathrm{HNO}_{3}$. After the first collection, clean the columns with $12 \mathrm{ml} 0.5 \mathrm{~N} \mathrm{HNO}_{3}$, and readd the collected samples into the columns and collect them another time to purify the solutions.

- Dry down the solutions on the hotplate by adding a drop of $0.025 \mathrm{~N} \mathrm{H}_{3} \mathrm{PO}_{4}$ (at NHMFL).

Nd chemistry: samples were prepared at the clean lab, NHMFL, under the tutelage of Afi Sachi-Kocher:

- The previously - collected REE splits $0.25 \mathrm{ml}$ in $0.25 \mathrm{~N} \mathrm{HCl}$ were added through the REE columns by three times of rinses with $0.25 \mathrm{ml} 0.25 \mathrm{~N} \mathrm{HCl}$. 
- Nd aliquots were collected by adding into the columns $30 \mathrm{ml} 0.25 \mathrm{~N} \mathrm{HCl}$ totally, waiting for 30-35 min (depends on each column), collecting 25 min, and emptying the rest of the solutions from the columns.

- Clean and condition the columns by loading $6.2 \mathrm{~N} \mathrm{HCl} 20 \mathrm{ml}, 10 \mathrm{ml}, 5 \mathrm{ml}$, respectively, into them. After the columns were cleaned, load $5 \mathrm{ml} 0.25 \mathrm{~N}$ $\mathrm{HCl}$ into them and hold the solutions with parafilms to keep them from being dry.

- Add a drop of $0.025 \mathrm{~N} \mathrm{H}_{3} \mathrm{PO}_{4}$ into the collected $\mathrm{Nd}$ samples and evaporate them on the hotplate.

The sample loading procedures at NHMFL are:

- Sr: use W-single filament, degas it, load the mixture of the TAPH solution and a suitable amount of sample (usually 200ng) in $\mathrm{HNO}_{3}$ drop by drop on it at $1 \mathrm{Amp}$, and increase the current to evaporate $\mathrm{H}_{3} \mathrm{PO}_{4}$. Finally, flash the sample to bright red at $~ 3.0-3.2 \mathrm{Amp}$.

- $\mathrm{Pb}$ : use Commercial-Re single filament, degas it, load the mixture of the silica gel, $\mathrm{H}_{3} \mathrm{PO}_{4}$ and a suitable amount of sample (usually $75 \mathrm{ng}$ ) in $\mathrm{HNO}_{3}$ drop by drop on it at $\sim 1 \mathrm{Amp}$, and increase the current to evaporate $\mathrm{H}_{3} \mathrm{PO}_{4}$. Finally, flash the sample to dull red at $\sim 2.0-2.2 \mathrm{Amp}$.

- Nd: use Ta-double filament as evaporation filament and zone-refined Re-double filament as ionization filament (or reversed), degas them, load the mixture of $\mathrm{HCl}$, $\mathrm{H}_{3} \mathrm{PO}_{4}$ and a suitable amount of sample (usually 200ng) drop by drop on the evaporation filament at $\sim 0.7 \mathrm{Amp}$, and increase the current to evaporate $\mathrm{H}_{3} \mathrm{PO}_{4}$. Finally, flash the sample to dull red briefly at $\sim 1.4-1.5 \mathrm{Amp}$. Locate the two filaments directly opposite and as close as possible without touching.

\section{Pb Blanks:}

$\mathrm{Pb}$ blanks were spiked (with ${ }^{208} \mathrm{~Pb}$ ) after they were collected from the columns. Two $\mathrm{Pb}$ blanks were run on the machine together with the SEC and CLV samples and the results are shown in the following table (Table $3-8$ ): 


\section{Table 3-8 The Pb blank results}

\begin{tabular}{|c|c|c|c|}
\hline Whole procedure $\mathrm{Pb}$ blank (pre - fire)* & \multirow[t]{3}{*}{$\begin{array}{l}{ }^{208} \mathrm{~Pb} \\
{ }^{204} \mathrm{~Pb}\end{array}$} & \multirow[t]{3}{*}{$\begin{array}{l}{ }^{207} \mathrm{~Pb} \\
f^{204} \mathrm{~Pb}\end{array}$} & \multirow[t]{3}{*}{$\begin{array}{l}206 \mathrm{~Pb} \\
\text { l }^{204} \mathrm{~Pb}\end{array}$} \\
\hline Spike Weight: $0.1024 \mathrm{~g}$ & & & \\
\hline Spike Conc.: $6.10 \mathrm{E}-10 \mathrm{~m} / \mathrm{g}$ & & & \\
\hline Unspiked Sample & 38.471 & 15.626 & 18.558 \\
\hline Measured Ratios & 533.4291 & 15.87274 & 19.6544934 \\
\hline Fractionation Corrected Ratios & 536.4085 & 15.9406 & 19.7109 \\
\hline Isotopic Comp. (Spike Corrected) & 38.883 & 15.699 & 18.757 \\
\hline $\mathrm{Pb}$ in Blank (ppm) $* *$ & \multicolumn{3}{|l|}{0.002} \\
\hline $\mathrm{Pb}$ in Blank (ng) $* *$ & \multicolumn{3}{|l|}{1.930} \\
\hline $\mathrm{Pb}$ in Blank (ng) & \multicolumn{3}{|l|}{0.965} \\
\hline
\end{tabular}

\begin{tabular}{|c|c|c|c|}
\hline Whole procedure $\mathrm{Pb}$ blank $(04 / 99)$ & \multirow[t]{3}{*}{$\begin{array}{l}{ }^{208} \mathrm{~Pb} \\
f^{204} \mathrm{~Pb}\end{array}$} & \multirow[t]{3}{*}{$\begin{array}{l}{ }^{207} \mathrm{~Pb} \\
\rho^{204} \mathrm{~Pb}\end{array}$} & \multirow[t]{3}{*}{$\begin{array}{l}{ }^{206} \mathrm{~Pb} \\
\rho^{204} \mathrm{~Pb}\end{array}$} \\
\hline Spike Weight: $0.1022 \mathrm{~g}$ & & & \\
\hline Spike Conc.: $6.10 \mathrm{E}-10 \mathrm{~m} / \mathrm{g}$ & & & \\
\hline Unspiked Sample & 38.471 & 15.626 & 18.558 \\
\hline Measured Ratios & 1080.058 & 16.1093 & 20.401175 \\
\hline Fractionation Corrected Ratios & 1086.1171 & 16.1751 & 20.4700 \\
\hline Isotopic Comp. (Spike Corrected) & 38.266 & 15.666 & 18.459 \\
\hline $\mathrm{Pb}$ in Blank (ppm) ** & \multicolumn{3}{|l|}{0.001} \\
\hline $\mathrm{Pb}$ in Blank (ng) $* *$ & \multicolumn{3}{|l|}{0.897} \\
\hline $\mathrm{Pb}$ in Blank (ng) & \multicolumn{3}{|l|}{0.448} \\
\hline
\end{tabular}


* Pre - fire: There was a fire in PC building in $06 / 98$ and the clean lab of the Geology Department of FIU was somewhat affected. After the fire, the whole lab was reestablished and everything in the room including the air filters was all replaced. The $\mathrm{Pb}$ "pre - fire" blank was prepared before the fire, and the other one - prepared in 04 / 99 is a "post - fire" Pb blank. And the calculated results did show that the quality of the FIU clean lab is acceptable and improved after it was recleaned in Feb., 1999. The lower of the two blanks is comparable to those measured by Hickey - Vargas (unpublished) over the period of $1995-1997$.

**: The $\mathrm{Pb}$ blanks were approximately doubled during preparation by accidentally adding the dissolution reagents into the sample beakers one more time before drying them down. Since most of the $\mathrm{Pb}$ blanks come from the impurity of the chemical reagents used to dissolve samples in the lab, the final results of the $\mathrm{Pb}$ blanks were calculated by dividing the raw data by a factor of 2 .

Radiogenic isotopes $\mathrm{Sr}-\mathrm{Nd}-\mathrm{Pb}$ were run at the geochemistry lab of NHMFL between $02 / 98-04 / 00$ and the following table (Table $3-9$ ) shows the analyzed isotopic compositions of the chosen SEC and CLV samples: 
Table 3 - 9 Radiogenic isotopes measured for the SEC and CLV samples

\begin{tabular}{|c|c|c|c|c|c|c|}
\hline \begin{tabular}{|l|} 
Sample \\
Location
\end{tabular} & $\begin{array}{l}\text { Sample } \\
\text { Number }\end{array}$ & ${ }^{87} \mathrm{Sr} /{ }^{86} \mathrm{Sr}$ & ${ }^{143} \mathrm{Nd} /{ }^{144} \mathrm{Nd}$ & ${ }^{206} \mathrm{~Pb} /{ }^{204} \mathrm{~Pb}$ & ${ }^{207} \mathrm{~Pb} /{ }^{204} \mathrm{~Pb}$ & ${ }^{208} \mathrm{~Pb} /{ }^{204} \mathrm{~Pb}$ \\
\hline Rucapillan & $010494-1 \mathrm{~A}$ & $0.70341 \pm 1$ & $0.512953 \pm 10$ & 18.558 & 15.626 & 38.471 \\
\hline Rucapillan & 010494-1B* & $0.70370 \pm 1$ & $0.512873 \pm 10$ & 18.565 & 15.605 & 38.471 \\
\hline Huelemolle & 110194-02 & $0.70390 \pm 1$ & $0.512829 \pm 10$ & 18.561 & 15.607 & 38.467 \\
\hline Caburgua & $150194-03$ & $0.70376 \pm 1$ & $0.512832 \pm 10$ & 18.594 & 15.615 & 38.513 \\
\hline C. Redondo & 140194-09 & $0.70389 \pm 1$ & $0.512835 \pm 10$ & 18.553 & 15.603 & 38.452 \\
\hline La Barda & 150194-06 & $0.70373 \pm 1$ & $0.512838 \pm 10$ & 18.528 & 15.610 & 38.440 \\
\hline La Barda & 150194-5B & $0.70374 \pm 1$ & $0.512824 \pm 10$ & 18.560 & 15.596 & 38.436 \\
\hline Huililco & 240394-6A & $0.70399 \pm 1$ & $0.512866 \pm 10$ & 18.575 & 15.614 & 38.507 \\
\hline $\mathrm{CLV}$ & $160295-01^{*}$ & $0.70405 \pm 1$ & $0.512889 \pm 10$ & 18.601 & 15.633 & 38.568 \\
\hline CLV & $120295-01$ & $0.70406 \pm 1$ & $0.512825 \pm 10$ & 18.576 & 15.605 & 38.478 \\
\hline $\mathrm{CLV}$ & $180295-08$ & $0.70403 \pm 1$ & $0.512817 \pm 8$ & 18.564 & 15.596 & 38.433 \\
\hline CLV & 080295-02 & $0.70406 \pm 1$ & $0.512864 \pm 10$ & 18.604 & 15.633 & 38.574 \\
\hline CLV & 170295-02 & $0.70405 \pm 1$ & $0.512865 \pm 8$ & 18.598 & 15.620 & 38.531 \\
\hline CLV & 070295-03 & $0.70411 \pm 1$ & $0.512851 \pm 10$ & 18.592 & 15.612 & 38.507 \\
\hline CLV & 180295-03 & $0.70415 \pm 1$ & $0.512839 \pm 10$ & 18.598 & 15.618 & 38.526 \\
\hline CLV & $170295-01$ & $0.70401 \pm 1$ & $0.512883 \pm 10$ & 18.599 & 15.620 & 38.529 \\
\hline
\end{tabular}




\section{Replicates:}

The $\mathrm{Pb}$ isotopes of sample 010494 - 1B were loaded and run twice and the results for both times are:

${ }^{208} \mathrm{~Pb} /{ }^{204} \mathrm{~Pb}$ : I) 38.475 ; II) 38.467

${ }^{207} \mathrm{~Pb} /{ }^{204} \mathrm{~Pb}$ : I) 15.606 ; II) 15.604

${ }^{200} \mathrm{~Pb} /{ }^{204} \mathrm{~Pb}$ : I) 18.566 ; II) 18.564

So the reproducibility of the $\mathrm{Pb}$ isotopic ratios on the MS of NHMFL as shown above within \pm 0.004 for ${ }^{208} \mathrm{~Pb} /{ }^{204} \mathrm{~Pb}$ and \pm 0.001 for both ${ }^{207} \mathrm{~Pb} /{ }^{204} \mathrm{~Pb}$ and ${ }^{206} \mathrm{~Pb} /{ }^{204} \mathrm{~Pb}$ - is excellent therefore the differences between different sample runs could be pretty much negligible.

Also analyzed for $\mathrm{Sr}$ reproducibility is sample 160295 - 01 from Carran - LV area. It was prepared first in the FIU clean lab and later in the NHMFL again and measured on the MS separately:

$160295-01$ (FIU): $\quad 0.704068 \pm 0.000008$

$160295-01$ (NHMFL): $\quad 0.704024 \pm 0.000008$

It was shown that there exist some inter - lab errors for the Sr analyses. However, this difference is not significant comparing with the whole range of the CLV samples and therefore should not create any problem for the interpretation of Sr isotopes in the studied area.

In addition, the run replicate results of the Nd isotope of sample $010494-1$ A show that the stability of the MS of the NHMFL is excellent:

Run1: $0.512949 \pm 0.000010$

Run2: $0.512957 \pm 0.000010$

\section{Standards:}

E\&A Sr standards, NBS $981 \mathrm{~Pb}$ standards and La Jolla Nd standards were also run within the same batch with the samples to calibrate the measurement accuracy.

- $\mathrm{Pb}$ : 24 NBS $981 \mathrm{~Pb}$ Standards were analyzed for the first time (Feb. / 99) and 14 for the second time (March / 00) and each time the fractionation factors for each of the three $\mathrm{Pb}$ isotopic ratios were calculated based on the consensus values by Todt et al. (Table 3 - 10). The measured samples were corrected for their fractionation by multiplying the measured raw data with the corresponding fractionation factors. 
Table 3-10 The results of the measured Pb NBS 981 standards

\begin{tabular}{|l|l|l|l|l|l|}
\hline Standard (02/99) & ${ }^{208} \mathrm{~Pb} /{ }^{204} \mathrm{~Pb}$ & ${ }^{207} \mathrm{~Pb} /{ }^{204} \mathrm{~Pb}$ & ${ }^{206} \mathrm{~Pb}{ }^{204} \mathrm{~Pb}$ & ${ }^{208} \mathrm{~Pb}{ }^{206} \mathrm{~Pb}$ & ${ }^{207} \mathrm{~Pb}{ }^{206} \mathrm{~Pb}$ \\
\hline$\# 1$ & 36.473 & 15.419 & 16.882 & 2.1605 & 0.9134 \\
\hline$\# 2$ & 36.500 & 15.427 & 16.889 & 2.1612 & 0.9135 \\
\hline$\# 3$ & 36.535 & 15.439 & 16.897 & 2.1622 & 0.9137 \\
\hline$\# 4$ & 36.508 & 15.431 & 16.891 & 2.1614 & 0.9135 \\
\hline$\# 5$ & 36.489 & 15.425 & 16.886 & 2.1609 & 0.9134 \\
\hline$\# 6$ & 36.502 & 15.429 & 16.890 & 2.1612 & 0.9135 \\
\hline$\# 7$ & 36.549 & 15.443 & 16.900 & 2.1627 & 0.9138 \\
\hline$\# 8$ & 36.471 & 15.419 & 16.883 & 2.1602 & 0.9133 \\
\hline$\# 9$ & 36.471 & 15.419 & 16.882 & 2.1603 & 0.9133 \\
\hline \#10 & 36.448 & 15.412 & 16.877 & 2.1596 & 0.9132 \\
\hline$\# 11$ & 36.476 & 15.421 & 16.883 & 2.1605 & 0.9134 \\
\hline$\# 12$ & 36.518 & 15.433 & 16.893 & 2.1617 & 0.9136 \\
\hline \#13 & 36.479 & 15.421 & 16.884 & 2.1606 & 0.9134 \\
\hline \#14 & 36.489 & 15.424 & 16.887 & 2.1608 & 0.9134 \\
\hline \#15 & 36.520 & 15.436 & 16.897 & 2.1613 & 0.9135 \\
\hline \#16 & 36.481 & 15.421 & 16.884 & 2.1607 & 0.9134 \\
\hline \#17 & 36.484 & 15.423 & 16.886 & 2.1606 & 0.9134 \\
\hline \#18 & 36.502 & 15.429 & 16.891 & 2.1609 & 0.9134 \\
\hline \#19 & 36.527 & 15.439 & 16.898 & 2.1615 & 0.9137 \\
\hline \#20 & 36.501 & 15.428 & 16.890 & 2.1610 & 0.9135 \\
\hline \#21 & 36.502 & 15.428 & 16.888 & 2.1613 & 0.9135 \\
\hline \#22 & 36.486 & 15.424 & 16.886 & 2.1606 & 0.9134 \\
\hline \#23 & 36.479 & 15.421 & 16.884 & 2.1604 & 0.9134 \\
\hline \#24 & 36.478 & 15.421 & 16.883 & 2.1605 & 0.9134 \\
\hline Ave. & 36.4945 & 15.4263 & 16.8880 & 2.1609 & 0.9134 \\
\hline RSD & 0.0234 & 0.0076 & 0.0058 & 0.0007 & 0.0001 \\
\hline \%RSD & 0.0640 & 0.0489 & 0.0346 & 0.0309 & 0.0155 \\
\hline Todt et al. & 36.7006 & 15.4891 & 16.9356 & 2.1670 & 0.9146 \\
\hline Diff(|Ave-Todt|) & 0.2061 & 0.0628 & 0.0476 & 0.0061 & 0.0011 \\
\hline$\%$ Diff & 0.5647 & 0.4069 & 0.2821 & 0.2808 & 0.1243 \\
\hline$\%$ Frac.Factor/amu & 0.141 & 0.136 & 0.141 & 0.140 & 0.124 \\
\hline & & & & \\
\hline
\end{tabular}

\section{(CONTINUED)}

\begin{tabular}{|l|l|l|l|l|l|}
\hline Standard $(03 / 00)$ & ${ }^{208} \mathrm{~Pb} /{ }^{204} \mathrm{~Pb}$ & ${ }^{207} \mathrm{~Pb}{ }^{204} \mathrm{~Pb}$ & ${ }^{206} \mathrm{~Pb} /{ }^{204} \mathrm{~Pb}$ & ${ }^{208} \mathrm{~Pb} /{ }^{206} \mathrm{~Pb}$ & ${ }^{207} \mathrm{~Pb}{ }^{206} \mathrm{~Pb}$ \\
\hline$\# 1$ & 36.497 & 15.427 & 16.888 & 2.1611 & 0.9135 \\
\hline$\# 2$ & 36.491 & 15.425 & 16.886 & 2.1610 & 0.9135 \\
\hline$\# 3$ & 36.505 & 15.429 & 16.888 & 2.1616 & 0.9136 \\
\hline$\# 4$ & 36.504 & 15.429 & 16.889 & 2.1614 & 0.9136 \\
\hline$\# 5$ & 36.498 & 15.427 & 16.888 & 2.1612 & 0.9135 \\
\hline$\# 6$ & 36.520 & 15.434 & 16.893 & 2.1618 & 0.9136 \\
\hline$\# 7$ & 36.487 & 15.423 & 16.885 & 2.1609 & 0.9134 \\
\hline$\# 8$ & 36.495 & 15.427 & 16.887 & 2.1611 & 0.9135 \\
\hline$\# 9$ & 36.521 & 15.434 & 16.893 & 2.1619 & 0.9136 \\
\hline$\# 10$ & 36.502 & 15.428 & 16.888 & 2.1614 & 0.9135 \\
\hline$\# 11$ & 36.468 & 15.417 & 16.880 & 2.1604 & 0.9133 \\
\hline$\# 12$ & 36.480 & 15.421 & 16.883 & 2.1608 & 0.9134 \\
\hline$\# 13$ & 36.481 & 15.422 & 16.883 & 2.1608 & 0.9135 \\
\hline$\# 14$ & 36.471 & 15.418 & 16.881 & 2.1605 & 0.9133 \\
\hline Ave. & 36.4943 & 15.4258 & 16.8866 & 2.1611 & 0.9135 \\
\hline
\end{tabular}




\section{(CONTINUED)}

\begin{tabular}{|l|l|l|l|l|l|}
\hline Standard $(03 / 00)$ & ${ }^{208} \mathrm{~Pb} /{ }^{204} \mathrm{~Pb}$ & ${ }^{207} \mathrm{~Pb} /{ }^{204} \mathrm{~Pb}$ & ${ }^{206} \mathrm{~Pb} /{ }^{204} \mathrm{~Pb}$ & ${ }^{208} \mathrm{~Pb} /{ }^{206} \mathrm{~Pb}$ & ${ }^{207} \mathrm{~Pb}{ }^{206} \mathrm{~Pb}$ \\
\hline RSD & 0.0160 & 0.0052 & 0.0039 & 0.0004 & 0.0001 \\
\hline \%RSD & 0.0439 & 0.0336 & 0.0232 & 0.0208 & 0.0112 \\
\hline Todt et al. & 36.7006 & 15.4891 & 16.9356 & 2.1670 & 0.9146 \\
\hline Diff(|Ave-Todt|) & 0.2063 & 0.0633 & 0.0490 & 0.0059 & 0.0011 \\
\hline \%Diff & 0.5653 & 0.4104 & 0.2903 & 0.2718 & 0.1203 \\
\hline \%Frac.Factor/amu & 0.141 & 0.137 & 0.145 & 0.136 & 0.120 \\
\hline
\end{tabular}


- Sr: Three E\&A Sr Standards $\left({ }^{87} \mathrm{Sr} /{ }^{86} \mathrm{Sr}=0.7080\right)$ were analyzed along with the first batch (five) of the rock samples and the results of ${ }^{87} \mathrm{Sr}{ }^{86} \mathrm{Sr}$ are as follows:

Std.\#1: $0.708009 \pm 0.000008$

Std.\#2: $\quad 0.708012 \pm 0.000008$

Std.\#3: $\quad 0.708005 \pm 0.000008$

Two more Sr standards were loaded in the second batch of the samples and the results of them are:

Std. \#1: $0.708001 \pm 0.000008$

Std. \#2: $0.708001 \pm 0.000008$

As shown above, the MS in the NHMFL is very stable on measuring $\mathrm{Sr}$ isotopes, and the errors of the measured results of the SEC / CLV samples (Table 3 - 9) are basically 0.000008 , and at most 0.00001 . This quality can be very well accepted in the analyses and further interpretations of $\mathrm{Sr}$ isotopes.

${ }^{87} \mathrm{Sr} /{ }^{86} \mathrm{Sr}$ is normalized to ${ }^{86} \mathrm{Sr} /{ }^{88} \mathrm{Sr}=0.1194$

- Nd: Totally four La Jolla Nd Standards were loaded and analyzed in 2 batches of rock samples and the measured results are as follows:

Std. \#1: $0.511861 \pm 0.000010$

Std. \#2: $0.511855 \pm 0.000010$

Std. \#3: $0.511846 \pm 0.000010$

Std. \#4: $0.511851 \pm 0.000009$

The averaged Nd standard result measured above is 0.511853 , only 0.000003 higher than the consensus value of the La Jolla $\mathrm{Nd}$ standard $\left({ }^{143} \mathrm{Nd} /{ }^{144} \mathrm{Nd}=0.511850\right)$. Therefore the quality of the measured Nd results of the SEC and CLV samples can be very well accepted. The errors of the Nd isotopes of both standards and the rock samples are mostly 0.000010 or better $(0.000009$ or 0.000008$)$.

${ }^{143} \mathrm{Nd} /{ }^{144} \mathrm{Nd}$ is normalized to ${ }^{146} \mathrm{Nd} /{ }^{144} \mathrm{Nd}=0.7219$. 


\section{5. $\mathrm{U}$ - Series disequilibrium and ${ }^{10} \mathrm{Be}$}

1. U-Series:

U - Series results were measured on the Alpha - spectrometry at University of Iowa by Dr. Mark Reagan and his Ph.D. students. A total of 12 volcanic samples (3 from V.V.Villarrica, 8 from Villarrica SEC and 1 from Carran - LV SEC) were analyzed and the results are shown in Table $3-11 \mathrm{a}$.

\section{2. ${ }^{10} \mathrm{Be}:$}

5 fresh sample chunks ( 1 from V.Villarrica and 4 from SEC) were analyzed on the Accelerator Mass Spectrometer at Lawrence Livermore National Laboratory by Dr. Julie Morris, Marc Caffee and John Southon and the results are shown in Table $3-11 \mathrm{~b}$. The total chemistry blanks during 2000 (including one prepared in parallel $w /$ these samples) are 0.02 million a $/ \mathrm{g} \pm 50 \%$, and the quoted detection limit $=5 \mathrm{x}$ blank $=0.1 \mathrm{million} \mathrm{a} / \mathrm{g}$. All non - historic lavas were leached and in all the samples below the concentrations of leachable ${ }^{10} \mathrm{Be}$ are negligible. 
Table 3-11a The U-Series results

\begin{tabular}{|l|l|l|l|l|}
\hline Sample Number & Location & ${ }^{238} \mathrm{U} /{ }^{232} \mathrm{Th}$ & ${ }^{230} \mathrm{Th} /{ }^{232} \mathrm{Th}$ & ${ }^{210} \mathrm{Po} /{ }^{230} \mathrm{Th}$ \\
\hline $010494-1 \mathrm{~A}$ & Rucapillan & 0.92 & 0.93 & 1.04 \\
\hline $110194-03$ & Huelemolle & 0.82 & 0.87 & 1.10 \\
\hline $130194-02$ & Llizan & 1.00 & 0.85 & 1.01 \\
\hline $140194-01$ & San Jorge & 1.34 & 0.73 & 1.60 \\
\hline $140194-09$ & Cerro Redondo & 0.92 & 0.92 & 1.13 \\
\hline $150194-01$ & Caburgua & 0.86 & 0.94 & 1.00 \\
\hline $150194-06$ & La Barda & 0.85 & 0.89 & 1.02 \\
\hline $151282-2$ & Villarrica I & 1.00 & 0.79 & 1.11 \\
\hline $151282-3$ & Villarrica II & 0.97 & 0.90 & 1.06 \\
\hline $180295-08$ & Carran - LV & 0.73 & 0.77 & 1.01 \\
\hline $210281-1$ & Villarrica (1971) & 1.16 & 0.77 & 1.57 \\
\hline $240394-6 \mathrm{~A}$ & Huililco & 0.94 & 0.87 & 1.28 \\
\hline
\end{tabular}

Table 3 - 11b The ${ }^{10} \mathrm{Be}$ results

\begin{tabular}{|l|l|l|l|}
\hline Sample Number & Location & ${ }^{10} \mathrm{Be}\left(10^{6}\right.$ atom/gram $)$ & $1 \sigma \%$ \\
\hline $150194-01$ & Caburgua & 0.97 & 3.4 \\
\hline $110194-03$ & Huelemolle & 1.10 & 4.1 \\
\hline $140194-01$ & San Jorge & 1.20 & 3.3 \\
\hline $150194-06$ & La Barda & 0.98 & 3.5 \\
\hline $210281-1$ & Villarrica (1971) & 1.70 & 3.0 \\
\hline
\end{tabular}


VITA

MURONG SUN

February 20, 1972

$1990-1995$

$1995-1996$

$1996-2001$

$1996-2001$
Born Lanzhou, P.R.China

B.S., Geochemistry

University of Science and

Technology of China (USTC), Hefei, P.R.China

Graduate student in

Geochemistry, USTC

Ph.D. student in Geology

Florida International University

Miami, Florida

Teaching / Research Assistant in Geology

Florida International University

Miami, Florida

\section{PUBLICATIONS AND PRESENTATIONS}

Murong Sun and Rosemary Hickey - Vargas (1998) Geochemical Patterns Among the Small Eruptive Centers Near Villarrica Volcano, Central Southern Volcanic Zone, Chile. Poster at American Geophysical Union 1998 Fall Meeting 